Szegedi Tudományegyetem

Természettudományi és Informatikai Kar

Földtudományok Doktori Iskola

Gazdaság- és Társadalomföldrajz Tanszék

\title{
A LAKOSSÁGI SZUBURBANIZÁCIÓ SZEREPE A HAZAI VIDÉKI AGGLOMERÁCIÓK KÜLTERÜLETEINEK ÁTALAKULÁSÁBAN
}

Doktori (Ph.D.) értekezés

Vasárus Gábor László

Témavezető:

Dr. Bajmócy Péter

egyetemi docens

Szeged

2018 


\section{Tartalomjegyzék}

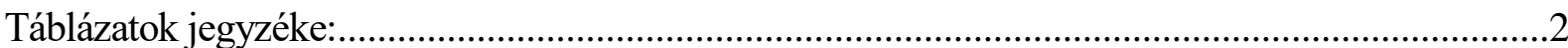

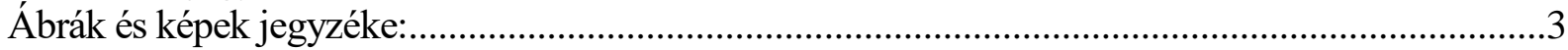

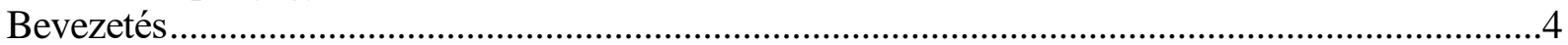

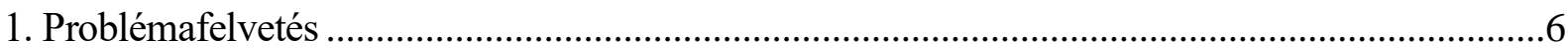

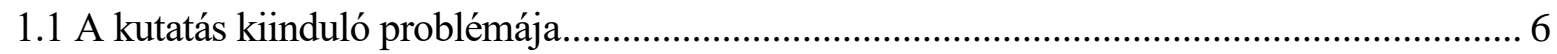

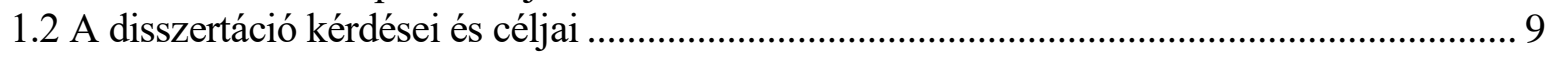

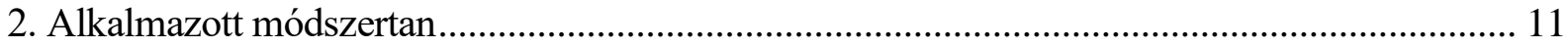

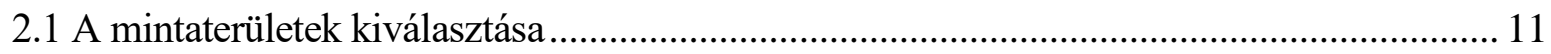

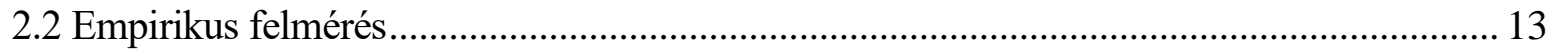

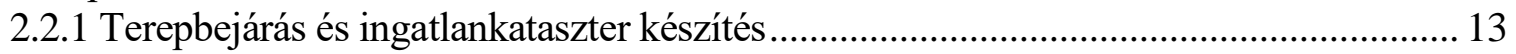

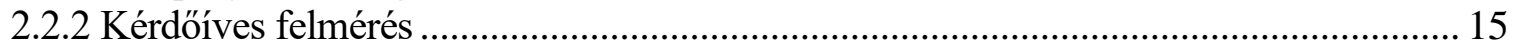

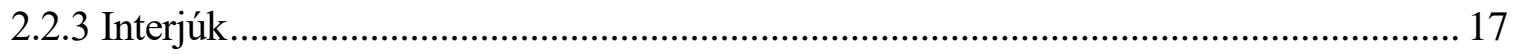

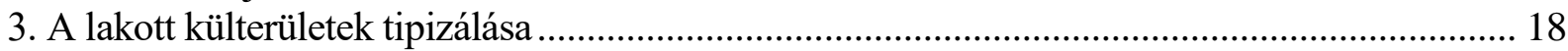

3.1 Lakott külterület, mint településföldrajzi fogalom .......................................................... 18

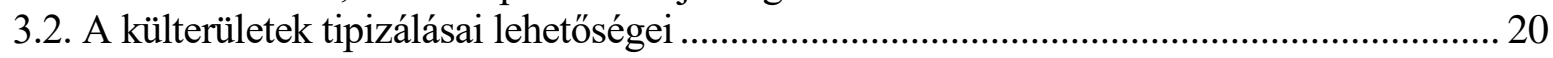

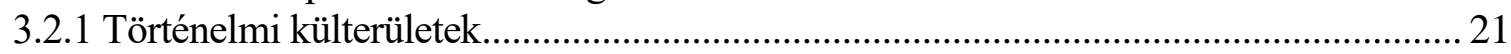

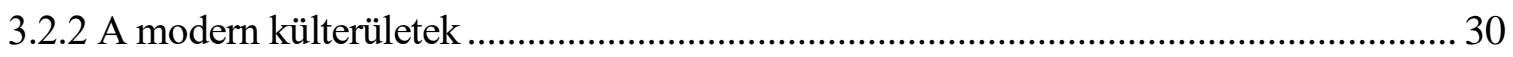

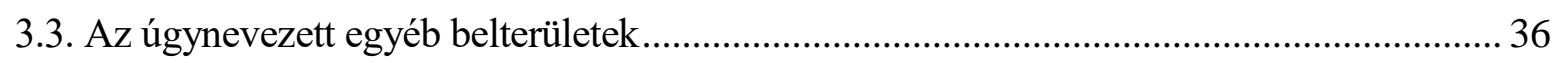

4. A lakóhelyi szuburbanizáció tásadalomföldrajzi értelmezése.................................................... 38

4.1 A lakóhelyi szuburbanizáció vizsgálatánál alkalmazott fogalmak ..................................... 38

4.2 A szuburbanizációt mozgató tényezők és a szuburbán öv fejlődésének szakaszai .............. 43

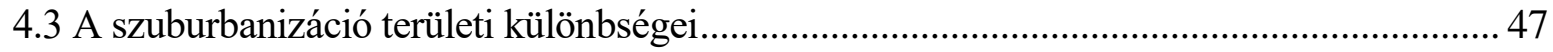

4.4 A posztszocialista országok és különösen Magyarország szuburbanizációs sajátosságai ... 50

4.4.1 A posztszocialista szuburbanizáció társadalmi-gazdasági jellemzői............................... 51

4.4.2 A posztszocialista szuburbanizáció térszerkezeti jellemzői .......................................... 55

4.5. A szuburbanizáció részfolyamatai, hatásai a társadalomra és környezetére ........................57

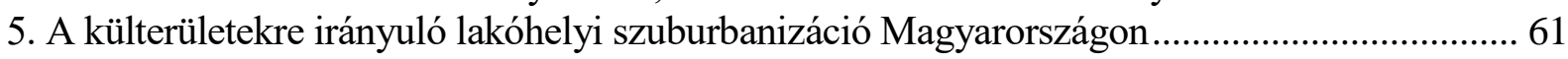

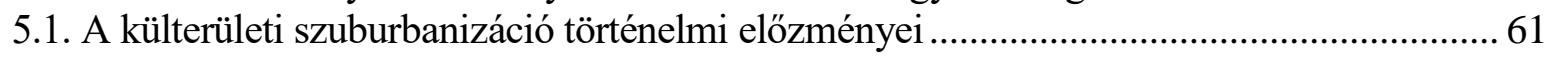

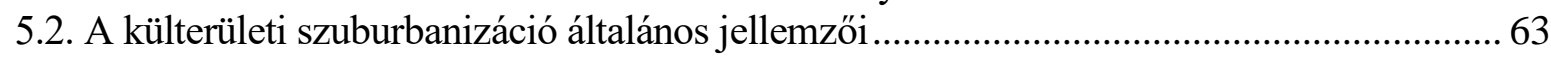

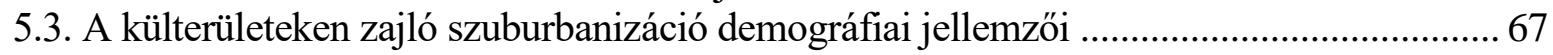

5.4. Területhasználat átalakulása és annak következményei a lakosok életvitelében ................. 71

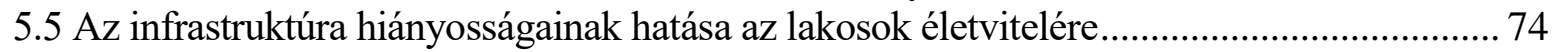

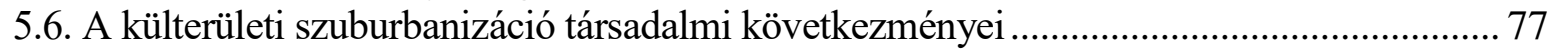

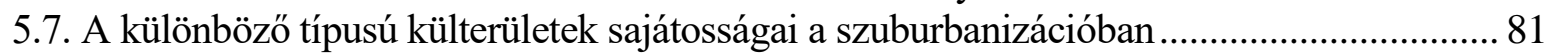

6. Külterületek és egyéb belterületek térfolyamatainak jellegzetességei .................................... 91

7. A külterületi lakóhelyi szuburbanizáció térszerkezeti modellje ............................................. 98

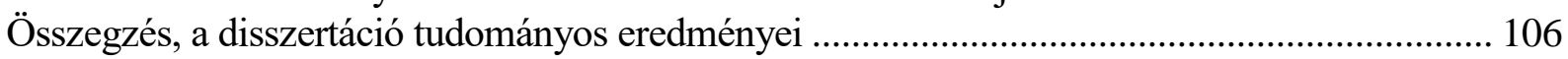

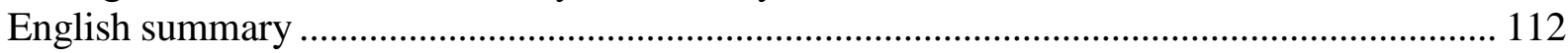

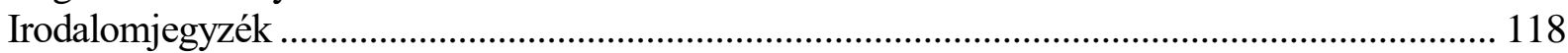

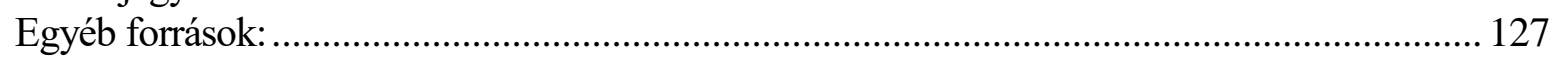

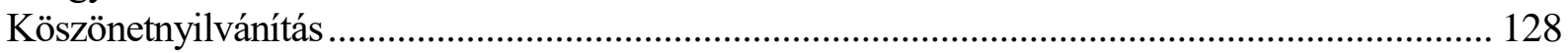

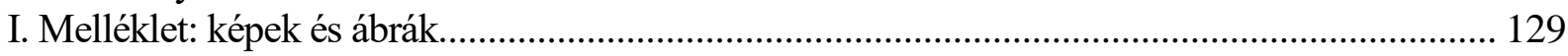

II. Melléklet: A mintaterület településeinek adatbázisa ............................................................. 136

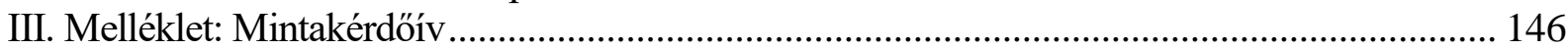




\section{TÁBLÁZATOK JEGYZÉKE:}

1. táblázat: Az empirikus felmérés során felvett minták megoszlása .........................................................................13

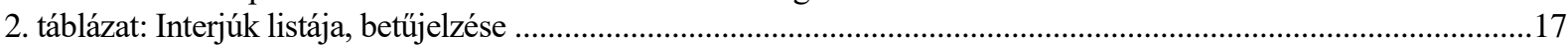

3. táblázat. A külterületek települési jelleg szerinti megoszlása a KSH osztályozása alapján, 2011-ben. .......................21

4. táblázat. Példák a szuburbanizáció definíciós lehetőségeinek sokszínüségeire. ……………………………….......42

5. táblázat: A külterületek népességszámának alakulása Magyarországon 1970 és 2011 között. ...................................63

6. táblázat: A külterületi szuburbanizáció területi megoszlása.....................................................................................66

7. táblázat: a külterületre költözés motivációi (\%) ....…………......................................................................69

8. táblázat. A külterületi ingatlanok funkció és állag szerinti megoszlása a terepbejárás eredményei alapján. ...............73

10. táblázat: A hazai agglomerációk és településegyüttesek külterületek típusainak főbb statisztikai jellemzői.............83

11. táblázat. Az egyéb belterületek jelentősége a hazai településstruktúrában .........................................................91

11. táblázat, a helyi közösség migrációs jellemzöinek összehasonlítása az egyéb belterületeken, külterületeken és

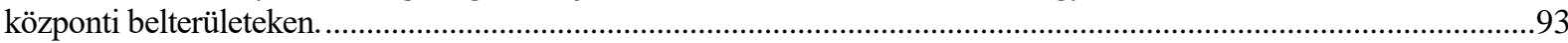

12. táblázat: A külterületek adottságaiból fakadó föbb fejlődési pályák..................................................................99

Table 1. The role of outskirts and other inner areas as suburban destinations in Hungary. Share of population

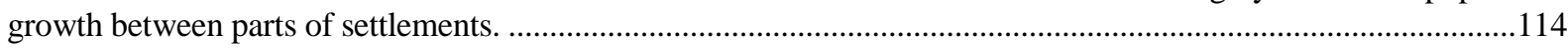

Table 2. The composition of local population of the sample areas $(\%)$...........................................................114

Table 3. Population growth of outskirts in agglomerations of Hungary …………………….................................115 


\section{ÁBRÁK ÉS KÉPEK JEGYZÉKE:}

1. ábra: a külterületek és egyéb belterületek jelentősége a KSH által lehatárolt hazai vidéki agglomerációkban és településegyüttesek népességnövekedésében 1990 és 2011 között................................................................7 2. ábra: A külterületek és egyéb belterületek szerepe a vidéki agglomerációk népességében és annak növekedésében

3. ábra: A lakott külterületek foóbb típusainak sematikus településszerkezete.

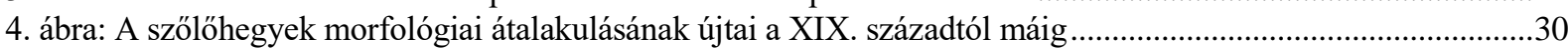

5. ábra. A posztszocialista városok funkcionális területhasználati modellje..........................................................56

6. ábra: A szuburbanizáció dinamikája az agglomerációk központi- és egyéb belterületein, valamint külterületein 1990-2011 között.

7. ábra: A külterületek népességének növekedése 1990 és 2011 között a 1990 évi népesség \%-ban kifejezve a KSH által lehatárolt agglomerációkban és településegyüttesekben.

8. ábra: A külterületi lakosság megoszlása kereset és iskolai végzettség szerint................................................68

9. ábra: A külterületek típusainak dinamikája az országban, valamint az agglomerációk és településegyüttesek

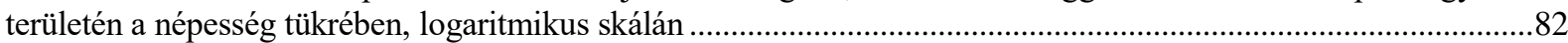

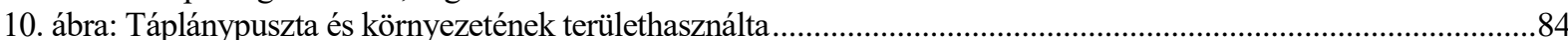

11. ábra: Győr dél-keleti külterületeinek területhasználati változásai ..................................................................86

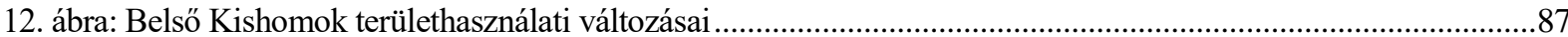

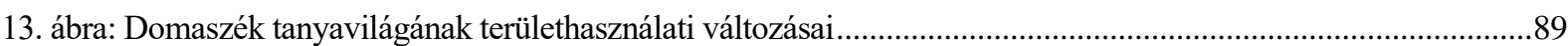

14. ábra: Az egyéb belterületek növekményének aránya a település teljes népességnövekményében. ......................92

15. ábra: Győrszentiván területhasználati átalakulása és a kialakult konfiktusok térbelisége.....................................95

16. ábra: A hazai városok szuburbiáit meghatározó részfolyamatok térbelisége .................................................101

17. ábra: A vidéki szuburbanizáció mozaik-modellje. A külterületekre és egyéb belterületekre irányuló migráció hatása a magyarországi közép- és nagyvárosi szuburbiák térszerkezetére ....................................................................102

Figure 1. The spatial structure of suburbanisation in case of a city with outskirts and other inner areas.

\section{Melléklet:}

1. ábra: Magyarország Agglomerációinak, Település-együtteseinek és Hódmezővásárhely külterületi lakosságának aránya (\%), 2011

2. ábra: A vizsgálatba vont települések a felmérés szintje szerint ........................................................................129

3. ábra: A Győri agglomeráció külterületei és egyéb belterületei, .......................................................................130

4. ábra: A Zalaegerszegi településegyüttes külterületei és egyéb belterületei, 2011 ...............................................130

5. ábra: A Szegedi Településegyüttes és Hódmezővásárhely külterületei és egyéb belterületei, 2011 ...........................131

1. kép: Hanyatló tanyák Domaszék és Sándorfalva határában .......................................................................131

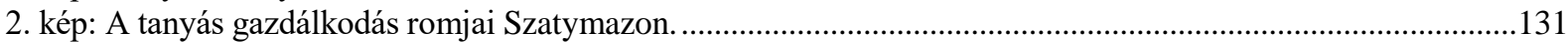

3. kép: Sikeresesen megújuló tanyák Szeged és Domaszék között. ................................................................132

4. kép: Hanyatló, de növekvő népességü (Nagyszertjános) és elnéptelenedő (Győrság) major...............................132

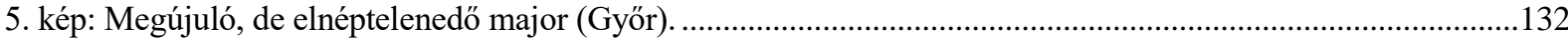

6. kép: Példák jellegzetes szőlőhegyi területhasználatra.................................................................................132

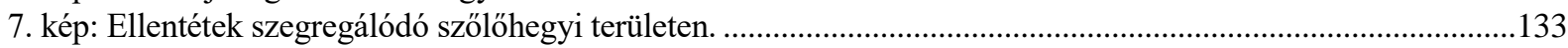

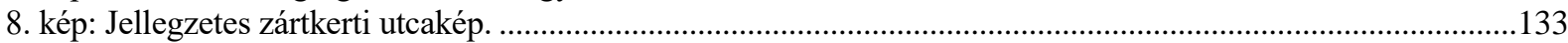

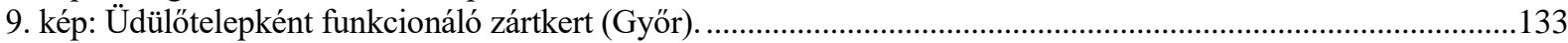

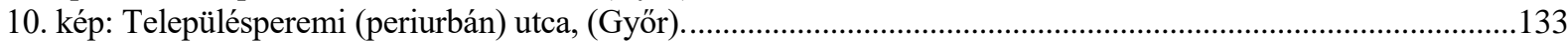

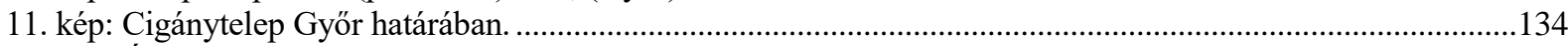

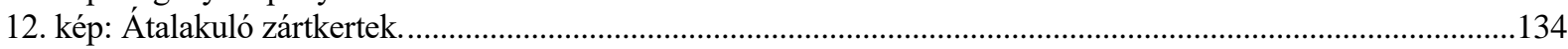

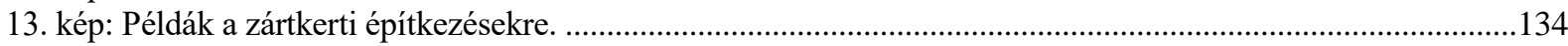

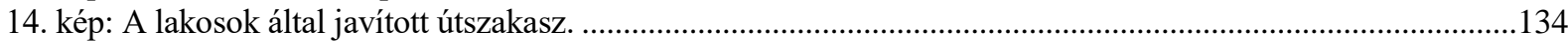

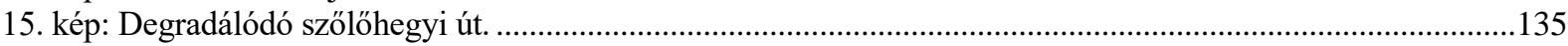

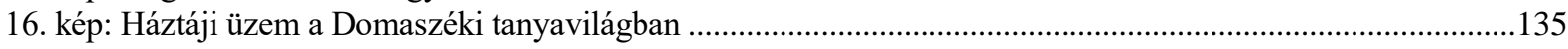

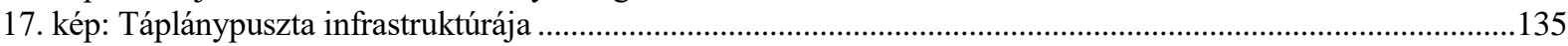

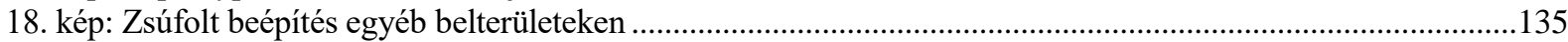




\section{BEVEZETÉS}

\section{„Egy alig ismert településszerkezeti elem...”}

1982-ben BELUSZKY PÁL (325. p.) a kertségek, mint a városfejlődés sajátos színterei kapcsán fogalmazta meg e gondolatát, és ez a feltevés a mai napig megállja a helyét. Hazánk településföldrajzi sajátossága, hogy a közigazgatásilag önálló települések magját alkotó belterületek mellett külterületeken és a külterületekből létrehozott egyéb belterületeken is nagy számú népesség él. Az ilyen helyek többsége az 1700 és 1900 közötti időszakban jött létre a mezőgazdasági konjunktúra hatására, valamint a bányászat és az ipar településektől távol jelentkező munkaerőigényének kielégítésére. Az alföldi tanyák talán a legismertebb és a geográfiában leginkább kutatott külterületek, de emellett a Dunántúlon és Észak-Magyarországon igen gyakoriak a majorok, a szőlőhegyek, valamint erdész- és bányásztelepek. Az eltérő típusok társadalma a sajátosan szerveződő élet és zártság révén meglehetősen egyedi, a közigazgatásilag önálló településekétől eltérő volt, amelyet többek között Illyés Gyula szociográfiai munkái mutatnak be plasztikusan.

A szocializmusban a külterületek egy millió fős népessége a táblásítás, a szövetkezetesítés és a rurális lakóhelyeket hátrányosan érintő településpolitikai beavatkozások miatt 290000 fő alá csökkent miközben a négy és fél évtized alatt évenként 2-300 lakott külterület néptelenedett el. 1990 után azonban a folyamat az ellenkezőjére váltott, megindult a városok környéki külterületek növekedése, újak kialakulása, sőt korábban elnéptelenedettek újra benépesülése. A települési szint hangsúlya miatt a városok és agglomerációik területén lévő ilyen lakott helyekről és azok szerepéröl a recens folyamatokban azonban kevés információval rendelkezünk.

Az agglomerációk alakulása és különösen a lakossági szuburbanizáció a szakmai diskurzus hangsúlyosabb problémaköréhez tartozik, társadalmi és gazdasági hatásait, a kialakuló konfliktusokat számos szerző vizsgálja globális és lokális léptékben egyaránt. Hazánkban a rendszerváltás után felgyorsuló elővárosi fejlődés átszabta a külterületek fejlődési útjait. Bár e lakott helyeken az agglomerációk populációjának csak kis része él, mégis ide irányult a migráció egy jelentős része vidéki városaink esetében. Mivel bizonyos típusú külterületek (szőlőhegyek, zártkertek, üdülők) kiemelt népességnövekményt értek el a vidéki szuburbiák alakulásában a korábbi kutatásokban feltételezetteknél lényegesen nagyobb lehet e területek szerepe.

A szuburbanizációt kutató hazai vizsgálatok többségében a folyamatot a közigazgatásilag önálló települések közötti migrációhoz kötötték, azonban ez a megközelítés leszükítőnek bizonyulhat. A posztszocialista városfejlődési sajátosságokat mutató, a település-összevonások és a bemutatott külterületi jellegzetességek miatt komplex szerkezetü vidéki városaink esetében a folyamatot a közigazgatási-statisztikai beosztás alatti léptékben is célszerü vizsgálni az egyes településrészek közötti nagymértékü különbségek fényében. Ezt indokolja, hogy a vidéki agglomerációink külterületeire és egyéb belterületeire irányult a népességbeáramlás 55,1\%-a 1990 és 2011 között.

Mivel a külterületek az építésügyi és földügyi szabályozásban sajátos helyet foglaltak el, valamint az önkormányzatok érdeklődése is váltakozó intenzitású volt e lakóhelyek irányába az itt zajló folyamatot leginkább a kaotikusság, szervezetlenség és szabályozatlanság jellemzi, ahogy az BELUSZKY PÁL (1982) már idézett írásában is kiemelte. Az itt található telkek olcsósága és a laza szabályozás miatt a városokból kiszoruló és az ország perifériájáról beköltöző elesett, kedvezőtlen szocioökonómiai helyzetü személyek nagyobb arányban költöztek e helyekre, számos konfliktust megélve. Mivel legkevésbé ezen hátrányos helyzetü csoportok tudnak önerőböl tenni sorsuk jobbra fordításáért ezért véleményem szerint kiemelten fontos e területek fejlesztése a külterületek társadalom- és településföldrajzi sajátosságainak figyelembevételével.

Ezen kérdéskör problematikájának feltárása érdekében kutatásom során - az eredmények gyakorlati felhasználhatóságát szem előtt tartva - azt kívánom megvizsgálni, hogy a lakott külterületek milyen szerepet töltenek be a hazai vidéki városaink alakulásában, mekkora szerepet játszanak a lakossági szuburbanizációban. Véleményem szerint ez az indokoltnál a kevesebb 
figyelmet kapott téma feltárása jelentősen előrelendíthetné a mai magyar vidéki városi terek több társadalmi problémájának megoldását.

A disszertáció hét nagy fejezetből áll. Az első, bevezető fejezetben mutatom be a dolgozat kiinduló problémáját, a témaválasztás indokait és a kutatás céljait. A második rész az empirikus kutatás mintaterületeinek kiválasztását írja le, majd feltárom a terepbejárás során alkalmazott metodikákat. A kutatási kérdések megválaszolásához megvalósításához szakirodalmi elemzéseket, statisztikai, illetve empirikus kvalitatív és kvantitatív településföldrajzi kutatási módszereket, azaz kérdőívezést, terepbejárást és telekosztályozást, valamint interjúk készítését használtam. A kérdőíves felmérés mintaválasztási logikája után annak módszertanát és a feldolgozás menetét írom le. Végül a fejezet végén az interjú alanyok kiválasztása és a felmérés technikáinak elemzése után az alkalmazott széles körü informatikai eszközökre is kitérek.

A munka harmadik egységében a külterületek fogalmát, településföldrajzi értelmezéseit és tipizálási lehetőségeit mutatom be. A külterületek eltérő típusait a kutatás megalapozásához definiálni kellett, ezért a külterület-kutatás elméleti, jogi és történeti hátterét feldolgozva A szakirodalmi előzmények szintézisével létrehozott külterület-tipizálásomat a fejezet második felében tárgyalom. E fejezetben az egyes külterületi típusok történetét, társadalmitelepülésföldrajzi jellemzőit, illetve azokat a külterületek genetikájából fakadó feltételeket, amelyek meghatározzák a rendszerváltozás utáni átalakulási folyamatok menetét tárom fel.

A negyedik fejezet a lakóhelyi szuburbanizáció elméleti hátterét, föbb összefüggéseit feltárja fel a hazai és nemzetközi szakirodalom áttekintésével. Az első részfejezetben a szuburbanizáció értelmezésének sokszínüségéből fakadó ellentmondásokat kívánom feloldani, majd a szuburbanizáció szakaszait elemzem. Ezután három alfejezetben taglalom a folyamat területi különbségeit, a poszt-szocialista államok és hazánk sajátosságait, végül a szuburbán fejlödés során végbemenő változások társadalmi-gazdasági és környezeti hatásait mutatom be. E fejezet célja bemutatni a szuburbanizáció sokszínü megjelenési formáit, egyenlőtlen hatásai a társadalmi csoportokra. ezáltal bemutatom a kutatás során várhatóan feltárásra kerülő részfolyamatokat.

Az ötödik fejezet mutatja be a statisztikai és empirikus kutatás eredményeire alapozva a külterületi szuburbanizáció jellemzőit a vizsgált mintaterületeken. E fejezet hét alfejezetre osztható, az első az 1989 után kialakuló szuburbanizáció előzményeit ismerteti. Azután a következő szakasz a demográfiai változásokat, a lakhelyváltás motivációit és a közösségek összetételét elemzi, majd az 5.3. alfejezet az infrastrukturális változásokat összegzi azok következményeivel párhuzamosan. A következő szakasz a folyamat komplex társadalmi hatásait és a szuburbanizáció veszteseinek körét mutatja be, külön figyelmet fordítva a szegregáció jelenségére. Az 5.6. alfejezet esettanulmányok segítségével feltárja az egyes külterület-típusok különbségeit, a szuburbanizáció mikroszintü megjelenési formáit, valamint az ebből fakadó társadalmi hatásokat.

A hatodik fejezetben a győri agglomeráció példáján keresztül összehasonlító elemzést végzek a közigazgatásilag önálló települések belterületeire, egyéb belterületeire és a külterületekre irányuló szuburbanizáció főbb jellemzőiröl. E fejezetben elemzem a közigazgatási változások hatásait az egyes külterületekre és azok társadalmára, valamint azt, hogy egyéb belterületté átsorolás miként hat e lakott helyek folyamataira. A hetedik fejezetben bemutatom a kutatás eredményei és a szakirodalmi előzmények alapján készült sematikus térszerkezeti modellt, mely szemlélteti, hogy a hazai közép- és nagyvárosi térségek fejlödési folyamataiban milyen szerepe van a külterületi szuburbanizációnak, a kialakuló mozaikos, települési szint alatt differenciálódó térszerkezetnek.

A nyolcadik, összegző fejezet egybeveti a disszertáció kérdéseit a kutatás eredményeivel, ennek során a fejezetekben bemutatott részfolyamatok trendjeinek, valamint azok társadalmi hatásainak összegzésével megválaszolja a kutatási kérdéseket, továbbá a fejezet végén megfogalmazza a dolgozat tudományos eredményeinek újszerüségét. A dolgozat végén kap helyet a felhasznált irodalom, az ábrák és táblázatok jegyzéke. 


\section{Problémafelvetés}

\subsection{A kutatás kiinduló problémája}

Bár a szuburbanizáció kiemelt figyelmet kapott a hazai szakirodalomban is, bizonyos részelemei mégis kevésbé kerültek a szakmai diskurzus középpontjába. A folyamat csökkenő népességszám mellett, 1990 után felgyorsulva rövid idö alatt teljesedett ki (BAJMÓcY P. et al. 2012, SzIRMAI V. 2011a). Hazánkban a kutatások leginkább a városból kiszorulók, a város felé igyekvő vidékiek és a második otthonok jelentőségét emelik ki a szuburbiák népesedési folyamatainak sajátosságaként (BRADE, I. et. al. 2009, DövÉNYI Z. - KovÁCs Z. 1999, IZSÁK É. 2003). A kevésbé felkapott elővárosi települések a szegény, kevésbé tehetős rétegek migrációs célpontjai lesznek. A belvárosok megújulása és a munkahelyek centralizálódása révén pedig a reurbanizációs tendenciákkal is zajlanak párhuzamosan (KovÁcs Z. 1999, TIMÁR J. 1999, VÁRADI M. M. 1999).

A nagyvárosok környezetében a korábbi mezőgazdasági jelleggel rendelkező falvakban és kisvárosokban jelentős társadalmi és területhasználati változások indultak meg. Az érintett települések alvótelepüléssé alakulása, népességnövekedése és társadalmi átrétegződése különösen az ezredfordulótól gyorsult fel a vidéki városok környezetében (BAJMÓcY P. 2001a, CSANÁDI G. CsIZMADY A. 2002, TózSA I. 2002). Megváltozott a települések közötti munkamegosztás, kapcsolati és viszonyrendszer (BAJMÓCY P. 2006, SCHUCHMANN J. 2010, SZIRMAI V. et. al. 2011, TIMÁR J. 1993). Az agglomeráció településein fejlődésnek indult a szolgáltató szektor és a gazdasági szuburbanizáció is megjelent, miközben a magvárosok és a községek közötti kapcsolatok az ingázás és a népesség migrációja révén megerősödtek (BAJMÓCY P. 2004, BROWN, L. D. - SchaffT, K. A. 2002, CSATÁRi B. 2002, EdeléNyi B. 2002, VÁradi M. M. 1999).

A hazai szakirodalom nagyobbik része a föváros körül kialakult agglomerációs öv folyamatait vizsgálja. Vidéki nagyvárosaink körüli szuburbanizáció az ezredfordulótól egyre nagyobb figyelmet kapott különösen, mivel a folyamat meghatározó elem az ország térszerkezeti átalakulásában, belső migrációs folyamataiban (EDELÉNYI B. 2002, GÁBOR P. 2001, HARDI T. 2010, HARDi T. 2012, JANKó F. 2004, KÓKAI S. 2011, PRISNYÁK E. - KÓKAI S. 2012).

A szuburbanizáció értelmezésében a hazai szakirodalomban, mint lépték uralkodó a közigazgatási határok szerinti települések közötti migráció, továbbá a KSH adatgyüjtési rutinja is e szintet tekinti alapvetőnek, teljes körü adatbázis is erre érhető el (BAJMÓCY P. - MAKRA Zs. 2016, CsATÁRI B. et. al. 2013, PóCSI G. 2009a). E megközelítés azonban sok esetben túlzottan leszükítőnek bizonyulhat a vidéki folyamatok vizsgálatában. Számos országban a közigazgatási határok nem az egyes lakóhelyek téregységeit jelentik, ahol a közigazgatás községszinten, vagy LAU1 léptéken (illetve ezek helyi megfelelőin) szerveződik (Lengyelország, Szerbia), ott a városok peremén fekvő településgyürü nem önálló. Számtalan országban a lakott helyek és a közigazgatásilag önálló települések kategóriái elválnak (USA), mivel a település-összevonások, politikai döntések, vagy hagyományok alapján meghúzott határok nem képezik le a személyek egyéni térhasználatát, mozgáspályáit, ide értve a megye és járáshatárokat is. Így az urbánus központok körül kialakuló fragmentált térszerkezetü város-vidék peremzóna alakul ki, ami a közigazgatási határokon átnyúlik, a települési szint alatt is differenciálódik (PACIONE, M. 2013, Pryor, R. J. 1968, Sharp J. S. - Clark J. K. 2008, TimÁR J. 1993, TimÁR J. - BAUKÓ T. 1999, WEAVER, D. B. - LAWTON, L. J. 2001, VASÁRUS G. 2015,[1]).

Azért is leszükítő az ilyen megközelítés, mert a tér szubjektív érzékelését és leképeződését a társadalmi folyamatokban az egyének saját elvárásaik és elképzeléseik alapján teremtik meg azáltal, ahogy a teret használják, és ahogy az megjelenik a társadalmi diskurzusban. Így az egyének lakhelyválasztásában az életminőséggel, környezettel, az egyéni életstílussal összefüggő racionális és szubjektív szempontok jelentősége várhatón magasabb az adminisztratív-statisztikai határok szerepénél (BOROS L. 2010, CsuRGÓ B. 2013, NAGY G. - TíMÁR J. 2010, TIMÁR J. 2006). 
A közigazgatási határok szerinti települések dominanciája miatt a hazai szakirodalomban nem terjedt el a külterület használata földrajzi fogalomként. Jelentősebb figyelmet a tanyakérdés kapott, ugyanakkor további sajátos hazai települési formákat alkotnak a szőlöhegyek, zártkertek, majorok és az egyéb típusok. Azonban e témakör relevanciája az elmúlt években megnőtt a hazai kutatásokban (BECSEI J. 2015a, BECSEI J. 2015b, CSATÁRI B. - FARKAS J. 2012, PÓCSI G. 2009a, PÓCSI G. 2009b, PÓCSI G. 2011, TÍMÁR J. - BAUKÓ T. 1999).

A külterületek vizsgálatát azok társadalmi, településszerkezeti és fejlődéstörténeti sajátosságai mellett az is indokolja, hogy a 2011-es népszámláláskor 9272 külterületen 306514 lakos élt. Kiemelendő, hogy a vidéki szuburbiák népességnövekedésének 55,1\%-a nem közigazgatásilag önálló településre irányult (1. ábra), 29\%-a irányult 1990 és 2011 között külterületekre és 26,1\%-a egyéb belterületekre, ezért szerepük magas (I. melléklet, 1. ábra) a térfolyamatokban (BAJMÓCY P. 2014, BAJMÓCY P. et. al. 2018, BALOGH A. 2012a, BALOGH 2012b).

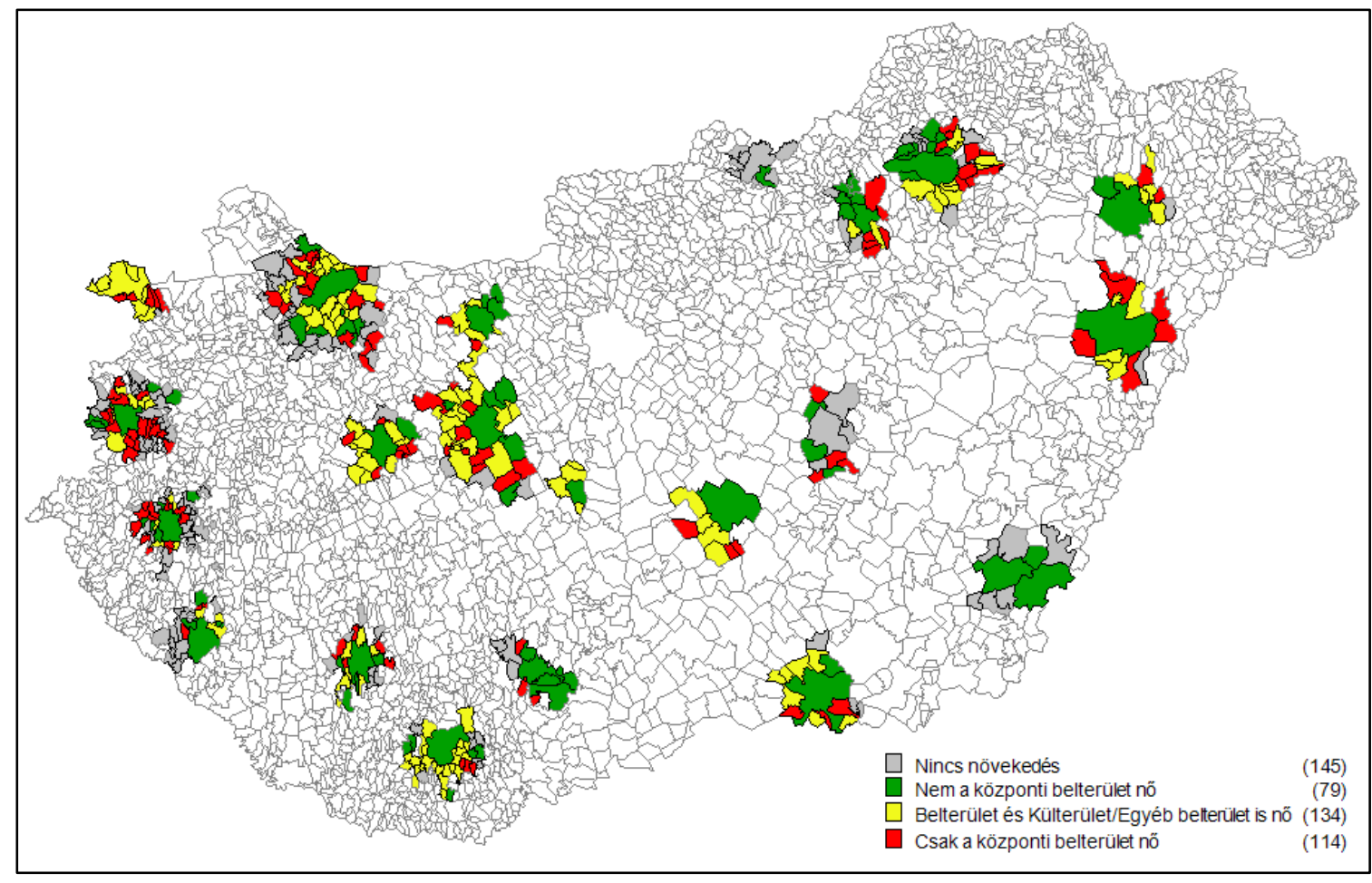

1. ábra: a külterületek és egyéb belterületek jelentősége a KSH által lehatárolt hazai vidéki agglomerációkban és településegyüttesek népességnövekedésében 1990 és 2011 között (KSH Helységnévtár alapján saját számítás).

A folyamat jelentősége a területtípusok dinamikáján keresztül mutatható be. Hazánk Budapesten kívüli agglomerációinak és településegyütteseinek népessége 2001 után kis mértékben csökkent a vándorlási egyenleg és a természetes népszaporulat révén. A városok központi belterületei szintén folyamatosan csökkentek, míg az agglomerációs települések növekedtek. Azonban, ha a vizsgálatot települési szint alatt folytatjuk azt kapjuk sokkal összetettebb képet kapunk. Ha csak az agglomerációk növekvő népességü településrészeit vizsgáljuk akkor a népességnövekmény 24,9\%-a egyéb belterületeken és 31,9\%-a külterületeken realizálódott, miközben a népességnek csak 5,2 és 4,0\%-a él kül- vagy egyéb belterületen (2. ábra).

Ez alapján arra hipotézisre jutottam, hogy a hazai szuburbanizáció fejlődésében a külterületek szerepe nagy, a közigazgatásilag önálló településekre irányuló migrációt kiegészíti, azonban a statisztikai sajátosságok miatt részben rejtve maradt máig.

A külterületek azonban nem alkotnak egységes kategóriát. Jelentős különbségek mutatkoznak a szórványok (tanyák, őrházak), a csoportos lakóhelyek (majorok, szőlőhegyek, zártkertek) között. Az eltérő lakott külterületek nagymértékben differens ingatlanállománnyal, infrastrukturális 
ellátottsággal és településképpel rendelkeznek. Ebből fakadóan a demográfiai jellemzőik és a különböző társadalmi csoportokat vonzó adottságaik is heterogének. E típusok térben is differenciáltan jelennek meg az országban, míg a tanyák az alföldön dominálnak, addig a Dunántúlon nagy a szőlőhegyek és majorok jelentősége, továbbá ki kell emelni, a szocialista érában a városok peremén nagy számban kialakított, sakktáblás szerkezetü üdülőket és zártkerteket (BAJMÓCY P. - MAKRA Zs. 2016, CSATÁRI B. et. al. 2016, PÓCSI G. 2009a).

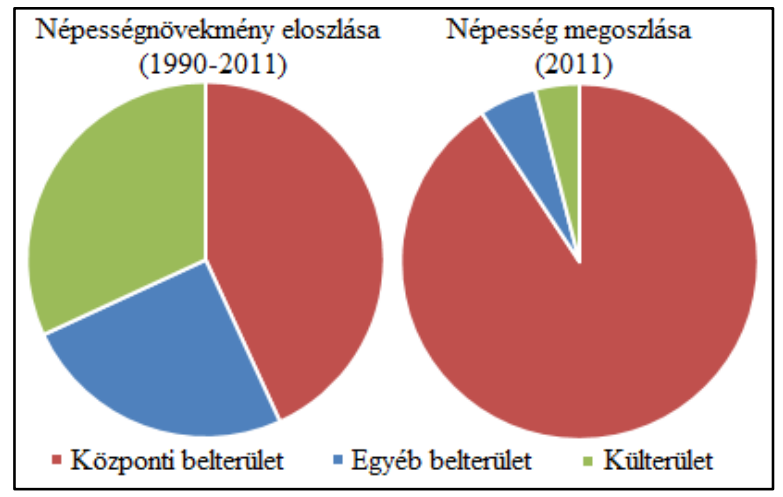

2. ábra: A külterületek és egyéb belterületek szerepe a vidéki agglomerációk népességében és annak növekedésében (KSH Helyiségnévtár alapján saját számítás).

Második hipotézisem szerint a különböző területeken, az eltérő adottságú külterületek jelenléte miatt a lakossági szuburbanizáció is eltérően, a helyi településföldrajzi adottságokhoz adaptálódva zajlik.

A vidéki agglomerációink fejlödésében sajátos részfolyamat a településen belüli szuburbanizáció, mely során az egyén úgy vált rurálisabb lakóhelyre, hogy a település közigazgatásai határait nem lépi át (BAJMÓCY P. 2003b, BAJMÓCY P. - MAKRA Zs. 2016, HARDI T. 2002, PÓCSI G. 2009a). Bár paradoxonnak tünhet településhatáron belüli szuburbanizációról beszélni, számos érv áll a fogalom használata mellett.

A nagyvárosi terek átalakulását a térszerkezeti adottságok jelentősen befolyásolják. A városokhoz csatolt falvak és lakott külterületek az urbánus térben rurális zárványként jelentkeznek a szuburbanizációs folyamatban. A városokhoz csatolt egykor önálló falvak - a mai egyéb belterületek -, továbbra is örzik rurális jellegüket. A városhatáron belüli szuburbanizáció keretében ezek az egykor önálló községek mutatták a legjelentösebb növekedést, és átlagos növekményük sem marad el a közigazgatásilag önálló nagyváros környéki falvaktól. A külterületek szintén olyan rurális lakóhelyeket alkotnak a városok peremén, amelyek a szuburbán költözők számára vonzók lehetnek, hiszen a kertvárosias életmódot a városokhoz közel is realizálni tudják, gyakran sokkal kisebb ingatlanárak mellett. Így a város adminisztratív határain belül is megjelennek a szuburbán övre jellemző településföldrajzi formák és társadalmi folyamatok. Ugyanakkor e nem önálló településekröl és lakott helyekröl csak kevés adattal rendelkezünk, és részben emiatt nincs kiforrott módszertan a külterületeken zajló folyamatok önkormányzati kezelésére (BAJMÓCY P. 2003a, BALOGH A. 2012a, CSATÁRI B. et. al. 2013, TIMÁR J. 1993, SZIRMAI 2011).

A szuburbiák kontrollálatlan fejlődése a nemzetközi és hazai tapasztalatok számos negatív környezeti, társadalmi és gazdasági következménnyel járhat. Mivel a hazai városperemek átalakulása jelentős részben a külterületi és egyéb belterületi jelleg révén és a hiányos törvényi háttér miatt spontán módon zajlott a kialakuló ellentétek erösebbek e területeken (CSATÁRI B. et. al. 2016, Csurgó B. 2013, ÓNODI G. - CROs KÁRPÁTi Zs. 2002, PóCSI G. 2009a, Pócsi G. 2009b, PóCsi G. 2011). A mezőgazdasági területek, erdők és zöld területek, és általában a hagyományos rurális területhasználat visszaszorul, a városi területhasználat behatol a környező térségekbe. Mivel a peremzónák egyik fó vonzereje a táji szépség a természetes felületek és a tájképi elemek degradációja, fragmentálódása gyakori konfliktusforrás. (ANTROP, M. 2004, NIKODEMUS, O. et. al. 
2005, Sharp, J. S. - Clark, J. K. 2007, Theobald, D. M. 2005). Ugyanakkor a megmaradó zöldfelület tartalmilag kiürül, egy idealizált vidék képéhez igazodó lakóhely-imázs díszletévé silányul (CSURGÓ B. 2013, WEAVER, D. B. - LAWTON, L. J. 2001).

A külterületek már a rendszerváltás elött is rendkívül változatosak voltak földrajzi adottságaik, méretük és történelmi fejlődésük miatt a sokszínü társadalmi és területhasználati átalakulások még tovább növelték a divergenciát (BAJMÓCY P. - MAKRA ZS. 2016, BALOGH A. 2012a). Jellemző, hogy a városok leginkább alacsony keresetü lakosai az agglomerációk rosszul elérhető, de emiatt olcsó területeire szorulnak a belső szuburbán öv ingatlanárainak és a városi megélhetési költségek növekedése miatt. A nők helyzete különleges figyelmet érdemel e területeken, mivel a háztartások vezetése jelentős áldozatvállalást követel meg részükröl (GRANT, J. L. et. al. 2014, HIRT, S. A. 2008, VÁRADI M. M. 1999). A „Keno kapitalizmus” jelenség hatására a különböző funkciók, az eltérő identitások térbeli elhelyezkedése tervezetlen, véletlenszerü lesz, térben össze nem férö funkciók (nyugdíjasotthon-szórakozóhely, családiházak-üzemek) egymás közvetlen szomszédságában jelennek meg, állandó alkalmazkodási kényszerben tartva a populációt. Markáns jelenség az anyagi helyzet alapján történő szegregáció, a jelentős elkülönülés zárt csoportok kialakulásához vezet melyek között erős ellentétek feszülnek (BOROS L. 2010, DUNAY, A. et. al. 2001, IzSÁK É. 2003, SzIRMAI V. 2011b, THEOBALD, D. M. 2005, TózSA I. 2002).

Harmadik hipotézisem, a fentiek alapján, hogy a falvaknál eleve rosszabb infrastruktúrájú lakott külterületekre irányuló szuburbanizáció a tervezetlen, szabályozatlan jellege miatt számos konfliktussal jár, negatívan hat a helyi közösségekre.

Mindezek alapján kérdésként merül fel, hogy e folyamatok - különösen a 2007 utáni válság hatásait figyelembe véve - eredményeképpen milyen társadalmi ellentmondások, konfliktusok alakultak ki, milyen következményei voltak a külterületek átalakulásának a települési életminőségre, ez hogyan befolyásolta a városi térségek fejlődését (TIMÁR J. 2001A, VÁRADI M. M. 1999, KOVÁCS K. - VÁRADI M. M. 2003).

\subsection{A disszertáció kérdései és céljai}

Disszertációmban e problémakörön belül arra vállalkozom, hogy a hazai vidéki nagy- és középvárosi térségekben megvizsgáljam a lakossági szuburbanizáció külterületeken zajló részfolyamatait, annak változásait, néhány fontos meghatározó tényezőjét és ezek összefüggéseit a tágabb agglomeráció térszerkezeti folyamataival. A kutatás megvalósítása szempontjából a kitüzött célok, a föbb kutatási kérdések és hipotézisek, valamint a konkrét elemzési módszerek körének meghatározása szükséges, ezek megszabják az elemzés föbb irányvonalát és feltételrendszerét.

Az értekezés négy átfogó kérdésre keresi a választ, melyeket további al kérdések egészítenek ki. Az egyes kérdésekhez kapcsolódnak a konkrét kutatási célok. Dolgozatom fő kérdése, hogy:

1. A külterületekre irányuló lakossági szuburbanizáció miben különbözik motivációit tekintve a településekre irányuló általános kiköltözésektől?

1/I. A lakott külterületeken milyen társadalmi és területfelhasználási változások zajlanak a szuburbanizációs folyamat során?

E kérdés megválaszolásához célom a vonatkozó nemzetközi és hazai szakirodalom alapján feltárni a lakóhelyi szuburbanizáció társadalmi-területfelhasználási összefüggéseit, különös tekintettel a kelet-közép- európai és hazai lakóhelyi szuburbanizációs folyamatok különbségeit és hasonlóságait, meghatározó okokra. Majd ezt kívánom összevetni a külterület-állomány statisztikai adatbázisával, a lakosság demográfiai mutatóival.

2. A lakott külterületek hogyan tipizálhatóak, az eltérö típusai között van-e kimutatható különbség, a szuburbanizációs folyamat jellegét illetően?

2/I. A különbözö külterületek milyen szempontok alapján vonzották a különbözö társadalmi csoportokat? 
2/II. Ennek következtében milyen sajátos társadalmi rétegzödés alakult ki és milyen sajátosságokat mutatnak a demográfiai változások?

E kérdéskört empirikus kutatási módszerek társadalomstatisztikai elemzésével kívánom feltárni, melyben kiemelt szerepet kapnak a költözési szándékokat befolyásoló társadalmi, gazdasági, életmódbeli okok, valamint az egyes lakóhelyek életminőséget meghatározó településföldrajzi adottságok.

3. A szuburbanizációs folyamatok hogyan hatottak a közösségek összetételére, a társadalmi kapcsolatok rendszerére?

3/I. A kialakuló konfliktusok milyen módon hatottak az életminöségre, milyen kritikák fogalmazhatók meg az átalakulás társadalmi-gazdasági hatásait illetően?

3/II. A helyi infrastruktúra helyzete, a tájkép és a mezögazdaság fennmaradása mennyire biztositott? A dinamikus átalakulásból fakadó károsodásai, vagy örökölt hiányos jellege milyen hatással van a lokális társadalomra?

Kérdöíves felmérésem kvalitatív elemzésével fel kívánom tárni, hogy a kialakult konfliktusok és hatások közül mely tényezők szerepe a legfontosabb a közösségek funkcionalitása és a lakóhely népességmegtartó képessége szempontjából. Továbbá terepbejárás és telekosztályozás segítségével kívánom meghatározni azon leginkább jelentős változásokat, amelyek rontották a lakott külterületek természeti és épített környezeti adottságait.

4. Milyen módon hat a külterületekre irányuló szuburbanizáció a városi térségek térszerkezetére, van-e különbség a belterületekre és az egyéb belterületekre irányuló migrációban?

Célom e kérdéskör megválaszolásán keresztül egy agglomerációban bemutatni a különböző besorolású területek eltéréseit, valamint fel kívánok vázolni egy olyan sematikus térszerkezeti modellt, amely alapján bemutatható a város-vidék peremzóna sajátos fragmentálódása a hazai közép- és nagyvárosi térségekben. Továbbá célom vizsgálni, hogy az egyéb belterületté átsorolás után milyen módon változik e területek fejlődése, hogy milyen a külterületektől eltérő átalakulási folyamatokat indulnak meg? 


\section{AlKalmazott MóDSZertan}

\subsection{A mintaterületek kiválasztása}

A hazai külterületekkel foglalkozó szakirodalom megismerése során megismert kutatási előzmények alapján a disszertáció kérdéseinek megválaszolása csak összetett, többlépcsős módszertan alapján lehetséges, melyben figyelembe kell venni a külterületek változatos jellegét. Ennek érdekében a kutatási kérdéseket meghatározott különböző primer és szekunder módszerekkel vizsgáltam, empirikus felmérésemben kvalitatív és kvantitatív lépéseket egyaránt alkalmaztam. Az alkalmazott módszereket, a mintaterület-kiválasztás metodikájának ismertetése után mutatom be.

Külterületek esetében a mintaterületek kiválasztása során nagy jelentőségü, hogy mely bázisév külterület-állományát tekintjük mérvadónak, hiszen a településállomány rendkívül dinamikusan változó eleméről van szó (BALOGH A. 2012, PóCSI G. 2009a VALLER É. 1996). A hazai szakirodalomban - bár nincs teljes konszenzus a szerzők között - megközelítőleg 1998 és 2007 közötti időszakra teszik a hazai szuburbanizáció kiteljesedését és legdinamikusabb időszakát (BAJMÓCY P. 2014, BAJMÓCY P. et. al. 2012). Ennek megfelelően kutatásom során a 2001. évi népszámlálás időpontjában lakott külterületnek számító, a KSH Helységnévtárában szereplő egységeket tekintettem külterületnek. Így a vizsgálatba külterületként bekerültek olyan területi egységek, amelyek a szuburbanizáció „csúcsán” lakott külterületek voltak, mára azonban lakatlanná váltak, vagy fejlődésük révén egyéb belterületi státuszba kerültek, ez egyben lehetővé teszi a szuburbiákban található külterületek fejlödésével, illetve hanyatlásával járó folyamatok vizsgálatát.

A kutatás kérdéseinek megfelelően mintaterületeim kiválasztásakor arra törekedtem, hogy olyan területek kerüljenek a mintába, amellyel a hazai külterületek típusainak lehető legszélesebb körét reprezentálják, olyan településeken, melyek részesei a hazai vidéki szuburbanizációnak. Ennek érdekében a vizsgált településegyütteseket a következő szempontok alapján választottam ki.

Olyan területek kerülhettek a kutatásba, melyek vonzáskörzetében a szuburbanizáció statisztikailag kimutathatóan jelen van, mértéke 2001 és 2011 között dinamikus átalakulásokat feltételez a településstruktúrában. E módon a hazai középvárosi települések túlnyomó többsége és a kevésbé dinamikus megyeszékhelyek kizárásra kerültek a lehetséges lokációk sorából, így Veszprém, Szekszárd és Szolnok is. Mint azt majd a 3. fejezetben bemutatom, bizonyos külterület-típusok kizárólagosan, vagy jellemzően az ország különböző területein fordulnak elő. A statisztikai adatok, valamint a szakirodalom (BALOGH A. 2012, BALOGH A. - BAJMÓCY P. 2011, BALOGH A. - CsAPÓ T. 2013) áttekintése után egyértelmüvé vált, hogy egy alföldi (tanyák, kertségek) mellett legalább egy dunántúli vagy észak-magyarországi (szőlőhegyek, majorok) településegyüttesnek szerepelnie kell a mintában, hogy a tájak szerint domináns formák megfelelően reprezentálva legyenek az empirikus vizsgálatban.

Mivel a 10 fö alatti külterületek (örházak, kis népességü majorok) esetében a népességnövekmény 1-2 fös változás esetén is rendkívül magas lenne ezrelékben kifejezve, valamint a kérdőíves vizsgálat eredményessége is kérdéses - ezt később a Győrben végzett próbakérdőívezés során tapasztalt alacsony válaszadási hajlandóság alátámasztotta - a kevés megkérdezhető lakos miatt, a vizsgálat torzulásának megelözése érdekében a 10 fő alatti külterületeket ennél a lépésnél nem vettem figyelembe.

A külterületek darabszáma mellett kritérium volt, hogy az átalakulásban a külterületek népességnövekménye értékelhető hányadot képezzen, tehát a külterületek megfelelően érintettek legyenek az átalakulásban, és lakosságszámuk elegendő legyen, hogy megfelelö elemszámot biztosíthassak az empirikus kutatáshoz. Így a csak kevés növekvő külterülettel rendelkező Eger, Sopron és Székesfehérvár nem bizonyult alkalmasnak. A különböző típusú lakott külterületek összehasonlítása érdekében a túlzottan homogén külterület-állománnyal rendelkező városokat 
szürtem ki (Tatabánya, Pécs), mivel ezek nem lettek volna alkalmasak a vizsgálati kérdések érdemi megválaszolására. Miskolc esetében szintén korlátozta volna az összevethetőséget az ország többi településével a sajátos külterületi formák és a cigányság kiemelkedően magas aránya.

Az eddig felvázolt feltételeknek a Dunántúlon három város és azok vonzáskörzete felelt meg, a kevésbé dinamikus Kaposvár helyett azonban Győr mellett Zalaegerszeg került a mintába, mivel ezek a városok és a közvetlen vonzáskörzetükben található települések nagyszámú, változatos méretü és adottságú és különböző típusokba tartozó lakott külterülettel rendelkeztek.

A fentiek alapján olyan alföldi várost kellett keresnem, amely esetében nem csak a külterületi népesség és a szuburbán öv településeinek lélekszáma hasonló léptékü, de a külterületekre áramlás mértéke is összevethető e két várossal. Mivel Debrecen és Kecskemét tanyavilágának mérete nagyságrendileg több, mint a vizsgálandó két dunántúli város külterületeinek összessége ezért, összehasonlíthatóságuk megkérdőjelezhető lenne. Ezért a már kiválasztott két településegyütteshez hasonló külterületi lélekszámú Szeged és Hódmezővásárhely központú településegyüttesek vizsgálata mellett döntöttem mivel a tanyák mellett egyéb típusok (majorok, üdülők, zártkertek, periurbán egységek) is jelen vannak területükön (I. melléklet, 2. ábra).

A két regionális központ, Győr és Szeged a hazai településföldrajzi szakirodalomban kiemelt helyet kapott az elmúlt évtizedekben, továbbá a külterületekből létrehozott egyéb belterületek és a változatos külterületi típusok megléte is indokolta kiválasztásukat. Győrhöz a hetvenes évek során több szomszédos, dinamikusan fejlődő községet csatoltak, ezek közül három ma jelentős népességü egyéb belterületet alkot. Maga a város, a városba korábban becsatolt falvak és az agglomeráció községei egyaránt számos külterülettel bírnak, ezek közül meghatározóak a majorok, szőlőhegyek, zártkertek és üdülők. Az agglomeráció délkeleti harmadában és a Pannonhalmi dombság területén jellemzőek a szőlőhegyek és a síkvidéki részeken a majorok, a többi külterület típus a térben elszórva jelenik meg, a változatos méretü, jellemzően 2 és 4 ezer fö közötti szuburbán falvakban, melyek közül sok bír mára egyéb belterületi státuszba emelt külterülettel. (CSAPÓ T. 2007, CSAPÓ T. - KOZMA K. - LENNER T. 2015, HARDI T. 2002, HARDI T. - NÁRAi M. 2005, HARDi T. 2012, VASÁRUS G. - MAKRA Zs. 2015.VASÁRUS G. et. al. 2018).

Szeged kiválasztását alátámasztja, hogy alföldi településként a nagyszámú tanyán kívül a város közvetlen vonzáskörzetében zártkertek, üdülök és periurbán utcák is találhatóak és számos korábbi kertes külterület ma már egyéb belterület, amely lehetővé teszi a fejlődési pályák követését. A településegyüttes falvainak többsége szintén tanyás-zártkertes külterület-állománnyal bír, melyet azonban jelentősen differenciálnak a különböző közlekedési lehetőségek ezáltal széles körü tapasztalatokkal szolgálhat vizsgálatom során e mintaterület (BAJMÓCY P. 2000a, BAJMÓCY P. et. al. 2012, Boros L. 2012, MÉSZÁRos R. 2004, NAGY E. et. al. 2003, TímÁr J. - VÁRAdi M. M. 2000, ZSÓTÉR B. - NAGY A. 2013).

Közepes méretü megyei jogú városaink kisebb figyelmet kaptak az elmúlt évtizedek hazai szuburbanizációs szakirodalmában, mint a regionális központok (BELUSZKY P. 2005, GYENIZSE P. et. al. 2016, HEGEDÜs G. 2012). Zalaegerszeg és Hódmezővásárhely vizsgálatától e szempontból új tudományos eredmények várhatóak, különösen mivel külterületi népességük jelentősen növekedett az elmúlt évtizedekben, így feltételezhető volt a városhatáron belüli szuburbanizáció jelenléte (BAJMÓCY P. 2003A, HARDI T. 2002, TIMÁR J. 1993).

Zalaegerszeghez az évtizedek során számos szőlőhegyet és korábban önálló falut csatoltak, emellett területén számos major és szölöhegy is található, egy részük pedig már egyéb belterületté lett átsorolva. Hódmezővásárhely tanyás város, melynek tanyavilágában a táblásításkor számos tanyaközpontot hoztak létre, ahová be kívánták telepíteni a szórványtanyák lakosságát. Ezek jelenleg zártkertesedő külterületek, vagy fejlődésükben megrekedt egyéb belterületek. A város tanyái több eltérő adottságú körzetre vannak beosztva, azonban a tanyaállomány általánosan elöregedett és csökkenő a főutaktól távolodva.

A négy településegyüttes meghatározása után következett az empirikus felmérés elvégzéséhez a felmérendő települések és külterületek pontos lehatárolása statisztikai úton. Mivel e dolgozatnak nem célja a hazai szuburbanizáció térbeliségének meghatározása, ezért nem kívántam 
meghatározni az egyes városok szuburbán gyürüinek kiterjedését. A négy centrum vonzáskörzeteiben az egyes települések vizsgálatba vonását így azok külterületeinek elemzése alapján határoztam meg községenként. Ebben minden, a KSH által [6] az adott városok agglomerációiba és település-együtteseibe sorolt települést figyelembe vettem, valamint az összes olyan községet, amelyet a hivatal ugyan nem sorolt be ezekbe, de közvetlenül érintkezik a megyei jogú városokkal, hiszen lehetséges, hogy egy nem szuburbán község külterületét érintse a kiköltözési folyamat (I. melléklet, 3-5. ábra).

A fenti megfontolások alapján azok a települések kerültek a vizsgálatba, melyeknek van legalább egy 10 főnél népesebb, növekvő lakosságú lakott külterülete (II. melléklet). Továbbá azon községek, amelyek lakott külterületei ugyan vesztettek népességükböl, de a település egésze népességnövekményt mutatott. Az empirikus vizsgálat kivitelezhetősége érdekében a 10 fö alatti népességü és 2011-ben lakatlan külterületeket - a korábban vázolt okok miatt - nem vettem figyelembe ennél a lépésnél sem, azonban a kutatásba bekerült települések területén lévő 10 fő alatti külterületen is megkíséreltük az empirikus mintavétel elvégzését. Így összesen 36 darab település 157 külterülete került a kutatás mintavételezési tervébe (1. táblázat).

A szuburbanizációs és külterületi fejlődési tendenciák általános vizsgálatát alapvető társadalomstatisztikai módszerekkel végeztem Microsoft Excel, valamint az IBM SPSS programok segítségével. A külterületek vizsgálatát Bajmócy Péter gyüjtése alapján készült - a mindenkori Helységnévtárak adatsoraiból összeállított - adatbázis, a települések értékelését a KSH, VÁTI TeIR-ben elérhető településsoros 1990, 2001 és 2011 évi népszámlálási adatok felhasználásával hajtottam végre. Az empirikus felmérés eredményeit szintén e programok segítségével elemeztem ki. Az eredmények ábrázoláshoz térinformatikai (Mapinfo) és grafikai (Adobe Photoshop CS, Blender 3D, GIMP) szoftvereket használtam fel.

\subsection{Empirikus felmérés}

\subsubsection{Terepbejárás és ingatlankataszter készités}

A hazai szuburbiák és város-vidék peremzónák vizsgálatával foglalkozó kutatások alapján e területeken jelentősen átalakul a területhasználat és heterogén, fragmentált tájkép, valamint komplex társadalmi viszonyrendszer alakul ki, amelyet összetett, primer és szekunder (kvalitatív és kvantitatív) módszereket is alkalmazó kutatásokkal lehet feltárni (BRYANT, C. R. 1995, CsanÁdy G. - Csizmady A. 2002, Csurgó B. 2013, Nikodemus, O. et. al. 2005, Pócsi G. 2011, PRYOR, R. J. 1968 , TIMÁR J. - BAUKÓ T. 1999).

Az empirikus felmérés a különböző kérdések megválaszolása érdekében három fő elemből állt. A városrendezési terv és a fejlesztési dokumentumok megismerését követően végezte részletes terepbejárás során ingatlankatasztert készítettem, ez a későbbi kérdőíves felmérés előzménye volt. A lakosok tapasztalatainak és véleményének feltárása során kívántam meghatározni a szuburbanizációs folyamat meglétét, pozitív és negatív hatásait a helyi közösségre, egyben ez lehetőséget nyújthat a különböző típusok átalakulása során megmutatkozó eltérések leírására. Végül az önkormányzati és egyéb szervezetek tapasztalatait, rutinját kívántam interjúk során felmérni, mellyel igyekeztem az esetleges ellentmondásokat is feltárni.

1. táblázat: Az empirikus felmérés során felvett minták megoszlása

\begin{tabular}{|l|c|}
\hline Felmért ingatlanok száma & 9290 \\
\hline Külterületi kérdőívek száma & 1112 \\
\hline Egyéb belterületi kérdöívek száma & 598 \\
\hline Győri agglomeráció belterületein felvett kérdőívek száma & 153 \\
\hline Interjúk száma & 23 \\
\hline
\end{tabular}

Forrás: saját szerkesztés. 
A külterületek bejárása során a vizsgálandó jelenségek természetes közegét és olyan tényezöit igyekeztem megismerni, melyek a statisztikai eredmények alapján láthatatlanok maradnának. Ennek megfelelően az egyes lokációk infrastrukturális ellátottságát, közlekedési helyzetét, az ingatlanállomány minőségét, a területhasználati módok megjelenését, valamint a külterület településföldrajzi jellemzőit akartam felmérni. Ennek célja az volt, hogy bepillantást kapjak a térhasználatról, annak alakulásáról, valamint arról, hogy a klasszikus, a 3. fejezetben bemutatandó külterület-típusokra jellemző településszerkezeti formák mennyire maradtak fenn.

A külterületekről készült müholdképekre a terepi bejárás során színes jelzések segítségével minden telkeket, ingatlant és közterületet egyenként osztályoztam három dimenzió mentén.

1. Elöször a telek által betöltött funkciót értékeltem; megkülönböztettem lakóhelyként, hobbikertként, üdülöként, üzemi telephelyként és mezőgazdasági földként használt parcellákat, használaton kívüli telkeket, valamint a sajátos egyéb funkciójú telkeket (templom, strand, erdők és ligetek, romok). Amennyiben nem lehetett megállapítani a telek funkcionalitását egyértelmüen a telken látható objektumok (medence, góré, stb.) alapján próbáltam következtetni a fö funkcióra.

Azokat az ingatlanokat, melyeken a lakó-, üdülő teleki és mezőgazdasági funkción túl egyéb speciális funkció is megjelent, külön jelöltem felmérésemben, ennek alapján megkülönböztettem a szolgáltatásokat nyújtó (bolt, szórakozóhelyek, fodrász, stb.), ipariüzemi telephelyeket, különleges rendeltetésủ építményeket (átemelő szivattyú, vasútállomás) valamint egyéb ingatlanokat.

2. Második lépésként a telkeken található épületeket azok rendeltetése és állaga alapján soroltam be. Ebben az értelemben a lakóházként, gazdasági épületként, kerti melléképületként, valamint különleges ingatlan (templom, kápolna) lettek besorolva az építmények. Amennyiben a fentiektől eltérő ingatlan volt az egyes külterületeken, azt egyedileg kódoltam. Az épületek állagát szubjektív módon tudtam értékelni, azonban egységes kritériumok alapján egymással összevethető kategóriákat dolgoztam ki. Azokon a telkeken, ahol több eltérő állagú épület volt, ott a központi épületet vettem figyelembe, a melléképületeket (ól, istálló, szerszámos bódé) figyelmen kívül hagytam, illetve ahol egyenértékü ingatlanokból volt több (számos lakóépület osztatlan telken), ott külön értékeltem az ingatlanokat.

- Újnak és újszerünek tekintettem a hibátlan állapotú tetővel, nyílászárókkal és újszerü homlokzattal rendelkező, valamint a felújítás alatt álló épületeket.

- Jó állapotúként kerültek besorolásra a kisebb homlokzati hibákkal, alapvetőn hibátlan tetőzetü és jó állapotú nyílászárókkal rendelkező ingatlanok.

- Átlagos állapotú ingatlanok kategóriájába kerültek azok az építmények, melyek esetében a homlokzat megviselt, esetleg piszkos, de a falazat nem látszik ki és nincsenek jelentős repedések a falon, a tetőzet kisebb sérülései ellenére várhatóan nem ázik be (vagy erre utaló jel nem látható), a nyílászárók nem hiányoznak, de állapotuk nem feltétlen kifogástalan.

- Rossz állapotú ingatlanok így értelemszerüen azon házak lettek, melyek tetőzete hiányos, a falon a vakolat nagyobb felületen hiányzik, esetleg a falakon jelentős repedések találhatóak.

- Lakatlannak azokat az épületeket tekintettem, melyek láthatóan elhanyagoltak, vagy állapotukból kifolyólag lakhatásra alkalmatlanok (beszakadt tetőzet, teljesen hiányzó nyílászárók, hiányos falazat).

- Továbbá a nagyobb romokat és félbe maradt épületeket külön jelöltem.

A külterületeken jelenlévő infrastruktúrát a különböző objektumok megléte alapján értékeltem, a terepbejárás során térképen jelöltem az elemeket. A vizsgált objektumok körébe tartozott a közvilágítás, szilárd burkolatú úttest, rendezett állapotú földutak, járda, esö- és belvízelvezetés. A településkép felmérése érdekében értékeltem a közterületek rendezettségét, ápoltságát, szemétlerakás vagy allergén növények (különösen a parlagfü) meglétét, illetve a veszélyes települési elemek (romok, illegális hulladéklerakók, leromlott hidak és átjárók) számát. A külterületek elérhetőségének felmérése érdekében az egyes helyszínekre a településről vagy a 
legközelebbi fóútról bevezető utak állapotát, a lehetséges tömegközlekedési megállók elérhetőségét vizsgáltam. Külön gyüjtöttem azon utakat, melyek időszakosan vagy állandóan járhatatlanok, itt feltételnek - korábbi felmérésem alapján- azt tekintettem, hogy egy mentőautót jelképező átlagos furgon képes lenne-e elhaladni, valamint, hogy gyalogosan járható-e (VASÁRUS G. 2013, VASÁRUS G. 2016a).

Az elkészült térképek adatait excel táblázatban összegeztem, melynek segítségével értékeltem az ingatlanállományt, annak megújulását és funkcionalitását. Ez, valamint a településkép alapján a külterületeket besoroltam a 3 . fejezetben bemutatott tipizálás szerint, az egyes típusokba markánsan beletartozó egységek mellett lehatároltam az átmeneti és jelenleg funkcióváltás alatt lévő területeket. A terepbejárás során valamennyi vizsgálatba vont külterületen és településrészen fotódokumentációt készítettem, mely a dolgozat ábraanyagában fellelhető.

\subsubsection{Kérdöives felmérés}

A külterületi lakosság attitüdjeinek, mindennapi életéből fakadó szubjektív tapasztalatainak és a tér megélésében döntő sajátos elvárásainak, a jövőről való elképzeléseiknek feltárása érdekében elengedhetetlen volt a kérdőíves felmérés alkalmazása. Nem mérhető statisztikai adatokkal a kulturális hagyományok megörzése, az értékrendek-életmódok közötti összeférhetőség, az önkormányzati és lakossági aktivitás, a lakosságon belüli konfliktusok alakulása, a személyes preferenciák alapján az emberek véleménye eltérhet a tényleges helyzettől, ezért ennek felmérése a vizsgált téma jellegéből adódóan fontos (BABBIE, E. 2003, HARDI T. 2002, KovÁcs A. D. 2010, LETENYEI L. 2005, TIMÁR J. 1990).

A kérdőíves felmérés során célom volt meghatározni a helyi lakosság demográfiai összetételét, térhasználatuk főbb jellegzetességeit és szuburbanizációhoz kapcsolódó tapasztalataikat, továbbá a város-vidék peremzónákra jellemző átalakulási folyamatok, konfliktusok jelenlétét, végül a külterületi életvitelből származó vélt és valós elönyöket illetve hátrányokat.

Az empirikus felmérés fö pillérét a 2014. 06. 01. - 2016. 08. 29. között végzett nagy volumenü lakossági kérdőívezés adta. Bár a mintaterületek felét személyesen mértem fel a legnagyobb népességü külterületeket a Szegedi Tudományegyetem Gazdaság- és Társadalomföldrajz Tanszék geográfus szakos hallgatóinak segítségével végeztem. Módszertani szempontból szükséges volt a hallgatók megfelelő felkészítése az egységes végrehajtás érdekében, ami három alkalmas gyakorlati kurzus keretében történt meg. Ennek során a terepbejárás, a lekérdezés és a fotódokumentáció készítésének mikéntje és a fogalmi magyarázatok összehangolásra kerültek

A kivitelezés során a próba-kérdőívezés tapasztalatai alapján az 50 fő feletti népességü területeken lakosságarányosan rétegzett, szisztematikusan minden 5 . háztartást érintő felmérést végeztem. Ennek során igyekeztem biztosítani, hogy a véletlenszerü, kvótával súlyozott mintavétel a lehető legjobban fedje le a helyi közösséget, az így elérhető legkisebb torzítással. Amennyiben a lakó nem válaszolt, a módszertan szerint következő házzal folytattam a felmérést, az üres telkeket és lakatlan házakat azonban nem vettem figyelembe. Minden területegységen törekedtem arra, hogy az összes tömbböl és utcából legalább egy kérdőív le legyen kérdezve az alacsony válaszadási hajlandóság ellenére is.

Azokon a külterületeken, ahol a lakosság száma 50 fó alatt maradt, e módszertan használhatatlan lett volna az ingatlanok alacsony száma miatt. Az ilyen kis lélekszámú majorok, szőlőhegyek, az egyes magányos őrházak és egyéb külterületek esetében az elérhető alanyok megkérdezésére voltam kénytelen hagyatkozni. Ennek tükrében a felvételre került minta a kis elemszám miatt nem alkalmas az egyes külterületek értékelésére, célja az, hogy az eredményekböl felmérhető legyen a külterület-állományra jellemző egyes folyamatok, jelenségek és fejlődési tendenciák iránya, valamint azok intenzitására és elterjedtségére következtethetünk.

A megközelítés célszerüsítése érdekében a különbözö településszerkezeti, demográfiai adottságok és a szuburbanizáció hatásainak felméréséhez a szociálgeográfia módszertanában általánosan használt alapfunkciók alapján hét konfliktusmezőbe soroltam a kérdéseket. E 
funkciók szerinti bontás lehetővé teszi egyben a különböző részfolyamatok és konfliktusok egymásra gyakorolt hatásának bemutatását, ezért a Partsch-féle, azaz a német irányzatnak megfelelö funkció-katalógus BERÉNYI IsTVÁN által megfogalmazott és a magyarországi viszonyokhoz igazított rendszerét, mint logikai vezetővonalat használva állítottam össze a kérdőívet (BERÉNYI I. 1992, BERÉNYI I. 1997). A kérdöív összeállítása során törekedtem arra, hogy a véleményeket ne az „Ön szerint jellemzö-e az, hogy (...)?”, vagy „Tapasztalta-e, hogy (...)?" típusú kérdésekkel mérjem fel. Vagyis nem általam feltételezett tényezők meglétére kérdezzek, hanem a lakosok az általuk fontosnak tartott jellegzetességeket, folyamatokat emelhessék ki nyitott kérdések formájában (JózSA K. 2008, LETENYEI L. 2005).

A kérdőívek (III. melléklet) első harmadában a háztartás lakhatással kapcsolatos adataira kérdeztem rá, itt szerepeltek a külterületi ingatlan használatát, az esetleges költözések motivációit és az épület felszereltségét firtató kérdések. A kérdőív második oldalán szerepeltek a külterületi létből fakadó sajátosságokat, a napi életvitellel kapcsolatos tényezőket, valamint a helyi közösség megítélését megérdeklődő itemek. A 32.-től az 55. kérdésig Likert-skálás, táblázat formátumú kérdéssor volt, melyben értékelhette a válaszadó az adott külterület jellemzöit. A harmadik oldalon a különböző nehézségek és a lakóterület sajátosságainak értékelése következett, valamint a háztartás demográfiai adatai kerültek felmérésre. A negyedik oldalon a mezőgazdasági aktivitást és a különböző vizsgált területek (külterületek, vagy egyéb belterületek, vagy belterületek) sajátosságaira kérdeztem rá. Nyílt kérdések formájában a résztvevőknek lehetősége volt saját problémáik és elvárásaik megfogalmazására is.

A nyílt kérdésekre kapott válaszok feldolgozása adatsürítő módszert igényel, mely során a lehető legkisebb adatvesztéssel kell kvantifikálni az eredményeket, de ennek célja nem a szó szerinti, hanem tartalom szerinti átvétel (LETENYEI L. 2005). Ezt úgy hajtottam végre, hogy a különbözö válaszokat betükóddal jelöltem és csoportosítottam, például a járdák hiányával kapcsolatos panaszok ,j” jelet kaptak. Ahol az említett tényezőket nem lehetett összevonni teljes mértékben, ott alcsoportokat határoltam le (állattartással kapcsolatos panaszok ,e”, a kóbor állatok jelenléte „ee” jelzéssel). Ennek megfelelően minden felmerülő jelenség és folyamat az 58., 61., 64., 68. és 69. számú nyílt kérdésekre kapott válaszok alapján elöállított kódok szerint értékeltem, nem az 57., 60., 63. és 67. alapján. Ezt indokolta az is, hogy a válaszadók gyakran nem is tudták elkülöníteni, bizonyos tényezők mely csoportba sorolhatóak be; szemléletes példa, hogy közlekedési, vagy önkormányzattal kapcsolatos problémának tekintjük-e a közvilágítás hiányát.

A felmérés előtt végzett próba-kérdőívezés célja volt megtudni, hogy mennyire érhetőek a kérdőívek kérdései a lakosság számára, felmerülnek-e olyan szempontok, amelyek az eredeti kérdőívben nem szerepeltek, valamint a tartalmi és formai hibákat javítani akartam, a kérdöívezés általánosan elfogadott módszertanát követve (BABBIE, E. 2003, LETENYEI L. 2005, MAJOROS P. 2004). A felmerült hiányosságokat a tapasztalatok és a válaszadói tanácsok alapján pótoltam.

A tapasztalatok szerint a válaszadási hajlandóság igen alacsony volt a bizalmatlanság miatt, ezért a kérdőív első felében egyszerübb felvezető kérdések kaptak helyet, fokozatosan haladva a szenzitívebb adatok felé. Különösen a konfliktusokban való érintettséget vállalták fel nehezen a lakók, mivel féltek, hogy az önkormányzatok a kapott eredmények alapján retorzió alá vonják az „árulkodót”, e szorongást a kutatás céljának rövid elmagyarázása és néhány felvezető kérdés oldotta. Emellett a problémaként jelentkezett, hogy a lakosok által használt helynevek sok esetben nem egyeztek a hivatalos elnevezésekkel, valamint sokan egyszerüen nem voltak tisztában azzal, hogy lakó helyük külterület-e és esetenként, hogy mely településhez tartozik. Ennek ellenére a főutak menti dűlökön épült gyakran luxuskivitelü ingatlanok lakói annyira elzárkózóak voltak, hogy ilyen külterületröl egyetlen választ sem sikerült felvenni, volt ahol többszörös (elektromos) kerítés, kamerarendszer volt kiépítve és egy esetben már lőfegyverrel várt a kapuban a tulaj, mire egyáltalán beértem a bejárón.

A válaszadók értékelése gyakran eltért az általam használt definícióktól. Gyakori példa volt, hogy a magát külterületen állandó lakosnak tartó egyénről a későbbi válaszok alapján derült ki, hogy ő valójában városi lakással is rendelkező kétlaki és az ideje nagyobb részét ott tölti. Ennek 
feloldása érdekében, ha ellentmondásosan válaszolt a lakó vissza tértem a kérdésre hogy a válasz biztosan releváns legyen. Végül kiemelném, hogy bizonyos kérdések esetében a válaszok érvényessége kérdéses, különösen az olyan jogi következményekkel járó cselekmények, mint az illegális építkezés, lakásfoglalás, a lakcím átjelentés, vagy épp a müvelési kötelezettség bejelentésének elmulasztása esetében a válaszadók csak ritkán vállalták fel érintettségüket, vagy az általuk ismert eseteket.

\subsubsection{Interjúk}

A felmerült ellentmondások, további kérdések és az önkormányzatokkal, vagy intézményekkel, civil szervezetekkel szemben megfogalmazott kritikák mélyebb feltárása érdekében a geográfia egyik gyakran alkalmazott módszerét, az interjút alkalmaztam. Az érintett önkormányzatok és szervek szakembereivel készült interjúk során sikerült feltárni, a központi települések vezetésének külterületekkel kapcsolatos fejlesztési elképzeléseit és napi rutinját a mintaterületek tervezési és ellátási feladataiban.

Kutatásom során, mivel a statisztikai elemzés, a kérdőívek és a terepbejárás alapján előzetes információkkal rendelkeztem, strukturált személyes interjúk készítését terveztem. Annak érdekében, hogy a minél több, az interjúalany szerint meghatározó témát érinthessünk, valamint a válaszoló saját véleményét mélyebben és szabadon megfogalmazhassa a félig strukturált forma mellett döntöttem, melynek vezetőjeként az kérdőívek és a korábbi interjúzás során felmerült kérdések szolgáltak (BABBIE, E. 2003, MAJOROS P. 2004). Minden személlyel egyedi, az adott települések és témakörrel kapcsolatos addigi eredményeim alapján készült vázlat segítségével kezdtem el a kérdéseket feltenni, majd a beszélgetés során megismert információkkal kapcsolatban felmerült további kérdéseket is feltettem szükség esetén.

$\mathrm{Az}$ interjúkat transzkriptálás után összevetettem az elkészült kataszter és a kérdöívek eredményeivel, valamint a szakirodalmi előzményekkel. Problémaként merült fel - a korábbiakhoz hasonlóan - hogy a KSH által használt külterületnevek és a helyiek szóhasználata nem mindig egyezett, illetve számos önkormányzati alkalmazott nem volt tisztában a település közigazgatási beosztásával, településföldrajzi adottságaival így a 2. interjútól már minden esetben vittem magammal térképet az egyértelmüsítés érdekében.

$\mathrm{Az}$ interjúalanyok személyét a felmerült kérdések alapján határoztam meg, a társadalmi és települési problémák kapcsán a városok szociális és építéshatósági osztályait, a kisebb települések esetében a polgármestert, vagy a jegyzőt kerestem meg, illetve az általuk ajánlott illetékest. Az egyes intézmények, civil szervezetek esetében pedig a vezetőt kerestem meg. A felmérés során a hólabda módszert is alkalmaztam, így az interjúalany által ajánlott szakértőt vagy érintettet is felkerestem. A települések kiválasztása a terepi empirikus tapasztalatok alapján történt, a 5.6 fejezetben bemutatandó esettanulmányokhoz igazodva. Sajnálatosan több érintett intézmény és kisebbségi önkormányzat elutasította a válaszadást. Ahol az alany kérte nevének diszkrét kezelését, ott a szakirodalom (LETENYEI L. 2005) ajánlásai szerint visszakövethetetlenül elemzem csak véleményét. Az interjúkat a település nevével és a lekérdezés sorrendjében növekvö betűkódjukkal (például: Abda: a, Zalaegerszeg: c) hivatkozom a munkában (2. táblázat).

2. táblázat: Interjúk listája, betüjelzése

\begin{tabular}{|c|c|c|c|c|c|c|c|c|c|c|}
\hline Beosztás & 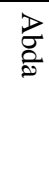 & 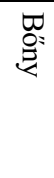 & 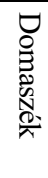 & $\stackrel{\Omega}{\vdots}$ & 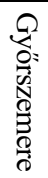 & 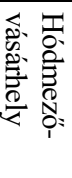 & 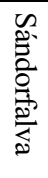 & $\begin{array}{l}\text { N } \\
\text { D } \\
\text { OQ } \\
\mathbb{R}\end{array}$ & 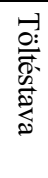 & 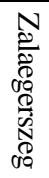 \\
\hline Polgármester vagy képviselő & a & & a & $a, b$ & & & & a & a & \\
\hline Önkormányzati tisztviselő & & $\mathrm{a}$ & & $\mathrm{c}$ & $\mathrm{a}$ & $a, b$ & & & & \\
\hline Építési /építéshatósági osztály tisztviselője & & & & $\mathrm{d}$ & & & & $\mathrm{b}$ & & $\mathrm{a}$ \\
\hline Szociális osztály munkatársa & & & & $\mathrm{e}$ & & $\mathrm{c}$ & & $\mathrm{c}$ & & $\mathrm{b}$ \\
\hline Civil szervezet, vagy közszolgáltató szakértője & & $\mathrm{b}$ & $\mathrm{b}$ & & & & $\mathrm{a}$ & $\mathrm{d}$ & & c \\
\hline
\end{tabular}

Forrás: Saját szerkesztés 


\section{A LAKOTT KÜLTERÜLETEK TIPIZÁLÁSA}

\subsection{Lakott külterület, mint településföldrajzi fogalom}

A külterület földrajzi fogalomként való használata nem terjedt el a hazai szakirodalomban, a közigazgatási önállósággal nem rendelkező - így csak néhány statisztikai adatközlésben szereplő - lakott helyek vizsgálata háttérbe szorult az önálló községek és városokhoz képest (BECSEI J. 2007a, BECSEI J. 2015b, BAJMÓCY P. - BALOGH A. 2011). Ugyanakkor a szuburbanizációban mutatkozó szerepük miatt vizsgálatuk számos új tudományos értékkel szolgálhat, így az elmúlt évtizedben e témakör relevanciája megnőtt a hazai kutatásokban (BAJMÓCY P. 2000b, BAJMÓCY P. 2014, BALOGH A. 2012a, CSATÁRI B. 2006, CSATÁRi B. et. al. 2013, CSATÁRI B. - FARKAS J. 2012, PóCsı G. et. al. 2008). A külterületek vizsgálatához azonban tisztáznunk kell a külterület fogalmát, annak tartalmi kérdését és helyét a településföldrajzi kategóriákban.

E fejezetben bemutatom a külterület, mint településföldrajzi kategória értelmezési lehetőségeit, definícióját. A fejezet második felében célom összeállítani a kutatási kérdéseknek megfelelö, egységes külterület-tipizálási rendszert a szakirodalmi előzmények szintézisével, amely alkalmas lehet minden külterület lehatárolására azok településföldrajzi adottságai alapján. Részletesen elemzem e típusokat, azok történelmi fejlődését, általános földrajzi és demográfiai adottságaikat, valamint azon tényezőket, melyek a rendszerváltás utáni átalakulásukat jelentősen befolyásolhatták. A kutatás során e beosztást használom, mivel lehetővé teszi az eltérô adottságú lokációk összevetését, a fejlődési utak feltárását és az egyes sajátos jellemzőkkel leírható külterületek várható alakulását analógiákon és az empirikus kutatás eredményein keresztül.

Lakott külterületi településrész a KSH módszertana szerint olyan terület, melyet nem sorol belterületekbe a települési rendezési terv, és legalább egy lakos él ott, vagy lakosság hiányában legalább egy lakatlan, de egyébként lakható ingatlan található területén. Ez a meghatározás azonban nem földrajzi kategória, vizsgálatukhoz településföldrajzi értelmezési keretben szükséges elhelyezni a külterületeket (BALOGH A. 2012a).

A külterület tehát olyan közigazgatási egység, amely a települések (város vagy falu) tömör területén, a belterületen kívül fekszik. A kül- és a belterület határa azonban jogi döntés eredménye, ezért nem feltétlenül követi pontosan a tömör beépítés területhasználatát (ERDEI F. 1976). A lehatárolás kérdését a MENDÖL TIBOR-féle (1963) településfogalom alapján vizsgálva megállapíthatjuk, hogy minden olyan terület egy település, amely egy embercsoport lakó- és munkahelyének térbeli együttese, ahol a lakó és más funkciók jelen vannak. Így a külterületek településként értelmezhetőek függetlenül attól, hogy a közigazgatási szabályozásban hol helyezkednek el (BALOGH A. 2012a).

A településföldrajz az alaprajz alapján két fö kategóriát meghatározva magányos és csoportos településeket határol el, előbbi csoport esetében az elemi lakóegységek a térben elkülönülten, utóbbi esetén az egymással érintkezve, zárt településmagot alkotva helyezkednek el. Több szerző szerint a magányos településeknek nem kell feltétlenül egyetlen házból állnia, néhány ház és a kapcsolódó gazdasági építmények is szórványt alkotnak 10 fó alatti népesség esetén. A csoportos település további jellemzői alapfunkciók jelenléte (bolt, templom, stb.), valamint a közigazgatási önállóság és a zárt településmag megléte (MENDÖL T. 1963, BALOGH A. 2012a, KovÁCs Z. 2002b). Több szerző e szempontok alapján - indokolatlanul - azonosította a külterületek fogalmát és a tanyák kérdéskörét, szórványtelepülésként értelmezve a külterületeket (BECSEI J. 1993).

A külterületek azonban nem feltétlenül sorolhatók be e két kategóriába, mivel nem szórványjelegü az alaprajzuk, de jelentősen különböznek akár a falvak, akár a városok térszerkezetétől. Szükséges lehatárolni egy köztes kategóriát, melyet leginkább átmeneti településeknek nevezhetünk, ami kevés, de több mint 1-2 lakóházból álló, 10-50 fö közötti népességszámú zárt településmaggal nem rendelkező település (KovÁCs Z. 2002b). 
BALOGH A. és BAJMÓCY P. (2012) felhívja a figyelmet, hogy a közigazgatási szerepkör figyelmen kívül hagyása esetén a magányos települések (tanyák, őrházak) mellett megfigyelhető hazánkban egy átmeneti típus is, melynek jellemzője, hogy több házból áll és rendelkezik zárt településmaggal, az azonban funkciókkal nem ellátott. A szórványok és a csoportos települések közötti átmeneti lakóhelyek a majorok, a szerek, a sortanyák, a cigány-, fürdö-, és a bányatelepek, valamint a zártkertek (BALOGH A. 2012a, BALOGH A. - BAJMÓCY P. 2012, JóZSA K. 2008).

A Kárpát-medencei szórványokat másodlagos szórványnak, vagy másodlagos hézagkitöltő szórványnak lehet tekinteni, utóbbi megközelítés szerint a településekhez kapcsolódóan a magányos települések a közigazgatásilag önálló település részeként értelmezhetők. (BALOGH A. BAJMÓCY P. 2012, BECSEI J. 2008). E megközelítés alapján az egyes lakóház (tanya, szőlöhegyi ház) a magányos település, a magányos lakóhelyek (tanyaközség, önálló szőlöhegyi szórvány) összességéből álló község a szórványtelepülés (BALOGH A. - BAJMÓCY P. 2012, ÉGETŐ M. 1978, MENDÖL T. 1963; BELUSZKY P. 2001). Ugyanakkor sok szerző nem választja külön e két fogalmat (BECSEI J. 2008; KovÁCS Z. 2010), vagy a külterületi lakott helyeket - a csoportos település határán lévő tanyás dűlőt, vagy szőlőhegyet - tekintik szórványtelepülésnek (SÁRFALVI B. 1991).

E dolgozatban BALOGH A. - BAJMÓCY P széles körű elméleti kutatás és empirikus felmérés alapján kialakított véleményét elfogadva a közigazgatási határok figyelembevétele mellett szórványtelepülésen több, magányos vagy átmeneti képződmény csoportosulásából álló önálló települést értek. Ilyenek a tanyaközségek, szeres-szeges községek, vend vidéki falvak, tanyabokrokból, majorokból vagy szölöhegyekböl létrejött falvak. Az olyan települést, amely rendelkezik zárt településmaggal rendelkező nagyobb csoportos maggal - tanyás város, majoros falu - nem tekintem szórványtelepülésnek (BALOGH A. - BAJMÓCY P. 2012).

A települések alaprajzi osztályozásában a települést alkotó formák csoportosítása több dimenzió mentén lehetséges. Az első dimenzió az alapformák jellege, azaz, hogy a lakóingatlanok sorokat vagy halmazokat alkotnak-e, e halmazokat tovább csoportosíthatjuk négyzetrácsos és radiális (rundling) elemekre. Második jelentős dimenzió a település kompaktsága, hogy az egyes ingatlanok között vannak-e jelentős be nem épített területek. Ilyen értelemben a települést alkotó elemek a csoportos települések esetében sem feltétlen alkotnak összefüggő településmagot. Összetett települések esetén egymástól térben távoli, különböző településföldrajzi-alaprajzi besorolású elemek (szórványok, sorok és halmazok) is alkothatnak egy falvat, míg több magvú települések esetében több, önmagában is zárt településmagnak minősülö lakóegység-halmaz található a község területén (HORNBY, W.-JONES, M.1997 DANIEL, P. - HOPKINSON, M. 1996).

E tipizálás alapján a közigazgatásilag önálló települések besorolhatóak aszerint, hogy a központi belterületen kívül milyen és hány, térben elkülönülő szórvány, átmeneti és csoportos településtípus található közigazgatási határaikon belül. Mivel minden ilyen települést több ház alkot, nem beszélhetünk magányos településről ez esetben, több belterület és lakott külterület összességéből áll a hazai városok és falvak jelentős része (BALOGH A. 2012A, BALOGH A. BAJMÓCY P. 2012).

Összegezve a közigazgatási határokat figyelembe véve a klasszikus falvak és városok egyetlen, nagyobb méretű csoportos egységből álló települések. A magányos házakból álló települések a tanyaközségek, a szőlőhegyekböl önállósult községek és a vend vidéki községek szórványtelepüléseket alkotnak. A több, vagy egy majorból, tanyabokorból álló községek, valamint irtvány-, szeres és szeges falvak több kisebb, külön is több házból álló egységekből felépülö települések átmeneti típust alkotnak. Természetesen a legtöbb hazai település valamilyen átmeneti helyzetet jelenít meg. A tanyás városok és szőlőhegyes falvak a csoportos mag mellett számos szórt lakóegységet tartalmaznak. A majorokkal, bányatelepekkel és tanyabokrokkal rendelkező településeknél a csoportos képződményeket kisebb csoportos egységek kísérik. A több település összekapcsolásából létrejött városok és községek esetében több csoportos egység van jelen (BALOGH A. - BAJMÓCY P. 2012).

A külterületek fogalmát illetően el kell még határolni egymástól a lakott és lakatlan külterületeket. Természetüknél fogva a külterületek egy részén, csak időszakosan, szezonálisan, 
vagy életmódból fakadó sajátos ritmus szerint van jelen a használó személy (üdülök, tanyák), nem állandó jelleggel (BALOGH A. 2012a). Ritkábban előfordulhat, hogy egy lakóegységet időlegesen - akár több évig - nem laknak, azonban ez nem jelenti automatikusan a lakott külterületi jelleg elvesztését, hiszen a tanya akkor is tanya marad, ha a gazda akár egy évig távol van például betegség miatt. E megfontolás alapján a tartós ott lakás fogalmán azt is értem, - a KSH módszertanát elfogadva - amikor a külterületen legalább egy lakhatásra alkalmas, állandóan nem lakott, de hasznosított ingatlan van, ahol a használó esetleges igénye szerint letelepedhetne.

A fentiek alapján a lakott külterületeket a következőképpen értelmezem: A lakott külterület legalább egy fó által tartósan lakott olyan (a hazai településállományban sajátos) magányos, szórt vagy csoportos lakóhelytípus, mely közigazgatási önállósággal nem rendelkezik, a területrendezési terv nem sorolja belterületbe. Morfológiáját meghatározza a kialakulását indukáló tevékenység, és jellemzően nem rendelkezik városias vagy falusias zárt településmaggal, vagy ha igen, az magasabb szintü funkciókkal nem ellátott, így lakossága az alapellátás többségét a magtelepülésen veszi igénybe. $E$ jellemzőkből fakadóan a külterületeken élők speciális napi kapcsolatban vannak a magtelepüléssel, életmódjuk valamilyen mértékben eltér a falusi és városi népességétől.

E definíció lehetővé teszi az összetett települések eltérő településföldrajzi adottságú külterületi lakott helyeinek elkülönítését a településekhez csatolt (közigazgatásilag szintén nem önálló), magasabb funkciókkal is ellátott településmaggal rendelkező falvaktól anélkül, hogy az átmeneti típusokba eső külterületeket kizárja. A fogalom egyben kitér a külterületi lakosság a központi településhez a falvakénál erősebben kötődő és a helyben szinte kizárólagosan meglévő lakó- és mezőgazdasági funkciók miatt sajátosan szervezett életmódját, melyben dominál a kettős térbeliség (BALOGH A. - BAJMÓCY P. 2012).

Mint az már az eddigiekben is említésre került a külterületek adottságai változatosak, az 1-2 házból álló szórványos tanyától az akár ezres lélekszámot is elérő sakktáblás, tervezett utcahálózatú zártkertekig terjed, de léteznek panelházas technológiával készült üzemi lakóhelyek is. Ennek megfelelően a külterületeket nem lehet homogén csoportként vizsgálni, az egyes típusokat el kell különíteni, azonban a hazai szakirodalomban nincs egységes konszenzus a felosztás mikéntjéröl (BALOGH A. 2012a).

\subsection{A külterületek tipizálásai lehetőségei}

Hazánkban hivatalos beosztásnak a Központi Statisztikai Hivatal Magyarország Helységnévtárában használt külterület-tipizálása tekinthető, mely a lakott külterületek fő funkció alapján történő besorolását kívánja megvalósítani. Így e lehatárolás megkülönböztet 13 kategóriát (3. táblázat). Sajátos kategóriát jelentett a külterület összeírt lakóegység és népesség nélkül, mely egységeken közel kétezer honfitársunk élt. Ennek oka abban keresendö, hogy a besorolás és a népességszám megállapítása nem azonos évi adatok alapján történik (BALOGH A. 2012b).

E csoportosítás bár viszonylag precízen visszaadja a külterületek funkcióellátottságát csak közvetetten utal a külterületek településföldrajzi és társadalmi jellemzöire. Sajnálatosan a földhasználattal kapcsolatos törvények (1997. évi CXLI. és 2013. évi CXXII. törvények, 109/1999. FVM rendelet) sincsenek segítségünkre, hiszen csak a tanyát és zártkertet nevesítik, mint jogi jelleget, valamint a szőlőhegyeket említik, mint sajátos müvelési igényű lokációt.

Erdei Ferenc külterület-tipizálása bár széleskörüen tárgyalta a kor jellemző típusait (ERDEI F. 1976), az általa lehatárolt csoportok mára kevésbé használhatók, mivel a külterületek rendkívül nagy változáson esetek át, nem csak a szocializmus éveiben, de továbbra is differenciálódnak, és e kutatás kérdéseinek megválaszolásához egy az aktuális állapotnak megfelelö tipológia szükséges.

A szakirodalom alapján kialakulásuk, történeti fejlődésük, településszerkezeti adottságaik alapján két fó típusba sorolhatjuk a külterületeket: a történelmi elözményekkel rendelkezö, útfüggő fejlődés során kialakult, jellemzően mezőgazdasági hagyományú és ehhez igazodó településszerkezetü, ingatlanállományú külterületek mellett léteznek a modern, gazdasági igény 
vagy politikai döntés nyomán tervszerüen kialakítottak (BAJMÓCY P. et. al. 2018, BALOGH A. 2012a, BALOGH A. - BAJMÓCY P. 2012, MENDÖL T. 1963, SÁRFALVI B. 1991). Ezért szükségszerü a hazai településföldrajzi irodalomban feltárt sajátos jellemzőkkel bíró típusok alapján értelmezni a külterületeket (BALOGH A. 2012b, TIMÁR J. 1990a, VASÁRUS G. et. al. 2018).

3. táblázat. A külterületek települési jelleg szerinti megoszlása a KSH osztályozása alapján, 2011-ben.

\begin{tabular}{|c|c|c|c|}
\hline Külterület települési jellege & Száma (db) & Aránya $(\%)$ & Lakosság (fó) \\
\hline Bányatelep & 27 & 0,29 & 1335 \\
\hline Forgalmi település (vasútállomás, vasúti őrház stb.) & 338 & 3,60 & 1880 \\
\hline Gyógyintézet, kórház, szanatórium és fekvőbetegeket ellátó egyéb intézmény & 8 & 0,09 & 540 \\
\hline Ipartelep & 120 & 1,28 & 1709 \\
\hline Kulturális, oktatási vagy sportlétesítmény & 30 & 0,32 & 380 \\
\hline Külterület összeírt lakóegység és népesség nélkül & 1009 & 10,75 & 1842 \\
\hline Gazdasági tevékenységhez, vagy egyéb funkcióhoz nem köthető lakóhely & 2027 & 21,60 & 88681 \\
\hline $\begin{array}{l}\text { Mezőgazdasági jellegü (készenléti, szolgálati) lakótelep, illetve lakóhely, } \\
\text { mezőgazdasági jellegü tanyák }\end{array}$ & 4501 & 47,97 & 194064 \\
\hline Örházak, erdőőrház, erdészlak, erdészház, útőrház, gátőrház, csatornaőrház stb. & 591 & 6,30 & 1344 \\
\hline Szálloda, turistaszálló, menedékház, üdülö, tanyai vendégfogadó, panzió stb. & 119 & 1,27 & 1942 \\
\hline Szociális otthon, egyéb szociális jellegü létesítmény & 46 & 0,49 & 4206 \\
\hline $\begin{array}{l}\text { Üdülőhely, üdülőterület, üdülöként vagy hétvégi pihenésre használt tanya, } \\
\text { présház, gazdasági vagy egyéb rendeltetésü épület }\end{array}$ & 390 & 4,16 & 9152 \\
\hline Üzemi (ipari üzemi) szolgálati vagy készenléti lakás & 171 & 1,82 & 19779 \\
\hline Be nem sorolt & 6 & 0,06 & 0 \\
\hline Összesen & 9383 & 100 & 326854 \\
\hline
\end{tabular}

Forrás: KSH Helységnévtár alapján saját számítás

A következőben ennek megfelelően kívánom bemutatni a szakirodalmi előzmények szintézisével általam lehatárolt típusokat. A külterületek jelenkori adottságait döntő mértékben meghatározza a kialakulásuk története folyamán létesült településszerkezet, melyet a szórvány, átmeneti vagy zárt lehet. Az 1945 előtt kialakultak ingatlanállományát, infrastrukturális ellátottságát és így népességszámukat. függ a korai mezőgazdasági tevékenység sikerességén, annak munkaerő-szükségletén túl a szocializmus évei során végbement átalakulások nagymértékben befolyásolják. Az újabb külterületek jelentős része tervszerüen került kiépítésre, így a zártkertek, üzemi lakóhelyek és üdülök településképük és ellátottságuk nagymértékben függ a létrehozáskor elkészített beruházásoktól, befektetésektől.

E külterületek tipizálását a fentieknek megfelelően a történelmi (jellemzően 1918 előtti) külterületekre és a modern, döntően az államszocializmus évei alatt kialakult külterületeket külön csoportosítom. A típusok kialakítása során figyelembe vettem az egyes területek szakirodalom segítségével feltárt történelmi fejlődését, útfüggő kialakulásuk során képződött településföldrajzi adottságaikat (3. ábra), amelyek jelentősen befolyásolták nem csak a demográfiai folyamatokat, de jelentősen megszabják a jelen kor folyamatainak peremfeltételeit.

\subsubsection{Történelmi külterületek}

A tanya a hazai településhálózat egyik legsajátosabb, tipikusan magyar eleme. Kizárólag e településforma kapott jelentős figyelmet a geográfus diskurzusban a különböző külterületek között a XX. százat első évtizedétől, mivel Erdei Ferenc, Győrffy István, Mendöl Tibor, Márkus István és Szabó István munkássága révén a harmincas évtized során szakmai irodalom homlokterébe került. Bár a tanyakérdést 1990 után újra felfedezte a hazai szakirodalom, azonban jelentős hiányosság, hogy azóta sem készült a tanyavilág egészét lefedő felmérés, ezért recens folyamatairól máig nincs teljes körü tudáskészlet (BAJMÓCY P. 2001b, BAJMÓCY P. 2003b, CSATÁRI B. 2010, TiMÁR J. 1990a, TIMÁR J. 1990b). 


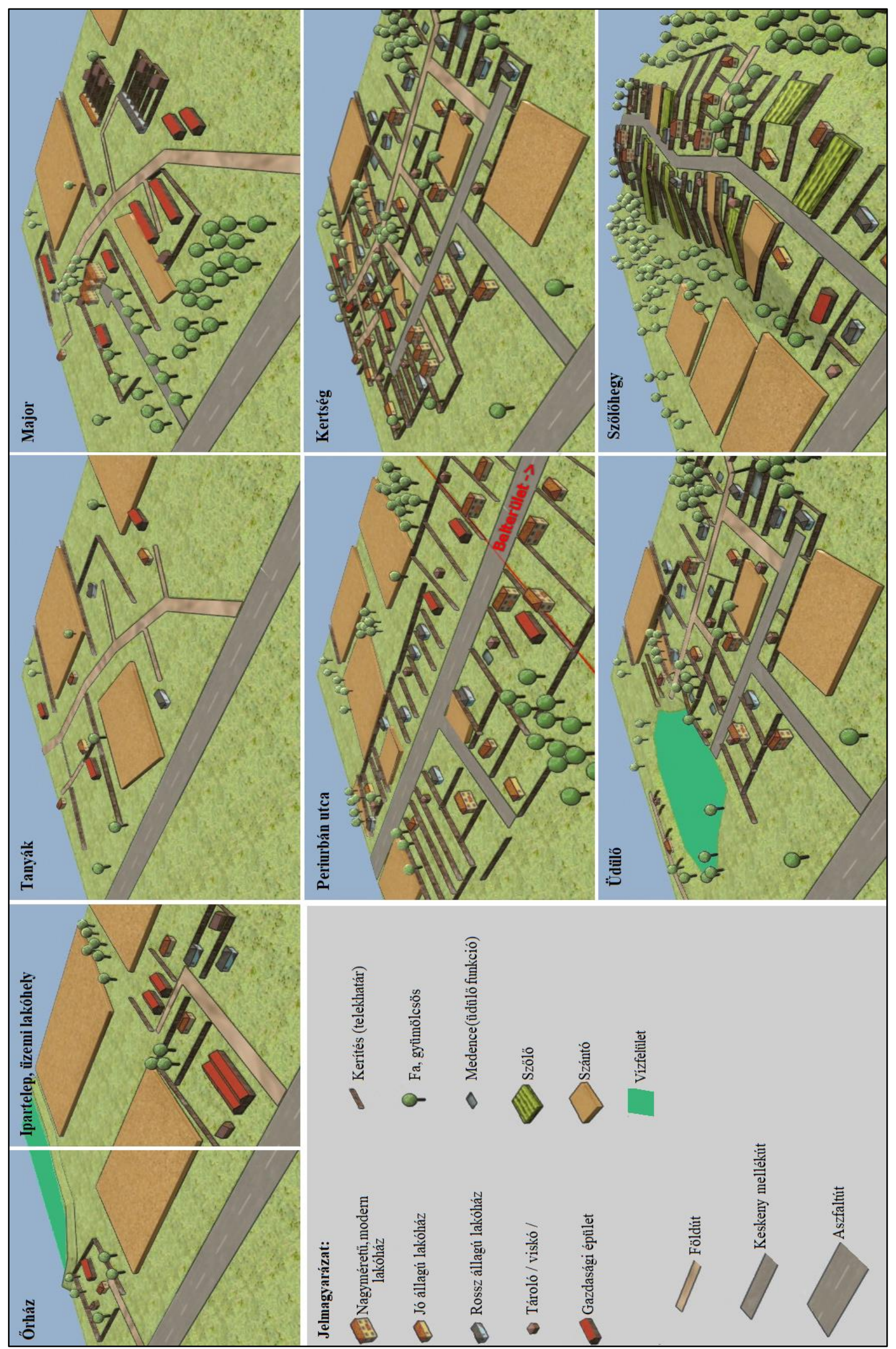

3. ábra: A lakott külterületek föbb típusainak sematikus településszerkezete (készítette a szerző). 
A tanya a hazai jogrendben egy jogi jelleg típus az ingatlan-nyilvántartásban (109/1999. FVM rendelet), amely a mező- és erdőgazdasági földek forgalmáról szóló 2013. évi CXXII. törvény szerint külterületen fekvő, legfeljebb 1 ha méretü földrészlet, amelyhez a föld mellett növénytermesztés és állattenyésztés, továbbá az ezekkel kapcsolatos termékfeldolgozás és tárolás céljára létesített lakó- és gazdasági épület-épületcsoport tartozik, illetve minden földrészlet, amely az ingatlan-nyilvántartásban tanyaként szerepel. E fogalom azonban túl tág és a külterületek jelentős részére igaz lehet.

A tanya fogalmát illetően máig nincs teljes körű egyetértés (BECSEI J. 1993, BECSEI J. 2007A, ERDEI F. 1976, GYÖRFFY I. 1937, MENDÖL T. 1963, MAKSAY F. 1971). A következökben jelen kutatás szemszögéből legfontosabb megállapítások és ellentmondások tárgyalását kísérlem meg, hiszen a hazai tanya-irodalom értékelése meghaladná e munka kereteit.

GYÖRFFY I. (1937) értelmezése szerint a ,tanya, vagy régebbi nevén szállás alatt a magyar Alföld szétszórt, magányos telepjeit értjük, melyek ma a mezőgazdasági munkák, $\mathrm{s}$ általában a gazdálkodás középpontjai, régebben pedig a lábas jószág teleltető helyei voltak. A tanya azonban nem önálló településforma, hanem a hozzá tartozó földbirtokkal együtt valamely város vagy nagyközség függvénye”. Azaz a tanyák az alföldi városi földmüvesek nyári szállásául szolgáló lakóháza a városi, tehát téli ingatlana mellett.

ERDEI F. (1976, 15-16. p.) szerint viszont a tanya „1. magános telep, olyan épület, vagy épületcsoport, amely kívül esik a városok vagy falvak zárt tömbjén, 2. mezőgazdasági, ill. általánosabban östermelöi célt szolgál, tehát vagy állattartásnak, vagy földmüvelésnek, vagy erdőgazdaságnak, vagy halászatnak a színhelye, 3. az illető termelésben foglalkozónak a tartózkodási helye, vagy rövidebb, vagy hosszabb időre, de semmi esetre sem egyszerüen a települési helye", Azaz a tanya az alföldi mezőváros szerves egysége, a városi ház és a tanya a sajátos gazdálkodási forma két helyszíne, a család mindkét helyen szervezi és vezeti életét, hiszen míg a tanyán intenzív termelést folytatott, addig városi ingatlanában az urbanizáció előnyeit is élvezhette.

Jelentősen eltér MENDÖL TIBOR. értelmezése, aki szerint minden egyes tanya önálló magányos település, szórvány, amely egyszerre mezőgazdasági lakóhely és munkahely. Véleménye szerint az alföldi közigazgatási egységek nem jelentenek földrajzi településegységeket, a városok határát a beépített terület szélén kell meghúzni. A tanyák sajátos foglalkoztatási-társadalomszerkezeti adottságai lényegesen különbözőek, ezért e felfogás az eltérésekre helyezi a hangsúlyt, mindemellett tagadja a szerző, hogy a tanyasiak többségének lenne ingatlana a városokban, így a város-külterület kapcsolat szorosságát is vitatta (MENDÖL T. 1963).

A meghatározások közötti különbségek mellett számtalan hasonlóságot is megfigyelhetünk a szakirodalomban, valamennyi szerző kiemeli, hogy a tanya egy sajátos üzemforma, mely a tágas határok intenzív müvelésére jött létre. Sajátos szokásai miatt elkülönül más szórványoktól, egyben egyedi társadalmi rendszer és funkcionális (de a falu-város relációtól különböző) napi kapcsolat a várossal. Továbbá egyedi életforma, melynek során az alapellátás többségét is a városban veszik igénybe, ugyanakkor erős meghatározója az individualitás (BECSEI J. 1993, BECSEI J. 2002, BECSEI J. 2007a, TIMÁR J. 1990a). A kisbirtokos tanyák Eredi Ferenc, míg a farmtanyák a Mendöl-féle fogalmaknak felelnek meg szigorúbban, így a bemutatott fogalmak a történeti fejlödést figyelembe véve nem mondanak ellent, hanem kiegészítik egymást (BECSEI J. 1992, BECSEI J. 1993, BECSEI J. 2002).

A tanya kialakulásának sajátos feltételei határozzák meg a máig is jellemző térszerkezetét, a tanyafejlödés korszakait a következőkben foglalhatjuk össze:

1, A XVIII. századtól indult meg a tanyavilág kiteljesedése, a tanyasi társadalom kialakulása, és általános érvényűvé válik a sajátos város-tanya kapcsolat, mivel alapját a középkori falupusztulás révén létrejövő nagy kiterjedésű határok adják, melyek megmüvelését már nem lehetett napi utazással megoldani. Szükséges volt a kellő méretü népességtartalék, az előnyös jogviszonyok; hogy a tanyás város megváltotta úrbéli terheit, valamint, hogy a földterület állandó jelleggel, vagy 
legalábbis huzamosabb ideig egyéni birtokba kerüljön, hogy megérje ingatlant építeni rá (BECSEI J. 1993, BECSEI J. 2007a).

2, A XIX. századtól a vízszabályozás, a jobbágyság felszabadulása és a föld öröklés útján való osztódása révén megsokszorozódik a tanyák száma, e gazdálkodási-települési rend általánosan elterjed az Alföldön. Ekkor alakulnak ki a tanyák föbb típusai, a családok által művelt kisgazda tanya, a jelentős területeket birtokló tulajdonosok nagygazda tanyái, amelyeket cselédekkel múveltettek, az állandó lakóhelyként szolgáló farmtanyák, valamint a termény egy részének fejében használt haszonbéres tanyák (BECSEI J. 1992, BECSEI J. 1993, BECSEI J. 2002).

3, A kiegyezéstől a 2. világháború végéig zajlott a tanyavilág technológiai csúcskorszaka, melynek fő hajtóereje az volt, hogy újonnan bevonható földterületek hiányában a termelés intenzitását kellett fokozni. Az önellátás helyére a piacra termelés lépett, így a kiköltözö szegények mellett a munkásokkal dolgoztató módos gazdák révén is növekszik a tanyák száma. Trianon és a gazdasági válság miatt bekövetkező piacvesztés hatását csak részben tudta ellensúlyozni a tanyasi iskolák építése, valamint a gyümölcsös program (BECSEI J. 1993).

A tanyák különböző típusai eltérő térbeli szerkezetet mutatnak, mely a mai településföldrajzi adottságokra is hatással van. 10-20 kataszteri hold feletti földterületnél szórt (szinguláris) tanyák alakulnak ki, az úttól és egymástól eltérő távolságban épülnek belvízmentes pontra, ahonnan a telek minden része jól elérhető. Sortanyák (tanyautcák) kisebb, 20-25 m széles 500-600 m hosszú telkeken képződnek, a házak az út mellett vagy a dülő legmagasabb pontján sorakoznak. Tanyautcák ott alakultak ki, ahol csak 2-5 kataszteri holdas telek állnak rendelkezésre, és minden talpalatnyi földet meg kell müvelni, ezért még a bejáró út is pazarlás lenne. A bokortanyák (tanyabokrok) a szlovák telepesek Nyírségben, védelmi célból létrehozott rundlingjaihoz formailag hasonló, 10-20 épületből álló csoportjai (BECSEI J. 1993, BECSEI J. 2010).

A tanyakérdés rendezésére a 1944. évi II. törvénycikk sajátos tanyasi igazgatást megszervezését rendelte el, hogy az akkor elhanyagolt és elszigetelt helyzetéből újra bekapcsolhassák a tanyasiakat (és majorságiakat) a nemzeti közösségi életbe. Kötelezte a városokat, hogy a hivatalok és tisztviselők a tanyákról egy óra sétával elérhető helyeken rendszeres ügyfélfogadását szervezzék meg, majd idővel iskolákat építsenek és iparosok megjelenését is elő kell mozdítaniuk a tanyaközpontokban. Ahol lehetséges volt állandó kirendeltségek építését is ajánlotta, mivel ezek későbbi településközpontok magvai lehetnek. Végül elrendelte az olyan besürüsödött és funkciókkal relatíve jól ellátott tanyagócok felmérését, amelyekböl önálló falvakat lehet létrehozni. A lakosság ennek a törekvésnek élesen ellenállt a városokhoz szorosan kapcsolódó életmódjuk miatt, ráadásul a szükséges pénz sem állt rendelkezésre, ugyanakkor sok mai tanya és tanyás falvak alapjait sikerült ekkor letenni.

4, 1945 után Az új földosztás során megfelelő tudáskészlet nélküli szegények tömege áramlik a gazdaságilag hanyatló tanyavilágba, mely ekkor 977000 fóvel (az alföldi lakosság 30,0\%-a) éri el csúcsnépességét. E folyamatot azonban hamar derékba törte a 600/1945. M.E. rendelet, a 1946. évi IX. és a 1947. évi XI. törvény melyek a szövetkezetesítés célja alá rendelte a tanyák sorsát.

A szövetkezetesítés során megindul az eröszakos tanyarombolás, mely során a könnyen táblásítható területekről adminisztratív és tényleges fizikai kényszerítés útján eltávolítják a lakosságot, majd lerombolják az épületeket. A domborzati és talajtani (homokhátság) adottságaik miatt nem táblásítható területeken maradtak fent nagy számban a tanyák (BECSEI J. 1993, BELUSZKY P. 2001, TÓTH L. 2004).

Az állandóan tanyán élők jelentős része ingázni kezdett - különösen a szakképzettek -, így már csak másodlagos bevétel volt a föld. A megmaradt, 1956 elött is létezett tanyákon eleinte jellemzően a szövetkezetek számára végeztek bedolgozást a lakók, majd az 1970-es évektől megindult új funkciók kialakulása. Jellemzővé váltak a második otthonként, üdülőként használt tanyák, a nemzeti parkok révén az idegenforgalmi szerepkör is megjelenik. A lakáshiány miatt a hetvenes évektől jelentős volt a tanyavilágban is az önerős lakásépítés, amely gyakran hozzájárult a tanyák zártkertesedéséhez a városok peremén. A nyolcvanas évek második felétől a szegények és munkások városokból való kiáramlása megindította a városperemek átalakulását, ugyanekkor a 
klasszikus kettős szálláselvet megvalósító tanyák marginálissá váltak (BAJMÓCY P. 2000b, BECSEI J. 2004, DúRÓ A. 1993, TIMÁR J. 1990b, TIMÁR J. 1992).

A rendszerváltás után felsejlett a reménye egyfajta tanyasi reneszánsznak, a föld kárpótlás, a vállalkozások, a meginduló mezőgazdasági támogatások, valamint a szociális hiányosságokat ellensúlyozni kívánó tanyagondnoki rendszer nyújtotta lehetőségek révén. Új funkciók megjelenése is kibővítette a lehetőségek körét, így az ipar, valamint a tercier szektor vállalkozásainak telephelyei, a szuburbanizációs területek kiépülése, illetve a modern biotermelök, valamint az életmódváltók tanyahasználata egyaránt alkalmas volt e külterülettípus dinamizálására (BAJMÓCY P. 2003b, BECSEI J. 2004, BECSEI J. 2015b, CSATÁRI B. 2006, CSATÁRI B. 2010, CSATÁRI B. - KisS A. 2003, Kiss A. 2004, MolnÁR M. 2004, TimÁR J. 1992).

Ugyanakkor hamar szertefoszlott az esély a tanyai gazdaságok megújulására. A kárpótlás nem hozta előnyös helyzetbe a vidéki földmüveseket, ugyanakkor a mezőgazdaság tartós válsága jelentősen rontotta a meginduló vállalkozások piaci lehetőségeit és fokozódott az, elidegenedés a földtől és a tradícióktól. Elszaporodtak a farmtanyák, azonban többnyire csak kényszerü másodlagos bevételt jelentett a földművelés, valamint a munkanélkülivé válók számára nyújtott túlélési esélyt. A szocializmusban fennálló bővítési és felújítási tilalmak miatt 1990-re a lakó- és gazdasági épületállomány állaga annyira leromlott (I. melléklet, 1. kép) a rendszerváltozás idejére, hogy felújításuk költségei meghaladták a tanyákat használni kívánók lehetőségeit (BECSEI J. 1996, CSATÁRi B. et. al. 2013, CSATÁRI B. - FARKAS J. 2012, DúRÓ A. 1993, FARKAS J. 2004, FARKAS J. ZS. - CSATÁRI B. 2011, KISS A. 2004, PETRÁS E. 2006, 1993. évi II. törvény).

A tanyák és általában a külterületek átalakulásának, fejlődésének jelentős jogi akadályai is voltak. A 2007. évi CXXIX. törvény a termőföld védelméről, a 2013. évi CXXII. törvény a mezőés erdőgazdasági földek forgalmáról, továbbá a 109/1999. FVM rendelet a tanyákat a szántóföldekkel azonos elbírálás alá emelte, nem tett különbséget a lakott és pusztán termőföldi ingatlanok között. Ennek következtében a földekre vonatkozó szigorú termelési, müvelési ág váltási, adásvételi és müvelés alól való kivonási (belterületesítés, vagy lakóházbővítés) szabályok nagymértékben nehezítik a tanyák adásvételét, alakítását, újak építését. Egy 1 hektáros tanyatelek építési célú művelés alól kivonása a termőföld védelméről szóló 2007. évi CXXIX. törvény által meghatározott földvédelmi járulékokkal együtt meghaladta a 200000 Ft költséget. Ez mára tovább bonyolódott, ugyanis az aranykorona értékkel rendelkező tanyák eladása a szántóföldekhez hasonlóan a 2013. évi CXXII tv. értelmében kifüggesztéshez, záradékoláshoz és hatósági engedélyezéshez között, amely legalább fél éves időt és többletköltségeket jelent.

Az úgy nevezett utó-paraszti életmód kiterjedté vált a 80-as évektől, melynek célja a szegénység felszámolása volt. A tanyasiak (és falusiak) szakmát tanulva a szekunder és tercier szektorban vállaltak fó állást, a mezőgazdasági bevétellel pedig anyagi helyzetüket kívánták javítani. E folyamat azonban elhúzódott, sikertelenné vált (I. melléklet, 2. kép.) az 1990 után általánossá váló munkanélküliség, ingázási kényszer (nincs idő a földmüvelésre) és a lecsúszástól való félelem miatt. Általánossá vált - különösen 2007 után -, hogy a tanyamüvelés és a területalapú támogatások felvétele egyfajta szociális mezőgazdaság, a lecsúszás elleni küzdelem eleme lett. Összességében a tanyasi társadalom újra integrációja elmaradt (CSATÁRI B. 2010, CSATÁRI B. Kiss A. 2003, CsOBA J. 2017, FARKAS J. 2004, KovÁCs K. - VÁRADi M. M. 2003).

E folyamat kedvezőtlenül befolyásolja a nők helyzetét, hiszen költségeik minimalizálása érdekében olcsó, alacsony technikai színvonalú háztartást vezetve csapdahelyzetbe kerülnek a tanyán, ahonnan sokszor a leépülö tömegközlekedés - melynek a tanya szórvány-jellege miatt különösen kitett - és az személygépkocsi hiánya miatt ténylegesen nem is tudnak kimozdulni. A rossz elérhetőségü területen élő anyák számára pedig külön kihívást jelent a gyermekek közlekedésének megoldása, melynek időigényessége és stresszes jellege hátrányosan befolyásolja az asszonyok egészségét és pszichológiai terhelését (KELLY, R. - SHORTALL, S. 2002, MOLNÁR M. 2004, TIMÁR J. 1992)

Ez különösen az elesettek külterületre kiszorulása, a szociális szuburbanizáció során vált egyre jelentősebb problémává, melynek eredményeként a lecsúszó szegények hanyatló és a tehetősek 
fejlődő szuburbiái térben teljesen heterogén gyürüt kezdtek kirajzolni az alföldi városok köré. E folyamat hatására a tervezetlen, kontroll nélküli szuburbanizáció teljesen kaotikus térszerkezetet hívott életre, különösen a városperemek besürüsödö öveiben, amely jelentős akadálya lett a későbbi beavatkozásoknak (BeCSEI J. 1996, CsATÁri B. et. al. 2013, Kelly, R. - SHORTALl, S. 2002, KovÁcs A. D. 2010, TimÁR J. 1990B).

A szuburbiák fejlődésében az alföldön nagy a tanyák - különösen az eleve sürübben beépült és mára zártkertesedő tanyasorok és tanyautcák - szerepe, ahol jelentősen bővül a lakófunkció, új házak, esetenként lakóparkok is épülnek (3. kép). Ugyanakkor az eredetileg is tanyasi származású gazdák átlagos életkora magas, így e helyeken a lakosság részbeni revitalizációjával az elöregedés és a fiatalok beáramlása párhuzamosan zajlik. Sikeres megújulásban a megfelelö orvosi, iskolai ellátás, a munkahely megfelelő elérhetősége (járda, bicikliút, tömegközlekedés) szerepe fontosabb, mint a helyi központ kiépültsége. Fontos, hogy a helyiek idetartozónak érezzék magukat, fenn akarják tartani a közösséget, aminek kulcseleme a helyi közösséget dinamizáló közösségi csoport (egyesület), vagy fókuszáló helyszín (templom). (BECSEI J. 2015b, BAJMÓCY P. 2006, BAjMóCY P. - SzebéNYi A. 2007, DúRó A. 1993, KovÁCS, A. D. 2010, Pócsi G. 2009a, PÓCSI G. 2009b).

A 2001-es népszámlálás alapján 207 ezer fó élt még tanyán, ebből 90 ezer fő a Homokhátságon, így a külterületi népesség már csak mérsékelten csökkent (-3,3\%). A 2011-es cenzusig a külterületen élők aránya némileg nőtt $(+3,1 \%)$, de erős a területi differenciálódás. Az agglomerációk városi (szuburbán) tanyái, lumpentanyái és a zárkertté sürüsödött tanyahalmazain kívül csak kevés új falusi lakótanya, második otthon és üdülő létesült. A falusi farmtanyák és a telephelyként használt tanyák többsége esetében tovább nőtt az elnéptelenedés lendülete (KSH, BECSEI J. 2004, BECSEI J. 2015a, CSATÁRI B. 2013).

Az elhúzódó, lassú hanyatlással jellemezhető folyamaton ráadásul a tanyaprogramok se tudtak fordítani, az igényelt fejlesztések és a pályázati kiírások között jelentős az eltérés, a területi allokáció az eddig is sikeresebben dinamizálódó területeket helyezte előnybe (DúRÓ A. 2013, ROMVÁRI R. 2014). Megállapítható, hogy a tanyai népesség esélyegyenlőségét nem sikerült megteremteni (1993. évi III. törvény) az ellátás, az infrastruktúra és a munkaerö-piaci hozzáférés szempontjából sem jelentős előrelépést a tanyagondoki szolgálat kiteljesedése jelent.

A major a hazai településhálózat másik jellegzetes, ugyanakkor meglehetősen nehezen definiálható eleme, mivel a hagyományos településföldrajzi kategóriákba nem illeszthető be. Bár egyes kutatók a tanyával rokonítják üzemforma-jellegükböl adódó hasonlóságaik révén, azonban településföldrajzi eltéréseik miatt a két külterülettípust külön érdemes kezelni (EREDI F. 1976, BALOGH A. - BAJMÓCY P. 2011). A majorok kérdésköre - a tanyához hasonlóan - a két világháború között megjelent szociográfiák révén került a köztudatba. ILLYÉS GYULA Puszták népe címü 1936. évi müve bemutatja a kiszolgáltatott cselédsorsot, mely egy zárt, a falvak és a városok világától élesen különböző és lelkileg is bezárkózó közösséget hívott életre, melynek jellegzetessége a szoros összetartozás tudat és a szolganépi lelkület (ILYÉS GY. 1972).

BALOGH ANDRÁS és BAJMÓCY PÉTER $(2011,15$. p.) széles körü kutatás alapján megfogalmazott véleményét elfogadva a ,major olyan, általában $10-50$ fös népességszámmal és zárt településmaggal rendelkezö, többnyire a városok és községek külterületén fekvő, mind genezisében, mind eredeti morfológiájában a hazai településrendszer többi elemétől elkülönülö térbeli egység, amely eredendően valamely nagybirtok üzemviteli, igazgatási központjaként, illetve az ott dolgozók lakóhelyeként funkcionált; nagy részük napjainkra megsemmisült, kisebb részük pedig zömében lakó- és agrártevékenységnek otthont adó, sajátos, átmeneti településtípust alkot a hazai településrendszeren belül".

A major azonban nem csak lakóhely, hanem a tanyához hasonlóan sajátos mezőgazdasági üzemforma. Alapját a XIII. század során kialakult prédiumok jelentik, melyek a földesurak földjeinek megmüvelését szolgáló üzemek voltak, egyben az ott dolgozók lakóhelyei is. Ezen üzemforma nem volt sikeres amíg a XVI. századtól elterjedt a bérmunkások részfoglalkoztatása e központokban. Az elterjedő allodiális gazdálkodás keretében az úri tulajdonú, korábban nem 
használt irtásföldek és puszták feltörésére és müvelésre alakították ki a majorok egész sorát, azonban a jobbágyi robotmunkára támaszkodás a nyugati példákkal ellentétben korlátozta sikerüket (BALOGH A. - BAJMÓCY P. 2011, BELUSZKY P. 2005, KRISTÓ GY. et. al. 2002).

Jelentős áttörést a XIX. század hozott a majorok elterjedésében, mert a jobbágyfelszabadítás és a gabonakonjunktúra lehetővé tette a termelés hatékonyságának fokozását, melynek egyik kiváló módszerét a puszták kínálták. A birtokosok - ekkor már kapitalista alapon - a falvaktól rendszerint távoli földjeik intenzív müvelésére azok egy központi helyszínén letelepítették az éves szerződés alapján bérért foglalkoztatott cselédséget, kialakították a szükséges infrastruktúrát, amely gyakran kisiparosok jelenlétét is igényelte (BAJMÓCY P. - PÓCSI G. 2008, KOZÁRI M. 1999, Pócsi G. et. al. 2008).

A legtöbb majorban jelen volt e korban egy kastély vagy kúria, mint a birtokos lakóhelye, e körül terült el a néhány száztól több ezer holdig terjedő birtok. A kastély mellett a szakképzett és különböző feladatokat ellátó intézők és gazdatisztek laktak önálló épületben. Kiemelt jelentőségü épületek voltak az istállók, melyek rendszerint a kastély után a legszínvonalasabban kivitelezett ingatlanok voltak. Ezután következtek a gazdaság méretének megfelelö számban és kialakításban az egyéb épületek, gabonatárolók, ólak. Végül a cselédség lakott a legrosszabb kivitelü, földszintes sorházakban, melyekben kis méretü, közös konyhás lakásokon voltak kénytelenek osztozni. Ennél rosszabb elhelyezést csak az időszakos munkákat végző summások kaptak, akik az üresen álló ólakban aludtak. Egyes majorok mérete kisebb falvakkal vetekedett, ilyenkor már boltok, templomok és iparosok is jelen voltak külön ingatlanokban, e majorok már uradalmi falvakként is értelmezhetőek (BALOGH A. - BAJMÓCY P. 2011, EREDI F. 1976, ILLYÉS GY. 1972).

A majorok szakszerü átalakítására több esetben volt törekvés, még a földosztást megalapozó 1919. évi XVIII. néptörvény is rendelkezett arról, hogy tanyák, majorságok, valamint egyéb gazdaságok a földosztások után is gazdaságilag használhatók maradjanak a régi tulajdonos számára. Az1936. évi XXVII. törvénycikk a telepítésről és más földbirtok-politikai intézkedésekről rendelkezett arról, hogy a majorsági földek kiadása során az okleveles gazdákat előnyben kell részesíteni (TóTH L. 2004). 1945-ig a majorságok - mint lakóhely és üzemforma fejlődése a hullámvölgyek ellenére tartós, a prosperáló mezőgazdaság egy sikeres formája volt. A világháború után azonban az államosítás, a szövetkezesítés és a kapitalista termelés megszunnése miatt elvesztették létalapjukat. A telekosztás során a föld eltünt alóluk, a kastélyokat kifosztották, gyakran ideológiai alapon rombolni kezdték, vagy új funkciót kaptak, mint szociális otthonok, vagy szükséglakások, esetenként TSZ központ lett belölük (BAJMÓCY P. - BALOGH A. 2012).

A majorsági földek szétosztásakor elméletileg próbálták figyelembe venni a korábbi cselédség érdekeit, de ezt ritkán sikerült teljesíteni, gyakran a községek lakossága igyekezett a majorságiakat kiszorítani, esetenként a falusi gazdák kiszántották a házhelyeket. 1945-47 között a földreform során csak a földek 58,2\%-a került magánszemélyekhez, mindössze 1,9\% lett házhely céljára kiosztva és az előnyben részesítési követelmények sem valósultak meg. A kényszerü elköltözések s kitelepítések mindennapossá váltak, de a mobilitás lehetősége és a majorság meglehetősen zárt közösségéből való kilépés a cselédek jelentős részének ténylegesen vonzó alternatíva volt. Ugyanakkor a nincstelen lakosok egy része képtelen elköltözni és csapdahelyzetbe kerül, így a cselédség kiáramlása lassú folyamat volt, a nyolcvanas évek derekára cserélődött ki a majorok lakossága. Ennek megfelelően ma a „tősgyökeresek” leszármazottjai marginális kisebbséget képviselnek a majorok társadalmában (ORBÁN S. 1996).

A szocializmus évei alatt a majorok hasonlóan nehéz helyzetben voltak az adminisztratív akadályok miatt, mint a tanyák és a kúriák jelentős része leromlott. A majorok egy részébe megindult a cigányság áttelepítése a felszámolásra ítélt telepekről, azonban a legtöbb esetben ez semmivel sem jelentett jobb életkörülményeket és az elzártságuk sem csökkent. A mezőgazdaság gépesítésével pedig a munkaerő egy része kénytelen volt elhagyni lakóhelyét, vagy a közeli településekbe ingázni a gyakran tragikusnak mondható közlekedési helyzet ellenére (BALOGH A. -CSAPÓ T. 2013, BAJMÓCY P. - PÓCSI G. 2008, PÓCSI G. et. al. 2008). 
Azon a majorok esetében, amelyek fejlődése nem szakadt meg, gyakran falusias képet alakítottak ki a társadalmi folyamatok (Győrszemere - Nagyszentpál), esetleg önálló településsé váltak (Töltéstava). A rendszerváltás után a jó elérhetőségü majorok egy jelentős részét a szuburbán átalakulás (Sopron- Brandmajor) és az ipari telephelybővítések (Győr-Somosmajor) felfedezték. Mindhárom esetben gyakori az ingatlanállomány teljes kicserélődése, a klasszikus majorsági jelleg teljes elvesztése, azaz csak a külterület helye kerül hasznosításra, az eredeti település megszünik (BAJMÓCY P. - BALOGH A. 2012, JANKÓ F. 2004).

1990 után jelentős differenciálódás alakul ki az infrastruktúra és az elérhetőség függvényében. A szerencsésebb fekvésű majorok funkcióellátottsága jelentősen kibővült, megjelentek az ipari, turisztikai és kereskedelmi egységek, ahol megfelelő tőke állt rendelkezésre, a mezőgazdasági termelés is újjáéledt (I. melléklet, 4. kép). A majorok egy része jelentős turisztikai és müemléki értéket is képvisel, ennek megfelelően 21 majort nevez meg a nemzeti vagyonról szóló 2011. évi CXCVI. törvény a nemzeti vagyonnak minősülö, müemléki védelem alatt álló építmények és építmény együttesek között. Ellenben a városoktól távolabbi majorok többségének népességvesztése és gazdasági hanyatlása felgyorsul (I. melléklet, 5. kép). Az 1990 előtt fejlődést mutató puszták jelentős része sem tudja már megőrizni dinamizmusát, mivel a TSZ igényeihez igazodó infrastruktúra a lakócélú használatot nem elégíti ki (NAGYVÁRADI L. - SZABÓ-KOVÁCS B. 2008, BAJMÓCY P. - PÓCSI G. 2007). Emellett a tanyákhoz hasonlóan a mezőgazdasági területekkel egy ingatlant képező majorokra is érvényesülnek a földtörvény és a földvédelem szigorú regulái.

A szőlőhegyek olyan, korábbi szőlö- és gyümölcsmüvelési célból kialakult történelmi külterületek, melynek fejlődését meghatározza a szőlőmüvelési területhasználatból átörökölt telek-, utca- és ingatlanszerkezet. Általában a szőlők egyutcás, hosszú szalagtelkes kialakítása máig meghatározza a településképüket, ebböl kifolyólag olyan átmeneti települések, melyek több házból állnak, nincs zárt településmagjuk, a lakófunkción kívül legfeljebb agrár- és rekreációs hasznosítás a jellemző, az erdők, szőlők és gyümölcsösök aránya lényegesen nagyobb területükön, mint a zártkertek esetében. A szocializmus alatt többségük zárkertesedési, ritkábban belterületesedési folyamaton ment keresztül vagy romlásnak indult (I. melléklet, 6. kép). Kedvező adottságaik miatt 1990 után a szuburbanizáció kiemelt területei lehetnek, ha infrastruktúrájuk képes kielégíteni a modern igényeket (ÉGETŐ M. 1974, ÉGETŐ M. 1985, ÉGETŐ M. 1999 ÉGETŐ M. 2003, ÓNODI G. - CROS KÁRPÁTI Zs. 2002).

A szőlöterületek igazgatástörténete több száz évre nyúlik vissza, a XIV. századtól kezdve sajátos jogállásuk volt a munka intenzív jellege és a befektetések szükségessége miatt Magyarországon. A jog megkülönböztette a majorsági és a jobbágyszőlőt, utóbbi lehet kertszőlő (háztáji müvelés a jobbágytelken), vagy nem-jobbágytelki szőlő, ami a tulajdonos által szabadon adható-cserélhető volt, a jobbágy ezt a földesúrtól bérelte, de meg is vásárolhatta, azonban adóznia kellett a termény után. Ha túl nagy volt a szőlő területe, hogy a családjával megmüvelje a bérlő vagy tulajdonos, akkor bérmunkások műveltették, a majorsági szőlőkben pedig napszámosok dolgoztak. E tulajdonjogilag kevert állapot tisztázásának szándéka vezetett a hegyközségek kialakulásához (ÉGETŐ M. 1985, ÉGETŐ M. 2004, MOHOS M. 2008).

A hegyközség a szőlő birtokosainak, bérlőinek és a szőlőműveseknek, önkormányzati jellegü, de hatósági jogkör nélküli intézménye volt. Feladata a szőlő- és borgazdálkodás feladatainak, a művelésnek, az őrzésnek és az értékesítésnek az összehangolása; a minőségvédelem, azaz a borfajták, müveletek, technológiák és az optimális területhasznosítás meghatározása; az érdekvédelem, ebben a formában a nemes, a polgár, a jobbágy és vincellérek közös intézménye volt. A hegynép maga közül választott elöljárót, hegymestert, akinek a feladata a hegytörvények betartatása, a birtokosok érdekeinek képviselete a földesúrral és a várossal szemben, továbbá a hegykönyv vezetése (ÉGETŐ M. 1985, ZACHAR P. K. 2005).

A község vezető testülete a hegyi tanács volt, amelyet 6-12 jó hírü szakember alkotott, ez évi két gyülést tartott, ahol elhangoztak a beszámolók a határbejárásról, a büntetésekröl, és itt volt lehetőség a viták rendezésére. E tanács a hegytörvények alapján müködött a XVI-XIX. század 
során, ez alapján kötelessége volt meghatározni a feudális szolgáltatásokra vonatkozó kötelességeket, a szőlőmunkák végzésének idejét, módját, technikáját, a gazdasági és társadalmi viselkedés erkölcsi kereteit, valamint a hegybíró hatásköreit. A testület biztosította a hegybíró házát (ÉGETŐ M. 1985, ÉGETŐ M. 1999), amely nívós épületek máig megtalálhatóak több szőlőhegy területén.

A XVI. századtól területileg, közigazgatásilag és jogilag elkülönültek, az önállósuló szőlőhegyi birtokos-közösségek a XIV. századra autonóm önkormányzati szervezetekké váltak, de XVIXVII. századok között autonómiájuk a földbirtokosok és földesurak nyomására korlátozódott, a két csoport közötti változó sikerü ,párviadal” követhető a kor törvényeiben. Jelentősek voltak a változások a XVIII. sz. közepétől, mivel az egyes vármegyék saját hatáskörükben próbálták immár szabályozni a szőlöhegyeket, ekkor indult meg a mai településképre is hatást gyakorló egyutcás szalagtelkes kép elterjedése (ÉGETŐ M. 1985, ÉGETŐ M. 1993, FRISNYÁK S. 1984).

1753-ban Zala megye - ahol erős volt a kis- és középnemesség - adta ki az első megyei statútumot. A városi polgárok egyre több szőlőt vettek befektetésként ebben az időszakban és bérmunkásaik (vincellér) kiköltöznek a hegyekbe, amelyekben a tanyákkal rokonítható külterületi lakóhely alakult ki. Ennek típusai: a faluban lévő ház elszórt hegyi birtokkal; a szőlőhegyen lakó szórt birtokai és külön telken lévő lakóingatlana; vagy külterületi kompakt gazdaság. Utóbbi megjelenésében és fejlődésében tényleges követi a tanyák alakulását a korban. Fontos kiemelni, hogy a szőlőhegyekben csak az ott termeléssel foglalkozó tulajdonosok és munkások építkezhettek (KovÁCs K. 1985, MoHOS M. 2007).

A XIX. sz. végén azonban a hegyek fejlödési pályáját megtörte a szőlögyökértetü járvány (Phyloxera vastatrix), amely az 1880-as években a dombvidéki, kötött talajú magyar borvidékek szőlőiben jelentős pusztítást végzett. A szőlő területek aránya lecsökkent, a meglévő hegyeken nőtt a gyümölcsfák jelentősége. Elterjednek a homoki szőlősök, amelyek gyakran megőrizték a hegy szót nevükben (ÉGETŐ M. 2003, MoHOs M. 2007, MoHOS M. 2008).

A filoxéravész utáni válság enyhítése a cél, amikor minisztériumi szintre helyezik a hegyközségek irányítását, az 1884. évi önkormányzati törvény újra létrehozta a hegyközségeket és a munkaigény kiköltözési hullámot generált. Ekkorra alakul ki a hegyek eszményi formája, a területet kerítés és árkok (gyepü) veszi körbe a lopás és vadkár megelözésére, ezen csak 1-2 kapun lehetett átjárni és kialakítottak meghatározott szekérutat, sok helyen így az úthálózat máig ezt követi (holott már szölö sincs), és a telkek összevisszaságát a gyepü szabályozatlan igénybevételének nyomait viselik (hosszú/kanyargós telkek). Megyekövek jelölték a telekhatárokat, maximalizálták és meghatározták a gyümölcsösök helyét (pl.: telekhatáron), ezáltal az ingatlanállomány és a telekszerkezet alapjait ekkor rakták le (ÉGETÖ M. 1974, ÉGETÖ M. 1978, ÉGETŐ M. 2003, ÉGETŐ M. 2004, MOHOS M. 2007).

A szőlőhegyekre történő tartós betelepülés nyugatról haladt kelet felé, és alapvetően szegény felszabadult parasztokat és városból kiáramló - általában előtte is szőlőt müvelő parasztpolgárokat vonzott a szórvány jellegü lakóhely. 1894 után sok hegyet faluhoz csatoltak, többől új falu lett, vagy majorként került számításba. A Klebelsberg-féle tanyaprogram, új községek kialakítása hegyekből, vagy a faluhoz csatolások javították az életminőséget, különösen ott, ahol vasút vagy köves út volt, továbbá a Balaton-Felvidék sajátos szölöhegyein. Gyakran a lakásállomány 10-20\%-os bővülése is elegendő volt a lakosság kétszereződéséhez, a kint élők aránya ekkorra a telektulajdonosok 30\%-a fölé emelkedett a legjobb adottságú hegyekben (ÉGETŐ M. 1993, KovÁcs K. 1985, MoHOS M. 2007).

Az első világháború alatt a munkák jelentős része elmaradt, majd a piacvesztés (Trianon) és a világválság hatására tovább csökkent a szőlő jövedelmezősége és új funkciók jelentek meg, így a kavics- és homokbányák, majd a turizmus. A 3300/1949. (IV. 9.) rendelet egyszerüen államosította a hegyközségek minden vagyonát és megszüntette őket. Mindössze tíz év múlva átmenetileg ismét megjelentek e községek az erőszakos kollektivizálás buktatói miatt, mivel az 1958. évi 6. törvény szerint a szőlő- és gyümölcstermelök öntevékeny csoportok müködése szükséges, ezek szervezik és fejlesztik a termelést, tapasztalataikkal elősegítik a nagyüzemi 
átalakulást. Sajnos e törvény sem volt hatékony, idővel egyszerüen nem alkalmazták, majd a 1968. évi 36. törvény hatályon kívül is helyezi és az 1994 évi CM. törvény megjelenéséig teljesen megszünt a szölöhegyi rendtartás klasszikus formája. A külterületi lakosság csökkentését célzó politikák miatt a tanyáknál is gyorsabban veszítették el lakosságukat és sokszor olyan településhez kapcsolták őket melyekhez nem kötődtek (MOHOS M. 2008, ZACHAR P. K. 2005).

A mezőgazdasági hasznosításra alkalmasabb területeken a táblásítás eltörölte a hegyek egy részét, sok település határában így szinte csak a rossz talajú és elaprózódott területek maradtak meg. A jobb elérhetőségü hegyek megindultak a beépülés útján, és e zártkertesedés sokszor teljes beépüléssel járt (belterület), vagy üdülőkké alakítással, föleg a jó táji adottságú területeken. A fragmentált, de jó talajadottságú területeken a gyümölcsösök és kisebb részt zöldségesek terjedésével megindult a kertséggé, végül zárkertekké alakulásuk (4. ábra; I. melléklet, 7. kép) A jó talajú, jó fekvésü, de kevésbé jól elérhető hegyek esetében általános a teljes hanyatlás, területüket vagy a táblásítás keretében beszántották, vagy feladásuk után mára benőtte őket az erdő (ÉGETŐ M. 2004, ÓNODI G. - CROS KÁRPÁTI Zs. 2002, ZACHAR P. K. 2005).

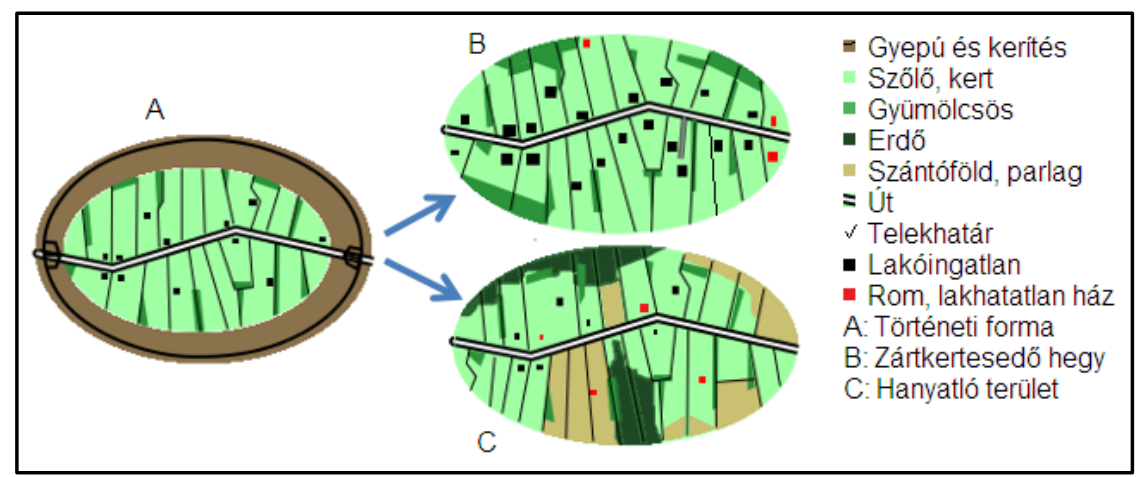

4. ábra: A szőlőhegyek morfológiai átalakulásának újtai a XIX. századtól máig (szerkesztette a szerző).

A rendszerváltás után a legtöbb szőlőhegyre vagy - a következőkben bemutatandó - zártkerti szabályozás érvényesül, vagy a 1994. évi CII. törvény által helyreállított hegyközségek sajátos rendtartása. Ezek értelmében az ingatlan-nyilvántartásban zártkertként nyilvántartott ingatlanokra a termőföldre vonatkozó szabályokat kell alkalmazni, így a szőlőhelyek esetében is, a tanyáknál már bemutatott, egyre szigorodó regulák váltak irányadóvá. A szőlőtermesztést és a borgazdálkodást szabályozó 1997. évi CXXII. és 2004. évi XVIII. törvények értelmében a bortermelő vidékeken található szőlőhegyek szőlő és gyümölcsös müvelési ágú ingatlanaira érvényes a hegyközségek szigorú szabályzata. Ez határozza meg az ingatlanok, az utak, vízelvezető árkok állapotára és növényvédelmére, valamint az ingatlanok rendeltetésszerü használatával kapcsolatos létesítmények karbantartására vonatkozó szabályokat.

Fontos kiemelni, hogy e rendtartások előírásait a szőlőhegy területébe eső, más müvelési ágú külterületi ingatlanok használóinak és az utak kezelöinek is be kell tartaniuk. Így például a művelési kötelezettség be nem tartása esetén 200000 forintig terjedő bírság vagy kényszerkivágás is lehet a retorzió, továbbá a müvelési ág váltásokat (például lakóingatlanra) a hegybírók engedélyéhez és a szőlö kivágásához köti a 1997. évi CXLI. törvény. Ez jelentős terhet ró az itteni telkeket kertnek, üdülőnek, vagy lakóingatlannak használókra.

\subsubsection{A modern külterületek}

A zártkert előzményeinek, a kertségeknek Európában hosszú hagyománya van; az ipari forradalom után terjedtek el a munkásság életminőségének javítása érdekében létrejövő kiskertegyesületeknek köszönhetően. E mozgalom célja az volt, hogy a vidéki életmód pótlásán és a konyhára való zöldség megtermelésén túl szociális kapcsolatokat is teremthessenek az érintettek. A két világháború időszakában a kertek nem csak a nélkülözés miatt váltak fontos termőfölddé, de a kerti viskók szükséglakásként szolgáltak a háború áldozatai számára. A 
tanyáknál és majoroknál már tárgyalt 1919. évi XVIII. néptörvény rendelkezett a kertségek újraosztásáról is, melyben a hadirokkantak és özvegyek előnyben részesítését írta elő (ÓNODI G. et. al. 2002).

1945 után számuk jelentősen visszaesett, mert a városok bővülése során területüket beépítették, de sok kertség kaotikus bódévárossá züllött. Nyugat-Európában a rekreációs, oktatási, rehabilitációs és szociális szempontból fontos kertek maradtak meg leginkább. A kontinens e felén a kertek többsége érdekvédelmi feladatokat is ellátó közösségi együttesek tulajdonában vannak, ahol a parcellákat a használók hosszú távon bérlik. A törvény a legtöbb országban a kiemelten védi a tartósan fennálló kerteket eredeti céljuk és zöldfelületi jellegük miatt, a később beépítendö tartalékterületeken pedig ideiglenes kertek müködnek. Ezzel szemben KeletEurópában a kertségek a termelőszövetkezetek és szakszervezetek tulajdonába kerültek, jellemzően mezőgazdasági termelés és csak másodsorban rekreációs célok miatt. Az 1945 utáni földosztás során a kertek jelentős része is újraosztás alá került, azonban ennek hatása kevéssé volt jelentős, mint más külterület-típusok esetében (ÓNODI G. et. al. 2002, TóTH L. 2004).

Történelmileg hazánkban az osztott földhasználat révén alakult ki a dunántúli szőlőhegyek mintájára a kertek jogi rendszere, majd idővel az alföldi mezővárosok belső legelöiben is létesültek vegyesen hasznosított szőlős-, zöldséges- és gyümölcsöskertek. Kertek, kertségek a legtöbb város, mezőváros és nagyobb község körül megtalálhatóak voltak, ezek feladata a piacra termelés mellett, az olcsó, nem szabályozott lakóhely biztosítása volt a város felé igyekvők és a városból kiszorulók számára. A jobb adottságúak fokozatosan beépülve hochstadtá, majd zárt települési utcává fejlődtek, ritkán elit villanegyedek is képződtek a legjobb természeti adottságú helyszíneken. Beépülésük után újabb kertek jöttek létre, melyek újra bejárták e fejlődési lépcsőket a város természetes növekedési ritmusának megfelelően. A kertségek a 19. század elejétől is a kiköltözési hullámok sorait vették fel (BELUSZKI P. 1982).

A kertek köre tovább bővült, amikor az urbanizáció révén bővülő vidéki gyökerű városi polgárság, majd a munkásság létrehívta a hazai kertmozgalmakat. A rekreációs használatot erősítette a 2. világháború utáni üdülőtelek-osztás, azonban a mezőgazdasági szövetkezetesítés a legjobb földeken elterülö kertségek egy jelentős részének megszünésével járt, az alulról építkező kert-mozgalmak pedig ideológiai alapon kerültek hátrányos megkülönböztetés alá (AZARI B. 2004, ÓNODI G. - CROS KÁRPÁTI Zs. 2002, [3]).

A kertségek nagy léptékü kiteljesedése, a zártkertek tömeges elterjedése a hetvenes évek elejére tehető. A zártkerteket az 1967. évi IV. törvény hívta életre (26-32. §), amelyet kiegészített a 36/1967. /X.11/ Kormányrendelet és a 7/1967. /X.2./ MÉM. rendelet, valamint az 1969. évi Zártkert Rendezési Útmutató. E jogszabályok alapján a zártkert a városok és községek külterületeinek nagyüzemileg nem müvelhető, elkülönített része. Azaz a zártkert a terepviszonyai, tagoltsága vagy más adottsága miatt az üzemi müvelésböl kizárt, kertes használatra szánt, kis méretű parcellákra tagolt terület, melynek célja a lakosság földhasználatának és földtulajdonának állandósítása.

A hivatkozott elöírások alapján a zártkerti földek jogszerúen 800 és 222 négyszögöl közötti parcellákra voltak oszthatóak. Az elöírások szigorúan mezőgazdasági hasznosítást írtak elő a területekre, így a kertmozgalmak által is támogatott „háztáji” termelés mellett eleinte legfeljebb rekreációs hasznosítás volt jellemző. Morfológiailag kis méretű telkekkel, sakktáblás utcahálózattal tervszerüen kialakított rekreációs és kertészeti célokat szolgáló külterület. Jelképes összegért bérbe lehetett venni, amely némi bevételhez juttatta az Tsz-eket (AZARI B. 2004, ÓNODI G. - CROS KÁRPÁTI Zs. 2002).

A nagyvárosok környékén azonban a hetvenes évek elejére újra "elfogytak" a zárkertek, mivel területük beépült vagy táblásítás alá kerültek. Így a korábbi századokhoz hasonlóan újak iránti igény keletkezett, főleg az ipari munkahelyek reményében vidékről a városi szükös bérlakásokba és panellakásokba a költöző tömegek részéröl. A TIT keretében kialakuló kertbarát körök az ÁFÉSZ számára termeltek, ez ösztönzően hatott a várostól távolabb fekvő területek 
zártkertesítésére és 1989-ig több, mint 40000 ha zártkert került kijelölésre (CsORDÁs L. 1993, CSORDÁs L. 2007, ÓNODI G. - CROS KÁRPÁTI Zs. 2002).

A zártkerti földek eladása esetén a termelöszövetkezetet elővásárlási jog illette meg, mivel azonban nem volt megfelelően regisztrálva és rendezve a tulajdonlás, az ingatlan-átruházások és hagyatéki ügyek kapcsán kaotikus tulajdonjogi és földhasználati állapot alakult ki, amely a termelőszövetkezetek bevételeire is hatással volt. A felülvizsgálatok - többnyire - rendezték a kérdést, azonban a rendszerváltás időszakára újra általánossá vált a rendezetlen tulajdonjogi státusz, és az osztatlan közös tulajdonú telkek száma is tetemes lett. Emiatt a telkek megítélése meglehetösen ambivalens volt, a zürzavaros tulajdonviszonyok és településkép miatt az építészeti szakma negatívan értékelte a folyamatot, míg a szükös panellakásban élök telkezési vágya létezö társadalmi igényt fejezett ki (CSORDÁs L. 1993, ÓNODI G. - CROS KÁRPÁTI Zs. 2002).

A kertségekben telekosztási tervek nélkül kijelölt területeken kialakuló háztáji gazdaságok és a tervezetlenül, gyakran ad-hoc módszerekkel készült ingatlanok a kaotikus településképet eredményeztek, mivel sem az Országos Építészeti Szabályzatok, sem a helyi településrendezési tervek nem tudták kezelni a perifériális helyzetü, kisméretü kerteket (AZARI B. 2004). A tulajdonszerzési korlátozások is gyorsították a zártkertek kiépülését, mint a befektetés egy sajátos formája, hiszen egy család egy lakás és egy üdülő mellett is még birtokolhatott egy zártkerti ingatlant. Az 1967 évi. IV. törvény alapján személyi tulajdonban belterületen 1600 négyszögöl, zártkertben 800 négyszögöl szőlőnek vagy gyümölcsösnek kijelölt terület és legfeljebb 1600 négyszögöl egyéb használatú föld lehetett.

Elöször a klasszikus szőlős, zöldséges és gyümölcsös müvelés terjedt el, azonban már a hetvenes években megindult a termesztő kertek egyre nagyobb arányú átalakulása üdülőkké, díszkertekké. Bár szigorú tilalom volt a szocializmus éveiben az ideköltözésre, hamar megindultak a kiköltözések, idöszakos (nyári), majd tartós lakhatási célból. Különösen ott volt kiemelkedő a beépülés gyorsasága a hobbikertes-üdülős övvé válást követően (esetenként azzal párhuzamosan), ahol volt áram, ahol közel volt a városhoz a kertség, valamint ahol a nagyvárosba beköltöző vidékiek, valamint a panelban lakók igényelték a zöldfelületet és a mezőgazdaságot, mint rekreációs eszközt. 12-33 $\mathrm{m}^{2}$-s üdülők és mezőgazdasági célú épületek ellepték a tájat, a vonatkozó szabályozás gyakori változása és nem megfelelő betartatása miatt meglehetősen kaotikus településképet eredményezve (ÓNODI G. - CROS KÁRPÁTI Zs. 2002).

A szuburbanizációt helyettesítő tevékenységek, a vidéki üdülök és hobbikertek tartása is emelte a beépülő zártkertek számát. Számtalan idős lakos, valamint értelmiségi idővel városi lakását eladta, és véglegesen kiköltöztek a korábbi hobbikertbe, hasonlóan azokhoz, akik válás, vagy más okok kapcsán kényszerültek a kerti ingatlanba. Szociálpszichológiai hajtóeröi azonosak/hasonlóak voltak az 1990 után felfutó szuburbanizációhoz, azonban az államszocialista rendszer és a piac hiánya miatt más a folyamat jellege (CSORDÁs L. 1993, ÓNODI G. - CROS KÁRPÁTI Zs. 2002).

Sajátos esetekben megindult a korábbi szőlőhegyek és tanyás tájak olyan mértékü beépülése, hogy azok átalakulnak a zártkerti fejlődés valamely szintjére. Ezt a szabályozás is elősegítette azáltal, hogy számtalan esetben majorok, korábbi üdülők, szőlőhegyek és tanyás területek zártkerti besorolást kaptak (PÓCSI G. 2009a, PÓCSI G. 2011).

A zártkertek tulajdonszerkezetére jellemző volt a városiak hegemóniája, még a Budapesttől 100$120 \mathrm{~km}$ távolságra található vidéki középvárosi zártkertek esetében is $20 \%$-os részesedése is volt a fövárosiaknak, mivel gyakran a vidékröl felköltözők vásároltak szülöhelyükön üdülönek kertet. Mivel a zártkertek túlnyomó többsége a hetvenes években került kijelölésre, az ekkor koraközépkorú népesség jellemezte a tulajdonosi kört, és így a rendszerváltásra elöregedő, 50-60 éves közösség elkezdte felhagyni a telkeket. Továbbá a kárpótlással és a földprivatizációval járó telekaprózódás és a megöröklött rendezetlen tulajdonviszonyok jelentősen hátráltatták a zártkertek adaptálódását a piaci viszonyokhoz (CSORDÁs L. 1993, ÓNODI G. - CROS KÁRPÁTI Zs. 2002).

Külön kategóriát képviseltek a zártkerteken belül az úgynevezett „,vitézi telkek”, amelyeket politikai érdemeik elismerésére kaptak a rendszer kedvezményezettjei a legjobb táji értékü és jó elérhetőségü földeken történt, ugyanakkor ugyanolyan hiányos telek- és településrendezési 
feltételekkel, mint a többi kertség. E területeket fedezte fel leghamarabb a szuburbanizáció, többük mára elit lakóterület lett, míg mások önálló faluvá váltak (Remeteszőlős) (ÓNODI G. CROS KÁRPÁTI Zs. 2002).

Mivel az 1967. évi IV. törvény 1987-ben hatályát vesztette konkrét sajátos szabályozás nélkül maradtak a jogi értelemben eddig is hányattatott sorsú zártkertek. Az új földtörvény (1992. évi XVII.) a zártkertek fogalmát megszüntette, innentől azonos szabályozás alá kerültek a többi mezőgazdasági területtel, majd az 1997. évi OTÉK (253/1997.) meg is szüntette a kertség területfelhasználási kategóriát. A rendezetlenség miatt a helyi közösségek, önkormányzatok gyakran csak utólag próbálják a meglévő esetenként anarchikus állapotokhoz igazítani a szabályozást, legalizálva azt, mert a rendezéshez, vagy belterületbe vonáshoz szükséges infrastruktúra-fejlesztéshez nincs anyagi hátterük (ÓNODI G. - CROS KÁRPÁTI Zs. 2002).

1990-ig a zártkerti szabályozás szerint alakult beépítettségük öröksége meghatározó volt, azonban a rendszerváltozás utáni átalakulás során erős divergenciát mutatnak. A többszöri bővítések és a módosított telekhatárok miatt jellemzőjük a kaotikus településkép (8. kép), a zárt mag és az ellátó funkció hiánya, de gyakori a lakó- és agrárfunkció mellett az üdülők és ritkábban üzemi telephelyek kialakulása. A rendszerváltás óta sem sikerült rendezni e területek szabályozását, zártkerti területeken belüli differenciált, a létező funkciókat elismerő terv alig készült hazánk településein (Pócsı G. 2009a, PóCSI G. 2011, [4]).

1990-1995 között tehát válság határozta meg e területek többségének alakulását, egyre több ingatlan került feladásra, több kertes-szőlős egység kiürült az országban. Ugyanakkor egy jelentős része a kertségeknek elkezdett bódévárosokká degradálódni, ahogy a posztszocialista urbanizációra jellemzően a kevésbé tehetős lakosság elkezdett kiszorulni a városokból. 1995 után kezdi a piac a kerteket újra felfedezni, föleg a régi kerttulajdonosok és pályakezdő fiatalok költöztek ki az olcsó telekre, az egyszerübb megélhetés miatt. Emellett gyakori, hogy az értelmiség rekreációs kertjeit a lecsúszottabb egzisztenciák pótkeresetet adó művelt kertjei, és régen felhagyott parcellák szegélyezik. Tájkép és elérhetőség függvényében tehát lepusztult bódéváros, modern lakóingatlanok, parlagon hagyott területek teljesen heterogén utcái alkotják a külterületeket ekkor (CSORDÁs L. 1993, PóCSI G. 2009b, SOLTÉSZ J. 1990).

A 1994. évi CII. törvény rendezte a zártkertek kisebb részének sorsát, azonban a külterületek jogi helyzete is meglehetősen komplex volt az elmúlt évtizedekben. A többször módosított OTÉK és 1997. évi CXLI., valamint a 2007. évi CXXIX. törvények révén egyre szigorúbb szabályozás nehezítette a zártkertek fejlődését. Mivel az ingatlan-nyilvántartásban zártkertként nyilvántartott ingatlanokra a termőföldre vonatkozó - a tanyakérdésnél már bemutatott - szabályokat kellett alkalmazni azok adásvétele, alakítása és beépíthetősége szigorúan kötött volt. Ugyanakkor nagyon gyakoriak voltak a jogszabályi változások, így például a beépíthetőség korlátja is esetenként évente változott. Ráadásul, ha a tulajdonos vétett e szigorú szabályok vagy a mủvelési kötelezettség ellen akkor elvileg a 2007. évi CXXIX. törvény alapján az önkormányzatok 1 évre saját használatba vehették az ingatlanokat. 2013 után pedig az új földtörvény már bemutatott eljárását kellett alkalmazni a zártkerti ingatlanok adásvétele során.

1995 után a zártkertek - mivel a napi rutinban e kifejezés ragadt meg a kertségekre, így e dolgozat során is ezt alkalmazom szinonimaként a kertségekre - jellemzően a kevésbé tehetős rétegek lakhelye lett, ritkábban, a jobb infrastrukturális állapotú és jó elérhetőségü területeken a klasszikus középosztályhoz kötődő klasszikus szuburbanizáció is jelentkezik. A rosszabb adottságú területeken a lakófunkció mellett a mezőgazdaság és az üdülö jelleg dominál, a föutak mentén fekvő néhány területen az ipari szektor is megjelenik. Ennek meghatározója a fekvés, a táji szépség, az úthálózat és az infrastruktúra állapota (Pócsi G. 2009B, PóCSI G. 2011).

Csupán a 2016. évi CLXXXVII. törvény reagált a bemutatott nehézségekre. A zártkerti ingatlanok ma már hobbitelkek vagy állandó lakhatás célját szolgálják és a tulajdonosok általában nem tettek eleget hasznosítási kötelezettségeiknek, de az önkormányzatok sem tudtak érvényt szerezni a helyi szabályoknak, így a zártkertek müvelés alól kivonása indokolt. Ennek megfelelően az addig helyrajzi számonként sok százezer forintba kerülő eljárások helyett a 
tulajdonos ingyenesen kérhette az ingatlan-nyilvántartásban zártkertként nyilvántartott ingatlan művelés alól kivett területként történő átvezetését. Továbbá a beépíthetőségi korlátot is 10\%-ra emelte a 156/2016. kormányrendelet. Ebböl kifolyólag megszünt a müvelési kötelezettség, könnyebbé vált zártkertek forgalma és a bankok is már elfogadhatták hitelfedezetként e telkeket.

A bánya- és ipartelepek olyan külterületi lakott helyek, melyek részben régi bányászkolóniák, részben pedig a különböző üzemek mellett kiépült szolgálati lakásokból vagy készenléti lakótelepből és a kapcsolódó gazdasági telephelyekből állnak. 1909. évi XV. törvény az állami kőszénbányászat fejlesztéséről a munkaerő biztosítása érdekében már kiemelten kezeli a lakásépítések kérdését, azonban a szénbányászat államosításáról szóló 1946. évi XIII. törvény az üzemekkel együtt a munkáslakásokat, tartozéképületeket és a munkavégzés során használt egyéni ruházatokat is állami tulajdonba emelte. Infrastruktúrájukat a bányászati üzem határozta meg, ingatlanállományuk összetétele vegyes, panel-technológiájú ingatlanok, vagy csökkentett értékü lakások is alkothatják. Tartósan 17 db létezett azonban 1970 után megszünésük általános a bányászat hanyatlásával párhuzamosan (BALOGH A. 2012, VALLER É. 1996).

$\mathrm{Az}$ ipartelepek jelentős része valamilyen külterületi üzem munkaerőigényét kielégítő lakóhelyek, valamint a vízügy és a különböző távvezetékek készenléti lakótelepei. Hazánk történelmi iparvidékein találhatóak hagyományos téglaépítésü, majorokra emlékeztető megjelenésü egységek, míg a szocializmusban épületekre a paneltechnológia is jellemző. A még lakottak többsége olyan téglagyári, cukorgyári telephelyek mellett fekszenek, ahol a gazdasági termelés megszünt és csak a lakófunkció maradt meg (BALOGH A. 2012).

Sajátos esetet képeznek az állami gazdaságok vagy termelőszövetkezetek állandó munkaerö jelenlétet igénylő üzemei mellett kialakított szolgálati lakótelepek. E telepek lakói az adott gazdaság dolgozói és azok családtagjai alkották, a lakások az üzem tulajdonában voltak, azonban 1990 után a lakók kiválthatták a tégla- vagy panelépítésü, jellemzően földszintes vagy 1 emeletes többlakásos házakat. Jellegükben nem különböznek ma már az azonos adottságú majoroktól (BALOGH A. 2012, VALLER É. 1996).

Őrházak és forgalmi települések közé a különböző külterületi objektumok ellátását, felügyeletét vagy müködtetését biztosító út és víz menti karbantartók és őrök lakóhelyei, valamint az erdészházak sorolhatóak. Általában magányosan álló szolgálati lakások vagy 3-6 lakásból álló kis telepek, melyeket kisebb gazdasági épületek (raktárak, mühelyek) vagy müszaki berendezések (átemelök, szivattyúházak) egészítenek ki. Jellegükből fakadóan nincs két egyforma térbeli és müszaki kialakítású egység, ugyanakkor társadalmuk meglehetősen homogén. Az őrházakat szinte minden esetben az ott élő alkalmazott (gátör, pályaőr) és családja lakja állandóan, míg a forgalmi településen gyakoriak a szolgálati lakások (vasútállomások), esetenként a tulajdonos vállalat nyugdíjasainak lakásai. Ebből kifolyólag többségük ma is lakott, megszünésük oka leggyakrabban a müszaki fejlődés következtében való feleslegessé válásuk (bakterházak), kevésbé a társadalmi folyamatok (BALOGH A. 2012a, VALLER É. 1996).

Külterületi szociális intézmények jellemzően korábbi majorok kastélyaiban, ritkábban újonnan épült ingatlanokban található szanatóriumok, kórházak, elmegyógyintézetek, szociális otthonok, nem kórház jellegü szociális elmeotthonok és nevelőotthonok tartoznak ebbe a típusba, kisebb arányt képviselnek az oktatási- és sportlétesítmények. Számuk kicsi, azonban - kiemelten az idősek otthonaiként és szociális otthonként szolgálók - jelentősen tudják befolyásolni a település demográfiai mutatóit a halálozások és a beköltözések számának emelésével. Azonban fontos kiemelni, hogy ezen intézmények részéről mutatkozó népességváltozás nem tekinthető a szuburbanizáció részének, mert a létszámokat jellemzően adminisztratív döntések határozták meg (BALOGH A. 2012a, VALLER É. 1996).

Üdülők és külterületi szálláshelyek, üdülőként használt ingatlanok nagy számban találhatóak az országban. Ezek felszíni vizek, termálfürdők közelében, hegyvidékeken és más természeti szempontból értékes területeken kialakult üdülötelepek, vállalati üdülök és szállodák, továbbá ide sorolhatók még a külterületi, lakossággal rendelkező turistaházak és munkásszállások. Emellett ki kell emelni, hogy számtalan zártkert és szőlőhegy is üdülőteleppé alakult a 
szocializmus évei alatt (I. melléklet, 9. kép), ezek társadalmi összetétele és területhasználata jelentősen eltér a többi zártkerttől. Lényegesebben fejlettebb e területek átlagos elérhetősége, infrastrukturális ellátottsága, a telkek mérete kisebb, magasabb a beépítettség, ugyanakkor a kertekben ritka a mezőgazdasági termelés, azok inkább díszkertként, vagy gyepes pihenőhelyként szolgálnak. Az egyéb funkcióval nem bíró második otthonokból álló zártkerti és szőlőhegyi, vagy tanyás külterületek, valamint az üdülőként használt présházak és egyéb épületek is e kategóriába tartoznak (BALOGH A. 2012a, VALLER É. 1996). Jogi szabályozást tekintve a zártkertekhez hasonló utat jártak be az üdülők, ugyanakkor a 156/2016. kormányrendelet e területeken 30\%-ban határozza meg a beépítés felső korlátját, jelentősen javítva az ingatlanok értékét, hasznosíthatóságát.

Periurbán vagy településperemi utcák létezésének oka általában az igazgatás lemaradása a valóságos területhasználathoz képest. Jellemzően úgy alakultak ki, hogy egy utca túlnőtt a közigazgatási határon, és a lakóingatlanok egy része külterületi ingatlanként épül meg, ritkább eset, amikor a tervezett, de nem teljesen befejezett ingatlanfejlesztés során épült ingatlanok tervezett belterületbe vonása marad el. Többnyire nincs külterületi jellege e területeknek, településképét és a napi valós életvitelt tekintve a település egy átlagos utcája, ezért többségük várhatóan belterületté lesz nyilvánítva, amennyiben ennek anyagi fedezete megteremtődik. Dinamikusan bővülő népességü településeken a szocializmusban és a rendszerváltás után is előfordult, hogy a korábbi külterületet utolérte a belterület bővülése és peremmé váltak, ezek jellemzően szőlőhegyek, zártkertek, üdülők és majorok (BAJMÓCY P. - MAKRA Zs. 2016).

Cigánytelepekben, a városok és a falvak határán kívül lévő zárt közösségekben, ,putrikban” lakott, értéktelen földön, esetenként árvízveszélyes térszínen, vagy korábbi gazdasági telephely helyén 1945 előtt a cigányság egy jelentős része. 1960 után az állam sürgette a telepek felszámolását, a 2/1965. ÉM-PM rendelet kimondottan a legrosszabb lakóhelyek megszüntetését célozta ingyenes lakáshelyek adásával. Ez a folyamat azonban nem teljes körüen zajlott le, továbbá a telepekről gyakran szintén félreeső külterületekre kerültek a lakók, így helyzetük nem változott vagy romlott. Cigánytelepek külterületen jellemzően majorban, bányatelepen, üzemi lakóhelyen, vagy periurbán utcában alakultak ki. 1945 után a falvak határában megmaradt vagy újonnan létesült, csökkentett értékü ingatlanokból épült („,cs. lakás”) telepek rendszerint jelentős népességnövekedésen mentek keresztül. A teljes szegregáció miatt kialakuló zárt közösség, védekező szubkultúra alakult ki, az infrastruktúra, a szociális ellátás és a szakképzettség szinte teljes hiánya egyfajta gettósodási folyamatot indított be maguknak (KRISTÓF A. 2015, [5]).

A szocialista gazdaság válságtüneteinek megjelenése, és különösen a rendszerváltás után sok új telep képződik (11. kép) vagy népesül be újra, ezek jellemzően olyan bányásztelepek, tanyabokrok, munkásszállók vagy zártkerti egységek területén alakulnak ki, amelyek rossz elérhetősége és infrastruktúra-állapota hiányos. E szegregátumokban az épületek többsége komfort nélküli, még vezetékes víz sincs. Lyukótelep és Lyukóvölgy az újonnan kialakult ilyen lakott helyek legjellegzetesebb hazai példája a 2004-ben bezárt bánya. A területen nem adnak építési engedélyt, mert a környék nem alkalmas a lakhatásra, közmủ nincs, csak áram. Miskolc városából a legszegényebb háztartások kényszerültek a gyakran teljesen téliesítetten ingatlanokba, a legkevésbé szerencsések pedig illegálisan építettek viskókat maguknak (KRISTÓF A. 2015, [5]).

A Vegyes szerkezetü és besorolhatatlan külterületek száma nagy, esetükben mára oly mértékben átalakult vagy leromlott az adott lakott hely, hogy meghatározhatatlan eredeti morfológiája és genetikája. A legtöbb ilyen külterület eredeti épületállománya lepusztult, és az újabban kialakult szerkezetben meglévő kevés régi ingatlan alapján legfeljebb csak következtethetünk arra, hogy major, telep, szőlőhegy vagy épp kertség volt-e korábban. Ide sorolhatók, azon külterületek is, melyek eredeti alaprajzát valamilyen tudatos beavatkozás (telephelybővítés, úthálózat-fejlesztés) tette felismerhetetlenné.

Szintén gyakoriak azon külterületek, melyek településképe előrehaladott funkcióváltás miatt vált nehezen kategorizálhatóvá. Többek kötött ilyenek a zártkertesedő tanyautcák (DomaszékÁbrahám), üdülőteleppé bővült majorok (Győr-Károlyháza), lakóutcává váló üdülők (Győr- 
Horgásztanya). Még bonyolultabbak azok a lakott helyek, amelyek területén több eltérö morfológiájú és történelmü külterület mára oly mértékben össze nőtt, hogy nem lehet különválasztani öket. Szemléletes példa Győr-Sashegypuszta, melynek területén egy egykori major, egy ipartelep és egy zártkert is található, vagy Győr-Újmajor, ahol az egykori cselédlakásokat zártkerti ingatlanok és víkendházak veszik körül. Továbbá sajátosak azok a cigánytelepek, melyekben még az eredeti gazdasági funkciót szolgáló ingatlanok is megtalálhatóak, azonban azok már üzemelnek (Miskolc-Lyukótelep).

\subsection{Az úgynevezett egyéb belterületek}

A disszertáció kérdéseinek megválaszolásához szükséges beszélni az egyéb belterületekröl is. Számos külterület eléri a fejlettség azon fokát, ahol infrastruktúrája már közelíti a belterületekkel szemben támasztott jogi követelményeket és ekkor egyé belterületté sorolják át őket. (BAJMÓCY P. 2003a, BAJMÓCY P. 2003b, BAJMÓCY P. - MAKRA Zs. 2016).

A 1992. évi LXXXIX. Törvény: 23. § alapján a települések lakott területeit a következő elemekre oszthatjuk:

- Központi belterület, az a belterületi település, amelynek területén az igazgatási szervek és általában az ellátó intézmények többsége található.

- Egyéb belterület, a központi belterülettel földrajzilag általában nem összefüggő város-, illetve községrész(ek), amely(ek) fejlesztése a belterületre érvényes szabályok szerint történik.

- Külterületi lakott hely, a város, község közigazgatási határa, valamint a belterületek határai közötti településrészek.

Földrajzilag általában elkülönülnek a központi belterülettől, megszünésük oka többnyire a központi belterülettel való egybeépülés. Az egyéb belterületek településföldrajzi megközelítésben eltérő genetikájú egységek csoportjaira oszthatók: Lehetnek korábbi önálló községek, melyek közigazgatási összevonás során a másik település egyéb belterületévé válnak, ritkábban egy köztes időszakban annak külterületei voltak és csak később nyilvánítják őket egyéb belterületté. Lehetnek tervszerủen kialakított üdülőhelyek, ipartelepek, üzemi lakóhelyek. Valamint korábbi külterületi lakott helyek, amelyeket valamilyen speciális adottságuk vagy a népességszám növekedése miatt belterületté nyilvánítottak. Ritkább esetben a városok központi belterületeit jogi szempontok alapján nyilvánítják utólag egyéb belterületté.

A külterületekből létrehozott egyéb belterületek tartósan örzik örökölt adottságaikat, mivel az épített környezet átalakulása és a népesség cserélődése lassú folyamat. Ennek megfelelően a szőlöhegyi, zártkerti, üdülöterületi vagy majorsági térszerkezet tartósan megmarad, miközben a közigazgatásilag önálló falvak belterületeire jellemző, zártabb településkép kezd kialakulni.

Kiemelt szerepü eszköz volt az államszocialista várospolitikában a település-összevonásoknak. A város közigazgatási területébe bevont korábbi falvak a város-vidék kontinuum értelmezési keretében rurális lakóhelyek, városi térbe ágyazódó enklávéinak sajátos téregységeket alkotják. 1990 után e korábban önálló falvakat, rekreációs övezeteket, és volt külterületeket a szuburbanizáció felfedezi és elkezdi átalakítani. (ClOUt, H. D. 1976, NUISSL, R. - RINK, D. 2005, OtT, T. 2001, Pócsi G. 2009, PrYOR, R. J. 1968, TimÁr J. 1993; TiMÁr J. - BAUKó T. 1999, Yue, W. et. al. 2013).

Nagy Budapest kialakítása során a városhoz csatolták a 23 dinamikusan növekvő szomszédos települést és azok lakott külterületeit. Így kiterjedtebb és funkcionálisan tagoltabb főváros jött létre, melyben az erőltetett iparosodás révén nagy számú lakos költözött a becsatolt területekre, átalakítva azok társadalmi szerkezetét. Emellett újabb városperemi gyürü kezdett kialakulni, az új közigazgatási határon túli falvak felduzzadásával. Hasonló módon a vidéki városok fejlesztésében is fontos eszköz volt a városokhoz legközelebbi falvak több lépcsős becsatolása, mivel a beruházások munkaerőigényét e módon tudták fedezni (BELUSZKY P. 2007, IZSÁK É. 2003, SCHUCHMANN J. 2010). 
Az egyes falvak azonban nem veszítik el társadalmukat és településszerkezetüket azáltal, hogy egy városba bevonták. Különösen hangsúlyos ez az olyan esetekben, amikor a falu később újra önálló lesz, vagy a várostól fizikailag is elkülönülő egyéb belterület marad. A városokhoz csatolt egykor önálló falvak részben továbbra is őrzik rurális jellegüket, mint lakóhely a falu nem szünik meg a bevonás jogi aktusával. A városokba csatolt, majd újra önállósodó falvak, mint a korábban Szegedhez tartozó Algyő esetében sem szüntek meg a köztes időszakban falusias lakóhelynek lenni (BAJMÓCY P. 2003a, BAJMÓCY P. 2003b, BAJMÓCY P. - MAKRA Zs. 2016, CSATÁRI B. et. al. 2013). A közigazgatásilag létező falvak mellett tehát további nagyszámú rurális lakóhely van az ország agglomerációinak területén (CSATÁRI B. 2013, KOVÁCS Z. 1999, OTT, T. 2001, VASÁRUS G. et. al. 2018).

Megállapíthatjuk az e fejezetben bemutatott tipizálás alapján, hogy a külterületeknek számtalan típusát lehet és szükséges elhatárolni azok útfüggő fejlődéséből, földrajzi adottságaiból és demográfiai hátteréből fakadó szignifikáns különbségek miatt. Egyértelműen elválnak az szórvány jellegü lakott helyek (tanyák és örházak) a csoportos jellegü majoroktól és üzemi lakóhelyektől, valamint egy harmadik, ma már nagyszámú közös problémákkal bíró, kertes területhasználatú típuscsoportot képeznek az olyan átmeneti településformák, mint szőlőhegyek és zártkertek, valamint üdülök. Figyelembe kell venni, hogy a külterületek jelentős része nem ennyire „,vegytisztán” jelenik meg, az egyes típusok élesen nem válnak el egymástól, sok az átmeneti vagy átalakuló forma. Az egyéb külterületek pedig e három csoporttól is különbözö, rendkívül egyedi nehézségekkel és adottságokkal rendelkeznek. E típusok diverz attribútumaik miatt a külső behatásokra, gazdasági és politikai változásokra, valamint az esetleges beköltözési hullámokra eltérő módon reagálhatnak, amelyre a bemutatott történeti analógiák is utalnak.

Különösen fontos azon egyéb belterületek vizsgálata, amelyek korábbi külterületekből jöttek létre, mert e területeken keresztül megvizsgálhatjuk, hogy a tartós népességnövekedés, infrastrukturális fejlődés milyen jövőképet mutat a külterületi lakott helyek fejlődésére nézve. Ennek megfelelően a kutatás során a mintaterületek kiválasztásában és az elemzés során kiemelt hangsúlyt kívánok fektetni az egyes típusok közötti hasonlóságok és eltérések bemutatására, mivel a feltárt tapasztalatok alapján csak így lehetséges majd releváns ajánlásokat összeállítani. 


\section{A LAKÓHELYI SZUBURBANIZÁCIÓ TÁSADALOMFÖLDRAJZI ÉRTELMEZÉSE}

\subsection{A lakóhelyi szuburbanizáció vizsgálatánál alkalmazott fogalmak}

Az előző fejezetben bemutatott sajátosságaik miatt a külterületek messze nem olyan kiváló adottságokkal és infrastruktúrával rendelkeznek, mint a nemzetközi szakirodalomból és napi életből is ismert zöldmezős beruházások, vagy színvonalas település-megújulás során kialakult szuburbiák, elővárosok. Ennek tükrében szükséges a szuburbanizáció fogalmi keretén, történetén, területi sajátosságain túl annak lehetséges negatív hatásait is feltárni, hiszen e rurális lakóhelyek már a korábbi politikai és demográfiai változásokra is érzékenyen reagáltak, tehát e folyamat hatásai esetében is fenn állhat a fokozott kitettség.

A szuburbanizáció a településállomány fejlődését és a belső migrációt jelentősen meghatározó folyamat, amely a hazai és nemzetközi településföldrajzi kutatások kiemelt területe. A szerzők széles körben feltárták a folyamat számos előnyét, pozitív gazdasági hatásait és negatív következményeit a közösségekre (BROWN, L. D. - SCHAFFT, K. A. 2002, CsANÁDI G. - CsIZMADY A. 2002, KoK, H. 2000, KuBES, J. 2013, SCHUCHMANN J. 2013). Mivel a dinamikus változások átrendezik a helyi társadalom tradicionális rendszereit, viszonyait és identitását súlyos konfliktusokhoz vezetnek (DövÉNYI Z. - KovÁcs Z. 1999, KoK, H. - KovÁCs Z. 1999. KovÁCS Z. 2010, SZIRMAI V. 2011b, VÁRADI M. M. 1999).

A szuburbanizációt vizsgáló széles körü szakmai diskurzus fő kérdései között kiemelt szerepet kapott annak eredete, a folyamatot müködtető társadalmi mechanizmusok feltárása (GRANT, J. L. et. al. 2014, McMAnus, R. - ETHINGTON, P. J. 2007) az eltérő részfolyamatok tipizálása, kulturális, politikai és gazdasági beágyazottsága, térben és időben elérően zajló folyamatok összehasonlítása (BAJMÓCY P. 2002, BAJMÓCY P. 2014, BRYANT, C. R. 1995, Helling, A. 2002, RoOSE, A. et. al. 2013, ŹRÓBEK-RÓŻAŃSKA, A - ZADWORNY, D. 2016), valamint a folyamat során keletkező, rendkívül diverz módon jelentkező szuburbán térszerkezeti formák természetének (OUŘEDNÍČEK, M. 2007, YUE, W. el. al. 2013), és divergens fejlődési útjaiknak vizsgálata (Costello, L. 2007, CotTer, N. 2011, Görgl, P. 2011, ReEH, H. - Zerlug, M 2011).

A különböző szerzők természetszerüleg a változó megközelítésekből adódó számtalan, egymástól lényegesen eltérő értelmezést alkottak a szuburbanizáció lényegét illetően. A különböző országokban és más szakterületekben tevékenykedő szerzők mást értenek a szuburbanizáción, eltérő folyamatokat és területhasználati mintázatokat vizsgálnak. Továbbá McManus, R. és EthingTON, P. J. (2007) kiemeli, hogy a kifejezés hétköznapi és szakmai interpretációja is dinamikusan változott DYOS, H. J. 1961-ben megjelent Victorian Suburb címü munkája óta, követve a társadalmi trendeket, a tudomány fejlődését, és az egyes jellemző szuburbán formák, részfolyamatok jelentősége közötti hangsúlyeltolódásokat is.

E dolgozatban nem kívánom a teljesség igényével tárgyalni az eltérö megközelítések definícióhasználatát, ugyanakkor a koherens vizsgálat megköveteli a kutatás során használt szuburbanizáció-fogalom tisztázását, melyet a sajátos vizsgálati mintaterületek is indokolnak, ezért e fejezetben a dolgozat fogalomhasználatát befolyásoló fóbb szempontokat csoportosítva összegzem, majd megalkotva a dolgozat során alkalmazott definíciót. Ezután feltárom a 4.2. fejezetben a szuburbanizáció kiváltó okait, motivációit és bemutatom a tárgyalt folyamat fejlődési modelljét. Ezután kitérek a szuburbanizáció időben és területileg változó jellemzőire globális léptékben a 4.3 szakaszban, majd a poszt-szocialista országok és különösen hazánk ettől eltérő sajátosságaira a 4.4 alfejezetben. Ezt követően a folyamat negatív társadalmi hatásaira is kitérek, mivel mint azt az előző fejezetben bemutattam, a külterületek adottságai közel sem ideálisak így a bemutatott történelmi analógiák alapján feltételezhető, hogy kitettségük is magasabb a társadalmigazdasági változásokkal szemben.

A szuburbia kifejezés a középkor kezdetétől a XIX. századig a város (urbs) közelében, a város alatt, a falon túl (sub) elhelyezkedő alacsony státuszú, szennyezett, veszélyes, kereskedelmi 
funkciójú és a mindenkori „underclass” által lakott területek voltak. Ezen területek egyértelmü negatív kontextusban szerepeltek irodalmi müvekben és a történelmi forrásokban, mely alól kivételt csak a városok körüli kertségek jelenthettek (JACKSON, K. T. 1985, MCMANUS, R. ETHINGTON, P. J. 2007).

A pozitív jelentéstartalmú, modern értelemben vett szuburbanizáció az XIX. század első felében az Egyesült Államok nagyvárosai körül kezdett kialakulni. A városi indusztrializáció káros környezeti hatásai elöl, a vasúti és omnibusz közlekedés fejlesztésével párhuzamosan, megindult a középosztály kiáramlása a városok peremére. Itt parkok és mezők is voltak az igényes házak, villák között, ahol a szabadság érzete és a zöldfelület jelentett vonzerőt (JACKSON, K. T. 1985 ).

A szuburbanizáció legkorábbi definíciói ennek megfelelően a klasszikus leiró, a földrajzi fekvésen alapuló kvantitativ értelmezések, melyek szerint a szuburbanizáció a város adminisztratív határán túl, de ingázási távolságon belül (jellemzően fél órás útidő) fekvő elővárosi gyürü népességnövekedése, melynek jellemzője a lakófunkció és a központi településre irányuló napi ingázás. E statisztikai szemléletű definíciók változatai gyakran még a népességszámhoz, népességnövekedéshez, vagy a városba történő napi ingázás bizonyos értékéhez is kötik a lehatárolt terület méretét. Ezzel a szuburbiákat egy bizonyos kertvárosias, családi házas építészeti és településtervezési jelleggel azonosítják (LUCY, W. L. - PHILLIPS, D. L. 1997, MCGRANAHAN, D. A. 2008, WOLF, T. - MEYER, B. C. 2009).

E lehatárolások azonban több szempontból is kritizálhatók. A városok határai a települések hozzácsatolásával, vagy városrészek önálló településsé válásával változnak, így a települések közigazgatási határai politikai képződmények, továbbá a városok ingázási vonzáskörzete sok esetben túlnyúlik a szuburbán öv területén, ugyanakkor nem minden város körül mutatható ki szuburbanizációs öv. Emellett a szuburbiák területe messze nem ilyen homogén, tömbházas lakónegyedek és ipari elővárosok is tarkíthatják azokat (ANTROP, M. 2004, BAJMÓCY P. 2003a, TIMÁR J. 1999). E megközelítések tehát önmagukban nem elégségesek, a szuburbiák demográfiáját is szükséges vizsgálni.

A szociálpszichológia és a viselkedésföldrajz irányzatai a folyamat létrejöttének társadalmi okait emelték ki a múlt század derekán, a kvantitatív forradalom hatására. E szerint a szuburbanizáció olyan vándorlás, mely során a háztartások a jobb életminőség elérése érdekében az egészségtelen és zsúfolt, épített és természeti környezetében hanyatló városból a környező rurálisabb településekre költöznek. E megközelítések gyakran a szuburbiát úgy értelmezték, mint egy társadalmi csoport, a fiatal, fehér, gyermekes középosztálybéli családok életmódjának színtere, mely visszatérés a konzervatív értékekhez szemben az elidegenedő városi társadalommal (BOURNE, L. S. 1999, DÖVÉNI Z. - KOVÁCs Z. 1999, GÁBOR P. 2001, TiMÁR J. 1992).

Bár e motiváció jelentős, az elővárosok urbanizálódásával, az ipari szuburbanizációval és a policentrikus várostérségek kialakulásával az ingázás egyoldalúsága és a homogén demográfiájú elővárosi övek megszüntek (KoCsIS J. B. 2000, SzIRMAI V. 2011, YUE, W. et. al. 2012). Az eddig bemutatott meghatározások a területileg és időben változó folyamat súlypontjait és részfolyamatait jól megfogják az egyes léptékek szintjén könnyen elérhető adatok alapján, azonban a szuburbanizáció teljes körü lehatárolására kevésbé alkalmasak.

A szuburbanizáció korábbiaktól eltérő megközelítési módja nem az eredményt - az elővárosi övet - akarja lehatárolni, hanem a szuburbanizációt, mint társadalmi-gazdasági folyamatot kívánja definiálni a tágabb értelemben vett városfejlődés menetében (BAJMÓCY P. 2004, TIMÁR J. 1999). A humánökológia képviselöi által megfogalmazott globális urbanizációs ciklusmodell, ENYEDI GY. által továbbdolgozott $a$ városnövekedés szakaszai címü modellje szerint a szuburbanizáció a városrégiók növekedési ciklusának második szakasza, melyben a népességnövekedés területe a városról a város környéki területekre helyeződik, ezáltal relatív dekoncentráció valósul meg. $\mathrm{Az}$ elővárosi gyürü népessége növekedni kezd a természetes szaporodás és a városból való kiáramlás révén. Ennek mozgatója a mobilizáció fejlödése, a szolgáltató-szektor jelentőségének növekedése, és a gazdaság átalakulása, amely lehetővé teszi a lakó- és munkahelyek éles térbeli elkülönülését (BAJMÓCy P. 2003a, ENYEDi Gy. 2011a, TiMÁR J. 1999, TÓTH J. 2006, TóTH J. 2007). 
Ennél tágabb megközelítésben a városi népesség és tevékenységek dekoncentrációjával azonosítható tehát a szuburbanizáció. A városi központ helyett a környező településeken koncentrálódik és/vagy oda fizikailag át is települ a termelö- és nem termelő tevékenységek, a tőke, valamint a népesség egy része. Ennek következtében a városi térségben dekoncentráció zajlik, míg regionális és országos léptékben a centralizáció fokozódik. E megközelítésre alapozva TIMÁR J. (1999) definícióját módosítva BAJMÓCY P. a szuburbanizációt úgy értelmezi, hogy ,a városi népesség és tevékenységek dekoncentrációja, amely átfogó részét képezi az urbanizációs folyamatnak. Dekoncentráció abban az értelemben, hogy az urbánus népesség, a termelö és nem termelő emberi tevékenységek egy része, a tőke, a beruházások, a városi központok helyett az azokat övező térségekbe koncentrálódnak. Ugyanakkor dekoncentráció abban az értelemben is, hogy a népesség és/vagy tevékenységeinek (termelés, szolgáltatások igénybevétele, rekreációs tevékenység) egy része ténylegesen ki is települ a városból annak közvetlen környékére." (BAJMÓCY P. 2014, 25.p.).

E megfogalmazás széleskörüen lefedi a szuburbanizáció térformáló szerepét, hatását a városi és regionális településszerkezetre. $\mathrm{E}$ folyamat azonban nem azonos a funkcionális várostérség fejlődésével, az agglomerációval, mely egyben a város környezetének városiasodását, a települések közötti funkcionális kapcsolatok erösödését is jelenti (SCHUCHMANN J. 2013, SZIRMAI V. 2011a). További lehetőség tehát az agglomerációs térségekre ható részfolyamatok differenciálása, célszerü elkülöníteni a szuburbanizációt - az elővárosi öv növekedése nagyobb, mint a centrumvárosé -, a szuburbán növekedést - az elövárosi öv népességének változása -, és a szuburbán fejlödést, amely a város körüli települések minőségi változása, urbanizálódása a centrifugális és centripetális hatások eredőjeként (TAMMARU, T. 2001). E modellt a változatos szociális státuszú és eltérő motivációs szándékokat mutató érintettek azonosításával tovább bontva, OUŘEDNÍČEK, M. (2007) hét részfolyamatot határolt le a szuburbán fejlődést vizsgálva:

1: Klasszikus szuburbanizáció, mely során a jellemzően magasabb státuszú csoportok a városból város körüli rurálisabb lakóhelyekre áramolnak, átalakítva azok társadalmi és müszaki jellemzőit.

2: Migráció a régi lakóházakba, mely során a pályakezdők és a szerény anyagi lehetőségekkel rendelkezők a hagyományos falusias területek megüresedő régi, olcsó házaiba költöznek, mivel e folyamat szórtabb hatása is kisebb a helyi közösségekre.

3: Az idősek migrációja az ápoló otthonokba. Az elöregedő városi magvak jelentős migrációs tartalékokkal rendelkeznek, azonban hatásaik korlátozott a szuburbán terület térszerkezetére.

4: A második otthonokba történő migráció, mely különösen a posztszocialista országokra jellemző; ennek során a korábbi üdülőkbe és hétvégi házakba költöznek ki az idősek és a városból kiszorulók, gyakran csak szezonálisan, a nyári időszakra.

5: Migráció a távoli falvakba. Az angolszász és nyugati mintájú városfejlődéstől eltérően a „keleti” szuburbanizációban a városból kiszorulók és a vidékről a város felé igyekvő szegények szerepe nagy, ők a szuburbiák nehezen elérhető, alacsony státuszú területeire költöznek.

6: Érintőleges migráció. A lakóhelyváltások jelentős része, nem jár együtt a lakóhely minőségi változásával, az életmód módosulásával, hanem családi vagy más magánéleti változáshoz (házasság) köthetők, ezáltal e rövidtávú migráció hatása eltérő a szuburbanizációtól.

7: A hosszú távú migráció során az ország más, az agglomeráción túli részéröl költöznek a lakók a szuburbán öv településeire. Attól függően, hogy a kiindulási terület falu vagy egy másik agglomeráció központi települése, tekinthető szuburbanizációnak és urbanizációnak is a folyamat.

Ezáltal a szuburbanizációt egy komplex, a tágabban értelmezett elővárosi terület átalakulásában résztvevő folyamatok eredőjeként zajló folyamat egyik meghatározó, de nem önmagában álló elemének tekinthetjük, így a szuburbán öv sem kizárólagosan a szuburbanizáció és/vagy a városiasodás terméke (OUŘEDNÍČEK, M. 2007, TAMMARU, T. 2001).

A szuburbán övek azonban nem különülnek el élesen a környező vidéktől (CSURGÓ B. 2013), ezért szükséges megvizsgálni annak kapcsolatát a rurális terekkel, különösen, az általam vizsgált külterületek rurális jellege miatt. A vidékföldrajz megközelitésében a szuburbiák tehát a városból történő kiáramlás és a városi területhasználat, valamint funkciók rurális térbe történő 
behatolásának terei, azaz a város-vidék peremzóna sajátos részei, annak sajátos új szociális terei, melyek fö jellemzője a folyamatos átalakulás (BOURNE, L. S. 1996, TiMÁR J. 1993). A város-vidék peremzóna (urban-rural fringe) a városias területhasználat és életmód expanziója, a relatív dekoncentráció révén az urbánus és a rurális tér találkozási zónájában kialakult összetett, rendkívül fragmentált térszerkezetü terület a város-vidék kontinuumban (PRYOR, R. J. 1968, Sharp, J. S. - Clark, J. K. 2008, Nikodemus, O. et. al. 2005). E peremzónában jellemző a társadalom, a területhasználat és településszerkezet, valamint a gazdasági közeg dinamikus átalakulása, amely a helyi társadalmi hierarchiát, kapcsolati hálókat és életvitelt jelentősen átszabja (Bryant, C. R. 1995, Clout, H. D. 1976, CzEnE Zs. 2007, PACiONE, M. 2013).

A város-vidék perem zóna tehát a szuburbanizáció fó, de nem kizárólagos területe e megközelítésben, hiszen a peremzóna nem azonosítható a szuburbanizáció akcióterületével, mivel a város-vidék kontinuumban számos további folyamat is zajlik. (CSATÁRI B. et. al. 2013, Costello, L. 2007, Csurgó B. 2013, GANT, R. L. et. al. 2010, NiKODEMUS, O. et. al. 2005).

Tehát „legjellemzőbb meghatározóik - az urbánus és rurális területhasználat, valamint népesség keveredése, a városi expanzió révén az élettevékenységek, tulajdonformák rendkívül gyors változása, az eltérő érdekek ütközése - miatt az ilyen térségek egyfajta „konfliktuszónának” tekinthetők" (TíMÁR J. - BAUKÓ T. 1999, 95. p.). A peremzónák pontos lehatárolására ugyanakkor nincs kialakult és széles körben elfogadott módszertan, diszciplínánként és nézőpontonként (városi/falusi, lépték) eltérő a megítélése. Ebben a nehézséget a változékonyság, a módosulások sokszínűsége és az érintett terület fragmentáltsága okozza.

Két részre osztható, a külső falusias perem (rural-fringe) területén a mezőgazdasági földek aránya $50 \%$ feletti, alacsonyabb a népsürüség és a területhasználati változásokat a lakóterületek lassú bővülése dominálja (CLOUT, H. D. 1976, KISS J. 1999, TíMÁR J. 1993). Belső fele a városiasabb és nagyobb népsürüségü város-perem (urban-fringe), mely a lakó, kereskedelmi és ipari terek magas arányával, így a mezőgazdasági területhasznosítás $50 \%$ alatt maradásával jellemezhető. A belső perem távolsága az esettanulmányok alapján a központi településtől $25-50 \mathrm{~km}$, a külső perem 75 $100 \mathrm{~km}$-ig is terjedhet a közlekedési és földrajzi adottságok, valamint a népességszám függvényében. A szuburbiák e peremzónában mozaikosan jelennek meg, jellemzően a belső perem területén, így jellemzőjük a konfliktusokkal terhelt átalakulása (PÓCSI G. 2009a, CARruthers, J. I. - Vias, A. C. 2005, PrYOR, R. J. 1968, ShARP, J. S. - ClARK, J. K. 2007, ).

A konstruktivista vidékszociológia megközelitése tovább lép, e szerint a vidékre költözés nem azonos a szuburbanizáció, a dezurbanizáció vagy a vidék-dzsentrifikáció kategóriájával, azok mindegyike és több is azoknál: összetett társadalmi-kulturális jelenség, a migráció rövid távolságú fajtája, amely életútesemény és élmény, kulturális folyamat. A város-vidék különbség nivellálódott, pusztán diskurzív kategória, a városból kiáramló csoportok saját vidék-ideájuk terét kívánják létrehozni, melyhez a szuburbán táj csupán tájképi elem. A városból kiköltözők vidékkonstrukciója újrastrukturálja a teret és az azt használó közösséget. Ez az idealizált kép eltér a helyiekétől - a vidéki ember képe is külső konstrukció -, valójában több csoport összetett identitásának összege, így a vidék-diskurzus teremti meg a szuburbán teret, ahol az eltérő preferenciák konfliktusokat okoznak a helyiekkel (COSTELLO, L. 2007, CSURGÓ B. 2013, SOMERVILLE, P. 2013).

Ebből fakadóan a szuburbanizáció, különösen annak rurálisabb lakott helyeinek alakulása során sajátos kölcsönhatás a városias és a vidékies életmódok, értékrendek, és az azokat képviselö társadalmi csoportok között, ezáltal egy konfliktusok által körülhatárolható dinamikusan változó térszerkezeteként értelmezendő. A bemutatott különböző szuburbanizációs megközelítések a számtalan ellentmondás ellenére meghatározzák a szuburbanizáció fő tényezőit, a különböző megközelítések a folyamat különböző időben, eltérő térbeli helyszíneken különböző kutatói nézőpontokból alkalmasak a folyamat leírására (4. táblázat).

A definíciók közös elemei, hogy a szuburbanizáció, a korábbi lassú városfejlődéstől eltérően egy új, dinamikusan változó térszerkezetet kialakító, a relatív dekoncentrációt elősegítő folyamat, mely a város körüli teret birtokba veszi, átalakítja és termékké, imázs-elemmé alakítja (CsURGÓ 
B. 2013, Schuchmann J. 2013, Szirmai V. 2017, Timár J. 1999, WeAVER, D. B. - LAWTON, L. J. 2001). Fő meghatározója nemcsak a migráció célterületének áthelyeződése a várost körülvevő vidéki térre, hanem a városkörnyék újrastrukturálódása, épített és természeti környezetének, társadalmának és viszonyrendszerének gyökeres átalakulása (BRADE et. al. 2009, DUNAY, A et. al. 2001, GANT, R. L. et. al. 2010, PACIONE, M. 2013, TiMÁR J. - VÁRADI M. 2000) Ezáltal a különböző érdekcsoportok és életmódok harcainak területévé válik ez a mozaikos jellegü terület, mely a központi városnál rurálisabb - azonban nem homogén - lakóhely.

4. táblázat. Példák a szuburbanizáció definíciós lehetőségeinek sokszínűségeire.

\begin{tabular}{|c|c|}
\hline Megközelítés & A szuburbanizáció mibenléte a megközelítés alapján: \\
\hline Kvantitatív leíró társadalomföldrajzi & $\begin{array}{l}\text { A város adminisztratív határán túl, de ingázási távolságon belül fekvő elővárosi } \\
\text { gyürü fejlődése. Meghatározott népességszámhoz, népességnövekedéshez, és/vagy } \\
\text { a városba történő ingázás értéke alapján lehatárolt, a város adminisztratív határán } \\
\text { túli terület népességnövekménye, melyet a kertvárosias, családi házas, sajátos } \\
\text { utcahálózatú építészeti és településtervezési forma elterjedése. }\end{array}$ \\
\hline Szociálpszichológiai & $\begin{array}{l}\text { Olyan vándorlás, mely során a jobb életminőség elérése érdekében az egészségtelen } \\
\text { és zsúfolt, épített és természeti környezetükben hanyatló városokból az azt } \\
\text { körülvevő rurálisabb településekre vándorolnak a háztartások }\end{array}$ \\
\hline Humánökológiai & $\begin{array}{l}\text { A szuburbanizáció a városrégiók növekedési ciklusának második szakasza, melyben } \\
\text { népességnövekedés területe a városról a város környéki területekre helyeződik, } \\
\text { ezáltal relatív dekoncentráció valósul meg. Az elővárosi gyürü népessége növekedni } \\
\text { kezd a természetes szaporodás és a városból való kiáramlás révén }\end{array}$ \\
\hline Komplex településföldrajzi & $\begin{array}{l}\text { A városi népesség és tevékenységek dekoncentrációja, amely átfogó részét képezi } \\
\text { az urbanizációs folyamatnak. Dekoncentráció abban az értelemben, hogy az urbánus } \\
\text { népesség, a termelö és nem termelö emberi tevékenységek egy része, a töke, a } \\
\text { beruházások, a városi központok helyett az azokat övezö térségekbe } \\
\text { koncentrálódnak. Ugyanakkor dekoncentráció abban az értelemben is, hogy a } \\
\text { népesség és/vagy tevékenységeinek (termelés, szolgáltatások igénybevétele, } \\
\text { rekreációs tevékenység) egy része ténylegesen ki is települ a városból annak } \\
\text { közvetlen környékére }\end{array}$ \\
\hline Vidékföldrajzi & $\begin{array}{l}\text { A városból történő kiáramlás és a városi területhasználat, valamint funkciók rurális } \\
\text { térbe történő behatolása, azaz a város-vidék peremzóna sajátos, urbanizálódó tereit } \\
\text { alkotó folyamat. }\end{array}$ \\
\hline Konstruktivista vidékszociológiai & $\begin{array}{l}\text { A migráció rövid távolságú fajtája, amely életútesemény és élmény, kulturális } \\
\text { folyamat. A városból kiköltözők vidék-konstrukciója újrastrukturálja a teret és az } \\
\text { azt használó közösséget, így a konfliktusokkal terhelt vidék-diskurzus megteremtett } \\
\text { tér }\end{array}$ \\
\hline
\end{tabular}

Forrás: Saját szerkesztés BouRnE, L. S. 1999, CsuRGó B. 2013, MCMANUS, R. - ETHINGTON, P. J. 2007, OUŘEDNíČEK, M. 2007, SHARP, J. S. - ClARK, J. K. 2007, TIMÁR J. 1999 alapján.

A kutatás során definícióként a TIMÁR J. (1999) és BAJMÓCY P. (2014) által használt fogalmi keret módosított változatát alkalmazom. melyet a bemutatott definíciók összevetése során leszürt tapasztalatok szerint módosítottam. Így a szuburbanizáció a városi népesség és tevékenységek relatív dekoncentrációja, amely részét képezi az átfogó urbanizációs folyamatnak. Dekoncentráció abban az értelemben, hogy (jellemzően, de nem kizárólagosan) az urbánus népesség, a termelő és nem termelő emberi tevékenységek egy része, a tőke, a beruházások, a városi központok helyett az azokat övező rurálisabb térségekbe koncentrálódnak és egy részük ténylegesen ki is települ a városból annak közvetlen környékére. Területe a fragmentált területhasználatú város-vidék peremzóna, melyben a szuburbanizáció mozaikosan, más térfolyamatokkal együtt, a helyi természeti- és társadalomföldrajzi adottságokhoz adaptálódva különböző módokon rekonstruálja a lokális közösségeket a beköltözők heterogén csoportjainak sajátos igényeihez igazodva.

Dolgozatom szuburbanizáció fogalma lényegileg abban tér el az alapjául szolgáló meghatározásoktól, hogy szükségesnek tekinti a városi lakosság és tevékenységek kiáramlását a városok vonzáskörzetébe, ezáltal különbözik az urbanizáció által hajtott agglomerálódástól. Ugyanakkor nem tekinti a népességnövekmény kizárólagos forrásának a várost, hiszen hasonló motivációk alapján választhatják a szuburbia területeit a vidékröl vagy más városokból érkezők, 
mint a városból kiköltözők (BAJMÓCY P. 2000a, OUŘEDNíČEK, M. 2007). Ennek föbb indokai a következökben foglalhatók össze:

A szuburbanizációt diverz folyamatnak tekintem, melyben a különböző társadalmi csoportok és az eltérő életmódok sajátos értékeiknek és érdekeiknek megfelelően megpróbálják átalakítani a város-vidék peremzóna területét. Saját tereik megalkotása során a legkülönbözőbb érintettek, igazodva az egyes lokációk adottságaihoz komplex, sokszínü térszerkezetet alakítanak ki. Ezáltal a különböző vidékkonstrukciók ütközésének, a társadalmi konfliktusok és a gazdasági, politikai és társadalmi csoportok érdekérvényesítési harcainak színtereként értelmezhető a szuburbán öv. Ebből kifolyólag a területet mozaikos, fragmentált térszerkezet jellemzi, ahol nem csak a különböző funkciók, de a már bemutatott eltérő migrációs és urbanizációs folyamatok is egyszerre jelennek meg (CSURGÓ B. 2013, OUŘEDNÍČEK, M. 2007, SCHUCHMANN J. 2013).

Az észlelt tér nem egy abszolút, objektív képződmény, hanem az egyének és társadalmi csoportok, valamint a gazdaság interakciójaként, a lokáció sajátos használatával konstruált szubjektív leképződése a tapasztalatoknak, egyben a használat módjának reprezentációja, amelyet a különböző érdekek, értékek és eltérő értelmezések határoznak meg. A társadalmi változások megalkotják az új társadalmi kapcsolatok újfajta térrendszereit, a lakóhelyváltás során így meghatározó, hogy milyen társadalmi csoportok és milyen közösség tagjai szeretnének lenni a költözni szándékozók. Így a tér nem egy „,késztermék”, hanem egy dinamikus folyamat alkotja, mely interakcióban áll a társadalmi és politikai diskurzusokkal, azaz a szuburbán fejlődés egy társadalmi folyamat, amely térbeliségét az egyének életvitelükkel alakítanak (BoROS L. 2010, NAGY G. - TÍMÁr J. 2010, TIMÁr J. 2006).

E megközelítés nem köti a szuburbanizáció értelmezését a városok közigazgatási határához. Ennek megfelelően a település-összevonások során közigazgatási önállóságot elvesztett különböző falusias településrészek is a szuburbán öv részei lehetnek, függetlenül attól, hogy egy másik faluhoz vagy a városhoz kapcsolták-e, mivel a települések falusias jellege, népessége, a helyi kapcsolati hálók és interakciók nem szünnek meg a jogi aktus következtében (BAJMÓCY P. 2004, CSATÁRI B. et. al. 2013, CZENE Zs. 2007, TIMÁR J. 1999). A különböző adminisztratív határok (többek között megyék, járások) sem határozzák meg a város-vidék átmenet térbeliségét, nem igazodnak a napi térpályákhoz (SHARP, J. S. - CLARK, J. K. 2008). Így dolgozatomban az adminisztratív határok alapján nem zárok ki területi egységet a vizsgálatból (városhatáron belüli egységek), mivel a közigazgatási határok politikai produktumként nem reprezentálják a társadalom és gazdaság térbeliségét, bár ki kell emelni, hogy a lokális adminisztratív szabályozók, önkormányzati tevékenységek és a gazdasági helyzet révén jelentősen befolyásolhatják azokat.

Dolgozatomban ennek megfelelően, a bemutatott definíciók kritikáit figyelembe véve, nem kívántam lehatárolni az egyes városok szuburbán övének kiterjedését, hanem a vizsgált területeken belül a statisztikai és empirikusan felvett adatok elemzésével kívánom majd meghatározni, hogy az egyes lakott helyek és településrészek részei-e a folyamatnak és hogy ez milyen térstruktúrát alakít ki a város-vidék peremzónában. Ezzel igyekszem a folyamat térbeliségét a folyamat oldaláról feltárni, nyitva hagyva a kérdést, hogy a $\mathrm{KSH}$ által lehatárolt agglomerációk és településegyüttesek térbelisége milyen mértékben esik egybe a külterületeken és egyéb belterületeken zajló szuburbanizációs folyamatokkal.

\subsection{A szuburbanizációt mozgató tényezők és a szuburbán öv fejlődésének szakaszai}

A szuburbanizáció fejlődése során az idő elörehaladtával különböző migrációs, társadalmi és gazdasági folyamatok határozzák meg az itt élők életminőségét, életmódját, azaz végső soron a folyamat hatását a populációkra és az egyénekre. A következőkben be kívánom mutatni a szuburbanizáció fó fejlődési modelljeit, valamint történetének e kutatás szempontjából legrelevánsabb tényezőit a fejlett nyugati országokban. A már ismertetett városfejlödés szakaszai modell a relatív dekoncentráció szakaszát, a szuburbanizációt két meghatározó szakaszra bontja, valamint feltárja a szuburbanizáció visszaszorulásának okait is (ENYEDI GY. 2011a). 
1, Az első, kezdeti szakaszban a funkcionális városrégiót intenzív növekedés jellemzi. A város fejlődése jelentős népességet vonz, a beruházások, a munkahelyek és a lakások többsége még a központi településen jön létre, ugyanakkor a magas szintü szolgáltatások és a közlekedés fejlödése lehetővé teszi a napi szintü ingázás kialakulását. Megkezdődik a népesség kiköltözése a városok peremének jobb életmódot lehetővé tevő területeire, így a szuburbia dinamikája meghaladja a központi település növekedését. Ekkor jellemzően nem alakul ki összefüggő szuburbán gyürü a város körül, hanem bizonyos felkapottá váló területeken, falvakban szigetszerúen indul meg a lakosság letelepedése (ENYEDI GY. 2011a, TIMÁR J. 1999).

A szuburbanizáció kialakulásának okait sokszínü irodalom tárgyalja, az egyes szerzők különböző társadalmi, gazdasági és infrastrukturális alaptényezőket és jellemzőket emelnek ki. Ugyanakkor a különböző tényezők jelentősége időben és térben, a szuburbanizáció fejlődésével, az egyes területek adottságainak megfelelően változik, egymásra, így a különböző magyarázatok nem kizárják, hanem kiegészítik egymást, az összetett folyamat különböző elemeit megvilágító faktorokként értelmezhetőek (TIMÁR J. 1999, BOURNE, L. S. 1996).

A szuburbanizáció technológiai feltételei között a közlekedés fejlődését tekinti számos szerző döntő jelentőségü feltételnek, mely elengedhetetlen a lakóhely és a munkahely elválásában. Mivel a munkahelyek jelentős része továbbra is a városban tömörül, és az agglomeráció lakosságának jelentős része ingázik naponta, ezért nem minden háztartás tudja vállalni ennek költségeit, így különösen a korai szakaszban csak a tehetösebbek (háztartásonként több autó fenntartása, lakáshitel felvétele) vesznek részt benne (DUNAY, A et. al. 2001, HELLING, A. 2002, HARDI T. NÁRAI M. 2005, KISS J. 1999, TIMÁR J. 1999). A közlekedési technika fejlődése a szuburbanizációnak szükséges, de nem elégséges feltétele. Az eltérő országok eltérő közlekedési szokásai, a tömegközlekedés tarifapolitikája és társadalmi viszonyai miatt nem mindenhol alakult ki népességnövekedés az elővárosi terület közlekedésének fejlödésével. (MCMANUS, R Ethington, P. J. 2007, MieszKowski, P. - Mills, E. S. 1993, Timár J. 1999).

A szuburbanizáció folyamatában döntő jelentőségü motivációs tényező az életkörülmények javítása és az erre költeni tudó tömegek léte, mint társadalmi feltétel. A lakóhelyválasztásban meghatározó a táji szépség, így a beköltözők sajátos vidék-elképzelése által ideálisnak tartott környezet létrehozását is magával vonja (CSURGÓ B. 2013, IZSÁK É. 2003). A kutatások alapján ebben a domborzat, a fás-füves (a szavannákhoz hasonlatos) növénytakaró szerepe kiemelt (Wolf, T. -MeYER, B. C. 2010), e tágas, környezeti elemekkel tarkított megjelenés éles ellentétben áll a városok szögletes, zsúfolt beton-tégla képével. Sok szempontból e tájképi elvárás egyben természetes vonzódás az ember hagyományos történelmi élettereihez (BAJMÓCY P. 2001a, MCGRANAHAN, D. A. 2008).

A szuburbanizáció ugyanakkor egy életút-esemény, mely az életmódváltás eszköze. Az eltérő életmódokat követők különböző szempontok alapján választják a szuburbiát lakóhelyüknek, diverz módokon integrálódnak a helyi közösségbe, eltérő ideig laknak helyben, és heterogén társadalmi csoportok tagjai (JETZKOWITZ, J. et. al. 2007). A behaviorista földrajz szerint a szuburbanizáció az egyes háztartások tudatos, logikus döntéseinek következménye. A zsúfolt különösen a „baby boom” után -, társadalmi és környezeti problémákkal küzdö városok helyett az elővárosok vélt és valós előnyeit választják. A feminista geográfia képviselői felhívják a figyelmet a kis család, a reprodukció és a nemek szerepének fontosságára. Eszerint a nőcentrikus szuburbán reprodukciós élettér és a férfiközpontú város munkavilág szétválasztása is motiválta a folyamatot (TIMÁR J. 1999).

2. A szuburbanizáció második, tömeges szakaszban a városból kiáramlás a folyamat előrehaladtával oly mértékben nő, hogy az meghaladja a városba migrálás mértékét, és a központi város lakosságszáma csökkenni kezd, ugyanekkor az elővárosi gyürü növekedése stabilan magas. Összefüggő szuburbán gyürü formálódik, és immár ez lesz a népességnövekmény, a befektetések és a munkahelybővülés gyújtópontja, míg a központi város a népességvesztés és a munkahelyek kitelepülése miatt gyakran hanyatláson esik át (ENYEDI GY. 2011a, TIMÁR J. 1999). 
E tömeges lakossági szuburbanizációt gazdasági érdekek is hajtják. Az elővárosok imázsát, avagy mítoszát, tudatos befektetői szándék és önkormányzati tevékenység hívja életre a profitmaximalizálás érdekében, nem kis részint a média használatával. Ingatlanfejlesztői és földtulajdonosi oldalról is szükséges az elővárosi ábránd kiemelésére. Nem csak hozzáigazítják a tervezett településképet egyfajta vidék-képhez - amely jellemzően az amerikai álom gyepes előkertes családi háza -, de az utcanevek, a reklámok és a szlogenek presztízs-szimbólummá emelik (SZIRMAI V. 2011b, TIMÁR J. 2001b). Az eltérő fogyasztócsoportoknak szánt lakóterületekben a befektetők diverzifikálják a kínálatot, így az ingatlanok mérete, az infrastruktúra színvonala igazodnak a feltételezett kereslethez és vagyoni helyzethez. Az önkormányzatok pedig adóbevételeik maximalizálását, földterületeik értékesítését célozzák úgy, hogy a helyi közösség elvárásaihoz lehetőleg igazodjon a beköltözők száma és státusza (DUNAY, A et. al. 2001, MCMANUs, R - EthingTON, P. J. 2007).

A folyamatot nagymértékben hajtják a tudatos állami és önkormányzati döntések. Az államok a lakáshiány csökkentése, valamint a gazdaság és az építőipar támogatása érdekében adókedvezményekkel és lakáshitelekkel ösztönözték az a családi házas övezetek kiépítését (CARruthers, J. I. - Vias, A. C. 2005, Mcmanus, R - Ethington, P. J. 2007, SQuires, G. D. 2002, SZABÓ J. 2003, TiMÁR J. 2001b, TóTH Z. 2000). A marxista földrajz magyarázata tovább lép, a folyamat nem csak a népesség, hanem a töke és a beruházások dekoncentrációjaként értelmezi a szuburbanizációt. Ilyen értelemben tehát a folyamat föszereplői az ingatlanfejlesztők, pénzintézetek, önkormányzatok és építőipari vállalatok, akik közös érdekeik mentén alakítanak, ki olyan kereteket melyek meghatározzák, hogy konkrét anyagi hátterü fogyasztói rétegek döntései milyen meghatározott alternatívák között történhet csak (TIMÁR J. 1999, TIMÁR J. 2001b).

A szuburbanizáció hanyatlása is következik a modellből. A 3., dezurbanizációs szakasz (abszolút dekoncentráció) során a teljes funkcionális városrégió veszíteni kezd népességéböl a távolabbi vidéki területek javára. Azonban nem beszélhetünk egy újravidékiesedési folyamatról, az ipar kiszervezése (technopoliszok) és a város-falu életszínvonal-különbség nivellálódása, valamint a távmunka elterjedése mozgatja, így a megújuló területek az alapvetően továbbra is elnéptelenedő vidéki területekbe ágyazódnak szigetszerüen (ENYEDI GY. 2011b, MITCHELL, C. 2013, PHILIPS, M. 2009) Három fó részfolyamat alkotja ezt az összetett jelenséget: 1, a periurbanizáció a szuburbanizáció tovagyürüzése, a középosztály a telítődő elővárosi gyürün túlra kezd költözni, de városba ingázik ezután is. 2, a kényszerü urbanizáció nem önkéntes folyamat, a lakos a munkahelyek elérése miatt vált lakóhelyet, de ha lenne munkahelye, visszamenne az urbánus központba. 3, jelentős életmódváltással járó részfolyamat az ellenurbanizáció, mely során a népesség kevésbé koncentrált állapot felé mozdul el térben és a településhierarchiában is; nem csak lakóhelyét, de munkahelyét és tevékenységeit is kihelyezi a városi térségböl (BAJMÓCY P. et. al. 2012, Mitchell, C. 2004, Phillips, M. 2009, CARruthers, J. I. - Vias, A. C. 2005, SHUCKSMITH, M. - WATKINS, L. 1991, THEOBALD, D. M. 2005). E migrációs tendencia azonban gyakran visszaáramlást jelent: a vidékről korábban városba költöző aktív korúak munkahelyük elvesztése miatt, vagy a nyugdíjasok szentimentális szempontok alapján visszatérnek szülöhelyükre (COSTELLO, L. 2007).

A reurbanizáció alapvetően városi agglomerációkon belüli népesség-átrendeződést jelent, nem új városnövekedési szakaszt, sokkal inkább beszélhetünk a globalizáció urbanizációjáról. A dzsentrifikáció jelentősen, a szuburbanizációtól eltérö irányban befolyásolja a migrációs folyamatokat. A hanyatló belvárosi terek, barna mezők és lakóterületek rehabilitációja, valamint az új, belvárosokhoz kötődő új szolgáltató- és infokommunikációs (high-tech) üzletágak, a fiatal technokrata rétegek (yuppie, dinky) térnyerése révén a városok népességvonzó ereje megerősödik. A szuburbán öv maga is differenciálódni kezd, az új, magas hozzáadott értékü ágazatokat vonzó települések elővárosi fejlődése dinamikus marad, edge-citykké (exurbiák) fejlődhetnek. (ENYEDI GY. 2011a, PHILLIPS, M. 2009, THEOBALD, D. M. 2005).

Kiemelendő, hogy e szakaszok egymástól nem válnak el élesen, széles átmenetekkel jelentkeznek. Egy-egy régió különböző területei a modell eltérö pontjánál tarthatnak egy adott 
időpontban, továbbá a különböző részfolyamatok (ipari, kereskedelmi, lakossági, stb.) is eltérő szakaszokban lehetnek. Ennek megfelelöen az egyes szakaszok vegytisztán csak ritkán jelentkeznek az egyes városok fejlődését vizsgálva. Hasonlóan nem különülnek el élesen, heterogén térszerkezetet alkotva keverednek a mozaikos térszerkezetü városi övezetekben és peremükön túl az urbánus, szuburbán és exurbán, valamint rurális területek. Egy területegységen így a szuburbán övben a dezurbanizációs motivációk által hajtott lakhelyváltók megjelenhetnek, míg az érett szuburbiák (elővárosok) területén dzsentrifikációs folyamatok is jelentkeznek (Mitchell, C. 2004, Nelson, P. B. et. al. 2010, SCHuchmann J. 2010, TimÁr J. 1999, Tóth J. 2006, ТóTH J. 2007).

Az elővárosi gyürü fejlődése nem csak a funkcionális városrégiók léptékében mutat több lépcsős jelleget, minden egyes szuburbia alakulása is szakaszokra bontható a társadalmi összetétel és épített környezet fejlődését tekintve. A városperemeken létrejövő új lakóhelyek maguk is végighaladnak egy sajátos településfejlödési folyamaton, ezt két szempont alapján lehet szakaszokra osztani (MCMANUS, R - ETHINGTON, P. J. 2007). Elöször a lakosság összetételének változásaira, majd az épített környezet alakulására térek ki.

A lakosság saját életciklusán (gyerektelen párok - családok - idős párok), valamint az egymást követő társadalmi csoportok szukcesszióján keresztül jelentősen átalakul a szuburbiák demográfiája. A különböző társadalmi (és etnikai) csoportok bizonyos területekre migrálnak be, melyek anyagilag hozzáférhetők számukra, életmódjukhoz igazodó presztízst mutatnak. Egy új, fiatalos szuburbia elkészülte után 20-40 évvel azonban már kopottas épített környezetü nyugdíjas övezetté válik, megindul a népesség csökkenése. Ezzel új csoportok számára nyílik meg a lehetőség a beköltözésre, a területek egy része felkapottá válik valamilyen szubjektív (történeti múlt, híres lakó, stb.), környezeti vagy infrastrukturális ok miatt, és megindul a dzsentrifikáció, vagy ellenkezőleg a szegényebbek, vidékröl (külföldröl) bevándorlók lakóterületei lesznek (JaCkson, K. T. 1985, McManus, R - Ethington, P. J. 2007, Nelson, P. B. et. al. 2010).

A kialakuló szuburbiákra jellemző épített környezet a laza, családi házas beépítés, amely megfelel az elővárosi életmód klasszikus képének. A telekárak emelkedésével és a lakosság elöregedésével, vagy a megfelelő anyagi háttérrel rendelkező kiköltözni vágyó középosztálybeliek számának csökkenésével a befektetők kénytelenek a kevésbé tehetősek számára megfelelö többlakásos társasházak kialakításával fenntartani a bővülést. A népsürüség és vásárlóerö növekedése magával hozhatja a különböző szolgáltatások, üzemek megtelepedését, ezáltal a szuburbiában olyan alközpont alakul ki, amely később önálló városias maggá fejlődhet. A városias beépítettséget elérő szuburbiák idővel a város szerves részeivé válnak, urbánus városrésszé alakulnak, mint az egykor ikonikus előváros, Bronx. (EDELÉNYI B. 2002, JACKSON, K. T. 1985, McMANUS, R - ETHINGTON, P. J. 2007)

Ilyenkor a város addigi peremén túl rendszerint újabb szuburbia kiépülése kezdődik meg, amennyiben elegendő népességtartalékkal rendelkezik az urbánus központ. Ez a folyamat rendszerint élesen megosztja a lakóközösséget, mivel a falusiasabb életmód reményében korán kiköltözők számára értékvesztéssel járhat a tájkép beépülése, elvárosiasodása. Ugyanakkor saját vonzáskörzettel rendelkező elővárosi központok alakulhatnak ki, amelyek policentrikus várostérség kialakulását indítja meg. Ennek során a város felé tartó egyoldalú ingázás mellett kiteljesednek a transzverzális, érintőleges és a városból kifelé, az alközpontokba tartó napi mozgások. Ezáltal nő a területi specializáció, a lakókörnyezet heterogénebb lesz és a gazdaság is jobban ki tudja aknázni az urbanizációs elönyöket (MCMANUS, R -ETHINGTON, P. J. 2007, SZABÓ et. al. 2014, TIMÁR J. 1999).

Amennyiben a lakosság anyagi lehetőségei korlátozottak (alsó rétegek szuburbiái), a városiasodás és az elővárosi gyürü egyes területeinek öregedése nem jár együtt városias környezet kialakulásával, hanem az épített környezet leromlásán keresztül „gettósodási” folyamatok indulhatnak be. Több nyugati város területén elöregedett családi házas lakónegyedek adják a kisebbségek enklávéinak épületállományát. Az ipari hanyatlással és demográfiai recesszióval sújtott városok esetében az ilyen típusú átalakulások gyakoribbak. Természetesen nem minden 
szuburbia megy át ennyire jelentős átalakuláson, sok esetben tartósan megmaradnak a kezdeti feltételek és így fenntartható marad, vagy csak részlegesen módosul a kialakult térszerkezet (McManus, R. - EthingTon, P. J. 2007).

A szuburbiák átalakulása tehát folyamatos, kialakulásuk után tovább fejlődhetnek, vagy épp hanyatlásnak indulhatnak a társadalmi és gazdasági tartalékok függvényében. Mivel a hazai külterületekre alapvetően jellemző a kevésbé előnyös infrastruktúrájú területek (majorok, tanyák) és a kimondottan vonzó táji adottságú lakóhelyek (szőlőhegyek, üdülők) vegyes megjelenése az eltérő fejlődési pályák egyaránt jellemzőek lehetnek. Mivel azonban a folyamat hazánkban csak 10-15 évvel ezelőtt érte el csúcsát (2000-2007) még hosszú távú átalakulási folyamatokra kell számítanunk. Ezen fejlődési pályák tapasztalatainak feltárása érdekében a bemutatom a továbbiakban a szuburbanizáció fóbb területi globális jellegzetességeit, majd az azt követő részfejezetben a poszt-szocialista államok azon sajátosságait emelem ki, amelyek jelentősen befolyásolják a hazai elővárosi átalakulás menetét.

\subsection{A szuburbanizáció területi különbségei}

Az első szuburbán jellegü migrációs folyamatokat 1820-tól érzékelhetjük az USA akkor legfejlettebb városai körül, a relatív dekoncentráció szakasza Nyugat-Európában és ÉszakAmerika városaiban a XIX. század második felében kezdődött. A városok méretének növekedése, a jelentős zsúfoltság, és az új, városperemeken megvalósult üzemek erodálni kezdték a „sétáló várost" (JACKSON, K. T. 1985, MCMANUS, R. - ETHINGTON, P. J. 2007).

A közlekedés fejlődése lehetővé tette a menekülést a zsúfolt, társadalmi és etnikai konfliktusok által terhelt lakónegyedekböl. Az akkor 4400 lelkes Brooklyn az East River kompjai révén vált New York első dokumentált szuburbiájává 1820 és 1890 között közel 800000 fös népességnövekedéssel. Az omnibusz, a lóvasút és a vasút által felfüzött közeli településeken hamarosan beindult a népességrobbanás. Ebben az időszakban vált meghatározóvá az individualizmus, a külön házban élö kis család ideálja, ugyanekkor a belvárosok lakótömbjei egyre taszítóbbá váltak. Egyben az ekkor alakuló nőmozgalmak is a tiszta nőiesség elemének tekintették a rendezett, ízléses szuburbán családi házat. A világ nagy részén ekkor még igen kis fokú az elővárosiasodás, leginkább a nagyobb, gazdaságilag fejlett ország fővárosai (London, Párizs) körül indul be a korai szuburbanizáció. (JACKSON, K. T. 1985, MCMANUS, R. ETHINGTON, P. J. 2007).

Az ingatlanbefektetők néhány év alatt felfedezték a fogyasztói igényekben rejlő lehetőségeket, a városi telkeknél olcsóbban juthattak földekhez, ahol az ingatlanok tucatjainak eladása magas bevételt ígért. Tudatos fejlesztések alapján piacszegmentált, térben jól elkülönülő elit villanegyedek, felső középosztálybeli egyedi házak sorai és a kevésbé tehetőseknek készülö típusházakkal teleszórt területek egyaránt jellemezték már a korai szuburbiákat is. Tehát a fehér középosztály sajátos életmódja által jellemzett, a város körüli településeken kialakuló homogén szuburbiák képe már ekkor sem állta meg a helyét (JACKSON, K. T. 1985, MCMANUS, R. ETHINGTON, P. J. 2007).

A fejlett államok szuburbán növekedésének nagy lendületet adott a második világháború utáni „baby boom”, valamint - különösen az USA területén - az ingatlanhitelek széles körü elérhetősége, a mobilizáció növekedése, és az ingatlan-befektetők nagy léptékü kertvárosias építései. 1960-ban az USA lakosságának több, mint fele élt az elővárosi gyürüben (GRANT, J. L. 2014, SQUiRES, G. D. 2002). A XX. század második felében a kisebbségi lakosság és az alsó osztály is meghatározóvá vált a világ szuburbiáiban, ahol megjelentek a gyermektelenek, csonka családok, elváltak, majd a bevándorlók telepei is. Különösen fontos a városból kiszoruló alsóbb osztályok szerepe az alacsonyabb státuszú és elöregedő szuburbiák hosszú távú fejlődésében is (MiesZKowski, P. - Mills, E. S. 1993, SzIRMAi V. 2011, TiMÁR J. 1992, TimÁR J. 1999).

1945 után a fordista termelés kiteljesedése mellett politikai döntések sora is indukálta a szuburbán fejlődés új, még dinamikusabb szakaszát. A Federal Housing Administration 
gyámkodásával megszületett lakáshitel-program a Baby-Boomer időszakban 11 millió ház építését támogatta (Greenbelt Town Program), a hitelt nem tették elérhetővé felújításra, így paradox módon olcsóbbá vált új ingatlant venni, mint bérelni, vagy felújítani (BOURNE, L. S. 1999, DUNAY, A. et. al. J. 2001, JACKSON, K. T. 1985, TIMÁR J. 2001b).

Európában szintén ekkor indult meg a szuburbiák robbanása, részben azonos indító tényezőkkel. A baby-boomer generáció számára a háború utáni gazdasági fejlődés, állami támogatás és a fellendülő motorizáció megteremtette a szükséges feltételeket, ráadásul a városok háború utáni rekonstrukciója is konfliktusokkal terhelten zajlott. Ugyanakkor, hogy Európában egy tradicionális kisvárosi és falusi állományban indult meg az új elővárosi térségek kiteljesedése, amelyek így igazodtak a meglévő települési elemekhez és általában is „,színesebbek” mint a gyakran homogén észak-amerikai párjaik (GALLENT, N. et. al. 2003, VALDUNCIEL, J. 2014).

A szuburbiák típusainak új sora alakult ki, az ipari, kereskedelmi, alvó-települési, és bányászati szuburbiák jelentősen különböztek a bennük található ipari, kereskedelmi telephelyek és ellátó intézmények számában, térbeli elhelyezkedésében. A szuburbiák területén megtelepedő ágazatok egyben befolyásolták a demográfiai összetételt, a fehérek és színes bőrüek, a munkások és értelmiségiek megoszlását, valamint a korcsoportok alakulását a különböző jellegü szuburbiákban. Kimondottan a kékgalléros munkaerőnek szánt negyedek is jellemzővé váltak, kiemelendőek a kanadai, brit és ír világháborúk után állami (tanácsi) befektetéssel kialakított, a slumok felszámolása érdekében épített nagy népességü kertvárosi lakóhelyek (MCMANUS, R. ETHINGTON, P. J. 2007).

Ezáltal fokozódott a szuburbiák területegységeinek specializációja. Kialakultak a lakóhelyeken kívül, az irodaházak, a szolgáltató szektor (áruházak, téma-parkok), az ipar, az oktatás és a rekreáció térben jól elkülönülő diszperz egységei. A legtöbb helyi terv ezeket a demográfiai folyamatokat túlbecsülve jelentősen felülméterezte a várható népesség- és vásárlóerő növekedést, illetve gyakran a terveket a fejlesztők ráhatásainak engedve módosították túlzóra. A szuburbanizáció további időszakos migrációval járó módja lett a vidéki házak, az úgynevezett második otthonok rendszere (GALLENT, N. et. al. 2003, VALDUNCIEL, J. 2014).

Nagymértékben könnyíti az egymást követő különböző társadalmi csoportok betelepülését, ha az elővárosi fejlődés jól tervezett, szabályozott, mint Koppenhága esetében. A kis sürüségü beépített elővárosi területeken 1970 után a tömbházas beépítés indult meg, ahogy a kisebb keresetü háztartások kiáramlása is megindult, majd az olcsó, többszintes tömbházak számának növekedésével megjelentek a saját jármüvekkel nem rendelkező külföldi bevándorlók is. NyugatEurópa nagyvárosaiban a szolgáltatásokkal alig ellátott területeken - ahol a napi vásárláshoz is ingázni kellett - a jól kiépült elövárosi vasút segítette a heterogén csoportok életvitelének megszervezését (REEH, H. - ZERLUG, M. 2011).

Párizs szuburbanizációja jól szemlélteti a vidékről beáramlók szerepének jelentőségét az európai városok térfolyamataiban. 1960-as évek derekától 1975-ig dinamikus kiáramlás történt a városból a környező településekre, majd ezután az áramlás lelassult. A következő jelentős növekedési hullámban, az addigra kialakult szuburbiákon túli településgyürü dinamizálódott és ekkor már a vidékről beáramlók alkották a beköltözők többségét. E folyamat 1990-re újra megfordult és a városból való kiáramlás felé helyeződött a hangsúly, ami által jelentősen differenciálódott az elővárosi övezet, kimondottan felkapott zónák mellett a városból kiszorulók szegregátumai is kialakultak, miközben a városrehabilitáció révén megindult a reurbanizáció is (CATTAN, N. 2011).

Másik jellegzetes utat képvisel Bécs, ahol a világháború óta konzekvensen folytatott bérlakásprogram miatt a város folyamatosan rendelkezett nagyszámú, elérhető és megfelelö minőségü ingatlannal. Ezért, amikor - a nyugatabbi fővárosokhoz képest megkésve - 1970 után megteremtődött a szuburbanizáció feltételrendszere a folyamat nem járt drasztikus népességveszteséggel, 1990 után pedig a nemzetközi bevándorlás révén újra nőni kezdett a város lélekszáma (GörGL, P. et al. 2011).

A nyugat-európai várások esetében megindult a policentrikus várostérségek kialakulása. Ennek során az elővárosok (esetenként a szomszédos nagyvárosok) miatt a népesség és munkaerővonzás 
sugaras jellege mellett megjelennek az érintőleges és kétirányú ingázások. Az egyes elővárosi térségek specializációja révén kialakulnak üzleti, ipari (technopoliszok) és szolgáltatásokkal jellemezhető alcentrumok, melyek fokozatosan sajátos vonzáskörzeteket alakítanak ki. Ennek következtében a szuburbán öv diverzifikációja jelentősen nő (CATTAN, N. 2011, SZABÓ T. et. al. 2014, TIMÁR J. 1999).

A reurbanizáció megindulásával a szuburbanizáció lelassult, a középosztály által lakott elővárosok elidegenedett, sekélyes kapcsolataitokkal jellemezhető atomizálódott közösségének, a klasszikus felső középosztálybéli családmodell sikertelenségének területi megnyilvánulásai meghatározzák korunk szuburbiáinak helyzetét. Az elővárosi gyürübe költözők gyermekei rendszerint már nem kívánnak ott maradni, (2000-ben a baby-boom generációja már a hatvanas éveiben járt!). A szülöktől külön, új szuburbiában, vagy a megújuló belvárosokban kerestek lakóhelyet. Ez gyökeresen átalakította a szuburbákban élő háztartások szerkezetét, a gyerekeikkel együtt élő családok arányának rovására nőtt az egyszemélyes, gyereknélküli és egyszülös háztartások száma (DuNAY, A. et. al. 2001, SQUIRES, G. D. 2002, SZIRMAI V. 2011a).

E folyamatok a városokra kedvezőtlen hatással vannak, az adó városból a szuburbiába csoportosul át, azonban az ott élők rendszeresen használják a városi infrastruktúrát és ellátórendszert. A forráshiány és a képzett, tehetős lakosok kiáramlása miatt a város bizonyos részei leépülnek, szegregátumok és slumok alakulhatnak ki. Bizonyos országokban pedig kialakulnak a speciális, eleve szegregált sajátos lakóhelyek, a zárt lakóparkok, melyek izolált közössége és az erőteljes elszigetelödés kedvezőtlen társadalmi és pszichológiai hatásokkal jár (BORUNE, L. S. 1999, HEGEDÜs G. 2008, MARCINCZAK, S. et. al. 2011).

Ezzel szemben a világ jelentős részén a szuburbanizáció ettől nagymértékben eltérően indult meg és zajlik napjainkig. A gazdaságilag feltörekvő országokban a szuburbanizáció a hetvenes években indult meg, sajátosságuk, hogy a városok eröteljes növekedésével párhuzamosan zajlik az elővárosi gyürü, valamint a távolabbi kisvárosok erősödése. Ezen országokban tehát a relatív dekoncentráció nem új szakaszt alkot, hanem kiegészíti a városrobbanást. Ezekben az ázsiai (Kína, India) és dél-amerikai (Brazília) országokban a gyors gazdasági növekedés mellett a városfalu szakadék növekedéséből adódó vidéki elvándorlás is döntő tényező (ENYEDI, GY. 2011a, LOPES DE SOUZA, M. 2001).

A merev szocialista tervezés helyébe lépő piaci mechanizmusok révén Kínában rendkívül kevert területhasználat jött létre a városok peremén. A térbeli struktúrákat az ipar területi igényei határozzák meg nem a népesség elvárásai. Jelentős a mezőgazdasági területek visszaszorulása, a beépítés bakugrásokkal és szelektív besürüsödésekkel jellemezhető szerkezete miatt rossz, kedvezőtlen településstruktúra alakul ki, melyben a legrosszabb területi egységeken a vidékről nagy számban bevándorlók gettóit találjuk. A rossz közbiztonság elősegíti a zárt, gyakran fegyveresen örzött lakóparkok kialakulását (YUE, W. et. al. 2013, WU, F. 2010).

A szuburbanizáció tehát számos részfolyamatra bontható, amelyek globálisan területileg és időben is jelentősen eltérő megjelenési formákat mutat, továbbá az egyes elemek jelentősége is változó időben, ráadásul számos konfliktus kíséri a szuburbiák fejlődését. Ennek következtében a szuburbiák épített környezete, a lakossági összetétele és e területek társadalmi szerepe dinamikusan változik. Európa szuburbanizációja eltér az észak-amerikaitól, hiszen itt egy kiteljesedett faluhálózatban indult meg a folyamat, melyben a városból kiszorulás sokkal jelentősebb szerepet tölt be. Párizs példája jól szemlélteti, hogy az elővárosi gyürü fejlődésének területi hangsúlyai és az oda költözők összetétele jelentősen változhatnak rövid távon is, ezáltal a szuburbiák eltérő területei a folyamat elörehaladtával a társadalmi rétegződés eltérő fokán álló csoportok lakóhelyeivé differenciálódnak, miközben a növekedés súlyponti területei egyre kijjebb húzódnak a város határától. Ennek számos társadalmi és gazdasági jelenség mellett oka, hogy az agglomerációs övezetek belső gyürüjében elfogynak az olcsó, még beépíthető területek így az ingatlanárak is folyamatosan növekszenek, miközben egyes területek leértékelödnek a hátrányos helyzetüek oda költözése által. Ellenben Bécs példája szemléletesen mutatja, hogy a népességvesztés visszafogható megfelelő lakáspolitikával. 


\subsection{A posztszocialista országok és különösen Magyarország szuburbanizációs sajátosságai}

A szakirodalomban számos kutatás kiemelte, hogy a posztszocialista városfejlődési sajátosságok révén a szuburbanizáció egyedi jellemzőkkel rendelkezik a kelet-közép-európai térség államaiban (KuBES, J. 2013, OTT, T. 2001, SyKORA, L. - BouZAROVSKY, S. 2011). A szakmai diskurzusban kitüntetett helyzete ellenére azonban számos kérdés megválaszolatlan, és nyitott a vita a szocialista, majd posztszocialista városfejlődéssel kapcsolatban. Az urbanizáció menetének eltérése a „nyugati” országokban tapasztaltaktól kiterjedt nemzetközi vitát indukált és két fó irányvonal határozza meg a szakirodalom megközelítéseit. Az első szerint a gazdasági fejlettség a meghatározó, a társadalmi és politikai tényezők csak módosító hatással vannak, a városok fejlődése azonos séma szerint zajlik, de a lokális fejlettség függvényében fáziskésésekkel. A másik megközelítés az útfüggő fejlődés elméletére alapozva eltérő városfejlődési útvonalak meglétét feltételezi, amelyet a történeti és társadalmi tényezök határoznak meg (BAJMÓCY P. et. al. 2012, CSATÁRI B. 2002, ENYEDI Gy. 1989, HARDi T. 2010, HiRT, S. 2013, KovÁCs Z. 2002a, CSANÁdi G. - CSIZMADY A. 2002).

Elfogadva ENYEDI GYÖRGY véleményét a posztszocialista urbanizáció nem különbözik gyökeresen a nyugat-európai országok folyamataitól, azonban történelmi és politikai okokból kifolyólag egyedi jegyekkel tarkítva zajlik, az útfüggő fejlődés által meghatározva. (ENYEDI GY. 1989, ENyedi Gy. 2011, HiRT, S. 2013, KovÁCS Z. 2002a, SCHUCHMANN J. 2010). E megközelítést támasztja alá, hogy a városfejlődési szakaszok e területeken is megfigyelhetőek, azonban a különböző szakaszok összecsúszva, megkésve alakulnak ki. Ennek megfelelöen a rendszerváltozás után a kelet-közép-európai városok esetében is hamar megjelent szuburbanizáció és dezurbanizáció (BAJMÓCY P. et. al. 2012, CsATÁRI B. 2002, SZELÉNYI I. 1996, SZIRMAI V. 2017, То́тн J. 2006, То́тH J. 2007).

A posztszocialista országokra általánosan jellemző a késleltetett jelleg, mivel Kelet-KözépEurópa jelentős része csak a XIX. század elején lépet, a modern urbanizáció útjára és megrekedtek a városfejlődés első szakaszában. Ennek következtében a nyugati országokra jellemző kis- és közepes városok száma alacsony. A szocialista érában ezen országok alul urbanizáltak voltak, az extenzív szocialista iparfejlesztés során megnövekvő ipari és szolgáltatószektor-beli munkahelyek számától elmaradt a városi lakosság. Ennek oka nem csak a városok megkésett fejlődésében, hanem az ingázás kiteljesedésében, a háztáji termelés népességmegtartó erejében is keresendő (BELUSZKY P. 1999, KOVÁCs Z. 2002a, SZELÉNYI I. 1996, SZIRMAI V. 2013).

Budapest esetében a szuburbanizáció a múlt század hajnalán - hasonlóan a nyugat-európai városokhoz - el kezdett kibontakozni. A vasútépítések következtében a Budapesttel szomszédos településeken egyre nagyobb olyan tömeg élt, amely a kertvárosias lakóhelyéröl a városba ingázott naponta. Emellett számos további települést duzzasztott jelentősen fel a vidéki munkások és családjuk beáramlása. A fejlődés révén több település teljes értékü, saját vonzáskörzettel is rendelkező várossá nötte ki magát, különösen Újpest dinamikája volt kiemelkedő. A harmincas évektől napirenden volt a belső elővárosi gyürü beolvasztása a fövárosba, így 16 község és 7 város becsatolásával létrejött Nagy-Budapest (BELUSZKY P. 2007).

Ez a minta egyben jellemző volt volt - bár jóval kisebb léptékben - a vidéki városok fejlödésére is, hiszen a esetükben is jellemző volt, hogy a szuburbanizáció potenciális területeit jelentő falvak becsatolták. Fontos kiemelni, hogy a település-összevonásoknak már a kiegyezés óta nagy hagyománya van a hazai városfejlesztési politikákban. A településösszevonások „eltüntették” az embrionális szuburbiákat és Budapest esetében a policentrikussá váló várostérség újra monocentrikussá vált.

A kezdetleges csírázó elővárosi fejlődés a piaci szabályozók kikapcsolásával megszünt, valamint a település-összevonások rutinja, mint a városfejlesztés és erőltetett urbanizáció eszköze - a vidékről beáramlók révén növekedő, a szuburbanizáció jeleit is mutató - településeket meg is szüntette (BEluszKY P. 1999, CsANÁdi G. - CsIZMADY A. 2002, DöVÉNYi Z. - KovÁCs Z. 1999, 
HIRT, S. 2013). A szocialista várospolitika az addigi, a tőkés országokhoz hasonló fejlődési pályát megtörte. Az adminisztratív korlátok rendszere és a lakáspolitika 1945 és 1989 között hibernálta a folyamatot, ugyanakkor a vidékiek beáramlása továbbra is növelte a városok peremén lévő települések népességét (BELUSZKY P. 2007, TIMÁR J. 1999).

A szocialista államok a fejlődés kulcspontjának az ipart és az azoknak munkaerőt biztosító nagyvárosokat tekintették. Ennek megfelelően a fejlesztéspolitika a településhálózat magas szintjén lévő városokra koncentrált. A falvak infrastruktúrája, ellátottsága és a munkahelyek száma jelentősen elmaradt a városokhoz képest a teljes időszakban, ezáltal a központok felé tartó migráció határozta meg a településhálózat alakulását. Némileg lecsökkent a földrajzi lokáció szerepe és a településhierarchiában elfoglalt helyzet határozta meg a községben a várható életminőséget. Ezt a szemléletet hazánkban az Országos Településhálózat-fejlesztési Koncepció foglalta jogi keretbe (KovÁcs Z. 2002a, KóKAI S. 2011).

Az állami földtulajdon, az erős szabályozottság és a piaci szabályozók hiánya révén nem indult meg az elővárosokba áramlás, kompaktak maradtak városok, amely igazodott a szocialista ipar fordista jellegének igényeihez is. A fejlesztési források és a döntéshozatal erős centralizáltsága miatt a teljes településhálózatot fejlesztették, a helyi érdekek nem érvényesültek a döntéshozatalban (DÖVÉNYI Z. - KOVÁCs Z. 1999, KovÁCs Z. 2002a, KovÁCs Z. 2010).

Ez egyes szocialista államok között is jelentős különbség mutatkozott, keleti irányban egyre fokozottabb a késleltetettség. Míg az NDK területén több kisebb város estében is megindultak a szuburbanizáció sajátos szocialista elözményei, addig az a köztes Európában jobbára már csak a fővárosokra és néhány központi funkciójú településére korlátozódott. A Balkánon és a Szovjetunióban a gazdasági helyzet, a szigorú szabályozás és az ipari igényeket fokozottan érvényesíteni akaró mesterséges urbanizáció is akadályozta ennek kiteljesedését (HIRT, S. 2013).

Összegezve tehát a jelentős területi különbségek ellenére a posztszocialista városokban alapvetően hasonló helyzet alakult ki az elővárosi fejlődés feltételeit tekintve 1989-re. A piac hiánya és a felülről vezérelt iparosítás révén sajátos térszerkezet vált általánossá, nagy léptékü iparterületekkel, lakótelepekkel és a városok peremén a vidékről beáramlók által felduzzasztott községekkel. A rendszerváltások azonban élesen átszabták a kelet-európai városok fejlődési ívét, ebben kiemelt szerepe volt a 1990-es évet követő sokkszerü társadalmi-gazdasági változásoknak.

\subsubsection{A posztszocialista szuburbanizáció társadalmi-gazdasági jellemzői}

A rendszerváltás utáni elővárosi robbanás visszarendeződésként is értelmezhető, az államszocializmus alatt megakasztott elővárosi fejlődés abba az irányba tett nagy ugrást, ahol tartana az 1945 utáni beavatkozás nélkül (OUŘEDNíčEK, M. 2007). Azonban a szuburbán fejlődés elöregedő, csökkenő népesség és külföldre áramlás mellett indult meg, így a mobilizálódni képes háztartások száma korlátozott, a községek stabilan stagnáló népességszáma relatív növekedésként értelmezhető (BAJMÓCY P. 2000a, GÁBOR P. 2001, MYKHNENKO, V. - TUROK, I. 2008).

1990 után a politikai átalakulások megrendítő hatással voltak a posztszocialista városfejlődés menetére. Az addig felülröl vezérelt tervezés helyére az önkormányzati rendszerek kerültek, akik immár a helyi érdekeket képviselték; orvoslásra került az erőszakos település-összevonások egy része. Meghatározóvá vált a piac, a települések közötti verseny, a különböző lokációknak már küzdeniük kellett a töke és a befektetők odacsábítása érdekében, különösen a külföldi tőkebefektetések esetében (IZSÁK É. 1999, KovÁCs Z. 2002a, KovÁCS Z. 2010, NAGY S. GY. 1999, NuISSL, R. - RINK, D. 2005, TIMÁR J. 2010).

A rendszerváltozás egyik legjelentősebb változása a lakásprivatizáció volt, hatására egyszerre jelentkezett a középosztály jobb életminőséget nyújtó területekre való kiáramlási igénye és az alsó rétegek költözési kényszere. A tehetősebb rétegek képesek voltak megváltani ingatlanukat és időben eladni, jelentős bevételhez jutva, számukra ez megnyitotta a lehetőséget, hogy saját, jó minőségü házat építhessenek a kedvező adottságú szuburbiákban. Ezzel szemben a korábban állami bérlakásban élő, tőkével nem rendelkezők vesztesei lettek a lakásprivatizációnak (CSANÁDI 
G. - Csizmady A. 2002, Egedy T. 2001, Kondor A. - Szabó B. 2007, KovÁCs Z. 2010, Roose, A. et. al. 2013, SZIRMAI V. 2011b).

A szuburbiába kiköltözés mellett döntők fö motivációi a szuburbanizáció fogalmi meghatározásánál bemutatott szempontok jelentős részét lefedik, jellegzetes céljuk a nagyobb, önálló háztartás, amely mentes a város környezeti problémáitól, ezt a családi okok és a munkahelyváltás követi. A konkrét lakóhely kiválasztásában 1990 és 1995 között inkább az ingázási távolság volt döntő, 2000-től viszont a lokáció presztízse, infrastrukturális állapota, a tájképi szépség és a költöző egyén informális kapcsolati hálója volt meghatározó, mivel a migrálók személyes kapcsolatai révén szereznek információt az egyes területekről (BIJKER, R. A. et. al. 2012, DövÉNYI Z. - KovÁCS Z. 1999, LAMPL Zs. 2010, WOLF, T - MEYER, B. C. 2010).

A lakóhelyváltók több további jellegzetes csoportja különíthető el, melyek életvitele nem feltétlen kompatibilis, együttélésük súlyos konfliktusok forrása. A helyhez kötődő tősgyökeres lakosok és s hosszú távon tervező beköltöző családalapítók érdekeltek a helyi közösség megfelelő müködésében és a település sikerességében. Ezzel szemben a helyi kötődéssel nem rendelkező bérlők, valamint a mobilis „újgazdagok” csoportjai számára a település történelmi öröksége, a helyi közösség indifferens, megörzik korábbi lakóhelyük baráti köreit, gyermekeiket a városi iskolába járatják és e csoportok számának növekedése az alvó településsé válás folyamatát indukálja. Köztes helyzetet foglalnak el a diverz napi mozgású új lakosok, bár gyenge szálak kötik őket új lakóhelyükhöz, azok a város irányában is kisebbek (JANKÓ F. 2004, JETZKOWITZ, J. et. al. 2007).

A szocialista városfejlődés sajátosságai miatt a bérházas területek leromlása és a rendszerváltás utáni lakhatási költségnövekedés miatt a bécsi példánál látottakkal ellentétben gyors ütemü kivándorlás alakult ki. A városból kiszorulók, munkanélküliek is jelentős részét teszik ki a szuburbiák népességnövekményének a posztszocialista térségben. A bérleti díjak emelkedése, az erőn felüli lakásmegváltás és a rezsiköltségek növekedése miatt nem voltak képesek ezen alacsony keresetűek, munkanélküliek és nyugdíjasok továbbra is megélni a dráguló városokban, számukra a kiáramlás túlélési stratégia (CSANÁDI G. - CSIZMADY A. 2002, CsOBA J. 2017, Daskalova, D. - Slaev, A. D. 2015, Egedy T. 2001, Kristóf A. - KóKAi S. 2015, Roose, A. et. al. 2013, SZIRMAI V. 2011b, TIMÁR J. 2010).

A vidékről a szuburbiákba költözők aránya magas a kelet-közép-európai szuburbiák fejlődésében a nyugat-európai példákhoz képest. A pályakezdők a munkalehetőségek miatt migráltak az urbánus központokba, ahol a szuburbiákat a saját lakáshoz jutás, családalapítás indokával választották (BROWN, L. D. - SCHAFFT, K. A. 2002, DövÉNYI Z. - KovÁCs Z. 1999, TunA, T. - KoK, H. 1999). Ugyanakkor a városi munkahelyek 1990-es évek eleji csökkenésével az ország perifériáira is jelentős visszaáramlás jelentkezett, valamint az életmódváltók és nyugdíjasok révén megjelentek a dezurbanizációs mozgások is (BAJMÓCY P. 2000a, OUŘEDNÍČEK, M. 2007, TIMÁR J. 2010).

Prága példáján bizonyítja OUŘEDNíČEK, hogy bár a posztszocialista városok átalakulásban is meghatározó a középosztály szuburbanizációja, a szegények kiszorulásának és a vidékröl a városok peremére költözőknek még nagyobb a szerepe. Fontos kiemelni, hogy a kelet-középeurópai városok szuburbanizációját 2000 előtt a magánberuházások alakították, addig az ezredforduló után egyre nagyobb hangsúlyt kaptak az ingatlan-befektetők. Ezzel párhuzamosan a városok népessége növekedni kezd, ebben a vidékről beáramlás és a szuburbiákból történő visszaköltözés jelentösége változó településenként (OUŘEDNIČEK, M. 2007).

Varsó esete ettől annyiban különbözik, hogy a népesség kiszorulását indukáló tényezőkben a lakónegyedek tömeges leromlása helyett a többi vizsgált városnál nagyobb hangsúlyt kapott a város sikeres nemzetköziesedése miatt megdráguló lakhatás. A kiterjedő szolgáltató-szektor a kevésbé tehetőseket kiszorította a belvárosi ingatlanpiacról, ezért az átlag alatti keresetűek kiszorulása dominálta a szuburbanizációt. Így kettős térszerkezet alakult ki, a belső településgyürüben a tehetősek lakóparkjai váltak jellemzővé, míg a szuburbán öv peremén már egyértelmüen a kiszorulók szegényesebb lakhelyei a tipikusak (SYKORA, L. 1998). 
Budapest e két példa között helyezkedik el, a városból a szuburbiába kikényszerülök a perem rosszul elérhető, már a szocializusban is az elesettek által felduzzasztott községeiben települnek meg, e területeken hátrányos helyzetüek aránya esetenként nagyobb, mint a városok hanyatló lakóterületein. Továbbá e hátrányos helyzetü személyeknek nincs lehetősége ingázni, de ott helyben sem találnak munkalehetőséget, csapdába kerülve (CsANÁDI G. - CsIZMADY A. 2002, GANT, R. L. et. al. 2010, SÁGI Zs. - TRÓCSÁNYI A. 1998, SzIRMAI V. et. al. 2011).

Bár a vidékröl jövők közt magas a fiatal pályakezdők aránya, a városból kiköltözők esetében jellemző a középkorúak mobilitása. Az ezredfordulón Budapest környékén végzett felmérések során a 35-54 év közöttiek (ma 50-70 évesek!) alkották a lakóhelyváltók felét. Az önkormányzatok által remélt megfiatalodás, amely a helyi intézmények (iskolák, óvodák) fenntartását is segíthetné, elöreláthatólag időszakos jelenség (DöVÉNYI Z. - KOVÁCS Z. 1999, EGEDY T. 2005, OUŘEDNíČEK, M. 2007). Az idős kiköltözők jellemzően az elzártsága miatt nyugodtabb magas táji szépségü területekre áramlanak. Lakóhelyválasztásukban meghatározóak a korábbi tapasztalatok, így gyakran a korábbi hobbitelkeikre költöznek ki. (GöRGL, P. et. al. 2011, SZEBÉNYI A. 2006, VÁRADI M. M. 1999)

Az ezredforduló után a posztszocialista városokban a szegregáció paradox módon a különböző léptékben egyszerre csökkent és nőtt. Jellemzővé vált a térbeli heterogenizáció, a Kenokapitalizmus folyamatában leírtak szerint mozaikosan, közel randomizáltan szóródnak funkciók és különböző társadalmi csoportok a városi térben, amit a posztmodern társadalmi közeg kiteljesedése mellett a hektikus ingatlanpiac is előmozdít (BRADE, I. et. al. 2009a, DASKALOVA, D. - SlaEV, A. D. 2015, KovÁCs Z. - SZABÓ B. 2016, TimÁR J. 2010).

Bár a fentieknek köszönhetően a legtöbb társadalmi csoport szegregációja csökkenést mutat települési szinten a tehetős, magasan képzett rétegek elkülönülése erösödik. Ennek oka az önkormányzatok és befektetők telekpolitikáján (esetenként telekspekuláció) túl a vidéki dzsetrifikáció kibontakozása. A jó adottságú szuburbiákból kiszorulnak a helyiek - különösen a fialok - az ingatlanpiacról, a földmüvelés visszaszorul a telekárak drágulása és a funkciók cserélődése miatt (BROwn, D. L. - SCHAFFT, K. A. 2002, EdELÉNYI B. 2002, PHILLIPS, M. 2002, TIMÁr J. 2001b, TuNA, T. - KOK, H. 1999, ŹRÓBEK-RÓŻAŃSKA, A - ZADWORNY, D. 2016).

A nyugati példákhoz hasonló - de az örökölt településstruktúra miatt sajátos - szektorális társadalmi megoszlás jellemzi a kelet-közép-európai szuburbiákat. Az államszocialista korszakban az elővárosi települések népességét a vidékről a nagyvárosi munkahelyekre törekvők duzzasztották fel, a város körüli falvakban a szegényebbek lakásöve alakult ki. Szuburbanizációt pótló, vagy annak előfutáraként értelmezhető folyamat a városiak második otthonainak, hétvégi házainak elterjedése volt, mely a nyolcvanas évekre gyakran időszakos, vagy a tilalom ellenére állandóan lakott övezetet képzett (BRADE, I. et. al. 2009b, DövÉNYI Z. - KOVÁCS Z. 1999, HARDI T. 2012, IZSÁK É. 1999, IZSÁK É. 2001, KoK, H. 1999, LAMPL ZS. 2010).

Az eltérő életvitelek együttélési nehézségei, a számtalan konfliktus a beköltözők integrációját elnyújtja, eszkalálódásuk pedig akár el is lehetetlenítheti a helyi közösség müködését. A beköltözők saját vidék-imázsukhoz kívánják alakítani a település képét és életmódját, jobb érdekérvényesítő képességük révén pedig kiszorítják az eredeti népességet a politikai életből (CSURGÓ B. 2013, GANT, R. L. et. al. 2010, TÓZSA I. 2002, ŹRÓBEK-RÓŻAŃSKA, A. - ZADWORNY, D. 2016a). Nem csak a közigazgatásilag önálló falvak, de a korábban a városokba becsatolt községek (a mai egyéb belterületek) esetében is fokozzák e problémakört a kevert területhasználatból fakadó társadalmi feszültségek. E feszültségek a napi életvitel nehezítése mellett a vidéki idillt is rombolják, ami azért nagy horderejű hanyatlás, mert e települések egyik fó vonzereje ebben rejlik (BROwn, D. L. - SCHAFFT, K. A. 2002, GYENIZSE P. et. al. 2016, JANKÓ F. KOMORNOKI M. 2008, KOK, H. 1999).

A differens életvitel, az anyagi lehetőségek, valamint a képzettség mentén történő szegregáció történelmi előzményekkel rendelkezik, a két világháború között is jelen voltak szegregált szektorok az elővárosi övekben. A szegregáció elmélyülése a migráció szelektivitásán keresztül a 
rendszerváltozás utáni hamar megindult (CSANÁDI G. - CsIZMADY A. 2002, ENYEDI GY. 2011, LADÁNYI J. - SZELÉNYI I. 1997, MARCINCZAK, S. et. al. 2011, SÁGI Zs. - TRÓCSÁNYI A. 1998).

A települések politikai vezetésének hozzáállása jelentősen hat a szuburbanizáció menetére. Míg Nyugat-Európában az agglomerációk fejlődését a területi tervezés irányította, kezelte, addig a posztszocialista térségben és így hazánkban a folyamat jobbára irányítatlan, spontán módon zajlik. Az agglomerációs tervezés legföbb nehézsége a döntési kompetenciák kérdése, hiszen a tervezési és rendezési dokumentumok az önkormányzatok jogkörébe tartoznak, a hazai agglomerációk esetében legfeljebb formális egyeztetés figyelhető meg, így a települések nem összpontosítják adottságaikat, versenytársaknak tekintik egymást. A demográfiai és területhasználati folyamatokat és beavatkozásokat saját belügyüknek tekintik és legfeljebb gazdasági és infrastrukturális együttmüködések jellemzőek. Az agglomerációk fejlesztése érdekében azonban elkerülhetetlen lesz, hogy a közigazgatási együttmüködéseken túlmutató, komplex fejlődést segítő szervezetek alakuljanak ki (IzSÁK É. 2001, LuX G. 2012, SomLYÓdinÉ PfEIL E. 2012, SuVÁK A. 2012a, SuVÁK A. 2012b, SZIRMAI V. et. al. 2011, TIMÁR J. 2010).

A nyitott személetü, funkcióváltó települések népessége gyorsan nő, a helyiek kisebbségbe kerülnek, de a település demográfiai és anyagi helyzete jelentősen javul. A legelterjedtebb laissezfaire hozzáállás célja a pénzügyi stabilitás, amivel azonban sokszor ad-hoc döntéseket alkalmaz így a kiszámíthatatlan és veszélyes lehet. A bezárkózó települések, általában lemaradnak a fejlődésben, de ez is lehet sikeres mód, amennyiben a település megfelelő demográfiai tartalékokkal rendelkezik (SZABÓ J. 2003). A társadalmi konfliktusok kezelése alapvetően a kiváltó okok kezelésén keresztül lehetséges. Az építési, területhasználati szabályozás jól társadalmasított felülvizsgálata, a leginkább hiányzó infrastrukturális elemek pótlása mellett a tartósan sikeres települési fejlődéshez elengedhetetlen, hogy a beépítettségi intenzitás fokozódásának és az ingatlanspekulációnak korlátot tudjon szabni a település vezetése. (ANAS, A. - PINES, D. 2008, VÁRAdi M. M. 1999).

A szuburbanizáció lelassulásával és az elöregedéssel az önkormányzatok számára a cél a település pénzügyi stabilitásának őrzése és a szegények beáramlásának elkerülése lesz. Azonban a pazarló szétterülő szuburbiák infrastrukturális fejlesztése, a szociális ellátó hálózat fenntartásának költségeit a szuburbán települések jelentős része nem bírja kigazdálkodni a jövőben a jelen trendek mellett (DUANY, A. 2001, SZIRMAI V. 2011a).

A szuburbiák megújulásának azonban számtalan akadálya van. A sikeres modellek alapján szükséges, de az eredményességet nem garantáló lépések a heterogén tájhasználat kialakítása monofunkciós zónák helyett, a közösségi terek kiépítése, a zöld felületek védelme, a gyalogos, kerékpáros és a tömegközlekedés fejlesztése. Az adminisztratív határokat és kompetenciákat szükséges lenne a szuburbanizáció által átszabott valós települési folyamatokhoz igazítani (ANAS, A. - Pines, D. 2008, DunAY, A. et. al. 2001, GANT J. L. - Nelson A. C. 2014, LuX G. 2012, ŹRÓBEK-RÓŻAŃSKA, A - ZADWORNY, D. 2016).

Jelentős nehézség azonban a szuburbanizáció statisztikai követésében, hogy a lakosok új lakcímükre nem jelentkeznek át, akár $15-20 \%$ is lehet a különbség a valós értékek és az adatok között. E jelenség okai közül kiemelendő, hogy főleg az idősebb háztartások belvárosi lakásaikat kiadják, vagy a gyereknek adják, amikor kiköltöznek a szuburbiákba, de tulajdonosok maradnak. A fiatal kiköltözők jellemzően a városi funkciók (iskola, háziorvos) használata érdekében, vagy adóoptimalizálási célból tartják meg korábbi címüket (DöVÉNYI Z. - KovÁCS Z. 1999, OUŘEDNíČEK, M. 2007, VÁRADI M. M. 1999).

A posztszocialista városok esetében tehát a belvárosi lakónegyedek leromlása, a piacgazdasági átmenet és így a belváros újra felértékelödése, citysedése döntő módon befolyásolta a szuburbanizáció mikéntjét, intenzitását. Emellett a vidéki lakosság beáramlása, majd a városrehabilitáció is jelentősen módosította a folyamat dinamikáját. A városok körüli szuburbán öv egyes szektorai, településeinek státuszát a táji és infrastrukturális adottságok mellett az önkormányzatok ellenkezése, vagy támogató hozzáállása is döntő volt. Az agglomerációk alakulásában tehát az egyes részfolyamatok jelentősége közt jelentős különbség mutatható ki, 
azonban azok motivációi és lefolyása hasonló volt. Mivel a nyugat-európai városokhoz hasonlóan megindult a városokba irányuló migráció a szuburbanizáció dinamikája lecsökkent. Ennek megfelelöen a kelet-közép-európai szuburbanizáció rövidebb idő alatt zajlott le, amely kelet felé haladva jellemzően fokozatosan csökken.

A bemutatott folyamatok és sajátosságok térben inhomogén, fragmentálódó térszerkezetet kialakítva jelentkeznek. Kutatásomnak célja feltárni, hogy az egyes részfolyamatok milyen területiség mellett milyen mértékben befolyásolják a szuburbán öv területének különböző adottságú lakott helyeit, mivel a konfliktusok kezelésében fontos a problémás területek azonosítása. Ugyanakkor a területi változásokban rejlő lehetőségek kiaknázáshoz is elengedhetetlen a pontos feltérképezés.

\subsubsection{A posztszocialista szuburbanizáció térszerkezeti jellemzöi}

Megnövekedett a földrajzi helyzet jelentősége a rendszerváltás után, mivel a szocialista iparterületek jelentős része válságba került, a gazdaság tartós recesszióba süllyedt és a külföldi beruházások csak bizonyos hídvárosok területén, valamint a fövárosokban jelentek meg. Mindez időben egybe esett a természetes népességfogyással és a külföldre való kiköltözések felfutásával. Összességében az átalakulások felkészületlenül érték a településhálózatot (KovÁcs Z. 2002a, TUNA, T. - KOK, H. 1999, OUŘEDNíČEK, M. 2007).

A posztszocialista átalakulás urbanizációs-településfejlesztési nehézségei annak erőteljes hatásai mellett lépcsőzetes lefutásából is következik. Az intézményi politikai átalakulást, a piaci és szabályozási liberalizációt, valamint a piacgazdaság megjelenését lemaradással követi a nemzetgazdaság újrastrukturálódása, a posztmodern kultúra és szemlélet (városvezetés) elterjedése. A települések épített környezete azonban lassabban változik, átalakulása évtizedekig tarthat, még ma sem feltétlen jeleníti meg a társadalmi átalakulások teljességét, a szuburbanizáció és a belvárosi rekonstrukció hatásait (BOROS L. el. al. 2007, KovÁCS Z. 2010, SYKORA, L. BUZAROVSKI, S. 2011).

A szocialista városokat erőteljes tagoltság jellemezte, a történelmileg kialakult lakónegyedek, a monoton lakótelepek és az ipari övezetek kompakt határokkal rendelkeznek, maga a beépített terület is éles kontúrral ér véget. Ugyanakkor a funkciók heterogén módon helyezkednek el a városokban. 1990 után viszont sajátos funkcionális terek (szupermarket-zónák, autókereskedések tömörülései, stb.) alakulnak ki (HIRT, S. 2013, TIMÁR J. 2010).

A földtulajdonlás rendszere több szakaszban alakult át a rendszerváltás óta, ezt hatást gyakorolt a szuburbanizáció formáira is. Az 1990-es években jelentősen hátráltatták a szuburbanizáció kialakulását a földszerzés nehézségei. Ebben a földprivatizáció és a kárpótlás hatására még inkább elaprózódó és a tisztázatlanná vált tulajdonviszonyoknak nagy szerepe volt. Az ezredforduló éveiben a földpiacot passzív, lassú változások jellemezték, majd 2003 után Kelet-KözépEurópában általános szuburbán robbanás zajlott. A külföldi tőke hatására az ingatlanpiac dinamizálódott, átminősítési hullám jellemezte a városok térszerkezetét. Nagy gyorsasággal szaporodni kezdtek a városok peremén a szupermarketek, raktáráruházak, ipari parkok és nagy léptékü ingatlanfejlesztések. E gyors változásokhoz képest a szabályozás lemarad, azonban elkezdődik a posztmodern, új (zöld, komplex) nézőpontok beszivárgása a területi tervezésbe. 2007 után a gazdasági válság és a lakáspiac recessziója a szuburbanizáció lassulását, megakadását váltja ki (KovÁcs Z. 2010, NAGy S. Gy. 1999, Roose, A. et. al. 2013, SZIRMAI V. 2011b).

A posztszocialista városok jellegzetes térszerkezetének sajátosságait OTT, T. (2001) térszerkezeti modelljének segítéségével mutatom be (5. ábra). E városokban a torz lakáspiac, a CBD-k kialakulása, a csökkenő háztartásméret és a bérházak kis száma miatt nagy ingatlanhiány mutatkozik. A területi tervezés gyengesége és a zöld területek drasztikus eltünése az addig is kedvezőtlen települési életminőséget tovább rontotta. A panel technológiájú lakótelepek népességvesztése a legdinamikusabb a korai időszakban. Ekkor jelennek meg az első plázák, szupermarketek, ipari parkok, de a tömeges gazdasági, intézményi (szociális intézmények, 
iskolák, stb.) és rekreációs szuburbanizáció pár éves lemaradással követi a lakossági migrációt. (HIRT, S. A. 2013, KovÁCs K.1999, OTT, T. 2001, TiMÁR J. 2010).

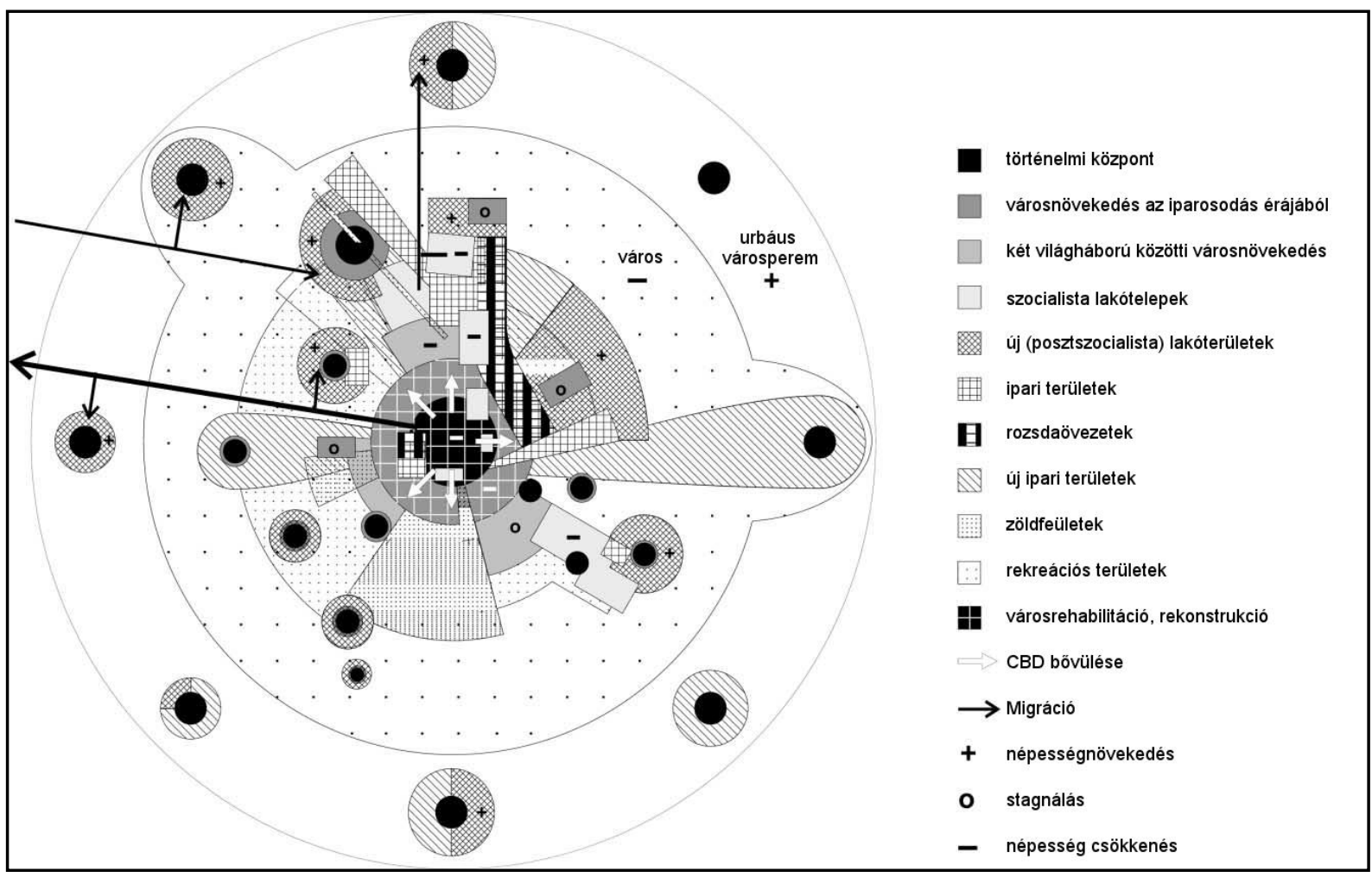

5. ábra. A posztszocialista városok funkcionális területhasználati modellje. Forrás: Ott, T. 2001, p. 406. alapján saját fordítás.

A rossz ingatlanszerkezet és a dráguló belváros miatt fokozódó kiáramlás igényeinek kielégítésére a peremeken van lehetőség, ott alakulnak ki gyors növekedési gócok, ahol nagy számban elérhetőek olcsó telkek (OTT, T. 2001, RoOSE, A. 2013). Szektorális jelleget tapasztalunk a kiköltözők lakóhelyválasztásában, mivel jellemzően a legközelebbi, elvárásaiknak megfelelő területre költöznek a lakosok, mivel nagy a földrajzi távolság és az informális kapcsolatok szerepe (BRADE, I. et. al. 2009b, DövÉNYI Z. - KovÁCs Z. 1999, NUISSL, R. - RINK, D. 2005).

Olyan új ingázási formák jelennek meg a gazdasági szuburbanizáció és a szuburbán települések urbanizációja során, mint a centrumból a környező településekre irányuló ingázás (reverse commuting), a szuburbán települések közötti, érintő irányú (agglomeráción belüli) ingázás. A dekoncentráció ellenére a jól fizető munkahelyek többsége továbbra is a szuburbia belső területein, a központi városhoz relatíve közel koncentrálódik (KovÁCs Z. et. al. 2015).

A nyugati elővárosi gyürükhöz képest magas a társasházak aránya, és az új ingatlanok jelentős része nem zöldmezős beruházásként, hanem a falvak hézagtelkein új építkezés vagy házfelújítás során valósul meg. Mindegyik esetben jellemző a laksürüség jelentős növekedése a tömbfeltárások, új utcák nyitása, a tartalékterületek beépülése miatt, valamint mert az ingatlanberuházók a telkek kis méretével próbálják maximalizálni profitjukat. Az új épületek teljesen elszórva jelennek meg az ingatlanállományban, a zártabb utcakép (sorházak) kialakulása és a parkok, játszóterek hiánya rontja a településkép falusias jellegét. Ez pedig a laksürüség növekedésével együtt differenciált -a falusias településképtől idegen - épületállományt alakít ki, ami számos konfliktus forrása a helyi és új lakosok között (BAJMÓCY P. 2000a, CsURGÓ B. 2013, OTT, T. 2001, SZEBÉNYI A. 2006, TÓZSA I. 2002).

A telekárak felfutása, a szabad területek telítődése révén több lépcsőben a várostól távolabb helyeződik a szuburbanizáció súlypontja, második szuburbán gyürüt kialakítva. Az alsó középosztály migrációja már a szuburbanizáció csúcsidőszakában típustervek szerint készülő 
tömb- és sorházas jellegü, nagy léptékü ingatlanfejlesztések területén valósul meg (EDELÉNYI B. 2002, OUŘEDNÍČEK, M. 2007).

Varsó, Prága és a többi nagyváros környezetében megindult a sajátos funkciókkal rendelkező elővárosok képződése, azonban hazánkban a policentrikus átalakulás alapvetően megmaradt a budapesti agglomeráció sajátosságának, ez azonban hasonló a poszt-szocialista városok általános folyamataihoz. Ellenben csak korlátozottan, sokszor pedig egyáltalán nem jelentkezett a vidéki városok esetében (KovÁcs Z. et. al. 2015, OUŘEDNíčEK, M. 2007, SZABÓ J. 2003).

A hazai szuburbanizáció jellegzetessége a sajátos településhálózatból és adminisztratív felosztásból adódó jelenség, mely a külterületekre és egyéb belterületekre irányuló szuburbanizációt jelenti. Az államszocializmus alatt a városokhoz csatolt, de a településmagtól fizikailag elkülönülő falvak és külterületeik máig őrzik rurális jellegüket, így kielégítik a költözni vágyók igényeit. $\mathrm{Az}$ agglomerációk településeinek belterületein nagymértékben megnő az ingatlanok ára, ezért egyre vonzóbbak lesznek e települések olcsóbb külterületei is. (BAJMÓCY P. 2000b, BAJMÓCY P. 2003a, HARDi T. 2002, PÓCSI G. 2011, TiMÁR J. 1993).

A folyamat jelentőségét mutatja, hogy a hazai, budapesti agglomeráción kívüli szuburbanizációs népességnövekmény 29,0\%-a külterületeken és 26,1\%-a egyéb belterületeken realizálódott (BAJMÓCY P. 2014). Ennek oka, hogy e területek nem csak a tehetősek számára jelentenek vonzó környezetü, alacsony költségü lakóhelyi alternatívát, de a városokba igyekvő hátrányos helyzetüeknek és a városból kiszorulók számára is lehetőséget biztosítanak az újrakezdésre. Jelentős differenciálódásuk és sajátosságaik révén a hazai településföldrajzi szakirodalomban folyamatosan növekszik a fejlödésüket vizsgáló publikációk száma (BAJMÓCY P. et. al. 2012, BAJMÓCY P. et. al. 2018, BALOGH A. 2012, BALOGH A. - CsAPÓ T. 2013, KovÁCS A. D. 2010).

Összegezve megállapíthatjuk, hogy a posztszocialista szuburbanizáció - bár követi a szuburbanizáció globális trendjeit - számos sajátossággal rendelkezik. Ebben nagyobb a városból kiszorulók és a vidékről beáramlók szerepe, a sajátos gazdasági átmenet, az önkormányzatok hozzáállása és a demográfiai helyzet miatt azonban a szuburbanizáció rövid idő alatt, a városfejlődés későbbi szakaszaival (reurbanizáció) párhuzamosan zajlott. Jelentős eltérés mutatkozik a városból kiszorulók arányában, azonban általános jelenség a fragmentált és így vélhetően konfliktusokkal terhelt térszerkezet létrejötte.

Hazánkban további sajátos részfolyamatok alakultak ki, amelyek révén a városok térszerkezetei egyedi jellemzőkkel bírnak, ebből hazánk sajátosságaként kiemelhető az egyedi közigazgatásnak köszönhetően a külterületek és egyéb belterületek nagy szerepe a folyamatban. Mivel azonban e területek közigazgatási képviselettel nem rendelkeznek, infrastruktúrájuk hiányos, és magas a hátrányos helyzetüek aránya kitett az intenzív változások negatív hatásainak, mint azt a 3. fejezetben feltártam. A következő fejezetben ezért be kívánom mutatni a spontán módon zajló, irányítatlan szuburbanizáció lehetséges káros hatásait nemzetközi példákon keresztül.

\subsection{A szuburbanizáció részfolyamatai, hatásai a társadalomra és környezetére}

Az elővárosi öv tervezetlen, gyors és irányítatlan kiterjedése számtalan társadalmi, gazdasági és környezeti értelemben kedvezőtlen hatással jár. Jelen kutatás szempontjából legfontosabb, a város-vidék peremzónákkal is összefüggő következményeket emelem ki, mivel a hazai és keletközép-európai városokat ezek nagymértékben érintik és a külterületek jellegükből adódóan kitettek e problémáknak (CSURGÓ B. 2013, DunAY, A. et. al. 2001, KISS J. 1999, KoÓs B. 2007, Pócsi G. 2009a, SZIRMAI V. 2011b, TimÁr J. 1993, TimÁR J. - BAUKó T. 1999, TózSA I. 2002).

A szuburbiák kontrollálatlan fejlődése révén a mezőgazdasági területek, az erdők és zöld területek fogyása, valamint a hagyományos rurális területhasználat visszaszorul, a városi területhasználat behatol a környező térségekbe. Nem csak az természetes felületek csökkenése jelent károsodást, hanem e tájképi elemek degradációja és jelentős fragmentálódása is rontja funkcionalitásukat, valamint a mezőgazdaság kultúrtáj-fenntartó képességét. Mivel a peremzónák 
egyik fó vonzereje a táji szépség ennek károsodása egyben gyakori konfliktusforrás. (ANTROP, M. 2004, NiKodemus, O. et. al. 2005, SharP, J. S. - ClarK, J. K. 2007, TheOBALD, D. M. 2005).

Ugyanakkor a zöldfelület tartalmilag kiürül, egy idealizált vidék képéhez igazodó díszletté silányul. A posztstrukturalista földrajz felfogása értelmében az ember formálja, jelöli ki a természetet, a természetes határát, ez esetben a beköltözők és befektetők tájkép-fetisizmusa meghatározza a lakók viszonyát a tájhasználathoz. A zöldfelület használhatatlan lesz, a kert meghosszabbítása, a táji szépség kimerül pár fában és dombban, vízfelületekben, melyeknek változatlannak kell maradnia, így a mezőgazdaság, vagy a gyerekek játéka zavaró. A vidékromantikát megtestesítő kultúrtáji objektumok (gyümölcsösök, szőlők, koros házak, majorsági épületek) e logika szerint védettek lesznek, de mezőgazdasági és lakó funkciójuk elveszik, csupán kellékei a lakóhely imázs-teremtésének (Boros L. 2010, CsurGÓ B. 2013, DuNAY, A. et. al. 2001, IZSÁK É. 2003, GRANT, J. L. et. al. 2014, WEAVER, D. B. - LAWTON, L. J. 2001).

Az egyes funkciók térbeli elhelyezkedésére jelentősen befolyásolja a lakók napi életvitelét. A jól tervezett szuburbiák esetében a funkciók erőteljes szétválasztását célzó zonális tervezés miatt a napi ingázási kényszer jelentősen megnő, a funkciók elérése személygépkocsi nélkül ellehetetlenedik, kizárva azok használatából a kevésbé tehetősöket (DUNAY, A. et. al. 2001). Ezzel ellentétes irány a térszerkezet fragmentálódása - a posztmodern városi fejlődés térszerkezeti megújulásának sajátossága - ezzel ellentétes folyamat. A „Keno-kapitalizmus” hatására a különböző funkciók, az eltérő identitások térbeli elhelyezkedése tervezetlen, véletlenszerü lesz a városi térben, így egyre több városközponti funkció települ az elővárosi gyürübe. Előjelezhetetlenné és kiszámíthatatlanná teszi e folyamat a városi térben az egyes térbeli pontok fejlődési irányait és hatását a környezetre. Ezzel térben össze nem férő funkciók (nyugdíjasotthonszórakozóhely, családiházak-üzemek) egymás közvetlen szomszédságában jelennek meg, állandó alkalmazkodási kényszerben tartva a populációt (BOROS L. - TÓTH P. 2007, BOROS L. 2010, NIKODEMUS, O. et. al. 2005).

A fentiek jelentőségét fokozza, hogy a szervesen fejlődő településekkel ellentétben a szuburbiák gyüjtő utakra felfüződő úthálózata kevés alternatívát kínál az egyes irányokba, ezáltal determinálja a forgalmi dugók kialakulását. Az állandósult közlekedési kényszer miatt mindennapos a gyorshajtás és gyakoriak a közlekedési balesetek. Mivel rendszerint - különösen a szuburbanizáció korai fázisában - hiányoznak a transzverzális útvonalak az alcentrumok és más szuburbiák közvetlen megközelítése igencsak nehézkes, tömegközlekedéssel szinte lehetetlen. Az elővárosi területek hosszú, tervezett - a szervesen fejlödött településekhez képest monofunkciós utcái biztonságosak, de nem kényelmes és élhető terek. A közösségi élet szerveződését nem képesek szolgálni az ilyen célra használható közterek (parkok, játszóterek) kis száma miatt (DunAY, A. et. al. 2001, KovÁCs Z. et. al. 2017, GALLENT, N. - et. al. 2003, VEDRÉDI K. 2012).

A motorizáció környezeti ártalmai közismertek, a szakirodalom az elmúlt évtizedekben a lakóés a munkahely közötti időigényes utazások egészségügyi hatásaira is felfigyelt. A lakóhelyváltásból adódó radikális életmódváltás negatív következményeit fokozza az ingázás által kiváltott stressz és életmódi sajátosságok. A 20 percnél hosszabb ingázási idő már szignifikánsan csökkenti a szociális kapcsolatokra és az egészség megörzésére fordítható idő (sport, minőségi pihenés) mennyiségét, ez hatással van egészségükre és csökkenti elégedettségüket életmódjukkal kapcsoltban (BESSER, L. M. et. al. 2008, Delmelle, E. C. et. al. 2013, HoEHNER, C. M. et. al. 2012, KovÁcs Z. et. al. 2017, RoBERTS, J. et. al. 2011, WiLSON, J. et. al. 2013, [2]).

A közösség fejlödése a peremzónákban eltér a hagyományos városi és falusi mintáktól, a nehézségeinek okaiként a szakirodalom több, egymástól (részben) független jelenséget emel ki. Ezek közös eleme, hogy a családi házak ideájához a napi rutinban valójában nem kötődő posztmodern család életmódja város-centrikus, oda járnak vissza naponta, eredeti lakóhelyük baráti körét tartják meg, nem alakul ki helyi identitásuk új lakóhelyükön (DUNAY, A. et. al. 2001, SQUIRES, G. D. 2002).

A nők helyzete a szuburbiákban különleges figyelmet érdemel, mivel a háztartások vezetése jelentős áldozatvállalást követel meg részükröl. A posztszocialista országokban különösen nehéz a 
nők helyzete, a szocialista gazdaság nemi különbségtételei és a tradicionális nemi szerepek berögzültségének fennmaradása mellett a kiépült városok sem nő-barátok, majd 1989 után a nő szerepe tovább romlott, mert jelentősebb a munkahelyvesztésük, mint a férfiaké (ENGLAND, K. 1991, HIRT, S. A. 2008 [2]).

A kiköltözők kényelmetlenséget vállalnak (boltok, szórakozóhelyek, stb. hiánya) a környezeti előnyökért, de idővel, a család bővülésével e hátrányok súlya nő. A szuburbiák hiányos infrastruktúrája miatt a háztartások vezetése is meglehetősen megterhelő a nők számára, hiszen a munkahelyeken kívül a szolgáltatások, kereskedelmi egységek elérése is nehézkes (DÖVÉNYI Z. KovÁCs Z. 1999, O'CONNOR, J. - BROWN, A. 2013, ROMAN, D. 2001). Az ingázás jobban hat a nök egészségi állapotára, annak ellenére, hogy átlagosan kevesebb időt töltenek utazással naponta. A fiziológiai hatások mellett a pszichológiai tényezőkre is érzékenyebbek. Az elővárosi öv tervezetlen, gyors és irányítatlan kiterjedése, mely számtalan társadalmi, gazdasági és környezeti értelemben kedvezőtlen hatással jár. Jelen kutatás szempontjából legfontosabb, a város-vidék peremzónákkal összefüggő következményeket emelem ki, mivel a hazai városokat ezek érintik a legjobban (FrUMKIN, H. 2002, KISS J. 1999, RoBERTS, J. et. al. 2011, TiMÁR J. 1993).

A szuburbiák gyermekei az elővárosi infrastruktúra bemutatott jellegzetességei miatt a zöldet és az utcákat nem élvezhetik, egész nap a házban kénytelenek lenni. Képtelenek eljárni egyedül a városokba, így vagy az anyáknak kell őket saját mindennapjaikat feláldozva fuvarozni programokra, sportolni, városi játszóterekre szórakozni, vagy pedig az állandó ingerszegény, homogén közeg okozta jelentős unalom által növekszik a későbbi deviáns viselkedések kockázata. Míg a szülök a városokban a devianciák miatt, addig a látszólag biztonságos szuburbán lakótereken a közlekedési kockázatok (járdák, kerékpárutak és zebrák hiánya), az elidegenedő társadalom miatt kénytelek félteni és kontrollálni a gyerekek időtöltését (DUNAY, A. et. al. 2001, ENGLAND, K. 1991, Helling, A. 2002, O'ConNOR, J. - Brown, A. 2013).

Összességében a szuburbiákban élő nők számára saját életvitelük fenntartásában a háztartás nehezebb vezetése és az ingázási kényszer akkora akadályt jelent, hogy többségüknek nehezére esik a szociális és szakmai életük menedzselése, fenntartása. Ez a szindróma főleg a személyes és rekreációs utakban okoz hátrányt a szegényebb háztartások nőinél és a gyerekeknél, hiszen e mozgásokon tudnak spórolni időt és útiköltséget. Továbbá az elszigeteltségből fakadó gyengébb szociális háló a reciprocitáson alapuló mikroközösségek kiépítését is nehezíti. A perifériákon saját autó hiányában csapdahelyzetbe került nőknél az elzártság pedig további lélektani kockázatokkal fenyeget (England, K. 1991, Frumkin, H. 2002, Helling, A. 2002, HiRT, S. A. 2008, [2]).

Az egy mintára épült nagy alapterületü családi házak idővel, a családban élők számának csökkenése (a gyerekek elköltözése) miatt túl méretesek lesznek, a drága fenntartási költségek a nyugdíjasoknak megterhelö, amennyiben egészségi állapotuk hátráltatja a mozgást, számukra börtön lesz a szuburbia. Ez a megállapítás a szuburbanizáció által átalakított községekben élők esetében is releváns, hiszen a településszerkezeti átalakulások itt is meghatározóak (DUNAY, A. et. al. 2001, SQUIRES, G. D. 2002).

A szegény népesség jelenléte az 1980-as évektől általános a világ szuburbán övezeteiben, sajátosan szegregált térszerkezetet létrehozva, ahogy azt a 4.3. fejezetben bemutattam. Az elöregedő és népességüket vesztő szuburbiákban megjelennek a szegényebb rétegek, a tehetősek tovább költöznek távolabbi területekre, az exurbiába vagy új szuburbán zónába. Legjellegzetesebbek a lakókocsi-parkok (trailer park), amelyek a városból kiszoruló, elesett, szegényebb rétegek számára készült olcsó életvitelt, illetve ideálisabb esetekben az újrakezdést lehetővé tevő megoldások (Borune L. S. 1999, COSTELLO, L. 2007, GRANT, J. L. et. al. 2014, MARCINCZAK, S. et. al. 2011).

Markáns jelenség az anyagi helyzet alapján történő szegregáció, az egyes ingatlanfejlesztések meghatározott társadalmi csoportok anyagi helyzetéhez és presztízséhez igazodnak, az elit területeken a megfizethetőség szitokszó, önmagában rombolja a mítoszt (DUNAY, A. et. al. 2001, MARCINCZAK, S. et. al. 2011, SQUIRES G. D. 2002, SZIRMAI V. 2011b). A jelentős elkülönülés zárt csoportok kialakulásához vezet, amelyek rendszerint nem képesek úgy funkcionálni, mint a 
heterogén városi és falusi közösségek. Az ilyen zárt csoportok - különösen a ténylegesen fallal körülvett és örzött lakóparkok - negatív pszichológiai hatásait a szakirodalom részletesen tárgyalja (CsÉfalvay Z. 2008, CsiZMADY, A. 2008, HegEDÜS G. 2008, LADÁNYI J. - SzELÉNYI I. 1997, TózSA I. 2002, WU, F. 2010). Még nagyobb jelentőségü a helyi közösségek szerveződésében a mikroszintü szegregáció. Az egyes környékeken belül lakótömbi bontásban jelentősen szegmentálódik az ingatlanpiac, akár néhány száz méteren belül is jelentősek a különbségek az épületek árában, ezzel együtt pedig azok állagában, méretében, a benne élö háztartás szociális státuszában (DUNAY, A. et. al. 2001, SQUIRES, G. D. 2002).

Az elővárosok fejlődésének jellemzője, hogy szektorális jelleggel helyezkednek el benne az egymástól nagymértékben eltérő helyzetü csoportok, például Párizs elővárosi gyürüjének nyugati, jó környezeti és társadalmi pozíciójú településeire és elővárosaiba költöztek, ugyanakkor addig délkeleten az alacsonyabb státusúak tömörülnek. Kisebb intenzitású, de hasonló folyamat figyelhető meg Bécs környékén, ahol még a korosztályok megoszlása is követi az anyagi és etnikai (kelet-európaiak, törökök, stb.) arányát (BRADE, I. et. al. 2009b, CATTAN, N. 2011, GöRGL, P. et. al. 2011, SZIRMAI V. 2011b).

A kedvezőtlen anyagi helyzetü lakók által benépesített lakóterületek a szuburbán gyürü azon szektoraiban helyezkednek el, ahol a környezeti adottságok és közlekedési lehetőségek rosszabbak. A befektetők minimalizálják a telkek méretét profitjuk maximalizálása érdekében, valamint a kivitelezés költségeinek csökkentése érdekében egyforma típusházak, ikerházak vagy sorházak készülnek. Gyakran hiányos marad az infrastruktúra, hiányoznak a járdák, közterek, esetenként teljesen hiányzik az ellátó funkció. E területek hosszú távon nem elégítik ki a beköltözők igényeit, elmarad a vártaktól az életminőség (DUNAY, A. et. al. 2001, GRANT, J. L. et. al. 2014, SQUiRES, G. D. 2002, TózSA I. 2002).

Ezzel párhuzamosan a reurbanizáció során a dzsentrifikálódó területekről kiszorulók jellemzően a szuburbiák hanyatló, illetve legkevésbé felkapott részeire, vagy a város-vidék peremzónák külső, olcsó, de rossz elérhetőségü, kedvezőtlen adottságú peremterületeire kényszerüek költözni. E kevésbé elönyös területek gyakran olyan ipari, közlekedési vagy más környezeti terheléssel esetenként egészségügyi kockázatokkal járó - objektum mellett fekszenek, amelyek miatt az itt élők környezeti igazságtalanság áldozataivá vállnak (GANT J. L. - NELSON A. C. 2014, GRANT, J. L. et. al. 2014, HeLLiNG, A. 2002, NAGY Gy. 2014).

Összegezve megállapíthatjuk, hogy a szuburbanizáció számos negatív hatással lehet a legkülönbözőbb társadalmi csoportokra, ha az elővárosi átalakulás negatív hatásait nem tudja ellensúlyozni az intézményi háttér. E nehézségeknek jellemzően a nők, a hátrányos helyzetü csoportok és az idősek a fö károsultjai és a teljes közösségre kihatnak a konfliktusok. A problémák jelentőségét az infrastruktúrával, a szegregációval és az elvárt életminőség-javulástól való elmaradás a társadalmi problémák mélységét jelentősen növelik. Sajátosságaik miatt a hazai külterületek várhatóan kietettek a folyamatnak. Ezért a szuburbanizáció folyamatának demográfiai és településföldrajzi jellegzetességei mellett, azok következményeit is be kívánom mutatni a dolgozat további fejezeteiben az empirikus kutatási eredmények alapján. 


\section{A KÜLTERÜLETEKRE IRÁNYULÓ LAKÓHELYI SZUBURBANIZÁCIÓ MAGYARORSZÁGON}

\subsection{A külterületi szuburbanizáció történelmi előzményei}

A külterületek szerepe hagyományosan kiemelkedő a hazai városok fejlődésében. A központok körüli kertségek a XIX. század elejétől kiköltözési hullámok sorait vették fel. Különböző szőlőhegyek, majorok, tanyák, lakóhelyek és üdülők, valamint a belölük képződött tanyabokrok és falvak beépülve lakóterületként a város szerves részévé - hóstát, majd urbánus terület -, vagy a helyigényes intézmények (temető, vasút, sport, majd lakótelep) területeivé váltak. A szegények (városból kiszorulók, pályakezdők, földtelenek, napszámosok) gyüjtőhelyei vagy a városi értelmiség és hivatalnokok nívós negyedei lettek, ahol a sajátos közösség, a kerti lét volt a meghatározó, nem a rang, vagy pozíció (BECSEI J. 2015a, BELUSZKI P. 1982, CSATÁRI B. 2013).

Magyarországon a település-összevonásoknak nagy hagyománya van. A városokhoz csatolt falvak és lakott külterületek az urbánus térben rurális zárványként jelentkeznek a szuburbanizációs folyamatban. Az egyes falvak azonban nem veszítik el társadalmukat és településszerkezetüket azáltal, hogy egy városba bevonták őket. Különösen hangsúlyos ez az olyan esetekben, amikor a falu később újra önálló lesz, vagy a várostól fizikailag is elkülönülő egyéb belterületté válik. A közigazgatásilag létező falvak mellett további nagyszámú falu van tehát az országban, jelentős részük agglomerációk területén (BAJMÓCY P. 2003, CSATÁRI B. 2013, CSATÁRI B. - FARKAS J. 2012, KovÁCs Z. 1999, KristóF A. - KóKAi S. 2015, TimÁR J. 1993).

Az 5.1 fejezet során be kívánom mutatni a külterületi szuburbanizáció peremfeltételeit meghatározó föbb történeti tendenciákat, majd az azt követő szakaszban tárgyalom statisztikai elemzés alapján a külterületi lakosság demográfiai átalakulását a szuburbanizáció során. Ezután az empirikus eredmények alapján fel fogom tárni a külterületekre irányuló migráció főbb motivációit, a helyi és beköltöző lakosság demográfiai jellemzőit. Az 5.4 fejezetben az egyes lakott helyek fejlődését befolyásoló általános és genetikus, típusonként eltérő területhasználati, majd infrastrukturális adottságait elemzem. Az. 5.6. szakaszban a szuburbanizáció társadalmi következményeit, a kialakuló konfliktusokat és s szegregáció jelenségét mutatom be. Végül esettanulmányokon keresztül kívánom jellemezni a különböző külterületek sajátos fejlődési útjait, az egyes típusokat jellemző egyedi problémákat és néhány sikeres fejlesztési beavatkozást.

Az elmúlt hetven év során a külterületek az aprófalvakhoz hasonlóan hosszú hanyatláson estek át. Az államszocialista településpolitika némileg tudta csökkenteni a regionális területi különbségeket, azonban a településméret és a városoktól való távolság élesen befolyásolta a települések fejlődési lehetőségeit, a településhierarchiában elfoglalt helyzetük alapján nagymértékben differenciálódott az életminőség, valamint az ellátás színvonala. (BALOGH A. 2008, BeluszKY P. - SiKOS T. T. 1982, JózSA K. 2008, MoHos M. 1996). Ennek hatására fokozódott a kisebb települések elöregedése, az infrastruktúra lemaradása, a munkahelyek számának csökkenése; e hatások az elvándorlást erösítették fel, amely hanyatlási spirálba sodorta a községeket, majd 1990 után jelentősen differenciálódott állományuk, melyben meghatározó a földrajzi fekvés, a demográfiai összetétel és az önkormányzatok sikeressége (BAJMÓCY P. BAlogh A. 2002, BeluszKy P. -Sikos T. T. 2007, CsAPó T. 1993, G. FeKeTE É. 2001).

Hasonló módon az államszocializmus időszakában (1947-1970 között különösen) a külterületek többsége a megszüntetendő, kisebb részük (zártkertek) a megtürt kategóriába tartozott, csak kivételes esetekben került néhány fejlesztendő besorolás alá. (BAJMÓCY P. - BALOGH A. 2002, BALOGH A. 2015, BAJMÓCY P. - MAKRA Zs. 2016). Ennek következtében az egymilliós külterületi népesség 1980-ra 416123 före csökkent, majd a rendszerváltásra lakosságszám elérté mélypontját 288043fövel. 1970 és 1990 között 5897 külterületi lakott hely szünt meg. A következőkben a területi differenciálódáshoz vezető fő tendenciákat foglalom össze, amelyek a meghatározták a szuburbanizáció megindulásakor létező területhasználati és demográfiai jellemzőket. 
Mint a 3. fejezetben bemutattam, 1945-től 1950-ig a birtokviszonyok és az üzemmód változása miatt nagyszámú tanya keletkezett, ekkor jelentkezett a külterületi népesség maximuma, azonban az évtized végétől a szövetkezesítés ellenkezőjére fordította a folyamatot, melyet ideológiailag indokolt a szórványban élő népesség nehezebb ellenörzése. A szövetkezetek nagyméretü földjeinek kialakításához a jó minőségü táblásításra alkalmas területein a tanyákat kitelepítették és elpusztították, ehhez a lakosokat állandó terror alatt tartották, fizikai (sokszor halált okozó) bántalmazást, alaptalan vádakat és megalázások sorát vették igénybe, a házakat olykor figyelmeztetés nélkül, a lakó távollétében bontották le (SZENTI T. 2003).

Hasonló, bár békésebb módon kezdtek megszünni a föld nélkül maradt majorok és bizonyos, táblásításra került szölőhegyek. A megmaradt ingatlanok hanyatlásnak indultak az általánosan életbe lépő felújítási tilalom és az elszegényedés miatt. Megindult a szelektív elvándorlás a munkahelyeket biztosító városokba, valamint a lakosoknak új házat csak a kijelölt központokban engedték építkezni, így koncentrációs folyamat indult be. 1956 után csak fokozatosan integrálódtak a külterületek a nagyüzemi mezögazdaságba, a tanyákon, majorokban és szőlőhegyeken élők a TSZ-ek számára bedolgoztak, bértartást végeztek, a kialakuló zártkertek pedig a kertszövetkezetek formájában végeztek termelést, paradox módon azonban a külterületi lakott helyek főleg a rossz, táblásításra alkalmatlan talajokon maradtak meg inkább.

A külterületek megszünése nem minden esetben jelentett elnéptelenedést, 1910 után kiválással létrejövő 239 új település egy része (Bordány, Gyál, Nagyhegyes, Remeteszőlős, Töltéstava, stb.) korábbi lakott külterületekböl jött létre. Ebben meghatározó az alföldi tanyaközségesítés, de a Dunántúlon is váltak önállóvá majorok, szőlöhegyek, üdülőtelepek. Egyediek azok a települések melyek külterületböl önálló községgé váltak, majd újra megszüntek a település-összevonások során (Hetényegyháza, Szandaszőlős). (BAJMÓCY P. et. al. 2014).

A különböző városokban és községekben a belterülethez közeli, ipari üzemmel rendelkezö, vagy más szempontból fejlesztendő külterületek egy jelentős része egyéb belterületbe vonással szünt meg, nem pedig elnéptelenedéssel. Jelentős részük mára teljesen elvesztette külterületi jellegét és falusias vagy városias beépítettségü városrésszé váltak. Mivel e területek a statisztika szemszögéből elvesztek még megbecsülni sem tudjuk mekkora lakosság él most ilyen területen. 1980 után, a „fejlesztendő külterület” kategória megszünése miatt gyakran a nagy lélekszámú, leginkább fejlett külterületek gyakran lettek belterületté nyilvánítva (CSATÁRI B. - FARKAS J. 2012, CSATÁRI B. et. al. 2016, TiMÁR J. 1990).

Jelentős területi differenciálódás figyelhető meg az ország területei között 1960 és 1990 között (5. táblázat), az államszocializmus alatt, 1990-ig az összes megyében legalább 50\%-al csökkent a kint élök aránya. A visszaesés a Kiskiskunságban a homokhátsági mezőgazdaságának köszönhetően (nem táblásítható földek), valamint Budapest környezetében a szegényebb rétegek beáramlása miatt szerényebb volt. 1960 és 1990 között csupán hét településen nőtt lényegesen a külterületi lakosság, a 3 Budapest környékin (Örbottyán, Csobánka, Albertirsa) kívül a külterületre (Helesfa, Diósjenő, Visonta, Zánka) települt intézmény volt a növekmény forrása. Csupán a három dél-alföldi megyében maradt 5\% felett a külterületi népesség aránya, a legjelentősebb népességvesztést pedig az Észak-Alföld tanyás területei (tanyarombolás) szenvedték el, 1990 után Békés és Jász-Nagykun-Szolnok esetében tovább folytatódott e tendencia. (BAJMÓCY P. - MAKRA ZS. 2016).

A foglalkoztatottsági átrétegzödés megváltoztatta a külterületek társadalmi helyzetét, egyre többen próbáltak kitörni a paraszti életmódból, ezért erőn felül termeltek a rossz talajokon és gyermekeik szakmákat tanultak. A városba ingázó szakmunkások számára innentől már csak másodlagos bevétel lesz a mezőgazdaság, bizonyos területeken (Balaton- Felvidék, Nemzeti Parkok) nő a második otthonok és üdülők száma (BECSEI J. 2015a, CSATÁRI B. - KISS A.2003). A rendszerváltás időszakára tehát jelentősen differenciálódott területileg a külterület-állomány, amit az általános tendenciák mellett az államszocialista rendszer hátrányosan megkülönböztető településpolitikája is okozott. A következő fejezetben az 1990 utáni szuburbanizáció a differenciálódó külterületekre gyakorolt hatásait kívánom feltárni. 
5. táblázat: A külterületek népességszámának alakulása Magyarországon 1970 és 2011 között.

\begin{tabular}{|c|c|c|c|c|c|c|c|c|c|c|}
\hline \multirow[b]{2}{*}{ Területi egység } & \multicolumn{5}{|c|}{ Külterületek népessége (fö) } & \multirow{2}{*}{ 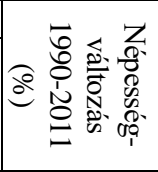 } & \multicolumn{4}{|c|}{ Külterületek száma, 2011 (db) } \\
\hline & 1970 & 1980 & 1990 & 2001 & 2011 & & $\begin{array}{l}\text { O: } \\
\mathscr{N} \\
\text { 尺) } \\
\mathbb{R}\end{array}$ & 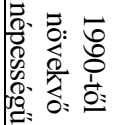 & 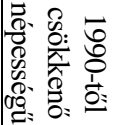 & 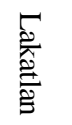 \\
\hline Bács-Kiskun & 154953 & 101836 & 68243 & 66642 & 66140 & -3.08 & 606 & 144 & 366 & 96 \\
\hline Baranya & 17711 & 11584 & 8278 & 7981 & 9482 & +14.54 & 669 & 245 & 158 & 266 \\
\hline Békés & 46296 & 31587 & 22112 & 19712 & 15704 & -28.98 & 419 & 76 & 242 & 101 \\
\hline Borsod-Abaúj-Zemplén & 17573 & 12185 & 7998 & 7571 & 10714 & +33.96 & 761 & 215 & 183 & 363 \\
\hline Budapest & 5556 & 7832 & 5705 & 6167 & 6445 & +12.97 & 71 & 20 & 12 & 39 \\
\hline Csongrád & 85896 & 56550 & 37063 & 36938 & 34783 & -6.15 & 387 & 105 & 235 & 47 \\
\hline Fejér & 17993 & 10136 & 7103 & 10296 & 11712 & +64.89 & 596 & 235 & 136 & 225 \\
\hline Györ-Moson-Sopron & 8425 & 5159 & 3711 & 4676 & 4755 & +28.13 & 381 & 120 & 94 & 167 \\
\hline Hajdú-Bihar & 40862 & 23686 & 16998 & 18974 & 27343 & +60.86 & 509 & 157 & 164 & 188 \\
\hline Heves & 4745 & 2996 & 2089 & 1637 & 1758 & -15.84 & 344 & 97 & 51 & 196 \\
\hline Jász-Nagykun-Szolnok & 43870 & 21363 & 13867 & 12020 & 10439 & -24.72 & 621 & 138 & 269 & 214 \\
\hline Komárom-Esztergom & 9768 & 6256 & 4270 & 4608 & 7074 & +65.67 & 363 & 139 & 86 & 138 \\
\hline Nógrád & 4959 & 3079 & 1989 & 2133 & 1640 & -17.55 & 254 & 65 & 69 & 120 \\
\hline Pest & 69624 & 47481 & 35196 & 40644 & 46658 & +32.57 & 1204 & 495 & 351 & 358 \\
\hline Somogy & 19744 & 12105 & 8351 & 9106 & 8916 & +6.77 & 538 & 162 & 163 & 213 \\
\hline Szabolcs-Szatmár-Bereg & 39816 & 28726 & 21419 & 21506 & 20173 & -5.82 & 642 & 154 & 245 & 243 \\
\hline Tolna & 17995 & 11400 & 7788 & 7300 & 6784 & -12.89 & 463 & 130 & 143 & 190 \\
\hline Vas & 5129 & 3426 & 2294 & 2205 & 1854 & -19.18 & 295 & 76 & 76 & 143 \\
\hline Veszprém & 17651 & 10957 & 7809 & 8393 & 7086 & -9.26 & 630 & 230 & 166 & 234 \\
\hline Zala & 13009 & 7779 & 5760 & 5669 & 7054 & +22.47 & 480 & 160 & 133 & 187 \\
\hline Összesen & 641575 & 416123 & 288043 & 294178 & 306514 & +6.41 & 10233 & 3163 & 3342 & 3728 \\
\hline
\end{tabular}

\subsection{A külterületi szuburbanizáció általános jellemzői}

A KSH Helységnévtár adatsorainak statisztikai elemzése alapján 1989 után jelentős differenciálódás zajlott le a külterületek állományában. A város felé igyekvők és a városból kiszorulók beáramlása felbontotta a közösségi szálakat és hanyatlásnak indultak a kevésbé vonzó területek. A jó adottságú lokációkban megindult a magas státuszúak inváziójával a lakosság kicserélődése, vagy ipari funkcióváltás miatt az elnéptelenedés.

A városkörnyéki községek már az 1980-as években is a belföldi migráció harmadát vonzották, a városokat elhagyók a közeli településekre mentek némileg jobb, nyílt környezet reményében. Emellett az állami lakásépítés elégtelen volta, majd megszünése, tehát az általános lakáshiány miatt sokan kénytelenek saját maguknak építeni a város szélén, a kis megtakarítások miatt a lehető legolcsóbb telkeken. A városból való kiáramlás lassan elkezdte duzzasztani a városperemi külterületeket, amelyek a szegényebbek és vidékről beáramló munkások számára jelentettek olcsó lakóhelyi alternatívát. A turisztikai helyszínek jelentős részén is a külterületek népességnövekményét a városokból kiköltöző (jellemzően idősek) növelték.

2011-ben a KSH 10233 külterületet tartott számon, ezek közül 1990-ben 3383 db nem rendelkezett lakónépességgel, de volt területükön lakható ingatlan, az ilyen külterületek száma jelentősen nem változott 2011-ig, de a számok dinamikus változásokat takarnak: $1680 \mathrm{db}$ külterület újra benépesedett és 2025 néptelenedett el a két évtized alatt. 1990 és 2011 között a külterületek növekedésének üteme meghaladta a szuburbán falvak központi belterületeinek növekedését a közép- és nagyvárosi agglomerációk esetében egyaránt (6. ábra).

A városok népességnövekedése a fentiek alapján jellemzően a külterületekből és korábban önálló községekből létrehozott egyéb belterületek dinamizálódására vezethetőek vissza, miközben a városmagok csökkenése folyamatos volt. A ténylegesen központi városi belterületek esetében is figyelembe kell venni a központi területekbe nagyszámban beolvasztott külterületek és egyéb belterületek népességét. Összességében tehát az agglomerációk fejlődésében meghatározóak a külterületek, bár jelentős területi különbségek állnak az országos átlagok mögött. Fontos tényező e 
differenciálódásban a regionális elhelyezkedés. Leginkább a népességet vonzó városi centrumok környékei, valamint a gazdaságilag sikeresebben modernizálódó megyékben (Pest, Fejér, Komárom-Esztergom, és Veszprém) nőtt a lakónépesség a külterületeken.

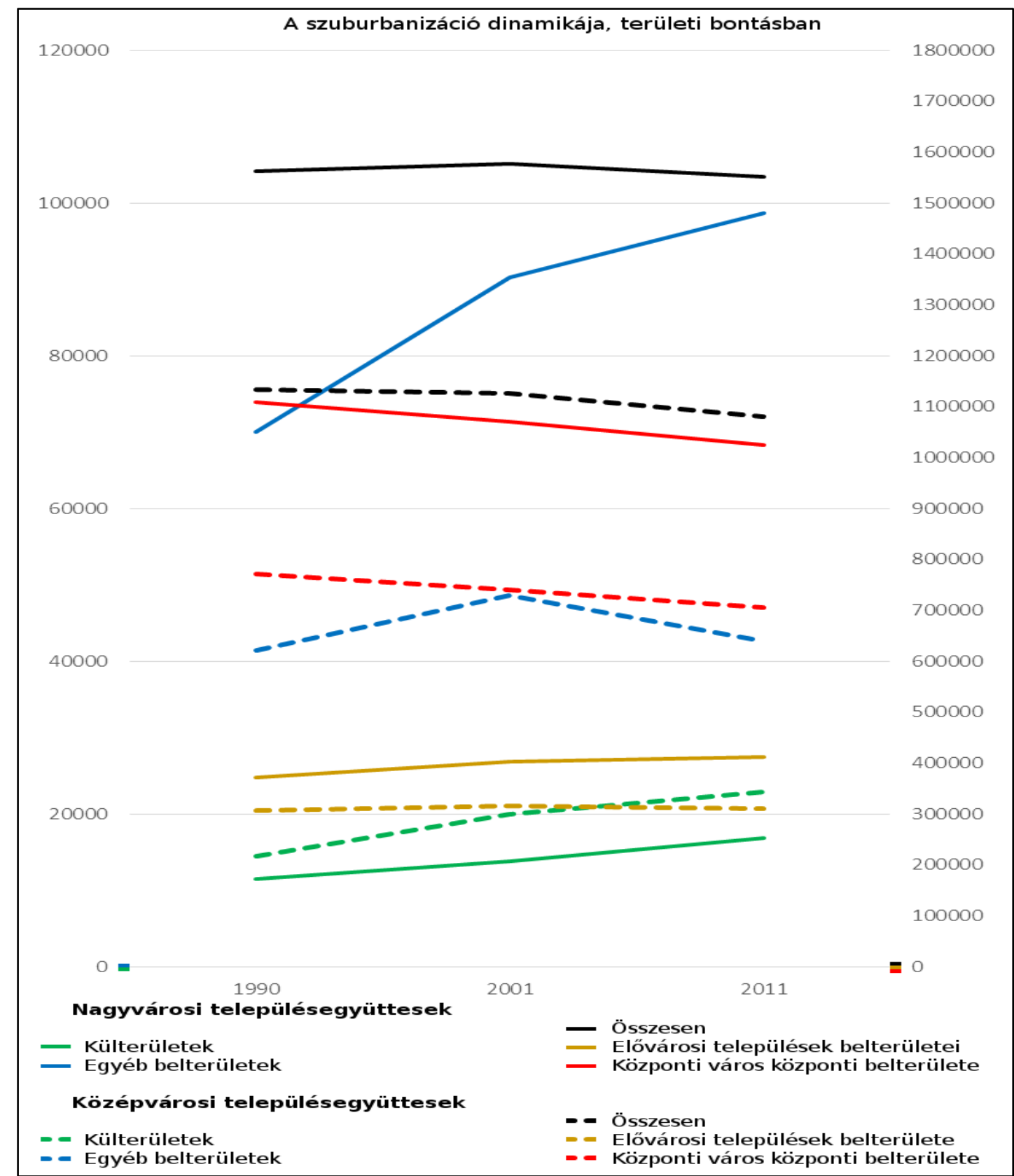

6. ábra: A szuburbanizáció dinamikája az agglomerációk központi- és egyéb belterületein, valamint külterületein 1990-2011 között (KSH helységnévtár alapján saját szerkesztés).

Az egyes lakott helyek hanyatlását vagy épp népességnövekményét nagymértékben meghatározta (az aprófalvakhoz hasonlóan) a külterület rendszerváltáskori lélekszáma, mivel a kis lélekszám, valamint szórvány jelleg, kis méret determinálja a kedvezőtlen körülményeket. Fokozza az elnéptelenedést a kedvezőtlenebb infrastrukturális és ellátásbeli adottság, valamint a kisebb, kevésbé funkcionáló közösség, az 1990 és 2011 közötti népességnövekedés és az 1990 évi lakosságszám között statisztikai összefüggés, közepes korreláció $\left(0,551 \mathrm{r}^{2}\right)$ mutatható ki.

Számos megyében növekedett a külterületi népesség aránya, részben a korábban is jelentősebb külterületi népességgel rendelkező megyékben (Hajdú-Bihar, Pest), de olyan megyékben is, ahol korábban alig éltek külterületen (Zala, Baranya, Fejér, Komárom-Esztergom, Borsod-Abaúj- 
Zemplén). 1970 után nem feltétlen az adott megyében hagyományos típusok (tanyák, majorok) okozzák a népességnövekedést, hanem a szociális intézmények, illetve a nagyvárosok környékén található települések (Fót, Törökbálint) szuburbanizálódó zártkertjei, szölőhegyei. Utóbbi jelentőségét mutatja, hogy 2011-ben 57 településen élt 1000-nél többen ember külterületen, ezek között nagyvárosok (Kecskemét, Debrecen, Budapest, Zalaegerszeg, Kaposvár, Nyíregyháza, Békéscsaba, Miskolc), tanyás települések (Szarvas, Jászberény, Szatymaz, Helvécia, Domaszék) találhatók. E települések mindegyikén nőtt a külterületen élők száma 1990-2011 között.

E fenti adatok egybevágnak a szakirodalmi előzményekkel, a tanyaöv szuburbanizációját az Alföldön, különösen Kecskemét esetében számos vizsgálat értékelte. A megállapítások alapján jellemző e külterületekre, hogy az elöregedő helyi társadalmat csak részben dinamizálják a kitelepülö fiatalok, akik paradox módon nem a centrumhoz közelebbi részeken jelennek meg, mert a belső öv már telítettebb. A tanyaövre jellemző a tanyán élő városi munkásság, a városból kiszoruló szegényebb háztartások és a tehetősebb szuburbán lakók nagy száma, valamint a második otthonok elterjedtsége (BECSEI J. 2009, CSATÁRI B. - FARKAS J. 2012, PÓCSI G. 2009). A helyi közösség hígulásával nő a széthúzás és a szegregáció. Az infrastruktúra jelentősen elmaradott a városhoz és még a környező falvakhoz képet is, de differenciált, hiszen számtalan színvonalas lakóparkot is találunk ott (CSATÁRI B. et. al. 2013, CSATÁRI B. et. al. 2016, LADÁNYI J. - SZELÉNYI I. 1997, MolNÁr M. 2004, SÁGI Zs. - TróCSÁNYi A. 1998, VASÁrus G. 2016b).

1990-hez viszonyítva a külterületek népességnövekedésének átlagos értéke a KSH által lehatárolt 21 agglomerációban és területegyüttesben 35,61\%. Leginkább a szuburbanizálódó elővárosi falugyürüvel rendelkező nagyvárosaik peremén nőtt méretük, ahol a szuburbanizáció általában is gyenge volt ott a külterületek sem tudták (migráló népesség hiányában) fokozni populációjukat. E települések esetében a külterületi növekedés kiegészítője a hagyományos, közigazgatásilag önálló falvakba és elővárosokba irányuló szuburbanizációnak.

A városhatáron belüli szuburbanizáció meghatározó azon centrumok esetében, ahol a központi település külterületeinek nagyarányú növekedése nem járt együtt a környező falvak szuburbanizációjával (6. táblázat). E településeken a rendelkezésre álló költözni akaró és anyagilag erre képes népesség többségét képesek voltak befogadni a város jól elérhető, de addig nem beépült, falusias jellegü területi egységei (külterületek és az egyéb belterületek). Ilyennek tekinthető Zalaegerszeg, Tatabánya, Nagykanizsa, Kaposvár, részben Miskolc.

Több megyében a hátrányos helyzetüek településekről való kiszorulása emelte a népességszámot. A rossz elérhetőségü külterületen a társadalom perifériájára szorultak élnek, mert e területek az olcsó megélhetés révén segítik anyagi stabilizációjukat. Míg a községek és városok szélén csökkentett értékü házakból álló cigánysorok népességét a magas természetes szaporodás emelte, addig a városok peremein a kivándorlás duzzasztotta a szegregátumok népességét. Félő, hogy e folyamat modern szegénytelepek kialakulásához vezethet, hasonlóan az hírhedté vált miskolci Lyukóvölgyhöz és Lyukótelep példájához.

2004 októberében bezárt a területen müködő bánya, a környező kertes terület pedig leértékelödött, mivel nem adtak ki építési engedélyt itt, hiszen a környék nem alkalmas a lakhatásra, közmüvek nincsenek, csak az elektromosság van bevezetve. A szegények jellemzően a városból kiszoruló cigányok - révén a két külterület együttes népessége 1990 és 2011 között 282 föről 2481 fö fölé emelkedett, azonban az illegális építkezések és a lakcímbejelentések elmulasztása miatt e szám sem tekinthető reálisnak, hiszen 2680 fö volt szavazásra jogosult e területen 2011-ben (KRISTÓF A. 2015).

Két város, Dunaújváros és Tatabánya peremén nött kiugróan a külterületi lakosság, ennek oka az, hogy mivel 1990-ben kevesen éltek a külterületeiken magas arányt jelent néhány jelentős növekményt elérő szociális otthon, börtön (Dunaújváros - Pálhalma, Nagyvenyim - Bernátkút), illetve periurbán utcák bővülése és több addig lakóhelyként nem követett, de létező zárkerti terület (Tatabánya - Szigeti dülö) megjelenése a statisztikában. A különböző szociális intézmények jelentős hányadot képviselnek a település együttesek külterületi növekményében. Az ország demográfiai, egészségügyi, gazdasági és bünözési (börtönök) folyamatai miatt lakosságuk a XX. 
század során tartósan nőtt, és e tendencia 1990 után is megmaradt. Ez pozitívum jellemzően az ott élők számának (férőhelyek) növekedéséböl és csak kisebb részben új intézmények kialakításából fakad, azonban a helyi külterületi lakosok csak ritkán dolgozhatnak ezen intézményekben szakképzettség hiányában.

A fentieknek megfelelően a legtöbb központi város külterületeinek (és egyéb belterületeinek) népessége jelentősen nőtt, kivételt csak azok a településegyüttesek jelentik, ahol nincs érdemi külterületi népesség vagy a teljes agglomeráció népességcsökkenést mutat. Összesen 132 olyan település volt (7. ábra), amelyen a külterületek és/vagy egyéb belterületek, valamint a központi belterületek is nöttek. 129 esetben csak a belterület nött, továbbá 66 településen csak a külterületek és egyéb belterületek népessége nőtt. 26 településen a növekmény több, mint $50 \%$-a és 53 esetében teljes egészében a külterületekre irányult. Minden agglomerációban található olyan település mely külterületeinek népessége nőtt, és legalább egy, amelynek esetében ez meghaladta a 25\%-os növekedést. Továbbá - a salgótarjánit kivéve - minden településegyüttesben legalább a lakott külterületek $28 \%$-a nött.

6. táblázat: A külterületi szuburbanizáció területi megoszlása

\begin{tabular}{|c|c|c|c|c|c|c|}
\hline \multirow{3}{*}{$\begin{array}{l}\text { Agglomerációk és } \\
\text { településegyüttesek }\end{array}$} & \multirow{3}{*}{$\begin{array}{c}\text { Népesség- } \\
\text { változás 1990- } \\
2011(\%) \\
\end{array}$} & \multirow{2}{*}{\multicolumn{3}{|c|}{ Külterületek }} & \multirow{2}{*}{\multicolumn{2}{|c|}{$\begin{array}{c}\text { Növekvö lakosságszámú } \\
\text { külterületek }\end{array}$}} \\
\hline & & & & & & \\
\hline & & $\begin{array}{l}\text { népessége 2011- } \\
\text { ben (fö) }\end{array}$ & $\begin{array}{c}\text { népesség-változása } \\
\text { 1990-2011 (\%) }\end{array}$ & száma (db) & száma (db) & aránya $(\%)$ \\
\hline Békéscsabai & $-8,74$ & 5498 & $-6,31$ & 63 & 24 & 38,10 \\
\hline Debreceni & 4,04 & 21167 & 104,65 & 130 & 48 & 36,92 \\
\hline Dunaújvárosi & $-8,22$ & 1773 & 918,97 & 49 & 23 & 46,94 \\
\hline Egri & $-4,43$ & 366 & 96,77 & 66 & 22 & 33,33 \\
\hline Győri & 4,15 & 3198 & 68,58 & 201 & 67 & 33,33 \\
\hline Hódmezővásárhely & $-10,03$ & 3470 & 41,34 & 24 & 22 & 91,67 \\
\hline Kaposvári & $-5,73$ & 2979 & 178,15 & 75 & 29 & 38,67 \\
\hline Kecskeméti & 9,95 & 24204 & 32,13 & 76 & 31 & 40,79 \\
\hline Miskolci & $-9,58$ & 7213 & 98,38 & 179 & 76 & 42,46 \\
\hline Nagykanizsai & $-8,78$ & 858 & 177,67 & 48 & 24 & 50,00 \\
\hline Nyíregyházi & 5,36 & 11851 & 10,90 & 121 & 52 & 42,98 \\
\hline Pécsi & $-2,71$ & 3512 & 59,49 & 175 & 85 & 48,57 \\
\hline Salgótarjáni & $-16,09$ & 646 & $-15,11$ & 41 & 6 & 14,63 \\
\hline Soproni & 12,00 & 510 & 89,59 & 34 & 13 & 38,24 \\
\hline Szegedi & 2,35 & 10748 & 30,71 & 84 & 43 & 51,19 \\
\hline Székesfehérvári & 0,40 & 2961 & 29,75 & 192 & 57 & 29,69 \\
\hline Szekszárdi & $-6,18$ & 1753 & 56,66 & 99 & 43 & 43,43 \\
\hline Szolnoki & $-5,61$ & 1405 & $-27,16$ & 67 & 19 & 28,36 \\
\hline Szombathelyi & $-4,15$ & 407 & 2,01 & 70 & 24 & 34,29 \\
\hline Tatabányai & $-5,04$ & 2109 & 311,91 & 54 & 30 & 55,56 \\
\hline Veszprémi & 2,36 & 567 & 35,97 & 57 & 21 & 36,84 \\
\hline Zalaegerszegi & $-4,11$ & 3935 & 168,60 & 125 & 51 & 40,80 \\
\hline Összesen & $-1,76$ & 111130 & 49,12 & 2030 & 810 & 39,90 \\
\hline
\end{tabular}

Forrás: KSH helységnévtár alapján saját számítás.

Az adatsor szerint 195 település esetében a különböző besorolású településrészek (külterületek, belterületek, egyéb belterületek) egymástól jelentősen eltérő átalakulást mutatnak, e településeken egyes egységek úgy tudták jelentősen növelni a népességüket, hogy a többi rész vesztett a népességéből. Ennek megfelelően a dolgozat hipotézisének megfelelően a szuburbanizáció települési szint alatt is differenciálódik.

Megállapíthatjuk, hogy a külterületi szuburbanizáció jelentős szerepet játszik a hazai vidéki agglomerációk és településegyüttesek 1990 utáni fejlödésében (I. melléklet, 1. ábra). Az alföldi tanyás városokon túl az ország nyugati és északi nagy- és középvárosainak vonzáskörzetében is megindult a kiáramlás. Nem csak a népességnövekedés mértéke, de annak a szuburbán települések belterületeihez mért aránya is magas.

A dinamikus átalakulások révén városaink peremzónáit az eltérő genetikájú és földrajzi adottságú (a történelem során kialakult külterületek, a szocializmus alatt létrehozott telepek és kertségek, valamint a rendszerváltást követő külterületi építkezések) sokszínűvé teszik. A 
következő fejezetben a külterületi lakosság demográfiai átalakulását és a lakóhelyváltás motivációit tárom fel, amely magyarázza is e lakóhelyek növekedésének társadalmi okait.

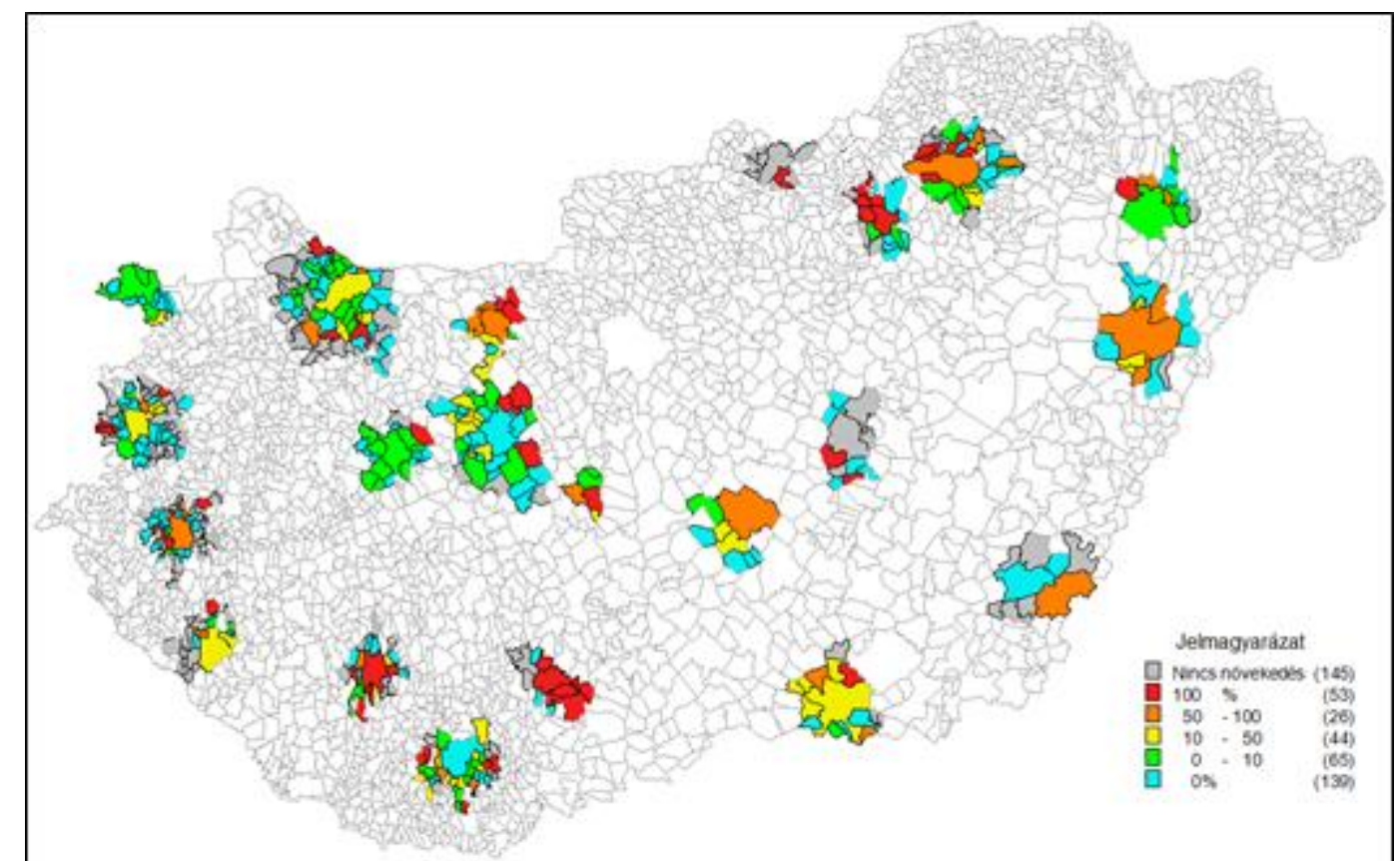

7. ábra: A külterületek népességének növekedése 1990 és 2011 között a 1990 évi népesség \%-ban kifejezve a KSH által lehatárolt agglomerációkban és településegyüttesekben (KSH Helységnévtár alapján saját számítás).

\subsection{A külterületeken zajló szuburbanizáció demográfiai jellemzői}

A külterületi lakosság viszonylag homogén volt a rendszerváltásig, a kertségekben és szőlőhegyekben maga a kerti lét - kerti tudat volt a csoportalkotó közös pont, míg a bányákban, majorokban és örházaknál a közös munka fogta össze a közösséget, az üdülökben és zárkertekben is kialakult sajátos genus loci (BALOGH A. 2015, KRISTÓF A. 2015, ÓNODI G. et. al. 2002). A hazai szuburbanizáció kiteljesedésével azonban a külterületekre is megindult a középosztály kiáramlása. Vonzó volt a lazább szabályozás, a telkek nagy mérete és viszonylagos olcsósága (CSATÁRI B. et. al. 2013, CSATÁRI B. - FARKAS J. 2012, TiMÁR J. - VÁRADI M. M. 2000). E fejezetben ezen átalakulást kívánom feltárni az empirikus eredmények alapján.

A fenti megállapításokat alátámasztja a kérdőíves felmérés eredménye. A külterületi társadalom egyik legföbb jellemzője az elöregedés, a válaszadók ( $n=1112$ fö) $43 \%$-a volt 65 év feletti és $38 \%$ nyugdíjas. Ennek ellenére a külterületek nagyobb részében részén a fiatalok száma jelentősen megnőtt. Az idősek 1-2 fős háztartásai mellett sok a fiatal pár $(8,1 \%)$, a nagycsaládos $(10,2 \%)$ és az egy háztartásra jutó több lakos miatt a népesség jelentős részét teszik ki ők. Az időskorúak aránya különösen a hobbikertezök és kétlakiak között volt magas, hiszen az 1970-1990 között kerthez jutott középkorúak mára a nyugdíjkor közelébe kerültek.

A háztartások összetétele alapján beköltöző a családok 72,1\%-ban nem volt gyermek, 12,9\%ban egy, 9,7\%-ban kettő vagy több gyermek volt, és csupán 1 háztartás jelezte, hogy 4-nél több gyermekük van. Ezzel szemben a helyieknél 79,3\%-ban nem volt gyermek, egy 12,1\%-nál, kettő pedig 4\%-nál volt. Jól látható, hogy a beköltöző családoknál a fiatalosabb jelleget nem csak a korkülönbség adja, de a későbbi gyermekvállalás is jelentős tényező. Az eltartottak számában nem volt érdemi eltérés a csoportok között, a háztartások 21,1\%-ban volt egy, 5,3\%-ban pedig kettő vagy több eltartott.

A szuburbanizáció következtében a külterületeken a demográfiai és társadalmi szerkezet átalakult, a kiköltözők általában fiatalabb korstruktúrája mellett magasabb iskolai és jövedelmi helyzetük javítja az övezet népességének mutatóit. Ugyanakkor markáns különbség volt a 
nagyméretű zártkertekbe, periurbán utcákba és szőlőhegyekbe költözők, valamint a többi külterületek adatai között.

A városból kiköltözők iskolázottsági és munkaerö-piaci mutatói jobbak, mint a helyi lakosoké (8. ábra). A legfeljebb általános iskolai végzettségüek aránya 16,7 és $14,5 \%$ volt, a szakmunkásés szakközépiskolai végzettségüeké 54,2 és $56,9 \%$, míg a diplomások aránya $8,2 \%$ volt a beköltözők és 4,4\% a helyiek körében. Ennek megfelelően alakultak a foglalkoztatottsági adatok is, a helyiek között a munkanélküliek aránya 7,6\% volt, a beköltözőknél csak $6,2 \%$, továbbá a nagyméretü zártkertekbe, periurbán utcákba és szölöhegyekbe költözők esetén 3,2\% volt ez az érték. A mezőgazdaságban dolgozók aránya $9 \%$ volt, a szekunder szektor, azon belül is a feldolgozóipar (14\%) és az építőipar (4\%) volt a legjelentősebb, míg a szolgáltatásokban dolgozók (28\%) között a nők aránya volt magasabb az átlagnál (32\%). A rokkantnyugdíjasok aránya külterületenként ingadozott, de jelentős kiugrás csak a kis elemszámú területeken volt, átlagos arányuk $10,6 \%$ volt.

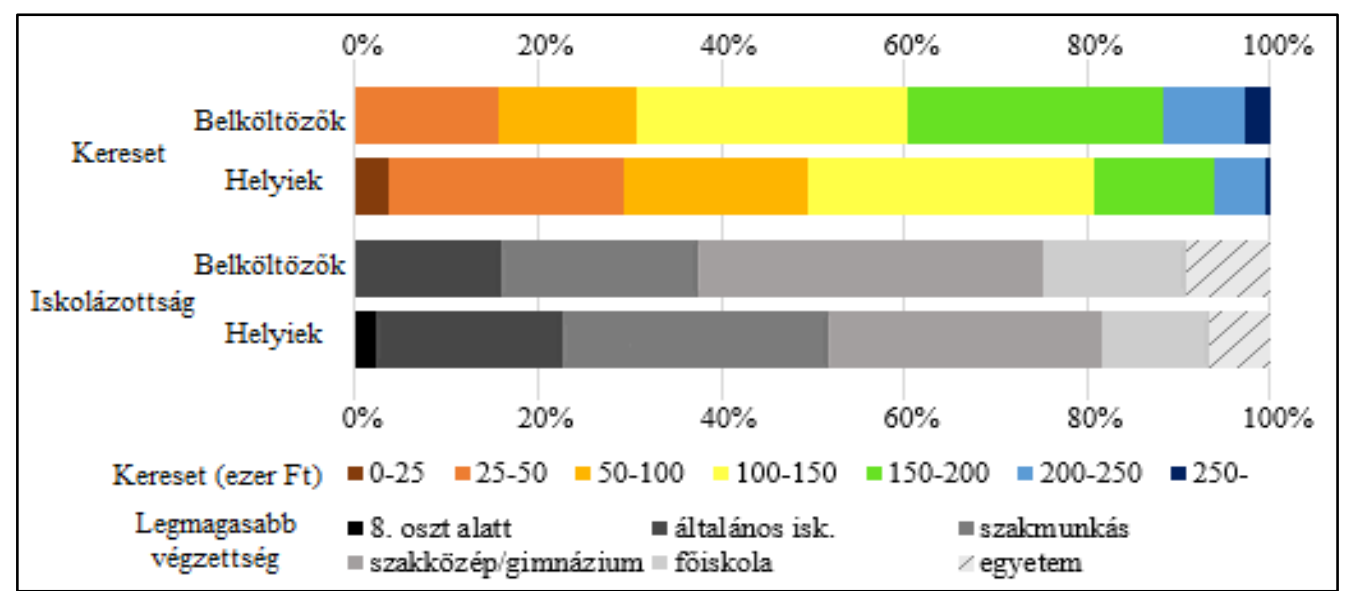

8. ábra: A külterületi lakosság megoszlása kereset és iskolai végzettség szerint (saját szerkesztés).

A kiköltözők kereseti viszonyai jelentős eltéréseket mutatnak a külterületek típusai között. A városok peremén lévő külterületeken (szőlöhegyek és kertségek) az átlagos kereset (módusz) 150000-200000 Ft, míg a távolabbi külterületeknél 100000-150000 Ft volt. A beköltözök tehetősebbnek bizonyultak, mint a helyi lakosság, ugyanakkor a különböző külterületek között jelentős különbség mutatkozik. A nagyméretü zártkertekbe, periurbán utcákba és szőlőhegyekbe költözők átlagos keresete 200000 Ft volt, ezzel szemben a majorokban, kisméretü (50 lakos alatti) kertekbe költözők átlagos keresete az 50000-100000 Ft-os kategóriába esett.

Ebböl megállapítható, hogy a beköltözők iskolázottsági és foglalkoztatottsági mutatói jobbak, keresetük lényegesen magasabb a helyben születetteknél. Ebben azonban az is szerepet játszik, hogy a helyiek között lényegesen több az alacsony nyugdíjat kapó egyén a kedvezőtlenebb korszerkezet miatt. A különbség részben a beköltözők összetételében rejlik, amelyet jelentősen meghatároznak a kiköltözés motivációs tényezői és az adott külterület melletti döntés okai.

A kapott értékek alapvetően megfeleltek a hazai és nemzetközi szuburbanizációs vizsgálatok értékelésénél már bemutatott motivációs tényezőknek (7. táblázat). Leginkább a környezet, a saját, kertes ház iránti igény és a munkahely közelsége volt meghatározó, a külterületek jellegéből adódóan még kiemelkedett a kertek iránti igény és az olcsóbb megélhetés. Láthatjuk, hogy a jobb életmód igénye inkább a zártkerti jellegü külterületek esetében döntő, míg az olcsóbb életvitel és családi ok nagy hangsúlyt kapott a többi külterületnél.

A fenti okok ésszerűen csoportosíthatók, egyértelműen kiemelkedik a jobb életminőség és rurális idill szerepe, amelyek klasszikus szuburbanizációs motivációk. Ezt követi az itt olcsóbban elérhető létfenntartás, amelybe bele értendő az is, hogy sokuk saját házat csak a külterületek kevésbé költséges ingatlankínálatából vehetett meg, amely inkább a kevésbé tehetős csoportok 
számára teszi vonzóvá e területeket. Ezt követően a munkahely elérhetősége, illetve más egyéni élethelyzetből fakadó okok szerepeltek.

7. táblázat: a külterületre költözés motivációi (\%)

\begin{tabular}{|l|c|c|c|}
\hline \multicolumn{1}{|c|}{ Költözési motiváció } & Összes külterület & $\begin{array}{c}\text { Zártkertek, Szölöhegyek és } \\
\text { Periurbán utcák }\end{array}$ & Többi külterület \\
\hline Falusias életmód & 15,2 & 16,2 & 14,0 \\
\hline Környezeti előnyök & 15,9 & 15,9 & 15,9 \\
\hline Munkahely közelsége & 11,8 & 13,2 & 10,1 \\
\hline Saját ház igénye & 16,0 & 17,4 & 14,2 \\
\hline Olcsóbb megélhetés & 10,5 & 8,5 & 13,1 \\
\hline Kertmúvelés & 7,3 & 6,2 & 8,6 \\
\hline Családi ok & 12,1 & 13,4 & 10,5 \\
\hline Egyéb okok & 11,2 & 9,3 & 13,6 \\
\hline \multicolumn{2}{|c|}{ Forrás: Saját számítás } \\
\hline
\end{tabular}

A szakirodalom eredményei szerint a migráció vizsgálatában el kell különíteni a lakóhelyválasztás általános motivációit a specifikus lakóhely kiválasztását befolyásoló tényezőktöl. Míg az általános költözési szándékot jellemzően az életmóddal, személyes elvárásokkal és környezeti szempontokkal összefüggö, gyakran absztrakt tényezők határozzák meg, addig a konkrét célpontot sokkal inkább pragmatikusabb indokok döntik el, mint a munkahely elérhetösége, a telekár, az épületek jellege, a környezet fizikai elemei, illetve egyéni tényezők, mint családi okok, korábbi ismeretek a helyszínről (BIJKER, R. A. et. al. 2012).

Ennek megfelelően a „miért választotta pont ezt a külterületet” kérdésre kapott válaszokban általánosan dominált a csendes életvitel (18,3\%), a munkahelyek közelsége (16,2\%), a telekár $(12,7 \%)$, valamint a korábban szerzett tapasztalatok $(12,1 \%)$ jelentősége. Kis eltérést tapasztalunk a nem fejlett infrastruktúrájú külterületekbe áramlók esetén, ahol a kevésbé tehetős beköltözők számára az olcsóság jelentősége még fontosabb volt (19\%). A kérdőívben rákérdeztem, hogy milyen más lakóhelyet mérlegeltek még költözéskor. A többség jellemzően hasonló adottságú másik külterületet, vagy hasonló falusias lakóhelyet keresett, csak kevesen $(15,1 \%)$ választottak jelentősen eltérő (városrész vagy faluközpont) terület helyett külterületet.

Láthatjuk, hogy a külterületre irányuló szuburbanizációban nagy szerepe van az életvitelt olcsóbbá tevő tényezőknek. Ez megfelel a szakirodalomban feltárt (4.4.1. fejezet) jelenségnek, miszerint hazánkban a szuburbanizációban nagy szerepe van a vidéki perifériákról a város felé tartók és a városból kiszoruló háztartásoknak. E csoportok számára a külterületeken végzett kerti munka (másodlagos bevétel), az alacsony rezsiköltségek és a reciprocitáson alapuló, szoros, összetartó közösségek a túlélési stratégia fő elemei. Így a külterületek szerepe e szempontból az olcsó lakóhelyek biztosítása az elesettek számára, mint azt a 4.5 fejezetben már bemutattam.

A zöldség és gyümölcstermelés aránya hagyományosan magas volt a hatvanas évek külterületein (3.2.2 fejezet), a legtöbb háztartás haszonállatot is tartott. A megélhetés segítése mellett ez az aktív pihenést és a rurális hagyományok ápolását is szolgálta. E folyamat azonban jelentős változásokon ment át az elmúlt évtizedekben, az összes válaszadó csupán 19,1\%-a müvelte kertjét önellátási, vagy eladási célból. Ennek oka a kutatások és az empirikus kutatás eredményei alapján is az, hogy az ingázási kényszer akkora időveszteséggel jár, hogy a központoktól távolabb élőknek már nem marad idejük megmüvelni a kertet. Interjúalanyaink (Győr: a, d, e; Szeged b, d; Zalaegerszeg a) egybehangzó véleménye is az volt, hogy a kertművelés - bár motivációs tényező volt a lakhelyválasztásban - visszaszorulóban van. Szintén kiemelték a válaszadók, hogy ennek további oka az elöregedés, mert az a generáció (1990-ben 4050 évesek) mára kikopott, aki ezt elkezdte és a fiatalabbak nem rendelkeznek ehhez sem tudáskészlettel sem akarattal. Haszonállatokat is leginkább az idősek és életmódváltók tartanak, illetve akiknek muszáj ezt tennie megélhetési kényszerből.

A migrációban meghatározó szerepe van a családi kapcsolatoknak és a személyes ismeretségeknek, ahogy azt a bemutatott szuburbanizációs- és tanyakutatások (3.2 és 4.4 fejezet) is bizonyították. A válaszadók jelentős hányada ismerősöktől szerzett információt a lakóhellyel 
kapcsolatban, illetve kimondottan családi okokból érkezett. Kiemelendő, hogy az agglomeráción belüli mozgások (külterület-külterület, falu-külterület) fó motiválói is a családi okok voltak.

A válaszadók 75,4\%-a lakott állandóan a külterületen és 13,7\% tartott fenn hobbikeretet vagy üdülöt, de a városban (esetenként másik agglomerációs településen) élt. 11,2\% vallotta magát kétlakinak, ők az év egy időszakában - nyári félévben vagy az év nagyobb részében életvitelszerüen a külterületen laknak és csak a téli időszakot töltik a városban lévő (jellemzően panel) lakásukban. Jelentős számban csak beköltözők (9,94\%) között akadt olyan, aki szeretne elköltözni. Ök leginkább az elzártság, családi okok és a környezet állapotának kedvezötlen alakulása miatt döntöttek így.

A beköltözők 75\%-a a magvárosból költözött a külterületre, 13,1\% érkezett az agglomeráción kívülröl és $8,8 \%$ az agglomeráció más településéröl érkezett, bizonyítva a szuburbán jelleget. Az agglomeráció más területéröl érkezők esetében a fö ok a költözésre a munkahelyváltás $(22,1 \%)$ és a családi ok $(35,1 \%)$ (házasságkötés vagy épp válás) volt, kevésbé az életminőséggel kapcsolatos indokok. Magas volt azok száma, akik az ország más részéböl áramlottak a városkörnyéki külterületekre, számukra meghatározó volt a korábban megszokott családi házas, falusias életmód fenntartása és az ingatlanok alacsonyabb ára a külterületek melletti döntésben. A lakótelepekről érkezők aránya időben is változó tényező, az 1990-2004 között érkezettek között 24,1\% volt arányuk, 2005 után már csak 12,2\%.

Tovább árnyalja azonban a képet, ha megvizsgáljuk hogyan értékelték a válaszadók a közösség összetételét. Dominánsnak tartotta a városból betelepülöket a válaszadók 59,2\%-a, azonban az esetek kétharmadában $(38,1 \%)$ városból kiszorulóként definiálták őket. Tehát olyannak tartják őket, akik például a magas rezsi vagy a bedőlt hitel miatt voltak kénytelenek a külterületre költözni. 12,5\% tartotta jellemzőnek a pályakezdőket és 10,6\% a nyugdíjasokat, míg a helyieket 31,9\% gondolta meghatározó csoportnak.

Ezt támasztja alá, hogy a válaszadók 45\%-a jellemzőnek tartotta a szegények és hátrányos helyzetủek jelenlétét. 17,8\% a pályakezdőket említette, akiket úgy jellemeztek, hogy a fiatal házasok kevésbé erős anyagi helyzetük és a lakáshitel-piac szükössége miatt olcsó alternatívaként választják a külterületi telkeket. Emellett leginkább a nyugdíjasok és a volt hobbikertesek bizonyultak jelentősnek. Külföldiek, a cselédség volt tagjai (majorok esetében) és vendégmunkások csak néhány speciális esetben voltak jellemzőek a lakosok szerint, a majorokban kialakult iparterületek (Győr - Somosmajor) és üdülö jellegü területek emelhetőek ki példaként (Győr - Károlyháza, Nyúl - Nyúlhegy).

A külterületek pontos népességszáma sok esetben igencsak eltért a népszámlálási adatoktól, azt gyakran jelentősen meghaladta az ott hivatalos lakcímmel nem rendelkezők miatt, ugyanakkor számos külterületen már elköltözöttek, de ki nem jelentkezettek duzzasztják a statisztikai adatokat. E tendencia általános, az önkormányzati interjúk során, mind a négy mintaterületen 10 és 30\% közötti alsó határt megjelölő becslés hangzott el a hivatalos lakcím nélkül a külterületeken élők számát illetően (Bőny a; Domaszék a; Győr b, e; Zalaegerszeg b). A becslést nem állt módomban ellenőrizni, hiszen a lakók a jogi körülmények miatt nem vállalják fel érintettségüket.

Ezt fokozza a második otthonok nagy száma, amelyek tulajdonosai a hétvégéket, vagy a teljes nyári félévet, esetenként az év egészét a külterületen töltik és az itteni infrastruktúrát használják, de a statisztikában nem jelennek meg. Jellemző életút esetükben, hogy a család először csak üres kertet vásárol (a hetvenes évektöl kezdve), majd fokozatosan kiépítettek egy nyaralót és egyre több időt töltenek a telken. A rendszerváltás után téliesítésre kerültek az építmények és a kétlaki életmódot folytatók egy jelentős része kiköltözött a városból. A városi házak gyakran nem kerültek eladásra, azt kiadják bérbe, vagy gyermekeik élnek benne és így az eredeti lakcímmel továbbra is városi lakosként jelennek meg a statisztikákban.

Markáns, kis számú, de a lakosságot zavaró csoport ebben a folyamatban az illegális lakásfoglalók köre. Az illegális lakásfoglalók és a legszegényebb beköltözők gyakran olyan kisméretü, nem téliesített építményekben élnek, amelyek alkalmatlanok erre. Az olcsó, alacsony színvonalú házak mellett vonzók a külterületeken az elfoglalható üresen álló épületek, ennek 
mértékét megbecsülni sem lehet, de a külterületek 36\%-án legalább egy válaszadó említette a jelenséget. A cigányság sajátos térbeli helyzetéről részletesebben az 5.4. fejezetben írok.

Ez a rétegződés alapvetően megfelel a 4. fejezetben bemutatott kutatások eredményeinek. Az agglomeráció peremei (a rural-urban fringe) a hazai és nemzetközi szakirodalomban feltárt eredmények alapján kiemelt területei a városból kiszorulók és városba igyekvők migrációjának. Jellemző, hogy a leginkább gyenge anyagi hátterű migránsok a külső perem (fringe) rosszul elérhető, de emiatt olcsó területeire kényszerülnek a belső szuburbán öv ingatlanárainak felfutása miatt, miközben a tehetösek a jobb adottságú területeken koncentrálódnak.

Az kérdőívekre kapott válaszok szerint a külterületekre költözéssel a lakók alapvetően kielégítik az életminőséggel kapcsolatos elvárásaik környezeti tényezőit. A válaszadók 81,5\%-a szeret a külterületen élni, leginkább a csendes, nyugodt életvitel és jó életminőség (50,0\%), a jó elérhetőség (munkahely) (15,4\%), valamint érzelmi-családi ok $(9,6 \%)$ miatt. Az erős önsegítő közösségek kevésbé jelentek meg a válaszokban, ugyanakkor az említett egyéb okok alapvetően erre vezethetők vissza, példaként említhetőek a „figyelünk egymásra a szomszédokkal”, „lehet számítani a többiekre”, „összetartunk”, stb. válaszok.

Ennek megfelelően a szomszédokkal való viszonyt alapvetően jónak jelölték meg a válaszadók (ötös skálán 3,8), a szomszédok egy közötti viszony állapotát $(3,4)$ némileg rosszabbnak ítélték, ebben (az elhangzott megjegyzések alapján is) hangsúlyosabban jelentek meg a társadalmi csoportok közötti konfliktusok. A közösséget összetartónak és befogadónak tartották a lakók, ahol segítik egymást az itt élök. Paradox módon a sikeresebben megújuló külterületeken trendszerüen 0,5 ponttal kevesebb volt a társadalmat értékelö mutatók átlaga, ami az új csoportok beáramlásából fakadó ellentétekre utal. Az újonnan beköltözőkkel szembeni fenntartások vegyesek voltak, minden részcsoportban közel semleges $(3,2)$ volt az érték. Összességében a problémák ellenére a külterületeket pozitívan érzékelik a helyiek és a beköltözők egyaránt, ebben döntő elem a falusias jellegünek gondolt, összetartó és kiszámítható közösség, ahol „mindenki ismer mindenkit" (Győrszemere a; Zalaegerszeg b).

Meghatározó a népességmegtartó erőben és a helyi közösség dinamizálásában, hogy vannak-e markáns fókuszáló pontok, amelyek köré kezdeményezések szerveződhetnek, vagy amik szubjektív szeretetet ébresztenek a terület iránt. Ilyen markáns elem lehet templom, iskola, müemlék, horgásztó, valamilyen tájképi elem (kilátó) vagy jól müködö közösségi szervezet (3.2.

fejezet). Továbbá meghatározó a terület öröksége, az itt születek ragaszkodása és büszkeségük a tájra, a csendes életmód vonzereje, az erős szomszédsági kapcsolatok a megkérdezettek szerint. Ugyanakkor a munkahelyek és a szociális ellátórendszer nehéz elérhetősége, a közmüellátottság, a szociális gondok, a helyiek elszegényedése, az ebböl fakadó szegregáció, valamint a fiatalok elvándorlásan befolyásolja a terület e képességét.

Megállapíthatjuk a fentiek alapján, hogy a külterületek népességét négy fő csoportra oszthatjuk, első a tehetősebb beköltözők tömege, a második a vidékről bevándorló és a városból kiszoruló alacsonyabb szocioökonómiai státuszúak közössége, a harmadik a rendszerváltás óta helyben lakók és itt születettek csoportja, végül a csak hobbikertet tartók kisebb köre. E négy csoport rendkívül eltérő jellemzőkkel bír és még a csoportokat is eltérő státuszú egyének és családok alkotják. E csoportok egyben - saját élethelyezük és életmódjuk miatt - igen eltérő elvárások és remények miatt választották a külterületeket. A lakóhelyválasztásban meghatározó környezeti és infrastrukturális motivációk teljesülését, a népességmegtartó erő alakulásában fontos tényezők meglétét az azt befolyásoló infrastrukturális és környezeti elemek elemzésén keresztül a következő fejezetben kívánom bemutatni.

\subsection{Területhasználat átalakulása és annak következményei a lakosok életvitelében}

A fragmentált és kevert, tervezetlen jelleg talán az egyik legmarkánsabb különbség a belterületekre irányuló beáramlás és a külterületi szuburbanizáció között. A vizsgált településrészek területhasználata jelentősen átalakult az elmúlt évtizedekben. Az új utcák nyitása 
mellett a tömbfeltárások intenzív módon is növelték a lakóterületek mennyiségét. Konfliktusforrásként különösen az utóbbi szolgált, hiszen a megnövekedő laksűrüség miatt az infrastruktúra elégtelenné válik, valamint a kicsi telkeken sürün épült ingatlanok erodálják a hagyományosan laza beépítettségü településképét, gyakran a mezőgazdasági területek kárára. Gyakori az egykori kis alapterületü, de magas zártkerti tornyok bővítése, és a több lépcsős hozzáépüléssel bonyolult szerkezetủ épület alakul ki. De az építkezések jó része illegális, legfeljebb csak fennmaradási engedélyt kérnek utólag. Ezáltal kaotikus kép alakul ki, melynek hatását fokozza az átalakulási és betelepedési folyamatok hektikussága.

A klasszikus elővárosi szuburbiák sokszor már-már homogén településképével szemben a legkülönbözőbb színvonalon és módon épült lakóházak, üdülők és gazdasági épületek közel véletlenszerủen helyezkednek el a külterületeken. De a különböző funkciók és az eltérő státuszú csoportok által dominált lakóterületrészek is nagymértékben kevertek. Egy külterületen belül lehetséges az ipari funkció, a mezőgazdaság jelenléte és beékelödése a tehetősebbek nagy alapterületü lakóházai, és az alacsony státuszúak kisméretü, rosszabb állagú házainak sora közé, úgy, hogy légvonalban ezek között gyakran nincs 200 m különbség.

Jelentős hiányosság a szuburbanizációs folyamat szabályozatlansága és tervezetlensége a külterületeken. Az újonnan épülő ingatlanok mérete lényegesen meghaladja a várostérség átlagát, több szobás, tetőtér-beépítéses ingatlanok terjednek el, a szorosan (nadrágszíjtelkek) épült sorházak és társasházak nem tudnak a városinál lényegesen jobb életkörülményeket biztosítani, miközben a rosszabb elérhetőség és a városi infrastruktúrához való nehéz hozzáférés miatt hamar elégedetlenségbe fordul a korai lelkesedés.

A dinamikusan megújuló lakóterületek területhasználata jelentősen átalakul, a kicsi telkeken sürün épült ingatlanok erodálják laza beépítettségü településképet. Az egyszerü $20-35 \mathrm{~m}^{2}$-es alapterületü, de sokszor emeletes zártkerti „tornyok” téliesítve lakóingatlanként, leromlott lakóházak és mezőgazdasági ingatlanok, modern luxusingatlanok és sorházak között fekszenek (I. melléklet, 11-12. kép). Mivel jellemzően az éppen üresen álló vagy eladó telkeken építkeztek az újonnan beköltözők a hektikusság fokozza a terület heterogenitását.

Mintaterületünkön gyakran akár 200 négyzetméteres alapterületü ingatlanok voltak a külterületeken, jelentősen meghaladva a beépítési korlátokat. Ahogy azt három, az önkormányzati szektor müködésére rálátó interjúalany is megerösítette: A:,,Esetenként a beköltözésétől várható adóbevételek miatt szemet hunynak a szabálytalanságok és fekete épitések felett. De az emberhiány miatt amúgy sem lenne lehetöségük terepen rendesen ellenörizni.” B. „Az így épült ingatlanok jó része nem felel meg az elöirásoknak, itt egy kis bövités, ott egy kis ráépités, de volt több olyan eset, hogy az elkészült ingatlan és az engedélyezésre benyújtott terv között nem volt hasonlóság.” C: „Szerencsére itt nincs visszabontási határozat a szakhatósági rutinban, mert akkor bajban lennének az ott élök, föleg az engedély nélküli bövitések miatt."

Az engedély nélkül épült, bövített, illetve a földhivatali jegyzékben nem szereplö ingatlanok aránya zártkertekben $20-25 \%$ is lehet a Családok a Kertekért egyesület szegedi gyüjtése és az önkormányzati tapasztalatok alapján egyaránt (Szeged: d; Győr: e). A kialakuló térszerkezet számtalan jelentős hátránnyal jár. Az épületek egy nagyobb része alig, vagy nem alkalmas a tartós bent élésre. Településszerkezeti szempontból a telkeken közel véletlenszerüen elhelyezkedő és változatos méretü és eltérő felszereltségü ingatlanok jelentősen megnehezítik az utcák fejlesztését (úttestszélesítés, telekrendezés, stb.), a hosszú távú tervezést, mint ahogy a zalaegerszegi szölöhegyek fejlesztésénél már többször is visszatérő gond volt a tapasztalatok alapján.

A beruházók által zöldmezős beruházással kül- vagy egyéb belterületen épített lakóegységeknél hasonló nehézségekkel találkoznak a lakók. A befektetők a lehető legkisebb ingatlanon próbálják megépíteni a házakat, sokszor típustervek alapján sorban. A telkek kis mérete ellehetetlenít minden kerti tevékenységet, és nem illeszkedik az életmódelvárásokhoz. „A sorházas beépités nem illik bele a tájba, a laksürüség is sokkal nagyobb és mivel egymás hegyén-hátán vannak az emberek értelemszerüen több a konfliktus is. Bár az önkormányzat szerzödést kötött minden beruházóval az utak kiépitésére, a közvilágtás, járda és zebra kialakitására, ebböl semmi nem lett, 
mert 2007 után csődbe ment a vállalat. Ma már minden beruházásnál kérünk pénzügyi garanciát, de a már elkészült és úgy maradt részeken nem tudunk segiteni pénz hiányában." (Győr: a).

A költözési motivációkban meghatározó volt a természetes környezet, a falusias jelleg, illetve (különösen az üdülöknél) a táji szépség, mint azt az előző fejezetben bemutattam. Környezeti előnyként azonban nem feltétlen a hely minőségét kell figyelembe venni, hiszen több külterületen is felsővezetékek haladtak át, valamint romos telkek, hulladéklerakók, nagy forgalmú főutak, illegális hulladéklerakók, vagy ipari területek mellett fekszenek a lakóingatlanok. A bővülő lakosságú zártkertek és szőlőhegyek mindössze felén nem volt a fentiekben taglalt negatívan értékelhető környezeti elem. Sok esetben a környező területek (közeli erdő, tó, folyópart, tájkép a szőlöhegyekről) adták meg a terület értékét, illetve gyakran pusztán a saját kert megléte volt vonzóbb, mint egy lakótelepi vagy belvárosi lakás. Így a környezeti értékeket tágan kell értelmezni a külterületek esetében.

A legtöbb utca $(66,5 \%)$ üdülős-családi házas, azonban különösen a keskeny utcákban kevés a jó állapotú ingatlan, a veteményesek válnak jellemzővé. A gazos kertek sokkal inkább elszórtak, mégis koncentrálódnak a félreeső, szük közökben és a területek peremein. Legtöbbször a hazai zártkertek esetében a relief, közeli erdő, vagy pusztán a nyílt kertes tér jelent jobb életminőséget, mint amit egy panel lakótelep tud nyújtani, ahogy azt korábbi kutatások is feltárták.

A külterületi ingatlanokra jellemző a megújulás, a terepbejáráskor az épületek csak kis része volt romos vagy lakatlan, ellenben az ingatlanok közel kétharmada átlagos, vagy jó (újszerü) állapotú volt. Az egyes területi egységeken belül jelentős különbségek mutatkoznak, a telkek elhelyezkedése szinte minden esetben heterogén volt, de általános jellegzetességeket figyelhettem meg a terepbejárás során. Így a keskeny utcákban kevés a jó állapotú ingatlan volt, a veteményesek válnak jellemzővé, míg a gazos kertek elszórtak voltak, de némileg koncentrálódnak a félreeső, szük közökben és a területek peremein.

Jelentős differenciálódás mutatkozik a különböző típusú külterületek között (8. táblázat). A legtöbb utca üdülős-családi házas vegyes területhasználatú lakóterület az azonos adottságú zártkertekben és szőlőhegyekben, valamint periurbán utcákban. Markánsan különböznek ettől a majorok, a félreeső szőlőhegyek, amelyek ingatlanállományának már $60 \%$-a romos és rossz állapotú. Az üdülők területén jellemzően átlagos és újszerü állapotú kis alapterületü hétvégi házakat találunk, csak elvétve akadnak ingatlan nélküli hobbitelkek.

8. táblázat. A külterületi ingatlanok funkció és állag szerinti megoszlása a terepbejárás eredményei alapján.

\begin{tabular}{|l|l|c|c|c|}
\hline \multicolumn{2}{|c|}{$\begin{array}{c}\text { Ingatlanok megoszlása, (\%) } \\
(\mathrm{n}=\text { 9290) }\end{array}$} & Külterületek & $\begin{array}{c}\text { Fejlett infrastruktúrájú külterületek } \\
\text { (Szölőhegyek, Zártkertek, } \\
\text { Periurbán utcák) }\end{array}$ & $\begin{array}{c}\text { Rossz adottságú } \\
\text { külterületek (többi) }\end{array}$ \\
\hline \multirow{2}{*}{ Kert 51,8\% } & Gazos/felhagyott & 10,9 & 5,6 & 11,4 \\
\cline { 2 - 5 } & Hobbitelek & 40,9 & 35,9 & 29,3 \\
\hline \multirow{2}{*}{$\begin{array}{l}\text { Lakóházak } \\
46,1 \%\end{array}$} & Jó & 7,9 & 13,8 & 7,1 \\
\cline { 2 - 5 } & Átlagos & 31,8 & 35,7 & 26,0 \\
\cline { 2 - 5 } & Rossz & 3,0 & 6,9 & 4,1 \\
\cline { 2 - 5 } & Lakatlan & 2,2 & 1,4 & 4,1 \\
\cline { 2 - 5 } & Rom & 1,2 & 0,1 & 16,1 \\
\hline \multicolumn{2}{|l|}{ Telephelyek } & 2,4 & 0,6 & \\
\hline
\end{tabular}

A majorok többsége fekvésüktől függetlenül rossz ingatlanállománnyal rendelkezik, az épületek közel kétharmada rossz állagú vagy romos. Bár a közös tulajdonú cselédházak kívülröl elhanyagoltak - mivel senki sem akar rájuk költeni - a bennük lévő saját lakások állapota gyakran kimondottan jó. Ennek megfelelően, a nehézségek ellenére, az erős közösség és az olcsó megélhetés olyan vonzerő, hogy csak a válaszadók 22,8\%-az akart elköltözni. Az elnéptelenedés gyakoribb oka, hogy a majorok tulajdonosai a gazdasági funkció erösítése miatt az épületek karbantartásának elhanyagolásával, az utak rossz állapotban tartásával, vagy a helyben élés különböző módokon történő akadályozásával próbálják tudatosan felgyorsítani a hanyatlást. 
A zártkertek és szőlőhegyek területén a rendszerváltás előtt a gyakran (esetenként évente) változó építési szabályozás, a besorolási övezetek gyakori változásai, valamint a követelmények be nem tartatása révén rendkívül heterogén összetételü és változatos müszaki állapotú ingatlanállomány jött létre. Ez a szabad, nem felügyelt jelleg egyben sajátos vonzerőt kölcsönzött a kertségeknek és a kevésbé tehetősek számára is lehetőséget biztosított az építkezésre - még ha szakszerütlenül is (3.3 fejezet). 1990 után a szabályozás megszünése révén a területek egyfajta homályzónába kerültek az országos és a települési hatóságok szemszögéből is, így tovább diverzifikálódott az ingatlanállomány.

Mint a fejezet elején bemutattam a telkek egy jelentős részén $(1,2 \%)$ romokat, lakhatatlanná vált házakat találunk. Emellett a félbehagyott építkezések száma rendkívül nagy, különösen a zártkertek területén, ebben kiemelkedőnek tartom a 2007 utáni válság hatását a félbemaradt épületek korát megbecsülve. A gazos, felhagyott és nem müvelt telkek számát $(10,9 \%)$ több tényező is emeli. Különösen a majorokban találhatunk korábbi gazdasági épületeket, amelyek statikailag is leromolva, esetenként életveszélyes állapotban állnak elkerítetlenül a lakóépületek közelében. Ez - tájképi hatásán túl - a gyermekek számára konkrét veszélyt jelent (Györ c).

$\mathrm{Az}$ egykori kiskertező generáció elöregedése és az ingázás miatti időveszteség mellett az osztatlan tulajdonú, ezért konkrét felelőssel nem rendelkező telkek száma is jelentősen növeli a hasznosítatlan ingaltanok számát. Az osztatlan tulajdonú telkek fö problemaikája, hogy a TSZ-k felszámolásakor kiosztott részaránytulajdon révén tulajdont szerzett, de elhunyt tulajdonostársak miatt eladhatatlan és kezelhetetlen ingatlanok sokasága alakult ki. E problémára megoldást jelenthet a 374/2014. kormányrendelet a részarány kiadás során keletkezett osztatlan közös tulajdon megszüntetésének részletes szabályairól. Ez lehetővé teszi az ilyen személyek arányának kiváltását, azonban a folyamat rendkívül lassan zajlik 2020-ig nem várható befejeződése, ráadásul a rendezetlen hagyatéki vagyonok részben újra kitermelik a jelenséget (Szeged: c).

Hasonlóan vegyes képet mutat az infrastruktúra kiépítettsége is, lehetséges, hogy egy külterület különböző pontjainak elérhetősége markánsan különbözzön még a kisebb térbeli kiterjedéssel bíró külterületek esetében is. Ez különösen azért fontos, mert jelentősen befolyásolja a beköltözők státuszát az ingatlanárakra gyakorolt hatása miatt, valamint az egyes gazdasági funkciók megtelepedését. A következőkben ezért az infrastruktúrát, azon belül is elsősorban a közlekedési lehetőségeket, azok életvitelre gyakorolt negatív hatásait, majd az egyéb infrastruktúraelemek hiányosságainak hatásait elemzem.

\subsection{Az infrastruktúra hiányosságainak hatása az lakosok életvitelére}

A mezőgazdaság kiszolgálására kiépített infrastruktúra nem alkalmas a lakossági mai igények kielégítésére. Az utak sok esetben csak az egyes külterületi üzemegységekhez vezetnek, a házakig onnantól csak rossz, szük földutakon közelíthetők meg. A zártkertekben és egykor zártkerti besorolású szőlőhegyekben a telkek kiosztása nem tervek szerint történtek, hanem gyakran adhoc módon (3.2 fejezet) zajlott, így az úttestek tervezetlenül alakultak ki, mivel a nem pontosan kimért telekhatárok révén a gyakorlatilag a lakosok oda építettek kerítést, ahova gondoltak. Ennek eredményeképpen az utcák keresztmetszete sokszor nem éri el a két métert, sok a kicsi keresztutca, zsákutca, ahova alig lehet bekanyarodni az íves sarkok hiányában. Az átjárhatatlan úttestek gyakorisága változó, a félreeső szőlőhegyekben szakaszosan jelentkezik a gond, a zártkertek esetében leginkább a legszélső utcákban és kis mellékutcákban vannak használhatatlan részek, valamint a tanyavilágban a földutak minősége a főutaktól távolodva gyorsan hanyatlik.

Számtalan majorban, üzemi lakóhelyen és tanyasorban utcákról nem is beszélhetünk, legfeljebb közlekedésre is használt közterületi földdarabokról. Sok esetben az utcáknak nincsenek nevei, vagy azok nincsenek kitáblázva, esetenként a házszámok is teljesen hiányoznak, vagy kaotikusak. Jó példa Győr- Kertváros, ahol egy utca egyik felén Fenyő sor, a másik végén Fenyves utca név szerepelt. Szomorú véletlen, ami jól jelzi a probléma súlyát, hogy a terepbejárások során két tüzeset is történt, melyek a külterületi úthálózat veszélyeire is felhívták a figyelmet. Az egyik 
esetnél a tüzoltók 40 perc alatt értek ki, mert nehezükre esett beazonosítani a helyszínt, a másik esetnél a szük és rossz utcába egyáltalán nem volt képes bejutni a jármü.

A mintaterületeken ennek megfelelöen az utak állapotát $21,5 \%$ emelte ki problémaként, Továbbá azok szükösségét $(9,3 \%)$ valamint a járdák és a gyalogos átkelőhelyek $(12,2 \%)$ szinte teljes hiányát veszélyesnek értékelték a válaszadók, különösen a gyermekekre és idősekre nézve (I. melléklet, 13-14. kép). A téli időszakban az iskolába járó gyerekeiket kiemelten féltik a szülők ilyen útviszonyok mellett. A megnövekedett laksürüség miatt emelkedő használati intenzitás pedig felgyorsította a már amúgy is rossz állapotú utak hanyatlását. A beton alappal nem rendelkező, csak aszfaltozott úttestek már a jelenlegi forgalmat sem képesek kiszolgálni.

$\mathrm{Az}$ infrastruktúra a népességüket intenzíven növelö külterületeken nagyobb terhelés alá kerül, mint amekkora annak tervezett kapacitása és drasztikus ütemben romlik állapotuk. Jellegzetes gond a vízelvezető árkok betemetése a kert növelése és kocsi feljárók készítése érdekében, ezzel a padkákat, valamint a földutakat teszik még inkább járhatatlanná a csapadékos időszakokban (Győr-Kertváros, Győr-Nagyhegy, Szeged-Marostő, Domaszék-Zártkert).

Új jellegü probléma, hogy a lakók egy része igyekszik kisajátítani az úttestet is. A terepbejárás során 6 esetben elzárták az utca egyik végét (például drótháló kihúzásával) zsákutcát képezve a fogalom csökkentésére, ezzel viszont a más utcákban élőknek nehézségeket okoznak, hisz olykor több km hosszú kerülőt kell tenniük (Győr-Górédülö, Győrújbarát-Paperdő, Nyúl-Nyúlhegy, Vámosszabadi-Győri út). Három esetben (két szőlőhegyen, egy üdülőben) az út egy részét két oldalról is teljesen lezárta az ott lakó (a szakaszra kapun át lehetett behajtani) és így az utca másik végét csak kerülővel lehetett elérni. Ennél gyakoribb, hogy a tulajdonos az út közepéig sajátjaként kezeli a közterületet és szemetet, eszközöket (hordót, autót, fát) tart azon, vagy kijjebb teszi a kerítését annyira, hogy az már akadályozza a gyalogos forgalmat. Mindhárom jelenségnél súlyos konfliktusok alakultak ki, azonban, a városok építési osztályain készül interjúk szerint a szükséges erőforrások hiányában az önkormányzatok nem, vagy csak jelentős késéssel tudnak beavatkozni (Abda: a, Sándorfalva: a, Zalaegerszeg: a).

A rossz elérhetőség a rekreációs és magáncélú utazásokban (különösen a gyerekek és édesanyák számára) nagy nehézség és hátráltathatja a helyi közösség müködését is. Az ingázás egyben gyorsítja a kertek felhagyását is, hiszen a müvelésére szánható szabadidő jó részét elveszi a közlekedés időigénye és az idősek nehezebben tudják elérni telkeit az egészségi állapotuk romlása esetén. Mivel a szolgáltatások, intézmények és munkahelyek jó része csak a városban érhető el, a tömegközlekedés a kevésbé tehetős és idősebb korosztályok számára elengedhetetlen. Így e kérdés kezelése döntő a külterületek jövőjének alakulásában.

A tömegközlekedéssel kapcsolatban a leggyakoribb panasz a legközelebbi megálló nehéz megközelíthetősége $(23,8 \%)$ volt, ennek hátterében részben a nagy, olykor $3 \mathrm{~km}$-t meghaladó távolságok, részben pedig az oda vezető utak rossz állapota, időszakos (téli) átjárhatatlansága állt. Kisebb arányt képviseltek $(8,8 \%)$ a menetrendet érintő kifogások, amelyek a járatsürüségen kívül a jármüvek útvonalát is kifogásolták, hiszen a külterületek egy részétől a legközelebbi települések és ipari foglalkoztatók csak körülményesen, átszállással érhetők el.

A szakirodalmi megállapításokat (4.5 fejezetben) alátámasztják a válaszok, abban, hogy az autó nélküli háztartásbeli nők számára jelentős kihívás kerékpárral, vagy gyalogosan megszervezni a gyermekek napi utazását és eljutni a kereskedelmi- és szolgáltató egységekbe. A kevésbé tehetős háztartások a nők nagymértékű házimunkájára alapozzák olcsó életvitelüket, akik így egy túlfeszített, mégis ingerszegény életmód csapdahelyzetébe kerülnek a külterületeken. A külterületen élők esetében e szempontok alapján is hátrányos, hogy a boltok hiányoznak, vagy ha vannak azok felszereltsége minden esetben alacsony volt, vagy drágának találják a lakók, és kénytelenek voltak a közeli településeken intézni a lehető legtöbb vásárlást.

Az önkormányzatok ismerik a lakosság közlekedéssel kapcsolatos kifogásait és nehézségeit, azonban „a nagy költségvonzat miatt nem tudja figyelembe venni azt...” (Győr: c). „Ahogy a közmü ellátottsági igényeket sem lehet megfinanszirozni, úgy az útfejlesztéseket sem. Képtelenség 
is, olyan keskenyek az utcák, hogy nincs is hely a kivitelezésre. Az pedig földtöl elrugaszkodott elképzelés, hogy a keskeny kerti utcákba beküldünk buszt." (Zalaegerszeg: e).

Sikeres fejlesztésekre ott volt példa, ahol a lakosságot be lehetett vonni, a kivitelezésbe, „Amiben van fantázia, az a részben önerös beruházás, amikor pályázatba beszállnak a lakók, úgy lenne remény és ösztönzően hat a helyi összefogásokra." (Győr: d). Fontos kiemelni, hogy a jó állagú utak egy részét a helyiek önerőből tették rendbe, amihez számtalan anyagot használnak, extrém esetekben a sírkő daraboktól az égett cserepeken át a beton talpfákig (Győr-Rabkert, Győrújbarát-Fehérkereszt).

A tanyagondnoki szolgálat a lakosság közlekedési és életviteli nehézségeinek enyhítésével legalább részben csökkentette az itt élök közlekedési helyzetéből fakadó elszigeteltségét, azonban az infrastrukturális hiányosságok (belvíz, téli közlekedési nehézségek) hatása továbbra is erősen hat a fiatalok helyben maradási hajlandóságára (Domaszék: b).

A tanyák a többi külterületnél is jobban kitettek a belvízkérdésnek és a rossz közlekedési viszonyoknak, az erős elszigeteltség akadályozza a közösség müködését, alig van kapcsolat a távoli tanyákon élők és a központi települések között. Az elszigeteltség érzete és a szociális gondok miatt a (részben a szocializmusból megörökölt) negatív kép erösödik. A fiatalok, diákok jelentős része szégyelli tanyasi származását (KISS A. 2010), amit a válaszok is alátámasztottak (Hódmezővásárhely: a).

A külterületek (és részben az egyéb belterületté átsorolt korábbi kiskertes külterületek) további funkciókkal rendelkeznek a városok térszerkezetében. Területükön gyakoriak a föbb belvízelvezető árkok, tartalékterületként funkcionáló szántók, erdők és vízfelületeknek adnak otthont. Továbbá e területeknek a városi hősziget jelenség hatásainak és a légszennyezés csökkentésében is szerepe van (CSAPÓ T. 2007, NiKODEMUS, O. et. al. 2005, RAKONCZAI J. et. al. 2009, Győr: d; Szeged: d). Ennek fényében sajnálatos, hogy a belvízkérdés újra megjelent a válaszadók $8 \%$-a szerint. Ennek oka leginkább a beépítettség növekedése és a kocsibehajtók építése közben feltöltött árkok nagy száma, kisebb részint, az hogy a helyi ismeretekkel nem rendelkező beköltözők korábban is időnként vizesedő területre építkeztek. Hasonlóan túlterhelt az áramellátás (7\%), ingadozik a közvilágítás (11\%), a telefonhálózat és a vízmü több külterületen és az egyéb belterületek bizonyos részein, peremutcáin, azonban e tendenciák egy-egy helyszínen jelentősen eltéröek, általános megállapításokat nem lehet meghatározni, az egyes külterülettípusok további infrastrukturális sajátosságait az 5. 6. fejezetben taglalom.

A lakott külterületek jelentős részén hazánkban a mezőgazdaság hanyatlani kezd, de fontos az itt élő képzetlenek foglalkoztatásában, legalább nyári alkalmi munkát biztosítva számukra (NAGYVÁRAdi L. - SZABÓ-KovÁcs B., PÓCSI G. 2009, TimÁr J. 1992). Mintaterületemen ez alól kivételt a mezőgazdasági vállalatok majorsági telephelyei, valamint a tanyavilág képez. A kárpótlás és privatizáció során az Alföldön földhöz jutott gazdák egy része tanyára költözött, amik ezzel visszanyerték eredeti funkciójukat és mint gazdálkodó egységek. A súlyos szociális gondokkal küzdők és az idös tanyalakók a létfenntartás miatt költöznek városközeli külterületre, ahol a mezőgazdasági bevételekből próbálják kiegészíteni szerény jövedelmeiket.

A tanyákra jellemző kisléptékü családi üzemek túl kicsi földekkel rendelkeznek a modern technológiák bevezetéséhez, illetve, ha beruházásokat eszközölnek, az adósságállományuk nő meg jelentősen. A tartós bevételi gondok állandósulása miatt a szociális háló szerepe nagy, ez a kisebb nehézségeken átsegíti őket, valamint a reciprocitás elvén keresztül müködő önsegítő mikroközösségek az ismerősi hálón belüli pénzmozgás nélküli kereskedelem révén járulnak hozzá a megélhetéshez (BALOGH P. 2013, FARKAS J. - CsATÁRI B. 2011, KISS A. 2004, VÁRADI M. M. 2013). Mivel a földek eladását a kisgazdák érzelmi alapon elutasítják, a bevételi diverzifikáció (turizmus, kisiparos munkák), a költségminimalizálás és olcsó házvezetés (nyugdíjasok), valamint a redisztribúcióra (területalapú támogatás, fiatal gazda pályázatok, stb.) alapozó földmüvelés jelenti a városperemi lakosok lehetőségeinek fő körét (I. melléklet, 15. kép). Azonban jelentős gond, hogy nincs tudáskészletük a lehetőségeikről, pályázati forrásaikról, valamint a pályázatok 
sem igazodnak a kisgazdaságok reális kívánságaihoz (CSATÁRI B. - KISS A. 2003, FARKAS J. 2004, KovÁcs K. - VÁRAdi M. M. 2003, PETRÁs E. 2006, RomVÁRI R. 2014).

A háztartások többsége legfeljebb hobbikertet vagy egyszerü füvesített udvart tart, persze számos ház mellett csak gazos telkek állnak. A válaszadók 19,1\%-a müvelt kiskertet, de csak 9\%a végzett jelentősebb mezőgazdasági munkát (saját megítélése alapján), vagy volt őstermelö. Jellemzően a tanyák esetében végzett kisléptékü növénytermelést néhány haszonállat egészítette ki. A gépesítettség alacsony, csak kevesen tervezik a gazdaság fejlesztését és a perspektívák szükösségét mutatja, hogy mindössze 41 válaszadó gondolta úgy, hogy van, aki tovább viszi majd a gazdaságot. Ez szemléletesen mutatja a mezőgazdasági funkció visszaszorulását a rekreációs és lakófunkció javára a külterületek esetében.

Ennek jelentőségét a törvényalkotó is felmérte és 2015 után lehetségessé vált a zártkerti besorolású külterületek (számos tanyás egység és szőlőhegy is ilyen besorolás alatt van a földnyilvántartásban) ingatlanainak müvelés alóli kivonása ingyenesen. A bortermő vidékeken található szőlőhegyek esetében azonban továbbra is fennállnak a szigorúbb szabályozók és művelési kötelezettségek. A majorok, őrházak és egyéb külterületek esetében pedig általános, hogy a lakóházak csak egy kis elökerttel esnek egy telekre, így a környező földek rendszerint más egyének tulajdonában vannak, a termelési kötelezettség nem érinti a lakókat, viszont így nincs is kapcsolatuk a földdel.

A területhasználattal kapcsolatos további problémák már közvetlen módon hatottak a lakosság életvitelére. Nagy jelentőséget tulajdonítottak a lakosok a környezet élhetőségét rontó jelenségeknek, ezek között kiemelkedik a szemetelés és hulladékégetés (14\%) kérdése. Utóbbi a legszegényebb lakosság sajátja, akik nem tudják kifizetni a kommunális díjakat, illetve a hulladékelszállítás nélküli várostól távoli kis szőlőhegyekben és majorokban megkerülhetetlen rutin. A szemetelésen alapvetően a főutak mentén fekvő közel valamennyi külterületre jellemző illegális hulladéklerakást kell érteni, nem a helyi lakosság tevékenységét. E szemetet (ami esetenként veszélyes hulladék) a szél széthordja, valamint a buszmegállók közelében fekvők a gyerekekre jelentenek veszélyt, továbbá a kóbor állatokat vonzza. Emellett a föutak mentén a városokból rendszeresen kiteszik a megunt házi kedvenceket, melyek szintén a külterületeken kötnek ki. A kóborló állatok problémáját összesen a válaszadók 11\% tartotta jellemzőnek.

Összegezve a területhasználat a demográfiai és gazdasági folyamatok hatására nagymértékben átalakult, és ez a transzformáció jelenleg is zajlik. Az ingatlanállomány bővülésének a lakóterület extenzív (új területek beépítése) és intenzív (tömbfeltárások) növekedése egyaránt konfliktusforrás, különösen a sürün és gyakran egyforma házakkal beépített egységeken. Az infrastruktúra-fejlesztések lemaradásba kerültek a változások során, és nem voltak képes adaptálódni a megváltozott társadalmi igényekhez.

A fejlődő külterületekre jellemző, hogy a hagyományos településkép rovására megindul a belterületi szuburbán utcák képére hasonló tájhasználat elterjedése. Különösen a majorok esetében jelentős a differenciálódás e folyamat során. Több pusztán a mezőgazdasági szerkezetváltás miatt eltünőben van a lakosság, és pusztulnak az ingatlanok, míg a fejlődők területén az új, modern épületek veszik át a típusos majorsági épületek helyét. A térszerkezet jelentősen fragmentálódik és módosul a szuburbanizáció során, amely nem csak számtalan konfliktust eredményez, de a lakosok egy jelentős része ezek miatt nem képes élvezni a lakhelyváltástól várt életminőségváltozást. A következő fejezetben a szuburbán átalakulás társadalmi hatásait kívánom megvizsgálni, különös tekintettel az életminőséget befolyásoló tényezőkre.

\subsection{A külterületi szuburbanizáció társadalmi következményei}

A külterületek esetében jelentős probléma, hogy nincs érdekérvényesítési képessége a lakosságnak, csak igen kevés település biztosít állandó képviseletet az önkormányzati testületekben. A külterületekre költöző sokaság jobb anyagi helyzete és eltérő életvitele miatt sok szempontból idegen a helyi falusias jellemzőkkel bíró lakosságtól növelve a társadalmi 
különbségeket. A két csoportnak más az aktivitása, érdekérvényesítő képessége a lokális közösségben és a jövőképük a terület fejlődését illetően, eltérő jelentőségü számukra a lakófunkció és a szolgáltatások minősége, vagy a táji értékek és a mezőgazdaság fennmaradása.

Sok lakos - kiemelten a saját autóval nem rendelkező kevésbé tehetősek és az idősek - számára megterhelő $(10,2 \%)$, hogy el kell járni ügyet intézni a falu belterületére. A városba ingázók számára ez nem esik útba, több külterületen jelentős kitérö, illetve nehézség, mivel az adott külterületröl közvetlenül nem érhető el tömegközlekedéssel a faluközpont, illetve csak nagyon kevés busz közlekedik, vagy nagy távolságban van a buszmegálló (Felpéc-Halipuszta, BőnyPáskum és Örkénypuszta, a közigazgatási határok menti tanyák általánosan). Szintén gyakori panasz volt a városban megszokotthoz képest nehézkesnek és „belterjesnek”, azaz az újakkal szemben hátrányosan megkülönböztetőnek tartott helyi ügyintézési rutin $(11,1 \%)$.

A beköltözők számára negatívum, ha nem tudnak beilleszkedni a helyi közösségbe, mivel így több remélt előnyből kimaradnak. A sokaság 23,1\%-a jelezte e probléma fennállását és az új utcai lakosok 10,5\%-a értékelte súlyos problémaként azt, hogy a helyi lakók egyáltalán nem befogadóak az újakkal szemben. Ez megnyilvánul az általános érdektelenségben, de gyakori a tényleges földrajzi elkülönülés, az iskolában, a boltban, de még az utcán való találkozáskor is sokuk tapasztalt hátrányos megkülönböztetést a tősgyökeres lakosok részéről. Az elkülönülést jól jellemzi, hogy a ,jelentős eltérés van beköltözők és a régi lakók között” állítással való egyetértést firtató kérdés válaszainak átlaga 3,93 lett ötös skálán. Mivel a 10 évnél régebb óta betelepülőknek is 26,5\%-a máig elszenvedője a szituációnak, így 10-15 évig tartó lassú folyamatnak tekinthetjük az integrációt a helyi közösségbe.

A „gyüttmentekkel” szembeni ellenállás okaként a sokaság 11,5\%-a az értékrendek eltérését, 7,7\% pedig az anyagi különbségeket jelölte meg. 15,3\% szerint egyértelmüen a beköltözök hibáiból ered az elkülönülés, nem képesek igazodni és a „panelos életvitelt” akarják folytatni, $8,1 \%$ pedig úgy tartja, hogy a beköltözők inváziója révén a helyi közösség atomizálódott. „A városból érkezök kapcsán nem is az új, tehetös beköltözökkel van a baj, hanem a 15-20 éve érkezett, panelból kiszorulókkal, azoknak az életmódja és a hozzáállása inkompatibilis az idösebb helyiekkel. (...) Közösségröl nehéz is már beszélni, egy-egy helyi eseményen ugyan annyian vannak, mint 30 éve, csak a népesség ott háromszorosára nöt közben." (Györ: a).

A szuburbanizáció során a tehetősek és a hátrányos helyzetüek beáramlása egyaránt konfliktusok kialakulását okozza, egyben az eredeti morfológia és a külterület történelmi településképének elvesztéséhez vezethet, mely folyamat végén a külterületnek csupán a területe kerül új hasznosításra (BALOGH A. 2015, TóTH Z. 2000, VASÁRUS G. 2016a). A rossz elérhetőségü külterületen a társadalom perifériájára szorultak élnek, mert e területek az olcsó megélhetés révén segítik anyagi stabilizációjukat. Ugyanakkor félő, hogy a jelenség modern szegénytelepek kialakulásához vezethet, hasonlóan a miskolci Lyukóvölgyhöz (3.3 fejezet).

A legrosszabb környezeti adottságú és elérhetőségü külterületek a cigányok, vendégmunkások, elváltak és csonka családok városból történő kényszerü kitelepülésének célterületei olcsóságuk miatt. Ilyen új, önkéntes szegregátumok Zalaegerszegen Csáford, a győri agglomerációban BőnyPáskum, Győr-Fazekasvermek, Pósdomb, Győrságpuszta és Ikrény-Dózsamajor a szegedi agglomerációban Sándorfalva-Kövágódülö, és részben érintett Tiszasziget-Térvárpuszta. A tanyavilág differenciálódása is abba az irányba mutat, hogy a marginális csoportok és az alacsony nyugdíjú egyedülálló idősek térben koncentrálódnak a legrosszabb elérhetőségü tanyákon (Bordány-Meződülö, Domaszék-Bojárhalom, részben Hódmezővásárhely-Kopáncs, Rárós).

„Vannak olyan élethelyzetek - válás például -, amikor csökken az életre forditható pénz és kiszorulnak a külterületre. Ez a folyamat szerintem nöni is fog rövidtávon. Az egészben az az ellentmondás, hogy ugyan azokon a helyeken paloták is épülnek párhuzamosan." (Györ: e). „Leginkább azért mennek ki, mert ott az eddigi életvitelnek legalább a látszatát meg tudják tartani, de a 80 \%-a annak, aki a kertek szélébe megy az alsó középosztály legfeljebb és félnek a lecsúszástól.” (Szeged: d). „Van egy szervezetünk, ami az elesetteknek segit, 98\%-ban a külterületen dolgoznak. Ez szerintem mindent elmond, arról, hogy kik kötöznek oda. A városi 
szegények, meg az ország minden részéröl a szegények. Van, akinek az eredeti lakóháza nem ér annyit, hogy itt egy sufnit vegyen a szölöhegyben." (Györ: a).

Az ilyen területeken azonban a lakosság nem feltétlenül érzi különösebben rossznak a helyzetét és a többség $(77,2 \%)$ szeret itt élni. Ök ebbe a helyzetbe szocializálódtak bele és az erős közösségek megszervezik a körülményekhez adaptált életmódjukat, megkönnyítve a nehézségek leküzdését. Ennek szemléletes példája Győrságpuszta, ahol a hátrányos helyzetü lakosok miután a földet müvelő vállalkozás beszántotta a kertjeiket nekiálltak újra kiásni a vízelvezető árkot, majd apránként elkezdték felújítani a felázott lakásokat. Bár lassan haladnak a közös cél összekovácsolta az addig apátiában élő közösséget.

A majorok, a TSZ-lakótelepek és zártkertek egy része jó elérhetőségü és rendelkezik megfelelö tartalékterületekkel, így vonzó az ipari szuburbanizáció számára. A tőkeerős vállalkozások, valamint a nagybirtokosok üzemei kiszorítják az ingatlanpiacról a helyi lakókat és megindul a szelektív elvándorlás a zaj-, és környezetszennyezés miatt (Abda-Pillingérpuszta, GyőrSomosmajor, Sashegypuszta). Az ilyen külterületeken - például Somosmajorban - csak az idős és cigány népesség marad meg. Ök képtelenek elköltözni, hiszen a környezeti igazságtalanság által sújtott területeken eladhatatlanná vált házaik miatt csapdahelyzet alakult ki.

Az agrárium is hozzájárulhat a külterületek pusztulásához, mert az iparnövény-termelés földigénye érdekében beszántják azokat. A tájképi degradáció mellett a por, az allergén növények megjelenése és a permetezőszerek oly mértékben rontják az életminőséget, hogy a lakók és kertmüvelők feladják kertjeiket-nyaralóikat. Az egykori szőlőhegyekből, zártkertekből és majorokból visszamaradt telkek tanyaszerü szigeteket képeznek a szántókban (Pér-Sótóidülő, Győrújfalu-Mártonháza), Pázmándfalu-Bercelen már csak egy elköltözni képtelen egyedülálló anya és két gyermeke maradt lakóként.

A majoroknál az állattartás helyébe lépő iparinövény-termelés feleslegessé teszi a legtöbb pusztai épületet és a lakók elvesztik munkahelyüket. Sok ilyen esetben a tulajdonos mindent megtesz, hogy megszüntesse a lakott helyet. Két ilyen esetben arról is beszámoltak, hogy bár a lakosok saját erőből elkezdték tatarozni a cselédlakásokat a tulajdonos visszabontotta a munkákat. Az ott élő, napszámos foglalkozású lakók csak a környező föld tulajdonosának engedélyével fogadhattak vendégeket, családtagokat, mondván, a major bevezető útja is az ő tulajdona (nem igaz). Sok beszámoló szinte már egy archaikus földesúr-jobbágy relációhoz mérhető kiszolgáltatottságot írt le, hiszen a munka, a lakhely, a közlekedés és az uzsorahitel is az őket elüzni szándékozó tulaj kénye-kedvéhez láncolta a családokat. Az válaszadók anonimitásának megőrzése miatt e területek neve nem kerül közlésre.

A korai beköltözők által javul a terület hírneve, ez újabb lakókat vonz oda, amivel felverik az ingatlanárakat. Érdekérvényesítő képességük révén az újonnan érkezők elkezdik a lakóhely képét saját vidékimázs-koncepciójukhoz alakítani, amiben a terület nem termőföld, csak az idealizált vidékkép díszlete. $\mathrm{E}$,tájkép-fetisizmus” hozzájárulhat a hagyományos területhasználat és ezzel a régi lakók kiszorításához, amint azt a 4.5. fejezetben bemutattam.

A népességüket növelni képes külterületeken a beköltözés csak a házak kis részének megújításához járul hozzá, mert inkább a hézagok és tartalékterületek beépítése a jellemző. Mindegyik mintaterületen jelen volt az illegális építkezés és lakásbővítés tájba nem illeszkedő ingatlanokkal, ami rontja a területek egyik vonzerejét, a környezeti szépséget. A több száz $\mathrm{m}^{2}$ alapterületü ingatlanokkal való beépülés azért is hátrányos, mert a későbbi területrendezést és útszélesítést ellehetetleníti (Zalaegerszeg-Jánka, Győr-Kishegy).

Zalaegerszeg - Budai-völgyben nem csak az eredeti lakosságot szorították ki a betelepedők, de az ingatan állomány is szinte teljesen kicserélődött. Egy 1990 óta ott élő alacsony státuszú férfi saját magát „utolsó mohikánnak” nevezte, hiszen az eredeti lakosokból már csak egyedül ö maradt meg és műveli meg szőlöjét a jóval gazdagabb új lakosság gyürüjében. Számára legalább akkora stresszor a dédszülők szőlőjének lehetséges elvesztése, mint a kirekesztettség érzete.

A szuburbán lakhelyváltók általában megőrzik korábbi lakóhelyük kapcsolatait és szociális hálójuk a városhoz kötődik. Nehezen integrálódnak az új közösségbe, annak nem képzik részét, 
legfeljebb közvetlen szomszédjaikkal van kapcsolatuk. A külterület számukra csak alvó-település, melynek közössége indifferens, de könnyen tudnak lobbizni erős érdekérvényesítö-képességük révén, ahogy egy zalaegerszegi interjúalany megfogalmazta: „Úgy hiszik a helyiek, nincs beleszólásuk ezért akkor sem fejtenek ki véleményt, ha kérdezik őket". (Zalaegerszeg: b). Inkább elzárkóznak és egyfajta védekező reakcióként akadályozzák a „gyüttmentek”, ,audisok” életét, többek között például zavarják a forgalmat, hajnalban végeznek munkálatokat.

A helyi lakók egy részére viszont jellemző a csendes beletörődés, ami sokszor a szociális helyzetre vezethető vissza. A városból a magas rezsi vagy a hitelproblémák miatt kiszorulók és a korábban magasabb státuszú, de némileg lecsúszott nyugdíjas lakók „a külterületeken tulajdonképpen elbújnak szégyenükben”, ahogy a Zalaegerszegi interjúalany (c) fogalmaz. Nem kérnek önkormányzati, vagy társadalmi segítséget akkor sem, ha erre égető szükségük van. Emiatt gyakori, hogy lakhatásra alkalmatlan, téliesítetten nyaralókban találhatunk nyugdíjas és hátrányos helyzetü háztartásokat, akikről a szociális ellátó rendszer és a helyi közösség semmilyen információval nem rendelkezik.

A fejlesztési ellentétekre kiváló példa a csatornázás. Az eredeti lakosság, valamint a városból kiszorulók számára a külterületek az olcsó életvitel miatt vonzóak, megélhetési stratégiájuk központi eleme a költségek csökkentése. Hódmezővásárhely-Kishomokon, a kiszorultak számára ezért rendkívül nagy érvágás a 70000 Ft-os kötelezö hozzájárulás a csatornázásra, valamint a belterületbe vonás után fizetendő ingatlanadó. Emiatt sok válaszadó (12\%) úgy gondolja kénytelen lesz elköltözni, ez a vélemény Szeged-Marostő és Bőny-Szőlőhegy esetében is gyakori volt. A belterületbe vonás a tehetőseknek kedvező, hiszen az ingatlanok értéke nő, javul az infrastruktúra, azonban a gyakran százezres költségek meghaladják a helyiek képességeit. Sokszor már a téma felvetésére is heves ellenséges reakciókat kaptam a válaszadóktól, hiszen ök képtelenek lennének az átsorolást megfizetni (Domaszék-Zártkert, Győr-Banai úti kertek, Kertváros, Sándorfalva-Kővágó dűlő, Zalaegerszeg-Becsali út).

A szegregáció fokozódását tovább segíti, hogy a szuburbanizációs lakhelyválasztásban magas a személyes kapcsolatok szerepe, azaz egy ismerős ajánlása (12\%). Ezért egy utcába, vagy utcaszakaszra hasonló státuszú lakók költöznek be, akik zárt téralkotó csoportot alkotnak a külterületeken. Az első kitelepülő jó hírnevét viszi a tájnak és kollégáik, ismerőseik költöznek később oda, ennek megfelelően voltak tanárok, orvosok és rendőrök által dominált külterületi részek. Fokozza a jelenséget, ha a házak csoportokba rendeződnek, mert erősebb az elkülönülés (Győr-Kertváros, Vámosszabadi-Zártkert), Győrzámoly-Solinka dűlőn pedig kizárólag rendvédelmi alkalmazottak élnek az egykori rendörüdülö teljesen körbe épült tavánál.

Alapvetö probléma a külterületek vizsgálatában, hogy nem egyértelmü, hogy egy külterület lakossága mely településhez vonzódik, hiszen sok külterület nem ahhoz a községhez tartozik közigazgatásilag, amelynek központi belterületéhez legközelebb fekszik. Egy külterület lakossága számára a napi rutinban az ,anyatelepülés”, ahol az alapszolgáltatásokat igénybe veszik, ez lehet olyan szomszédos község, amelyhez jobb a közlekedési lehetőségek állnak rendelkezésre, vagy ahol a szolgáltatások könnyebben elérhetőek, mint azon a teleülésen, amely közigazgatási határán belül fekszik lakóhelyük. Empirikus vizsgálatom során Bőrcs-Börcs Szőlőhegy és RétalapBalogh tag esetében egyértelmüen a szomszédos település (Abda és Bőny) volt a vonzásközpont, sok külterület esetében viszont vegyes a kép, az egyes ember napi útvonalaitól is függhet a kapcsolódás (Abda: a). Többek között Böny-Páskum, Domaszék-Zöldfás és a közben egyéb belterületté nyilvánított Győrszemere-Nagyszentpál esetében az idősebbek még inkább a falut tekintették a központnak, míg a 40 év alattiak számára kizárólagos a város szerepe.

Nincs országos vizsgáltból származó eredmény arról, hogy az egyes külterületek más településekhez hogyan kapcsolódnak (TIMÁR J. 1990). Ez az empirikus eredmények alapján súlyos hiány, amelynek orvoslása jelentősen csökkenthetné a külterületen élők nehézségeit. Továbbá az önkormányzatok több esetben tapasztalható külterületeikkel szembeni érdektelenségét is magyarázza az, hogy a külterület annyira egy másik településhez vonzódik, így nem alakult ki szerves kapcsolódás a közigazgatási központtal. Még gyakoribb, hogy a föutak 
mentén fekvő külterületekről nagyon könnyü a városba bejárni és mivel a többség a városba ingázik, egyszerüen kiesik napi térpályáikból a falu, amelyhez tartozik a lakott hely.

Összegezve megállapíthatjuk, hogy a szuburbanizáció során a szegregáció meglehetően eltérően alakul a különböző léptékeket vizsgálva. Mikroszinten, az egyes külterületeken belül csökkent a területi szegregáció, mert az új lakók eleinte heterogén módon, az éppen eladóvá vált, vagy megfelelő áru ingatlanba költöztek be. Ezzel párhuzamosan jelentős konfliktusok alakultak ki a helyiek és a beköltözők között, amit erősített, hogy a beköltöző jobb szocio-ökönómiai státuszú háztartások és vállalatok jobb érdekérvényesítő képessége miatt azok saját elképzeléseikhez kezdték igazítani a közösséget, valamint a telekárak emelkedése révén megindult a helyi fiatalok kiszorulása a lakáspiacról.

Az egyes külterületek közti különbségek ellenben jelentősen növekednek. Míg a városok peremén és a falvak jól elérhető területein fekvő zártkertek, periurbán utcák, szőlőhegyek és sürübb tanyabokrok jellemzően a városból kiköltöző középosztályt és kiszoruló alsóközéposztályt vonzzák. A rosszul elérhető tanyás területek, a majorok, a városi centrumból nehezen elérhető szőlőhegyek és kiskertek pedig a városból kiszoruló és a vidékről beáramló elesetteken kívül a cigányság számára nyújtottak olcsó lakhelyet. Sok esetben ez meglehetösen homogén és elzárkózó csoportokat hozhatott létre.

$\mathrm{Az}$ egyes külterületeken belül kialakuló mikro szintű megoszlások, infrastrukturális átalakulások, és szegregációs folyamatok, valamint az ebből fakadó konfliktusok megfelelő mélységben nem vizsgálhatóak csak a kérdőívek és terepbejárás statisztikai adatai alapján. A következő fejezetben esettanulmányokon keresztül kívánom bemutatni a különböző külterülettípusok sajátosságait, mivel az általános képet árnyalja a helyi adottságokkal való összevetés.

\subsection{A különböző típusú külterületek sajátosságai a szuburbanizációban}

A külterületek 3. fejezetben bemutatott adottságainak, a terepi munka során felmért infrastrukturális kiépítettségük, ingatlanállományuk, valamint az 5.3. fejezetben bemutatott lakossági elvárások és költözési motivációk összevetése (9. táblázat) alapján a jelen kor igényeit jobban kielégítő telekszerkezetünek tekinthető, zártabb településképü, jobb ellátású területek nőttek leginkább. Sajátos vonzerök révén az egyéb típusokba tartozó lakott helyek is növekedhettek, ha az elérhetőség és az épületállomány hiányosságait a közösség ellensúlyozta.

A külterület-típusok dinamikája a hazai vidéki agglomerációkban és településegyüttesekben hasonlóan alakul, mint az országos átlag, azonban a változások mértéke némileg pozitívabb. A tanyák és ipari lakóhelyek kis mértékben tudták növelni népességüket a városok környezetében az általános csökkenés ellenére (9. ábra). Az üdülők és szociális intézmények népességnövekedése azonban jelentősen lehagyja az országos tendenciákat ebben azonban meghatározó az új egységek kialakulása, illetve bekerülése a helységnévtár által követett lakott helyek közé. Jelentős eltérést találunk azonban a cigánytelepek alakulásában, hiszen a nemzeti szinten mért csökkenés ellenére az agglomerációk adataiban jelentős a népességbővülés. Ennek oka az észak-kelet- magyarországi városaink (különösen Miskolc) vonzáskörzeteinek sajátosságaiban keresendö.

A fentieknek megfelelően megállapíthatjuk, hogy a külterületek adottságai alapvetően nem csak a szuburbanizáció által érintett zónákban, de országosan is hasonlóan vonzónak vagy taszítóak a népesség számára. Ezen túlmenően kiemelendő, hogy az országosan növekményt mutató külterület variánsok növekedése döntően az agglomerációkban valósult meg, így a szuburbanizáció hatása meghatározza a tendenciákat.

A sikeres és sikertelen, avagy megújuló és leromló külterületek elkülönítése nem egyértelmű, még a népességszám változás, valamint az infrastruktúra mennyiségi és minőségi jellemzőinek alakulását ismerve sem. A megújuló infrastruktúrájú, de teljesen elnéptelenedő GyőrSomosmajorban a lakófunkciót teljesen kiszorítja a logisztikai cégek betelepülése és iparteleppé silányul. A rossz állapotú, leélt épületekkel rendelkező majorok példája Győr-Újmajor, ugyanakkor ezek a hanyatló állagú, de olcsó és az ipari területekhez közeli lakásai az elesett 
családok újrakezdését segítik. Számtalan terület térszerkezete pedig teljesen átformálódik, (GyőrSashegy, Domaszék-Ábrahám) eredeti épületeiknek hanyatlását funkcióváltás (zártkertesedés, üdülöteleppé alakulás) követi és jellemző a teljes lakosságcsere.

9. táblázat: a külterületek adottságainak összehasonlítása a beköltözők véleményeinek tükrében.

\begin{tabular}{|c|c|c|c|c|c|c|c|c|c|}
\hline Külterület típusa & 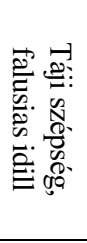 & 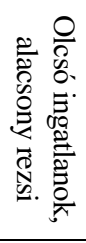 & 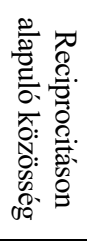 & 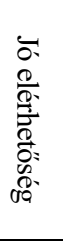 & 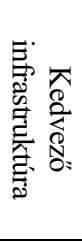 & 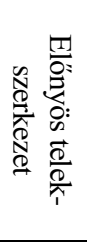 & 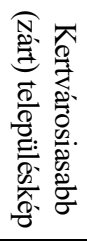 & 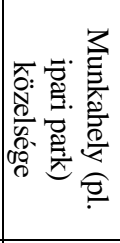 & 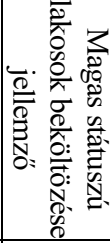 \\
\hline Szőlöhegy & ++ & + & + & & & & + & & $?$ \\
\hline Üdülő & ++ & & & + & $?$ & + & + & & + \\
\hline Major, Tsz-lakótelep & & ++ & ++ & & - & -- & - & $?$ & - \\
\hline Örházak, üzemi lakóhelyek & & + & & $?$ & & & & + & \\
\hline Ipar és bánya telep & - & ++ & + & & - & - & & & - \\
\hline Cigánytelepek & - & ++ & ++ & -- & - & & - & & -- \\
\hline
\end{tabular}

Jelmagyarázat: ++ kiemelt tényezö, + fontos tényezö, ? gyakori, de nem döntöen jellemzö, - ellentétes korreláció, - erös ellentétes korreláció, az üres cellák semleges, átlagos állapotot törköznek. Szerkesztette a szerzö.

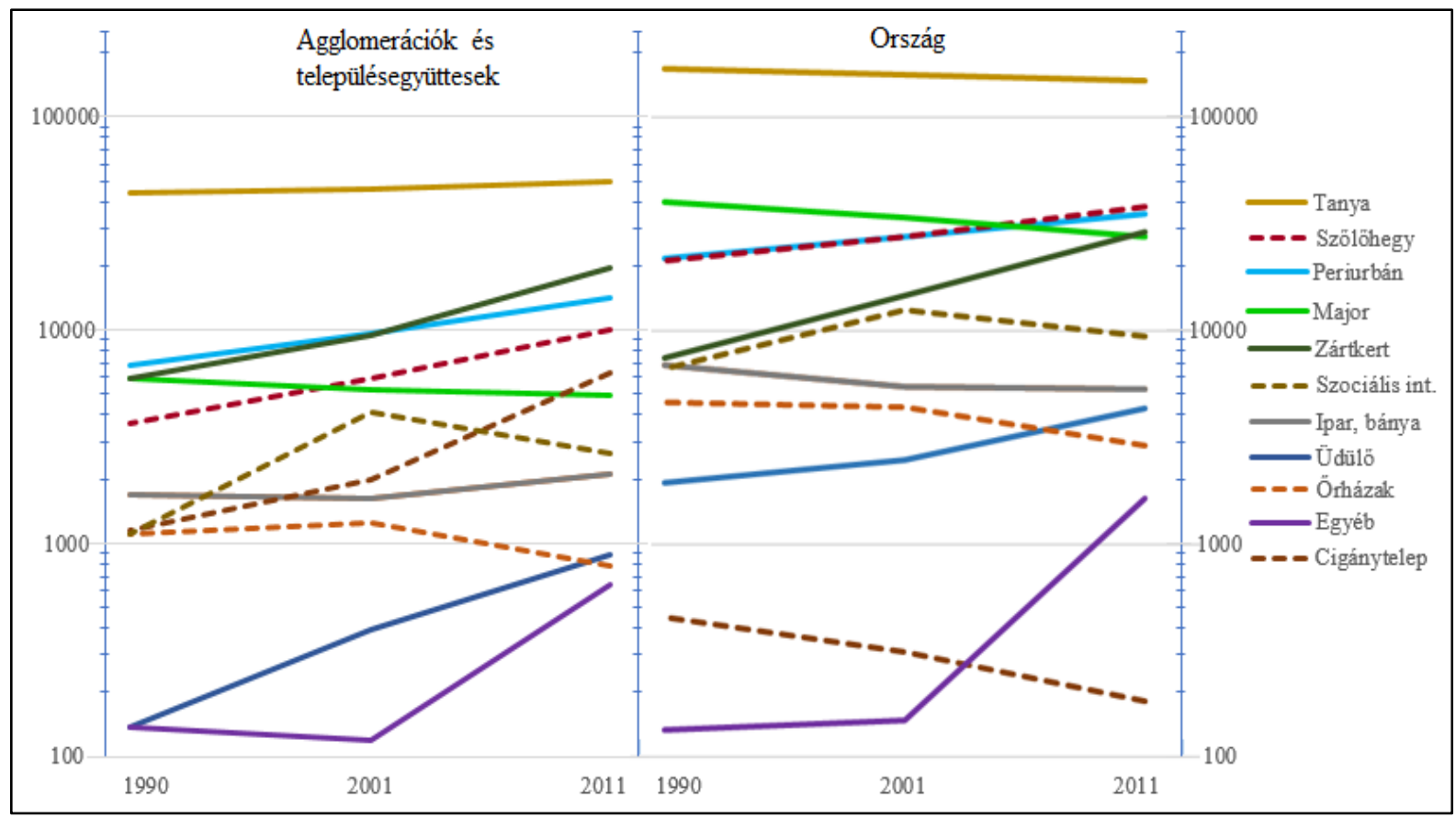

9. ábra: A külterületek típusainak dinamikája az országban, valamint az agglomerációk és településegyüttesek területén a népesség tükrében, logaritmikus skálán (Forrás: KSH Helységnévtár alapján saját számítás).

$\mathrm{Az}$ infrastruktúrájukban, funkcióikban és lakosságszámukban egy irányba változó területek könnyebben besorolhatók. Egyértelmüen sikertelennek tekinthetőek az olyan külterületek, melyek népessége csökken, vagy nulla és infrastruktúrájuk hanyatlik. Ezek jellemzőn rosszul elérhető (kivéve az őrházak), gyenge ellátottságú és elöregedett épület-állománnyal rendelkező területek. Egyértelmüen sikeresnek azon külterületek, ahol a külterületi jelleg és a településföldrajzi adottságok megmaradása mellett a népességszám is stabil vagy nő, de a fluktuáció nem elég erős ahhoz, hogy a meglévő közösséget szétzilálják a konfliktusok. 
Leginkább a szőlöhegyek és zártkertek növelték népességüket, a legtöbb szőlöhegyi és zártkerti utca ma már egymástól nem különböztethető meg, hasonló infrastrukturális jellemzőik, épületállományuk és lakossági összetételük révén (10. táblázat). A periurbán utcák esetében változatosabb a helyzet, e külterületek adottságai alapvetően megegyeznek a magtelepülés adottságaival, sajátos esetként kiemelhető Zalaegerszeg - Alsóerdei út, ahol egy társasház épült a város belterületének határán túl. Mivel ezek lényegesen nem térnek el a belső részektől, az életvitel szempontjából nem jelentkeznek külterületi sajátosságok

10. táblázat: A hazai agglomerációk és településegyüttesek külterületek típusainak főbb statisztikai jellemzői

\begin{tabular}{|c|c|c|c|c|c|}
\hline Típus & $\begin{array}{l}\text { Népesség } \\
1990 \text { (fö) }\end{array}$ & $\begin{array}{l}\text { Népesség } \\
2011 \text { (fö) }\end{array}$ & $\begin{array}{l}\text { Népességvált- } \\
\text { ozás 1990- } \\
2011 \text { (fö) }\end{array}$ & $\begin{array}{l}\text { Lakott 2011- } \\
\text { ben }(\mathrm{db})\end{array}$ & $\begin{array}{c}\text { Ideköltözök által említett leggyakoribb } \\
\text { lakóhely választási indok, a } \\
\text { mintaterületbe eső külterületeken }\end{array}$ \\
\hline Periurbán & 6897 & 14216 & 7319 & 144 & Nagyobb lakásméret \\
\hline Tanya & 43661 & 49928 & 6267 & 388 & Környezeti előnyök \\
\hline Szőlöhegy & 3675 & 10051 & 6376 & 252 & Környezeti előnyök \\
\hline Üdülö & 136 & 885 & 749 & 33 & Környezeti elönyök \\
\hline Major, Tsz-lakótelep & 5960 & 4980 & -980 & 188 & Olcsó megélhetés \\
\hline Vasút, gát & 1096 & 778 & -318 & 136 & Munka \\
\hline Ipar, bánya & 1702 & 2123 & 421 & 43 & - \\
\hline Szociális & 1113 & 2634 & 1521 & 14 & - \\
\hline Egyéb & 37 & 645 & 608 & 24 & Környezeti előnyök \\
\hline Kiskert, zártkert & 5884 & 19633 & 13749 & 76 & Környezeti előnyök \\
\hline Összesen & 72151 & 107884 & 35712 & 1298 & Környezeti előnyök \\
\hline
\end{tabular}

Csupán 9 major és TSZ-lakótelep népessége nőtt a vizsgált 34 közül, foútról mind jól elérhető és jó tömegközlekedési helyzetü (buszmegálló távolsága $1 \mathrm{~km}$ alatt). Ezek jellemzően az elesettek, hátrányos helyzetüek és idősek számára vonzóak olcsó ingatlanaik, a mezőgazdasági munka reménye és a viszonylag erős közösségek miatt. Az egyes őrházak, útőrházak alakulása esetleges, jellegükből adódóan az általuk kiszolgált infrastruktúra meglététől függenek

Sajátos külterülettípusként jellemezhető az elzárt új szórványház; olyan magányos településforma, melyek legfeljebb néhány tanyaházból, vagy valamilyen nagyobb külterület peremén épült ingatlanból áll. Az ,egy lakásos külterületi lakópark”-ban - ahogy egy válaszadó találóan nevezte öket - az ingatlanhoz nagy földterület tartozik, melyet gyakran nem csak közvetlenül kerítenek el, hanem az erős elzárkózási szándék miatt sokszor elektromos kerítést és kamerarendszert építenek ki és már több száz méterrel az ingatlan előtt a bevezető utat is elzárják. Gyakori, hogy az ingatlan és környezetének kiépítése luxusjellegü, de nem ritka az sem, hogy régi vadászházak vagy tanyák kerülnek átalakításra. Az elzárkózási szándék oly erős az itt lakóknál, hogy egyetlen kérdőívet sem sikerült felvenni nagy számuk ellenére.

A külterületek közötti hasonlóságok és különbségek bemutatása a nagymennyiségü empirikus tapasztalaton keresztül szétfeszítené a dolgozat kereteit. Ezért a továbbiakban négy kiválasztott esettanulmányon keresztül kívánom bemutatni a szuburbanizáció településföldrajzi hatásait, valamint társadalmi-környezeti következményeit. A mintaterületek kiválasztásakor a terepbejárás tapasztalatain és az interjúk eredményein túl a kérdőívezés során feltárt tulajdonságok alapján igyekeztem kiválasztani azon területi egységeket, amelyek a lehetö legjobban képesek voltak reprezentálni a külterületek településrészi szintű sajátosságait. A szőlőhegyek és periurbán utcák átalakulását Győr Dél-keleti peremének külterületein, a zártkertek fejlődését Hódmezővásárhely Kishomokon, a majorok és külterületi intézmények adottságait Töltéstava-Táplánypusztán, valamint a tanyás területek folyamatait Domaszék-Zöldfás példáján keresztül tárom fel. $\mathrm{E}$ külterületeket az empirikus mintavétel eredményei alapján választottam ki, mivel adottságaik és a szuburbanizáció során megjelenő részfolyamatok révén képesek a külterületek tágabb körének jellemzésére. E területek megfeleltek a kérdőíves válaszok alapján az egyes típusokra kapott értékek átlagainak, ugyanakkor a folyamatok térbeliségének bemutatására is alkalmasak. 
A mintaterületek elemzésének célja, hogy az egyes, eddig bemutatott bővülési folyamatok, valamint konfliktusok, problémák és társadalmi változások hatásai a térben, hogy koncentrálódnak az egyes külterületeken. Emellett elemzésük lehetővé teszi, hogy bemutassam az egyes lakott helyeken belül mikroszinten létrejövő területi különbségeket. További célom az esettanulmányok bemutatásával az egyedi külterületi fejlődési pályák bemutatása, amely akár közvetlenül egymás mellett lévő külterületi lakott helyek esetében is élesen különböző lehet.

Töltéstava - Táplánypuszta és környezete példáján keresztül majorsági szindróma (BALOGH A. 2015) és a slumosodás komplex jelenségét mutatom be, mivel bár jól elérhető és népessége sem kicsi mégis a jelenség minden jellegzetes ismérvét mutatja (10. ábra). Táplánypuszta, jól elérhető (82-es föút melett, rendelkezik saját buszmegállóval), 100 évnél korosabb épületeinek körülbelül a fele áll még, de a régi gazdasági épületek a szövetkezetesítés áldozatává váltak. A gazdasági hasznosításában jelentős visszaesést jelentett a sertéshizlalda 1992-es bezárása, a mezőgazdaságban foglalkoztatott lakosság jó része elvándorolt. Az nyomott áron $(10-20000 \mathrm{Ft})$ értékesített ingatlanokat a beköltöző szegény lakosság nem tudta karban tartani így megindult a hanyatlás, azonban a magántulajdonú ingatlanokat az önkormányzat sem tudja rendezni.

A lakóépületek állaga rendkívül vegyes, a fơút felőliek inkább jobb állagúak ( 5 felújított), majd befelé haladva egyre rosszabb ingatlanokat láthatunk, összesen a 37 ingatlanból 17 volt rossz és 3 lakhatatlan állagú Területén mindössze két kert volt és két üzemi telephely, valamint a csak részben elbontott egykori sertéstelep romja található, ami jelentős veszélyforrás, mivel a lakosság egy része az építőanyagok elhordásával egészíti ki bevételeit. A pusztától keletre építőipari telephely található, valamint a Pozsgai tanya nevü külterületi jól felszerelt (medence) luxusingatlan áll nagyméretü elkerített földterületen.

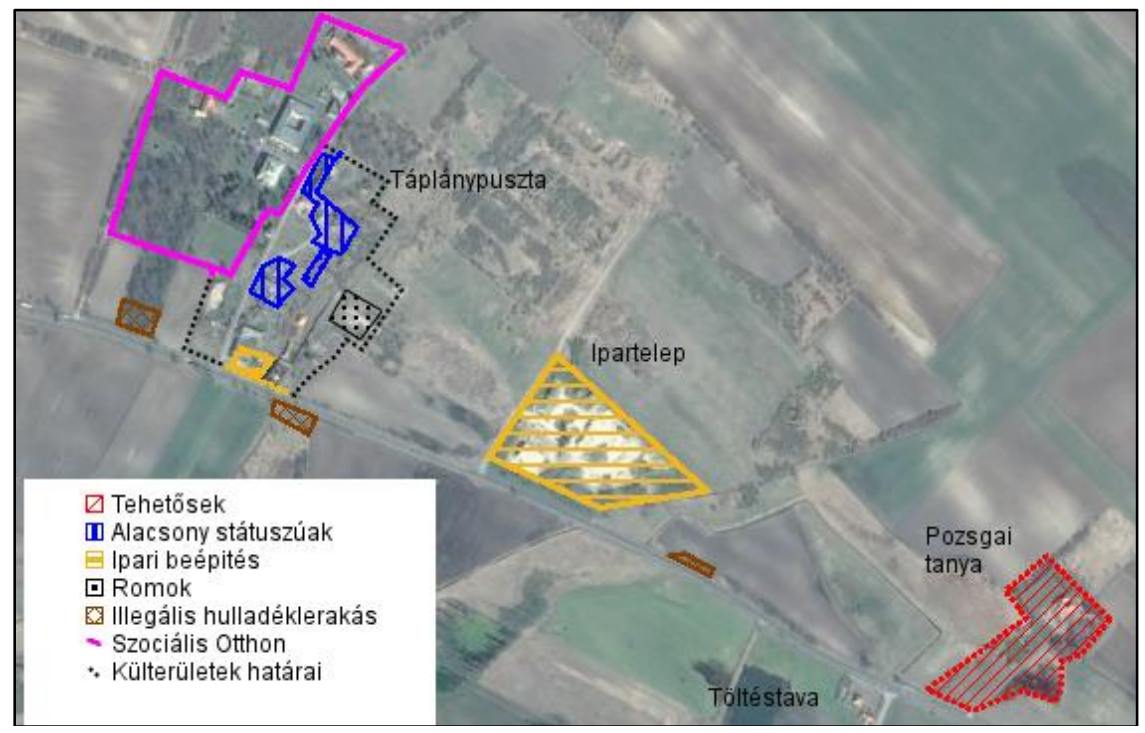

10. ábra: Táplánypuszta és környezetének területhasználta (Saját szerkesztés, alapkép forrása: Goole Earth).

A helyi közösség viszonylag erös, a lakók a rossz elérhetőség és szükös anyagi lehetőségeik miatt egymásra vannak utalva. Megindult egy elzárkózó és védekezö, a reciprocitáson és a közös depriváltság-tudaton alapuló helyi közösség kialakulása, ezért a stabilan fejlődő faluban lakókkal szinte már minden kapcsolata megszünt az itt élöknek. Magas az alkoholproblémákkal küzdők száma, a legtöbb helybéli időszakosan vagy tartósan munkanélküli. A közösség gyenge, az erős fluktuáció és egy problémás cigány család miatt, így 3 család is tervezi elhagyni a majort. Táplánypusztán a szolgáltatások hiányát az önkormányzat tulajdonában álló kisbusz segíti áthidalni, valamint a gyerekeket behordják a faluba (Töltéstava: a).

Az utcafront közelében laknak a beköltözők, míg a délkeleti peremen a cigánysort, északon pedig az idősebbek lakásait találhatjuk. A puszta mellet kiterjedt illegális szemétlerakó és számtalan romos épület jelent veszélyt. Az elmúlt évtizedben 3 tüzesetben hat lakás semmisült 
meg, ezek oka az illegális áramvételezés volt. Jó állapotú viszont a pusztán álló templom, valamint a Lévay kastély, utóbbiban müködik 1957 óta a Dr. Piróth Endre Szociális központ, ami kórházi kezelést nem igénylő pszichiátriai betegek ápoló-gondozó otthona 350 féröhellyel. A helyi lakosok szakképzettség hiányában azonban nem tudnak itt dolgozni és a településsel sem erős az intézmény kapcsolata (Töltéstava: a).

Töltéstava község kutatásom szempontjából azért is érdekes, mert az Pér három lakott külterületéből, Töltés, Táplánypuszta és Söptérpuszta majorokból vált önállóvá 1934-ben. Az önállósodáshoz vezető népességnövekmény részben a Győr közelsége miatt betelepülöknek volt köszönhetö (RECHNITZER J. et. al. 2007, VARGA B. 2003). Az 1949-ben 1011 lakosú település központja már falusias településképüre épült ki, fejlödését a háború után a TSZ növekedése biztosította, ugyanakkor Söptér és Táplány fejlesztését nemkívánatosnak minősítette a hatóság ezért ezek leromlása megindult. 1990 után az autópálya közelsége révén gazdaságilag is szuburbanizálódó faluvá vált, kialakult a helyi foglalkoztatás így a településen alacsony a Győrbe ingázók aránya, ugyanakkor a falu újonnan kialakított utcái révén jelentős $(21 \%)$ népességnövekményt ért el. A terepbejárás során a település délkeleti peremén a Helységnévtár lakott külterületei között még nem szereplő szőlős müvelésü területen két lakó (egy idős hölgy és lánya) élt, azaz új külterület vált lakottá 2011 óta itt.

E terület alapján bepillantást kaphatunk arra, hogy a majorokban milyen zárt, de a saját életét sikeresen megszervezö közösség tud kialakulni, amelynek azonban alig van kapcsolta a magtelepüléssel és a helyi intézményekkel, iparral. Látható, hogy a külterületek és a belterület fejlődési pályái egymástól lényegileg eltérhetnek, hanyatló, növekvő népességü de elszegényedő külterület mellett tehetősek által felújított egység és zöldmezős beruházásokkal jelentősen bővülö, a gazdasági szuburbanizációt is vonzó falu lehet.

Győrszentiván délkeleti peremének összekapcsolódó külterületein keresztül a szuburbanizációs folyamatok különböző hatásainak vegyes jellegü és szőlöhegyes külterületekre jellemző formái (Külső Vasút sor, Nagyhegy, Szarkavár, Wittman-tag) jól összegezhetőek. A vasútállomás és a helyi városi buszmegálló közelsége miatt nagyszámban költöztek ki a területekre a városból a jellemzően a közeli ipari parkban foglalkoztatott szakképzett, jó keresetü dolgozók. A Nagyhegy vasút közeli részén 2007-ig felújították az úttestet, a közvilágítást és kiépült a csatorna. Ugyanakkor a legtöbb szabad telek beépült, elveszett a korábbi szőlős jelleg, és már a beköltözők is élesen ellenzik (61\%), hogy további családok telepedjenek itt le.

A szőlőhegy közepe zártkertesedő, ritkábban lakott terület. Vegyesen találunk itt tehetős és hátrányos helyzetü csoportokat. Itt fennmaradt a hagyományos szőlős-gyümölcsös kultúra és sok több, mint 100 éves vincellérlak került felújítása, de számtalan - hétvégi háznak készült - komfort nélküli épületben is laknak. Az út végén és a földutas Szarkavárban csoportosulnak az idősek, valamint az elesett és halmozottan hátrányos helyzetü lakosok (11. ábra). Rossz állagú egykori hétvégi házakban laknak, itt már az utak alig járhatóak, mellettük illegális szemétlerakás zajlik, közvilágítás nincs vagy hiányos, és részben emiatt állandóak a betörések. Az utcát hipotetikusan felharmadolva azt kapjuk, hogy az első szakaszban $60 \%$ feletti az új és átlagos állapotú házak aránya, míg az utolsó szakaszban ugyanekkora a rossz állagúaké. A kertek müveletlenek, hiszen a $3 \mathrm{~km}$-re megálló buszok miatt - mint az gyakori a szuburbiákban - a városba való ingázás elveszi azt az időt, amit a kertmüvelésre tudnának szánni, pedig ideköltözésük fő oka pont a kertmüvelésből származó szerény jövedelem-kiegészítés vágya volt.

A Szarkavár nevü szőlöhegy földútja az év egy részében (őszi és tavaszi esők, enyhe téli napok) személygépkocsival alig átjárható. A közepén lévő egykori major eredeti épületei már nem találhatóak meg, a hetvenes évekig épült téglaépületek, valamit újabb baromfi ólak jellemzik, jelenleg sertéshízlalás zajlik itt, amely jelentős konfliktusforrás a folyóalmos tartás szagterhelése miatt. Az út első harmadánál készült zsákutcában hat új ingatlan már a szuburbanizáció eredménye, azonban 2007 után már nem épültek újabb házak. E terület a Helységnévtár adatai szerint lakatlan, azonban a kérdőívezés időpontjában legalább 13 fó élt régóta ott, jelezve a statisztikák már többször említett eltérését a valóságtól. 


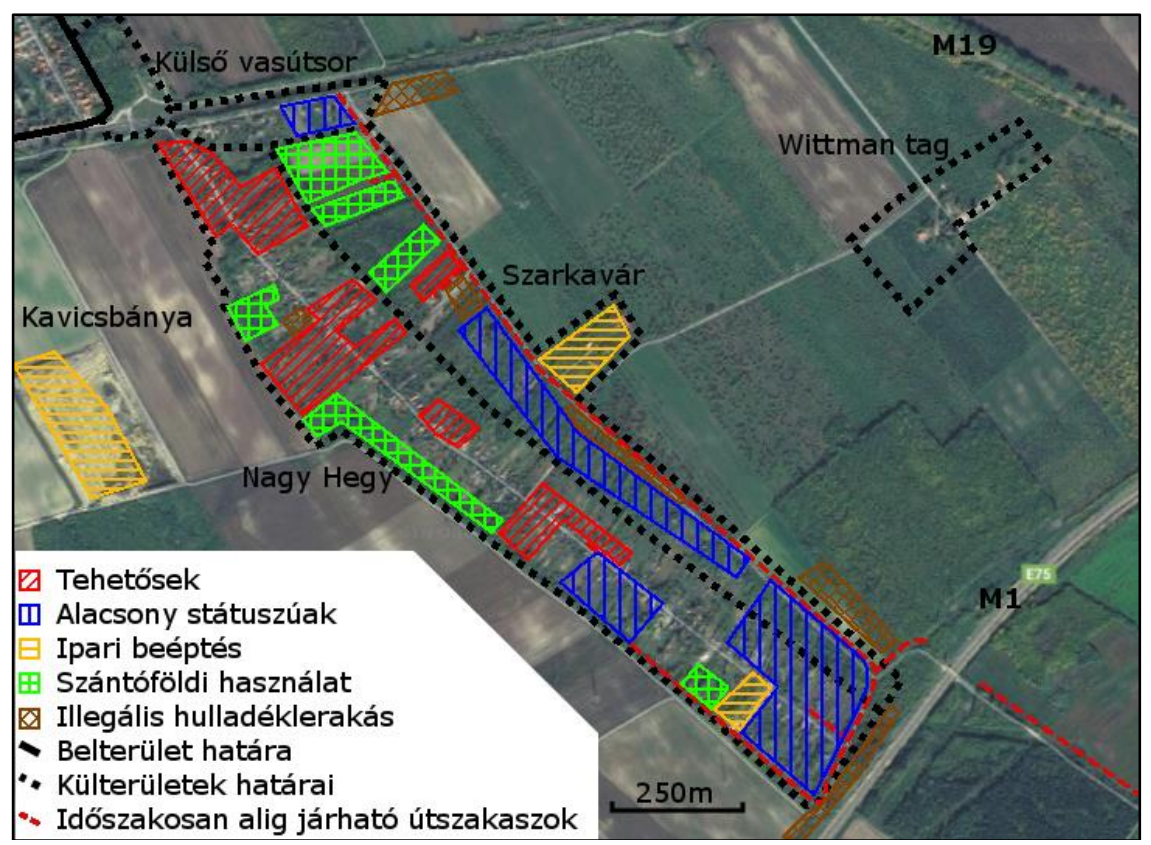

11. ábra: Győr dél-keleti külterületeinek területhasználati változásai (Saját szerkesztés, alapkép forrása: Goole Earth).

A Külső Vasút sor klasszikus periurbán külterület, teljesen kiépült az infrastruktúra és a településképe teljesen egyezik a belterületi Vasút sorral, az itt válaszolók mindegyike úgy vélte a kérdőívezéskor, hogy belterületen lakik. Jelentős konfliktusként a vasúti zajterhelés és az átmenő traktorforgalom mondható. Utóbbi a közeli Wittman-tagra irányul, e volt major jelenleg több gyümölcsöt termelö vállalat központja és telephelye, egyben 1 fö alkalmazott szolgálati lakása. Az erdő kétoldalt illegális hulladéklerakás és állandó falopás területe, amely a városperemeken általános. Itt halad át a Nagyhegy utca végétöl Bőny külterületei felé a 6. számú EuroVelo kerékpár fóút, mely a rossz úttest után egy biciklis közlekedésre alig alkalmas puha homokosföldes útra vezet. Ebben az elmúlt 3 évben több szakaszban végzett útfelújítás sokat segített, amely egyben a Bőny irányában lévő külterületeket is sikeresen bekapcsolták a helyi életbe, sokban javítva a helyi közösség müködését, amit az évente megrendezett szőlöünnepségen részvevők számának folyamatos növekedése is mutat.

Mindössze 300 m-es távolságokban is rendkívül nagy a differencia a lakosság státuszában és az épített környezet minőségében a bemutatott területen. Ez erőteljes polarizációt okoz, ami miatt alig beszélhetünk közösségről, így sem a tehetős beköltözők, sem a városból kiszorulók, sem a helybeli származásúak nem részesülhetnek a szuburbanizáció lehetséges pozitívumaiból. Mivel a fö vonzerőt a külterületeken a jó elérhetőség mellett a rurális településkép jelenti a további urbanizálódás ellentétes a kiköltöző és a helyi lakók elvárásaival, idővel a betelepülők még a helyieknél is jobban ellenzik a további népességnövekedést. Ugyanakkor a rengeteg felhagyott, gazos telek is nagymértékben zavaró, különösen a többszöri aljnövényzet-tüzek után.

Összegezve e terület alapján megállapítható, hogy az ilyen megújuló területeken is teljesen vegyesen jelennek meg kis távolságban a legszegényebb és legtehetősebb beköltözők ingatlanai, miközben a hagyományos településkép erodálódik. Ez nem csak a napi életet nehezíti meg az itt élők számára, de az önkormányzat fejlesztési terveinek kialakításában is akadály (Győr, b). Az ipari és mezőgazdasági funkciónak is előnyösek a lakossági szuburbanizáció számára vonzó, jól elérhető külterületek, amely tovább bonyolítja a térszerkezet alakulását, hiszen miközben a terület egy részén a kerteket beszántják és lerombolják az üdülőket, addig az utca más részeire folyamatosan áramlik be a lakosság és épülnek a házak. Sikeres példa a fejlesztésekre, hogy az úttest szélesítése és részleges újrabetonozás révén jelentősen nőtt a lakosság elégedettsége. 
Belső-Kishomok Hódmezővásárhely nyugati peremén, a Szeged irányába tartó fơút és vasút mellett, helyközi buszmegállóval, kerékpárúttal és vasútállomással rendelkezö, betonozott úthálózatú, kedvező adottságú zártkerti terület az egykori tanyás terület helyén (12. ábra) alakult ki. Utcahálózatát a tanyás időből örökölt széles utak és az utólag kiépített szükös zártkerti jellegü tömbök kettősége határozza meg, így ideális a tanyasi eredetü, zártkertesedett térségek leírására.

A beáramlók kettőssége hasonló a győri mintaterületnél bemutatottakhoz, azonban e terület két város vonzáskörzetébe is beleesik. Hódmezővásárhelyről a középosztály kertek iránt vonzódó tajgai költöztek ki leginkább, míg Szegedről a visszavonuló időskorúak. A szegényebb, városból kiszoruló háztartások ugyanakkor térben kevésbé váltak el az előbbi két csoporttól. A zártkerületekre jellemző utcahálózatban a beköltözés randomizált jellegü, az aktuálisan megüresedő telkekre történik.

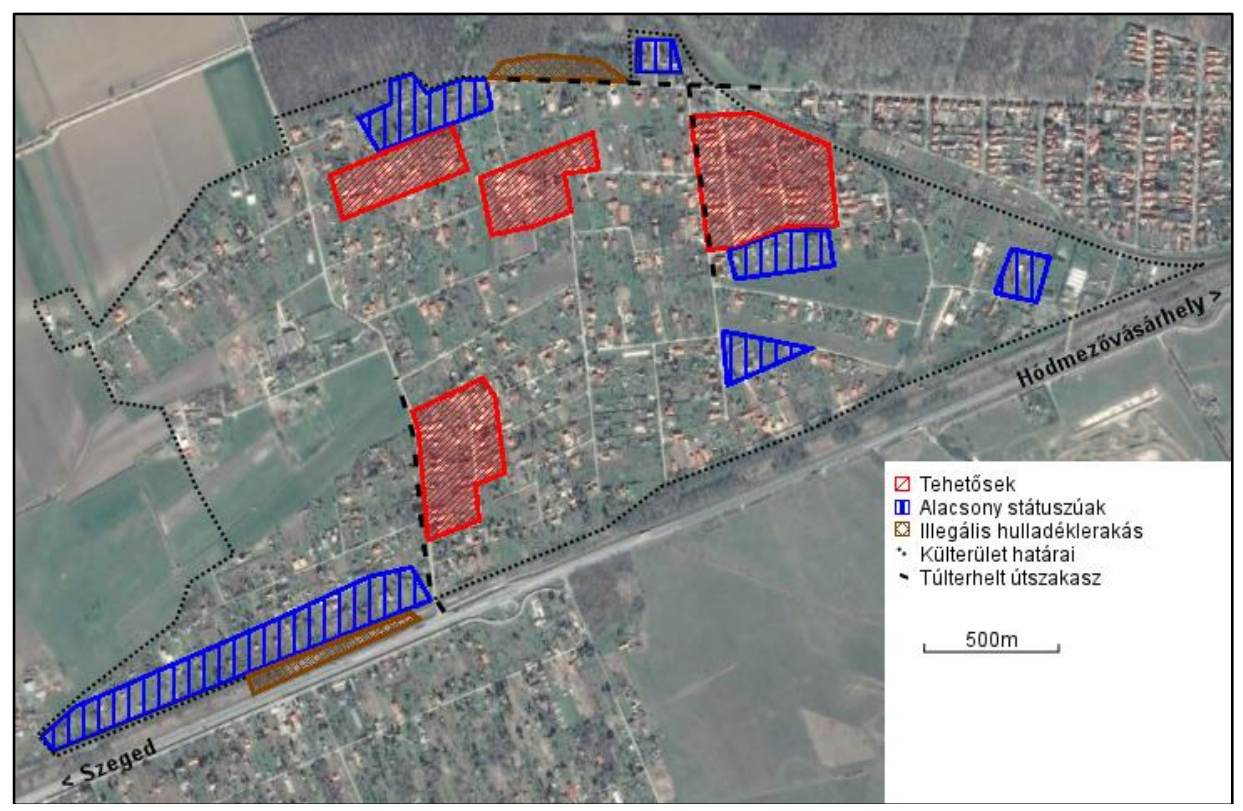

12. ábra: Belső Kishomok területhasználati változásai (Saját szerkesztés, alapkép forrása: Goole Earth).

E mintaterületen a tehetősek jellemzően a terület középső, nagyobb méretü telkekkel rendelkező részére költöznek, míg a legkevésbé tehetősek a vasúthoz legközelebbi és a terület dél-nyugati peremén lévő rosszabb telekszerkezetü részeire áramlottak be. A többi területegységen a heterogén elhelyezkedés nem problémamentes, a szerény téliesített, korábban gazdasági épületnek készült ingatlanban szorongók telkei mellett több száz négyzetméteres luxusingatlanokat találunk. Mint az egyik helyi interjúalany megfogalmazta, az építési szabályozás gyakori változtatása és a változásokkal járó „rendszeres amnesztia révén e rendkivül ellentmondásos településkép még jogszerü is" (Hódmezővásárhely: a). Jelentős gond a két bevezető út szük keresztmetszete is, amit a válaszadók is kiemeltek.

A zártkeretekben jellemző, hogy egy-egy csoport egy utcában felülreprezentált, mivel a korai beköltözők ismerősi körükben jó hírét viszik a területnek. Ennek megfelelően északi peremén építöipari munkások, közepén pedig korábbi hódtói lakosok élnek. Utóbbi csoport bár társadalmilag diverz, de egymáshoz közeli panellakásokban éltek. Paradox módon azokon a külterületeken, ahol a beköltözők legtehetösebb és legelesettebb csoportjai heterogén módon helyezkednek el (Kishomok), ott nagyobb arányban jelezték $(36,1 \%)$ a lakók életmódjaival kapcsolatos konfliktusokat, mint azokon a területeken, ahol klaszteres jellegü mintázat szerint települtek be (Nagyhegy). Ennek oka többek között az lehet, hogy az egymáshoz közel élő tehetősebbeknek kevesebb interakciója van az eltérő életvitelü helyiekkel, így kisebb a konfliktusok kialakulásának az esélye (Szeged: d).

E külterület 2013 közepe óta egyéb belterületté lett nyilvánítva. A belterületbe vonás a tehetőseknek kedvező, hiszen az ingatlanok értéke nő, javul az infrastruktúra, azonban a gyakran 
százezres költségek meghaladják a helyiek képességeit. A változás a válaszadók véleménye alapján nem változtatta meg jelentősen az életvitelt, azonban jelentős anyagi terheléssel járt a mủvelésből kivonás, majd a csatornázás és szemétszállítás költségessége. A fejlesztési ellentétekre kiváló példa a csatornázás. Az eredeti lakosság, valamint a városból kiszorulók számára a külterületek az olcsó életvitel miatt vonzóak, megélhetési stratégiájuk központi eleme a költségek minimalizálása. Hódmezővásárhely-Kishomokon a kiszorultak számára rendkívül nagy érvágás a 70000 Ft-os kötelező hozzájárulás a csatornázásra, valamint a belterületbe vonás után fizetendő ingatlanadó. Emiatt sok válaszadó úgy gondolja, kénytelen lesz elköltözni, ez a vélemény gyakori Szeged-Marostő és Bőny-Szőlőhegy esetében is.

Sokszor már a téma felvetésére is heves ellenséges reakciókat kaptunk a válaszadóktól Kishomokon kívül is, hiszen többségük képtelen lenne helyben maradni ilyen átsorolás esetén (Domaszék-Zártkert, Győr-Banai úti kertek, Kertváros, Sándorfalva-Kővágó dülő, Vámosszabadi-Zártkert, Zalaegerszeg-Becsali út, Luka). A bemutatottak alapján láthatjuk azt a tipikus esetet, miszerint a külterületeken kialakuló csoportok (beköltöző tehetősek, valamint a városból kiszorulók és helyiek) közötti ellentétek miatt a lakosság még a fejlesztésekkel szemben is gyakran ellenkezik, mert valamelyik csoport mindig félteni fogja sajátos érdekeit. Ez azzal a sajátos helyzettel jár, hogy a jó irányú beavatkozások is gyakran ellenállásba ütköznek.

Domaszék-Zöldfás a Szeged és Domaszék közötti tanyás terület a megyeszékhely egykori tanyavilágában kialakult tanyaközpont-kezdemény volt, ahol templom és iskola létesült már a világháború előtt. 1947 után ideológiai alapon (például 1988-ig a faluközpontban nem volt templom) a területtől nyugatra jelölték ki a kiépítendö faluközpontot így Zöldfás és környéke külterület maradt (BÁLINT I. 2001).

A terület már ekkor három részre szakadt a fejlődés menetét illetően. A kialakuló faluhoz közelebbi Ábrahám nevü homokos területen zártkertet jelöltek ki, a Zöldfás jó fekvése miatt a két háború között több részen tanyautcává sürüsödött. Mivel a TSZ számára bedolgozó munkát végeztek az itt lakók, a hatvanas évektől a hatósági eljárások megengedőbbek voltak az országos tendenciáknál. A távolabbi részeken így is megindult a hanyatlás a tanyaépítési tilalom miatt, különösen a bajai fóúttól délre fekvő, rossz állapotú dülőutakon elérhető egymástól is nagy távolságban szétszórt tanyákat jellemzi az elnéptelenedés. Az 1945 utáni eredeti tanyás épületállomány közel egyharmada maradt meg, a jelenlegi ingatlanállományban az 1970-1990 között zajló hobbikert kialakítás, majd az 1990 utáni építési hullám mérvadó.

1990 után a városból kiköltözők felfedezték a zártkertet és a tanyavilágot, megindult a lassú kiáramlás, valamint több kisebb vállalkozás telephelye jelent meg a területen. Az autópálya építése után az attól keletre került tanyák periférikus helyzete mélyült, míg az útfelújítások révén a faluhoz közelebbi területeken jelentősen nőni kezdett a népesség. A bajai foúttól délre fekvő hagyományos tanyás területen (13. ábra) csak a fóút mentén épülnek új házak és telephelyek, jelentős kontrasztot alkotva az elöregedett helyi lakosság 50-100 éves tanyaházaival.

A zártkerti formát, zárt településképet mutató Ábrahámi terület belső, falu-felőli oldalán a lakóingatlanok dominálnak, míg déli területén még a hobbikertek és üdülök jellemzőek. Zöldfás tanyautcás részén és a buszmegállók közelében számos új ingatlan épült, köztük több nagy alapterületü amerikai stílusú gipszkarton-technológiás ház is. A föutaktól távolodva fokozatosan romlik az épületek állaga, $1 \mathrm{~km}$ távolságtól jellemzően csak helyi születésü idősek tanyáit, városból kiszorult cigányok leépült házait találjuk, mezőgazdasági telephelyeket ritkán $(4 \mathrm{db})$. A legrosszabb ingatlanok az időszakosan átjárhatatlan útszakaszok és a belvizes területek közelében sürüsödnek, a legújabb épületek pedig a buszmegállók körzetében lévő közlekedési csomópontokban. A köztes területekben heterogén képet kapunk az épületek és a bennük élők státuszát illetően a tanyánként eltérő infrastrukturális állapot és elérhetőség alapján.

Az elesettek és szép korúak rászorulnak a tanyagondnoki szolgálatra, nem képesek egyedül megoldani az utazásokat, boltba, orvoshoz, esetenként a gyerekeket a szolgálatnak kell elvinni iskolába, sokszor segíteni kell a fütés és kisebb karbantartások megoldásában. Egyúttal a tanyagondnokok és az önkormányzati szociális ellátó intézmények teremtik meg a kapcsolatot a 
szórványban elzártan élők és a közösség között. Ezért minél inkább szórvány jellegü a terület térstruktúrája, annál fontosabb az önkormányzat tevékenysége (Domaszék, b).

E terület jól szemlélteti az alföldi városok peremén található tanyás területek átalakulását. A közlekedés jelentősége kiemelkedő a tanyák szelektív megújulásában, ugyanakkor csak kevesen költöznek ide mezőgazdasági munkák céljából, az legfeljebb kiegészítő kereset. A zártabb, zártkertiesebb településképű egységek vonzóbbak a beköltözők számára, leginkább az ilyen egységekre általánosan jellemző jobb infrastruktúra és szorosabb kapcsolati háló miatt. Ezzel ellentétben a szórt tanyákon a rossz közlekedés miatt sokszor egyfajta csapdahelyzetet jelentenek az idősek és alacsony keresetüek számára, ezért a tanyavilág társadalmának müködéséhez elengedhetetlen a tanyagondnoki szolgálat müködése, és a tanyacsoportosulásokban, központokban társadalmi kohéziót erősítő programok szervezése. Erre jó példa Domaszék esetében a tanyasiakat is bevonó ifjúsági önkormányzat.

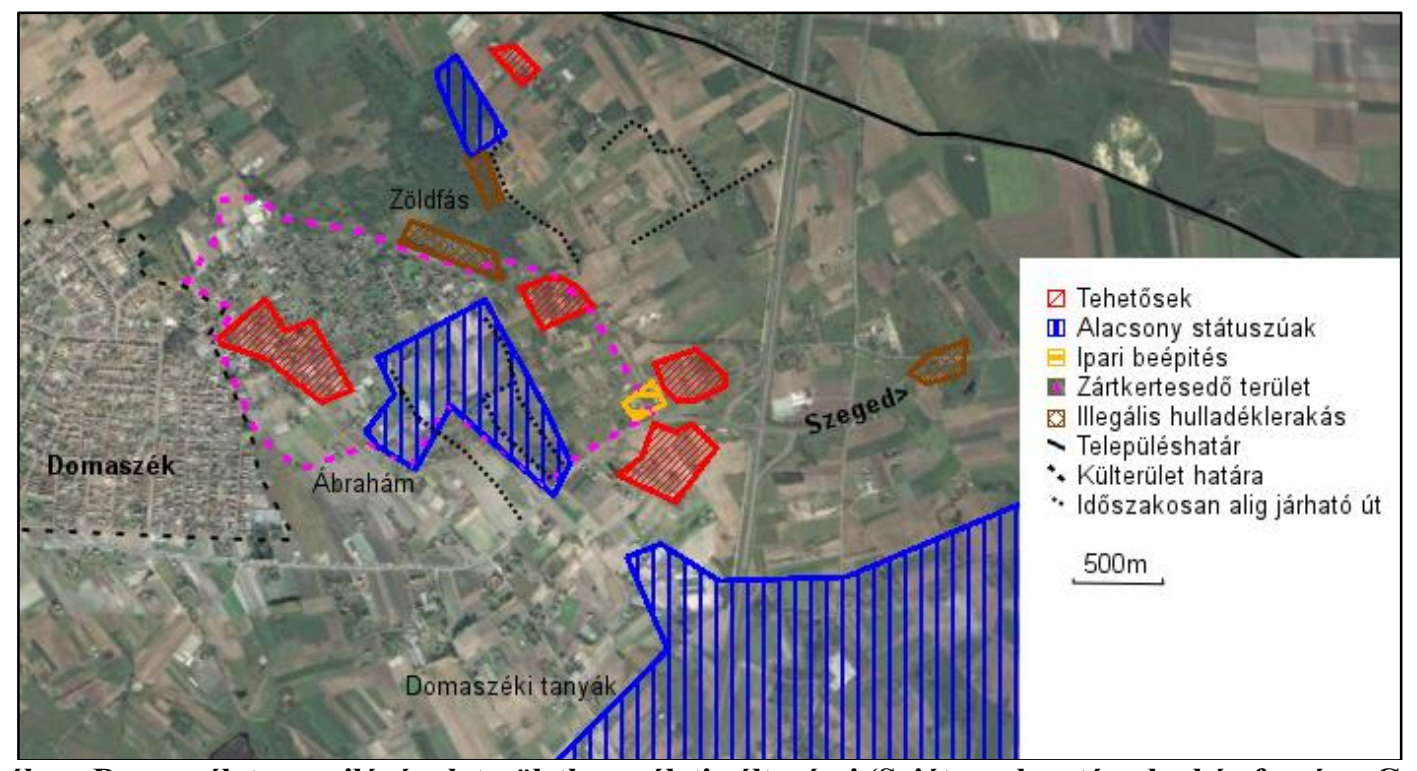

13. ábra: Domaszék tanyavilágának területhasználati változásai (Saját szerkesztés, alapkép forrása: Goole Earth).

Összegezve megállapíthatjuk, hogy a külterületi szuburbanizáció megfelel a poszt-szocialista államok jellemző folyamatainak, azonban annak a hazai településállományra adaptált formában. A városból kiszorulók és az átlagos keresetüek a szuburbiák külső, kevésbé felkapott és drága részeire áramlottak a kelet-közép-európai városok esetében. Az általam vizsgált külterületek és azokból létrehozott egyéb belterületek szintén ezt a szerepet töltötték be a vizsgált időszakban, de a várostól való relatív távolságot itt nem a földrajzi távolság adja meg, hanem a lakott helyek fejlettségi (városiasodottsági) hierarchiájában történő vertikális elmozdulás. A város közigazgatási határa mentén elterülő külterület így értelmezhető egyfajta rurális zárványként, amelynek településföldrajzi adottságai megfeleltethetőek a város-vidék peremzónában a várostól valamilyen távolságban megtalálható falu központi belterületének.

A vizsgált külterületek egyharmada tudta növelni népességét a szuburbanizációs folyamat során. Az egyes lakott helyek differenciáltan viselkedtek 1990 után, amiben döntő az infrastrukturális állapot, az elérhetőség, a külterület tipológiájából fakadó térszerkezet (szórványjelleg vagy zárt utcakép), az ingatlanállomány (müemlékek, cselédlakások, tanyaházak) összetétele, valamint a táji szépség. Népességvonzó erejüket növeli a telekárak és megélhetési költségek relatív alacsony szintje, különösen, ha bizonyos presztízs biztosítását a táji adottságok lehetővé tetszik.

A legnagyobb jelentősége a zártkerteknek van a szuburbanizációban, nem csak ezek vonzották a legtöbb lakost, de az egyéb típusokba tartozó dinamikus lakott helyek többsége is mára (legalább részben) kertségi településképet vett fel. E területek sikerességének fö oka, hogy amellett, hogy részben kielégítik a városból kiköltözők vidéki idill iránti igényét, elég olcsók ahhoz, hogy a 
városból kiszorulók és a vidékről érkezők számára is megtelepedési esélyt nyújtsanak. E területek ingatlanállománya, telekszerkezete és úthálózata bár kedvezőtlen, ezt telekrendezéssel vagy épp illegális, vagy „szürke” építkezéssel át tudták hidalni a háztartások, ráadásul a lakosság lélekszáma is elég, hogy akár közösségi kezdeményezésként részt vegyenek az út felújításában.

Az önkormányzatok szemszögéből is a zártkertek és zártkertesedő szőlőhegyek, üdülők és tanyagócok a legideálisabbak, hiszen a némileg zártabb településkép révén a szükséges beavatkozások költsége is kisebb, könnyebb felmérni a lakosság igényeit és a vonzó jelleg miatt a beköltözések adóbevételekkel is kecsegtetik a beruházó településeket. Ez a jelenség nem teljesen új a hazai városfejlödésben. Ahogy a dolgozat elején idéztem, többek között BELUSZKY PÁL (1982) is megállapította, hogy a kertségek e csoportok számára vonzó helyek, melyek hosszú távú fejlödéssel új településrészeket alakítanak ki, majd ahogy elfogynak a kertek újak képződnek és a ciklus újra indul, amíg van mobil népesség a migráció fedezésére.

A külterületi szuburbanizáció egyik legjelentősebb sajátossága a tervezetlenségböl és a részleges szabályozatlanságból fakadó komplex, kaotikus térszerkezet, rendkívül eltérő státuszú háztartások ingatlanainak és a különböző funkciók mozaikos, ugyanakkor gyakran halmazokba rendező megjelenése. E térszerkezet, a hiányos és túlterhelt infrastruktúra, valamint az önkormányzatok hiányos információ-ellátottsága révén rögzül és tartós konfliktusok forrása az eltérő érdekcsoportok között. Az egyes funkciók gyakran elkezdik kiszorítani a lakófunkciót, és mezőgazdaságot, az ott élőket környezeti igazságtalanságnak kitéve; illetve a túlzott beépülés is növelheti egyes kockázatok (belvíz) és nehézségek jelentőségét. Emellett az illegális építkezések, lakásfoglalók, valamint a lakcím átjelentésének esetlegessége miatt a KSH helységnévtárban szereplő adatainál a terepi és önkormányzati tapasztalatok szerint akár 10-20\%-al is magasabb lehet egyes külterületek népessége és ingatlanainak száma, így a statisztikai elemzések alapján tett becslésekhez képest a külterületek valós szerepe magasabb lehet a hazai térfolyamatokban.

Jellemző eltérésük a hagyományos (belterületi) szuburbiákhoz képest a szegény lakosság nagyobb aránya és a jelentős elöregedés. Szerepük az agglomerációk fejlődésében jelentős, és a folyamatos beáramlás miatt a népességük száma várhatóan tartósan növekedni fog, illetve kevésbé csökken, mint az országos átlag. A zártkertek és szőlőhegyek a leginkább vonzók a szuburbán lakosság számára kedvező településszerkezeti adottságaik miatt, míg a majorok az utcaszerkezet hiánya és a soklakásos ingatlanok miatt a legkevésbé attraktívak, ugyanakkor ezen olcsó házak újrakezdési lehetőséget biztosíthatnak a szociálisan rászorultaknak. A tanyavilágban heterogén, mozaikos kép alakult ki, amiben a buszmegállók és főbb közlekedési útvonalak elérhetősége mellett több környezeti elem, különösen a belvízkérdés döntő jelentőségü

Az egy-egy lakásból álló dülőkőn található új lakóingatlanok, az út- és gátőrházak, valamint a korábbi üzemi lakóhelyek sorsa hektikusan alakul, addig megmaradnak, amíg az ott élők számára a megélhetést a gazdasági funkció biztosítja. Szintén külső hatások - adminisztratív döntések határozzák meg a különböző intézmények lakóinak számát, e téren jelentős változások nem valószínúek. Az üdülők lakóhellyé válása annak függvénye, hogy térszerkezetük milyen mértékben közelít a zártkertekhez, mennyire jó az infrastruktúra kiépültsége, illetve az árvízvédelem milyen szintü. A lemaradó, népességüket elvesztő külterületek hanyatlásának oka a gyengén kiépített infrastruktúra, a szolgáltatások (szemétszállítás) hiánya, valamint a lakosság és az ingatlanok elöregedése. Az előzők mellett különösen az elzártság miatt nem kedvező a lakóhelyet választó családoknak, így a beáramlás kényszerü költözésekre korlátozódik.

A következő fejezetben azt vizsgálom meg, hogy azon külterületek, amelyek belterületté válással szünnek meg, mennyire követik a korábbi, külterületi fejlődés során tapasztalt pályákat, illetve miben különböznek a korábban önálló falvakból létrehozott egyéb belterületektől. Továbbá a győri mintaterületen keresztül bemutatom, hogy a változások milyen szerepet töltenek be a városi térség fejlődésében. Ezzel kívánom elhelyezni az eddig bemutatott eredményeket elhelyezni a tágabb agglomerációs átalakulások településföldrajzi kontextusában. 


\section{KÜLTERÜLETEK ÉS EGYÉB BELTERÜLETEK TÉRFOLYAMATAINAK JELLEGZETESSÉGEI}

E fejezetben az egyéb belterületek jelentőségét vizsgálom meg a hazai szuburbanizációs folyamatban, különös tekintettel a külterületekböl, valamint a korábban önálló falvakból létrehozott egyéb belterületek különbségeire. A fejezet első felében az általános országos tendenciákat értékelem, majd a fejezet második részében a győri agglomeráció példáján keresztül mutatom be a külterületek, egyéb belterületek és a központi belterületek sajátos szerepét a hazai szuburbanizációban. Ezzel be kívánom mutatni, hogy a települési szint alatt milyen diverzifikációs folyamat zajlik e területeken, a külterületekböl létrehozott egyéb belterületek szerepét az agglomerációk fejlődésében.

1960 óta folyamatosan nő az egyéb belterületen élők száma, 1990 után mind országosan, mind a KSH által lehatárolt vidéki agglomerációk és településegyüttesek területén fokozódott a beáramlás (11. táblázat). Az egykor önálló községek mutatták a legjelentősebb növekedést és átlagos növekményük sem marad el a közigazgatásilag önálló nagyváros környéki falvaktól. A vidéki szuburbiák népességnövekedésének 26,1\%-a irányult 1990 és 2011 között a városok és az agglomerációs települések egyéb belterületekre, így a hazai szuburbanizáció fejlődésében szerepük jelentékeny. Azonban, számuk csökkenőben van, aminek az oka, hogy számos önkormányzat az egyéb belterületeket a központi belterületbe olvasztja

11. táblázat. Az egyéb belterületek jelentősége a hazai településstruktúrában

\begin{tabular}{|l|l|c|c|c|c|}
\hline \multirow{2}{*}{ Területi egység } & \multicolumn{2}{|c|}{ Lakott területek száma $(\mathrm{db})$} & \multicolumn{2}{c|}{ Lakott területek népessége (fö) } \\
\cline { 3 - 6 } & & 1990 & 2011 & 1990 & 2011 \\
\hline \multirow{2}{*}{$\begin{array}{l}\text { Agglomerációk és } \\
\text { település- } \\
\text { együttesek }(\mathrm{KSH})\end{array}$} & Központi belterület & 471 & 472 & 2557457 & 2448217 \\
\cline { 2 - 6 } & Egyéb belterület & 231 & 202 & 111442 & 141199 \\
\cline { 2 - 6 } & Külterület & 1311 & 1277 & 74522 & 111130 \\
\hline \multirow{3}{*}{ Összesen } & Központi belterület & 3153 & 3154 & 9846349 & 9313589 \\
\cline { 2 - 6 } & Egyéb belterület & 790 & 925 & 239943 & 314739 \\
\cline { 2 - 6 } & Külterület & 6852 & 6505 & 288056 & 306514 \\
\hline
\end{tabular}

Forrás: KSH Helységnévtárak alapján saját számítás.

A jelentős népességvonzó képesség révén a külterületek népességnövekedése nagyobb arányú volt, mint a szububrán települések központi belterületéjé. Így települési szintü adatok alapján a klasszikus reurbanizációt feltételező migráció valójában vidékies lakóhelyekre történő áramlás volt. 1990 és 2011 között továbbá nagyszámú kül- és egyéb belterület lett központi belterületekhez csatolva, duzzasztva azok statisztikai népességét, 2595 és 4243 fövel. A növekvő népességü városok és agglomerációs telekülések esetében tehát a lélekszám többlet több, mint a fele a külterületek és egyéb belterületek területén realizálódott. Fontos kiemelni, hogy ebben a közép városok és a nagyvárosok esetében a külterületek dinamikája közel azonos. A mag városok népességnövekedésének jelentős része hátterében is a külterületen és - különösen a 100000 fö feletti városok esetében - az egyéb belterületeken valósult meg. E városok esetében tehát reurbanizáció helyett sokkal inkább egyfajta városhatáron belüli rurális lakóhelyeket célzó szuburbán, vagy szurburbanizációt helyettesítő migráció ált.

Az egyéb belterületek jelentősége abban is megmutatkozik, hogy területükön valósult meg az elmúlt évtized népességnövekményének jelentős része a vidéki közép- és nagyvárosok többségének esetében, 9 városnál pedig több, mint a fele az egyéb belterületeken realizálódott. A városok népességnövekményének egy jelentős része tehát az elmúlt években nem a központi belterületek újraurbanizációjának köszönhetö, hanem a városperemek (14. ábra) fejlődésének. Az egyéb belterületek fejlődése öt településegyüttesben maradt el a többitől, Eger, Kaposvár, Salgótarján, Szekszárd és, Szolnok marad el, azonban e településegyüttesek szuburbanizációja általában is gyengébb, ráadásul az egyéb belterületekböl is kevesebb van jelen területükön. 
A városhoz a hetvenes évek során csatolt települések alkották a városok leginkább urbanizálódott községekből álló agglomerációs gyürüjét. Területükön a funkcióellátottság széles, a településkép falusias, a jó életkörülmények révén, már 1989 elött megsokszorozhatták lakosságszámukat, amit 1990 után a szuburbanizáció tovább duzzasztott, leginkább az egykor önálló települések tudták növelni népességüket. Ugyanakkor nem önálló településekröl csak kevés adattal rendelkezünk, valamint saját önkormányzat hiányában kevésbé tudnak reagálni a kihívásokra (BAJMÓCY P. 2003, BAJMÓCY P et. al. 2012, HARDI T. 2002, PÓCSI G. 2011, SZIRMAI V. 2011, TIMÁR J. 1993, TIMÁR J. 2001b).

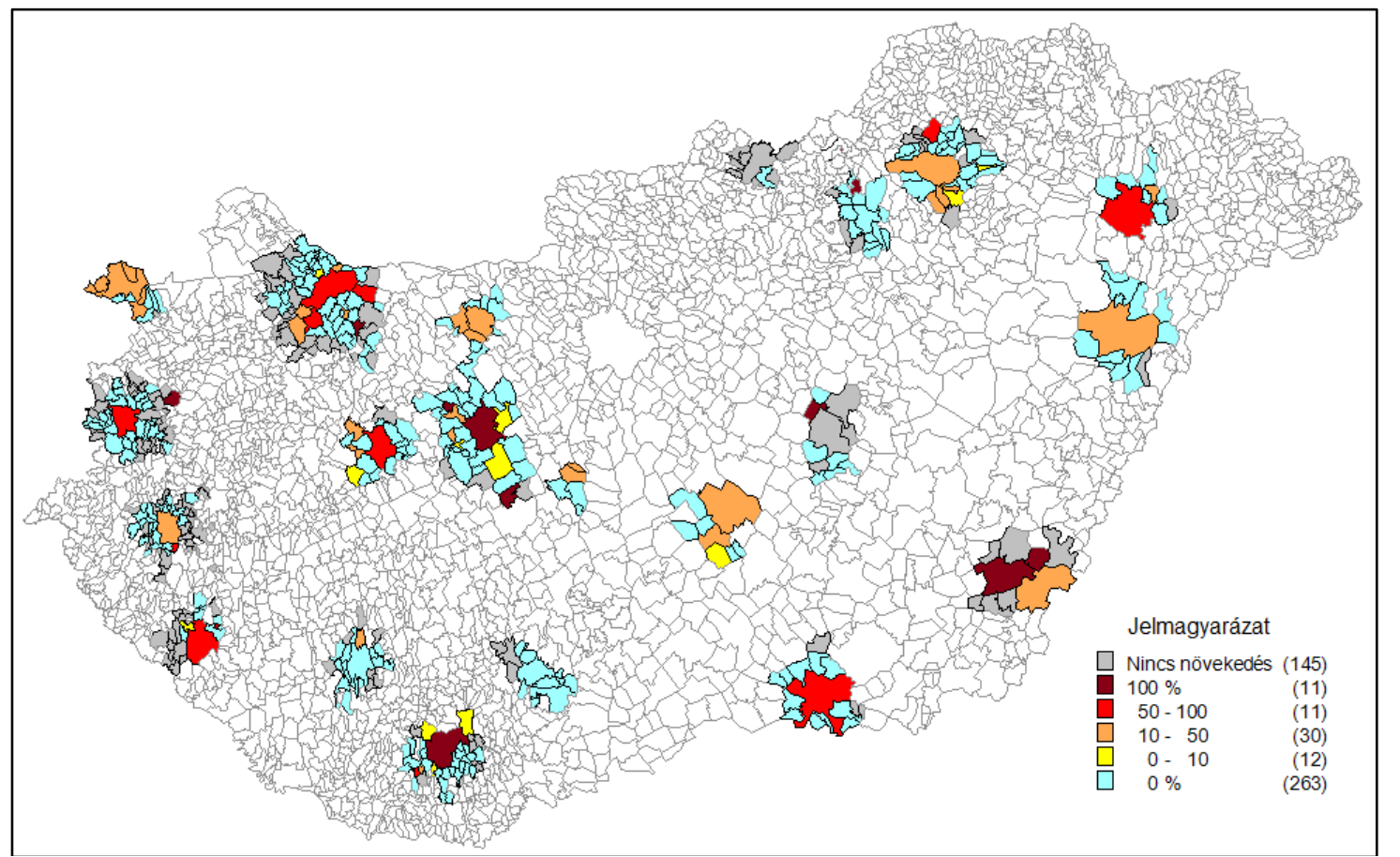

14. ábra: Az egyéb belterületek növekményének aránya a település teljes népességnövekményében (KSH helységnévtár alapján saját számítás).

Ezért a következőkben a Győri Agglomeráció területét szeretném bemutatni, mint esettanulmányt. E mintaterület az egyéb belterületbe vont korábbi külterületek nagy száma révén lehetőséget ad az ilyen külterületek fejlődésének útját bemutatni, és összevetni a korábban önálló falvakból létrehozottak pályáival. A terület kiválasztását a külterületek és az azokból létrehozott valamint önálló falvakból kialakított egyéb belterületek nagy száma és változatos típusuk indokolja (HARDI T. 2002).

Györhöz a hatvanas évek második felében és a hetvenes évek elején csatolták a legközelebbi falvakat, Gyirmót, Győrszentiván és Ménfőcsanak megőrizte egyéb belterületi besorolását, lakosságuk 19283 fö volt 2011-ben. Ezen alacsony laksürüségü kertvárosias területek megjelenítik a falusias életmódot, területhasználatot, miközben a városi lét előnyeit is megtartják. E területek sajátossága a városhatáron belüli szuburbanizáció, melynek során a lakosság úgy költözik „faluba”, hogy nem hagyja el a település határait. A győri szurburbán tér ezért kivállóan alkalmas az egyéb belterületek és külterületek összehasonlítására, annál is inkább, mert a szuburbanizáció a 2007-es válság hatásai ellenére is dinamikus maradt e területen (BUNOVÁCz D. - TuBA L. 2002, CSAPÓ T. et. al 2015, FEHÉRNÉ BRANDISZ K. et al. 2003, HARDI T. 2012 [7], VASÁRUS G. et. al. 2018). Az agglomeráció településein több korábbi külterület vált egyéb belterületté, lakosságszámuk 2860 fó (2011), a legjelentősebb méretüek GyörszemereNagyszentpál és Szőlőhegy nevü területei, valamint Pér - Mindszentpuszta (együtt 1484 fő 2011ben). 
Kutatásomban e 25 egyéb belterületen 146 db és 6 falu központi belterületén 153 db kérdőív került felvételre a 2. fejezetben bemutatott általános módszertanát követve (az agglomeráció külterületein 279 készült). A hat, külterületekkel rendelkező települést (Abda, Győrújbarát, Győrújfalu, Győrzámoly, Nyúl, Töltéstava) úgy választottam ki, hogy a külterületek térbeli eloszlása alapján szektorokra felosztva az agglomerációt a részterületek összehasonlíthatóak legyenek egymással. Az északi szektorból Győrújfalu és Győrzámoly, a nyugatiból Abda, Győrújbarát és Nyúl, valamint a délkeleti részből Töltéstava került a mintába. E kérdőíveknek nem volt célja reprezentatív mintát alkotni az agglomeráció községeinek egészéről, csak a főbb tendenciák összehasonlítását hivatott segíteni.

A belterületbe vonás okai változatosak, elsődleges jelentőségü a lakosság dinamikus növekedése, a beépültség fokozódása és az infrastruktúra megfelelö szintü kiépültsége. Számos esetben az ipar kívánalmai vagy támogatások feltételei (belterület veheti igénybe) állnak a döntés mögött. Ugyanakkor a lakók jelentős része (21\%) a 2001 után belterületté nyilvánított mintaterületeken ingatlanspekulációt és az önkormányzat pénzszerzési müveletét (az aktus költségeit a lakókra hárítják) sejtik.

Az agglomerációban az egyéb belterületek fele tudta növelni népességét a rendszerváltás óta, 2001 és 2011 között össznépességük 28,2\%-kal, a külterületeké 69,1\%-kal, a központi belterületeké viszont csak 1,4\%-kal növekedett. A vizsgált területek társadalmát jelentősen átszabja a beköltözők tartósan magas száma. A válaszadók többsége Győrből kiköltöző volt, magas azok aránya, akik az ország más részéböl érkeztek a területre (11. táblázat). Az egyéb belterületeken a lakosság 14,9\%-a az agglomeráció más részéről költözött ide, jellemzően családi okok, vagy a munkahely jobb megközelíthetősége érdekében. Jellegzetes tendencia, hogy a szuburbanizációs folyamat csak 2000 után futott fel a vizsgált területeken, és a válaszadók közel fele az ezredforduló után költözött ide.

11. táblázat, a helyi közösség migrációs jellemzőinek összehasonlítása az egyéb belterületeken, külterületeken és központi belterületeken.

\begin{tabular}{|c|c|c|c|c|}
\hline \multicolumn{2}{|c|}{ Lakosok csoportjai } & $\begin{array}{l}\text { Egyéb } \\
\text { belterület }\end{array}$ & $\begin{array}{c}\text { Külterület } \\
n=299\end{array}$ & $\begin{array}{c}\text { Belterület } \\
n=153\end{array}$ \\
\hline \multirow{5}{*}{$\begin{array}{c}\text { A válaszadók migrációs } \\
\text { jellemzői }\end{array}$} & Mindig itt élt & 47,0 & 8,4 & 50,2 \\
\hline & Beköltözők & 52,6 & 58,4 & 48,0 \\
\hline & 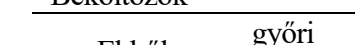 & 22,8 & 43,6 & 28,7 \\
\hline & $\begin{array}{ll}\text { Ebbol } & \text { külföldi } \\
\end{array}$ & 7,8 & 4,0 & 0,5 \\
\hline & Kétlakiak, hobbikertezők & 0,4 & 33,2 & 0,8 \\
\hline \multirow{4}{*}{$\begin{array}{l}\text { A helyi közösséget alkotó } \\
\text { csoportok említettsége } \\
\text { (több választ is } \\
\text { megjelölhettek) }\end{array}$} & Helyiek & 74,1 & 12,6 & 71,3 \\
\hline & Városi tehetősek & 54,5 & 20,0 & 63,1 \\
\hline & Városból kiszorulók & 15,7 & 41,0 & 8,8 \\
\hline & Pályakezdők & 9,4 & 19,8 & 12,3 \\
\hline
\end{tabular}

Forrás: Saját számítás.

A külterületre és egyéb belterületre költözők fele (55\%) már korábban is családi házas területen élt, és lakhelyválasztásukban fontos motiváció volt, hogy ezt az életformát a későbbiekben is megtarthassák. Emellett az egyéb belterületek lakosai (az agglomeráció más részéböl költözők különösen) családi ok (37,3\%), vagy a munkahely közelsége $(30,6 \%)$ miatt döntöttek az ideköltözés mellett. Ettől némileg eltérően a külterületeken, az ideköltözők szerényebb jövedelmének megfelelően, az olcsóbb megélhetés $(29,7 \%)$ és a vonzó környezet $(25,4 \%)$ volt meghatározó a győri agglomerációban.

A belterületre migrálók esetében az életmóddal kapcsolatos elvárások $(24,7 \%)$, a saját $(27,0 \%)$ és nagyobb lakás iránti igény $(28,2 \%)$ és a környezeti szempontok $(17,7 \%)$ mellett a munkahelyek közelsége $(27 \%)$ volt jellemző indok a városból kiköltözőknél, némileg eltérően a korábbi két területtípustól. Fontos kiemelni, hogy az agglomeráció más részéröl az összes (mindhárom területtípusra) érkezők 55\%-a családi ok miatt (válás, házasság, stb.) költözött új lakóhelyére. 
Mindhárom területre jellemző a városból kiszorulók és a környezeti előnyöket kereső tehetősek kettőssége, a beköltözők magas aránya miatt a területen súlyos társadalmi konfliktusok alakultak ki, a válaszadók a régi és új lakók elkülönülését emelték ki mindkét területen (külterület: 59,6\%, egyéb belterület: 47,5\%, belterület: 29,8\%). Leggyakrabban az anyagi különbségeket, az eltérö életvitelt, illetve az újonnan beköltözők gyenge helyi kapcsolatait (alvótelepüléssé válás) emelték ki forrásként.

A beköltözök korszerinti megoszlása ugyanakkor szignifikánsan különbözött, a válaszadók átlagos életkora a külterületeken 53, az egyéb belterületeken 38, a központi belterületeken 34 év volt. Hasonlóan diverzifikálódik a diplomások (20,0, 22,2 és 38,0\%) és a 200000 Ft felett keresők aránya $(16,3,25,7$ és 39,9\%) a három területtípuson, amely jól szemlélteti, hogy az egyéb belterületek a külterületek és a közigazgatásilag önálló falvak társadalmi megoszlása közötti átmeneti helyet veszik fel a társadalmi diverzifikálódásában. A közigazgatásilag önálló falvak demográfiai adottságai követik a 4.5. fejezetben feltárt általános szuburbán jellemzőket, míg a külterületek 5.1-5.4 fejezetekben leírt általános jellemzői közül a legjobb adottságú külterületeknél is jobb, az önálló falvak mutatói felé tartó társadalmi adottságokat mutattak.

A letelepedők jobb keresetük és eltérő életvitelük miatt idegenek a helyi, rurális jellegü lakosságtól, jellemzőjük a jobb kereset és a gyermekek magasabb száma, valamint a helyi jellegtől elütő városias gyökerek (Győr a). Más az érdekérvényesítő képességük és a jövőképük a terület fejlődését illetően, számukra a lakófunkció és a szolgáltatások minősége lényegesebb, mint a táji, kulturális és építészeti értékek megmaradása. Amennyiben a betelepülők új kialakítású utcákba, zárt lakóparkokba költöznek, térbeli elkülönülés is megjelenik, amely tovább nehezíti ezt. Az öt évnél régebb óta ott lakók esetében is magas volt e konfliktus említettsége, így az 5.6 fejezetben bemutatottakkal összhangban tartós nehézségekkel kell számolni.

A fenti konfliktusok ellenére $81,5 \%$ szeret új lakóhelyén élni, leginkább a csendes, nyugodt életvitel $(50,0 \%)$ és a jó elérhetőség $(15,4 \%)$ miatt, ebben nem volt szignifikáns eltérés a külterületek, egyéb belterületek és központi belterületek kötött. Az infrastrukturális hátrányokat az erős közösség, a könnyebb megélhetés ellensúlyozza, mivel az ideköltözők bizonyos nehézségeket tudatosan vállalnak az elönyökért cserébe. $E$ tény jelentős, mivel a legtöbb külterület és az egyéb belterületek bizonyos részeinek infrastrukturális állapota jelentős kívánnivalókat hagy maga után.

A társadalmi folyamatok hatására megindult a mozaikos településkép kialakulása. A felmérés alapján az új lakók modern házainak területe, valamint a leginkább leromlott ingatlanállományú, jellemzően idős helyiek által lakott részek koncentrálódnak az egyéb belterületeken, ahol volt elég üres telek. Gyakori, hogy az új építésű utcák a legszegényesebb külterületi részek közelében lettek kialakítva. A jelentős és látványos eltérés miatt a településszerkezet megbomlása még szembeötlőbb és zavaróbb lesz, ami egyúttal a hagyományos utcák relatív leértékelődését okozza az új utcák bővülő épületállományához képest.

A beépítettség növekedése Győrszentivánon alapvetően intenzív módon valósult meg, a hézagtelkek beépítésével és tömbfeltárásokkal. Gyirmóton és Ménfőcsanakon leginkább a Győrbe vezető föutak mentén alakítottak ki új utcákat, extenzíven növelve a lakóterületek méretét. A 2000 után kialakított telkek mérete rendkívül kicsi, mivel a beruházók így próbálnak magasabb profitot elérni, továbbá magas az ikerházak, több lakásos házak száma is. Ez a ,fekvő panel” jelleg ahogy az interjúalanyok (Győr: a, d) nevezték - a később bővülő családok számára kezd igazán problémává válni, és gyakori súrlódásokat okoz a szomszédokkal (I. melléklet, 16.-17. kép).

A laksürüség növekedése egyben magával hozta a település-földrajzi adottságokból fakadó, már korábban is meglévő nehézségek fokozódását. Sajátos példa erre a belvízkérdés, mivel Győrszentiván (15. ábra). és részben Gyirmót fekvéséből adódóan sok a lefolyástalan térszín területükön. Bár a vízelvezető rendszer kiépült a hetvenes évekre, a hiányos karbantartás és az intenzíven bővülő beépítettség miatt hatásfoka lecsökkent. Számtalan, a helyi viszonyokat kevésbé ismerő beköltöző betemette az előkertben futó vízelvezető árkot. Ménfőcsanakon, a 
domboldalon lévő utcák besürüsödése és a csapadékelvezető csatornák szintén gyakori feltöltése általánossá tette az esővízproblémákat.

Győrszentiván példája egyben jól szemlélteti azt, hogy az egyéb belterületeken is jellemző az a mozaikos és fragmentált térszerkezet, amelyet a 5.6 fejezetben bemutattam a külterületek kapcsán. Az ingatlanállomány bár rendezettebb és az infrastruktúra állapota is jobb mégis jelen vannak a leromlott, szilárd burkolat nélküli utak, a beékelődő nagyobb mezőgazdasági területek. A helyi lakosság leginkább hátrányos helyzetü csoportjainak leromlott ingatlanai és az újépítésü utcák modern ingatlanai a térben koncentrálódnak, mozaikos térszerkezetet alkotva. Emiatt az egyéb belterület egészét nézve kis fokú a szegregáció, hiszen a társadalmi csoportok széles köre található meg területén, azonban mikroszinten jelentős a szegregálódás, ezt az egyéb belterületi lakosok 18,2\%-a tartotta általános problémának.

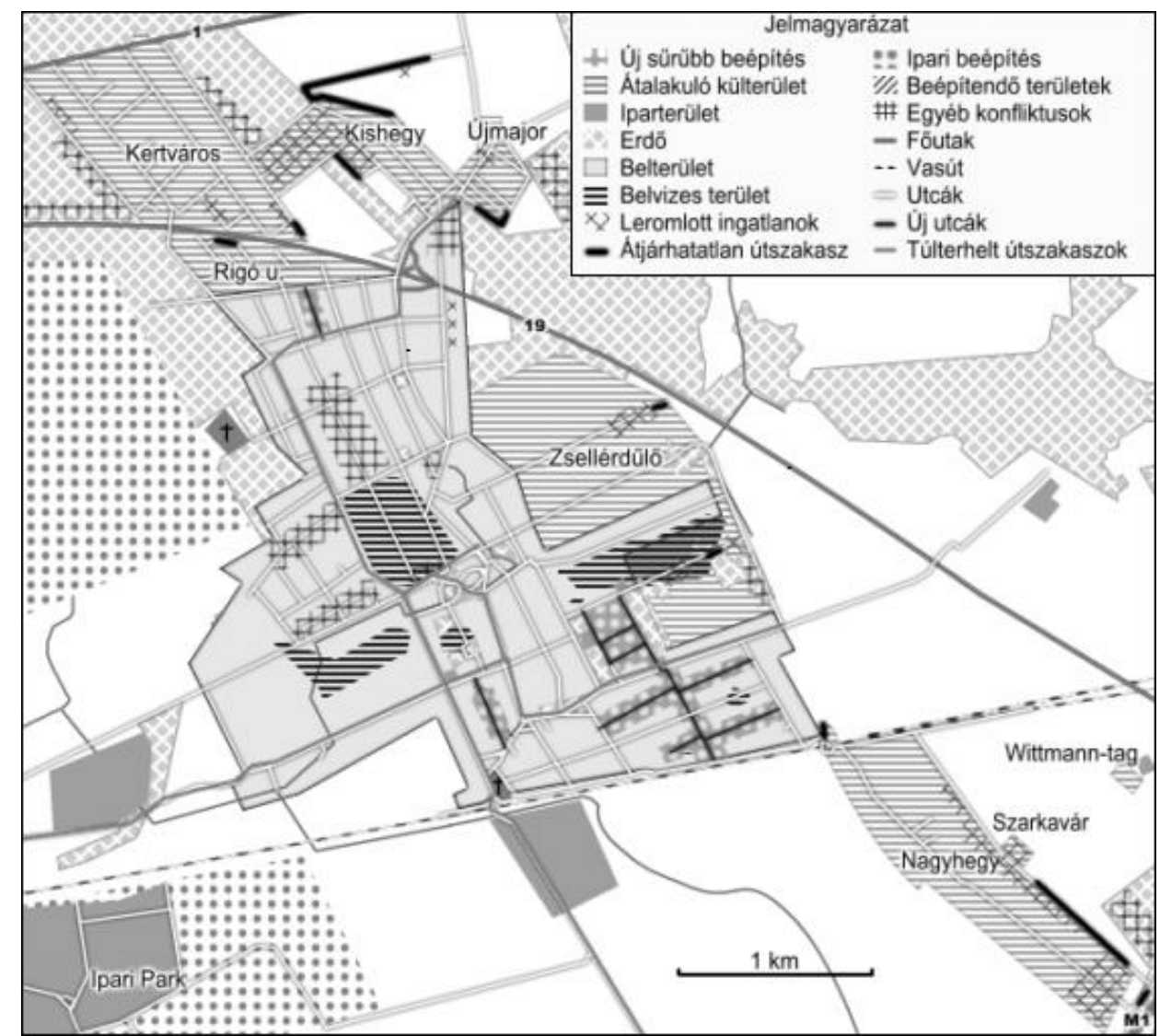

15. ábra: Győrszentiván területhasználati átalakulása és a kialakult konfliktusok térbelisége (Saját szerkesztés).

Az egyéb belterületeken a külterületekkel $(11,2 \%)$ és a belterületekkel $(2,1 \%)$ ellentétben jelentős konfliktusforrásként jelölték meg a cigányságot is $(27,8 \%)$. Jellemzően nem a helyi kisebbséget, hanem az ország perifériáiról betelepülő romákat említették, a válaszadók szerint részvételük különösen magas a zártkerti és a peremi utcák illegális lakásfoglalási hullámában. Pozitívumként kiemelhetö, hogy a cigányság térbeli szegregációja nem jellemző a legtöbb mintaterületen, a terepbejárás tapasztalatai alapján teljesen keverten élnek a többségi lakosokkal, azonban az új építésű utcákban nem volt magát cigánynak tartó válaszadó.

A kutatás többi területén is számos egyéb belterületté nyilvánított külterület fekszik. Szeged hét ilyen egységén (Baktói kiskertek, Bodomi kiskertek, Gyálaréti kiskertek, Marostői kiskertek, Subasa, Tápéi kiskertek, Tompaszigeti kiskertek) 3201 fó él. A Baktói, Bodomi, Marostöi és Tápéi kiskertek ma zártkerti tájképü területek, Gyálarét korábbi major mára szintén zártkerti képet mutat, a tartós kiáramlás révén népességszámuk és beépítettségük nő, míg Subassa üdülős beépítésű terület, ahol inkább a nyaralók dominálnak. E zártkertjek a helyi lakosság kívánságára 
váltak belterületté, jellemzőik a győri egyéb belterületnél és a zártkertek általános jellemzőinél bemutatotakkal egyezik a kérdőívek adatai és az interjúk alapján (Szeged: b, d).

Kiemelendö, hogy a területükön élökböl alakult a Családok a Kiskertekért Egyesület civil szervezet. Az Egyesület a várost körülölelő kiskertek problémáira keresi a megoldási lehetőségeket, különös tekintettel a beépítési korlátokra és a területrendezési kihívásokra. $\mathrm{Az}$ egyesület tevékenysége jelentős hatással volt az országos, külterületi lakott helyekre vonatkozó szabályozás változására. Az új szabályozás alapján az eddigi - jellemzően 3\%-os - beépítési korlát 10\%-ra emelésével és a müvelésből való kivonás 2016 során ingyenes lehetősége várhatóan hozzájárul nemcsak a város, hanem az ország külterületeinek jövőbeli növekedéséhez (Szeged: d).

Hódmezővásárhely egyéb belterületein jelenleg 1951 fö él. Batida, Erzsébet, Kútvölgy és Szikáncs 1950 után létrehozott és rosszul megtervezett tanyaközpontok. E területeken nem épült ki a megfelelő infrastruktúra, azonban a lakásépítési tilalom nem vonatkozott rájuk, így a lakosság beáramlott a környező földekröl, különösen mert a termelöszövetkezetek munkát adtak. Ennek ellenére a kimért telkek mennyisége túlméretezett, miközben a településrészi központokká szerveződés nem teljesedett ki. Mártélyi üdülőterület, nevének megfelelően hobbitelkes, nyaralókból álló terület közel a Tiszához. Belső Kishomok az 5.6. fejezetben bemutatásra került.

Zalaegerszeg egyéb belterületein 11914 fó él, jellemzően korábbi önálló falvak voltak, ebböl kifolyólag falusias településképúek (Andráshida, Bazita, Botfa, Csácsbozsok, Ebergény, Pózva, Ságod, Szenterzsébethegy, Vorhota, Zalabesenyő), míg Nekeresd és Neszele külterületek voltak. Jellemző e területekre is, hogy a beköltözők keresete és iskolai végzettsége jelentősen meghaladja a helyben születettek értékeit, ugyanakkor a két csoport között jelentős konfliktusok vannak jelen (NAGY GY.-HEGEDÜS T. 2016, [8]).

A vizsgált külterületek és egyéb belterületek részei a szuburbanizációs folyamatnak, tartós a beköltözés e városrészekbe. Az egyéb belterületek jó elérhetőségük, viszonylag színvonalas infrastruktúrájuk és a város közigazgatásához tartozás előnyei miatt váltak vonzóvá a szuburbán lakosok számára. A beköltözők összetétele átmenetet képez a közigazgatásilag önálló településekre s a külterületekre migrálók között, ennek megfelelően magas a városból kiszorulók és a városból kitelepülők aránya, azonban a jelentős beépülés és népességnövekmény, valamint a zárt településkép miatt jellemzően alacsonyabb a hobbikertezők és kétlakiak aránya a külterületekhez képest.

A területhasználat a demográfiai folyamatok hatására nagymértékben átalakult és ez a transzformáció jelenleg is zajlik. Az ingatlan állomány bővülésének a lakóterület extenzív és intenzív növekedése egyaránt konfliktusforrás, különösen a sürün és gyakran egyforma házakkal beépített egységeken. Az infrastruktúra fejlesztések lemaradásba kerültek a változások során és nem voltak képesek adaptálódni a megváltozott társadalmi igényekhez.

A fejlődő egyéb belterületekre jellemző, hogy a hagyományos településkép rovására megindul a belterületi szuburbán utcák képére hasonlító tájhasználat elterjedése, de jelentős különbség mutatkozik az egyes helyszínek között. Számos esetben a rövid idő és a lassú beáramlás miatt csak néhány utca alakult át, és a terület java máig külterületi jellegü (Bőny - Szőlőhegy, Pér Mindszentpuszta, Szeged-Bodom, Sziksós, Zalaegerszeg-Csácsbozsok), ellenben számos esetben rövid idő alatt megváltozott a térszerkezet és mára csak elvétve találhatunk az eredeti településképre utaló elemeket (Szeged-Marostői kertek, Győrszemere-Nagyszentpál, Szőlőhegy, Zalaegerszeg-Ebergény, Neszele). Természetesen gyakoriak azok a külterületekből létrejött egyéb belterületek is, amelyek bár jelentősen átalakultak átsorolásuk után, azonban a folyamat egy szinten hamar meg is akadt és máig külterületi jellegük van (Győrság-Halomalja, KoroncóHaraszt, Hódmezővásárhely legtöbb egyéb belterülete).

A fentiek alapján láthatjuk, hogy a fejlettebb külterületektől a közigazgatásilag korábban önálló községekböl létrehozott egyéb belterületekig tartó fejlettségi skálán helyezkednek el a külterületekből létrehozott egyéb belterületek. Az átalakulás, városiasodás függvénye a rendelkezésre álló időnek, a népességszámnak és a tőkének (önkormányzati és magánberuházások). Mindebben jelentős a közlekedés szerepe, ezért a külterület egyéb 
belterületté válása, majd hosszú átalakulás után a központi belterület részévé válása inkább csak a jól elérhető területeken várható. Fontos kiemelni, hogy a folyamat nem feltétlen járja végig ezt az utat, ha a népességtartalék és a potenciálisan oda beruházható tőke nem elégséges a folyamat egy köztes szinten megrekedhet, vagy akár visszafejlődés is történhet, különösen, ha a szükséges lakossági összefogás és közösség nem alakul ki (Szeged: b, d).

Összességében az ilyen, átsorolással létrehozott egységek az átalakulás legkülönbözőbb fokain álltak az empirikus felmérés időpontjában, melyben meghatározó volt a lakosság aktivitása, az átalakulásra rendelkezésre álló idő és a beruházások mértéke, amelyeket azonban közvetlenül határoznak meg a közlekedési viszonyok. Az egyes külterületek adottságaiknál fogva a fejlettebb külterületek és a közigazgatásilag önálló falvak között helyezkednek el településkép és demográfiai mutatók tekintetében. A külterületre jellemzö konfliktusok jelen vannak e területeken is, a hangsúlyok azonban természetesen fokozatosan eltolódnak az átalakulási folyamatok során, hiszen maga a lakott terület is változik.

A fejlödési sorrend úgy határozható meg, hogy: külterület - besürüsödő külterület külterületből létrehozott egyéb belterület - faluból létrehozott külterület - központi belterület. Természetesen fejlesztési beavatkozásokkal egy-egy szakaszt átalakíthat a fejlődés, illetve annak hiányában megakadhat, ezért számos külterületből létrehozott egyéb belterület sosem fogja elérni a belterületek fejlettségét, míg például egy major lebontásával létrehozott zöldmezős lakópark egyböl megközelíti a központi belterületek fejlettségét.

A városhatáron belüli szuburbanizáció a hazai településfejlödés meghatározó részfolyamata, egyedi területi jellemzőkkel és konfliktusokkal. A külterületekböl létrehozott egyéb belterületek vonzóak a kisebb keresetü szuburbán lakhelyválasztók számára. Azonban e területek sajátosságaikból fakadó lehetőségek kiaknázása és a meglévő nehézségek kezelése érdekében szükséges alaposabb, a gazdasági és mélyebb társadalmi folyamatokra is kiterjedő feltárása, melyben a hazai településföldrajz szerepe kiemelkedő lehet. A következő fejezetben megkísérem felvázolni a hazai városrégiók szuburbanizációjának sematikus szerkezeti ábráját. 


\section{A KÜLTERÜLETI LAKÓHELYI SZUBURBANIZÁCIÓ TÉRSZERKEZETI MODELLJE}

A szuburbán fejlődés során a hazai közép- és nagyvárosok peremterületein egy rendkívül összetett térszerkezet alakul ki azok, különösen ott, ahol az egyéb belterületek és külterületek térben koncentrálódnak. Ezen területeken az eltérő területhasználati formák és az életmódok, társadalmi csoportok keveredése meghatározó. Az olcsóbb életvitel, a telkek olcsósága és a táji szépség a szuburbanizáció kiemelt célterületévé emeli a külterületeket és egyéb belterületeket az alsóbb középosztály és a városból kiszorulók számára. Ebben nem a várostól való kilométerben vett távolság, hanem az elérhetőség - különösen a tömegközlekedés - határozzák meg leginkább e területek fejlődését, mivel e csoportok számára a közlekedési kényszer döntő jelentőségü.

A külterületek térszerkezetét vizsgálva általában vegyes (kaotikus) kép uralja. Az egyes külterületek elérhetösége és településföldrajzi adottságai a recens folyamatokon túl a genetikájukból fakadó sajátosságok által is meghatározottak, így hézagos, mozaikos a térszerkezet, összefüggő gyürü nem alakul ki. A külterületek infrastrukturális adottságai nem homogének, az egyes külterületi övek statisztikai alapon lettek lehatárolva, nem morfológiai szempontok szerint. Továbbá a területi tervezés gyengesége és a zöld területek drasztikus eltủnése, valamint az engedély nélküli beruházások a települési életminőséget módosítják, ezáltal az egyes KSH által lehatárolt külterületek részei egymástól jelentősen eltérő lakóhelyek lehetnek, gyakran ellentétes lokális folyamatokkal. Nem csak a különböző külterületek eltérőek, de az egyes külterületi lakott helyeken belül is diverzifikálódik a beáramlás mértéke és az új lakók szocioökonómiai státusza, amennyiben jelentős eltérés mutatkozik a terület infrastruktúrájában (betonút vége, közvilágítás hiányossága, elaprózódott telekszerkezet).

Mivel a városok külterületei jobban különbözhetnek a város belterületeitől, mint a város a környező (vagy akár távolabbi) falvaktól, így a várostól való távolság nem csak a földrajzi távolság és útidő dimenziójában értelmezhetö, hanem mint infrastrukturális-életmódbeli távolságként is. A beköltöző csoportok összetételét tovább differenciálja a terület presztízse, a közmüellátottság, a táji szépségek megléte és a telekszerkezet, valamint az épületállomány összetétele. A kialakuló konfliktusok és ellentétek hatására a helyi társadalom hanyatlásnak indul, az újonnan érkezők pedig saját képükre kezdik alakítani a terület képét.

A fentiek alapján a külterületek csoportosíthatóak a szerint, hogy a városi urbánus területtől milyen mértékben vannak távol útidő és a település hierarchiában meglévő községek fejlettségi szintjében hova sorolhatók. Mivel ezek az adottságok meghatározzák a beáramlás ütemét és az oda költözni akarók szocioökonómiai jellemzőit e két tengely mentén való elhelyezkedése alapvetően determinálja a területen várható folyamatokat (12. táblázat).

Vonzók a lakosság számára a városperemek (periurbán utcák, zártkertek) kertes részei akkor is, ha közmüellátottságuk rossz és degradált környezeti részek mellett fekszenek, mert életminőségüket alacsony költségek mellett tudják javítani. A volt második otthonok öve, jellemzően táji szépségekkel (domborzat, vízfelületek) rendelkező szőlőhegyek és üdülők relatív olcsóságuk, táji értékeik és még relatív jó elérhetőségük miatt a korábbi hobbikerteseken túl az időseket és a városi zsúfoltság elöl menekülőket vonzzák. A távolabbi majorok, szőlőhegyek és volt őrházak, valamint tanyás területek elérhetőségük és ingatlanaik (cselédlakások aránya) függvényében az elesettek, a városból kiszorulók számára jelentenek lehetősége az újrakezdésre, valamint a reciprocitáson alapuló közösségek előnyeinek kiaknázására és életviteli költségeik minimalizálására, mint egy sajátos túlélési stratégia.

A hátrányos helyzetü csoportok és a tehetősek térben egymás közelségében koncentrálódnak, ezért látszólag csökken a szegregáció. Ugyanakkor az egyes külterületek eltérő mértékben vonzóak a kevésbé tehetősek és a jó keresetüek számára egyaránt, ezért mikroszinten jelentős az elkülönülés a lakosság eltérő anyagi lehetőségü csoportjai között. A számtalan kialakuló konfliktus miatt azonban egyik csoport sem képes maradéktalanul élvezni a várt előnyöket, és 
hosszú távon a helyi közösség összetartó ereje csökken. Továbbá a túlhasznált vagy hiányos infrastruktúra is csökkenti az életminőséget e területeken.

12. táblázat: A külterületek adottságaiból fakadó főbb fejlődési pályák

\begin{tabular}{|c|c|c|c|}
\hline & \multicolumn{2}{|c|}{ A külterület infrastruktúrájának állapota } \\
\hline & & Jó & Rossz \\
\hline \multirow{2}{*}{ 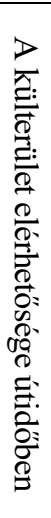 } & o: & $\begin{array}{l}\text { Jelentős szuburbanizáció, mely szegregációt és a } \\
\text { helyiek kiszorulását okozza, a terület korábbi } \\
\text { genetikájából adódó szerkezetét elveszti. } \\
\text { Kiskertek, Szőlőhegyek, Üdülök és Periurbán } \\
\text { utcák }\end{array}$ & $\begin{array}{l}\text { Amennyiben a külterület elegendö röldterülettel } \\
\text { rendelkezik, az ipari (mezőgazdasági) } \\
\text { kiszorítják a lelephelyek } \\
\text { adottságú területen a nyaralóba kiköltözö ionkciót, vagek és } \\
\text { életmódváltók lakóhelye lesz. } \\
\text { Majorok, Szölőhegyek, Üdülök, Örházak }\end{array}$ \\
\hline & & $\begin{array}{l}\text { Vegyes szerkezetü külterületek alakulnak ki, } \\
\text { ahol a városból kiszorulók, valamint a heterogén } \\
\text { társadalmi státuszú, a városi nyüzsgéstöl } \\
\text { menekülők, idősek telepednek le. Ritkábban } \\
\text { üzemi telephelyek alakulnak ki. } \\
\text { Kiskertek, Szölöhegyek, Üdülök és Periurbán } \\
\text { utcák }\end{array}$ & $\begin{array}{l}\text { A városból kiszoruló legszegényebb rétegek és az } \\
\text { ország perifériájáról érkező szükös anyagi } \\
\text { lehetőségekkel rendelkezö családok, (ritkábban } \\
\text { rokkantak, valamint deviáns viselkedésüek), } \\
\text { szegregátumaivá alakulnak, vagy teljesen } \\
\text { elnéptelenednek, ha az ingatlanok leromlanak. } \\
\text { Majorok, Szölőhegyek, Orrházak }\end{array}$ \\
\hline
\end{tabular}

Forrás: saját szerkesztés

A jó elérhetőségű és megfelelően zárt, kedvező infrastruktúrájú külterületek vonzzák a legjelentősebb lakosságot, ezért rendszerint ezek fejlődése dinamikus, népességük a legnagyobbak közé tartoznak. E folyamat számtalan pozitívummal jár, megújul az infrastruktúra, az ingatlanállomány, nő a népesség, és jelentős adóbevételek keletkezhetnek. Ugyanakkor a helyi lakosság számára a változások számtalan konfliktust generálnak, az infrastruktúra, túlterheltté válik; mindennaposak a jogszerütlen területhasználati módosítások és építkezések, de az adóbevételek reményében az érintett önkormányzatok számos szabálytalanság felett szemet hunynak.

A rosszabb elérhetőségü, de viszonylag jó településföldrajzi adottságú területekre jellemző, hogy vegyes folyamatok zajlanak párhuzamosan. Jellemző intenzív beáramlás egyaránt köthető a marginális csoportok és magas státuszúak beáramlásához, gyakran a két csoport egyszerre költözik egy-egy felkapott lakóhelyre, továbbá az életmódváltók és idősek számára is vonzóak lehetne. E területek szintén nagy jelentőségüek, mert a városból kiszorulók és a vidékröl beáramlók számára biztosítanak lehetőséget anyagi helyzetük rendezésére, illetve a kertvárosias környezetben fenntartani olyan életmódot, amire a városkörnyéki települések belterületein nem lenne pénzük.

Jellemzően rosszabb ingatlanszerkezetü majorok, tanyás, illetve kevésbé kiépített üdülös területek vonzóak a feldolgozó-ipari, logisztikai és mezőgazdasági üzemek bővítése számára amennyiben közúton jól megközelíthetők. Vonzó környezeti objektumok mellett azonban rendszerint rekreációs területek alakulnak ki, művésztelepek, illetve egyszerü hétvégi házas nyaralóövezetek, ritkábban - vállalati nyaralók és szolgálati lakások esetében - időskorúak által lakott kertes egység.

A legrosszabb adottságú területek rendszerint a leghátrányosabb helyzetű lakosság szegregátumainak, illetve életük krízis időszakában a városokból és azok környezetéből kiszorulók, valamint a társadalom perifériáira szorult cigány családok lakóhelyeit találhatjuk. Továbbá hanyatló egykori mezőgazdasági központokat, illetve leértékelödő és hanyatló épített környezettel jellemezhető majorokat, őrházakat, illetve üzemi lakóhelyek is sajnálatosan gyakoriak. Bár az életszínvonal nagyon alacsony e területeken, az olcsó megélhetés és a mezőgazdasági idénymunka lehetősége esetenként elősegítheti az anyagi helyzet javulását.

A szegregáció az érintett külterületeken egyszerre csökken és nő. A külterületeken belül jelentősen csökken az elkülönülés, mert a lakók vegyesen költöznek be az éppen eladó telkekre. Ugyanakkor a kedvező adottságú területeken dzsentrifikciós jellegü folyamat indul be, és az újak 
kiszorítják a régi lakókat. Ellenben a kevésbé vonzó lakóhelyeken a hátrányos helyzetủek beáramlásával slumosodás jelentkezik. Különösen a majorokban magas a hátrányos helyzetü csoportok aránya, és teljesen kiszolgáltatottak a földtulajdonosok irányába. A nagyobb lélekszámú külterületeken az alacsony státuszú népességre jellemző önkéntes elkülönülés és az érdekérvényesítő képesség hiánya miatt a szuburbanizáció hátrányait élik meg, előnyeiből nem részesülnek.

E jellemzők azonban csak ritkán jelennek homogén módon, a legtöbb terület vegyes jellegü, továbbá az adottságok idővel változnak, a beköltözések hatására az infrastruktúra bővül, vagy az elöregedés hatására romlik. Ennek ellenére a külterületek alaptípusainak jellemző fejlődési iránya felvázolható.

A hazai szuburbanizáció és a külterületek szakirodalomban feltárt sajátosságai, a saját empirikus kutatások eredményei, OTT, T. (2001) a posztszocialista városok szuburbanizáció során kialakuló térszerkezetének általános sajátosságait bemutatót modellje, valamint az Ouředníček, M. (2007) által leírt, a szuburbán fejlődést meghatározó részfolyamatokat összegző modellje alapján e fejezetben elkészítem a hazai nagy- és középvárosok térszerkezetének átalakulását bemutató sematikus ábrát. A lakosok heterogén csoportjainak eltérő választási motivációit és a külterületek típusainak sajátosságait egybevetve a külterületek fejlődésének föbb tendenciáit a következőkben foglalhatjuk össze.

A rendszerváltás után kialakult településszerkezet összetett a szuburbiák területén (16. ábra, 1.), a városok különbözö korú és jellegü lakó- és iparterületein túl hozzácsatolt falvakat találunk a központi belterületbe ágyazódva (A), vagy egyéb belterületként (EBT) rurális enklávét alkotva. A külterületek a városok és a város körüli községek esetében is mozaikosan helyezkednek el. Az e területekre irányuló beköltözés során több különböző migrációs forma alakul ki a hazai városokban, amely megfeleltethetőek az OTT, T. (2001) és Ouředníček, M. (2007) által kimutatott trendeknek.

A „klasszikus” szuburbanizáció, azaz a magasabb státuszú csoportok közigazgatásilag önálló városkörnyéki településekre kiköltözése és az idösek migrációja a második otthonokba meghatározó (16. ábra, 2.). A pályakezdők, valamint a szerény anyagi lehetőségekkel rendelkezők hagyományos falusias területek megüresedő régi, olcsó házaiba költözése egyéb belterületekre és külterületekre is irányulhat, amelyek közigazgatási besorolása nem mérvadó az életminőséggel kapcsolatos elvárásokhoz képest a lakók döntésében. A korábbi üdülök és hétvégi házakba költözés esetenként csak szezonális, a nyári időszakot töltik kint, így a hivatalos lakcímváltással nem jár. E folyamat jellemzően a jó vagy átlagos elérhetőségü és kedvező infrastruktúrájú külterületeken jellemzők, de kisebb arányban a rosszabb elérhetőségüeken is.

A második jelentős részfolyamat-csoportot a városból kiszorulók és az ország perifériáiból a várostérség olcsóbb, de a munkahelyek elérését lehetővé tevő területeire migrálása (16. ábra, 3.), egyfajta szociális szuburbanizációt alkotva. Ebben az egyéb belterületek és külterületek szerepe magas, mivel az itt található ingatlanok és a kisebb közmüvesítés, valamint a kertmüvelés lehetővé teszi az olcsóbb életvitel kialakítását. E folyamat jellemzően a kertes és falusias utcaképü, de kevésbé jó elérhetőségü külterületeken dominál. Hasonló folyamat a helyiek kiszorulása a szuburbán települések felkapottá váló területeiről annak külterületeire vagy a távolabbi falvakba, ahol a telkek és szolgáltatások drágulása egyfajta külterületi vidékdzsentrifikációt indít be. A külterületekről való kiszorulást a lakóhelyi szuburbanizáción túl a gazdasági telephelyek kiterjedése is okozhatja. E a részmigrációk fokozatosan az átlagos, majd a rosszabb adottságú területek felé mozdulnak el, de csak ritkán irányul a legrosszabbakra.

Mivel a nagyobb külterületek (100 fő feletti zártkertek, szőlőhegyek, valamint a tanyás zónák többsége) belső struktúrája is diverzifikálódik az épületállományt, az infrastruktúra állapotát és az elérhetőséget tekintve a leginkább növekvő külterületek vegyes szerkezetüvé alakulnak. Távolabbi, rosszabbnak tartott részeiken (belvíz, közeli üzem) a kis bevételü háztartások és csonka családok telepednek meg, míg a legértékesebb adottságú szakaszokba a legtehetősebb csoportok költöznek. Minél mozaikosabb a külterület szerkezete annál több konfliktussal járó 
interakció alakulhat ki az eltérő társadalmi csoportok között, így e területeken a szuburbanizáció néhány negatívtársadalmi következményeivel hatványozottan kell számolni.

Ahol a jó keresetü, magasan kvalifikált lakosok migrációja jelentős ott megindul a korábbi lakosság kiszorulása a területről. Ennek következtében, az ingatlanárak és a megélhetési költségek növekedésével a szuburbia legkülönbözöbb pontjairól szorulnak ki lakosok az olcsóbb külterületekre. E mozgások rendszerint szektorális jellegűek, egy-egy egyéb belterületről vagy külterületről a közeli külterületekre, vagy a dinamikus szuburbán településeken túli, kevésbé felkapott területekre szorulnak jellemzően sugárirányban.

A lakóhelyváltások jelentős része nem jár együtt a lakóhely minőségi változásával (16. ábra, 4.), az életmód módosulásával, hanem családi vagy más magánéleti változáshoz (házasság) köthetők, ezáltal e rövid távú érintőleges migráció motivációi és hatásai eltérőek a szuburbanizációtól. E költözések azért is elkülönülnek a szuburbanizációtól, hogy a költözés motivációiban az életmód vagy lakóhelyváltás nem elsődleges és vegyesen zajlanak a különböző adottságú lakóhelyeken.

$\mathrm{Az}$ ország perifériáiról (földrajzi és szocioökonómiai értelemben egyaránt) jellemzően az átlagos, vagy rosszabb adottságú területeire irányul, kivételt ez alól az egyes foglalkoztatók (üzemek, ipari parkok) mellett lévő külterületek, ahol a szakképzettek előszeretettel költöznek a rövid ingázási távok miatt, illetve esetenként szolgálati lakások is lehetnek itt. A kevésbé vonzók egy része a városból kiszoruló és az ország perifériáiról érkező elesett, a saját sorsuk jobbításáért önerőből tenni nem képes csoportok szegregátumaivá válnak.

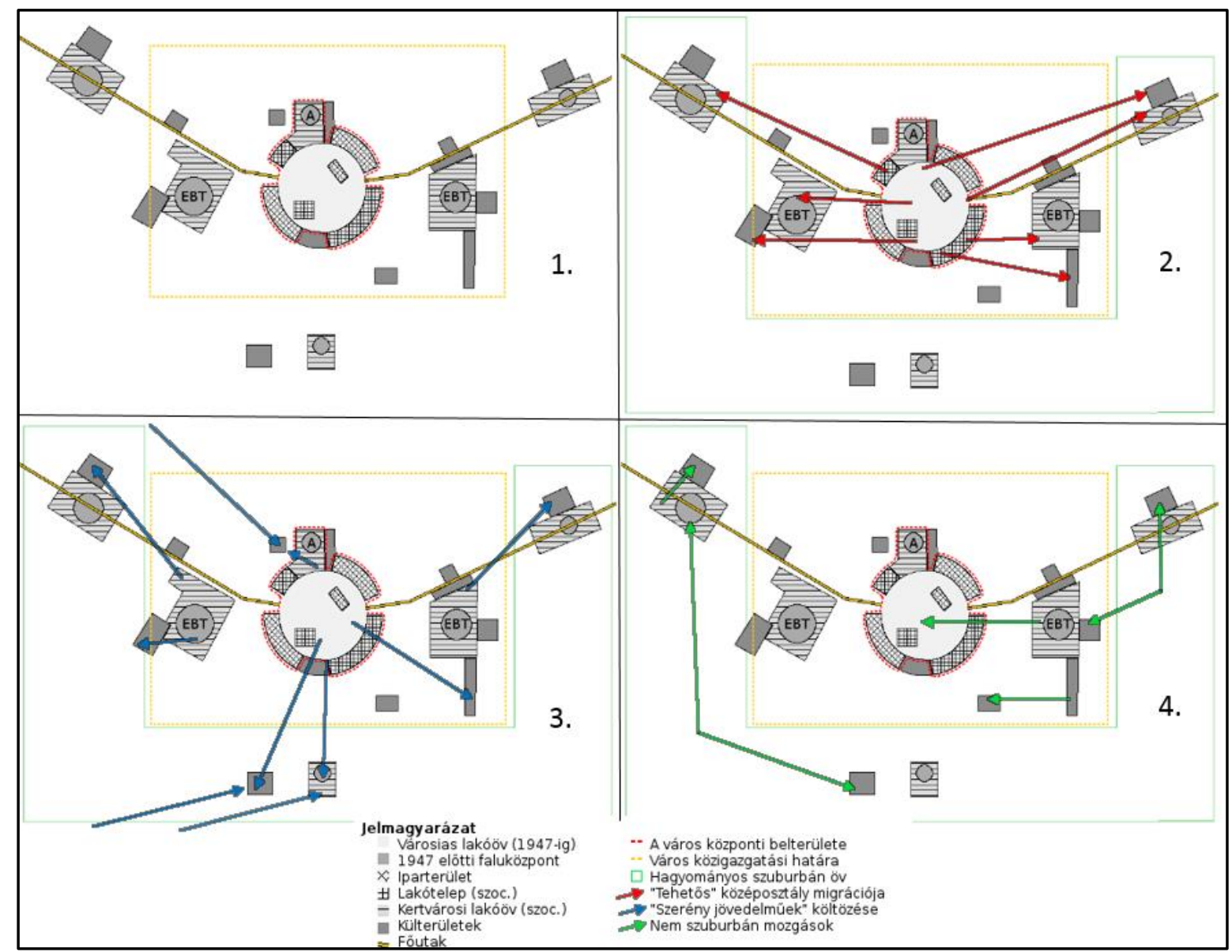

16. ábra: A hazai városok szuburbiáit meghatározó részfolyamatok térbelisége (Saját szerkesztés).

A mintaterületek empirikus felmérése alapján megállapítható a fenti mozgásformák aránya. A klasszikus szuburbanizáció a lakosok 49\%-át érintette ebböl 16\%-uk kimondottan életmódváltás céljából váltott külterületre. A szegények kiáramlása és kiszorulása 15\%-ot tett ki, további 13\%- 
az ország perifériáról történő beáramlás $10 \%$-ot, az érintőleges migráció 13\%-al részesedett. Ez természetesen területenként és időben is változó arányokat jelenthet.

A komplex, mozaikos és fragmentált térszerkezetet (17. ábra) kialakító folyamatok jelentős része a hivatalos statisztikában nem jelenik meg, mert az nem jár a közigazgatási határok átlépésével, illetve a magváros adatai között jelenik meg, így nehéz eldönteni, hogy a népességnövekmény mekkora része származik reurbanizációból, vagy szuburbanizációból. Mozaikosan jelennek meg fejlődő, hanyatló és elnéptelenedő területek, valamint ipari övezetek, így a keno-kapitalizmus elméletéből következő randomitásnak megfelelöen a teljes város-vidék peremzóna jellemzőjévé válik.

A külterületek általános is átalakulása számos módon mehet végbe, ez további komplexitást okoz a város-vidék peremzónák területén. Bizonyos területek, zónák külterületein teljesen kimaradhatnak a folyamatból, megmarad eredeti lakosságuk, vagy elnéptelenedve kezelendő felhagyott területté válnak. Ennek hátterében a közlekedési árnyékzóna-jelleg mellett környezeti hátrányok (regionális hulladéklerakó, dögkút) és kedvezőtlen önkormányzati politika egyaránt állhat. Más helyszíneken a lakott külterületi helyek átalakulását egy-egy felkapott lakóterület, üdülö, infrastrukturális fejlesztés, vagy nagyobb foglalkoztató nyitása tágabb körben megemelheti (Győrszentiván melletti külterületek, Újszeged környezetének külterületei).

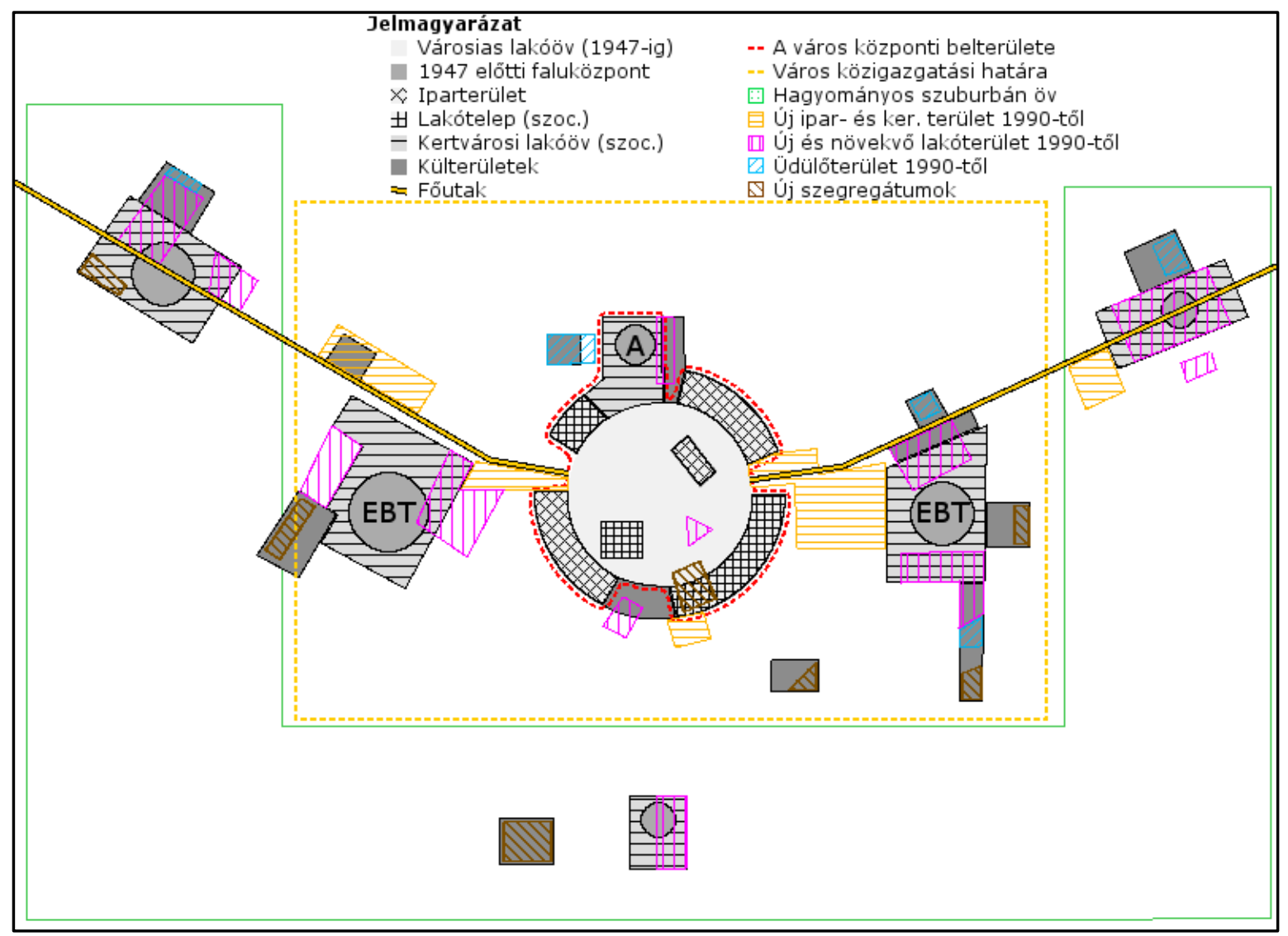

17. ábra: A vidéki szuburbanizáció mozaik-modellje. A külterületekre és egyéb belterületekre irányuló migráció hatása a magyarországi közép- és nagyvárosi szuburbiák térszerkezetére (Saját szerkesztés).

A jobb adottságú külterületekre az elérhetőségtől függő mértékben kötöznek be a tehetős életmódváltást kívánó lakosok és kevésbé elesett városból kiszorulók, valamint azok a vidékről beáramlók, akik meg akarják őrizni korábbi rurális életmódjukat. $\mathrm{E}$ részfolyamat történhet a külterületi ingatlanállomány megújulásával és lassú cserélődésével, vagy a külterület zöldmezős jellegü bővítésével. A jó adottságú, de nehezebben megközelíthető külterületekre jellemzően az elzárkózni vágyók, idősek költöznek, illetve üdülőterületté alakulnak. 
A városok peremén a közigazgatási hatás külső és belső oldalán gyakoriak a legvegyesebb összetételű területek, növekvő népességgel. A centrumtól távolodva egyre homogénebbek az egyes külterületen belül meglévő társadalmi és településszerkezeti adottságok, azonban az ilyen lakott helyek közötti differenciálódás egyre élesebb. Főutak mentén akár $30 \mathrm{~km}$ távolságig is kiterjedhet a külterületek dinamizálódásának határa, melyben döntő a szuburbanizáció szerepe (Sándorfalva-Kővágószőlős, Tényő-Táborvölgy). Ezzel szemben a közlekedési árnyékzónákban és zsákfalu-jellegü lakóhelyek esetében jelentősen rövidül az a táv, amíg jellemző a folyamat.

A leginkább kiépülő és a magtelepülésböl jól elérhető külterületek egy része fejlődése egy pontján belterületté lesz nyilvánítva, amennyiben a genetikus adottságaiból adódóan erre alkalmas. A külterületek ritkább esetekben - különösen a periurbán utcák - közvetlenül a központi belterület részévé válnak, amikor eléggé kiépülnek és/vagy a település egybefüggö beépített területe „utoléri” őket.

Az egyéb belterületek a külterületek és a közigazgatásilag önálló szuburbán községek között helyezkednek el infrastruktúrájukat és településképüket tekintve. A legfejlettebb, külterületekből régebben átalakult, valamint közigazgatásilag önálló falvakból létrejött egyéb belterületek lakosságának demográfiai összetétele közelíti a szuburbán gyürü átlagát, míg a kisebb, külterületekből átsorolással létrehozott újabb területek attól lényegesen elmaradnak.

Emellett az agglomerációkon belül számos olyan migrációs folyamat zajlik, amely nem kötődik közvetlenül a szuburbanizációhoz, mivel vagy nem jár az életmódváltással, vagy a motivációi ettöl függetlenek. Ilyenek az olyan külterület-külterület falu-külterület, falu-falu, város-külterület mozgások, amelyek például házasság, munkahelyváltás vagy más életesemény miatt történnek. Mivel e mozgások átlépik esetenként a közigazgatási határokat statisztikai megközelítésben re- és szuburbanizációként is értelmezhetőek. Továbbá a szuburbanizációval ellentétes folyamatok (város rehabilitáció, ellenurbanizáció) is jelen lehetnek.

A külterületekre irányuló szuburbanizáció fontos jellemzője a tervezettlenség és irányítatlanság. A laza szabályozás és a számos engedélyezetlen építkezés miatt, amely növeli az örökölt, vegyes településkép okozta kaotikus jelleget. Az egyes utcák és utcarészek merőben eltérő településképet mutatnak, nem alakul ki egységes megjelenésü utcafront. Ennek következtében a legkülönbözőbb funkciók és társadalmi csoportok jelennek meg egymás mellett a térben, ezáltal egy rendkívül fragmentált térszerkezet alakul ki. A kis távolságban megjelenő eltérő érdekü csoportok jelenléte pedig tartósan konfliktusokkal átitatottá teszi a közösség életét, így e területek a város-vidék peremzónák elméletében leírt gyorsan változó, konfliktusokkal terhelt térszerkezeteként értelmezhetőek.

Az önkormányzatok e jelenségeket nem tudják kezelni, mert egyrészt anyagi lehetőségük nincs rá, másrészt már a problémák teljes körü felméréséhez sincs elegendő információjuk a helyi lakosok beletörődő elzárkózása és a statisztikai adatbázisok hiánya miatt. Ezért a településföldrajznak kitüntetett szerepe lehet a külterületi szuburbanizáció számos előnye ellenére elhúzódó fennálló konfliktusok megoldását célzó gyakorlati beavatkozások megalapozásában.

A feltárt részfolyamatok és térszerkezeti elemek e sematikus ábrán elkülönítve jelennek meg, azonban a települések adottságai és társadalmi-gazdasági jellemzői jelentősen változtatnak megjelenésükön. Egyes adott településegyüttesben a részfolyamatok közül több nem feltétlen jelenik meg, míg a különböző elemek jelentősége eltérő lehet. Ebből kifolyólag a modell nem alkalmas konkrét területi egységek várható fejlődésének előjelzésére, azonban segít bemutatni, hogy az önkormányzatok milyen társadalmi-települési folyamatokat kénytelenek kezelni.

A modell egyben segít feloldani azt a paradoxont, hogy beszélhetünk-e településhatáron belüli szuburbanizációról. A települési szint léptékéből kiindulva e folyamat, mivel alapvetően követi a szuburbanizációt mozgató motivációkat és feltételeket egyfajta szuburbanizációt helyettesítő folyamatként értékelhetjük, akárcsak a szocialista érában a városok az üdülőtelkekre történő időszakos kitelepülést. A városok hegemón vonzáskörzetének falvai esetében pedig egyértelmüen szuburbanizációként tekinthető azok külterületeire történő migráció. 
Amennyiben a lakók szemszögéből vizsgáljuk a folyamatot, a városok peremein lévő külterületeket és egyéb belterületeket az életmóddal, településkörnyezettel és közösséggel szembeni elvárásaikat kell összevetni, ha el kívánjuk határolni szuburbanizációt az egyéb folyamatoktól. A városból kiszorulók és az átlagos keresetüek számára a külterületek és azokból létrehozott egyéb belterületek a szuburbiák szerepét töltötték be a lakók szemszögéből, csupán a várostól való relatív távolságot itt a földrajzi távolság helyett a lakott helyek fejlettségi hierarchiájában az urbánusból a rurális tér irányába történő elmozdulás jelenti. A város közigazgatási határa mentén elterülő minden külterület így értelmezhető egyfajta rurális zárványként, amelynek településföldrajzi adottságai megfeleltethetök a város-vidék peremzónában a várostól valamilyen távolságban megtalálható egy-egy falu központi belterületének. Tehát a legjobb adottságú egyéb belterületektől a rossz adottságú külterületekig haladva az infrastruktúra úgy változik, mint a szuburbán községektől indulva a távoli vidéki aprófalvakig.

E szempontból e területek fejlődésében tehát jelentős, de nem kizárólagos tényező a szuburbanizáció, a reurbanizáció, a vidékről történő beáramlás, és az egyéb részfolyamatok mellett. A városok peremterületein található külterületekre és a belölük kialakított egyéb belterületekre tehát egyfajta átmeneti területként tekinthetünk a szuburbán öv és a városi területek között, ahelyett, hogy éles választóvonalként értelmeznénk az adminisztratív településhatárt.

A folyamatok részelemei összességében tehát a közigazgatási határokon átnyúló, esetenként a települési szint alatt is diverzifikáló térstruktúrákat alkotnak. Ugyanakkor a hazai agglomerációk és településegyüttesek esetében legfeljebb formális egyeztetés figyelhető meg, a tervezési és rendezési kompetenciák a települések szintjén vannak és az önkormányzatok nem hangolják össze lépéseiket (BALogh P. 2013, Csizmadia Z. 2010, LuX G. 2012, SomlyódyNÉ PfEIL E. 2010, SOMLYÓDYNÉ PFEIL E. 2012, SUVÁK A. 2012A). Célszerü lenne a közösségi terek kiépítése, a zöld felületek védelme, a gyalogos-, kerékpáros és a tömegközlekedés fejlesztése. A szétterülö szuburbiák infrastrukturális fejlesztése és a szociális ellátó hálózat fenntartása érdekében szükséges lenne az adminisztratív (legalábbis az intézményi ellátási) határokat szükséges lenne a szuburbanizáció által átszabott valós települési folyamatokhoz igazítani (ANAS, A. - PINES, D. 2008, Dunay, A. et. al. 2001, Gant J. L. - Nelson A. C. 2014, SuvÁK A. 2012B, SzIRMai V. 2011A, ŹRÓBEK-RÓŻAŃSKA, A - ZADWORNY, D. 2016).

A fentiek alapján, az empirikus felmérés és a szakirodalmi megállapítások alapján lehetséges olyan, gyakorlatban használható ajánlások megfogalmazása, amelyek segíthetnek a külterületekre jellemző problémák és fejlesztési nehézségek legalább részleges feloldására.

- A jogalkotó részéről a termőföldek adásvételével és a földvédelemmel foglalkozó jogszabályok felülvizsgálata célszerü lenne. A jelenlegi szabályozás nagymértékben megnehezíti a külterületek fejlődését, a lakosság életvitelét a körülményes adásvétel és átsorolások révén. Mivel ma már e területeken a lakó és üdülőfunkció a domináns - a zártkerti ingatlanok kivonásához hasonlóan - gyorsított és egyszerüsített eljárást kellene bevezetni a KSH által követett lakott külterületeken és a termőfölddel nem rendelkezö tanyaingatlanok esetében. Ez egyben az önkormányzati beavatkozások kivitelezését is jelentősen gyorsítaná, olcsóbbá tenné.

- Célszerü lenne felülvizsgálni a külterületek közigazgatási besorolását és azon lakott helyeket átemelni, amelyek egyértelmüen másik község központi belterületéhez vonzódnak. Ennek azonban jelentős akadálya, hogy számos önkormányzat érdekeit sértheti egy ilyen beavatkozás, ezért legfeljebb hosszú távú célként tüzhető ki ez.

- Jogalkalmazói és önkormányzati oldalról a rövid távú beavatkozások akkor hatásosak a mintatelepülések tapasztalatai szerint, ha a közösséget bevonják a tervezésbe és kivitelezésbe. A közösségi szellem és a részvétel élménye megnöveli az elköteleződésüket a tartós fenntartásban. Mindemellett az önkormányzat számára is szolgálhat tapasztalatokkal a külterületi lakosok sajátos nehézségeiröl. 
- A külterületek akkor tudnak sikeresen funkcionálni, ha megfelelö közösség alakul ki, amely nem csak segíti tagjait, de az elvárásaikat és igényeiket is hatékonyabban tudja kommunikálni a település vezetői felé. A tapasztalatok alapján erre leginkább a lakosság bevonásával végrehajtott fejlesztések, akciók alkalmasak, valamint a külterületeken megszervezett falunapjellegü összekovácsoló rendezvények. Emellett célszerü a hivataloknak és különösen a szociális ellátásban dolgozók kitelepülésével legalább időszakosan (havonta) lehetővé tenni a helyben történő ügyintézést, vagy legalább informálódást a külterületek központi pontjain.

- Költséges infrastruktúra-beruházások helyett lokális problémák kezelése is eredményes alternatíva lehet. A aszfaltozás helyett sok esetben elégséges lehet az utak tömörítése és kaviccsal való felszórása, amelynek fenntartására a közösség hajlandó lesz a szeged-környéki tapasztalatok szerint. Legalább a fő közlekedési csomópontokban és buszmegállóknál szükséges a közvilágítás megoldása és zebrák létesítésé, így kis befektetéssel is jelentősen javítani lehet az ott élők életfeltételeit, elégedettségét. Szükséges a növényzet időszakos nyesése, vagy a lakók erre kötelezése, az átjárhatóság (mentők, tüzoltók!) biztosítására.

- A fragmentált és illegális építkezések miatt sokszor kaotikus településkép nehezen kezelhető kérdés, melyre jelenleg nincs megfelelő módszertan és jogi háttér. Ennek ellenére a nehézségek utcaszélesítésekkel, kitérook kialakításával, valamint az elhagyott és romos ingatlanok kényszerbontásával könnyíthetőek lennének. A jelenlegi építési szabályozás már reálisan követi a külterületeken élök igényeit és lehetöségeit, ezért törvényi módosítás nem szükséges, azonban a betartatáshoz a hivataloknak biztosítani kell a szükséges támogatást.

- Az országos és helyi fejlesztési tervek készítésében nagyobb hangsúlyt kell helyezni a települési szint alatti különbségek tárgyalására. A városok fejlesztési terveiben szükséges lenne külön kitérni a külterületekre vonatkozó sajátos problémafeltáró elemzések és fejlesztési tervek elkészítésére. Szükséges adatbázis hiányában azonban jelenleg nincs meg ezen elképzelés technikai háttere, amelyet a KSH tudna biztosítani, a települési szint alatti téregységekre vonatkozó statisztikai adatbázis publikálásával.

- A külterületek pontos jellemzőinek, népességének (bele értve a kétlakiakat) általános felmérése országos szinten indokolt lenne, mert a meglévő népességszámok az illegális építkezések, és be nem jelentett költözések révén alulbecsülik a népességet. A megfelelő országos adatbázis hiánya nem csak a megfelelő tudományos elemzéseknek gátja, de a konkrét településfejlesztési programozási és tervezési tevékenységekben is jelentős nehézséget jelent. E felmérés során célszerü lenne lokális helyismerettel rendelkező szakértők (például tanyagondnokok) bevonása. Ez egyben az engedély nélküli építkezések, át nem jelentkezett lakók és a kétlakiak számának felmérésével lehetővé tenni a külterületek részesedésének pontos felmérését az országos demográfiai és településfejlödési folyamatokban. 


\section{ÖSSZEGZÉS, A DISSZERTÁCIÓ TUDOMÁNYOS EREDMÉNYEI}

Disszertációmban arra vállalkoztam, hogy megvizsgáljam a külterületek hazai vidéki közép- és nagyvárosi szuburbanizációk fejlődésében betöltött szerepét, az itt zajló társadalmi átalakulását meghatározó tényezőket, összevessem azokat az elővárosi fejlődés nemzetközi szakirodalmában feltárt folyamatokkal. Célom volt továbbá meghatározni a szuburbanizáció társadalmi és környezeti hatásainak következményeit a helyi közösségek müködésére és a külterületek genetikus adottságaiból adódó településszerkezetére.

Céljaim eléréséhez a szakirodalom feltárásán túl statisztikai adatelemzést, lakossági kérdőívezést, interjúkat, telektipizálást és fotódokumentáció-elemzést használtam fel. A föbb részfolyamatok megadása mellett a disszertációban felvázoltam a különböző külterületek fejlődési útjait, modelleztem a kialakuló térszerkezetet, amely segíthet a jövőben kijelölni az érintett területek fejlesztésének lehetséges irányait.

$\mathrm{Az}$ értekezés öt átfogó kérdését az első fejezetben határoztam meg, az egyes kérdésekhez kapcsolódnak a konkrét kutatási célok. A kérdésekre kapott válaszokat és a célok teljesítése során elért új tudományos eredményeket a következökben foglalhatjuk össze:

- Az értekezésben szakirodalmi összevetés és statisztikai adatelemzés révén a külterületek általános értelmezési lehetőségeit, valamint a kutatási előzmények szintetizálásával elkészítettem a külterületek átfogó tipizálási keretét (3. fejezet). E fejezetben indokoltam a külterületek általános és típusonkénti specifikus vizsgálatának szükségességét, feltártam az egyes típusok kialakulását és településföldrajzi sajátosságait. A típusok összehasonlításával kiemeltem a települési szint alatti vizsgálatok szükségességét a recens folyamatok feltárásában.

1. Disszertációm fó kérdése az volt, hogy a külterületekre irányuló szuburbanizáció miben különbözik motivációit tekintve a településekre irányuló általános kiköltözésektöl?

- A külterületi szuburbanizáció fő mozgatója, hogy a lehetővé teszi számos olyan háztartás életmódváltását, amelynek nem lenne lehetősége ezt a szuburbán gyürü ingatlanpiacán megvalósítani. Kisebb anyagi áldozatok és ingázási időveszteség révén képesek elérni azt a vidékies, csendesebb életmódot, vagy épp fenntartani egyfajta presztízst, mint ha a szuburbán gyürü távoli, olcsóbb településeire költöznének. Mindemellett a rurális jellegü közösségek számos előnye (többek között az erős reciprocitás, tradicionális értékrend) elérhető itt, még akkor is, ha számos konfliktust és nehézséget kell cserében elszenvedniük.

A dolgozat további fő és alkérdéseire adott válaszok alapján e kép tovább bontható:

1/I. A lakott külterületeken milyen társadalmi és területfelhasználási változások zajlanak a szuburbanizációs folyamat során?

- Az empirikus vizsgálat eredményei alapján, a külterületek a szuburbán lakhelyválasztók jelentős részét vonzzák az ország nagy- és középvárosi település-együtteseiben, ennek köszönhetően a külterületek részesedése a népességből 1990 óta stabilan nő. A KSH által lehatárolt vidéki településegyüttesek és agglomerációk többségében jelentős volt a külterületekre áramlók aránya és számos település esetében a teljes népességnövekmény külterületekre irányult. Népességvonzó erejüket a relatíve alacsony telekárak és megélhetési költségek biztosítják különösen, ha bizonyos presztízsszint biztosítását a táji és településszerkezeti adottságok lehetővé tetszik.

- A külterületek különböző típusainak differenciált átalakulása hozzájárul a nagyvárosi térségek fragmentálódásához. Sikerült feltárni a kelet-közép-európai és hazai lakóhelyi szuburbanizációs folyamatok különbségeit, és a külterületekre irányuló mozgások sajátosságait. Az eredmények bizonyítják, hogy a külterületi szuburbanizáció jelentősen különbözik a központi belterületre irányulótól több szempont szerint is. Az általam feltárt jelenségek, nem mondanak ellent az általános szuburbanizációnak, hanem az kiegészítik, továbbá sokszor ellentétes hatású részfolyamatok zajlanak, ezért az összkép, a statisztika elfedi a folyamat egyes részeit 
- Jelentős különbség, hogy a laza szabályozás és az illegális építkezések, valamint a szocializmus időszakából örökölt rossz térszerkezet miatt a folyamat tervezetlenül és ellenőrizetlenül zajlott. Rendkívül fragmentált térszerkezet alakul ki, amelyben markánsan különböző szocioökonómiai státuszú csoportok és területhasználati formák jelennek meg. Ennek köszönhetően nincs egységes településkép, az infrastruktúra állapota még egy lakott külterületen belül is jelentősen különbözik.

- A tervezettlenségből fakadó változatos formák miatt a külterületeken a fejlesztés nagy nehézségekkel járó folyamat, amelynek kezelésére az önkormányzatok jelenleg nem rendelkeznek megfelelő eszközökkel, rutinnal és a törvényi feltételek sem állnak maradéktalanul rendelkezésre. További probléma, hogy az engedély nélkül készült épületek száma és a be nem jelentett beköltözések miatt a KSH népszámlálási adatai gyakran jelentősen eltérnek a valós értékektől. A külterületek népességszáma több esetben jelentősen meghaladja a statisztikai értéket, vagy épp messze elmarad attól, ami tovább nehezíti az önkormányzati munkák és feladatellátás előkészítését.

- A posztszocialista országok tendenciájába e folyamat alapvetően beilleszkedik, ugyanakkor eröteljes tervezetlenségében, a kialakuló kaotikus és mozaikos térszerkezetben valamint a városból kiszoruló elesett csoportok nagyobb arányában tér el azoktól.

- A külterületek népessége pontosan nem ismert, az empirikus tapasztalatok alapján a helyben lakók száma akár 20\%-al is magasabb lehet, mivel sokan nem jelentik át lakcímüket életviteli okokból, vagy az illegális építkezések miatt. Emellett nagy számú kétlaki egyén tölti az év legalább felét e lakóhelyeken, valamint számos külterületen illegális lakásfoglalók is jelen vannak. Továbbá a kutatás során két, hivatalosan nem követett, lakott külterületet találtam. Ez alapján a külterületek szerepe a hazai belső migrációban lényegesen nagyobb lehet, mint ami a jelenleg elérhető statisztikai adatokból tünhet.

Második kérdésemben azt vizsgáltam, hogy a lakott külterületek hogyan tipizálhatóak, az eltérö típusok között van-e kimutatható különbség a szuburbanizációs folyamat jellegét illetően

- A harmadik fejezetben a szakirodalmi elözmények szintézisével elkészítettem a hazai külterületek tipizálására alkalmas keretet, amely alkalmas a külterületek településföldrajzi jellemzői szerint csoportosítani a külterületeket. Ennek során sikerült feltárni, hogy a különböző genetikájú külterületek településföldrajzi adottságai jelentősen eltérnek. A szórvány jellegü tanyáktól jelentősen különböznek az átmeneti településtípust alkotó majorok és szőlőhegyek, valamint a zárt települések irányába elmozduló zártkertek között. Ebben az infrastrukturális ellátottság, az ingázási távolságok, valamint a közösség müködését segítő interakciók gyakorisága jelentős differenciáló tényező.

2/I. A különbözö külterületek milyen szempontok alapján vonzották a különbözö társadalmi csoportokat?

- Az egyes különböző típusú külterületek eltérő társadalmi csoportokat vonzanak, amiben az elérhetőség és az infrastruktúra állapota meghatározó. Mivel az egyes külterületek különböző adottságú részletei különböző társadalmi csoportokat vonzanak egyszerre jelentősen eltérö szocioökönómiai státuszú háztartások migrálnak az elöregedő helyi lakosság mellé. Ebben döntő tényező az elérhetőség, az infrastrukturális állapot, a külterület tipológiájából fakadó térszerkezet (szórványjelleg vagy zárt utcakép), az ingatlanállomány összetétele, valamint a táji szépség.

- A külterületek népességét négy fő csoportra oszthatjuk, első a tehetősebb beköltözők tömege, a második a vidékröl bevándorló és a városból kiszoruló alacsonyabb szocioökonómiai státuszúak közössége, a harmadik a rendszerváltás óta helyben lakók és itt születettek csoportja, végül a csak hobbikertet tartók kisebb köre. E négy csoport rendkívül eltérö jellemzőkkel bír és még a csoportokat is eltérő státuszú egyének és családok alkotják. E csoportok egyben - saját élethelyezük és életmódjuk miatt - igen eltérő elvárások és remények miatt választották a külterületeket. 
- A külterületek közül a zártkertek és zártkertesedő szőlöhegyek, üdülők és tanyabokrok jelentősége a legnagyobb a szuburbanizációban. Ezek a lakóhelyváltók számos csoportjának igényeit tudják kielégíteni alacsony ingatlanárak és viszonylag zártabb, falusias településkép mellett. Az önkormányzatok szemszögéből is e típus az előnyös, mert koncentráltan, sok lakost érintő (ezért arányában költséghatékonyabb) beavatkozásokkal fejleszthetők. Így a legnagyobb népességnövekményt e területek érték el és gyakori a belterületbe vonásuk.

2/II. Ennek következtében milyen sajátos társadalmi rétegzödés alakult ki és milyen sajátosságokat mutatnak a demográfiai változások?

- A jó adottságú zártkertek, szőlőhegyek, üdülők és periurbán utcák leginkább az életmódjukat javítani szándékozó városból kiköltözőket vonzották, e területeken így fiatalosabb, iskolázottabb és jobb keresetü csoportok költöztek be. Fő vonzerejük az, hogy egyfajta csendes vidéki idillt képesek biztosítani a kiköltözőknek viszonylag kis ingatlanárak mellett. $\mathrm{E}$ területeken általánosan megindul a zártkertesedés és idővel falusiasabb településkép kialakulása is megindulhat. Ezért ma már általánosan nem különülnek el e külterülettípusok élesen azonban a nagyobb méretü zártkertek és szőlőhegyek a leginkább vonzók a szuburbán lakosság számára kedvező településszerkezeti adottságaik miatt.

- A majorok, rosszabb elérhetőségü zárkerti területek és szőlöhegyek esetében leginkább az ingatlanok olcsósága és az alacsony megélhetési költségek a döntő tényezők az ide költözők választásában. A majorok az utcaszerkezet hiánya és a soklakásos ingatlanok miatt a legkevésbé attraktívak, ugyanakkor ezen olcsó házak újrakezdési lehetőséget biztosíthatnak a szociálisan rászorultaknak különösen, ha kialakul egyfajta reciprocitáson alapuló helyi közösség. A tanyavilágban heterogén, mozaikos kép alakult ki, amiben a buszmegállók és főbb közlekedési útvonalak elérhetősége mellett több környezeti elem, különösen a belvízkérdés döntő jelentőségü. E típusok tehát jellemzően a város felé igyekvő és az onnan kiszoruló szükösebb anyagi hátterü lakosság számára biztosítanak lakóhelyet, vagy a kimondottan elzárkózni szándékozó életmódváltóknak nyújtanak lehetőségeket.

A lemaradó, népességüket elvesztő külterületek hanyatlásának oka a gyengén kiépített infrastruktúra, az olyan szolgáltatások, mint a szemétszállítás hiánya, valamint a lakosság és az ingatlanok elöregedése. Különösen az elzártság miatt nem kedvezőek a lakóhelyet választó családoknak a főbb közlekedési útvonalaktól távol eső egységek, így a beáramlás legfeljebb kényszerü beköltözésekre korlátozódik.

- Az egyéb külterület típusokra inkább a stagnálás és lassú hanyatlás, a népesség erőteljes elöregedése a jellemző. A külterületeken müködő szociális intézmények jelentősen tudják növelni a lélekszámot, azonban jellemzően a külterületi lakosok szakképzettség hiányában nem tudnak ezekben dolgozni és csak felszínes kapcsolatok vannak az itt élőkkel. Mára az üzemi jellegű lakóhelyek és őrházak jelentősége lecsökkent, egy részük a technológiai fejlődés feleslegessé vált és elöregedő lakossággal rendelkeznek. Az egy-egy lakásból álló dűlőkőn található új lakóingatlanok, az út- és gátőrházak, valamint a korábbi üzemi lakóhelyek sorsa hektikusan alakul, addig megmaradnak, amíg az ott élők számára a megélhetést a gazdasági funkció biztosítja. Szintén külső hatások - adminisztratív döntések - határozzák meg a különböző intézmények lakóinak számát, e téren jelentős változások nem valószínűek.

Harmadik kutatási kérdésem részelemei során azt vizsgáltam, hogy a szuburbanizációs folyamatok hogyan hatottak a közösségek összetételére, a társadalmi kapcsolatok rendszerére?

- A heterogén összetételü, de közeli ismeretségre és reciprocitásra alapozó külterületi közösségek müködését a jelentékeny fluktuáció károsan befolyásolja. Mivel a beköltözők életmódja különbözik a helyi lakók érdekeitől állandósulnak a konfliktusok, ami a társadalmi csoportok elkülönülését okozza. A szegregációt fokozza, ha a külterületre beáramló nagyszámú tehetős felveri az ingatlanárakat és a közmüfejlesztések növelik a megélhetési költségeket, mert ilyenkor megindul az elesettek kiszorulása. 
- A beköltözők a helyiek elvárásaival gyakran ellentétes irányba, a saját igényeik által teremtett vidékképhez kívánják alakítani a külterületet jobb érdekérvényesítő képességük révén. Ezen ellentmondások nem csak a területi tervezést nehezítik meg, de a területi egységek spontán fejlődését is lassítják és számos konfliktust generálnak.

3/I. A kialakuló konfliktusok milyen módon hatottak az életminöségre, milyen kritikák fogalmazhatóak meg az átalakulás társadalmi-gazdasági hatásait illetöen?

- A külterületeken a szegregáció alakulása a folyamat elörehaladtával kettősséget mutat. Az egyes külterületeken belül több különböző társadalmi csoport rendszerint elszórva jelenik meg. Azonban az egyes külterületek gyakran idővel felkapottá válhatnak és ilyenkor gyakran közel azonos státuszú háztartások költöznek be, különösen mivel a személyes ismeretség szerepe nagy a lakóhelyválasztásban. Ilyenkor az eredeti helyi lakosság kiszorul a területről vagy csak a legrosszabb állapotú épületekben maradnak meg, ami tartós konfliktusforrást képez.

- A különböző területi igazságtalanságok és az eltérő életvitelek ütközései számos súlyos konfliktust generálnak, melyek megoldására a fluktuáció és az eltérő érdekek miatt a közösségek nem képesek. Az új beköltözök integrálódása a közösségbe gyakran 10 éves időszakot is felölelhet, ugyanakkor a fluktuáció olyan magas sok területen, hogy a beköltözök válnak többséggé és a helyiek kerülnek alkalmazkodási kényszerbe.

- A felvázolt nehézségek és konfliktusok ellenére azonban a lakosok többsége szeret a külterületeken élni, nem szeretne elköltözni. Ennek oka, hogy a közösségek részcsoportjai jól müködően képesek megszervezni életmódjukat és a kiköltözéskor az előnyökért bizonyos hátrányokat tudatosan vállaltak a lakók, sokuk pedig e konfliktusokat kevésbé érzi megterhelőnek, mint a városi lét problematikáit. Sajátosak még azok a zárt közösségek, amelyek a félreeső és leginkább a társadalom perifériájára szorultak által lakott külterületeken alakulnak ki, ugyanis az erős egymásra utaltság miatt olyan közösségek alakulhatnak ki amelyek aktivizálják a helyi közösséget és lehetővé teszik az életvitelüket megkönnyítő összefogást, reciprocitást, viszont anyagiak terén külső forrásokra utaltak.

3/II. A helyi infrastruktúra helyzete, a tájkép és a mezögazdaság fennmaradása mennyire biztositott? A dinamikus átalakulásból fakadó károsodásai, vagy örökölt hiányos jellege milyen hatással van a lokális társadalomra?

- Az elmúlt évtizedek változásai során a mezőgazdaság szerepe csökkent a külterületi közösségek életében. Az ingázás miatti időveszteség révén a beköltözőknek nincs ideje a kertgazdálkodásra, míg az idős helyeiknek pedig egészségi állapotuk jelent akadályt. A nagyobb léptékü gazdaságok - a tanyák kivételével - általában nem a helyben élő és anyagi forrásokkal csak szükösen rendelkező gazdák tulajdonát képezik, legfeljebb kis intenzitású háztáji termelést végeznek. Fontos kiemelni, hogy erre a jelenségre a jogalkotó is felfigyelt és megkönnyítette a zártkerti jellegü külterületek müvelés alól történő kivonását.

- A leginkább dinamikusan átalakuló külterületeken az ingatlanállomány és a lakosság jelentős része kicserélődik, a korábbi kertes területhasználat átalakul, így a külterület, mint történelmileg kialakult települési forma megszünik létezni, csak a helye kerül újra hasznosításra. A kevésbé jó elérhetőségü, de lakóhelyileg vonzó településképü külterületeken jellemző a vegyes átalakulás, mely során a tehetősebbek beköltözése mellett megjelennek az ország perifériájáról érkező és a városból kiszoruló hátrányos helyzetű háztartások, valamint az egyéb funkciók (ipari telephelyek, mezőgazdaság) is.

- A jól elérhető, de kedvezőtlen táji adottságú vagy ingatlanállományú külterületeken általában az eredeti területhasználat helyét vagy az ipari funkció veszi át, vagy zöldmezős jellegü ingatlanfejlesztések révén új lakóhelyként születnek újjá. A legkevésbé vonzó külterületeken a szegény lakosság koncentrálódása, vagy az elnéptelenedés vezet a gyors hanyatláshoz, amelyet sokszor az ipar és a mezőgazdaság által okozott környezeti károk fokoznak.

- A rossz elérhetőség és a szolgáltatások hiánya különösen az itt élő idősek és nők számára jelentenek kimagasló nehézséget a napi életvitelük fenntartásában. Ugyanakkor figyelembe 
kell venni, hogy az alacsony jövedelmüek számára ez az olcsó életvitel a túlélési stratégia részét képezi. Mivel a külterületek e csoportok számára bár rendkívül eltérő okokból, de továbbra is vonzóak további népességnövekedéssel kell számolni esetükben.

Végül arra kerestem a választ, hogy milyen módon hat a külterületekre irányuló szuburbanizáció a városi térségek térszerkezetére, van-e különbség a belterületekre és az egyéb belterületekre irányuló migrációban?

- Települési szint alatt vizsgálva szuburbanizációt a korábban önálló falvakból létrejött egyéb belterületekre és a községek központi belterületeire irányuló migrációs folyamatok megfelelnek a hazai városok elővárosi gyürüjének fejlődési tendenciáinak. A külterületekből létrehozott egyéb belterületek sajátosságai beépültségük függvényében a külterületek és a közigazgatásilag önálló községekre irányuló szuburbanizáció között helyezkednek el. Az egyéb belterületek tartósan hordozzák a külterületi örökségüket és csak hosszú idő elteltével válnak teljesen falusias lakóhellyé. Fontos kiemelni, hogy számos egyéb belterület fejlődése során nem is alakul át teljes terjedelmében, részben megörzi a külterületi előzmény településképét, társadalmát. Ezzel szemben a falvakból létrehozott egyéb belterületek analógiát mutatnak a ma is közigazgatásilag önálló szuburbán falvakkal, így a város adminisztratív határain belül is megjelennek a szuburbán övre jellemző településföldrajzi formák és társadalmi folyamatok.

- A 7. fejezetben elkészítettem egy sematikus térszerkezeti modellt, amely alapján bemutatható a város-vidék peremzóna sajátos fragmentálódása és mozaikos térszerkezetének kialakulása a hazai közép- és nagyvárosi térségekben. A modell szemlélteti, hogy a szuburbán fejlődés eltérö irányú és motivációjú részfolyamatai a közigazgatási határokon átnyúló, esetenként a települési szint alatt is diverzifikáló térstruktúrákat alkotnak. Ennek fó eredménye, hogy a külterületekre irányuló migrációk több eltérő részfolyamatra bonthatóak. A legjelentősebb a „klasszikus” szuburbanizációval analóg városból történő kiáramlás, valamint a szegények kiszorulása a városból. Emellett jelentős a periférikus rurális tájakról történő beáramlás, valamint a szuburbanizációtól alapvetően függetlenül zajló érintőleges migráció. Ezzel párhuzamosan a városból és a felértékelődő szuburbiákból kiszorulók a kevésbé előnyös adottságú területekre, így jellemzően a távolabbi falvakba és a hiányos infrastruktúrájú külterületekre. Mivel az egyes külterületeken és egyéb belterületeken belül számos adottságú területi egység található meg a térszerkezetben az egyes funkciók és az eltérő státuszú csoportok koncentrálódnak, ezáltal a térhasználat mozaikosabb és fragmentáltabb lesz, mint a központi belterületeken zajló szuburbanizáció során.

- A külterületek és azokból létrehozott egyéb belterületek a szuburbán gyürü külső, kevésbé felkapott településeinek funkciójával analóg szerepet töltenek be az agglomerációk fejlődésében. Rurális zárványként értelmezve e lakott helyeket a külterületek várostól való relatív távolságát a földrajzi disztancia helyett a lakott helyek fejlettségi hierarchiájában történő - az urbánustól a rurális irányba - vertikális elmozdulás határozza meg. Ezáltal átmeneti sávot képeznek a város peremén az szuburbán tér és a központi beépített terület között.

- E folyamatok jelentős része a közigazgatásilag önálló települések szintje alá nem lépő kutatásokban nem feltétlen mutathatóak ki, így a szuburbanizáció mikroszintü vizsgálatának fontosságára hívja fel a figyelmet az alkalmazott földrajzi kutatásokban. Továbbá figyelembe kell fenni a folyamat értékelésekor, hogy a külterület-állomány maga is dinamikusan változik, folyamatosan vonnak egyéb belterületi státuszba külterületeket, miközben számos egyéb belterületet emelnek a központi belterületbe, így az ide irányuló migráció jelentősége még az eddig bemutatottakat is meghaladhatja.

- Több hazai város (Zalaegerszeg, Hódmezővásárhely) esetében a szuburbanizációs jellegű népességmozgás teljes egészében a város statisztikai-közigazgatási határán belül maradt, hiszen a jól elérhetőségű nagyszámú falusias külterületi és egyéb belterületi lakóhelyek a városok peremein képesek voltak felvenni a költözni szándékozókat. A hazai agglomerációk és településegyütesek területén 393 település népessége nőtt, ebből 261 településen a növekmény 
részben, 53 esetben kizárólagosan külterületre irányult (egy részük idő közben egyéb belterületté lett átsorolva).

A témával kapcsolatos érdeklődésemet felkeltő kezdeti hipotéziseim a kutatás eredményei alapján relevánsak. Igaznak bizonyult első hipotézisem, miszerint a hazai szuburbanizáció fejlődésében a külterületek szerepe nagy, a közigazgatásilag önálló településekre irányuló migrációt kiegészíti, azonban a statisztikai sajátosságok miatt részben rejtve marad.

Második hipotézisem, melyben azt feltételeztem, hogy a különböző területeken, az eltérő adottságú külterületek jelenléte miatt a lakossági szuburbanizáció is eltérően, a helyi településföldrajzi adottságokhoz adaptálódva zajlik, szintén megállja a helyét. Ez egyben a külterületekkel kapcsolatos kutatások szakmai fontosságát emeli ki.

Végül igaznak bizonyult, hogy a lakott külterületekre irányuló szuburbanizáció a tervezetlen, szabályozatlan jellege miatt számos társadalmi konfliktussal jár, amelyek negatív hatással vannak a helyi közösségekre, ugyanakkor fontos kiemelni, hogy a lakosok többsége ennek ellenére szereti a külterületi életmódot.

Eredményeim alapján javasoltam a területfejlesztő szakemberek számára, hogy a helyi lakosság különböző csoportjait a szuburbán települések fejlesztési folyamataiba vonják be, mert elvárásaik és jövőképük jelentősen eltérő lehet a belterületeken élők véleményétől. E lakóhelytípus szuburbanizációja kiemelten terhelt konfliktusokkal, így a különböző genetikájú területi egységek csak sajátosságaik figyelembevételével fejleszthetőek sikeresen, amelyben kiemelt szerepet kell kapnia, hogy mérsékeljék a szuburbanizáció társadalmi, gazdasági és környezeti következményeinek hátráltató hatásait. Mivel a feltárt folyamatok nem igazodnak az egyes települések közigazgatási határaihoz feltétlenül a külterületek jövője szempontjából is előnyös lenne az agglomerációk intézményesülése és az önkormányzatok tervezési és üzemeltetési stratégiáinak összehangolása, egységesítése. 


\section{ENGLISH SUMMARY}

\section{The role of the residential suburbanization in the transformation of outskirts of Hungarian agglomerations}

In Hungary, similarly to other post-communist countries, suburbanisation significantly contributes (SZELÉNYI, I. 1996) to the changes in the settlement system (BAJMÓCY, P. 2003), the land use system and internal migration patterns (DÖVÉNYI, Z 2009). While suburbanisation received special attention in the literature of post-communist settlement geography, some of its subprocesses have avoided large-scale scientific interest (HARDI, T. 2012, KovÁCS, Z. 1999). This is especially true for the transformation and emerging problems of other inner areas and outskirts within the administrative borders of the city, which areas have drawn only limited attention so far compared to the suburbanisation of sovereign settlements (BALOGH, A. 2012a). In order to address this neglected issue, our present analysis focuses on the demographic processes, the changes in the local society and new problems and conflicts of these areas in four case study cities.

In our research we used the following definition of suburbanisation: the process of decentralization of urban population and activities, in the sense of a part of the population, the productive and non-productive activities, the capital and the investments concentrate into the settlements around the cities instead of the urban centres, regardless of administrative borders (BAJMÓCY, P 2014, OUŘEDNÍČEK, M. 2007, TIMÁR, J. 1999).

This definition implies that the interpretation of settlements can deeply influence the perception of suburbanisation. Due to of the special settlement system in Hungary a municipality can be divided into three parts, the central inner area (core city), other inner areas (incorporated settlements) and outskirts. Because of this system and special settlement network, the process of suburbanisation in Hungary has some unique characteristics. In this paper we examined the spatial structure and social properties of the rural-urban fringe of four Hungarian cities, with emphasise on the other inner areas and the outskirts. The outskirts are mostly scattered or interim habitations within the administrative limits of a city or village but these are usually separated from the main built-up areas and almost all of them characterised remote-rural-like infrastructure and way of life. This spatial structure resulted in the phenomenon of the suburbanisation within city limits.

The major part (94\%) of the population lives in the central inner parts of the settlements, but 3\% live at the other inner parts and 3\% at the outskirts (BAJMÓCY, P. - MAKRA, Zs. 2016). In addition to the statistically-existent villages there are a large number of ones attached to cities; most of them are within the area of settlements of agglomerations (TIMÁR, J. 1993). While very often there is no difference between the processes and characteristics of the other inner areas and the neighbouring administratively independent villages, most of the statistical data collection and analysis focuses on local administrative units only. As a result, a large part of the transformation of the rural-urban fringe remains unseen (BALOGH, A. 2012a).

The geographical, historical and social characteristics of the country brought a range of special inhabited outskirts into existence. The individualism, the mosaic spatial structure and the emergence of internal frontiers after the decay of the medieval village system all contributed to the formation of these scattered settlement types (CSAPÓ, T. - BALOGH, A. 2013).

The ,tanya" is the most distinctive form of outskirts, it is a scattered farm-like habitat connected to the shift from semi-nomadic cattle-breeding to farming activity. Because the Ottoman rule left a very sparse settlement network, it was necessary to establish a system of scattered settlements in order to cultivate the inner frontiers of the Great Hungarian Plain. Though it is a scattered settlement, it was formed as an integral part of the city, because its inhabitants were traditionally urban citizens with a house in the inner area (BALOGH, A. - CSAPÓ, T. 2013, BECSEI, J. 2010). They spent their summers on the tanya with agricultural activity, while they lived in their home in the city 
during the winters and their old age. This double residential pattern is the main characteristic of the tanya system (BECSEI, J. 2015).

The wineyards form a system similar to tanyas, but the houses much more densely located along ridges due to the characteristics of the grape cultivation. Buildings typically form a street-like line, but similarly to the manors, this is a transition type between scattered and nucleated settlements, with no enclosed core (Égetö, M. 2003). They have strong ties to the city, since most of the residents and owners are citizens of the nearby town (BALOGH, A. 2012a).

The manor is a hamlet-like small-scale settlement (Figure 2.) without administrative sovereignty which was originally established around a landlord's property (BALOGH A. 2012a). The estate consisted of a castle or mansion, some poorly constructed rowhouses for the workers and numerous large agricultural structures, but most of them are now in ruined condition. Typical population size ranged between 10 to 100 residents, and in most cases only agricultural and residential functions appeared in these settlements (PÓCSI, G. 2011).

Garden zones are traditional appendixes of the core inner area since centuries in Hungary. Unlike other outskirts, they are not separated from the inner areas by physical distance but by function and morphological characteristics. While originally built for small-scale agricultural purposes, during the development of the Hungarian towns of the past 100 years, these zones also provided habitat for the underclass, people dislocated from the city, and the unemployed ones migrating toward the centres from peripheries due to cheap plots, additional income from garden work and loose building regulations.

This research is based on a statistical analysis that used conventional social geographical methodology on the data from the general population censuses and additional HCSO (Hungarian Central Statistical Office) data. Based on the examination of population data and internal migration we selected four Hungarian cities as our case studies. Györ and Szeged are regional centres with a large number of outskirts and with some incorporated settlements, thus a significant part of suburbanisation remains within city limits. Hódmezővásárhely and Zalaegerszeg are cities with county rights, they have many outskirts with significant population, and suburbanisation has remained almost entirely within the administrative borders.

The detailed analysis of the sample areas consisted of three steps: survey, field examination and interviews. First we conducted a stratified systematic survey that involved 1200 households in the outskirts and another 600 in the other inner areas of the four towns. With this method, every fifth household of the sample areas was included in the survey. The first third of the questionnaires were asked data about housing and migration-related questions. It followed by questions about the various difficulties and social characteristics of the living space. In the last part we requested details about the demographic characteristic of the household. The participants also had the opportunity to formulate their own problems and expectations in the open-ended questions.

Additional information for the surveys was provided by the accompanying fieldwork, during which we classified the household plots, the state of infrastructure and accessibility of the outskirts. Finally we prepared some interviews with local government leaders and other professionals in the sample area in order to examine their attitude toward development planning, supply tasks and daily routine in connection with outskirts and other inner areas.

From 1990 to 2010, 33.6\% of suburban growth took place in the outskirts and other inner areas (table 1). This is especially true for agglomerating cities besides Budapest (like our four case studies), where the thin majority of suburban migrants moved to these areas. Villages and the outskirts merged into cities can attract urban out-migrants, because they are mostly interested in the landscape, the condition of infrastructure and the reputation of the place, not in the administrative status of the location.

As a result, the demographic development of these areas after the transition is markedly different from the previous decades. The communist period brought a sharp decline in the population of the outskirts: they lost more than $70 \%$ of their inhabitants between 1960 and 1990. After 1990 the population decline of the outskirts stopped, and we can even see a moderate increase in their 
population (BALOGH A. 2012b). Between 2001 and 2014, the population of the outskirts increased by $92.8 \%$ and the other inner areas also experienced a $21.4 \%$ rise in the number of inhabitants. Garden zones, wine hills and social facilities have attracted the most newcomers (table 2).

Table 1. The role of outskirts and other inner areas as suburban destinations in Hungary. Share of population growth between parts of settlements.

\begin{tabular}{|l|c|c|c|c|c|c|}
\hline & Population growth 1990- & \multicolumn{2}{|c|}{ Cities (\%) } & \multicolumn{3}{c|}{ Other settlements (\%) } \\
\cline { 3 - 7 } & 2011 & Other inner areas & Outskirts & Central inner areas & Other inner areas & Outskirts \\
\hline Suburbs in Hungary & 484745 & 9.2 & 9.0 & 66.4 & 8.5 & 6.9 \\
\hline Suburbs around Budapest & 296412 & 0.3 & 1.3 & 80.1 & 12.0 & 6.2 \\
\hline Suburbs around other cities & 188333 & 23.1 & 21.0 & 44.9 & 3.0 & 8.0 \\
\hline
\end{tabular}

Source: own elaboration based on census data (HCSO)

The migration from city to second homes and to former villages and move from peripheries of the country to these affordable locations were main drivers of this process (TIMÁR, J. 1993). This trend continued in the 1990s and in some areas, even accelerated after the millennium (BAJMÓCY, P. 2003). Due to the previously described demographic differences, the integration of newcomers into the local community is laden with conflicts and may take 5-6 years (HARDI, T - NÁRAI, M. 2005). Due to their urban roots, higher earnings and their way of life, newcomers significantly differ from local-born people (CSURGÓ, B. 2013). Immigrants have strong lobbying ability (WEAVER, D. B. LAWTON, L. J. 2001) and a different vision of the future (SCHUCHMANN, J. 2013). Residential function and quality of services are more important in their vision (SHARP, CLARK, 2008) than the local landscape (GANT, J. L. et. al., 2010), architectural (ANTOP, M. 2004) and cultural heritage (PACIONE, M. 2013). If the newcomers move to newly built streets or gated communities whitin rural-urban fringe, spatial separation also appears (CLOUTH, H. D. 1976) which further hinders the integration (BRYANT, C. R. 1995, TIMÁR, J. - VÁRADI, M. 2001).

Table 2. The composition of local population of the sample areas (\%).

\begin{tabular}{|c|c|c|c|}
\hline \multicolumn{2}{|c|}{ Migration characteristics of respondents $(\mathrm{n}=1112)$} & Other inner areas & Outskirts \\
\hline \multicolumn{2}{|c|}{ Local born } & 45.8 & 8.4 \\
\hline \multicolumn{2}{|l|}{ Newcomer } & 53.4 & 58.4 \\
\hline \multirow{3}{*}{ Among newcomers } & From the main city & 22.8 & 43.6 \\
\hline & From other parts of the agglomeration & 14.9 & 7.8 \\
\hline & From abroad & 7.8 & 4.0 \\
\hline \multicolumn{2}{|c|}{ Periodically living in the city and at Outskirt/other inner area } & 0.8 & 33.2 \\
\hline
\end{tabular}

Source: own elaboration based on field survey

The society of the examined outskirts has significantly revamped by the persistently high number of immigrants (table 3). The majority of respondents came from the core city, but also a high proportion of people moved there from the peripheries of the country. Nearly half of the respondents only moved here after the millennium; this is in accordance with the general trend in Hungary that suburbanisation ran up only after 2000.

The newcomers' relations and social networks link them to the city. It is difficult to integrate into a new community, since they are not part of it and they have direct contact only with their direct neighbours. This results in a conflictfull situation and because of this communities trend to do not function properly. Some immigrants use the outskirt only as a commuter settlement and they are indifferent toward the local community. Local-born people do not have any lobbying ability, and as one interviewee from Zalaegerszeg expressed: „They believe they do not have a say in, so they do not express their opinion, even if you directly ask them...". As an easier way, most of them keep a distance from the newcomers, and they start to hinder the "non-locals" and "Audi-drivers'" life. For example, they disrupt the flow of traffic and deliberately schedule the noisy tasks in the garden for the dawn as a specific and pointless way to protect their interests.

This is especially true to the upper and middle class, which only began to outflow into the outskirt areas after the acceleration of suburbanisation. The relatively good environment, the looser regulations and the large and relatively cheap properties were attractive for this group (KovÁCS, Z. 
1999). The increasing number of wealthy households started a rural gentrification process in the outskirts (TIMÁR, J. et. al., 2000). The early settlers improve the reputation of the area; this attracts new residents, which raises real estate prices (BOURNE, L. S. 1996). Through lobbying, the newcomers start to reshape the place of residence to fit into their rural image concept (CSURGÓ, B. 2013).

However, according to interviewees in the outskirts, nearly $90 \%$ of the newcomers are form the lower third of middle class and are exposed to the risk of impoverishment. They are fleeing to the outskirts because there they are at least able to maintain the semblance of their previous status due to the reduced living costs. However, we can also find immigrants from the upper class concentrated in the best areas of the outskirts. Their answers also revealed the presence of some groups which do not appear in the official statistics. $13.1 \%$ of the population of outskirts are hobby garden cultivators or ones who lives partly at core city, but they live at the outskirts during the summer half of the year. Moreover, $11.8 \%$ of the respondents mentioned the problem of the illegal occupiers.

The different types of outskirts and other inner areas attract and provide home to different socioeconomic groups. The outskirts with the worst accessibility and environmental endowments attract gypsies, migrant workers, divorced people and single-parent families due to the low utility costs (VÁRADI, M. M. 2013). This is not a new phenomenon: after the elimination of Roma settlements in the socialist era, the families usually displaced to the worst quality outskirts (BALOGH, A. - BAJMÓCY, P. 2011). After the fall of the socialist regime, the forced migration of poor families from cities to these outskirts accelerated (BALOGH, A. - CSAPÓ, T. 2013). It is also a general experience in the post-communist cities that the real estate price boom of the inner suburban belt (SCHAFFT, K. 2000), the increasing unemployment and rising utility costs forced out the low income (MCMANUS, R. - Ethington, P. J. 2007) migrants to the affordable plots of the areas with poor accessibility (HELLING, A. 2002, KoK, H. 1999).On the other hand, bad accessibility does not always deter higher status migrants. With their preserved environment, even the remotest outskirts can be attractive for lifestyle changer seniors and artists.

Table 3. Population growth of outskirts in agglomerations of Hungary

\begin{tabular}{|c|c|c|c|c|}
\hline \multirow{2}{*}{ Type } & \multirow{2}{*}{$\begin{array}{c}\text { Number of outskirts with } \\
\text { growing population }\end{array}$} & \multirow{2}{*}{$\begin{array}{l}\text { Population change 1990- } \\
2011\end{array}$} & \multicolumn{2}{|c|}{ Population } \\
\hline & & & 1990 & 2011 \\
\hline Social institutes & 12 & 1521 & 1113 & 2634 \\
\hline Manors & 188 & -980 & 5960 & 4980 \\
\hline Inspector homes & 179 & 103 & 2798 & 2901 \\
\hline Peri-urban streets & 144 & 7319 & 6897 & 14216 \\
\hline Wine hills & 252 & 6376 & 3675 & 10051 \\
\hline Garden zones & 76 & 13749 & 5884 & 19633 \\
\hline Holiday cottage zones & 33 & 749 & 136 & 885 \\
\hline Tanyas & 406 & 6267 & 43661 & 49928 \\
\hline Others, mixed & 8 & 629 & 2027 & 2656 \\
\hline All outskirts & 1298 & 35733 & 72151 & 107884 \\
\hline
\end{tabular}

The results of the survey revealed some of the problems of the residents. $31.4 \%$ of the respondents considered the condition of roads a pressing issue, because many streets are dangerous due to the too narrow roadways and the nearly total lack of sidewalks. Roadways without concrete base and eroded shoulder are unable to satisfy the demands of the current traffic. In many manors and tanya areas there are no permanent streets, only pieces of land with trails on them. Especially families and single moms with children suffer from the transport constraints (HELLING, A. 2002), thus living in a poorly accessible area have greater impact on the lives of women (HIRT, S. A. 2008). Some of these wives described it as a „home imprisonment” for the winter half of the year. Long commuting also takes time from tending the gardens. Services, institutions and workplaces are only available in the inner core, thus city public transport is essential for the less affluent and older age groups. Therefore improving accessibility is decisive in shaping the future of these areas (HARDI, T. 2005). Public transportation is not able to offset the negative effects of poor accessibility. It is 
difficult to reach bus stops in most of the outskirts, $32.6 \%$ of the respondents claimed they need to walk more than $3 \mathrm{~km}$, on roads which are in a poor state and impassable after heavy rain or snow. The problems are further enhanced as some local residents are responding to the increasing traffic with the arbitrary closure of roads.

Disadvantages in infrastructure are compensated by the strong community and cheaper living, whereas people moved there accept certain difficulties in exchange for opportunities. Despite the hardships, $81.5 \%$ of the respondents like to live here, mostly because of the quiet way of life $(50.0 \%)$ and good accessibility (15.4\%). This fact is significant because most of the outskirts have degraded infrastructure.

Garden zones and wineyards are the most attractive outskirt types for suburban population. Their cheapness (28.6\%), the environmental conditions (29.6\%) and the possibility of horticulture $(37.1 \%)$ are the main appeals. However, environmental advantages do not necessarily relate to the quality of living place, because overhead lines may pass through some outskirts, ruins or industrial areas may lie next to residential properties. Usually, the relief, a nearby forest or simply an open green space promise relatively better quality of life than a block of flats. Most of the streets are characterized by detached houses and weekend homes. Along the narrow, unpaved roads, dead-end streets and at the perimeters of habited areas a higher frequency of weedy, unused gardens and properties in poor condition can be observed (CSURGÓ, B. 2013).

The increase in the population of the outskirts leads only to the renewal of a small percent of the houses, because most newcomers want to build a new home. According to our field survey $15.1 \%$ of the buildings are new or recently renovated, and $8.2 \%$ of them are ruined or deserted. In this regard, the distinctive types of outskirts significantly differ from each other. For example, $60 \%$ of property stock of manors are ruined or in bad condition.

The illegal construction and expansion of buildings were found in each sample area. The newly built buildings are often too big and/or do not fit into the landscape, which reduces the environmental beauty of the locality (VÁRADI, M. M. 1999). The construction of estates with a floor area of around $100 \mathrm{sqm}$ (without permission) on small plots renders the land-use planning and roadwidening almost impossible. Despite the aforementioned issues, the local governments rarely make steps against this illegal sprawl in order to acquire the expected tax revenue and due to the already chaotic townscape. In the other inner areas, the growth of housing stock is usually realized by increasing building density, filling out empty plots, carving out smaller empty plots from a larger property or opening new streets within low-density blocks rather than by greenfield investments.

In the other inner areas, the growth of housing stock is usually realized by increasing building density, filling out empty plots, carving out smaller empty plots from a larger property or opening new streets within low-density blocks rather than by greenfield investments. The relatively few new residential areas and gated communities are constructed along the main roads leading to the city centre from the other inner areas. This represents significant increase in the size of the residential areas for some areas. Investors are trying to achieve higher profits thus the typical sizes of plots developed after 2000 are extremely small; furthermore the number of duplexes and multi-unit houses are high.

As a result, a highly complex spatial structure was formed in the peripheral areas of cities, particularly where the other inner areas and outskirts are relatively close to each other (Figure 1). In these areas, the mixing of different land use forms, social groups and lifestyles are the main determinants of the chaotic land use patterns. As a consequence of the emerging conflicts and controversies, the local population declines and the newcomers begin to reshape the area according to their own perception. The existing development methods cannot handle the fragmented spatial structure. The fragmented spatial structure is typical in post-socialist cities (ОTт, T. 2001).

In some areas, marginal and wealthy groups are concentrated in close proximity to each other and segregation is not apparent in settlement level. Outskirts are attractive for both groups, but their land use profiles are different, thus there is a significant separation between groups of the population with distinct financial opportunities at micro level. Because of the myriad of emerging conflicts, 
neither groups are able to fully enjoy the benefits of the locality; moreover, the cohesive strength of the local community is eroded in the long term. In addition, the overused or missing elements of infrastructure further reduce the quality of life in these areas.

In contrast to the previous researches, neither the distance from the centre nor physical conditions are decisive factors. Accessibility - especially the availability of public transport - has the greatest impact on the development of those areas; hence a patchy and mosaic-like spatial structure is formed instead of a coherent ring of suburbias in the rural-urban fringe of Hungarian towns and cities. At a micro level renewing and rapidly declining zones are randomly located in the areas and there may be some hot spots of changes developing in the opposite direction within a street. Therefore suburbanisation at outskirts and other inner areas is slightly different from the forms of the sovereign villages and towns in agglomerations which have been examined in detail.

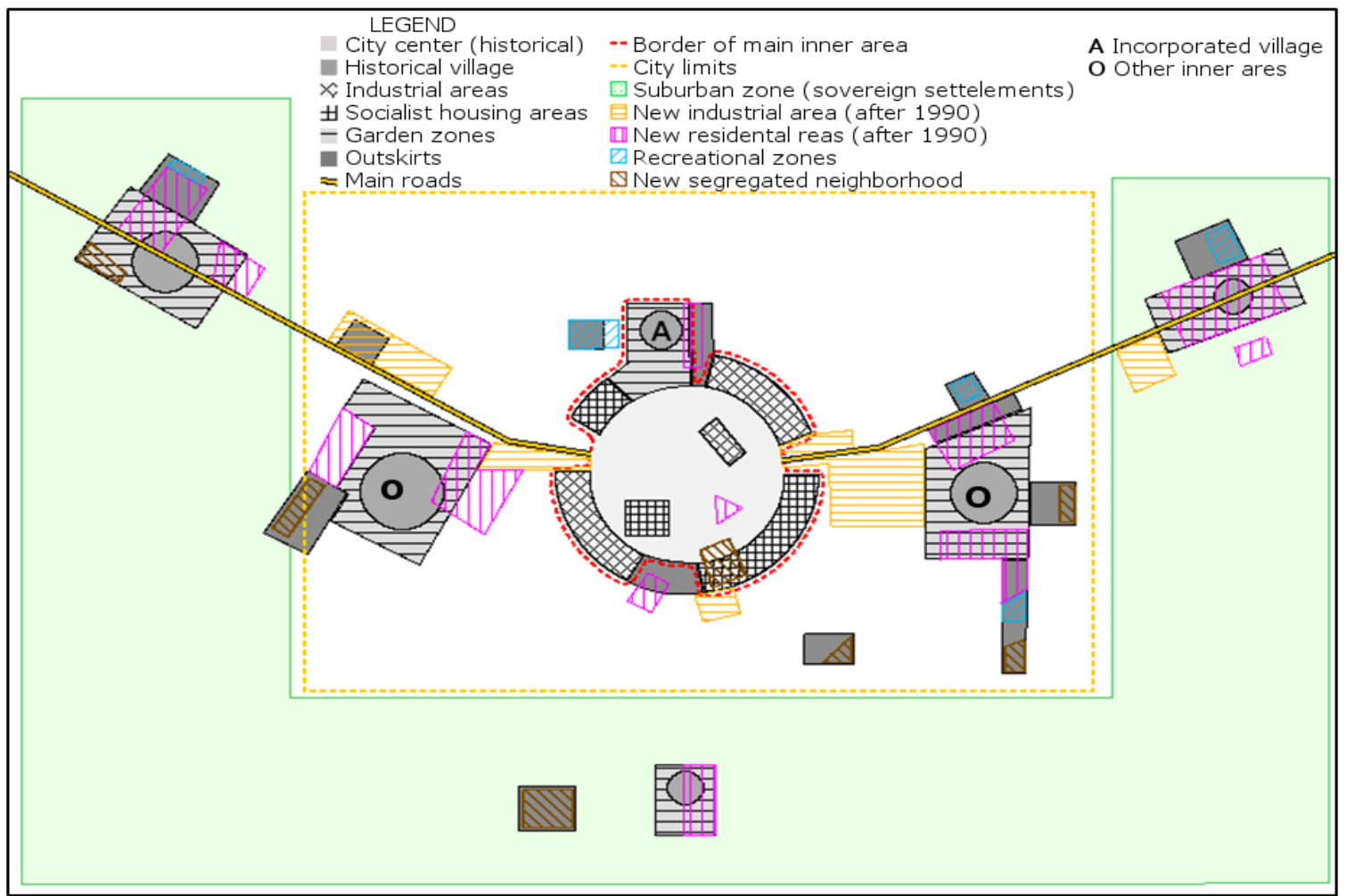

Figure 1. The spatial structure of suburbanisation in case of a city with outskirts and other inner areas. Source: Edited by author.

Dynamic changes have generated numerous conflicts, the infrastructure is overused, illegal land use changes and construction has become common. Local governments are often turning a blind eye to the numerous irregularities for the hoped tax revenues. Segregation in the outskirts decreases and grows simultaneously. Within the outskirts separation is greatly reduced because the newcomers are moving to plots currently available for sale. This leads to an almost random pattern, which is slightly modified by the state of infrastructure. However, in the attractive outskirts and other inner areas rural gentrification process starts, then newcomers may displace the old residents.

Local governments cannot handle these phenomena, because they do not have the necessary funding, and on the other hand, they don't have enough information even to survey the problem due to the distrustful, hardly approachable local residents and the lack of statistical databases. Therefore, settlement geography has a prominent role in laying the foundations of practical interventions aimed to resolve the numerous existing conflicts of the outskirts and other inner areas of the suburbs. 


\section{IRODALOMJEGYZÉK}

ANAS, A. - PINES, D. 2008: Anti-sprawl policies in a system of congested cities. - Regional Science and Urban Economics 5. pp. 408-423.

ANTROP, M. 2004: Landscape change and the urbanization process in Europe. - Landscape and Urban Planning 67. pp. 9-26.

AZARI B. 2004 Az erdő- és zártkert-rendezésről. - Geodézia és Kartográfia. 4. pp. 19-22.

BABBIE, E. 2003: A társadalomtudományi kutatás gyakorlata. - Balassi, Budapest. 723. p.

BAJMÓCY P. 1999a: Szuburbanizáció Pécs környékén. - Földrajzi Értesítő. 1-2. pp. 127-138.

BAJMÓCY P. 1999b: A szuburbanizáció sajátosságai Pécs környékén. - Földrajzi Értesítő 1-2. pp. 127-138.

BAJMÓCY P. 2000a: A vidéki szuburbanizáció Magyarországon, Pécs példáján. - Tér és Társadalom 2-3. pp. 323-330.

BAJMÓCY P. 2000b: Szuburbanizáció a Szeged környéki tanyás településeken. - In: Integrált vidékfejlesztés V. Falukonferencia. MTA RKK, Pécs. pp. 469-474.

BAJMÓCY P. 2001a: A szuburbanizáció motivációi Magyaroszágon. - In: DoRMÁNY G. - KovÁCS F. - PÉTI M. RAKONCZAI J. (szerk.): A földrajz eredményei az új évezred küszöbén [Elektronikus dokumentum]: A Magyar Földrajzi Konferencia tudományos közleményei. SZTE TTK Természeti Földrajzi Tanszék, Szeged. pp. 1-8.

BAJMÓCY P. 2001b: A tanyaközség útja a népesedési adatok tükrében. - In: DURÓ A. (szerk.): Zákányszék földje és népe az ezredfordulón. Zákányszék Község Önkormányzata, Zákányszék. pp. 65-90.

BAJMÓCY P. 2002: Szuburbanizációt kiváltó okok a vidéki Magyarországon. - In: ABONYINÉ PALOTÁS J. - BECSEI J. KovÁCS CS. (szerk.): A magyar társadalomföldrajzi kutatás gondolatvilága. SZTE TTK Gazdaság- és Társadalomföldrajz Tanszék, Szeged. pp. 247-255.

BAJMÓCY P. 2003a: Sikeresek, de falvak? Nagyvárosaink néhány egyéb belterületének fejlöbése 1980-tól napjainkig. In: KovÁCs T. (szerk.): A vidéki Magyarország az EU-csatlakozás elött. VI. Falukonferencia. MTA RKK - MRTT, Pécs, pp. 160-165.

BAJMÓCY P. 2003b: Az elővárosi fejlődés migrációs vonásai az Alföldön. - Alföldi Tanulmányok 19. pp. 84-99.

BAJMÓCY P. 2004: A lakóhelyi szuburbanizáció terének lehatárolása a vidéki Magyarországon. - In: Abonyiné Palotás J. - Komarek L. (szerk.): 40 éves a SZTE Gazdaság- és Társadalomföldrajz Tanszék. Szegedi Tudományegyetem Gazdaság- és Társadalomföldrajzi Tanszék, Szeged. pp. 61-69.

BAJMÓCY P. 2006: A hazai szuburbanizációs folyamatok trendjei 2000 után. - In: CsAPÓ T. - Kocsis Zs. (szerk.): Agglomerációk és szuburbanizálódás Magyarországon. Konferenciakötet. Savaria University Press, Szombathely pp. 112-127.

BAJMÓCY P. - SZEBÉNYI A. 2007: A tömegközlekedés és a szuburbanizáció kapcsolatrendszere Szeged, Pécs és környékük példáján. - In: Európai Kihívások IV. Nemzetközi Tudományos Konferencia, Szeged. pp. 269-274.

BAJMÓCY P. 2014: A szuburbanizáció két évtizede Magyarországon. - In: KÓRÓDI T. - SANSUMNÉ MOLNÁR J. - SISKÁNÉ SzILASI B. - DoBOS E. (szerk.): VII. Magyar Földrajzi Konferencia Kiadványa. Miskolci Egyetem Földrajz Geoinformatika Intézet, Miskolc, pp. 24-34.

BAJMÓCY P. - PÓCSI G. 2008: Somogy megyei majorságok településfejlesztési problémái. - In: SITÁNYI L. (szerk): II. Terület- és vidékfejlesztési konferencia. Kaposvár, pp. 208-228.

BAJMÓCY P. - BALOGH A. 2012: Egykori majorok tipizálása Vas megyei példákon. - Földrajzi Közlemények 2. pp. 165 181.

BAJMÓCY P. - DUDÁs R. - HOSSZÚ SZ. - FEKETE GY. 2012: Urbanizációs trendek a rendszerváltozás utáni Magyarországon. - In: PÁL V. (szerk.): A társadalomföldrajz lokális és globális kérdései: Tiszteletkötet Dr. Mészáros Rezső professzor 70. születésnapja alkalmából. SZTE TTIK Gazdaság- és Társadalomföldrajz Tanszék, Szeged. pp. 95-110.

BAJMÓCY P. - MAKRA ZS. - VASÁRUS G. 2014: A közigazgatásilag önálló települések számának változása és a változások tipizálása Magyarországon. - Településföldrajzi Tanulmányok 1. pp. 36-49.

BAJMÓCY P. - MAKRA ZS. - TÓTH L. 2018: A hazai külterületek átalakulása 1990 után. - Településföldrajzi Tanulmányok 1. pp. 3-17.

BAJMÓCY P. - MAKRA ZS. 2016: Központi-, egyéb belterületek és külterületek népesedési trendjei Magyarországon 1960-2011 között. - Településföldrajzi Tanulmányok 2. pp. 3-21.

BALOGH A.-BAJMÓCY P. 2011: Majorok a Nyugat-Dunántúlon. - Savaria University Press, Szombathely, p. 126.

BALOGH A. 2012a: A külterületek településföldrajzi vonatkozásai. - Nyugat-Magyarországi Egyetem Savaria Egyetemi központ Tudományos közleményei 19. (Természettudományok 14). NYME Kiadó, Szombathely, pp. 127-138.

BALOGH A. 2012b: A Nyugat-dunántúli régió külterületi településrészeinek földrajzi sajátosságai. - In: PÁL V. (szerk.): A társadalomföldrajz lokális és globális kérdései: Tiszteletkötet Dr. Mészáros Rezső professzor 70. születésnapja alkalmából. SZTE TTIK Gazdaság- és Társadalomföldrajz Tanszék, Szeged, pp. 134-145.

BALOGH A. - CSAPÓ T. 2013: Manors and scattered farms: special settlement forms of outskirt areas in Hungary. Revijja Za Geografijo / Journal For Geography 8. 2. pp. 81-94.

BALOGH P. 2013: A racionálistól a részvételig. Redisztribúció, területi gazdálkodás, területfejlesztési politika átalakulóban Magyarországon. - Belvedere Meridionale 3. pp. 51-67. 
BECSEI J. 1993: A tanya-fogalom tartalmáról. - Földrajzi Értesítő 1-4. pp. 35-39.

BECSEI J. 1996: Az alföldi tanyarendszer történeti földrajza. - In: FRISNYÁK S. (szerk.): A Kárpát-medence történeti földrajza, Nyíregyháza, pp.171-197.

BECSEI J. 2004: A tanyarendszer jellegének változásai. - In: CsAPÓ T. (szerk.): A hazai városok funkcionális morfológiája. Berzsenyi Dániel Főiskola Társadalomföldrajz Tanszék, Szombathely, pp. 16-29.

BECSEI J. 2007a: Vélemények a tanya kialakulásáról. - In: CSAPÓ T. - KoCSIS ZS. (szerk.): A kistelepülések helyzete és településföldrajza Magyarországon. III. Településföldrajzi Konferencia. Savaria University Press, Szombathely, pp. 1623.

BECSEI J. 2007b: Átalakuló alföldi városok. SZTE TTK Gazdaság- és Társadalomföldrajz Tanszék, Szeged, 176. p.

BECSEI J. 2010: Az alföldi tanyarendszer településmorfológiai sajátosságai. - Tér-Tálentum-Tanítványok I., Pécs, pp. 57 72.

BECSEI J. 2013: A Kárpát-medencei megtelepedés - In: FRISNYÁK S. - GÁL A. (szerk.): Kárpát-medence: természet, társadalom, gazdaság. NYF TFI, Bocskai István Gimnázium, Nyíregyháza - Szerencs, pp. 165-179.

BECSEI J. 2015a: Az alföldi tanyarendszer. - In: KÓKAI S. - BOROS L. (szerk.): Tiszteletkötet Dr. Gál András geográfus 60. születésnapja alkalmából. NyF TFI, Bocskai István Katolikus Gimnázium, Nyíregyháza - Szerencs, pp. 83-104.

BECSEI J. 2015b: A magyar urbanizálódás és az alföldi város. - Településföldrajzi Tanulányok (különszám) pp. 5-22.

BELUSZKY P. 1982: Egy alig ismert településszerkezeti elem, a kertség. - Földrajzi Értesítő 31. 2-3. pp. 325-328.

BELUSZKY P. - SIKOS T. T. 1982: Magyarország falutípusai. MTA Földrajztudományi Kutató Intézet, Budapest, 167 p.

BELUSZKY P. 1999: A budapesti agglomeráció kialakulása. - In: Társadalmi-gazdasági átalakulás a budapesti agglomerációban I. Regionális Kutatási Alapítvány, Budapest, pp. 27-68.

BELUSZKY P. 2005: Magyarország történeti földrajza I. kötet. Dialóg Campus Kiadó, Budapest-Pécs, 462. p.

BELUSZKY P. - SiKOS T. T. 2007: Változó falvaink. Magyarország falutípusai az ezredfordulón. MTA Társadalomkutató Központ, Budapest, 459 p.

Besser, L. M. - MARCUS, M. - FrumkIN, H. 2008: Commute Time and Social Capital in the U.S. - American Journal of Preventive Medicine, 3. pp. 207-211.

BERÉNYI I. 1992: Az alkalmazott szociálgeográfia elméleti és módszertani kérdései. Akadémiai, Budapest, 164. p.

BERÉNYI I. 1997: A szociálgeográfia értelmezése: egyetemi jegyzet. ELTE Eötvös, Budapest, 135. p.

BIJKER, R. A. - HAARTSEN, T. - STRIJKER, D. 2012: Migration to less-popular rural areas in the Netherlands: Exploring the motivations. - Journal of Rural Studies 4. pp. 490-498.

BOROS L.-TÓTH P. 2007: Urban development and the conflicts related to the urban space. - Geographica

Timisiensis 1.77-84.

BOROS L. 2009: Szeged belső térfolyamatai az 1950-es évektől napjainkig. - Földrajzi Közlemények 4. pp. $453-465$.

BOROS L. 2010: Posztstrukturalista elméletek: kihívások és lehetőségek a településföldrajz számára. - In: CSAPÓ T. Kocsis ZS. (szerk.): A településföldrajz aktuális kérdései. VI. Településföldrajzi Konferencia. Savaria University Press, Szombathely, pp. 392-405.

BOROS L. 2012: Szeged belső tagozódása a deprivációs indexek alapján - In: RÁCZ A. (szerk.): Város és Vidéke. Településszociológiai tanulmányok 2.: A város. Belvedere Meridionale, Szeged, pp. 19-54.

BOURNE, L. S. 1996: Reinventing the suburbs. Old myths and new realities. - Progress in Planning 3. pp. $163-184$.

BRADE, I. - SMIGIEL, C. - KovÁCS Z. 2009a: Suburban residential development in post-socialist urban regions: the case of Moscow, Sofia, and Budapest - In: KILPER, H. (szerk.): New Disparities in Spatial Development in Europe. Springer, Berlin - Heidelberg, pp. 79-104.

BRADE, I. - HERFERT, G. - WIEST, K. 2009b: Recent trends and future prospects of socio-spatial differentiation in urban regions of Central and Eastern Europe: A lull before the storm. - Cities 26. pp. 233-244.

BROWN, L. D. - SCHAFFT, K. A. 2002: Population deconcentration in Hungary during the post-socialist transformation. Journal of Rural Studies 18. pp. 233-244.

BuNOVÁCZ D. - TuBA L. 2002: Györ. A XXI. század küszöbén. CEBA, Budapest, 329. p.

BRYANT, C. R. 1995: The Role of Local Actors in Transforming the Urban Fringe. - Journal of Rural Studies, 11. 3. pp. 255-267.

CARRUTHERS, J. I. - VIAS, A. C. 2005: Urban, suburban, and exurban sprawl in the rocky mountain west: Evidence from regional adjustment models. - Journal of Regional Science 1. pp. 21-48.

CatTan, NAdine. 2011: Urban Sprawl in the Paris Metropolitan Area. - In: SzIRMAI V. (szerk.): Urban Sprawl in Europe. Aula, Budapest, pp. 107-140.

Clouth, H. D. 1976: Rural geography: an introductory survey. Pergamon, Oxford, 204. p.

COSTELLO, L. 2007: Going bush: the implications of urban-rural migration. - Geographical Research 1. pp. 85-94.

CSANÁDI G. - CsIZMADY A. 2002: Szuburbanizáció és társadalom. - In: Tér és társadalom 16. 3. pp. 83-107.

CSAPÓ T. 1993: A rendszerváltás hatása a Nyugat-Dunántúl aprófalvas településeire. - In: Kovács T. (szerk.): Kiút a válságból. II. Falukonferencia. MTA Regionális Kutatások Központja, Pécs. pp. 275-280.

CSAPÓ T. - KOZMA K. - LENNER T. 2015: Győr településmorfológiája. - Településföldrajzi tanulmányok 1. pp. 17-34.

CSAPÓ T. 2007: Szeged településmorfológiája. - In: KOVÁCs CS. - PÁL V. (szerk.): A társadalmi földrajz világai: Becsei József professzor 70. születésnapjára. SZTE TTIK Gazdaság- és Társadalomföldrajz Tanszék, Szeged, pp. 89-103. 
CSATÁRI B. - FARKAS J. Z. - LENNERT J. 2013: Land use changes in the rural-urban fringe of Kecskemét after the economic transition. - Journal of Settlements and Spatial Planning 2. pp. 153-159.

CSATÁRI B. 2002: Újabb kisérletek az 1990-es évek magyar városfejlődési sajátosságainak áttekintő értelmezésére. - In: Abonyiné Palotás J. - Becsi J. - Kovács Cs. (szerk.): A magyar társadaomföldrajzi kutatás gondolatvilága. SZTE Gazaság- és Társadalomföldrajz Tanszék, Szeged, pp. 228-252.

CSATÁRI B. - KISS A. 2003 (szerk.): Tanyai kaleidoszkóp, a 2002-2003. évi tanyakollégium munkájának eredményei. MTA RKK Alföldi Tudományos Intézet, Kecskemét, 192. p.

CSATÁRI B. 2006: Változások az Észak-Alföld településeinek átalakulási dinamikájában. - A Falu 1. pp. 51-62.

CSATÁRI B. 2010: A tanya, mint a településrendszer különlegesen változó eleme. - In: GLATZ F. - CSATÁRI B. - T. GÉMES T. (szerk.): A magyar tanyás vidékek: II. Országos Vidék Fórum, Lajosmizse, 2009. június 3-4. előadásai és hozzászólásai alapján készült: MTA Történettudományi Intézet, Budapest, pp. 9-20.

CSATÁRI B. - FARKAS J. 2012: A város-vidék peremzóna sajátos geográfiai jellemzői és konfliktusai Kecskemét példáján. - In: FARSANG A. - MUCSI L. - KEVEINÉ BÁRÁNY I. (szerk.): Táj - érték, lépték, változás. GeoLitera, Szeged, pp. 197210.

CSATÁRI B. 2013: A magyar tanya, tanyák az alföldi tájban. Orszagépítő 3. pp. 35-38.

CSATÁRI B. - FARKAS J. Zs. - KovÁCS A. D. 2016: Egy alföldi tanyás mezőváros terének dinamikus változásai Kecskemét példáján. - In: KóKAI S (szerk.): A változó világ XXI. századi kihívásai: tanulmánykötet Prof. Dr. Hanusz Árpád egyetemi tanár 70. születésnapja tiszteletére. Nyíregyházi Egyetem Turizmus és Földrajztudományi Intézet, Nyíregyháza. pp. 89-111.

CSÉFALVAY Z. 1999: Helyünk a nap alatt. Magyarország és Budapest a globalizáció korában. - Kairosz, Budapest, 227. p.

CSOBA J. 2017: A kertkultúra és a háztartásgazdaság szerepe a vidéki szegények társadalmi integrációjában - 25 éves a Szociális Földprogram. - Tér és Társadalom, 7. 3. pp. 85-102.

CsIZMADIA Z. 2010: Hálózatosodás, mint lehetőség. - In: HARDI T. - LADOS M. - TóTH K. (szerk.): Magyar-szlovák agglomeráció Pozsony környékén. MTA RKK NYUTI - Fórum Kisebbségkutató Intézet, Győr-Samorin, pp. 144-153.

CSORDÁS L. 1993: Zártkertek és üdülők a szolnoki agglomerációban. - In: TóTH J. (szerk.): A Szolnoki Agglomeráció. MTA RKK, Pécs, pp. 254-263.

CsORDÁs L. 2007: A második otthonok kialakulása a kezdetektől napjainkig. - In: Süli-Zakar I. (szerk.): Tanár úrnak tisztelettel: 56 tanulmány Dr. Korompai Gábor 70. születésnapjára. Debreceni Egyetem Társadalomföldrajzi és Területfejlesztési Tanszék, Debrecen, pp. 371-379.

CSURGÓ B. 2013: Vidéken lakni és vidéken élni. A városból vidékre költözők hatása a vidék átalakulására: a város környéki vidék. Argumentum Kiadó, Budapest, p. 291.

CZENE Zs. 2007: A vidéki térségek a programban: az 1.1.2. projekt: város-vidék kapcsolatok. - Falu város régió 4. pp. $25-35$.

DöVÉNYIZ. - KOVÁCs Z. 1999: A szuburbanizáció térbeni-társadalmi jellemzői Budapest környékén. - Földrajzi Értesítő 1-2.pp. 33-57.

DÖVÉNYI Z. 2009: A belső vándormozgalom Magyarországon: folyamatok és struktúrák. - Statisztikai Szemle 7-8. pp. 748-762.

DAHMS, F. - MCCOMB, J. 1999: 'Counterurbanization', Interaction and Functional Change in a Rural Amenity Area - a Canadian Example. - Journal of Rural Studies 2. pp. 129-146.

DANIEL, P. - HOPKINSON, M. 1996: The Geography of Settlement. Oliver \& Boyd, Harlow, 336. p.

Delmelle, E. C. - HASlaueR, E. - PRINZ, T. 2013: Social satisfaction, commuting and neighborhoods. - Journal of Transport Geography 30. pp. 110-116.

DASKALOVA, D. - SLAEV, A. D. 2015: Diversity in the suburbs: socio-spatial segregation and mix in post-socialist Sofia. Habitat International 50. pp. 42-50.

DuAnY, A. - Plater-ZYBerk, E. - SPECK, J. 2001: Suburban Nation: The Rise of Sprawl and the Decline of the American Dream. North Point, New York, 293. p.

DURÓ A. 1993: Az alföldi tanyaközségek helyi társadalma. - In: Timár J (szerk.): Az "alföldi út" kérdőjelei: Alföldkongresszus. MTA Regionális Kutatások Központja Békéscsaba, pp. 249-252.

DURÓ A. 2013: Tanyák és tanyagondnokságok az Alföldön. - Szociálpedagógia 3-4. pp. 15-25.

EDELÉNYI B. 2002: A telekárak változása a Győr környéki településeken 1998 és 2001 között. - Tér és Társadalom 3. pp. 153-164.

EGEDY T. 2001: A társadalmi kirekesztés és a lakótelepek. - Tér és Társadalom 1. pp. 91-110.

EGEDY T. 2005: A városrehabilitáció hatásai a lakásmobilitásra és a társadalmi mozgásfolyamatokra - In: Egedy T. (szerk.): Városrehabilitáció és társadalom. MTA Földrajztudományi Kutatóintézet, Budapest, pp. 103-158.

ÉGETŐ M. 1974: A szőlőművelés átalakulása a századfordulón a Solt-vidéken. - Cumania: a Bács-Kiskun Megyei Múzeumok közleményei 2. pp. 133-158.

ÉGETŐ M. 1978: A lakáshasználat változásai a szanki tanyákon az utóbbi száz évben. - Cumania: a Bács-Kiskun Megyei Múzeumok közleményei 5. pp. 159-197.

ÉGETŐ M. 1985: Szőlőhegyi szabályzatok és hegyközségi törvények a 17-19. századból. Budapest

ÉGETŐ M. 1993: A szőlőskertek rendszerének kiépülése a Tiszántúlon a 18-19. század folyamán. - Népi kultúra - népi társadalom 17. pp. 37-56. 
ÉGETŐ M. 1999: Adatok a Sárvár-Felsővidéki Uradalom szőlőhegyeinek életéhez a 19. század elején. - Soproni szemle 1. pp. 21-29.

ÉGETŐ M. 2003: A filoxéravésztől a második világháborúig. - Rubicon. 1-2. pp. 84-87.

ENGLAND, K. 1991: Gender relations and the spatial structure of the city. - Geoforum 22. 2. pp. 135-147.

ENYEDI GY. 1989: Van-e szocialista urbanizáció? - Tér és Társadalom 3. pp. 92-103.

ENYEDI GY. 2011: A városnövekedés szakaszai - újragondolva. - Tér és Társadalom 1. pp. 5-19.

ERDEI F. 1976: Magyar tanyák (Hasonmás kiadás). Akadémiai Kiadó, Budapest, 270. p.

FAN, J. X. - WEN, M. - KOWALESKI-JONES, L. 2014: An ecological analysis of environmental correlates of active commuting in urban U.S. - Health \& Place 30. pp. 242-250.

FARKAS J. 2004: A külterületi üzemek gazdálkodásának sajátosságai az ezredfordulón Bács-Kiskun megyében. - In: CSATÁRI B. - KISS A. (szerk.): Tanyai kaleidoszkóp: A 2002-2003. évi tanyakollégium munkájának eredményei. MTA RKK Alföldi Tudományos Intézet, Kecskemét, pp. 72-77.

FARKAS J. - CSATÁRI B 2011: Agrár- és vidékföldrajzi kutatások Bács-Kiskun megyei példákon. - In: UNGER J. - PÁLMOLNÁR E (szerk.): Geoszférák 2010: A Szegedi Tudományegyetem Földtudományok Doktori Iskola és a Környezettudományi Doktori Iskola eredményei. SZTE TTIK Földrajzi és Földtani Tanszékcsoport, Szeged, pp. 129168.

FEHÉRNÉ BRANDISZ K. et al. 2003: A nagyvárosok belső tagozódása: Győr. - Központi Statisztikai Hivatal Győr-Sopron Megyei Igazgatósága, Győr, 88 p.

FORNY, W. F. - JONES, M. 1997: An introduction to Settlement Geography. Cambridge, Cambridge, 145. p.

FRISNYÁK S. 1984: Adalékok a Zempléni-hegység történeti földrajzához (18-19. század.). - Földrajzi Értesítő 1-2. pp. 65-92.

FRUMKIN, H. 2002: Urban Sprawl and Public Health. - Public Health Reports 1. pp. 201-217.

G. FEKETE É. 2001: Aprófalvak az ezredfordulón - A Cserehát-Hernád-Bódva vidék. - In: DORMÁNY G. - KovÁCS F. PÉTI M. - RAKONCZAI J. (szerk.): A földrajz eredményei az új évezred küszöbén. I. Magyar Földrajzi Konferencia. CDROM. SZTE TTK Természeti Földrajzi Tanszék, Szeged, pp. 1-15.

GÁBOR P. 2001: Népességváltozás Magyarországon az 1990-es években. A szuburbanizáció kezdete? - Falu Város Régió 1. sz. 9-10.

Gallent, N. - Mace, A. - Tewdwr-Jones, M. 2003: Dispelling a myth? Second homes in rural Wales. - Area 3. pp. 271-284.

GANT, R.L. - RoBINSON, G. M.-FAZAL, S. 2010: Land-use change in the 'edgelands': Policies and pressures in London's rural-urban fringe - Land Use Policy 28. pp. 266-279.

GANT, J.L. - NELSON, A.C. - ForSYTH, A. - ThOMPSON-FAWCETT'S, M. - Blais, P. - Filion, P. 2014: The future of the suburbs. Interface. - Planning Theory \& Practice 3. pp. 391-415.

Görgl, P. - Helbich, M. - MATZENETTER W. - FASSMAnN, H. 2011: Spatial and Social Development Trends of Metropolitan Vienna: An Overview. - In: Szirmai V. (szerk.): Urban Sprawl in Europe. Aula, Budapest, pp. 107-140.

GyENIZSE P. - TRÓCSÁNYI A. - PIRISI G. - BogNÁR Z. - CZIGÁNY SZ. 2016: A multi-factor model developed on residents' opinions for the classification of urban residental areas. - Geografie 1. pp. 1-31

GYÖRFFY I. 1937: A magyar tanya. - Földrajzi Közlemények 4-5. pp. 70-93.

HARDI T. 2002: Szuburbanizációs jelenségek. Győr környékén. - Tér és Társadalom 3. pp. 57-83.

HARDI T. -NÁRAI M. 2005: Szuburbanizáció és közlekedés a győri agglomerációban. - Tér és Társadalom 1.pp. 81-101.

HARDI T. 2010: A szuburbanizáció jelenségei és hatásai - határon innen és túl. - In HARDI T. - LADOS M. - TóTH K. (szerk.): Magyar-szlovák agglomeráció Pozsony környékén. MTA RKK NYUTI - Fórum Kisebbségkutató Intézet, Györ - Samorin, pp. 11-26.

HARDI T. 2012: Győr, Miskolc és Pécs agglomerációja a vidéki szuburbanizációban - In: Somlyodyné Pfeil E. (szerk.): Az agglomerációk intézményesítésének sajátos kérdései. Publikon, Pécs, pp. 15-42.

HEGEDŰS G. 2008. - Az elzárkózó helyi társadalom - lakóparkok a vidéki magyar nagyvárosokban. - In: Szabó V. et al. (szerk.): IV. Magyar Földrajzi Konferencia. Rexpo Kft., Debrecen, pp. 285-291.

HeLling, A. 2002: Transportation, Land Use and the Impacts on Srawl on Poor Children and Families. - In: SQUIRES, G. D. (szerk.): Urban Sprawl: Causes, Consequences, and Policy Responses. Urban Institute, Washington DC, pp. 119139.

HIRT, S. A. 2008: Stuck in the suburbs? Gendered perspectives on living at the edge of the post-communist city. - Cities 25. pp. 340-354.

Hoehner, C. M. - BARlow, C. E. - Allen, P. - Schootman, M. 2012: Commuting Distance, Cardiorespiratory Fitness, and Metabolic Risk. - American Journal of Preventive Medicine. 6, pp. 571-578.

ILYÉS GY. 1972: Puszták népe. Szépirodalmi Kiadó, Budapest. 294. p.

IZSÁK É. 1999: A települési sorrend megváltozása a szuburbanizációs index alapján a budapesti agglomerációban. Földrajzi Értesítő 1-2. pp. 83-92.

IZSÁK É. 2001: Szuburbanizáció és gazdasági fejlődés: Budaörs, a legsikeresebb magyar város. - In: MAARTEN K.NEMES N. J. (szerk.): Helyi fejlődés, intézmények és konfliktusok a magyarországi átmenetben, Budapest, pp. 35-51.

IZSÁK É. 2003: A városfejlődés természeti és társadalmi tényezői. Budapest és környéke. Napvilág, Budapest, 178. p.

JACKSON, K. T. 1985: Crabgrass Frontier. Oxford, New York, 396. p. 
JANKÓ F. 2004: Szuburbán folyamatok Sopron térségében: a Lővérek átalakulása. - Földrajzi Értesítő 3-4. pp. $295-312$.

JANKÓ F. - KOMORNOKI M. 2008: Szuburbanizáció és választási földrajz. Átalakuló pártválasztás Budapest térségében. Tér és Társdalom 4. pp. 115-134.

JETZKOWITZ, J. - SCHNEIDER, J. - BRUNZEL, S. 2007: Suburbanisation, mobility and the 'good life in the country': a lifestyle approach to the sociology of urban sprawl in Germany. - Sociologia Ruralis 2. pp. 148-171.

JÓZSA K. 2008: Aprófalvas vonások néhány Somogy megyei egykori majorban. - In: SITÁNYI L. (szerk.): II. Terület- és vidékfejlesztési konferencia. Savaria University Press, Szombathely, pp. 195-208.

KELlY, R. - SHORTALL, S. 2002: Farmers' wives': women who are off-farm breadwinners and the implications for onfarm gender relations. - Journal of Sociology 38. pp. 327-343.

KESERÜ I. 2012: Bejárók és eljárók: A szuburbanizáció és az általános iskolások ingázásának összefüggései Budapest funkcionális várostérségében. - Tér és Társadalom 3. pp. 114-131.

KISS J. 1999: A város-vidék peremzóna személyközlekedésének átalakulási folyamatai az Alföld négy megyeszékhelyén (1980-1998). - Alföldi tanulmányok 17. pp. 112-130.

KoCsIS J. B. 2000: A szuburbanizáció jelenségének főbb elméleti megközelítései a városszociológiai és más rokon tudományterületek irodalmában. - Tér és Társadalom 2-3. pp. 311-321.

KoÓs B. 2004: Adalékok a gazdasági szuburbanizáció kérdésköréhez. - Tér és társadalom 18. 1. pp. 59-71.

KoÓs B. 2007: A szuburbanizációs folyamat a magyar gazdaságban. - Közgazdasági Szemle 4. pp. 334-349.

KOK, H. 2000: Migration from the city to the countryside in Hungary and Poland. - Geojournal 49. pp. 53-62.

KOK, H. - KovÁCS Z. 1999: The process of suburbanization in the agglomeration of Budapest. - Netherlands Journal Of Housing A: The Built Environment 2. pp. 119-142.

KÓKAI S. 2011: A szuburbanizáció néhány sajátossága Nyíregyházán. - In: CSAPÓ T. - KoCSIS Zs. (szerk.): Az 1971. évi OTK és hatása a hazai településrendszerre. Savaria University Press, Szombathely, pp. 166-180.

KONDOR A. -SZABÓ B. 2007: A lakáspolitika hatása Budapest városszerkezetére. - Földrajzi Értesítő 3-4. pp. $237-269$.

KovÁcs A. D. 2010: Kecskemét-Méntelek - a sajátos helyzetü, tanyás városrész - településkörnyezeti jellemzői és társadalmának jövőbeni elképzelései. - In: SzABÓ V. - FAZEKAS I. (szerk.): II. Települési Környezeti Konferencia. Debreceni Egyetem Tájvédelmi és Környezetföldrajzi Tanszék, Debrecen, pp. 49-54.

KovÁCS K. 1985: A dunántúli szőlőhegyek betelepülése Zalaszántó példája alapján. - Ethnographia XCVI. pp. 329-336.

KovÁcs K. - VÁRADI M. M. 2003: Hozzászólás egy nem létező tanyavitához. - In: KovÁCS T (szerk.): A vidéki Magyarország az EU-csatlakozás előtt: VI. Falukonferencia. MTA RKK - MRTT, Pécs, pp. 279-285.

KovÁCS Z. 1999: A szuburbanizáció jellemzői a budapesti agglomerációban. (Esettanulmányok). - Földrajzi Értesítő 1-2. pp. 93-126.

KovÁCS Z. 2002: Népesség- és településföldrajz. ELTE Eötvös Kiadó, Budapest, p. 239.

KovÁcs Z. 2010: A szocialista és posztszocialista urbanizáció értelmezése. - In: BARTA GY. - BELUSZKY P. - FÖLDI Zs. -KovÁcs K. (szerk.): A területi kutatások csomópontjai. MTA RKK, Pécs, pp. 141-157.

KovÁCS Z. - EGEDY T. - SZABÓ B. 2015: Az ingázás területi jellemzőinek változása Magyarországon a rendszerváltozás után. - Területi Statisztika 3. pp. 233-253.

KovÁCS Z. - SZABÓ B. 2016: Urban restructuring and changing patterns of socio-economic segregation in Budapest - In: Tammaru, T. - Marcińczak, S. - Ham, M. - Musterd, S. (szerk.): Socio-Economic Segregation in European Capital Cities: East meets West. Routledge, London-New York, pp. 238-260.

KovÁcs Z. - SzIGETI C. - EgEDY T. - SzABÓ B. - KonDOR A. Cs. 2017: Az urbanizáció környezeti hatásai - Az ingázás ökológiai lábnyomának változása a budapesti várostérségben. - Területi Statisztika 5. pp. 469-494.

KOZÁRI M. 1999: Adatok az uradalmi majorok életéhez (Somogy megye, 1930-40-es évek). - In: Ethnographia 1. pp. 91-96.

KRISTÓF A. - KÓKAI S. 2015: Adalékok a miskolci szuburbia lehatárolásához. - Településföldrajzi tanulmányok 4. pp. 56-72.

KRISTÓF A. 2015: Adalékok Miskolc külterületeinek sajátosságaihoz. - Településföldrajzi tanulmányok 2. pp. 55-67. KRISTÓ GY. - BARTA J. - GERGELY J. 2002: Magyarország története előidőktől 2000-ig. Pannonica, Budapest, 687 p.

KUBES, J. 2013: European post-socialist cities and their near hinterland in intra-urban literature. - Bulletin of Geography, Socio-economic series 19. pp. 19-43.

LADÁNYI J. - SZELÉNYI I. 1997: Szuburbanizáció és gettósodás. - Kritika 7. pp. 4-12.

LAMPL ZS. 2010: Túl a város peremén (Esettanulmány a Pozsonyból kiköltözött Felső-csallóközi és Rajka környéki lakosságról). - In: HARDI T. - LADOS M. - TÓTH K. (szerk.): Magyar-szlovák agglomeráció Pozsony környékén. MTA RKK NYUTI - Fórum Kisebbségkutató Intézet, Győr-Samorin, pp. 77-131.

LOPES DE SOUZA, M. 2001: Metropolitan deconcentration, socio-political fragmentation and extended suburbanisation: Brazilian urbanisation in the 1980s and 1990s. - Geoforum 4. pp. 437-447.

LUCY, W. L. - PHILLIPS, D. L. 1997: The post-suburban era comes to Richmond: city decline, suburban transition, and exurban growth. - Landscape and Urban Planning 36. pp. 259-275.

LUX G. 2012: Fejlesztési problémák és területi együttmüködési kapcsolatok magyar nagyvárosi agglomerációkban - In: SOMOLYDYNÉ PFEIL E. (szerk.): Az agglomerációk intézményesítésének sajátos kérdései. Publikon, Pécs, pp. 153-180.

MAJOROS P. 2004: A kutatásmódszertan alapjai. Perfekt, Budapest, 250. p.

MAKSAY F. 1971: A magyar falu középkori településrendje. Akadémiai Kiadó, Budapest, 238. p. 
MARCINCZAK, S. - MUSTERD, S. - STEPNIAK, M. 2011: Where the grass is greener: Social segregation in three major Polish cities at the beginning of the 21st century. - European Urban and Regional Studies pp. 1-21.

MCGRANAHAN, D. A. 2008: Landscape influence on recent rural migration in the U.S. - Landscape and Urban Planning 85. pp. 228-240.

MCMANUS, R. - EthingTON, P. J. 2007: Suburbs in transition: new approches to suburban history. - Urban History 34. 2. pp. 317-337.

MENDÖL T. 1963: Általános településföldrajz. Akadémiai Kiadó, Budapest, p. 567.

MÉSZÁROS R. 1989: A tanyák jövője. - In: CSATÁRI B. (szerk.): Az alföldi tanyák mai helyzete és jövő lehetőségei. MTA RKK, Pécs, pp. 75-83.

MÉSZÁROS R. 2004: Szeged jövőképei. - In: ABOnYINÉ PALOTÁs J. - KoMAREK L. (szerk.): 40 éves a Szegedi Tudományegyetem Gazdaság- és Társadalomföldrajz Tanszék. SZTE Gazdaság- és Társadalomföldrajzi Tanszék, Szeged, 231.p.

MoHOS M. 2007: Szőlőhegyi szórványból aprófalu. - In: Csapó T. - Kocsis Zs. (szerk.): A kistelepülések helyzete és településföldrajza Magyarországon. III. Településföldrajzi Konferencia. Savaria University Press, Szombathely. pp. 255-264.

MoHOS M. 2008: Egy régi borvidék a történeti Zala megyében. - Korunk, Harmadik folyam 9. pp. 28 -33 .

MOLNÁR M. 2004: Megélhetés a tanyán a mezőgazdaság talaján. - In: CSATÁRI B. - KISS A. (szerk.): Tanyai kaleidoszkóp: A 2002-2003. évi tanyakollégium munkájának eredményei. MTA RKK Alföldi Tudományos Intézet, Kecskemét, pp. 78-87.

MiTCHELL, C. 2004: Making sense of counterurbanization. - Journal of Rural Studies 20. pp. 15-34.

MiTCHELL, C. 2013: Creative destruction or creative enhancement? Understanding the transformation of rural spaces. Journal of Rural Studies 32. pp. 375-387.

MENDÖL T. 1963: Általános településföldrajz Akadémiai kiadó, Budapest, p. 567.

MIESZKOWSKI, P. - MiLLS, E. S. 1993: The causes of metropolitan suburbanization. - Journal of Ecomonic Perspectives 3. pp. 135-147.

MYKHNENKO, V. - TUROK, I. 2008: East European cities - patterns of growth and decline, 1960-2005. - International Planning Studies 4. pp. 311-342.

NAGY E. - NAGY G. - KISS J. P. 2003: Szeged: kihasználatlan tartalékok és részsikerek. - In: TiMÁR J. - VELKEY G. (szerk.): Várossiker alföldi nézőpontból. MTA RKK, Békéscsaba-Budapest, pp. 120-162.

NAGY E. - TIMÁR J. - NAGY G. - VELKEY G. 2015: A társadalmi-térbeli marginalizáció folyamatai a leszakadó vidéki térségekben. - Tér és társadalom 1. pp. 35-52.

NAGY G. - TÍMÁR J. 2010: Városrégiók a hazai térkutatásokban. 30. p. http://www.varoster.hu/docs/Városrégiók a hazai térkutatásokban.pdf, Elérés: 2014. 03. 01.

NAGY GY. 2014: A környezeti igazságtalanság fogalma és mérési lehetőségei. - Geographia Pannonica Nova 17. pp. 164-176.

NAGY Gy. - HEGEDÜS T. 2016: Urban sprawl or/and suburbanisation?: The case of Zalaegerszeg - Belvedere Meridionale 3 pp. 106-119.

NAGY S. GY. 1999: Külföldi müködőtőke a budapesti agglomerációban. - In: BARTA GY. BELUSZKY P. (szerk.): Társadalmi-gazdasági átalakulás a budapesti agglomerációban 1. pp. 69-90.

NAGYVÁRADI L. - SZABÓ-KovÁCS B. 2008: Tolna megye külterületi lakott helyeinek szociálökonómiai vizsgálata és tipizálása. - Területfejlesztés és Innováció 2. 1. pp. 10-20.

NELSON, P. B. - OBERG, A. - NELSON, L. 2010: Rural gentrification and linked migration in the United States. - Journal of Rural Studies 26. pp. 343-352.

NIKODEMUS, O. - BELL, S. - GRĪNEA, I. - LIEPI, I. 2005: The impact of economic, social and political factors on the landscape structure of the Vidzeme Uplands in Latvia. - Landscape and Urban Planning 1-2. pp. 57-67.

NUISSL, H - RINK, D. 2005: The 'production' of urban sprawl in eastern Germany as a phenomenon of post-socialist transformation. - Cities 22. 2. pp. 123-134.

O'CONNOR, J. - BROWN, A. 2013: A qualitative study of 'fear' as a regulator of children's independent physical activity in the suburbs. - Health \& Place 24. pp. 157-164.

ÓNODI G. - CROS KÁRPÁTI Zs. 2002: A kertségek és a kertkultúra eredete, alakulása Magyarországon. - Falu-VárosRégió 3. pp. 12-17.

ÓNODI G. - CROS KÁRPÁTI Zs. - GuBICUA Cs. - HoRVÁTH J. - MolNÁR M. 2002: A kertségek és kertmüvelés szerepe és jövője I.: Településrendezési, szabályozási javaslatok. - Falu-Város-Régió 2. pp. 3-8.

ORBÁN S. 1996: Mi történt a majorsági cselédséggel 1945 után? - In: Szili F. (szerk.): Somogy megye múltjából: levéltári évkönyv. Somogy Megyei Levéltár, Kaposvár, pp. 223-251.

OTT, T. 2001: From Concentration to Deconcentration - Migration Patterns in the Post-socialist City. - Cities 18. 6. pp. 403-412.

OUŘEDNÍČEK, M. 2007: Differential suburban development in the Prague urban region. - Geografiska Annaler, B Human Geography 89 B. 2. pp. 111-126.

PACIONE, M. 2013. Private profit, public interest and land use planning - A conflict interpretation of residential development pressure in Glasgow's rural-urban fringe. - Land Use Policy 32. pp. 61-77. 
PHILLIPS, M. 2009: Counterurbanisation and rural gentrification: an exploration of the terms. - Population, Space and Place 6. pp. 539-558.

PHILLIPS, M. 2002: The production, symbolization and socialization of gentrification: impressions from two Berkshire villages. - Transactions of the Institute of British Geographers 3. pp. 282-308.

PÓCSI G. - BAJMÓCY P. - JÓZSA K. 2008: A majorságok településföldrajzi fejlődése és jelenlegi differenciálódása Somogy megye példáján. - In: SZABÓ V., Orosz Z., NAGY R., FAZEKAS I. (szerk.): IV. Magyar Földrajzi Konferencia, Debrecen, pp. 322-327.

PÓCSI G. 2009a: Dinamikus átalakulások Budaihegyen, Kecskemét város-vidék peremzónájában - In: CsAPÓ T. KoCSIS Zs. (szerk.) A közép- és nagyvárosok településföldrajza. Savaria University Press, Szombathely, pp. 322-334.

PóCSI G. 2009b: Kiskertek a városok peremén. Kiskertek differenciálódása a rendszerváltozás óta, Szegeden. - In: Szabó V. - Fazekas I. (szerk.) Települési környezet Alföld nyomda, Debrecen, pp. 36-42.

Pócsi G. 2011: Land Use Change of the 'Small Hobby Gardens' in the Peri-Urban Area of Szeged, Hungary. - Forum geografic 10. 2. pp. 312-321.

PETRÁS E. 2006: A homokhátsági tanyák népesedési adatai és társadalmának néhány jellemzője. - A Falu 2. pp. 63-70.

PRISTYÁK E. - KÓKAI S. 2012: Az agglomerálódás és a szuburbanizáció jellemzői a nyíregyházi településegyüttesben. Településföldrajzi tanulmányok 2. pp. 87-103.

PRYOR, R. J. 1968: Defining the Rural-Urban Fringe. - Social Forces 47. 2. pp. 202-215.

RAKONCZAi J. - UNGER J. - MUCSI L. - SZATMÁRI J. - TOBAK Z. - BOUDEWIJN VAN L. - GÁL T. - FiALA K. 2009: A napfény városa napemente után - légi távérzékeléses módszerrel támogatott hősziget-térképezés Szegeden. - Földrajzi Közlemények 133. 4. pp. 367-383.

RECHNITZER J. 2007: Nyugat-Dunántúl. A Kárpát-medence Régiói, 5. - MTA RKK, Dialog Campus, Pécs-Budapest, 454. p.

REEH, H. - ZERLAG, M. 2011: Fairytales from the Fingerplan: Representing Strategies for Suburban Copenhagen. - In: Szirmai V. (szerk.): Urban Sprawl in Europe. Aula, Budapest, pp. 65-83.

ROBERTS, J. - HODGSON, R. - DOLAN, P. 2011: "It's driving her mad": Gender differences in the effects of commuting on psychological health. - Journal of Health Economics 5. pp. 1064-1076.

ROMAN, D. 2001: Gendering Eastern Europe: pre-feminism, prejudice and east-west dialogues in post-communist Romania. - Women's Studies International Forum 1. pp. 53-66.

ROMVÁRI R: 2014: A Tanyafejlesztési Programok eredményei. - A Falu 1. pp. 51-59.

Roose, A. - KULL, A. - GAUK, M. - TALI, T. 2013: Land use policy shocks in the post-communist urban fringe: A case study of Estonia - Land Use Policy 30. pp. 76-83.

SÁGIZS. - TRÓCSÁNYI A. 1998: Szegregáció a budapesti agglomerációs övezetben. - Földrajzi Értesítő 2. pp. $235-248$.

SÁRFALVI B. 1991: Magyarország népességföldrajza. - Tankönyvkiadó, Budapest, 116. p.

SCHAFFT, K. 2000: A network approach to understanding post-socialist rural inequality in the 1990's. - Eastern European Countryside 6, pp. 25-40.

SCHUCHMANN J. 2010: Szuburbanizáció vagy Reurbanizáció jellemzi ma a Budapesti agglommerációt? Válaszok az eltérő fejlettségű szuburbán lakosság lakóhelyi elégedettsége és költözési szándékainak elemzése alapján. - In: Csapó T. - Kocsis Zs. (szerk): A településföldrajz aktuális kérdései. Savaria Press, Szombahely, pp. 131-142.

SHUCKSMITH, M. - WATKINS, L. 1991: Housebulding on farmland: the distributional effects in rural areas. - Journal of Rural Studies 3. pp. 153-168.

SHARP J. S. - ClARK J. K. 2008. Between the Country and the Concrete: Rediscovering the Rural-Urban Fringe - City \& Community 7. 1. pp. 61-79.

SOLTÉSZ J. 1990: Borsod-Abaúj-Zemplén megye zártkertjeinek helyzete, különös tekintettel a Tokaj-Hegyaljai történelmi borvidékre. - A Falu 4. pp. 33-40.

SOMERVILLE, P. 2013: Changing social relations in the English countryside: The case of housing. - In: BOSWORTH, G. SOERVILLE, P. (szerk.): Interpreting rurality: Multidisciplinary approaches. Routledge, London, pp. 182-204.

SOMLYÓDYNÉ PFEIL E. 2010: Lehetőségek a szuburbán önkormányzatok intézményesített együttmüködésére. - In: HARDI T. - LADOS M. - TóTH K. (szerk.): Magyar-szlovák agglomeráció Pozsony környékén. MTA RKK NYUTI Fórum Kisebbségkutató Intézet, Győr-Samorin, pp. 154-162.

SOMLYÓDYNÉ PFEIL E. 2012: A nagyvárosi térségek intézményesítési feltételeiről az európai városverseny által befolyásolt térben - In: SOMOLYDYNÉ PFEIL E. (szerk.): Az agglomerációk intézményesítésének sajátos kérdései. Publikon, Pécs, pp. 43-66.

SQUIRES, D. S. 2002: Urban Sprawl and the Uneven Development of Metropolitan America. - In: Squires, G. D. (szerk.): Urban Sprawl: Causes, Consequences, and Policy Responses. Urban Institute, Washington DC, pp. 1-22.

STOCKDALE, A. 2010: The diverse geographies of rural gentrification in Scotland. - Journal of Rural Studies 26. 1. pp. $31-40$.

SUVÁK A. 2012a: Az agglomerációkhoz kapcsolódó szervezési és tervezési megfontolások Nyugat-Európában - In: SOMOLYDYNÉ PFEIL E. (szerk.): Az agglomerációk intézményesítésének sajátos kérdései. Publikon, Pécs, pp. 91-108.

SuVÁK A. 2012b: Az egy térségben való gondolkodás vizsgálata a tervezési gyakorlat és a központi városhoz kötődés néhány szempontján keresztül Magyarország három agglomerációjában - In: SOMOLYDYNÉ PFEIL E. (szerk.): Az agglomerációk intézményesítésének sajátos kérdései. Publikon, Pécs, pp. 181-200. 
SÝKORA, L. - BOUZAROVSKI, S. 2011: Multiple Transformations: Conceptualising the Post-communist Urban Transition. - Urban Studies 49. 1. pp. 43-60.

SZABÓ J. 2003: Települési stratégiák a budapesti agglomerációban. - Tér és Társadalom 4. pp. 101-116.

SZEBÉNYI A. 2006: A szuburbanizáció sajátosságainak vizsgálata Pécs környékén, 2005-ben. - In: CSAPÓ T.-KoCSIS Zs. (szerk): Agglomerációk és szuburbanizálódás Magyarországon. Savaria, Szombathely, pp. 196-215.

SzELÉNYI I. 1996: „Cities under Socialism - and After.” In Cities After Socialism: Urban and Regional Change and Conflict. - In: ANDRUSZ, G. - HARLOE, M. - SzELÉNYI I. (szerk.): Post-Socialist Societies. Blackwell, Oxford, pp. 286 317.

SzENTI T. 2003: Vásárhelyi emlékeim. Hódmezővásárhely Megyei Jogú Város Polgármesteri Hivatala, Hódmezővásárhely, 303. p.

SzIRMAI V. 2011a: Urban sprawl in Europe: An Introduction. - In: Szirmai V. (szerk.): Urban Sprawl in Europe: Similarities or Differences? Aula Kiadó, Budapest, pp. 15-44.

SzIRMAI V. 2011b: A nagyváros szélén: A városi terjeszkedés térbeli társadalmi problémái. - Tér és Társadalom 1. pp. $20-41$.

SzIRMAI V. 2013: „Városi világ” Enyedi György globális urbanizációs elmélete (egy személyes hangvételü írás). - Tér és Társadalom 3. pp. 163-171.

SzIRMAI V. 2017: Az új városi urbanizációs modell szocialista és/vagy globális természete. - Tér és Társadalom 3. pp. $25-43$.

SZIRMAI V. - VÁRADI, Zs. - KOVÁCS, SZ. - BARANYAI, N. - SCHUCHMANN, J. 2011: Urban sprawl and its spatial, social consequences in the Budapest metropolitan region. In: SZIRMAI, V. (szek.): Urban sprawl in Europe. Aula Könyvkiadó, Budapest, pp. 141-187.

TAMMARU, T. 2001: Suburban growth and suburbanization under central planning: The case of Soviet Estonia. - Urban Studies 38. pp. 1314-1357.

THEOBALD, D. M. 2005: Landscape Patterns of Exurban Growth in the USA from 1980 to 2020. - Society 1. pp. 32-66.

TuNA, T. - KOK, H. 1999: A Varsó kürüli szuburbanizációs folyamat jellemzői az 1990-es években. - Földrajzi Értesítő 1-2. pp. 159-172.

TIMÁR J. 1990a: Kérdőjelek és hiányjelek a tanyakutatásban. - Tér és Társadalom 2. pp. 49-62.

TIMÁR J. 1990b: A tanya fogalmának változása, a tanyák szuburbanizációja. - In: CsATÁRI B. (szerk.): Tanakodás a tanyákról. MTA RKK Településkutató csoport, Kecskemét, pp. 22-34.

TIMÁR J. 1993: A városok körüli rurális peremzóna átalakulásának néhány sajátossága az alföldön. - In: Kovács T. (szerk): Kiút a Válságból. II. falukonferencia. MTA RKK, Pécs, pp. 303-308.

TIMÁR J. 1999: Elméleti kérdések a szuburbanizációról. - Földrajzi Értesítő 48. 1-2. pp. 7-31.

TíMÁR J. - BAUKÓ T. 1999: A "város-vidék peremzóna" néhány sajátossága és szerepe az alföldi városok átalakulásában. - Alföldi tanulmányok 17.pp. 94-111.

TiMÁR J. - VÁRADI M. 2000: A szuburbanizáció egyenlőtlen fejlődése az 1990-es évek Magyarországán. - In: HORVÁTH GY. - RECHNITZER J. (szerk.): Magyarország területi szerkezete és folyamatai az ezredfordulón. MTA Regionális Kutatások Központja, Pécs, pp. 153-175.

TIMÁR J. 2001a: A háztartási „túlélési stratégiák” területi szempontú kutatásának néhány elméleti kérdése és empirikus eredménye az átmenet időszakában Magyarországon. - In: Ekéné Z. I. (szerk.): 10 éves a Debreceni Egyetem Társadalomföldrajzi és Területfejlesztési Tanszéke. DE Társadalomföldrajzi és Területfejlesztési Tanszék, Debrecen, pp. 209-218.

TIMÁR J. 2001b: Mégis, kinek az érdeke? Szuburbanizáció a kapitalizálódó Magyarországon. - In: A földrajz eredményei az új évezred küszöbén. SZTE TTK Természeti Földrajzi Tanszék, Szeged, pp. 1-10.

TIMÁR J. - VÁRADI M. M. 2001: The uneven development of suburbanization during transition in Hungary. - European Urban and Regional Studies 4. pp. 349-360.

TIMÁR J. 2010: Van-e posztszocialista urbanizáció? - néhány gondolat a magyarországi szuburbanizációról és dzsentrifikációról. - In: BARTA GY. et. al. (szerk.): A területi kutatások csomópontjai. MTA RKK, Pécs, pp. 121-139.

TIMÁR J. - KOVÁCS K. - VÁRADI M. M. 2015: A jól-lét deficit a hátrányos helyzetü kistérségekben. - In: SzIRMAI V. (szerk.): A területi egyenlötlenségektől a társadalmi jól-lét felé. Kodolányi János Főiskola, Székesfehérvár, pp. 269284.

TÓTH J. 1993: A szolnoki agglomeráció. MTA RKK, Pécs, 389. p.

То́тн J. 2006: Az agglomerálódás stádiumai. - In: Csapó T.-Kocsis Zs. (szerk.): Agglomerációk és szuburbanizálódás Magyarországon. Konferenciakötet. Savaria University Press, Szombathely, pp. 6-14.

Tо́тH J. 2007: Kistelepülések az agglomerációkban. - In: Csapó T.-Kocsis Zs. (szerk.): A kistelepülések helyzete és településföldrajza Magyarországon. III. Településföldrajzi Konferencia, Szombathely, pp. 38-48.

Tо́тн L. 2004: A nagybirtokrendszer megszüntetése és a földmíves nép földhözjuttatása Magyarországon. Acta Universitatis Szegediensis: acta juridica et politica 64. 1-28. pp. 439-460.

TÓTH Z. 2000: Településkörnyezet II. Az épített környezet - In: Enyedi Gy. (szerk.): Magyarország településkörnyezete. MTA, Budapest, pp. 151-186.

TÓzSA I. 2002: A „káros urbanizáció”. - Tér és Társadalom 1. pp. 1-17 
VÁRADI M. M. 1999: Hová megyünk lakni? Szuburbanizációs minták és konfliktusok a budapesti agglomeráció budai oldalán. Esettanulmány. - In: BARTA GY. - BELUSZKY P. (szerk.): Társadalmi-gazdasági átalakulás a budapesti agglomerációban. Regionális Kutatási Alapítvány, Budapest, pp. 115-129.

VÁRADI M. M. 2013: Megélhetés és támogató kapcsolatok - az aprófalusi szegénység arcai: Esettanulmány 2008-ból. In: Kovács K. - Váradi M. M. (szerk.): Hátrányban vidéken. Argumentum Kiadó, Budapest, pp. 106-131.

VÁRADI M. M. 2015: A túlélés és a társadalmi betagolódás között: szegénység, kirekesztettség és kapcsolatrendszerek. In: Virág T. (szerk.): Törésvonalak: Szegénység és etnicitás vidéki terekben. Argumentum Kiadó, Budapest, pp. 45-68.

VARGA B. 2003: Töltéstava község története. [s.ny.] 164. p.

VALDUNCIEL, J. 2014: The anatomy of urban sprawl in the Mediterranean region: the case of the Girona districts 19792006. - In: O'DONOGHUE, D. P. (szerk.): Urban Transformations: Centres, Peripheries and Systems. Farnham, Surrey Ashgate, pp. 5-14.

VALLER É. 1996: A lakotthely állomány változásai 1960-1990 között. T 14950 sz. OTKA kutatás: kutatási zárójelentés. VÁTI, Budapest, 15. p.

VARGA B. 2003: Töltéstava község története - [s.n.]. 164. p.

VASÁRUS G. - MAKRA Zs. 2015: Az agglomerációk lehatárolásának néhány kérdése Győr példáján. - Településföldrajzi Tanulmányok. 1.pp. 84-94.

VASÁRUS G. 2016a: Szuburbanizáció külterületeken és egyéb belterületeken, Győr példáján. - Településföldrajzi Tanulmányok. 2.pp. 22-37.

VASÁRUS G. 2016b: Külterületi szuburbanizáció és szegregáció: Példák vidéki agglomerációk konfliktusaira. Településföldrajzi Tanulmányok. 1. pp. 84-94.

VASÁRUS G. - BAJMÓCY P. - LENNERT J. 2018: In the shadow of the city: demographic processes and emerging conflicts in the rural-urban fringe of the Hungarian agglomerations. - Geographica Pannonica. 22.1. pp. 14-29.

VEDRÉDI K. 2012: A köztér fogalmának különféle értelmezései és területfejlesztési aspektusai. - In: PÁL V. (szerk.): A társadalomföldrajz lokális és globális kérdései. SZTE Gazdaság- és Társadalomföldrajz Tanszék, Szeged, pp. 291 - 299.

WEAVER, D. B. - LAWTON, L. J. 2001: Resident Perceptions in the Urban-Rural Fringe. - Annals of Tourism Research 2. pp. 439-458.

WILliAMSON, T. - IMBROSCIO, D. - AlPEROVITZ, G. 2005: The Challenges of Urban Sprawl. - In: Kleniewsk, N. (szerk.): Cities and Society. Blackwell Publishing Ltd., pp. 303-329.

Wilson, J. - SpinNEY, J. - Millward, H. - SCOTT, D. - HAYDEN, A. - TYEDMERS, P. 2013: Blame the exurbs, not the suburbs: Exploring the distribution of greenhouse gas emissions within a city region. Original Research Article. Energy Policy 62. pp. 1329-1335.

WOLF, T. - B. C. MEYER 2010: Suburban scenario development based on multiple landscape assessments. - Ecological Indicators 10. pp. 74-86.

WU, F. 2010: Gated and packaged suburbia: Packaging and branding Chinese suburban residential development. - Cities 5. pp. 385-396.

YUE, W. - LIU, Y. - FAN. P. 2013: Measuring urban sprawl and its drivers in large Chinese cities: The case of Hangzhou. - Land Use Policy 31. pp. 358-370.

ŹRÓBEK-RÓŻAŃSKA, A - ZADWORNY, D. 2016: Can urban sprawl lead to urban people governing rural areas? Evidence from the Dywity Commune, Poland. - Cities 59. pp. 57-65.

ZACHAR P. K. 2005: A hegyközségek önkormányzatiságának kérdéseiröl. - In: GERGELY J. (szerk.): Autonómiák Magyarországon 1848-2000 I. L'Harmattan Kiadó, Budapest, pp. 73-65. 


\section{Egyéb források:}

1. https://geonames.usgs.gov/apex/f?p=gnispq:8:14517156097426 Elérés: 2016. 11. 10.

2. http://www.eea.europa.eu/publications/urban-sprawl-in-europe/at download/file Elérés: 2016. 12. 10.

3. http://www.zemplenimuzsa.hu/09_1/soos.htm Elérés: 2016 10. 30.

4. http://epiteszforum.hu/a-kertsegek-es-a-kertmuveles-szerepe-es-jovoje-iii Elérés: 2017. 01.04.

5. http://www.tarki.hu/adatbank-h/kutjel/pdf/a124.pdf Elérés: 2016. 12. 05.

6. http://www.ksh.hu/docs/hun/xttp/idoszaki/mo telepuleshalozata/agglomeracio.pdf Elérés: 2016. 09. 20.

http://innovacio.gyor.hu/data/files/its/gyor_megalapozo_vizsgalat_2014_junius_tarsadalmasitasra.pdf Elérés: 2016. 03.02.

7. https://www.szegedvaros.hu///wp-content/uploads/docs/szeged tfk its megalapozo.pdf?894128 Elérés: 2015. 12. 01.

8. http://zalaegerszeg.hu/dokumentum/22886/1_ZEG_MEGALAPOZO_VIZSGALAT_20140304.pdf Elérés: 2015. 08. 01.

KSH Helységnévtár: www.ksh.hu/apps/hntr.kereses Elérés: 2016. 11. 30.

BAJMÓCY P. Magyarország külterületeinek adatbázisa., Gyüjtés.

1909. évi XV. törvény az állami kőszénbányászat fejlesztéséröl.

1919. évi XVIII. néptörvény a földmívelő nép földhöz juttatásáról.

1936. évi XXVII. törvénycikk a telepítésről és más földbirtokpolitikai intézkedésekröl.

1944. évi II. törvénycikk indokolása a tanyai igazgatás rendezéséről.

600/1945. M. E rendelet a nagybirtokrendszer megszüntetéséről és a földmíves nép földhöz juttatásáról.

1946. évi IX. törvény a telepitésről és a földreform befejezésének előmozdításáról.

1947. évi XI. törvénycikk a szövetkezetekröl.

3300/1949. (IV. 9.) kormányrendelet a hegyközségek és hegyközségi tanácsok megszüntetéséröl.

2/1965. (II. 18.) ÉM-PM számú együttes rendelet a szociális követelményeknek meg nem felelő telepek felszámolásáról. 1967. évi IV. törvény a földtulajdon és a földhasználat továbbfejlesztéséről.

36/1967. /X.11/ Kormányrendelet a földtulajdon és a földhasználat továbbfejlesztéséröl szóló 1967. évi IV. törvény végrehajtásáról.

7/1967. /X.2./ MÉM. rendelet.

1969. évi Zártkert Rendezési Útmutató.

1993. évi II. törvény a földrendező és a földkiadó bizottságokról.

1993. évi III. törvény a szociális igazgatásról és szociális ellátásokról.

1994. évi CII. törvény a hegyközségekröl.

1997. évi CXLI. törvény az ingatlan-nyilvántartásról.

253/1997. (XII. 20.) Korm. rendelet az országos településrendezési és épitési követelményekröl.

1997. évi CXXII. törvény a hegyközségekröl szóló 1994. évi CII. törvény módosításáról.

109/1999. (XII. 29.) FVM rendelet az ingatlan-nyilvántartásról szóló 1997. évi CXLI. törvény végrehajtásáról.

2004. évi XVIII. törvény a szőlőtermesztésről és a borgazdálkodásról.

2007. évi CXXIX. törvény a termőföld védelméröl.

2011. évi CXCVI. törvény a nemzeti vagyonról.

2013. évi CXXII. törvény a mezö- és erdőgazdasági földek forgalmáról.

2016. évi CLXXXVII. törvény a zártkertként nyilvántartott ingatlanok müvelés alóli kivonásával kapcsolatban egyes törvények módosításáról. 


\section{KÖSZÖNETNYILVÁNÍTÁS}

Legnagyobb köszönettel és hálával Dr. Bajmócy Péter egyetemi docensnek, témavezetömnek tartozom a doktori dolgozat elkészítésében nyújtott segítségéért, tanácsaiért, témavezetői munkájáért és türelméért. Külön megköszönöm az adatgyüjtés során nyújtott önzetlen segítséget, mely nélkül a dolgozat nem készülhetett volna el jelenlegi formájában.

Köszönettel tartozom Dr. Kovács Zoltán tanszékvezető professzor úrnak, aki észrevételeivel segítette munkámat és biztosította a kutatáshoz szükséges feltételeket.

Szintén köszönet illeti Dr. Csatári Bálint egyetemi docenst, aki segítette indulásom a választott téma irányába és tanácsaival segítette munkámat.

Köszönettel tartozom minden kollégámnak, akik a doktori dolgozat készítése során észrevételeikkel, javaslataikkal és kritikájukkal támogatták munkámat.

Továbbá köszönettel tartozom a lakossági kérdőív felvételében segitő hallgatóknak lelkes munkájukért. Szintén köszönöm a kérdőívekre válaszoló lakosok önzetlen segítségét, és hálás vagyok érintett önkormányzatok dolgozóinak és vezetőinek, hogy időt nem sajnálva közremüködtek doktori disszertációm megírásában.

Szeretetteljes köszönettel tartozom családomnak, a disszertáció megírása közben nyújtott végtelen támogatásukért, odafigyelésükért és türelmükért. 


\section{MELLÉKLET: KÉPEK ÉS ÁBRÁK.}

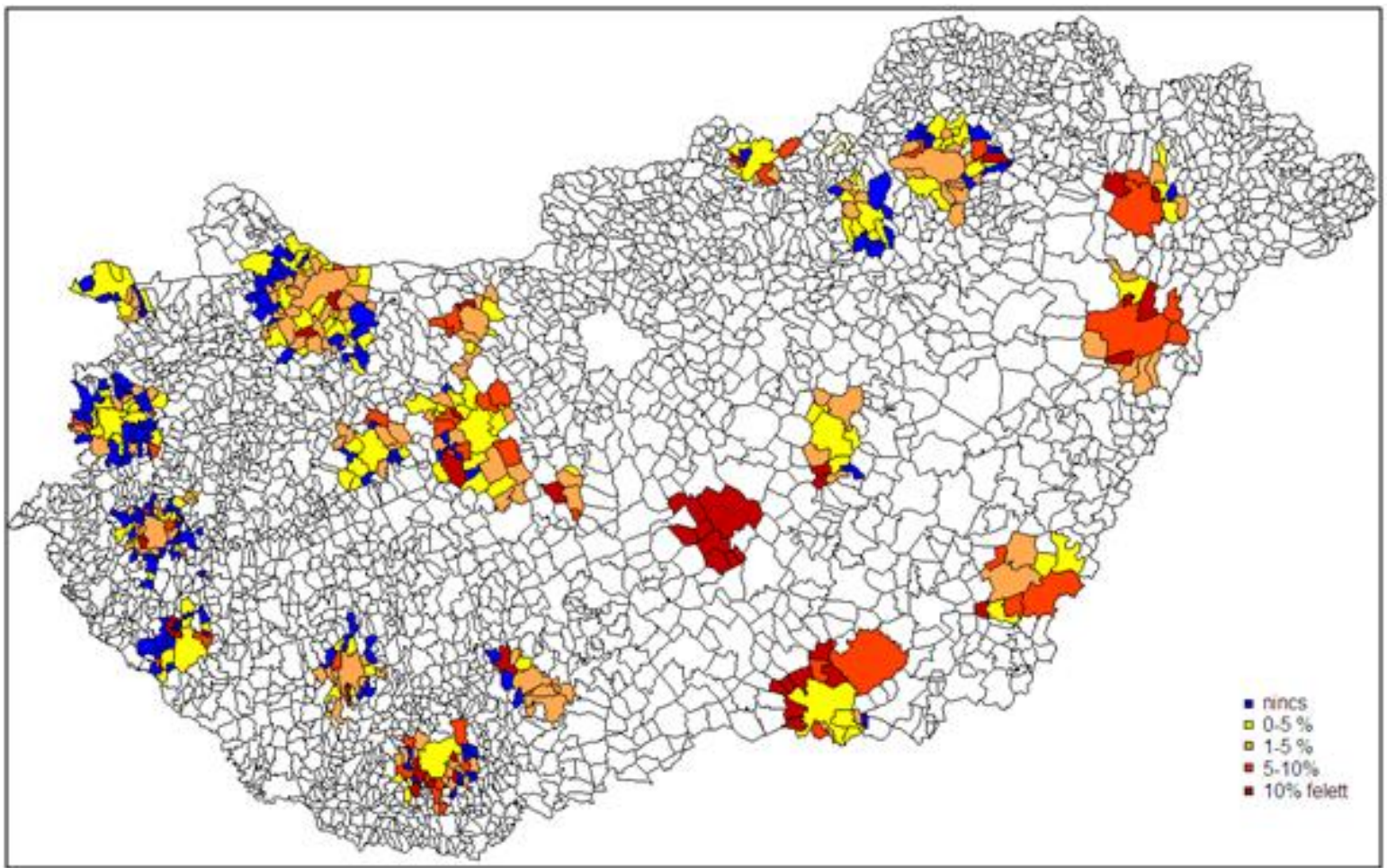

1. ábra: Magyarország Agglomerációinak, Település-együtteseinek és Hódmezővásárhely külterületi lakosságának aránya (\%), 2011 (Forrás: KSH Magyarország Helységnévtára alapján saját szerkesztés).

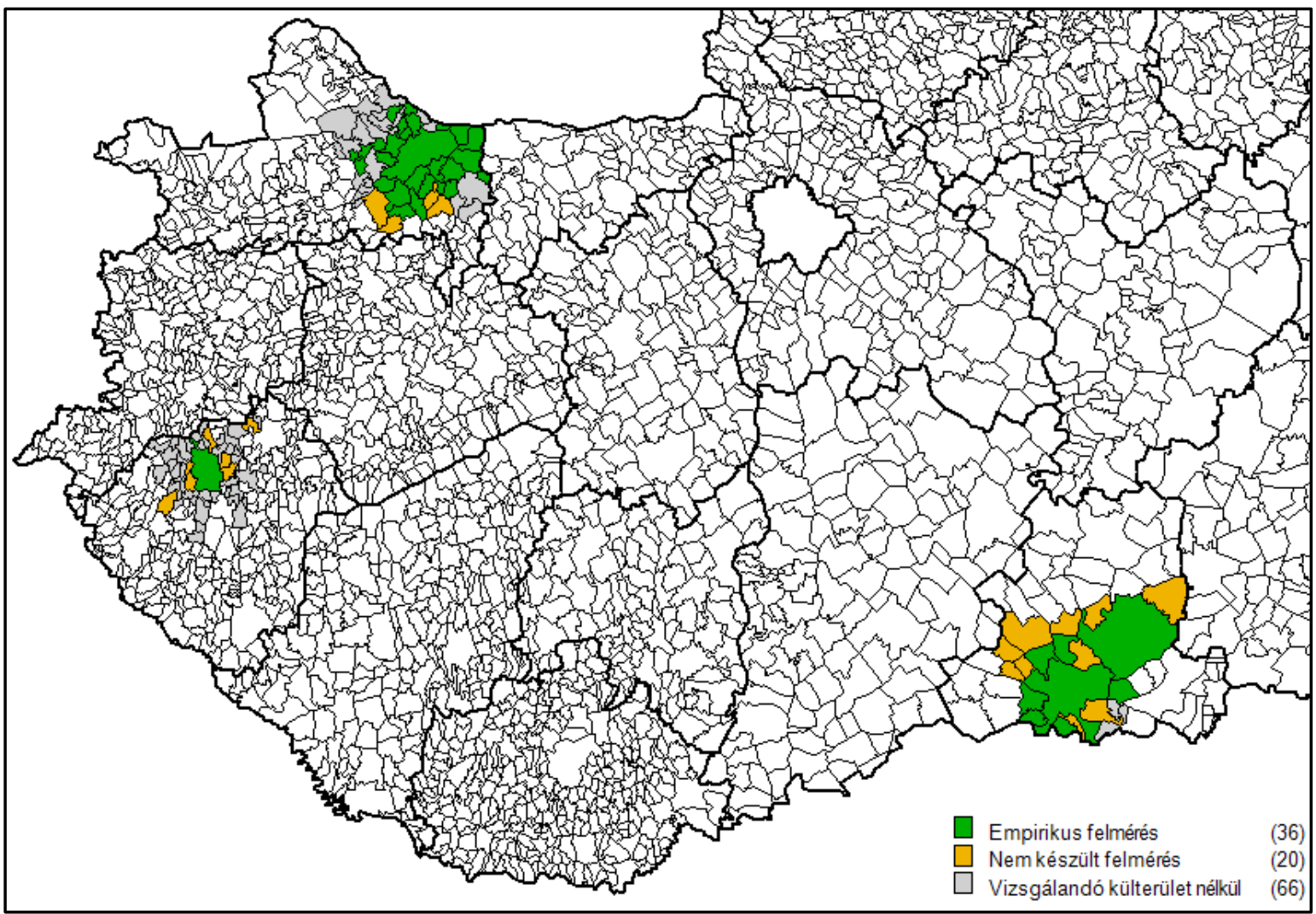

2. ábra: A vizsgálatba vont települések a felmérés szintje szerint (Forrás: Saját szerkesztés). 


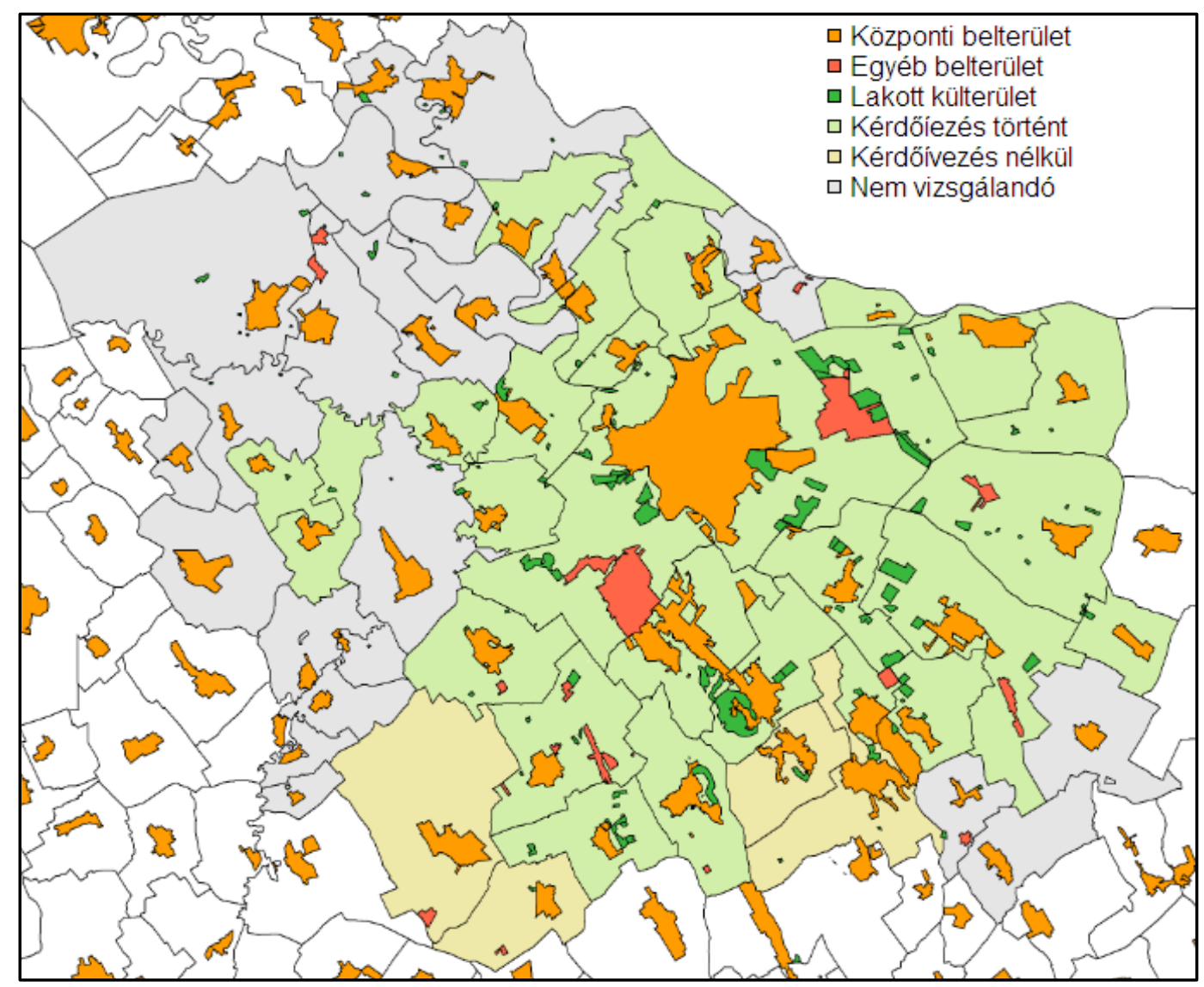

3. ábra: A Győri agglomeráció külterületei és egyéb belterületei, 2011 (Saját szerkesztés).

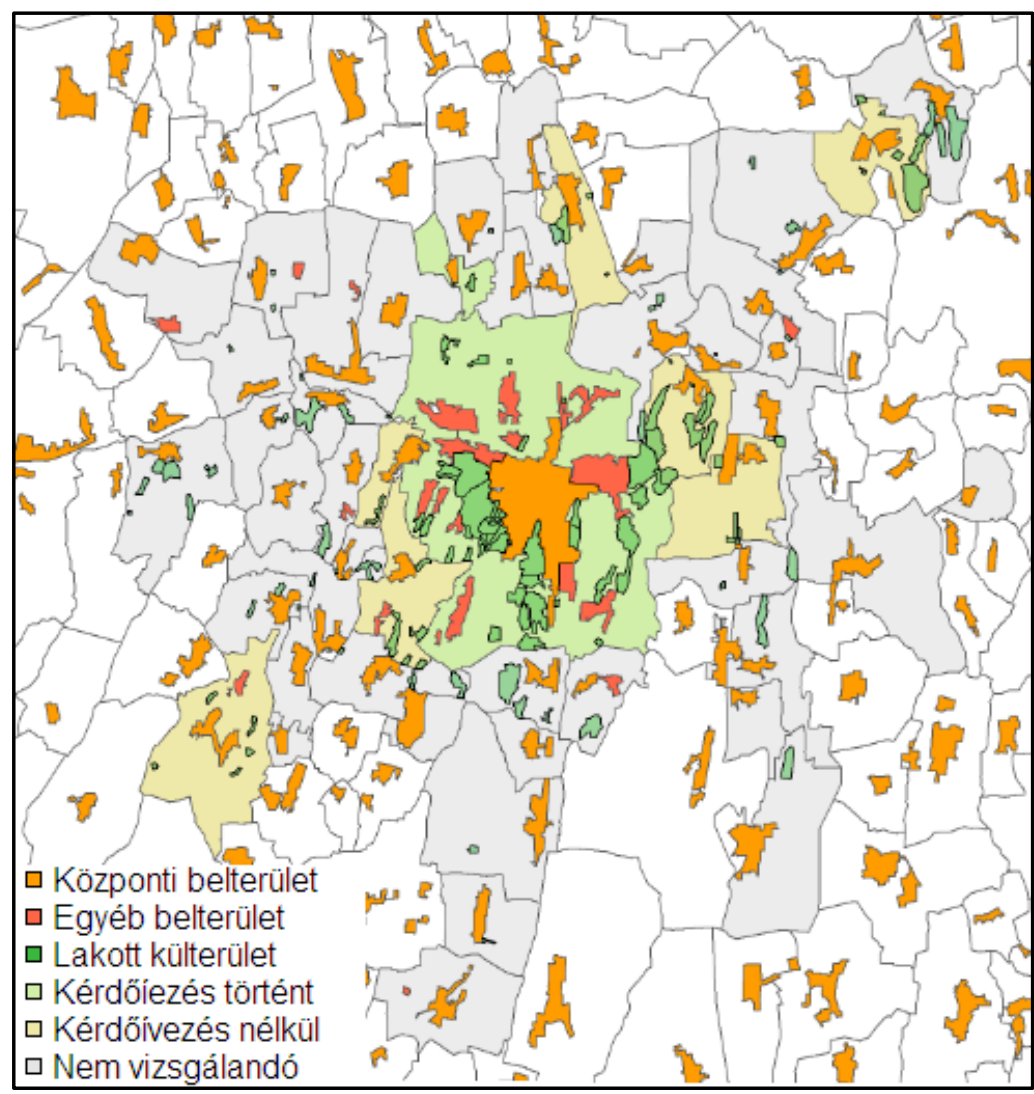

4. ábra: A Zalaegerszegi településegyüttes külterületei és egyéb belterületei, 2011 (Saját szerkesztés). 


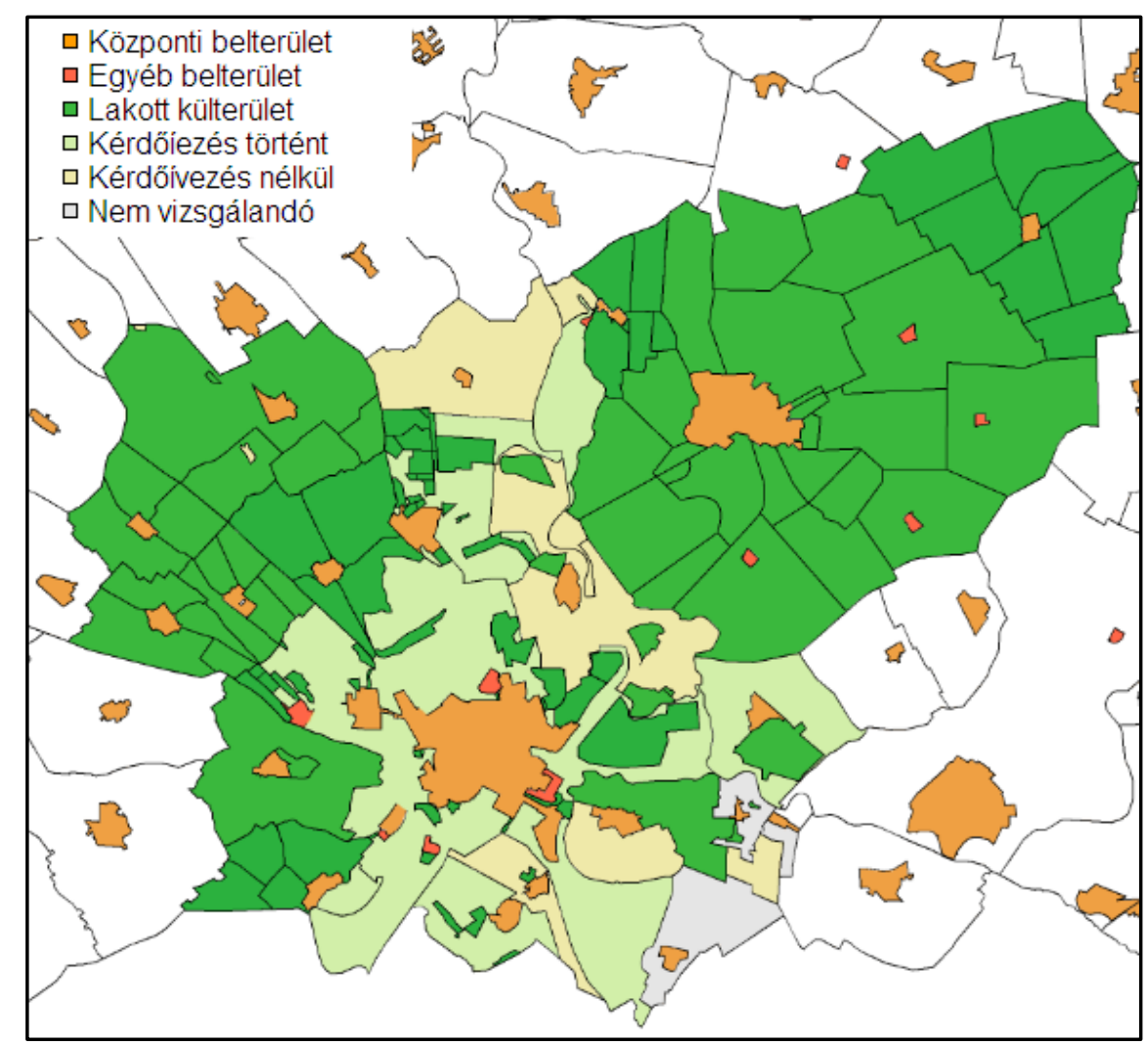

5. ábra: A Szegedi Településegyüttes és Hódmezővásárhely külterületei és egyéb belterületei, 2011 (Saját szerkesztés).

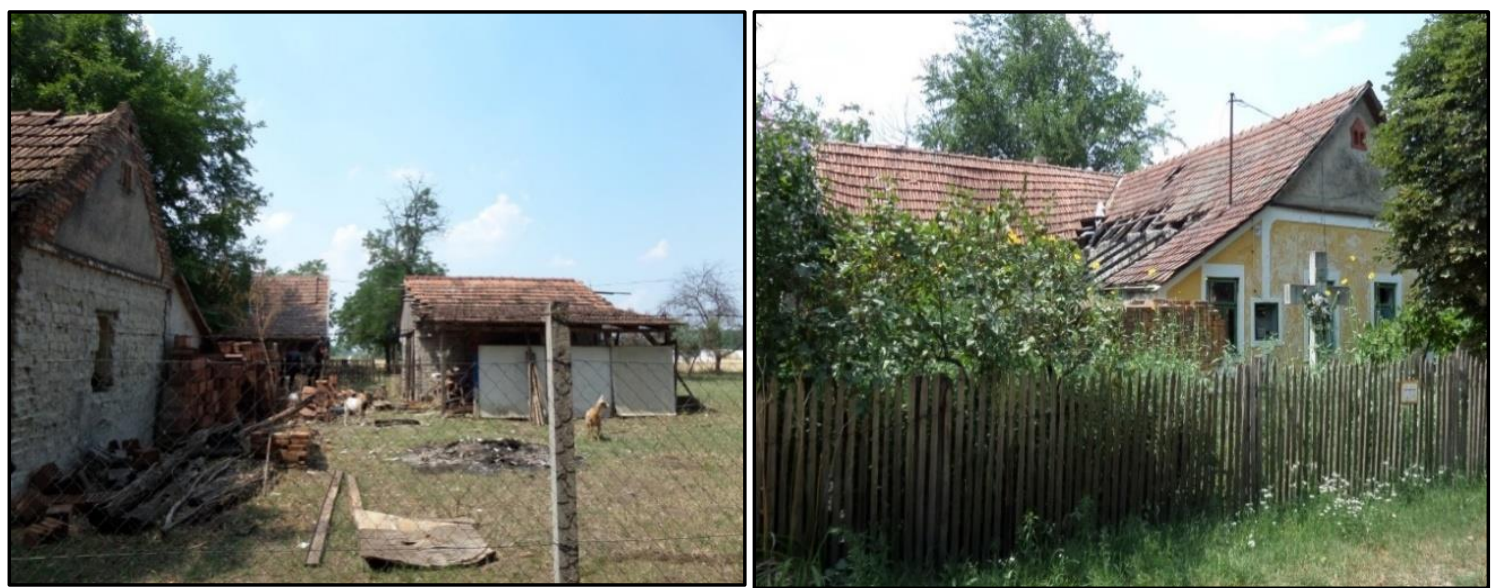

1. kép: Hanyatló tanyák Domaszék és Sándorfalva határában

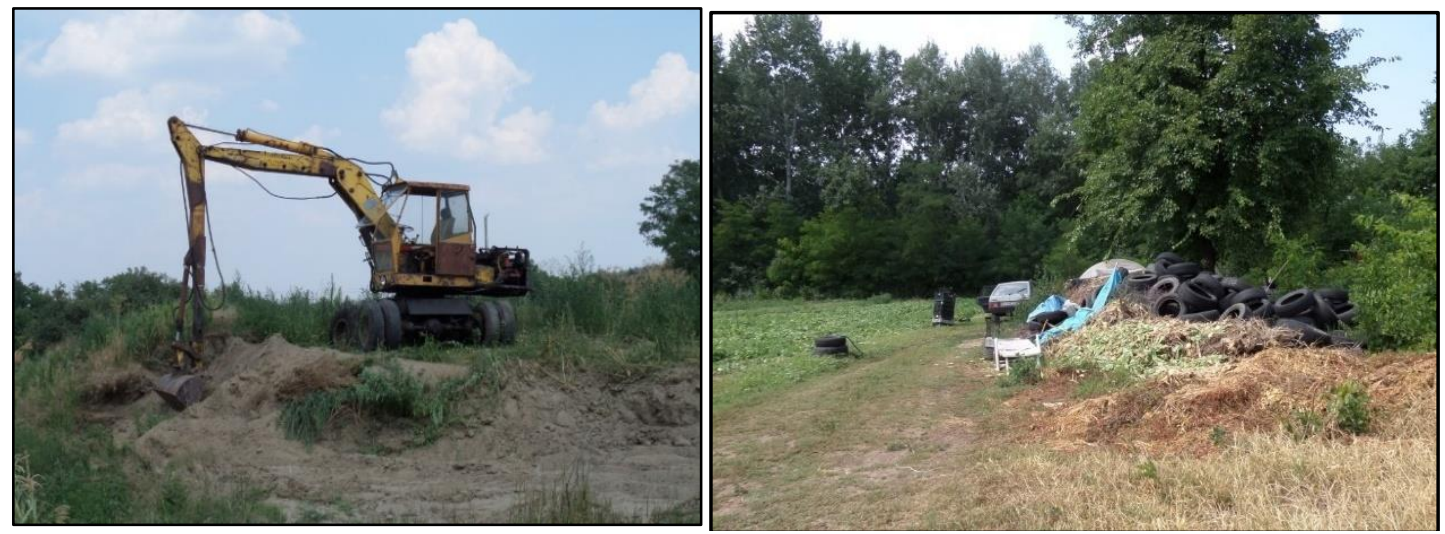

2. kép: A tanyás gazdálkodás romjai Szatymazon. 


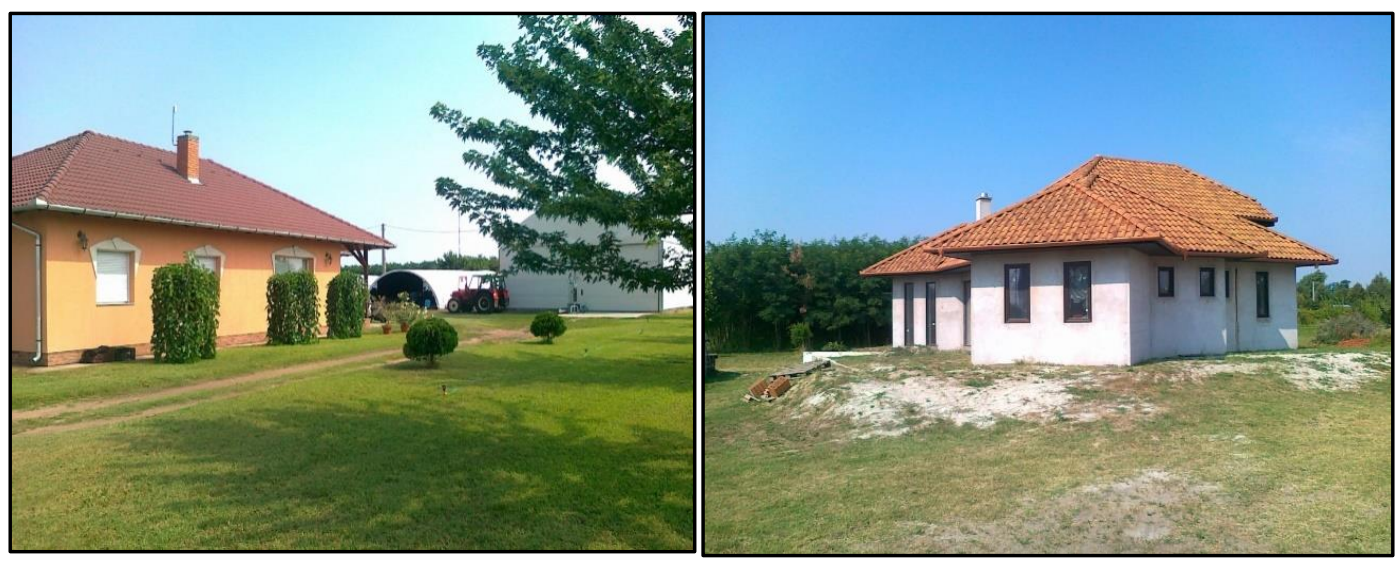

3. kép: Sikeresesen megújuló tanyák Szeged és Domaszék között.

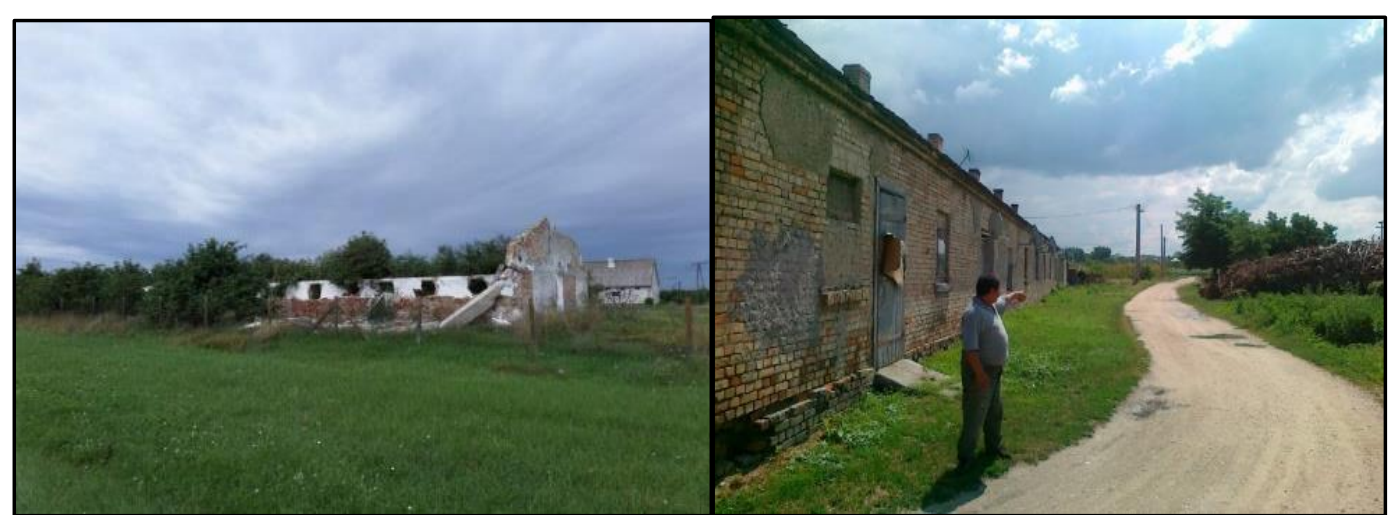

4. kép: Hanyatló, de növekvő népességü (Nagyszertjános) és elnéptelenedő (Győrság) major.

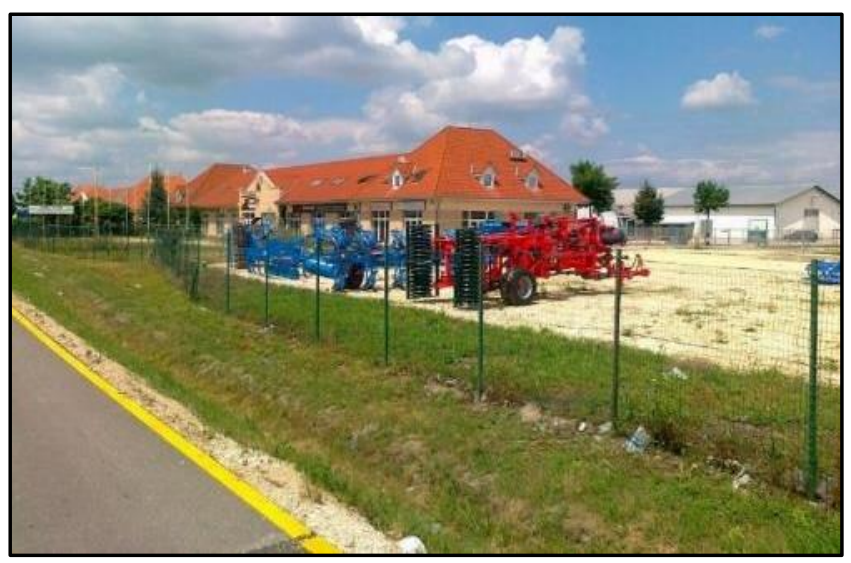

5. kép: Megújuló, de elnéptelenedő major (Győr).

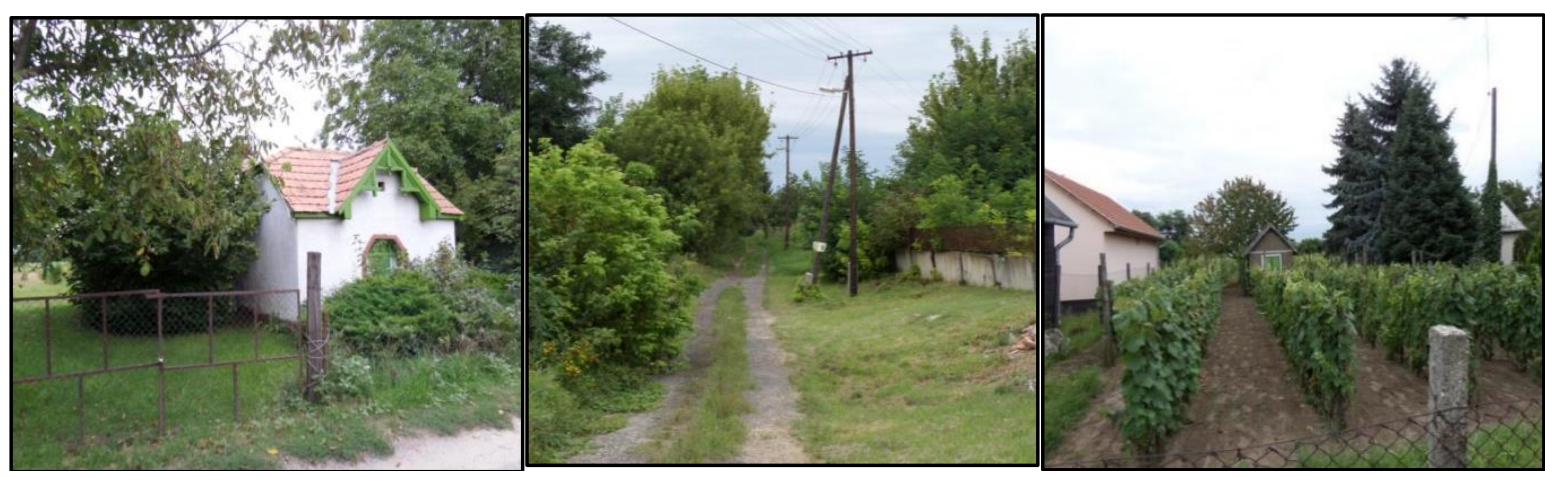

6. kép: Példák jellegzetes szőlőhegyi területhasználatra. 


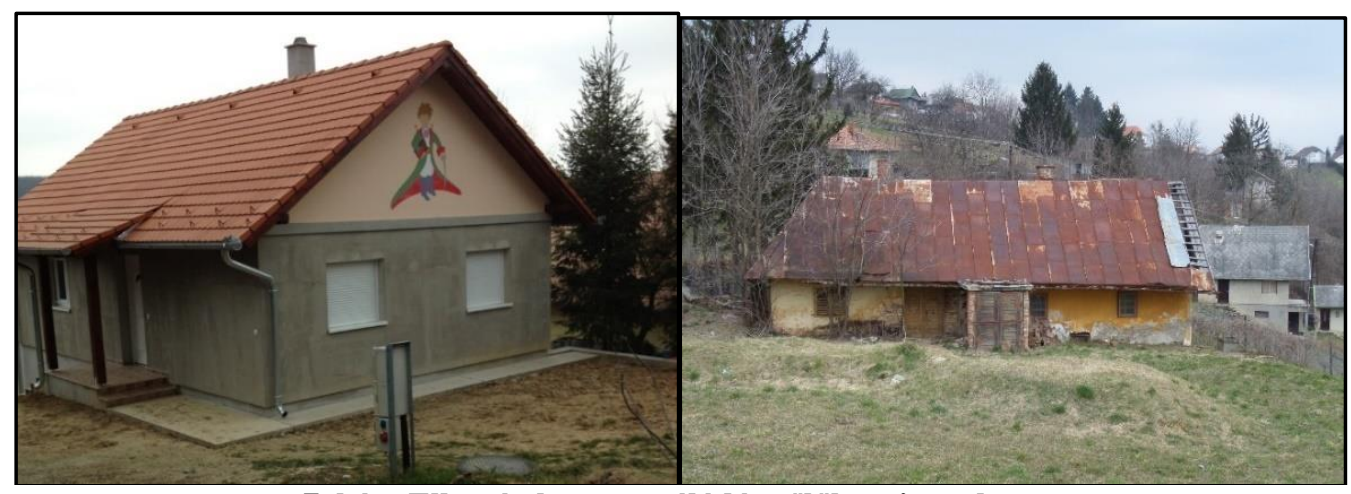

7. kép: Ellentétek szegregálódó szőlőhhegyi területen.

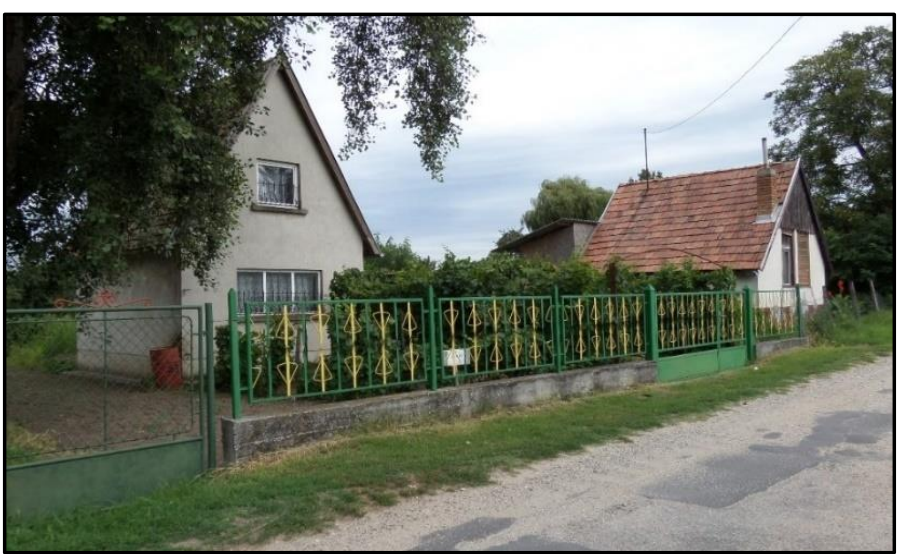

8. kép: Jellegzetes zártkerti utcakép.

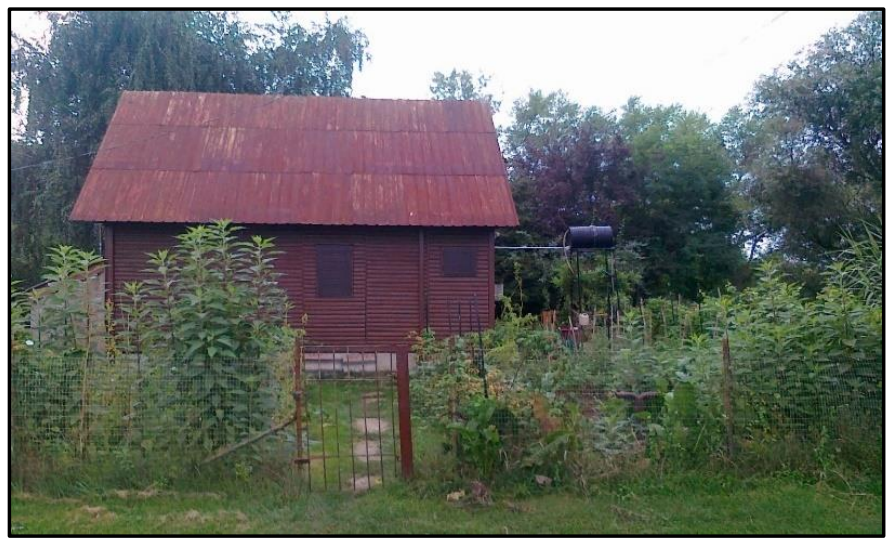

9. kép: Üdülőtelepként funkcionáló zártkert (Győr).

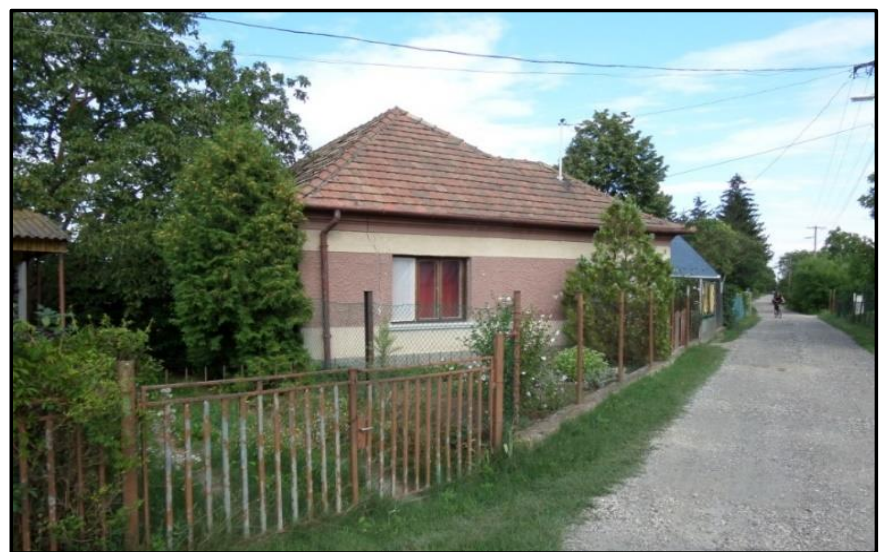

10. kép: Településperemi (periurbán) utca, (Győr). 


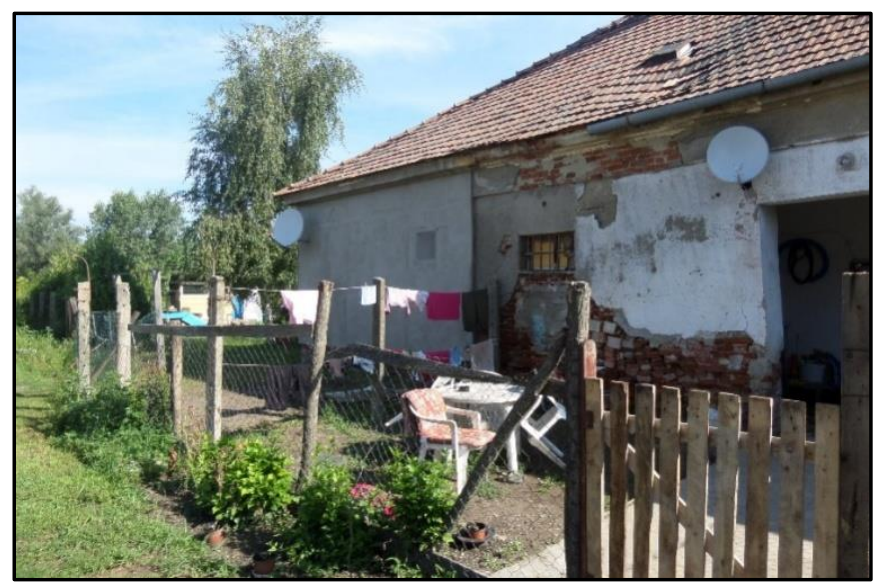

11. kép: Cigánytelep Győr határában.

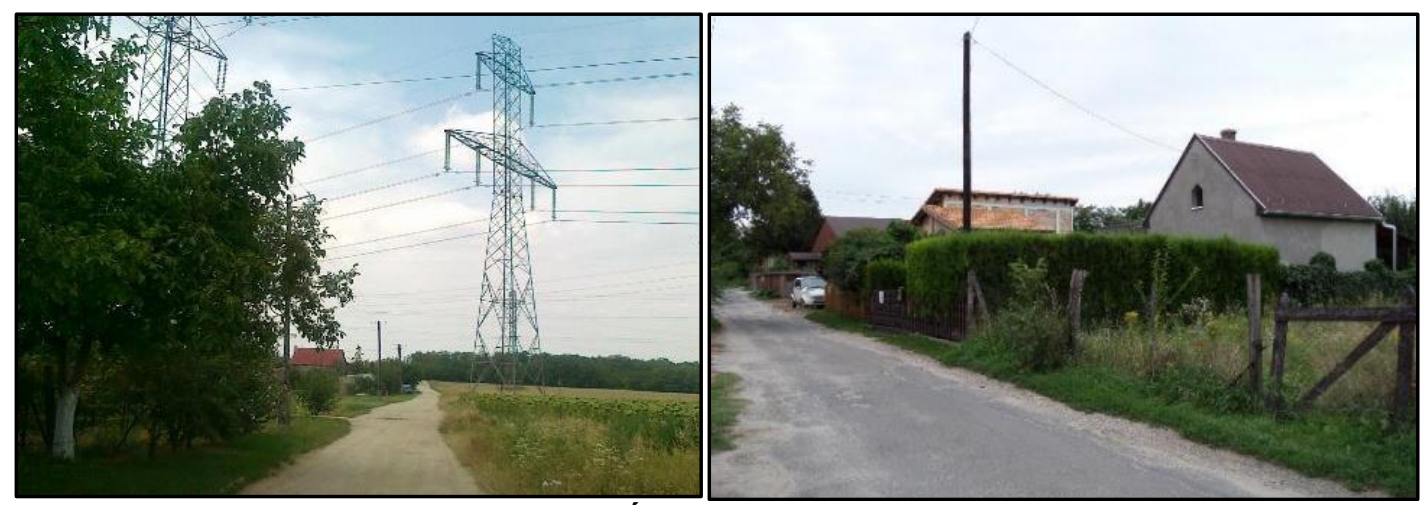

12. kép: Átalakuló zártkertek.

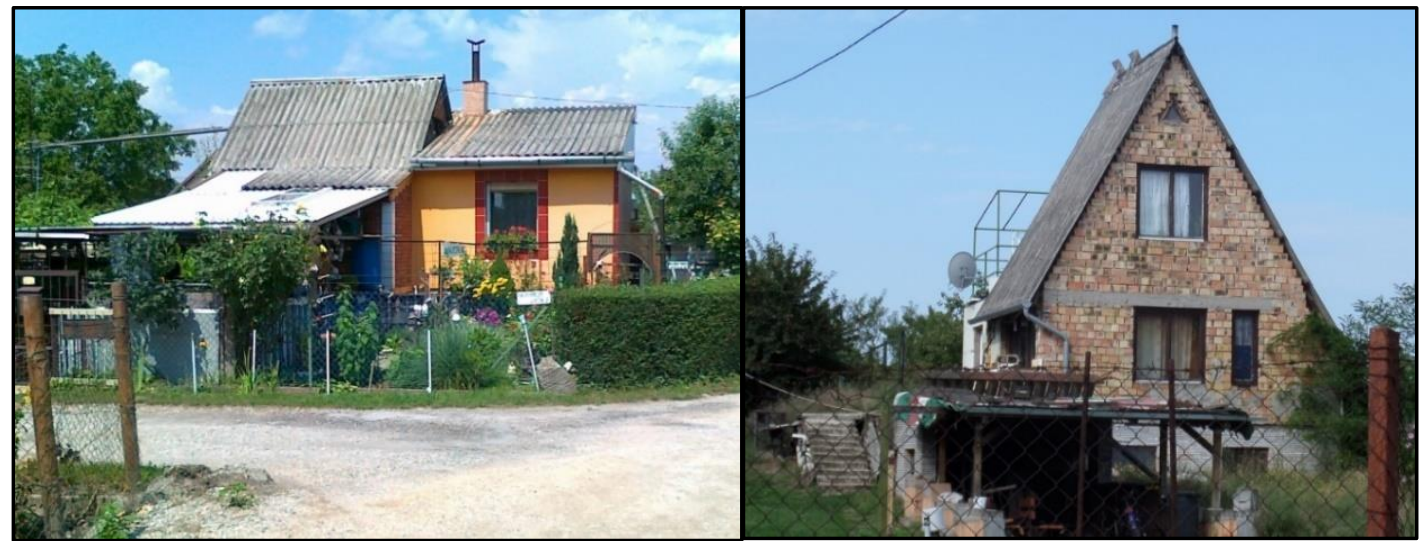

13. kép: Példák a zártkerti építkezésekre.

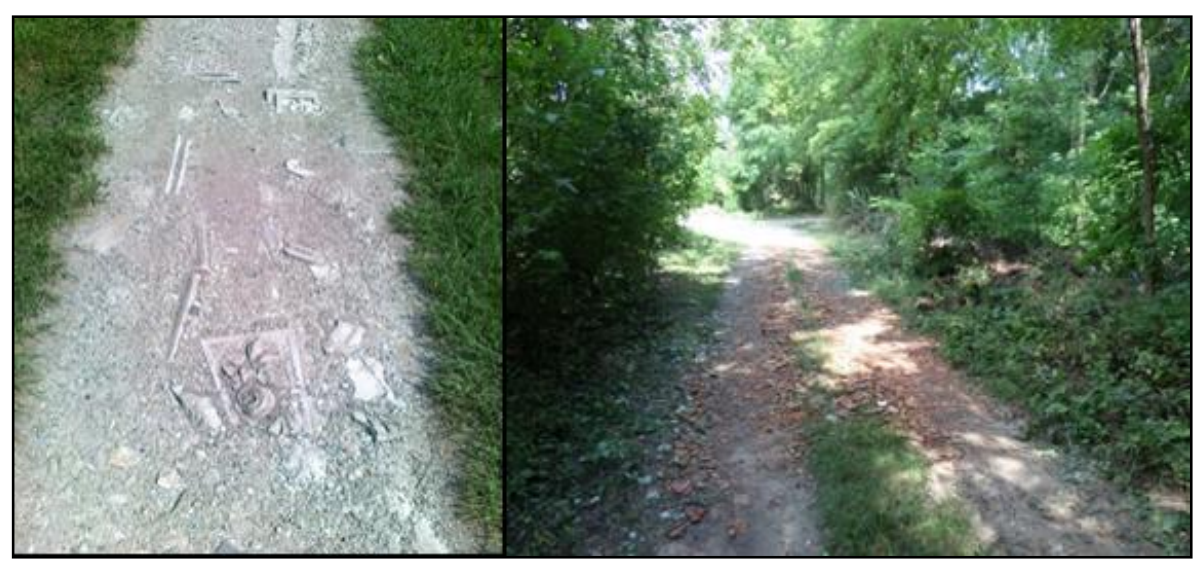

14. kép: A lakosok által javított útszakasz. 


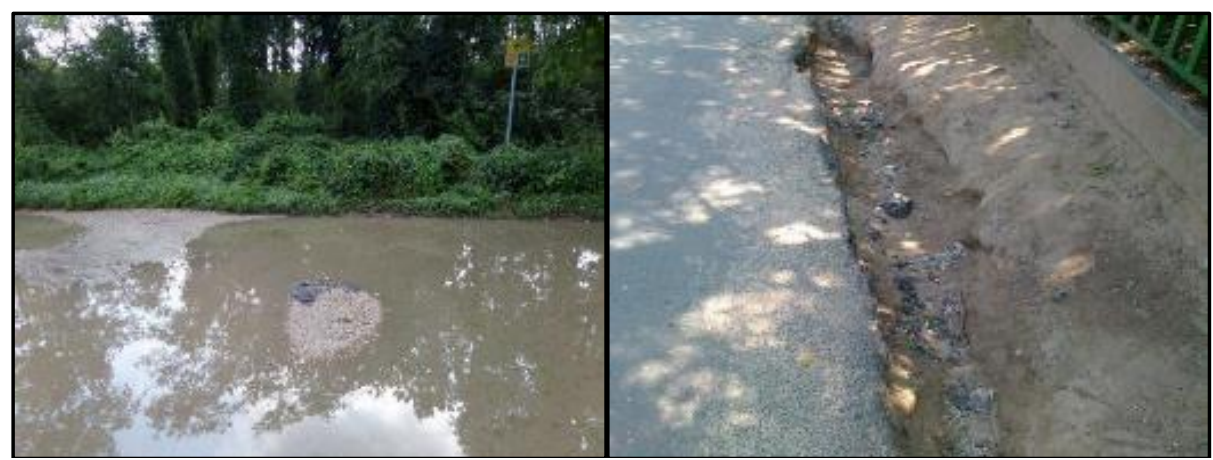

15. kép: Degradálódó szőlőhegyi út.

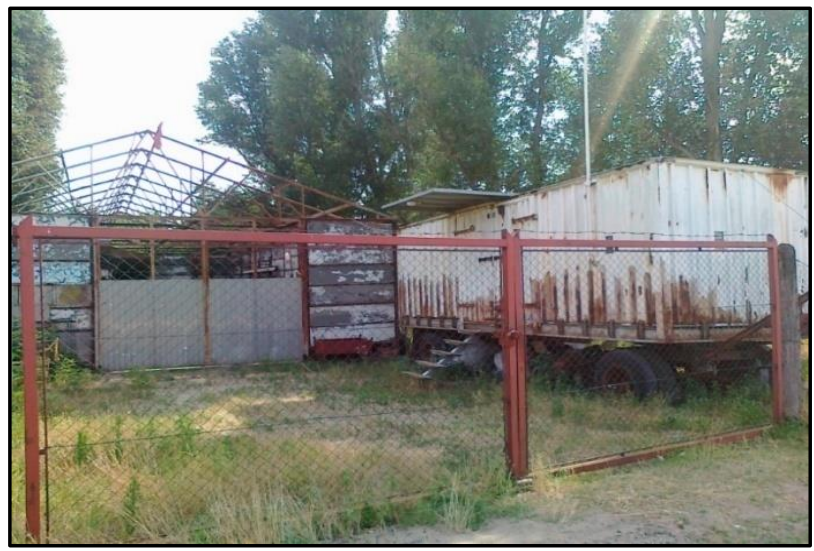

16. kép: Háztáji üzem a Domaszéki tanyavilágban

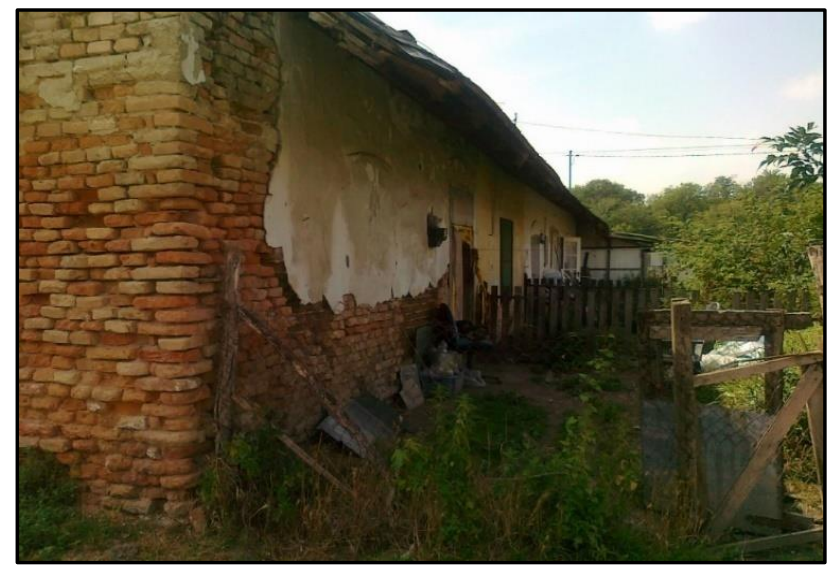

17. kép: Táplánypuszta infrastruktúrája

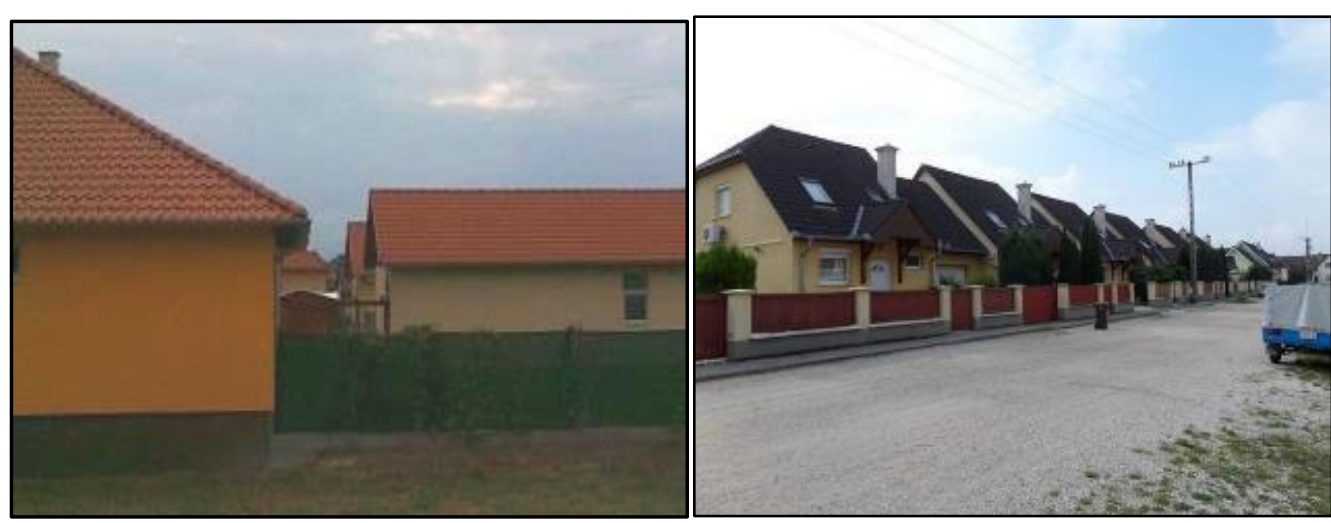

18. kép: Zsúfolt beépítés egyéb belterületeken

Az 1-18. képek a szerző empirikus munka során készült saját fotói. 


\section{MELLÉKLET: A MINTATERÜLET TELEPÜLÉSEINEK ADATBÁZISA}

\begin{tabular}{|c|c|c|c|c|c|c|c|c|c|c|c|c|}
\hline 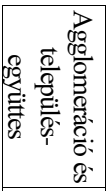 & $\frac{\overrightarrow{0}}{\frac{8}{8}}$ & 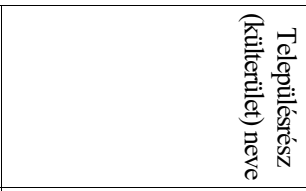 & 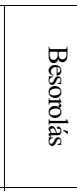 & $\begin{array}{l}\underset{G}{G} \\
\text { E् } \\
\text { E }\end{array}$ & 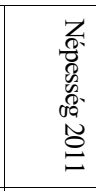 & 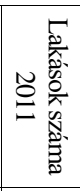 & 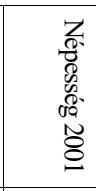 & 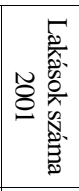 & 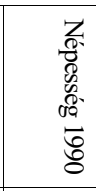 & 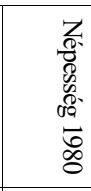 & 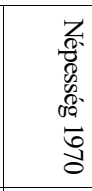 & 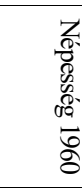 \\
\hline Győri & Abda & Káptalanmajor & KT & Major & 0 & 0 & 3 & 3 & 13 & 13 & 96 & 112 \\
\hline Győri & Abda & BT & BT & & 2967 & 1105 & 2879 & 979 & 2653 & 2389 & 2183 & 2302 \\
\hline Győri & Abda & Németh-gátőrház & KT & Örház & 11 & 2 & 11 & 3 & 7 & 2 & 4 & 3 \\
\hline Győri & Abda & Pillingérpuszta & KT & Major & 30 & 18 & 46 & 18 & 56 & 77 & 97 & 100 \\
\hline Győri & Abda & Virágkertészet & KT & Ipar & 3 & 1 & 0 & 0 & 0 & 1 & & \\
\hline Győri & Árpás & Dombiföld & EBT & & 22 & 12 & 26 & 10 & 36 & 44 & 60 & 71 \\
\hline Győri & Árpás & Gátőrház & KT & Örház & 3 & 1 & 4 & 1 & 0 & & 0 & 1 \\
\hline Győri & Árpás & Kálmánpuszta & KT & Major & 2 & 2 & 2 & 2 & 7 & 7 & 7 & 15 \\
\hline Győri & Árpás & BT & BT & & 228 & 113 & 246 & 114 & 307 & 318 & 438 & 508 \\
\hline Győri & Árpás & Szivattyútelep & KT & Örház & 4 & 1 & 4 & 1 & 3 & 4 & 2 & \\
\hline Györi & Ásványráró & Gátőrház & KT & Örház & 3 & 2 & 6 & 2 & 5 & 6 & 5 & 5 \\
\hline Győri & Ásványráró & BT & BT & & 1847 & 799 & 1935 & 746 & 1965 & 2107 & 2177 & 2369 \\
\hline Győri & Ásványráró & Malomhely & KT & Ipar & 3 & 1 & & & & & & \\
\hline Győri & Ásványráró & Somogyitanya & KT & Tanya & 0 & 1 & & & & & & \\
\hline Győri & Ásványráró & Zsejkepuszta & KT & Major & 0 & 1 & 0 & 0 & 0 & 36 & 86 & 125 \\
\hline Győri & Bágyogszovát & BT & BT & & 1285 & 543 & 1376 & 544 & 1463 & 1667 & 1814 & 1953 \\
\hline Győri & Barbacs & Huleschkertészet & KT & Major & 0 & 0 & 2 & 1 & 0 & 0 & 2 & 3 \\
\hline Győri & Barbacs & BT & BT & & 733 & 315 & 758 & 294 & 741 & 854 & 959 & 994 \\
\hline Győri & Bezi & BT & BT & & 496 & 195 & 424 & 173 & 432 & 503 & 560 & 587 \\
\hline Győri & Bezi & Pihenőpuszta & KT & Major & 16 & 7 & 10 & 7 & 12 & 20 & 22 & 20 \\
\hline Győri & Böny & Belényesitanya & KT & Tanya & 0 & 0 & 0 & 0 & 2 & 2 & 1 & 4 \\
\hline Györi & Böny & Györgyháza & KT & Major & 3 & 2 & 8 & 1 & 6 & 39 & 77 & 83 \\
\hline Győri & Bőny & Kiss Ernő-tag & KT & Major & 2 & 1 & 9 & 6 & 16 & 46 & 32 & 20 \\
\hline Győri & Bőny & BT & BT & & 1864 & 679 & 1958 & 626 & 1857 & 1808 & 1533 & 1422 \\
\hline Győri & Bőny & Mayertag & KT & Major & 0 & 0 & 0 & 0 & 0 & & 96 & 80 \\
\hline Győri & Bőny & Ottómajor & KT & Major & 0 & 0 & 0 & 0 & 0 & & 7 & 16 \\
\hline Győri & Bőny & Örkény & KT & Zártkert & 41 & 17 & 42 & 16 & 28 & 41 & 63 & 68 \\
\hline Győri & Bőny & Páskum & KT & Egyéb & 17 & 7 & 22 & 11 & 19 & 45 & 68 & 94 \\
\hline Győri & Bőny & Presznyáktag & KT & Major & 3 & 2 & 7 & 2 & 6 & 5 & 6 & 8 \\
\hline Győri & Bőny & Reformátustanya & KT & Tanya & 0 & 0 & 1 & 1 & 1 & 1 & 4 & 3 \\
\hline Győri & Bőny & Szőlőhegy & EBT & & 151 & 67 & 112 & 58 & 98 & 149 & 213 & 176 \\
\hline Győri & Böny & Tóth Zoltán-tag & KT & Major & 50 & 14 & 49 & 14 & 45 & 56 & 63 & 40 \\
\hline Győri & Börcs & Dabsai-rét szivattyútelep & KT & Örház & 4 & 1 & & & & & & \\
\hline Győri & Börcs & BT & BT & & 1235 & 438 & 997 & 336 & 932 & 984 & 1044 & 1065 \\
\hline Győri & Börcs & Öregszőlők & KT & Szőlöhegy & 16 & 9 & 9 & 4 & 9 & 19 & 14 & 14 \\
\hline Győri & Dunaszeg & Gyulamajor & KT & Major & 3 & 4 & 12 & 4 & 76 & 87 & 134 & 124 \\
\hline Györi & Dunaszeg & BT & BT & & 1934 & 692 & 1617 & 538 & 1406 & 1353 & 1283 & 1271 \\
\hline Győri & Dunaszentpál & BT & BT & & 688 & 261 & 589 & 208 & 538 & 574 & 623 & 657 \\
\hline Győri & Écs & BT & BT & & 1818 & 716 & 1744 & 631 & 1585 & 1714 & 1980 & 2206 \\
\hline Györi & Écs & Külterület & KT & Egyéb & 11 & 3 & & & & & & \\
\hline Győri & Enese & BT & BT & & 1759 & 600 & 1723 & 548 & 1578 & 1369 & 1002 & 909 \\
\hline Győri & Enese & Péterházapuszta & KT & Major & 28 & 12 & 32 & 14 & 26 & 85 & 133 & 130 \\
\hline Győri & Fehértó & BT & BT & & 459 & 224 & 493 & 213 & 551 & 623 & 654 & 678 \\
\hline Győri & Felpéc & Győri út & KT & Periurbán & 25 & 11 & 13 & 10 & 13 & 19 & 29 & 44 \\
\hline Győri & Felpéc & Halipuszta & KT & Major & 11 & 9 & 15 & 13 & 16 & 21 & 48 & 53 \\
\hline Győri & Felpéc & Horgasdülő & KT & Szőlőhegy & & & 0 & 0 & 0 & & & \\
\hline Győri & Felpéc & Karácsonydűlő & KT & Szőlőhegy & & & 0 & 0 & 0 & & & \\
\hline Győri & Felpéc & Keszővölgy & KT & Szőlőhegy & & & 0 & 0 & 0 & & & \\
\hline Győri & Felpéc & BT & BT & & 739 & 321 & 779 & 319 & 763 & 839 & 942 & 1064 \\
\hline Györi & Felpéc & Rádódülő & KT & Szőlöhegy & & & 1 & 1 & 0 & & & \\
\hline Győri & Felpéc & Szondi utca & KT & Periurbán & 43 & 16 & 6 & 4 & 5 & 6 & 11 & 18 \\
\hline Győri & Felpéc & Szőlőhegy & KT & Szőlöhegy & 18 & 5 & 4 & 1 & 1 & 7 & 38 & 43 \\
\hline Győri & Gönyü & Dózsamajor & KT & Major & 40 & 16 & 58 & 23 & 40 & 40 & 85 & 92 \\
\hline Győri & Gönyü & BT & BT & & 2908 & 1125 & 2871 & 1040 & 2616 & 2542 & 2346 & 2268 \\
\hline Győri & Gyarmat & BT & BT & & 1279 & 564 & 1306 & 523 & 1391 & 1530 & 1658 & 1691 \\
\hline Győri & Gyömöre & Gyömöre vasútállomás & KT & Örház & 14 & 10 & 21 & 10 & 26 & 29 & 31 & 49 \\
\hline Györi & Gyömöre & Ilonkapuszta & EBT & & 22 & 19 & 30 & 20 & 34 & 65 & 112 & 120 \\
\hline Győri & Gyömöre & BT & BT & & 1206 & 485 & 1316 & 472 & 1367 & 1499 & 1568 & 1461 \\
\hline Győri & Gyömöre & Sólinka & KT & Periurbán & & & 0 & & 13 & 24 & 22 & 21 \\
\hline Győri & Györ & Avar utca & KT & Periurbán & 204 & 0 & 197 & 0 & 0 & & & \\
\hline Győri & Györ & Banai úti kertek & KT & Zártkert & 105 & 57 & 48 & 22 & 0 & 1 & & \\
\hline Győri & Győr & Banai úti őrház & KT & Örház & 0 & 0 & 8 & 1 & 2 & 22 & 11 & \\
\hline Győri & Györ & Bécsi út & KT & Periurbán & 44 & 17 & 40 & 15 & 59 & 23 & 129 & \\
\hline Győri & Györ & Erdészház & KT & Örház & 0 & 0 & 2 & 1 & 4 & 2 & 3 & 3 \\
\hline Győri & Györ & Erdőtelep & KT & Örház & 1 & 2 & 12 & 2 & 11 & 14 & 35 & 48 \\
\hline
\end{tabular}




\begin{tabular}{|c|c|c|c|c|c|c|c|c|c|c|c|c|}
\hline 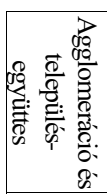 & $\begin{array}{l}\frac{\theta}{8} \\
\frac{8}{8} \\
\frac{D}{8}\end{array}$ & 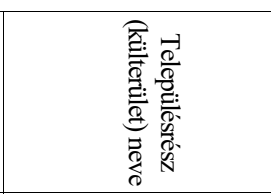 & 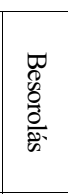 & $\begin{array}{l}\text { 屆 } \\
\text { 节 } \\
\text { ह }\end{array}$ & 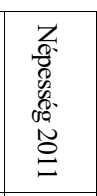 & 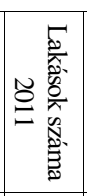 & 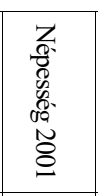 & 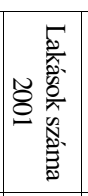 & 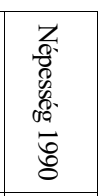 & 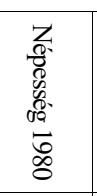 & 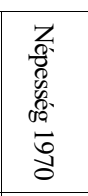 & 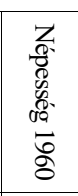 \\
\hline \begin{tabular}{|l|} 
Győri \\
\end{tabular} & Győr & Fazekasvermek & KT & Zártkert & 46 & 37 & 29 & 13 & 0 & & & \\
\hline Győri & Györ & Fehérváridűlő & KT & Periurbán & 64 & 31 & 12 & 3 & 8 & 14 & & \\
\hline Győri & Györ & Galántai úti kertek & KT & Zártkert & 4 & 1 & 0 & 0 & 0 & & 99 & 49 \\
\hline Györi & Györ & Górédülő & KT & Zártkert & 74 & 76 & 10 & 6 & 0 & 0 & 19 & 20 \\
\hline Györi & Györ & Gyirmót & EBT & & 1359 & 518 & 1252 & 435 & 1190 & 1171 & 1202 & 1119 \\
\hline Győri & Györ & Gyirmóti üdülő & KT & Üdülő & 0 & 0 & 0 & 0 & 0 & & & \\
\hline Győri & Györ & Győritanya & KT & Tanya & 0 & 0 & 2 & 1 & 0 & 9 & & \\
\hline Győri & Győr & Győrszentiván & EBT & & 8394 & 3066 & 7670 & 2593 & 6932 & 6099 & 6048 & 5695 \\
\hline Györi & Györ & Győrszentiváni útőrház & KT & Örház & 2 & 2 & 3 & 2 & 2 & & & \\
\hline Győri & Győr & Szentiváni vasúti őrház & KT & Örház & 4 & 4 & 13 & 6 & 14 & & & \\
\hline Győri & Györ & Holt-Duna körút & KT & Periurbán & 49 & 28 & 29 & 15 & 0 & & & \\
\hline Győri & Györ & Horgásztanya & KT & Üdülő & 18 & 8 & 19 & 9 & 0 & & & \\
\hline Győri & Győr & Ikrényidűlő & KT & Periurbán & & & 0 & & 4 & 8 & 7 & 9 \\
\hline Györi & Györ & Kakashegyidülö & KT & Periurbán & 0 & 0 & 5 & 1 & 0 & & & 34 \\
\hline Győri & Győr & Károlyháza & KT & Major & 34 & 12 & 27 & 10 & 27 & 32 & 56 & 58 \\
\hline Győri & Györ & Kertváros & KT & Zártkert & 438 & 240 & 205 & 72 & 0 & 5 & 1 & 1 \\
\hline Győri & Győr & Kishegy & KT & Zártkert & 62 & 34 & 80 & 35 & 24 & 38 & 67 & 84 \\
\hline Győri & Győr & Kishosszúvölgy & KT & Szőlöhegy & 0 & 0 & 0 & 0 & 4 & 12 & 5 & \\
\hline Győri & Győr & Kismegyeri vasúti őrház & KT & Örház & & & \begin{tabular}{|l|l|}
0 \\
\end{tabular} & & 2 & & & \\
\hline Győri & Győr & BT & BT & & 108581 & 49719 & 112107 & 45397 & 114188 & 109780 & 86134 & 70099 \\
\hline Győri & Györ & Külső vasútsor & KT & Periurbán & 34 & 13 & \begin{tabular}{|l|l|}
46 \\
\end{tabular} & \begin{tabular}{|l|l}
15 \\
\end{tabular} & 12 & 31 & 43 & 61 \\
\hline Győri & Győr & Likócs & KT & KBT & 0 & 0 & 454 & 0 & 0 & & & \\
\hline Győri & Győr & Mákosdűlői útőrház & KT & Örház & 5 & 2 & 0 & 0 & 7 & & 30 & 190 \\
\hline Győri & Győr & Malomszéki út & KT & Periurbán & 0 & 2 & 4 & 1 & 0 & & & \\
\hline Győri & Győr & Ménföcsanak & EBT & & 9530 & 3614 & 6964 & 2356 & 6632 & 6263 & 4979 & 4250 \\
\hline Győri & Győr & Vasúti örház & KT & Örház & 0 & 0 & 2 & 1 & 2 & & & \\
\hline Győri & Győr & Nagyhegy & KT & Egyéb & 205 & 89 & 44 & 20 & 73 & 108 & 151 & 167 \\
\hline Győri & Győr & Pápára vezető út & KT & Periurbán & & & 0 & & 11 & 12 & 13 & \\
\hline Győri & Győr & Ponty utca & KT & Periurbán & 4 & 4 & 5 & 3 & 0 & & & \\
\hline Györi & Györ & Pósdomb & KT & Egyéb & 4 & 4 & 0 & 0 & 0 & & & \\
\hline Győri & Györ & Rabkert & KT & Zártkert & 40 & 27 & 22 & 10 & 0 & & & \\
\hline Győri & Györ & Rigó út & KT & Periurbán & & & 0 & & 2 & & & \\
\hline Győri & Győr & Rókadülői vasúti őrház & KT & Örház & 1 & 1 & 5 & 3 & 4 & 16 & & \\
\hline Győri & Győr & Sashegypuszta & KT & Zártkert & 123 & 59 & 9 & 6 & 95 & 101 & 142 & 136 \\
\hline Győri & Györ & Somosmajor & KT & Major & 4 & 1 & 6 & 2 & 6 & 0 & 3 & \\
\hline Győri & Győr & Szarkavár & KT & Egyéb & 0 & 0 & 0 & 0 & 0 & 2 & 3 & 10 \\
\hline Györi & Györ & Szivárvány utca & KT & Periurbán & 15 & 8 & 9 & 4 & 0 & & & \\
\hline Győri & Győr & Szúnyogsziget & KT & Üdülő & 0 & 0 & 0 & 0 & 0 & & & 1 \\
\hline Győri & Győr & Tibormajor & KT & Major & 0 & 0 & 0 & 0 & 0 & 15 & 29 & 24 \\
\hline Győri & Györ & Újfalusi útőrház & KT & Örház & 0 & 0 & 4 & 1 & 0 & & & \\
\hline Győri & Györ & Újmajor & KT & Egyéb & 42 & 22 & 33 & 9 & 22 & 22 & 38 & 27 \\
\hline Györi & Györ & Wittmantag & KT & Major & 1 & 1 & 0 & 0 & 1 & 8 & 18 & \\
\hline Győri & Győr & Zsellérdülő & KT & Periurbán & 36 & 16 & 35 & 15 & 0 & & & \\
\hline Győri & Győrasszonyfa & Bakonypéterd állomás & KT & Örház & 1 & 1 & 2 & 1 & 1 & 1 & 4 & 2 \\
\hline Györi & Győrasszonyfa & BT & BT & & 495 & 199 & 501 & 192 & 559 & 629 & 653 & 603 \\
\hline Győri & Győrladamér & BT & BT & & 1556 & 533 & 1218 & 388 & 971 & 939 & 874 & 825 \\
\hline Győri & Győrság & Halomalja & EBT & & 196 & 77 & 217 & 70 & 186 & & & \\
\hline Győri & Győrság & BT & BT & & 1195 & 491 & 1181 & 433 & 1157 & 1370 & 1396 & 1437 \\
\hline Győri & Győrság & Puszta & KT & Major & 42 & 16 & 61 & 20 & 0 & & & \\
\hline Győri & Győrsövényház & Gátőrház & KT & Örház & 0 & 1 & 2 & 1 & 4 & 4 & 10 & 12 \\
\hline Győri & Győrsövényház & BT & BT & & 802 & 316 & 823 & 307 & 892 & 899 & 949 & 996 \\
\hline Győri & Győrsövényház & Szivattyútelep & KT & Ipar & 0 & 1 & 5 & 1 & 3 & 4 & 4 & 4 \\
\hline Győri & Győrszemere & Erdősor & EBT & & 84 & 31 & 99 & 31 & 93 & 130 & 124 & 95 \\
\hline Győri & Győrszemere & Gesztes & EBT & & 11 & 6 & 7 & 6 & 0 & & & \\
\hline Győri & Győrszemere & Józsefháza & EBT & & 1 & 1 & 0 & 0 & 4 & 6 & 35 & 51 \\
\hline Győri & Győrszemere & Kisszentpál & KT & Major & 0 & 1 & 0 & 1 & 0 & 5 & 11 & 35 \\
\hline Györi & Győrszemere & BT & BT & & 1942 & 676 & 1982 & 643 & 1931 & 1935 & 1898 & 1794 \\
\hline Győri & Győrszemere & Mélyfúróstelep & EBT & & 0 & 0 & 4 & 6 & 0 & & & \\
\hline Győri & Győrszemere & Nagyszentpál & EBT & & 531 & 177 & 147 & 59 & 120 & 148 & 174 & 189 \\
\hline Győri & Győrszemere & Nagyszentpál külterülete & KT & Egyéb & 0 & 0 & 15 & 4 & 0 & & & \\
\hline Győri & Győrszemere & Sárdos & KT & Major & 3 & 2 & 4 & 2 & 3 & 4 & 11 & 40 \\
\hline Győri & Győrszemere & Szőlőhegy & EBT & & 657 & 254 & 700 & 240 & 688 & 674 & 627 & 529 \\
\hline Győri & Győrszemere & Tóthtag & KT & Major & 0 & 0 & 0 & 0 & 0 & 2 & 15 & 13 \\
\hline Györi & Győrszemere & Törökház & KT & Egyéb & 1 & 1 & 2 & 1 & 2 & 3 & 3 & 3 \\
\hline Győri & Győrszemere & Vasútállomás & KT & Örház & 21 & 12 & 26 & 13 & 29 & 44 & 37 & 40 \\
\hline Győri & Győrújbarát & Fehérkereszt & KT & Szőlöhegy & 24 & 11 & 12 & 11 & 25 & 37 & & \\
\hline Győri & Győrújbarát & Kismegyer vasútállomás & KT & Örház & & & 12 & 4 & 13 & 15 & 19 & 25 \\
\hline Győri & Győrújbarát & BT & BT & & 5916 & 2157 & 4372 & 1590 & 3367 & 3423 & 3714 & 3881 \\
\hline Győri & Győrújbarát & Külterület & KT & Egyéb & 0 & 0 & & & & & & \\
\hline
\end{tabular}




\begin{tabular}{|c|c|c|c|c|c|c|c|c|c|c|c|c|}
\hline 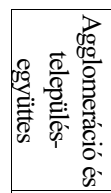 & $\frac{\overrightarrow{8}}{\frac{8}{8}}$ & 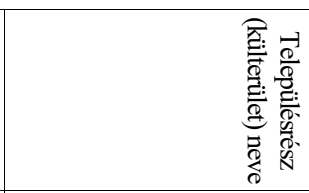 & 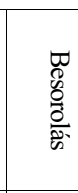 & $\begin{array}{l}\text { 즉 } \\
\text { 吾 } \\
\text { E }\end{array}$ & 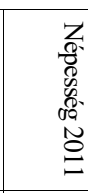 & 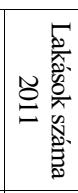 & 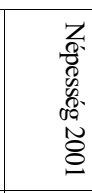 & 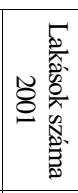 & 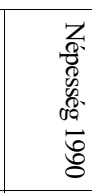 & 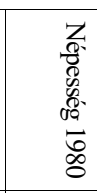 & 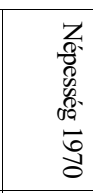 & 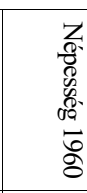 \\
\hline Győri & Győrújbarát & Külterületi üdülő & KT & Üdülő & 6 & 2 & 2 & 1 & 0 & & & \\
\hline Győri & Győrújbarát & Paperdő & KT & Szőlőhegy & 22 & 14 & 11 & 11 & 5 & 9 & & \\
\hline Győri & Győrújfalu & Fö tér & EBT & & 4 & 1 & 4 & 1 & 0 & & & \\
\hline Győri & Győrújfalu & BT & BT & & 1587 & 606 & 1079 & 365 & 923 & 882 & 871 & 859 \\
\hline Győri & Győrújfalu & Mártonháza & KT & Major & 10 & 5 & 12 & 6 & 8 & 17 & 22 & 31 \\
\hline Györi & Győrújfalu & Méhész utca & KT & Periurbán & 7 & 2 & 2 & 2 & 0 & & & \\
\hline Györi & Győrzámoly & BT & BT & & 2398 & 818 & 1549 & 493 & 1388 & 1363 & 1394 & 1281 \\
\hline Győri & Győrzámoly & Nagydunai gátőrházak & KT & Örház & 0 & 1 & 3 & 1 & 3 & 5 & 8 & 4 \\
\hline Győri & Győrzámoly & Patkányos(puszta) & KT & Major & 3 & 2 & 6 & 2 & 5 & 4 & 3 & 12 \\
\hline Győri & Győrzámoly & Solinkadülő & KT & Üdülő & 7 & 4 & 3 & 1 & 0 & & & \\
\hline Györi & Ikrény & Dózsamajor & KT & Major & 13 & 10 & 39 & 11 & 25 & 42 & 51 & 54 \\
\hline Györi & Ikrény & BT & BT & & 1728 & 572 & 1452 & 430 & 1305 & 1043 & 779 & 673 \\
\hline Győri & Ikrény & Lesvárpuszta & KT & Major & 17 & 7 & 33 & 9 & 38 & 25 & 39 & 39 \\
\hline Győri & Ikrény & Ószhelypuszta & KT & Major & 16 & 6 & 25 & 6 & 38 & 40 & 74 & 118 \\
\hline Győri & Ikrény & Szilágyitanya & KT & Tanya & & & 0 & & 6 & 2 & 1 & 4 \\
\hline Győri & Ikrény & Vasútállomás & KT & Örház & 1 & 1 & 3 & 1 & 5 & 4 & & 3 \\
\hline Győri & Ikrény & Vasúti őrházak & KT & Örház & & & 0 & & 4 & 6 & 12 & 12 \\
\hline Győri & Kajárpéc & Dózsa utca & KT & Periurbán & 15 & 7 & 14 & 7 & 17 & & & \\
\hline Győri & Kajárpéc & Kiskajár & KT & Szőlőhegy & 0 & 2 & 0 & 3 & 1 & 3 & 8 & 21 \\
\hline Győri & Kajárpéc & BT & BT & & 1241 & 554 & 1353 & 555 & 1412 & 1543 & 1746 & 1834 \\
\hline Győri & Kajárpéc & Miklósmajor & KT & Major & 2 & 6 & 0 & 5 & 3 & 10 & 26 & 36 \\
\hline Győri & Kajárpéc & Petöfi utca & KT & Periurbán & 7 & 3 & 15 & 4 & 7 & & & \\
\hline Győri & Kisbabot & BT & BT & & 209 & 107 & 242 & 110 & 264 & 346 & 381 & 391 \\
\hline Györi & Kisbabot & Lakómajor & KT & Major & 0 & 0 & 1 & 1 & 0 & & & \\
\hline Győri & Kisbajcs & Gátőrház és szivattyútelep & KT & Örház & 3 & 1 & 3 & 1 & 7 & 7 & 4 & 2 \\
\hline Győri & Kisbajcs & BT & BT & & 719 & 226 & 626 & 189 & 549 & 448 & 354 & 335 \\
\hline Győri & Kisbajcs & Szőgye & EBT & & 144 & 52 & 124 & 42 & 110 & 121 & 162 & 163 \\
\hline Győri & Kóny & BT & BT & & 2661 & 1046 & 2620 & 962 & 2545 & 2682 & 2737 & 2695 \\
\hline Győri & Koroncó & Bábota & KT & Periurbán & 4 & 1 & 0 & 0 & 0 & & & 4 \\
\hline Győri & Koroncó & Haraszt & EBT & & 151 & 58 & 142 & 53 & 116 & 150 & 201 & 210 \\
\hline Győri & Koroncó & BT & BT & & 1796 & 648 & 1688 & 562 & 1578 & 1567 & 1517 & 1534 \\
\hline Győri & Koroncó & Sóskadomb & KT & Szőlöhegy & 3 & 1 & 2 & 1 & 4 & 3 & 0 & \\
\hline Győri & Koroncó & Zöldmajor & KT & Major & 50 & 0 & 50 & 0 & 42 & 52 & 2 & 5 \\
\hline Győri & Kunsziget & BT & BT & & 1231 & 448 & 1183 & 398 & 1118 & 1179 & 1234 & 1208 \\
\hline Győri & Kunsziget & Mecséri út & KT & Periurbán & 2 & 1 & & & & & & \\
\hline Győri & Lázi & BT & BT & & 575 & 233 & 634 & 238 & 546 & 722 & 877 & 1009 \\
\hline Győri & Lébény & Barátföldpuszta & KT & Major & 3 & 3 & 4 & 4 & 10 & 17 & 36 & 67 \\
\hline Győri & Lébény & Bormászpuszta & KT & Major & 0 & 1 & 1 & 1 & 1 & 3 & 35 & 67 \\
\hline Győri & Lébény & Buriántanya & KT & Tanya & 0 & 1 & 4 & 1 & 0 & & & \\
\hline Győri & Lébény & Csatornaőrház & KT & Örház & 4 & 1 & 4 & 1 & 0 & 2 & 4 & \\
\hline Győri & Lébény & Erdőháztanya & KT & Tanya & 0 & 2 & 3 & 2 & 4 & & & \\
\hline Győri & Lébény & Gátőrház & KT & Örház & 0 & 1 & 2 & 1 & 4 & 4 & 3 & 3 \\
\hline Győri & Lébény & BT & BT & & 3146 & 1230 & 3146 & 1143 & 3164 & 5435 & 5553 & 3302 \\
\hline Győri & Lébény & Külterület & KT & Egyéb & 3 & 1 & & & & & & \\
\hline Györi & Mecsér & BT & BT & & 579 & 283 & 615 & 277 & 697 & 823 & 928 & 1013 \\
\hline Győri & Mecsér & Lickópuszta & KT & Major & 0 & 0 & 0 & 0 & 0 & 22 & 107 & 133 \\
\hline Győri & Mecsér & Rigótanya & KT & Tanya & 0 & 1 & 4 & 1 & 1 & 9 & 14 & 18 \\
\hline Győri & Mérges & Gátőrház & KT & Örház & 2 & 1 & 5 & 1 & 5 & 4 & 3 & 3 \\
\hline Győri & Mérges & BT & BT & & 77 & 52 & 75 & 51 & 92 & 127 & 176 & 210 \\
\hline Győri & Mezöörs & Kispervatpuszta & KT & Major & 0 & 1 & 0 & 0 & 4 & & 0 & 30 \\
\hline Györi & Mezőörs & BT & BT & & 939 & 341 & 948 & 314 & 980 & 1013 & 995 & 1059 \\
\hline Győri & Mórichida & BT & BT & & 820 & 353 & 858 & 357 & 913 & 1051 & 1125 & 1214 \\
\hline Győri & Mórichida & Tekepuszta & KT & Major & 6 & 2 & 7 & 2 & 8 & 0 & 5 & 46 \\
\hline Győri & Mórichida & Téti út & KT & Periurbán & 0 & 0 & & & & & & \\
\hline Győri & Mosonszentmiklós & Gyártelep & EBT & & 170 & 79 & 197 & 77 & 224 & 241 & 176 & 61 \\
\hline Győri & Mosonszentmiklós & BT & BT & & 2042 & 780 & 2104 & 738 & 2062 & & & 2288 \\
\hline Györi & Mosonszentmiklós & Mosonújhely & EBT & & 167 & 85 & 205 & 81 & 202 & 191 & 191 & 263 \\
\hline Győri & Mosonszentmiklós & Pálmajor & KT & Major & & & 0 & & 5 & 8 & 72 & 68 \\
\hline Győri & Mosonszentmiklós & Szivattyútelep & KT & Örház & & & 0 & 1 & 0 & 3 & 1 & 4 \\
\hline Györi & Mosonszentmiklós & Vasúti őrház & KT & Őrház & & & 1 & 2 & 1 & 28 & 27 & 17 \\
\hline Győri & Nagybajcs & 0112 Hrsz & KT & Periurbán & 3 & 1 & & & & & & \\
\hline Győri & Nagybajcs & Gátőrház & KT & Örház & 2 & 1 & 3 & 1 & 4 & 4 & 5 & 5 \\
\hline Győri & Nagybajcs & BT & BT & & 935 & 374 & 885 & 333 & 833 & 914 & 989 & 1038 \\
\hline Győri & Nagyszentjános & Kisszentjános & KT & Major & 7 & 4 & 41 & 10 & 40 & 72 & 122 & 119 \\
\hline Györi & Nagyszentjános & BT & BT & & 1794 & 616 & 1821 & 566 & 1798 & 1602 & 1233 & 826 \\
\hline Győri & Nagyszentjános & Krémertag & KT & Major & & & 0 & 0 & 0 & & 7 & 10 \\
\hline Győri & Nagyszentjános & Vasúti őrházak & KT & Örház & 1 & 1 & 3 & 1 & 10 & 30 & 60 & 60 \\
\hline Győri & Nyalka & Ilakszél & KT & Szőlöhegy & 0 & 1 & 0 & 1 & 1 & 2 & 3 & 4 \\
\hline Györi & Nyalka & Kishegy & EBT & & 11 & 11 & 9 & 10 & 6 & 15 & 36 & 52 \\
\hline
\end{tabular}




\begin{tabular}{|c|c|c|c|c|c|c|c|c|c|c|c|c|}
\hline 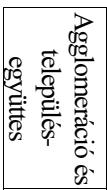 & 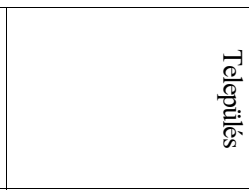 & 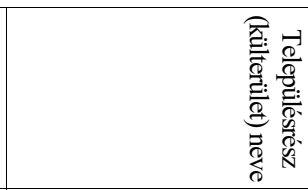 & 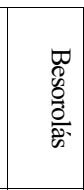 & $\begin{array}{l}\text { 즉 } \\
\text { 吾 } \\
\text { E }\end{array}$ & 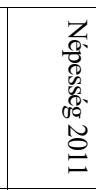 & 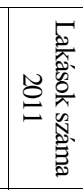 & 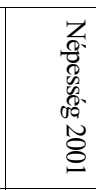 & 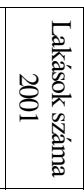 & 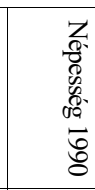 & 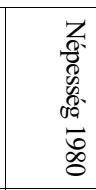 & 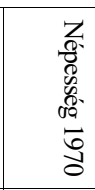 & 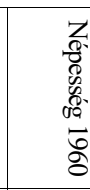 \\
\hline Györi & Nyalka & Kisnyalkapuszta & KT & Major & 1 & 1 & 0 & 0 & 0 & & 31 & 42 \\
\hline Győri & Nyalka & BT & BT & & 433 & 185 & 412 & 181 & 437 & 507 & 564 & 627 \\
\hline Győri & Nyúl & Kétútköz & KT & Egyéb & 0 & 0 & 11 & 3 & 7 & 12 & & \\
\hline Györi & Nyúl & BT & BT & & 4099 & 1543 & 3730 & 1289 & 3430 & 3516 & 3621 & 3586 \\
\hline Györi & Nyúl & Nyúlhegy & KT & Szőlöhegy & 88 & 47 & 27 & 23 & 32 & 89 & & \\
\hline Győri & Nyúl & Újmajor & KT & Major & 1 & 1 & 3 & 1 & 0 & & 8 & 35 \\
\hline Győri & Öttevény & BT & BT & & 2913 & 1063 & 2785 & 923 & 2598 & 2553 & 2454 & 2316 \\
\hline Győri & Öttevény & Sándorházapuszta & KT & Major & & & 0 & 1 & 0 & 31 & 82 & 84 \\
\hline Győri & Öttevény & Vasúti őrház & KT & Örház & & & 0 & & 1 & 6 & & \\
\hline Győri & Pannonhalma & Borosház & KT & Szőlőhegy & & & 0 & 0 & 0 & 0 & 1 & 1 \\
\hline Győri & Pannonhalma & Cseidervölgy & KT & Szőlőhegy & 10 & 3 & 10 & 7 & 0 & & & \\
\hline Györi & Pannonhalma & Jánosháza & KT & Major & 0 & 0 & 0 & 0 & 0 & 2 & 5 & 4 \\
\hline Győri & Pannonhalma & BT & BT & & 3681 & 1290 & 3897 & 1198 & 3720 & 4091 & 3712 & 3472 \\
\hline Győri & Pannonhalma & Ravazd vasútállomás & KT & Örház & & & 0 & 0 & 2 & 3 & 4 & 5 \\
\hline Győri & Pázmándfalu & Ámánd & KT & Szőlöhegy & 0 & 0 & 2 & 1 & 0 & & & \\
\hline Győri & Pázmándfalu & Bercel & KT & Üdülő & 10 & 3 & 0 & 0 & 0 & & & \\
\hline Györi & Pázmándfalu & Flóriányitanyák & KT & Tanya & 0 & 0 & 1 & 1 & 1 & 1 & 13 & 15 \\
\hline Győri & Pázmándfalu & BT & BT & & 956 & 419 & 899 & 332 & 934 & 1135 & 865 & 1330 \\
\hline Győri & Pázmándfalu & Tanyák & KT & Tanya & 0 & 1 & 1 & 1 & 2 & 1 & 3 & 10 \\
\hline Győri & Pér & Kámváskútidűlő & KT & Szőlőhegy & 6 & 6 & 7 & 5 & 5 & 7 & 33 & 47 \\
\hline Győri & Pér & BT & BT & & 1987 & 820 & 2027 & 762 & 1976 & 2138 & 2203 & 2077 \\
\hline Györi & Pér & Mindszentpuszta & EBT & & 296 & 128 & 333 & 123 & 354 & 404 & 446 & 469 \\
\hline Győri & Pér & Örkényihatárra dülő & KT & Szölöhegy & 0 & 0 & 0 & 1 & 1 & 2 & 39 & 66 \\
\hline Győri & Pér & Püspökalap & KT & Major & 28 & 11 & 17 & 12 & 28 & 48 & 83 & 80 \\
\hline Győri & Pér & Sóstóidűlö & KT & Szőlőhegy & 3 & 2 & 3 & 2 & 2 & 4 & 6 & 16 \\
\hline Győri & Pér & Söptérihatárra dülő & KT & Szőlőhegy & 1 & 2 & 1 & 5 & 3 & 7 & 13 & 36 \\
\hline Győri & Rábacsécsény & BT & BT & & 577 & 245 & 600 & 228 & 550 & 1233 & 1385 & 755 \\
\hline Győri & Rábacsécsény & Rózsástelep & KT & Major & 0 & 0 & 1 & 1 & 1 & 5 & 0 & 50 \\
\hline Győri & Rábapatona & Kosdombtanya & KT & Tanya & 0 & 1 & 0 & 1 & 4 & 4 & 7 & 12 \\
\hline Győri & Rábapatona & BT & BT & & 2420 & 941 & 2475 & 863 & 2569 & 2598 & 2585 & 2524 \\
\hline Győri & Rábapatona & Rábai gátőrház & KT & Örház & 3 & 1 & 4 & 1 & 2 & 3 & 2 & 4 \\
\hline Győri & Rábapatona & Vasútállomás és őrház & KT & Örház & & & 0 & & 1 & 7 & 9 & \\
\hline Győri & Rábaszentmihály & Gátőrház I. & KT & Örház & 0 & 0 & 0 & 0 & 4 & 2 & 5 & 6 \\
\hline Győri & Rábaszentmihály & Gátőrház II. & KT & Örház & 4 & 1 & 0 & 1 & 4 & 4 & & \\
\hline Győri & Rábaszentmihály & BT & BT & & 485 & 197 & 515 & 194 & 524 & & & 640 \\
\hline Győri & Rábaszentmihály & Országútba & KT & Örház & 6 & 1 & 6 & 1 & 5 & & & \\
\hline Győri & Rábaszentmiklós & Gátőrház & KT & Örház & 3 & 1 & 3 & 1 & 4 & 2 & 8 & \\
\hline Győri & Rábaszentmiklós & BT & BT & & 130 & 64 & 143 & 60 & 175 & 197 & 206 & 249 \\
\hline Győri & Ravazd & BT & BT & & 1189 & 470 & 1178 & 454 & 1147 & 1246 & 1401 & 1537 \\
\hline Győri & Ravazd & Vadalmás & KT & Szőlőhegy & 0 & 2 & 0 & 2 & 2 & 4 & 6 & 7 \\
\hline Győri & Rétalap & Baloghtag & KT & Major & 22 & 10 & 30 & 13 & 30 & 48 & 67 & 54 \\
\hline Győri & Rétalap & BT & BT & & 535 & 204 & 511 & 207 & 471 & 569 & 666 & 670 \\
\hline Győri & Románd & BT & BT & & 305 & 144 & 322 & 141 & 351 & 428 & 520 & 501 \\
\hline Győri & Sikátor & BT & BT & & 306 & 137 & 326 & 135 & 328 & 446 & 529 & 608 \\
\hline Győri & Sikátor & Vecseny & EBT & & 5 & 3 & 14 & 4 & 18 & 25 & 96 & 145 \\
\hline Győri & Sokorópátka & Győri utca & KT & Periurbán & 13 & 4 & 13 & 4 & 13 & 8 & 4 & \\
\hline Győri & Sokorópátka & BT & BT & & 1065 & 471 & 1038 & 462 & 1082 & 1254 & 1381 & 1449 \\
\hline Györi & Szerecseny & BT & BT & & 804 & 360 & 917 & 364 & 925 & 1111 & 1192 & 1190 \\
\hline Győri & Szerecseny & Táncsics utca & KT & Periurbán & 6 & 5 & 17 & 7 & 8 & 12 & & \\
\hline Győri & Szerecseny & Úttörő utca & KT & Periurbán & 0 & 1 & 1 & 1 & 1 & 3 & 5 & 19 \\
\hline Győri & Szerecseny & Vasúti őrház & KT & Örház & 0 & 0 & 1 & 1 & 2 & 4 & 4 & 3 \\
\hline Győri & Táp & BT & BT & & 720 & 295 & 709 & 272 & 792 & 891 & 1050 & 1163 \\
\hline Győri & Tápszentmiklós & Fö utca & KT & Periurbán & & & 1 & 1 & 0 & & & \\
\hline Győri & Tápszentmiklós & BT & BT & & 941 & 339 & 931 & 322 & 903 & 957 & 1016 & 1128 \\
\hline Győri & Tápszentmiklós & Kútföle utca & KT & Periurbán & 1 & 2 & 4 & 2 & 0 & & & \\
\hline Győri & Tápszentmiklós & Vasútállomás & KT & Örház & 0 & 0 & 12 & 2 & 17 & 7 & 7 & 6 \\
\hline Győri & Tarjánpuszta & Császárkert & KT & Zártkert & 8 & 4 & 10 & 3 & 0 & & & \\
\hline Győri & Tarjánpuszta & BT & BT & & 384 & 141 & 369 & 123 & 388 & 384 & 370 & 312 \\
\hline Győri & Tényö & Hollómajor & EBT & & 52 & 24 & 53 & 27 & 53 & 64 & 87 & 84 \\
\hline Györi & Tényö & BT & BT & & 1403 & 648 & 1348 & 583 & 1319 & 1491 & 1695 & 1878 \\
\hline Győri & Tényö & Parlag & KT & Szőlöhegy & 0 & 3 & 0 & 1 & 0 & 8 & 14 & 29 \\
\hline Győri & Tényö & Táborvölgy & KT & Szölőhegy & 27 & 19 & 27 & 19 & 7 & 33 & & \\
\hline Győri & Tét & Badicztag & KT & Major & 0 & 0 & 4 & 1 & 0 & 2 & 6 & 12 \\
\hline Győri & Tét & Betlehempuszta & KT & Major & 0 & 0 & 0 & 3 & 3 & 5 & 35 & 93 \\
\hline Győri & Tét & Gátőrház & KT & Örház & 0 & 0 & 0 & 2 & 0 & 0 & & 4 \\
\hline Györi & Tét & Gyömörei út & KT & Periurbán & 5 & 1 & 4 & 1 & 0 & 1 & 3 & 5 \\
\hline Győri & Tét & BT & BT & & 3710 & 1357 & 3992 & 1326 & 4039 & 4191 & 3904 & 3820 \\
\hline Győri & Tét & Külterület & KT & Egyéb & 3 & 2 & & & & & & \\
\hline Győri & Tét & Lesvárpuszta & KT & Major & 43 & 17 & 57 & 17 & 62 & 77 & 137 & 140 \\
\hline
\end{tabular}




\begin{tabular}{|c|c|c|c|c|c|c|c|c|c|c|c|c|}
\hline 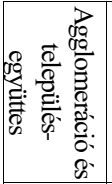 & $\begin{array}{l}\frac{\vec{\theta}}{8} \\
\frac{8}{8} \\
\frac{8}{8}\end{array}$ & 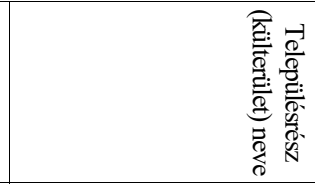 & 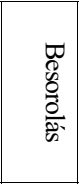 & 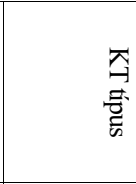 & 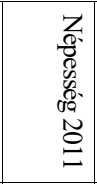 & 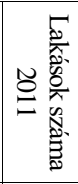 & 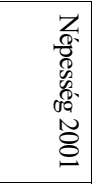 & 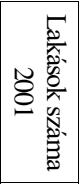 & 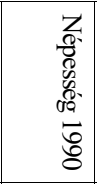 & 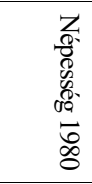 & 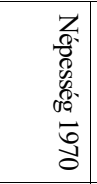 & 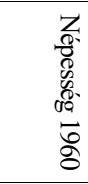 \\
\hline Györi & Tét & Pápai út & EBT & & 56 & 24 & & & & 6 & 5 & 4 \\
\hline Györi & Tét & Szentkút & EBT & & 62 & 33 & 90 & 54 & 105 & 128 & 173 & 190 \\
\hline Győri & Tét & Ürgehegy & KT & Szőlöhegy & 75 & 43 & 16 & 12 & 2 & 0 & 31 & 71 \\
\hline Győri & Töltéstava & BT & BT & & 1774 & 600 & 1358 & 425 & 1125 & 994 & 894 & 861 \\
\hline Győri & Töltéstava & Pozsgaitanya & KT & Egyéb & 0 & 0 & 0 & 1 & 10 & 12 & & 11 \\
\hline Györi & Töltéstava & Söptérpuszta & KT & Major & 1 & 0 & 13 & 0 & 13 & 42 & 37 & 24 \\
\hline Györi & Töltéstava & Táplánypuszta & KT & Major & 67 & 26 & 78 & 34 & 89 & 124 & 436 & 315 \\
\hline Győri & Töltéstava & Táplánypusztai otthon & KT & Szociális & 353 & 2 & 356 & 2 & 272 & 224 & & \\
\hline Györi & Vámosszabadi & Győri út & KT & Periurbán & 2 & 2 & 5 & 3 & 5 & 9 & & \\
\hline Győri & Vámosszabadi & BT & BT & & 1504 & 517 & 980 & 326 & 782 & 808 & 790 & 887 \\
\hline Györi & Vámosszabadi & Szúnyogháza & KT & Major & 3 & 1 & 0 & 1 & 0 & 0 & 10 & 0 \\
\hline Györi & Vámosszabadi & Újtelep & EBT & & 67 & 26 & 72 & 24 & 71 & 71 & 41 & \\
\hline Győri & Vámosszabadi & Zártkertek & KT & Zártkert & 13 & 8 & 10 & 4 & 0 & & & \\
\hline Győri & Vének & BT & BT & & 158 & 76 & 160 & 73 & 152 & 178 & 213 & 238 \\
\hline Győri & Vének & Zártkert & KT & Zártkert & 9 & 3 & 3 & 2 & 0 & & & \\
\hline Győri & Veszprémvarsány & Erdészház & KT & Örház & 0 & 0 & 0 & 1 & 5 & 0 & 3 & 3 \\
\hline Győri & Veszprémvarsány & Keresztúr & KT & Major & & & 3 & 1 & 2 & 3 & 5 & 3 \\
\hline Győri & Veszprémvarsány & Kinota & KT & Major & & & 0 & 0 & 0 & 0 & 5 & 3 \\
\hline Győri & Veszprémvarsány & BT & BT & & 1020 & 419 & 1025 & 400 & 933 & 992 & 1050 & 1204 \\
\hline Győri & Veszprémvarsány & Vásártér & KT & Periurbán & 4 & 2 & & & & & & \\
\hline Győri & Veszprémvarsány & Vasúti őrház & KT & Örház & 1 & 1 & 0 & 0 & 2 & 3 & 5 & 5 \\
\hline Szegedi & Algyő & Csergötelep & KT & Tanya & 12 & 9 & 21 & 6 & 18 & 35 & 68 & 142 \\
\hline Szegedi & Algyő & Farkirét & KT & Tanya & 43 & 23 & 59 & 17 & 48 & 65 & 134 & 242 \\
\hline Szegedi & Algyő & Gyevitanyák & KT & Tanya & 96 & 48 & 95 & 38 & 88 & 140 & 350 & 399 \\
\hline Szegedi & Algyő & Irmamajor & KT & Major & 3 & 3 & 3 & 2 & 9 & 14 & 43 & 96 \\
\hline Szegedi & Algyö & BT & BT & & 4768 & 1907 & 4864 & 1764 & 5050 & 5865 & 4637 & 4517 \\
\hline Szegedi & Algyő & Nagyfa & KT & Szociális & 540 & 48 & 768 & 59 & 84 & 142 & & \\
\hline Szegedi & Algyő & Rákóczitelep & KT & Tanya & 46 & 28 & 52 & 17 & 74 & 96 & 176 & 252 \\
\hline Szegedi & Bordány & Békedűlő & KT & Tanya & 168 & 93 & 171 & 86 & 151 & 226 & 318 & 378 \\
\hline Szegedi & Bordány & Bordánydülő & KT & Tanya & 371 & 217 & 373 & 227 & 348 & 485 & 757 & 905 \\
\hline Szegedi & Bordány & BT & BT & & 2132 & 849 & 2074 & 765 & 1921 & 1534 & 1005 & 764 \\
\hline Szegedi & Bordány & Meződülő & KT & Tanya & 181 & 103 & 210 & 99 & 232 & 251 & 367 & 437 \\
\hline Szegedi & Bordány & Seregélyesdülő & KT & Tanya & 378 & 214 & 317 & 160 & 173 & 270 & 344 & 424 \\
\hline Szegedi & Deszk & Deszkitanyák & KT & Tanya & 29 & 15 & 38 & 19 & 60 & 82 & 201 & 262 \\
\hline Szegedi & Deszk & BT & BT & & 3531 & 1305 & 3200 & 1078 & 2695 & 2695 & 2677 & 2628 \\
\hline Szegedi & Dóc & Alsóányás & KT & Tanya & 4 & 5 & 8 & 7 & 12 & 34 & 122 & 256 \\
\hline Szegedi & Dóc & Bodorszék & KT & Tanya & 191 & 81 & 214 & 106 & 223 & 273 & 350 & 439 \\
\hline Szegedi & Dóc & Kispercsóraitanyák & KT & Tanya & 2 & 2 & 4 & 2 & 2 & 13 & 9 & 20 \\
\hline Szegedi & Dóc & BT & BT & & 516 & 208 & 585 & 204 & 562 & 574 & 508 & 408 \\
\hline Szegedi & Dóc & Szentferencdülő & KT & Tanya & 20 & 5 & 12 & 5 & 6 & 8 & 32 & 18 \\
\hline Szegedi & Domaszék & Domaszéki külterület & KT & Egyéb & 2228 & 1117 & 2086 & 1054 & 1856 & 2573 & 3309 & 3944 \\
\hline Szegedi & Domaszék & BT & BT & & 2634 & 880 & 2080 & 700 & 1322 & 740 & 265 & 11 \\
\hline Szegedi & Ferencszállás & BT & BT & & 623 & 269 & 659 & 272 & 687 & 715 & 734 & 762 \\
\hline Szegedi & Klárafalva & Klárafalvitanyák & KT & Tanya & 5 & 1 & 4 & 1 & 1 & 3 & 8 & 9 \\
\hline Szegedi & Klárafalva & BT & BT & & 468 & 200 & 481 & 190 & 489 & 521 & 539 & 560 \\
\hline Szegedi & Klárafalva & Óklára & KT & Periurbán & 0 & 0 & 0 & 0 & 7 & 14 & 32 & \\
\hline Szegedi & Kübekháza & ATIVIZIG-őrház & KT & Örház & 6 & 2 & 0 & 2 & 2 & 4 & & \\
\hline Szegedi & Kübekháza & BT & BT & & 1457 & 582 & 1535 & 581 & 1453 & 1612 & 1677 & 1809 \\
\hline Szegedi & Röszke & I. körzet (Röszkei terület) & KT & Tanya & 71 & 33 & 79 & 48 & 78 & 136 & 388 & 158 \\
\hline Szegedi & Röszke & II. körzet (Feketeszél) & KT & Tanya & 176 & 107 & 224 & 121 & 204 & 306 & 415 & 508 \\
\hline Szegedi & Röszke & III. körzet & KT & Tanya & 211 & 127 & 286 & 137 & 260 & 370 & 457 & 643 \\
\hline Szegedi & Röszke & IV. körzet (Nagyszéksós) & KT & Tanya & 121 & 83 & 106 & 94 & 108 & 203 & 324 & 420 \\
\hline Szegedi & Röszke & BT & BT & & 2507 & 1043 & 2471 & 976 & 2329 & 2447 & 2158 & 2457 \\
\hline Szegedi & Sándorfalva & Büdöstó & KT & Tanya & 4 & 1 & 1 & 1 & 0 & 3 & 9 & 2 \\
\hline Szegedi & Sándorfalva & Csibafaszőlők & KT & Szőlőhegy & 89 & 65 & 31 & 15 & 0 & & & \\
\hline Szegedi & Sándorfalva & Csikójárás & KT & Tanya & 28 & 22 & 37 & 20 & 40 & 50 & 78 & 88 \\
\hline Szegedi & Sándorfalva & Csúzdidülő & KT & Tanya & 58 & 24 & 76 & 28 & 68 & 109 & 119 & 116 \\
\hline Szegedi & Sándorfalva & Eperjesdülő & KT & Tanya & 18 & 12 & 15 & 12 & 8 & 26 & 46 & 71 \\
\hline Szegedi & Sándorfalva & Fehérföldes & KT & Tanya & 25 & 13 & 14 & 6 & 2 & 6 & 8 & 3 \\
\hline Szegedi & Sándorfalva & Homokdülő & KT & Tanya & 9 & 4 & 7 & 5 & 2 & 5 & 15 & 8 \\
\hline Szegedi & Sándorfalva & Homokimajor & KT & Major & 7 & 4 & 10 & 2 & 7 & 11 & 10 & 20 \\
\hline Szegedi & Sándorfalva & Kapcaszékdülő & KT & Tanya & 1 & 3 & 3 & 3 & 6 & 9 & 16 & 20 \\
\hline Szegedi & Sándorfalva & Kéridűlő & KT & Tanya & 50 & 34 & 56 & 33 & 52 & 87 & 114 & 122 \\
\hline Szegedi & Sándorfalva & Kővágó & KT & Zártkert & 237 & 128 & 133 & 57 & 12 & & & \\
\hline Szegedi & Sándorfalva & BT & BT & & 7217 & 2874 & 7309 & 2714 & 6635 & 5963 & 5233 & 4958 \\
\hline Szegedi & Sándorfalva & Kútidülő & KT & Tanya & 51 & 31 & 71 & 35 & 58 & 68 & 122 & 178 \\
\hline Szegedi & Sándorfalva & Nádastó & KT & Tanya & 9 & 3 & 14 & 3 & 8 & 9 & 16 & 18 \\
\hline Szegedi & Sándorfalva & \begin{tabular}{|l|} 
Szaporhegy \\
\end{tabular} & KT & Szőlőhegy & 15 & 8 & 8 & 9 & 25 & 40 & 111 & 177 \\
\hline Szegedi & Sándorfalva & Szentjánosdűlő & KT & Tanya & 3 & 1 & 0 & 2 & 6 & 9 & 16 & 3 \\
\hline
\end{tabular}




\begin{tabular}{|c|c|c|c|c|c|c|c|c|c|c|c|c|}
\hline 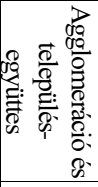 & 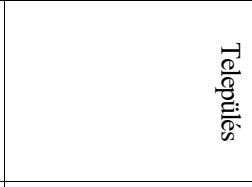 & 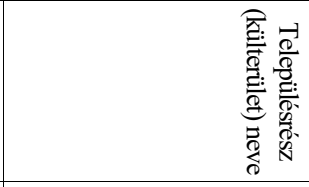 & 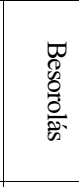 & $\begin{array}{l}\mathbb{G} \\
\text { Е } \\
\text { E }\end{array}$ & 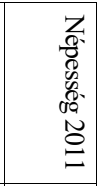 & 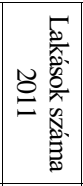 & 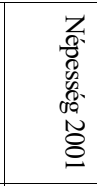 & 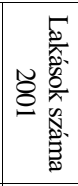 & 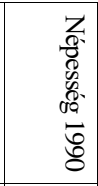 & 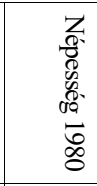 & 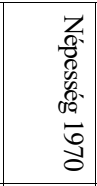 & $\begin{array}{l}7 \\
\frac{8}{8} \\
0 \\
0 \\
08 \\
0 \\
8 \\
8\end{array}$ \\
\hline Szegedi & Sándorfalva & Szokony & KT & Tanya & 6 & 1 & 5 & 1 & 4 & 4 & 5 & 11 \\
\hline Szegedi & Sándorfalva & Vedresszőlők & KT & Szőlöhegy & 44 & 25 & 13 & 5 & 0 & & & \\
\hline Szegedi & Szatymaz & I. körzet & KT & Tanya & 488 & 328 & 397 & 198 & 283 & 394 & 511 & 466 \\
\hline Szegedi & Szatymaz & II. körzet & KT & Tanya & 795 & 385 & 616 & 259 & 529 & 667 & 747 & 771 \\
\hline Szegedi & Szatymaz & III. körzet & KT & Tanya & 449 & 291 & 431 & 268 & 444 & 716 & 867 & 1053 \\
\hline Szegedi & Szatymaz & IV. körzet & KT & Tanya & 713 & 397 & 692 & 359 & 586 & 843 & 1158 & 1269 \\
\hline Szegedi & Szatymaz & BT & BT & & 2213 & 873 & 2140 & 799 & 1627 & 1161 & 865 & 448 \\
\hline Szegedi & Szeged & Alsó Kikötő sor & KT & Periurbán & 0 & 0 & 10 & 6 & 13 & 23 & 29 & 24 \\
\hline Szegedi & Szeged & Alsóvárosi feketeföldek & KT & Tanya & 52 & 23 & 25 & 17 & 38 & 207 & 254 & 49 \\
\hline Szegedi & Szeged & Ásványhát & KT & Tanya & 15 & 0 & 16 & 9 & 6 & 17 & 20 & 22 \\
\hline Szegedi & Szeged & Atkasziget & KT & Tanya & & & 16 & 11 & 15 & 27 & & \\
\hline Szegedi & Szeged & Bajai út & KT & Szociális & 217 & 0 & 255 & 11 & 0 & 38 & 46 & 40 \\
\hline Szegedi & Szeged & Baktói kiskertek & EBT & & 700 & 346 & 265 & 156 & 0 & & & \\
\hline Szegedi & Szeged & Ballagitó kiskertek & KT & Zártkert & 0 & 0 & 6 & 2 & 0 & & & \\
\hline Szegedi & Szeged & Bencfahát & KT & Tanya & 0 & 0 & 0 & 1 & 0 & 7 & 29 & 36 \\
\hline Szegedi & Szeged & Bodomikiskertek & EBT & & 51 & 25 & 36 & 22 & 0 & & & \\
\hline Szegedi & Szeged & Bodomtanya & KT & Tanya & 0 & 2 & 4 & 2 & 4 & & & \\
\hline Szegedi & Szeged & Daruhalomdülő & KT & Tanya & 3 & 2 & 4 & 2 & 2 & 4 & 3 & 9 \\
\hline Szegedi & Szeged & Faragódűlő & KT & Tanya & 64 & 25 & 50 & 22 & 37 & 51 & 68 & 108 \\
\hline Szegedi & Szeged & Fehértó & KT & Periurbán & 187 & 68 & 178 & 67 & 42 & 51 & & \\
\hline Szegedi & Szeged & Felsővárosi feketeföldek & KT & Tanya & 136 & 54 & 154 & 60 & 275 & 451 & 364 & 622 \\
\hline Szegedi & Szeged & Gyálarét & EBT & & & & 1123 & 389 & 919 & 935 & 689 & 536 \\
\hline Szegedi & Szeged & Gyálaréti kiskertek & EBT & & 239 & 123 & 140 & 95 & 0 & & & \\
\hline Szegedi & Szeged & Gyálarétitanyák & KT & Tanya & 4 & 2 & 12 & 4 & 9 & 14 & 26 & 35 \\
\hline Szegedi & Szeged & Harcos utca & KT & Periurbán & 58 & 23 & 56 & 17 & 53 & 68 & & \\
\hline Szegedi & Szeged & Ipardülö & KT & Tanya & 65 & 28 & 73 & 24 & 54 & 45 & 57 & 63 \\
\hline Szegedi & Szeged & Kettőshatári út & KT & Tanya & 0 & 0 & 0 & 0 & 0 & & & \\
\hline Szegedi & Szeged & BT & BT & & 163463 & 77818 & 164125 & 68636 & 167982 & 161490 & 136139 & 113685 \\
\hline Szegedi & Szeged & Külterület & KT & Egyéb & 6 & 3 & & & & & & \\
\hline Szegedi & Szeged & Légió-Törökkanizsa utca & KT & Periurbán & 108 & 41 & 119 & 50 & 83 & & & \\
\hline Szegedi & Szeged & Marostő & KT & Periurbán & & & 0 & 2 & 2 & 4 & 7 & 6 \\
\hline Szegedi & Szeged & Marostöi kiskertek & EBT & & 978 & 358 & 472 & 194 & 0 & & & \\
\hline Szegedi & Szeged & Mártákdülő & KT & Tanya & 20 & 13 & 15 & 13 & 20 & 31 & 60 & 96 \\
\hline Szegedi & Szeged & Öreghegydülő & KT & Tanya & 195 & 76 & 88 & 38 & 44 & 82 & 110 & 117 \\
\hline Szegedi & Szeged & Pihenő utca & KT & Periurbán & & & 0 & & 64 & & & \\
\hline Szegedi & Szeged & Repülőtér & KT & Egyéb & 0 & 0 & 0 & 0 & 0 & & & \\
\hline Szegedi & Szeged & Rózsalaposdülö & KT & Tanya & 7 & 4 & 4 & 4 & 6 & 12 & 18 & 17 \\
\hline Szegedi & Szeged & Seregélyesdülő & KT & Egyéb & 31 & 17 & 33 & 16 & 21 & 39 & 56 & 87 \\
\hline Szegedi & Szeged & Siadülö & KT & Tanya & 79 & 39 & 77 & 31 & 75 & 75 & 108 & 139 \\
\hline Szegedi & Szeged & Subasa & EBT & & 640 & 333 & 288 & 366 & 12 & 33 & 49 & 53 \\
\hline Szegedi & Szeged & Széktódűlő & KT & Tanya & 11 & 10 & 12 & 8 & 11 & 15 & 23 & 31 \\
\hline Szegedi & Szeged & Sziksós & EBT & & & & 212 & 188 & 16 & 0 & & \\
\hline Szegedi & Szeged & Szomolya & KT & Tanya & 3 & 1 & 5 & 1 & 5 & 5 & 4 & 15 \\
\hline Szegedi & Szeged & Szőregikiskertek & KT & Zártkert & & & 0 & 20 & 0 & & & \\
\hline Szegedi & Szeged & Szőregitanyák & KT & Tanya & 69 & 29 & 63 & 43 & 55 & 137 & 216 & 138 \\
\hline Szegedi & Szeged & Tápairét & KT & Tanya & 50 & 19 & 68 & 46 & 58 & 125 & 376 & 803 \\
\hline Szegedi & Szeged & Tápéikiskertek & EBT & & 158 & 66 & 3 & 57 & 0 & & & \\
\hline Szegedi & Szeged & Tompaszigeti kiskertek & EBT & & 435 & 188 & 264 & 155 & 0 & & & \\
\hline Szegedi & Szeged & Tóth János dombja & KT & Tanya & 4 & 3 & 2 & 2 & 9 & 27 & 22 & 5 \\
\hline Szegedi & Tiszasziget & BT & BT & & 1584 & 592 & 1607 & 556 & 1446 & 1511 & 1379 & 1325 \\
\hline Szegedi & Tiszasziget & Térvárpuszta & KT & Major & 89 & 32 & 65 & 29 & 69 & 106 & 122 & 144 \\
\hline Szegedi & Tiszasziget & Vedresházitanyák & KT & Tanya & 35 & 15 & 28 & 15 & 52 & 76 & 87 & 113 \\
\hline Szegedi & Újszentiván & BT & BT & & 1642 & 606 & 1650 & 524 & 1330 & 1346 & 1290 & 1199 \\
\hline Szegedi & Zsombó & Bábadülő & KT & Tanya & 569 & 278 & 513 & 232 & 342 & 463 & 499 & 602 \\
\hline Szegedi & Zsombó & Dózsadűlő & KT & Tanya & 354 & 167 & 374 & 157 & 285 & 370 & 464 & 510 \\
\hline Szegedi & Zsombó & BT & BT & & 2151 & 774 & 2038 & 673 & 1308 & 795 & 541 & 327 \\
\hline Szegedi & Zsombó & Lápastódűlő & KT & Tanya & 96 & 53 & 95 & 55 & 79 & 103 & 137 & 186 \\
\hline Szegedi & Zsombó & Mártákdülő & KT & Tanya & 59 & 32 & 61 & 34 & 62 & 81 & 83 & 99 \\
\hline Szegedi & Zsombó & Ménesjárásdülő & KT & Tanya & 133 & 89 & 152 & 88 & 149 & 205 & 286 & 390 \\
\hline ZEG & Alibánfa & BT & BT & & 431 & 165 & 474 & 161 & 476 & 476 & 470 & 408 \\
\hline ZEG & Alibánfa & Vasúti őrházak & KT & Örház & 2 & 1 & 0 & 1 & 3 & 8 & 6 & 8 \\
\hline ZEG & Almásháza & BT & BT & & 59 & 23 & 57 & 22 & 79 & 110 & 138 & 207 \\
\hline ZEG & Alsónemesapáti & Avashegy & KT & Szőlőhegy & 10 & 5 & 12 & 6 & 13 & 12 & 31 & \\
\hline ZEG & Alsónemesapáti & Csönkölejhegy & KT & Szőlöhegy & 2 & 1 & 0 & 1 & 1 & 2 & 2 & 7 \\
\hline ZEG & Alsónemesapáti & Hármastanya & KT & Tanya & 11 & 5 & 16 & 8 & 15 & 18 & 14 & 16 \\
\hline ZEG & Alsónemesapáti & BT & BT & & 705 & 261 & 744 & 258 & 734 & 778 & 834 & 874 \\
\hline ZEG & Alsónemesapáti & Nagykapornak állomás & KT & Örház & 1 & 2 & 6 & 2 & 2 & 10 & 10 & 9 \\
\hline ZEG & Alsónemesapáti & ZÁÉV-telep & KT & Ipar & 0 & 0 & 0 & 1 & 0 & 3 & 2 & 39 \\
\hline ZEG & Babosdöbréte & Kishegy & KT & Szőlöhegy & 2 & 1 & & & & & & \\
\hline
\end{tabular}




\begin{tabular}{|c|c|c|c|c|c|c|c|c|c|c|c|c|}
\hline 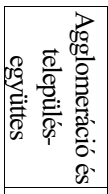 & 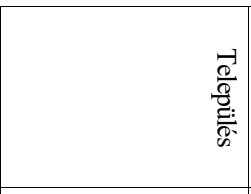 & 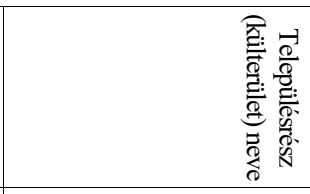 & 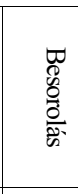 & $\begin{array}{l}\text { त् } \\
\text { Е } \\
\text { E }\end{array}$ & 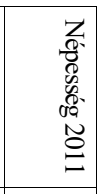 & 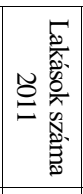 & 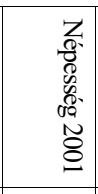 & 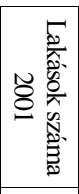 & 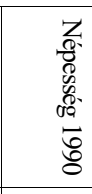 & 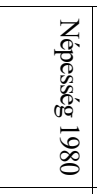 & 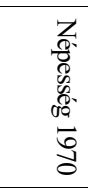 & $\begin{array}{l}Z \\
\frac{8}{8} \\
8 \\
0 \\
0 \\
0 \\
8 \\
8\end{array}$ \\
\hline ZEG & Babosdöbréte & Köhegy & KT & Szőlőhegy & 6 & 3 & & & & & & \\
\hline ZEG & Babosdöbréte & Kökényesmindszent & KT & & 34 & 16 & 29 & 11 & 14 & 19 & 32 & 60 \\
\hline ZEG & Babosdöbréte & BT & BT & & 379 & 161 & 398 & 149 & 430 & 512 & 598 & 668 \\
\hline ZEG & Babosdöbréte & Rám & EBT & & 42 & 33 & 57 & 31 & 83 & 122 & 148 & 188 \\
\hline ZEG & Babosdöbréte & Tordahegy & KT & Szőlöhegy & 3 & 2 & 0 & 0 & 5 & 9 & 18 & 26 \\
\hline ZEG & Babosdöbréte & Újavaspuszta & KT & Major & 24 & 11 & 5 & 2 & 1 & 4 & 23 & 29 \\
\hline ZEG & Bagod & BT & BT & & 1268 & 454 & 1281 & 419 & 1197 & 1206 & 1074 & 1105 \\
\hline ZEG & Bagod & Szentpál & EBT & & 20 & 12 & 37 & 16 & 33 & 72 & 129 & 131 \\
\hline ZEG & Bak & Hannamajor & KT & Major & 0 & 0 & 0 & 0 & 16 & 31 & 86 & 109 \\
\hline ZEG & Bak & BT & BT & & 1633 & 582 & 1767 & 590 & 1826 & 1807 & 1688 & 1653 \\
\hline ZEG & Bak & Nénai erdészlak & KT & Örház & 0 & 0 & 0 & 1 & 0 & 0 & 0 & 5 \\
\hline ZEG & Baktüttös & Báránytilos & KT & Major & 2 & 1 & 3 & 1 & 3 & 3 & 5 & 13 \\
\hline ZEG & Baktüttös & BT & BT & & 327 & 142 & 357 & 140 & 385 & 433 & 511 & 515 \\
\hline ZEG & Becsehely & Kossuth tér (Újmajor) & EBT & & 99 & 34 & 125 & 34 & 140 & 149 & 158 & 140 \\
\hline ZEG & Becsehely & BT & BT & & 2003 & 710 & 2155 & 697 & 2201 & 2397 & 2401 & 2590 \\
\hline ZEG & Bocfölde & Bogárd & KT & Egyéb & & & 0 & & 12 & 8 & 18 & 17 \\
\hline ZEG & Bocfölde & BT & BT & & 1193 & 414 & 1033 & 333 & 930 & 795 & 892 & 872 \\
\hline ZEG & Bocfölde & Országút & KT & Periurbán & 4 & 4 & 5 & 4 & 15 & 29 & 11 & 12 \\
\hline ZEG & Boncodfölde & Csurgasz & KT & Üdülö & 3 & 2 & 1 & 2 & 6 & 10 & 11 & 9 \\
\hline ZEG & Boncodfölde & BT & BT & & 321 & 125 & 218 & 84 & 184 & 233 & 255 & 296 \\
\hline ZEG & Boncodfölde & Martonfa & KT & Major & 3 & 1 & 3 & 1 & 7 & 6 & 7 & 6 \\
\hline ZEG & Boncodfölde & Nagyhegy & KT & Szőlöhegy & 0 & 1 & 0 & 2 & 3 & 4 & 13 & 10 \\
\hline ZEG & Boncodfölde & Újhegy & KT & Szőlőhegy & 3 & 2 & 1 & 1 & 1 & 7 & 14 & 8 \\
\hline ZEG & Böde & BT & BT & & 303 & 121 & 301 & 128 & 374 & 463 & 488 & 609 \\
\hline ZEG & Csatár & BT & BT & & 194 & 67 & 183 & 63 & 184 & 229 & 262 & 651 \\
\hline ZEG & Csatár & Petendhegy & KT & Szőlöhegy & 0 & 0 & & & & 2 & 11 & 16 \\
\hline ZEG & Csatár & Szélföld & EBT & & 366 & 143 & 366 & 121 & 328 & 331 & 375 & \\
\hline ZEG & Csonkahegyhát & Faluvég & KT & Periurbán & 1 & 1 & 1 & 1 & 1 & 2 & 2 & 2 \\
\hline ZEG & Csonkahegyhát & Haármashatár út & KT & Periurbán & 4 & 1 & & & & & & \\
\hline ZEG & Csonkahegyhát & Ján-hegy & KT & Szőlöhegy & 2 & 2 & & & & & & 7 \\
\hline ZEG & Csonkahegyhát & BT & BT & & 323 & 135 & 330 & 129 & 306 & 339 & 402 & 500 \\
\hline ZEG & Csonkahegyhát & Téglagyárirész & KT & Ipar & 2 & 2 & 3 & 2 & 8 & 7 & 9 & 18 \\
\hline ZEG & Dobronhegy & BT & BT & & 140 & 64 & 168 & 65 & 144 & 157 & 166 & 174 \\
\hline ZEG & Egervár & Halcsontmajor & KT & Major & & & 0 & & 12 & 5 & 10 & 11 \\
\hline ZEG & Egervár & Hegyalja utca & KT & Periurbán & 32 & 13 & 24 & 7 & 0 & & & \\
\hline ZEG & Egervár & BT & BT & & 998 & 371 & 1026 & 342 & 991 & 1010 & 944 & 1858 \\
\hline ZEG & Egervár & Templomeleje & KT & Periurbán & & & 0 & & 2 & 14 & 18 & \\
\hline ZEG & Gellénháza & BT & BT & & 1616 & 643 & 1707 & 615 & 1711 & 1632 & 1587 & 1508 \\
\hline ZEG & Gombosszeg & BT & BT & & 35 & 33 & 39 & 27 & 34 & 68 & 128 & 151 \\
\hline ZEG & Hagyárosbörönd & Böröndújmajor & KT & Major & 7 & 2 & 8 & 3 & 5 & 17 & 4 & 9 \\
\hline ZEG & Hagyárosbörönd & Hagyáros & EBT & & 44 & 26 & 38 & 23 & 55 & 69 & 100 & 106 \\
\hline ZEG & Hagyárosbörönd & Hagyárosimajor & KT & Major & 0 & 0 & 5 & 2 & 10 & 6 & 29 & 30 \\
\hline ZEG & Hagyárosbörönd & BT & BT & & 290 & 106 & 259 & 102 & 247 & 305 & 382 & 386 \\
\hline ZEG & Hottó & BT & BT & & 256 & 99 & 258 & 93 & 272 & 295 & 329 & 370 \\
\hline ZEG & Hottó & Perjászóhegy & KT & Szőlöhegy & 9 & 3 & & & & & & \\
\hline ZEG & Hottó & Zalaszentmihályfa & EBT & & 74 & 32 & 76 & 29 & 86 & 110 & 149 & 146 \\
\hline ZEG & Kávás & Iskolaköz utca & KT & Periurbán & 1 & 1 & 0 & 0 & 0 & & & \\
\hline ZEG & Kávás & BT & BT & & 238 & 98 & 242 & 94 & 262 & 332 & 374 & 380 \\
\hline ZEG & Kemendollár & Kemend & EBT & & 167 & 75 & 177 & 76 & 201 & 227 & 269 & \\
\hline ZEG & Kemendollár & BT & BT & & 358 & 131 & 386 & 129 & 414 & 448 & 446 & 736 \\
\hline ZEG & Kisbucsa & Csirkehegy & KT & Szőlöhegy & 0 & 0 & & & & & & 2 \\
\hline ZEG & Kisbucsa & BT & BT & & 446 & 185 & 460 & 182 & 475 & 526 & 617 & 633 \\
\hline ZEG & Kisbucsa & Szenttamáspuszta & KT & Major & 0 & 0 & 0 & 1 & 1 & 9 & 3 & 21 \\
\hline ZEG & Kisbucsa & Vasút utca & KT & Periurbán & & & 0 & & 3 & 11 & 3 & 5 \\
\hline ZEG & Kiskutas & Fácánkert utca & KT & Periurbán & 0 & 0 & & & & & & \\
\hline ZEG & Kiskutas & Kálócfapuszta & KT & Major & 21 & 11 & 10 & 9 & 8 & 18 & 35 & 55 \\
\hline ZEG & Kiskutas & BT & BT & & 170 & 73 & 206 & 72 & 177 & 184 & 213 & 227 \\
\hline ZEG & Kispáli & BT & BT & & 298 & 113 & 225 & 100 & 247 & 294 & 297 & 336 \\
\hline ZEG & Lakhegy & BT & BT & & 447 & 204 & 491 & 197 & 576 & 650 & 735 & \\
\hline ZEG & Milejszeg & Gesztenyés & KT & Tanya & 2 & 1 & 2 & 1 & 3 & 5 & 6 & 4 \\
\hline ZEG & Milejszeg & BT & BT & & 304 & 152 & 418 & 156 & 441 & 496 & 588 & 695 \\
\hline ZEG & Nagykapornak & BT & BT & & 899 & 368 & 975 & 388 & 1053 & 1057 & 1152 & 1351 \\
\hline ZEG & Nagykutas & Almasétány & KT & Periurbán & 0 & 1 & & & & & & \\
\hline ZEG & Nagykutas & BT & BT & & 443 & 185 & 450 & 175 & 449 & 521 & 586 & 682 \\
\hline ZEG & Nagylengyel & Csentericfa & KT & Szőlőhegy & 0 & 0 & 0 & 1 & 1 & 1 & 3 & 10 \\
\hline ZEG & Nagylengyel & BT & BT & & 481 & 195 & 438 & 169 & 421 & 471 & 562 & 604 \\
\hline ZEG & Nagylengyel & Pityerlap & KT & Szőlőhegy & 8 & 3 & 7 & 3 & 5 & 7 & 9 & 19 \\
\hline ZEG & Nagylengyel & Rózsásszegioldal & KT & Szőlöhegy & 1 & 1 & 3 & 1 & 6 & 4 & 10 & 16 \\
\hline ZEG & Nagylengyel & Újhegy & KT & Szőlöhegy & 9 & 5 & & & & & & \\
\hline
\end{tabular}




\begin{tabular}{|c|c|c|c|c|c|c|c|c|c|c|c|c|}
\hline 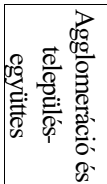 & $\frac{\overrightarrow{0}}{\frac{8}{8}}$ & 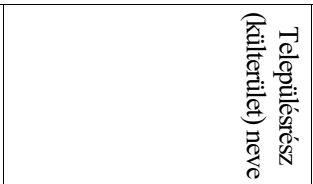 & 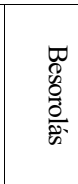 & 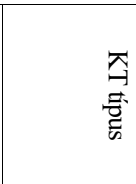 & 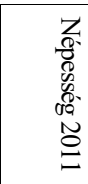 & 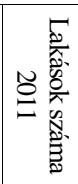 & 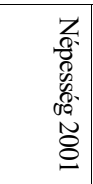 & 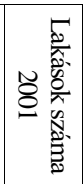 & 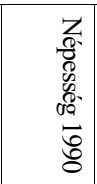 & 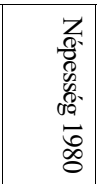 & 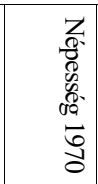 & 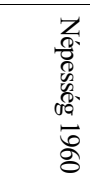 \\
\hline ZEG & Nagypáli & BT & BT & & 464 & 178 & 315 & 125 & 288 & 302 & 347 & 402 \\
\hline ZEG & Nemesapáti & BT & BT & & 500 & 217 & 501 & 208 & 523 & 586 & 689 & 818 \\
\hline ZEG & Nemessándorháza & BT & BT & & 301 & 171 & 316 & 175 & 406 & 545 & 695 & 769 \\
\hline ZEG & Nemesszentandrás & BT & BT & & 265 & 133 & 260 & 130 & 288 & 398 & 507 & 580 \\
\hline ZEG & Pakod & Átó & KT & Szőlöhegy & 1 & 5 & 6 & 6 & 11 & 20 & 24 & 28 \\
\hline ZEG & Pakod & Borbáshegy & KT & Szőlöhegy & 4 & 7 & 7 & 4 & 14 & 21 & 40 & 78 \\
\hline ZEG & Pakod & Csontosmajor & KT & Major & & & 0 & & 11 & 19 & 2 & 4 \\
\hline ZEG & Pakod & Endesmajor & KT & Major & 9 & 2 & 7 & 2 & 3 & 3 & 0 & 3 \\
\hline ZEG & Pakod & BT & BT & & 885 & 328 & 944 & 323 & 992 & 1086 & 1134 & 1112 \\
\hline ZEG & Pakod & Nándormajor & KT & Major & & & 0 & & 6 & 9 & 42 & 36 \\
\hline ZEG & Pakod & Pakodhegy & KT & Szőlőhegy & 22 & 17 & 15 & 16 & 25 & 56 & 102 & 129 \\
\hline ZEG & Pálfiszeg & BT & BT & & 158 & 65 & 207 & 69 & 233 & 273 & 273 & 329 \\
\hline ZEG & Pethőhenye & Cigányhegy & KT & Szőlöhegy & 9 & 5 & 0 & 2 & 3 & 2 & & \\
\hline ZEG & Pethőhenye & Cserlap & KT & Szölöhegy & & & 10 & 5 & 2 & 3 & 14 & 4 \\
\hline ZEG & Pethöhenye & Csillaghegy & KT & Szőlöhegy & 1 & 1 & 2 & 6 & 0 & 4 & 11 & 34 \\
\hline ZEG & Pethőhenye & Csortán & KT & Major & 17 & 10 & 21 & 21 & 20 & 36 & 45 & 45 \\
\hline ZEG & Pethőhenye & Csuhi örház & KT & Szőlőhegy & 1 & 1 & 0 & 1 & 4 & 3 & & 5 \\
\hline ZEG & Pethőhenye & Henyeimalom & KT & Örház & 12 & 3 & 14 & 3 & 15 & 23 & 14 & 19 \\
\hline ZEG & Pethöhenye & Köszörüshegy & KT & Szőlőhegy & 6 & 3 & 5 & 2 & 3 & 7 & 6 & 10 \\
\hline ZEG & Pethőhenye & BT & BT & & 395 & 160 & 342 & 147 & 347 & 433 & 552 & 574 \\
\hline ZEG & Pethöhenye & Tóthegy & KT & Szőlöhegy & 0 & 0 & & & & 0 & 4 & 18 \\
\hline ZEG & Pókaszepetk & Békepuszta & KT & Major & 5 & 2 & 1 & 3 & 8 & 28 & 27 & 65 \\
\hline ZEG & Pókaszepetk & BT & BT & & 954 & 356 & 1019 & 359 & 997 & 996 & 1007 & 1063 \\
\hline ZEG & Pókaszepetk & Külterületi major & KT & Major & 4 & 1 & & & & & & \\
\hline ZEG & Pókaszepetk & Vasúti őrház & KT & Örház & 0 & 1 & 4 & 2 & 0 & 2 & & \\
\hline ZEG & Salomvár & Cigányhegy & KT & Szőlöhegy & 1 & 4 & 2 & 4 & 0 & 8 & 43 & 58 \\
\hline ZEG & Salomvár & Dózsahegy & KT & Szőlöhegy & 2 & 1 & 2 & 1 & 7 & 16 & 28 & 39 \\
\hline ZEG & Salomvár & Erdeifalu & KT & Szőlőhegy & 0 & 1 & 0 & 1 & 2 & 4 & 35 & 64 \\
\hline ZEG & Salomvár & Harkályhegy & KT & Szőlőhegy & 1 & 5 & 7 & 5 & 11 & 18 & 41 & 46 \\
\hline ZEG & Salomvár & BT & BT & & 616 & 228 & 550 & 217 & 572 & 684 & 792 & 856 \\
\hline ZEG & Salomvár & Kurtamajor & KT & Major & 0 & 1 & 4 & 1 & 0 & 2 & 15 & 15 \\
\hline ZEG & Salomvár & Salamonhegy & KT & Szőlőhegy & 0 & 2 & 1 & 2 & 0 & 9 & 26 & 31 \\
\hline ZEG & Salomvár & Szélgyöp & KT & Major & 1 & 3 & 5 & 4 & 4 & 24 & 47 & 62 \\
\hline ZEG & Sárhida & BT & BT & & 806 & 278 & 782 & 257 & 758 & 844 & 828 & 737 \\
\hline ZEG & Teskánd & Alsómező & KT & Szőlöhegy & 32 & 11 & 24 & 12 & 28 & 32 & 39 & 52 \\
\hline ZEG & Teskánd & BT & BT & & 1079 & 381 & 929 & 297 & 735 & 585 & 397 & 360 \\
\hline ZEG & Tófej & Hencsepuszta & EBT & & 13 & 12 & 21 & 12 & 33 & 46 & 67 & 73 \\
\hline ZEG & Tófej & BT & BT & & 687 & 276 & 707 & 273 & 749 & 760 & 808 & 820 \\
\hline ZEG & Vaspör & BT & BT & & 293 & 159 & 324 & 157 & 380 & 457 & 589 & 640 \\
\hline ZEG & Vaspör & Velence & EBT & & 86 & 46 & 95 & 45 & 109 & 141 & 159 & 203 \\
\hline ZEG & Vöckönd & Kölcsey Ferenc utca & KT & Periurbán & 6 & 5 & 5 & 5 & 9 & 16 & 19 & 32 \\
\hline ZEG & Vöckönd & BT & BT & & 79 & 42 & 95 & 42 & 117 & 131 & 178 & 185 \\
\hline ZEG & Zalabér & Hegybal & KT & Szőlöhegy & 4 & 2 & 1 & 1 & 4 & 12 & 41 & 56 \\
\hline ZEG & Zalabér & Hegyjobb & KT & Szőlöhegy & 0 & 0 & 1 & 2 & 6 & 27 & 41 & 56 \\
\hline ZEG & Zalabér & BT & BT & & 723 & 325 & 745 & 322 & 816 & 920 & 1017 & 1148 \\
\hline ZEG & Zalabér & Tekevölgy & KT & Szőlöhegy & 0 & 0 & 0 & 3 & 7 & 11 & 13 & 24 \\
\hline ZEG & Zalaboldogfa & BT & BT & & 352 & 137 & 361 & 132 & 368 & 428 & 472 & 545 \\
\hline ZEG & Zalaegerszeg & Alsóerdei út & KT & Periurbán & 229 & 81 & 73 & 29 & 48 & 53 & 66 & 56 \\
\hline ZEG & Zalaegerszeg & Alsójánkahegy & EBT & & 0 & 0 & & & & & & \\
\hline ZEG & Zalaegerszeg & Andráshida & EBT & & 2409 & 867 & 2517 & 780 & 2270 & 1609 & 1262 & 1033 \\
\hline ZEG & Zalaegerszeg & Avashegy & KT & Szőlőhegy & 45 & 17 & 27 & 11 & 0 & 3 & 21 & 43 \\
\hline ZEG & Zalaegerszeg & Bazita & EBT & & 563 & 228 & 512 & 189 & 464 & 484 & 482 & 450 \\
\hline ZEG & Zalaegerszeg & Becsali út & KT & Periurbán & 683 & 284 & 221 & 78 & 144 & 140 & 201 & 265 \\
\hline ZEG & Zalaegerszeg & Becsalihegy & KT & Szőlöhegy & & & 108 & 44 & 46 & 23 & 25 & \\
\hline ZEG & Zalaegerszeg & Bekeháza & KT & Major & 3 & 6 & 25 & 11 & 36 & 43 & 90 & 96 \\
\hline ZEG & Zalaegerszeg & Belsőszeg utca & KT & Periurbán & & & 18 & 6 & 41 & & & \\
\hline ZEG & Zalaegerszeg & Botfa & EBT & & 748 & 278 & 776 & 251 & 748 & 755 & 840 & 807 \\
\hline ZEG & Zalaegerszeg & Botfa külterület & KT & Periurbán & 6 & 4 & & & & & & \\
\hline ZEG & Zalaegerszeg & Budaivölgy & KT & Egyéb & 5 & 1 & 80 & 27 & 48 & 44 & 59 & 79 \\
\hline ZEG & Zalaegerszeg & Búslakpuszta & KT & Major & & & 0 & 0 & 8 & 13 & 17 & 21 \\
\hline ZEG & Zalaegerszeg & Cimpóhegy & KT & Szőlöhegy & 6 & 2 & & & & & & \\
\hline ZEG & Zalaegerszeg & Csács külterület & KT & Periurbán & 62 & 35 & & & & & & \\
\hline ZEG & Zalaegerszeg & Csácsbozsok & EBT & & 2827 & 1037 & 3218 & 946 & 2491 & 1620 & 1174 & 964 \\
\hline ZEG & Zalaegerszeg & Csácsbozsok külterület & KT & Periurbán & 185 & 95 & & & & & & \\
\hline ZEG & Zalaegerszeg & Csácsihegy & KT & Szőlöhegy & 32 & 13 & 55 & 38 & 23 & 24 & 60 & 121 \\
\hline ZEG & Zalaegerszeg & Csáfordidülő & KT & Szőlöhegy & & & 49 & 19 & 10 & 38 & 73 & 89 \\
\hline ZEG & Zalaegerszeg & Csáfordiforduló & KT & Egyéb & 107 & 41 & 80 & 27 & 24 & 19 & 42 & 50 \\
\hline ZEG & Zalaegerszeg & Cserhegy & KT & Szölőhegy & & & 18 & 8 & 0 & 2 & 10 & 14 \\
\hline ZEG & Zalaegerszeg & Ebergény & EBT & & 273 & 117 & 209 & 80 & 171 & 198 & 241 & 259 \\
\hline
\end{tabular}




\begin{tabular}{|c|c|c|c|c|c|c|c|c|c|c|c|c|}
\hline 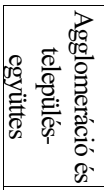 & $\frac{\frac{\vec{\theta}}{\theta}}{\frac{8}{\theta}}$ & 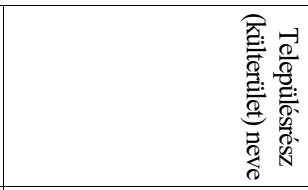 & 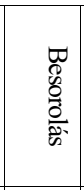 & 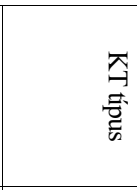 & 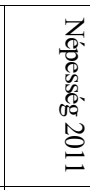 & 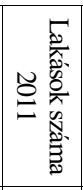 & 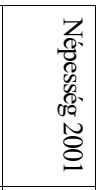 & 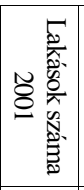 & 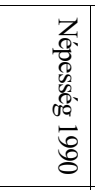 & 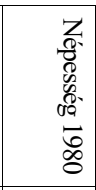 & 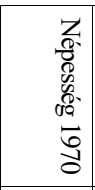 & 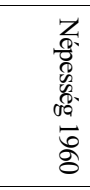 \\
\hline ZEG & Zalaegerszeg & Ebergénydűlö & KT & Szőlöhegy & 8 & 5 & 140 & 57 & 30 & 11 & 78 & 65 \\
\hline ZEG & Zalaegerszeg & Egerszeghegy & KT & Szőlöhegy & 573 & 250 & 366 & 149 & 108 & 152 & 177 & 216 \\
\hline ZEG & Zalaegerszeg & Gálafejpuszta & KT & Major & 87 & 38 & 26 & 13 & 6 & 7 & 23 & 71 \\
\hline ZEG & Zalaegerszeg & Gévahegy & KT & Szölöhegy & 108 & 54 & 83 & 34 & 30 & 26 & 28 & 25 \\
\hline ZEG & Zalaegerszeg & Gógánhegy & KT & Szölőhegy & 220 & 112 & 0 & 0 & 11 & 33 & 47 & 67 \\
\hline ZEG & Zalaegerszeg & Hatház & KT & Periurbán & 168 & 68 & 154 & 62 & 53 & 63 & 71 & 75 \\
\hline ZEG & Zalaegerszeg & Hóvirág utca & KT & Periurbán & & & 46 & 15 & 11 & & & \\
\hline ZEG & Zalaegerszeg & Jánkahegy & KT & Szölőhegy & 685 & 295 & 356 & 145 & 105 & 82 & 139 & 253 \\
\hline ZEG & Zalaegerszeg & Kápolnahegy & KT & Szölöhegy & & & 2 & 2 & 4 & 8 & 39 & 19 \\
\hline ZEG & Zalaegerszeg & Karácsonyhegy & KT & Szölőhegy & 8 & 7 & & & & & 0 & 8 \\
\hline ZEG & Zalaegerszeg & Kaszaháza & EBT & & 0 & 0 & & & & & & \\
\hline ZEG & Zalaegerszeg & Kertváros & EBT & & 0 & 0 & & & & & & \\
\hline ZEG & Zalaegerszeg & Kisbükidülő & KT & Szőlöhegy & 31 & 18 & 39 & 18 & 23 & 24 & 32 & 48 \\
\hline ZEG & Zalaegerszeg & Kiscsaritidülö & KT & Szölőhegy & & & 5 & 2 & 10 & 5 & 17 & 50 \\
\hline ZEG & Zalaegerszeg & Kökény utca & KT & Periurbán & & & 20 & 7 & 3 & & & \\
\hline ZEG & Zalaegerszeg & BT & BT & & 44023 & 20162 & 47289 & 18533 & 50703 & 46183 & 30130 & 21366 \\
\hline ZEG & Zalaegerszeg & Landorhegy & EBT & & 0 & 0 & & & & & & \\
\hline ZEG & Zalaegerszeg & Lukahegy & KT & Szölőhegy & 48 & 18 & 13 & 5 & 12 & 24 & 42 & 50 \\
\hline ZEG & Zalaegerszeg & Magasbük & KT & Szőlöhegy & 16 & 5 & 0 & 3 & 3 & 3 & 18 & 23 \\
\hline ZEG & Zalaegerszeg & Nekeresd & EBT & & 468 & 170 & 231 & 79 & 183 & 213 & 230 & 182 \\
\hline ZEG & Zalaegerszeg & Nekeresd külterület & KT & Periurbán & 4 & 2 & & & & & & \\
\hline ZEG & Zalaegerszeg & Neszele & EBT & & 575 & 200 & 432 & 127 & 350 & 266 & 249 & 213 \\
\hline ZEG & Zalaegerszeg & Neszele külterület & KT & Periurbán & 0 & 0 & & & & & & \\
\hline ZEG & Zalaegerszeg & Nevelőintézet & KT & Szociális & & & 18 & 3 & 59 & 173 & & \\
\hline ZEG & Zalaegerszeg & Ola & EBT & & 0 & 0 & & & & & & \\
\hline ZEG & Zalaegerszeg & Öreghegy & KT & Szőlöhegy & 91 & 42 & 24 & 12 & 7 & 18 & 30 & 61 \\
\hline ZEG & Zalaegerszeg & Pátesdomb & EBT & & 0 & 0 & & & & & & \\
\hline ZEG & Zalaegerszeg & Pipahegy & KT & Szölöhegy & 15 & 6 & & & & & & \\
\hline ZEG & Zalaegerszeg & Pózva & EBT & & 1167 & 210 & 1222 & 217 & 1103 & 1019 & 1360 & 521 \\
\hline ZEG & Zalaegerszeg & Ságod & EBT & & 941 & 382 & 892 & 306 & 826 & 811 & 832 & 827 \\
\hline ZEG & Zalaegerszeg & Ságod külterület & KT & Periurbán & 0 & 0 & & & & & & \\
\hline ZEG & Zalaegerszeg & Szekeresvölgy & KT & Szölöhegy & 15 & 6 & & & & & & \\
\hline ZEG & Zalaegerszeg & Szenterzsébet külterület & KT & Periurbán & 14 & 5 & & & & & & \\
\hline ZEG & Zalaegerszeg & Szenterzsébethegy & EBT & & 288 & 108 & 264 & 83 & 352 & 384 & 188 & 119 \\
\hline ZEG & Zalaegerszeg & Szívhegyi utca & KT & Periurbán & & & 170 & 50 & 55 & & & 102 \\
\hline ZEG & Zalaegerszeg & Szüret utca & KT & Periurbán & & & 76 & 26 & 89 & & & \\
\hline ZEG & Zalaegerszeg & Újhegy & KT & Szölöhegy & 10 & 3 & 26 & 8 & 10 & 25 & 155 & 164 \\
\hline ZEG & Zalaegerszeg & Vakaroshegy & KT & Szölöhegy & 98 & 37 & 18 & 9 & 13 & 23 & 50 & 73 \\
\hline ZEG & Zalaegerszeg & Vorhota & EBT & & 566 & 194 & 546 & 170 & 294 & 220 & 159 & 161 \\
\hline ZEG & Zalaegerszeg & Völgy & KT & Szölőhegy & & & 0 & 0 & 0 & 16 & 39 & 43 \\
\hline ZEG & Zalaegerszeg & Zalabesenyö & EBT & & 1089 & 383 & 1210 & 376 & 1187 & 1106 & 905 & \\
\hline ZEG & Zalaszentgyörgy & BT & BT & & 406 & 154 & 401 & 143 & 359 & 430 & 437 & 484 \\
\hline ZEG & Zalaszentgyörgy & Zélpuszta & KT & Major & 0 & 0 & 0 & 1 & 1 & 3 & 25 & 17 \\
\hline ZEG & Zalaszentiván & Kisfaludihegy & KT & Szölöhegy & 3 & 1 & 3 & 1 & 3 & 2 & 7 & 11 \\
\hline ZEG & Zalaszentiván & BT & BT & & 1068 & 397 & 1053 & 375 & 972 & 952 & 938 & 923 \\
\hline ZEG & Zalaszentiván & Nagyfaludpuszta & KT & Major & 4 & 3 & 4 & 4 & 6 & 22 & 14 & 26 \\
\hline ZEG & Zalaszentiván & Szárazdülö & KT & Szőlöhegy & 0 & 1 & 3 & 1 & 0 & 4 & & \\
\hline ZEG & Zalaszentlórinc & BT & BT & & 281 & 125 & 294 & 122 & 302 & 356 & 434 & 469 \\
\hline ZEG & Zalaszentmárton & BT & BT & & 58 & 43 & 70 & 40 & 81 & 150 & 229 & 297 \\
\hline HMVH & HMVH & Aranyág & KT & Tanya & 62 & 28 & 19 & 8 & 136 & 202 & 169 & 539 \\
\hline HMVH & HMVH & Barattyos & KT & Tanya & 9 & 2 & 0 & 0 & 0 & 21 & 26 & \\
\hline HMVH & HMVH & Batida & EBT & & 181 & 83 & 235 & 83 & 215 & 208 & 190 & 164 \\
\hline HMVH & HMVH & Batidaitanyák & KT & Tanya & 68 & 27 & 50 & 17 & 160 & 359 & 744 & 1836 \\
\hline HMVH & HMVH & Belsőkishomok & KT & Zártkert & 935 & 384 & 292 & 117 & 0 & & & \\
\hline HMVH & HMVH & Dilinkatanyák & KT & Tanya & 42 & 19 & 41 & 16 & 100 & 148 & 229 & 293 \\
\hline HMVH & HMVH & Erzsébet & EBT & & 157 & 56 & 178 & 57 & 174 & 175 & 96 & 87 \\
\hline HMVH & HMVH & Erzsébetitanyák & KT & Tanya & 270 & 148 & 365 & 183 & 232 & 475 & 1040 & 1476 \\
\hline HMVH & HMVH & Fürkehalom & KT & Tanya & 78 & 36 & 112 & 54 & 78 & 192 & 243 & 552 \\
\hline HMVH & HMVH & Gorzsa & KT & Tanya & 44 & 18 & 57 & 25 & 101 & 256 & 476 & 89 \\
\hline HMVH & HMVH & Hódtó & KT & Tanya & 113 & 76 & 5 & 2 & 227 & 223 & 311 & 808 \\
\hline HMVH & HMVH & Katraszél & KT & Tanya & 4 & 1 & 9 & 3 & 17 & 51 & 146 & 193 \\
\hline HMVH & HMVH & Kenyerepart & KT & Tanya & 25 & 15 & 19 & 16 & 22 & 46 & 68 & \\
\hline HMVH & HMVH & Kopáncs & KT & Tanya & 50 & 23 & 104 & 33 & 130 & 261 & 401 & 497 \\
\hline HMVH & HMVH & BT & BT & & 41561 & 18007 & 45260 & 17469 & 47504 & 48684 & 43206 & 40062 \\
\hline HMVH & HMVH & Kútvölgy & EBT & & 143 & 77 & 170 & \begin{tabular}{l|l}
74 \\
\end{tabular} & 236 & 197 & 202 & 147 \\
\hline HMVH & HMVH & Kútvölgyitanyák & KT & Tanya & 224 & 110 & 436 & 216 & 401 & 832 & 1416 & 1897 \\
\hline HMVH & HMVH & Külsőkishomok & KT & Egyéb & 387 & 262 & 172 & 59 & 0 & & & \\
\hline HMVH & HMVH & Máma & KT & Tanya & 10 & 4 & 4 & 4 & 7 & 36 & 73 & 295 \\
\hline HMVH & HMVH & Mártélyi üdülőterület & EBT & & 28 & 67 & 0 & 2 & 0 & 0 & & \\
\hline
\end{tabular}




\begin{tabular}{|c|c|c|c|c|c|c|c|c|c|c|c|c|}
\hline 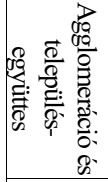 & 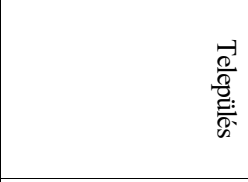 & 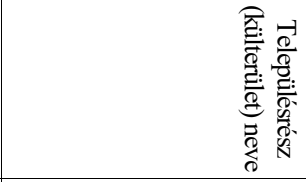 & 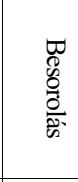 & $\begin{array}{l}\text { त् } \\
\text { 吾 } \\
\text { E }\end{array}$ & 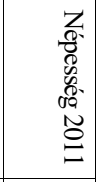 & 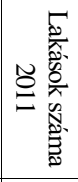 & 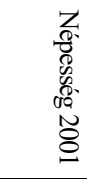 & 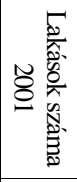 & 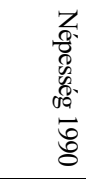 & 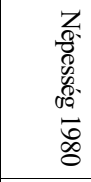 & 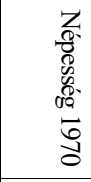 & 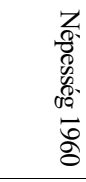 \\
\hline HMVH & HMVH & Nagyrétek & KT & Tanya & 31 & 11 & 117 & 41 & 191 & 356 & 493 & 380 \\
\hline HMVH & HMVH & Nagysziget & KT & Tanya & 217 & 96 & 267 & 96 & 161 & 250 & 254 & 448 \\
\hline HMVH & HMVH & Nyomásszél & KT & Tanya & 35 & 19 & 63 & 45 & 65 & 127 & 212 & 284 \\
\hline HMVH & HMVH & Rárós & KT & Tanya & 126 & 59 & 193 & 95 & 154 & 332 & 1047 & 1468 \\
\hline HMVH & HMVH & Sarkaly & KT & Tanya & 53 & 25 & 51 & 22 & 66 & 91 & 120 & 124 \\
\hline HMVH & HMVH & Sarkalyér & KT & Tanya & 228 & 113 & 37 & 22 & 47 & 82 & 157 & 88 \\
\hline HMVH & HMVH & Soltpalé & KT & Tanya & 319 & 133 & 368 & 134 & 58 & 93 & 194 & 254 \\
\hline HMVH & HMVH & Szikáncs & EBT & & 507 & 216 & 594 & 218 & 596 & 575 & 458 & 322 \\
\hline HMVH & HMVH & Szikáncsitanyák & KT & Tanya & 70 & 37 & 124 & 50 & 68 & 173 & 487 & 1047 \\
\hline HMVH & HMVH & Tegehalom & KT & Tanya & 70 & 38 & 40 & 26 & 34 & 41 & 142 & \\
\hline
\end{tabular}

Forrás: Bajmócy P. gyüjtése 1960-2011 KSH helységnévtárak alapján.

A II. mellékletben alkalmazott rövidítések:

BT: Központi belterület, EBT: Egyéb belterület, KT: Külterület.

HMVH: Hódmezővásárhely, ZEG: Zalaegerszegi agglomeráció.

Egyéb: vegyes szerkezetű, vagy jelentősen átalakult egyértelműen be nem sorolható külterület, Hegy: Szőlőhegyek, Ipar: Üzemi lakóhelyek, Major: Majorok és TSZ-lakótelepek, Periurbán: Településperemi utcák, Szociális: Intézmények és otthonok. 


\section{MELLÉKLET: MINTAKÉRDőÍV}

A külterületek társadalmi fejlődése - Kérdőív

201_...... Helyszín,

Kód:

1

A kérdőív kitöltése önkéntes, és anonim! Válaszait kizárólag tudományos célokra használjuk fel, az adatvédelmi szabályok betartásával.

1, Ön helyi lakos, máshonnan érkezett ide vagy csak tulajdonos?

Ha: $a \rightarrow 9$.

Itt élt mindig (a), Ide költözött (b), Kétlaki (c), Hobbikertje/üdülöje van itt (d), telektulajdonos (e), más................. NV (77)

2, Honnan érkezett ide? ............................................ (Szeged esetében a városrész neve)

NV (77)

3, Milyen indokkal költtözött ide, illetve miért vett itt telket? (többet is megjelölhet!)

Saját ház iránti igény (a) Nagyobb lakásméret igénye (b) Munkahely közelsége (c) Olcsóbb telek (d)

Olcsóbb megélhetés (e) Környezeti elönyök (f) Falusias közösség (g)

Itt volt korábban kertem (h)

Kert, gazdálkodási lehetőség (i)

Egyéb:.

NV (77)

4, Milyen házban lakott korábban:

(Kerttulajdonos estén: Milyen házban lakik?)

Családi ház (a); régi tömbház (b); panelház (c); 1990 utáni bérház (d); tanya (e); egyéb: .................. NV (77)

5, Honnan szerzett információkat a helysźńöl, amikor döntött? (többet is megjelölhet!)

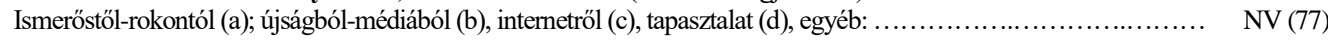

6, Mért választotta pont ezt a külterületet? NV (77)

7, Milyen más lehetőségeket mérlegelt?

NV (77) NT(88)

8, Mennyi időt tölt a külterületen? Csak ha $1=\boldsymbol{c}, \boldsymbol{d}, \boldsymbol{e}$ !

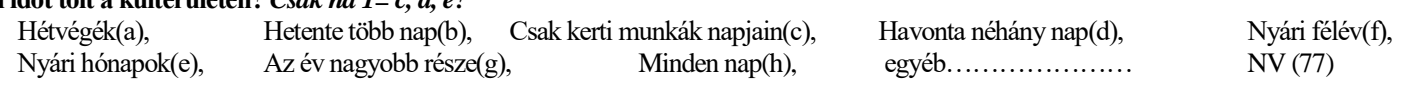

9, Szeret külterületen élni? (Kerttulajdonos estén: Szeret itt lenni?) Igen (1) Nem (2) NV (77) NT(88) Miért?

10, Mióta lakik ebben (mióta az öné) az épületben?

(év) Születése óta (1)

NV (77)

11. Idetartozónak érzi-e magát?

12, Ön hova kötődik leginkább?

Igen (1) Nem (2)

NV (77)

NV (77) NT(88) Szeged (a), Falu/városrész (b), Külterület (c), Más................. NV (77) NT(88)

13, Szándékozik-e elköltözni innen? (Kerttulajdonos esetén: feladni külterületi ingatlanát?) Igen(1), Nem(2)

NV(77) NT(88)

14, Miért?

15, Kinek a tulajdonában van az ingatlan? Saját (a), rokon (b), bérli (c), önkormányzati (d), ismeretlen (e), egyéb:

NV (77)

16, Mikor épült az ingatlan? NV (77) NT(88)

17, Mikor lett utoljára felújítva/átalakítva a lakóépület? _-_- $\quad$ Soha(1), $\quad$ NV (77) NT(88)

18, A ház építőanyaga:

19, Mire használja ezt az ingatlanát? Állandó lakás (a) Vályog/tömésfal(a), tégla(b), fa(c), vegyes(d), egyéb. második (időszakos) otthon (g), (többet is megjelölhet)

hobbikert (b), földművelés (c), egyéb .... üzemi telephely (e)

20, Milyen típusú a fütés? nincs (a), kályha (b), villanykályha (c), gázfütő (d), központi fǘtés (e), egyéb:

NV(77)

$\mathrm{NV}(77)$

21, Van-e ezen a telken? vezetékes víz (a), meleg víz (b), fürdőszoba (c), villany (d), csatorna (e), vízöblítéses Wc (f) NV(77)

22, Ezen ingatlanának távolsága: Szegedtől...... Falu/városrész központjától ...... Ön munkahelyétől...... Betonúttól...... Főúttól......

23, Van-e másik ingatlana a városban/a faluban? (Közigazgatás szerint! Többet is megjelölhet!) NV(77), nincs (a), nyaraló (b), lakás (c), telek (d), külterületi ház (e), egyéb:...

24, Milyen gyakran jár be Szegedre / jön Szegedről ide? naponta(a), hetente többször(b), hetente(c), havonta kétszer(d), havonta(e), ritkábban(f), soha(g),

25, Milyen gyakran jár be a falu/városrész központjába? naponta(a), hetente többször(b), hetente(c), havonta kétszer(d), havonta(e), ritkábban(f), soha(g), $\quad$ NV (77)

26, Leginkább milyen közlekedési eszközzel? .................................. NV (77)

27, Milyen közlekedési eszközük van? kerékpár (a), motorkerékpár (b), autó (c), kisteherg. (d), egyéb: ...........

28, Milyen szabadidős lehetőségekkel él? (többet is megjelölhet!) színház(a), mozi(b), koncert(c), helyi rendezvény(d), üdülés(e), fesztiválok(f), semmi (g), egyéb................. NV(77)

29, Az önkormányzat tudomása szerint tervezi-e lakhelye belterületbe vonását? Igen (1) Nem (2) Már nem(3) NV (77)

30, Az Ön tudomása szerint miért? .

31. Ön szerint jellemzően kik élnek itt? (többet is megjelölhet) Városból kiköltöző tehetősek (a), városból kiszorulók (b). gazdagok. (e), értelmiségiek (i), szegények (f), cigányok (j),

\begin{tabular}{|c|c|c|c|c|c|c|c|}
\hline & kelje a külterületet a következő szempontok szerint: & $1 \mathrm{rossz} / \mathrm{nem}$ & 2 & 3 & 4 & 5 jó / nagyon & $\mathrm{NV}(77)$ \\
\hline 32 & Ön viszonya a szomszédokkal & & & & & & \\
\hline 33 & A szomszédjai egymással való viszonya & & & & & & \\
\hline 34 & A tömegközlekedés minősége & & & & & & \\
\hline 35 & Az utak állapota & & & & & & \\
\hline 36 & A környezet és közterületek rendezettsége & & & & & & \\
\hline 37 & A kertek, udvarok rendezettsége & & & & & & \\
\hline 38 & A közbiztonság & & & & & & \\
\hline 39 & A közszolgáltatások (orvos, ügyintézés, iskola) & & & & & & \\
\hline 40 & A boltok, szórakozóhelyek, szolgáltatások & & & & & & \\
\hline 41 & Az önkormányzat tevékenysége & & & & & & \\
\hline 42 & E külterület lakásállományának minősége & & & & & & \\
\hline
\end{tabular}




\begin{tabular}{|c|c|c|c|c|c|c|c|}
\hline 43 & Saját lakása minősége & & & & & & \\
\hline & Egyetért a következő állításokkal? & 1 nem & 2 & 3 & 4 & 5 teljes mért. & NV(77) \\
\hline 44 & Fontos Önnek a környezet állapota lakhelyén. & & & & & & \\
\hline 45 & Fontos Önnek az épített örökség lakhelyén. & & & & & & \\
\hline 46 & Fontos önnek a mezőgazdaság fennmaradása lakhelyén. & & & & & & \\
\hline 47 & Összetartó a helyi közösség. & & & & & & \\
\hline 48 & Befogadó a helyi közösség. & & & & & & \\
\hline 49 & Segítik egymást a helyi lakók. & & & & & & \\
\hline 50 & Zavarja az itt végzett mezőgazdasági tevékenység. & & & & & & \\
\hline 51 & Örülök, hogy ha beköltöznek új emberek e külterületre. & & & & & & \\
\hline 52 & E külterület kiemelkedően jó lakóterület Szeged térségében. & & & & & & \\
\hline 53 & Örülnék, ha belterületbe vonnák lakhelyem. & & & & & & \\
\hline 54 & Jelentős eltérés van a beköltözők és régi lakók között. & & & & & & \\
\hline 55 & Jelen van a vandalizmus e külterületen. & & & & & & \\
\hline
\end{tabular}

56, Végez Ön mezőgazdasági tevékenységet e külterületen? (többet is megjelölhet!) Ha =C/D/egyéb akkor Mg. kérdések is!

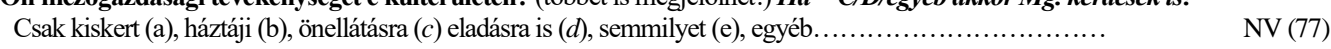

57, Van-e társadalmi elkülönülés a lakosság körében? Van (1), Nincs (2), (Ha nem $\rightarrow$ 60)

NV (77)
NV (77) NT(88)

58, Ha igen, mondjon rá példákat!

NV (77) NT(88)

59, Érinti-e önt személyesen az elkülönülés? Igen(1), Nem (2),

NV(77) NT(88)

60, Van-e a lakásállománnyal, kertekkel kapcsolatos konfliktus e külterületen? Van (1), Nincs (2) (Ha nem $\rightarrow 63$ )

61, Ha igen, mondjon rá példákat!

62, Érinti-e önt személyesen valamelyik? Igen, pozitívan (1), Igen, negatívan (2), Nem (3)

NV (77)

63, Van-e a közlekedéssel vagy a szolgáltatásokkal kapcsolatos konfliktus a külterületen? Van(1) Nincs(2) (Ha nem $\rightarrow 65)$

NV (77) NT(88)

64, Ha igen, mondjon rá példákat!

65, Hol veszi leginkább igénybe a közszolgáltatásokat (iskola, óvoda, orvosi ellátás, ügyintézés...)? helyben (a), falu/városrész (b), Szeged (c), máshol .............. NV(77)

66, Hol veszi leginkább igénybe a kereskedelmi szolgáltatásokat (bolt, fodrász, autószerelő, kocsma... )? helyben (a), falu/városrész (b), Szeged (c), máshol .............. NV(77)

67, E területnek vagy lakóinak van-e konfliktusa a helyi önkormányzattal? $\operatorname{Van}(1)$, Nincs(2) (Ha nem $\rightarrow 69)$

68, Ha igen, mondjon rá példákat!

69, Ön szerint miket kellene legsürgősebben fejleszteni e külterületen az életminőség javításához?

NV(77) NT(88)

70, A legtöbb újonnan beköltöző Ön szerint mennyi ideig lakik itt, mielőtt továbbköltözik? Hónapok (a), fél év (b), egy év (c), 1-3év (d), 3-5év (e), tovább (f)

71, Az Ön neme? ffi (a), nő (b)

72 , Születési éve?

NV (77)

73, Az Ön legmagasabb iskolai végzettsége?

8 oszt. kevesebb (a), Ált. isk. (b),

Szakmunkás (c), S Szakközép/gimnázium/technikum (d),

74, Az Ön foglalkoźsa?

74, Az On foglalkozása? ................................... munkanélküli esetén: egy évnél rövidebb ideje: „MN”, ha tartósabban:
75 , Hányan élnek a háztartásban? _ NV(77) $\quad 76$, Ebból 18 év alatti:__ NV(77) $77, \quad$ Eltartott/tanuló:
NV(77)

78, A háztartásuk összesen hány ezer Ft-ból gazdálkodik egy hónapban (nettó)? 0-25 (a), 25-50 (b), 50-100 Ft (c), 100-150 (d), 150-200 (e), 200-250 Ft (f), 250-(g)

79, Kapnak-e állami/önk.-i támogatásokat?

Családi pótlék(a), GYES/GYED(b), Segélyek(c), Lakhatási tám.(d) Egyéb:

NV (77) NT(88)

NV (77) NT(88)

Mezőgazdasági kérdések (Csak ha 56. = c/d/ egyéb!)

i, A mezőgazdasági tevékenység jellege:

nincs(a), önellátás (b), értékesít is (c), inkább eladásra (d), őstermelö/vállalkozó (e), egyéb..... NV (77)

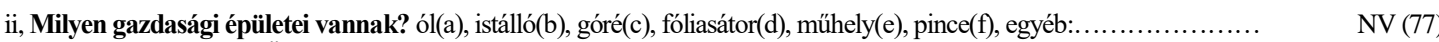

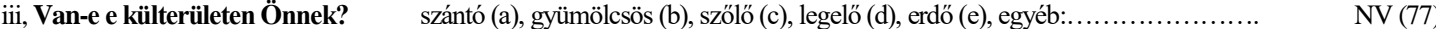

ló (a), marha (b), sertés (c), juh (d), baromfi (e), egyéb:...................... NV (77)

iv, Milyen gépparkkal rendelkezik? traktor (a), kombájn (b), öntöző (c), motoros kapa (d), mot. permetező (e), egyéb:... NV (77)

v, Mi a terve a gazdasággal a következő 10 évben? fejleszti (a), szinten tartja (b), leépíti (c), NV (77) NT(88)

vi, Van-e aki továbbviszi a gazdálkodást? $\quad$ igen (1) nem (2) NV (77) NT(88)

Csak belterületbe vont külterületek esetén!

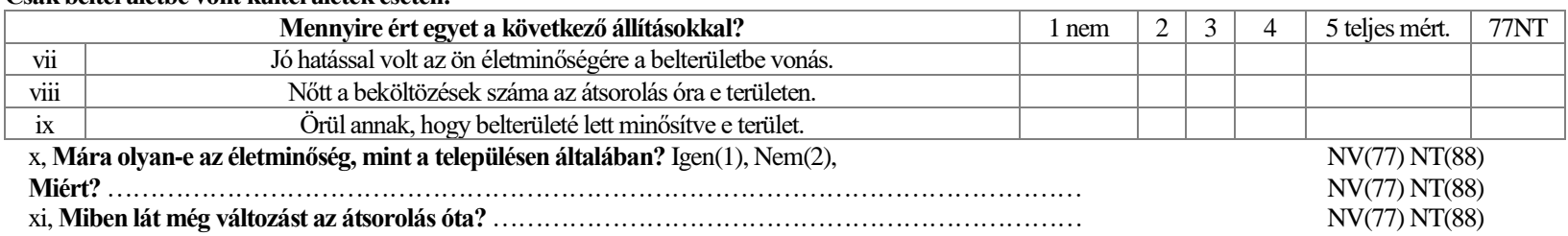

Köszönjük, hogy válaszával segítette kutatásunkat! 